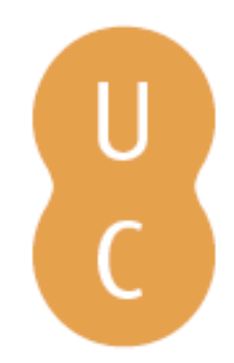

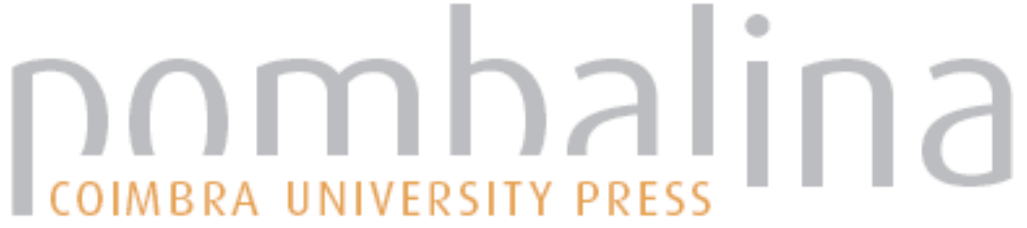

\section{Sidónio e Sidonismo: vol. 2 História de um caso político}

Autor(es): $\quad$ Silva, Armando Malheiro da

Publicado por: Imprensa da Universidade de Coimbra

URL

persistente: URI:http://hdl.handle.net/10316.2/39036

DOI: $\quad$ DOI:http://dx.doi.org/10.14195/978-989-26-1210-2

Accessed : $\quad$ 26-Apr-2023 11:02:33

A navegação consulta e descarregamento dos títulos inseridos nas Bibliotecas Digitais UC Digitalis, UC Pombalina e UC Impactum, pressupõem a aceitação plena e sem reservas dos Termos e Condições de Uso destas Bibliotecas Digitais, disponíveis em https://digitalis.uc.pt/pt-pt/termos.

Conforme exposto nos referidos Termos e Condições de Uso, o descarregamento de títulos de acesso restrito requer uma licença válida de autorização devendo o utilizador aceder ao(s) documento(s) a partir de um endereço de IP da instituição detentora da supramencionada licença.

Ao utilizador é apenas permitido o descarregamento para uso pessoal, pelo que o emprego do(s) título(s) descarregado(s) para outro fim, designadamente comercial, carece de autorização do respetivo autor ou editor da obra.

Na medida em que todas as obras da UC Digitalis se encontram protegidas pelo Código do Direito de Autor e Direitos Conexos e demais legislação aplicável, toda a cópia, parcial ou total, deste documento, nos casos em que é legalmente admitida, deverá conter ou fazer-se acompanhar por este aviso.

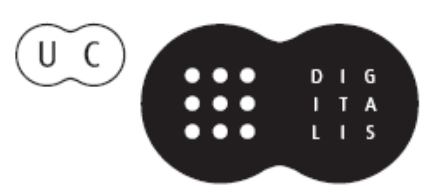


Armando Malheiro da Silva

\section{Sidónio e Sidonismo}

Ool. 2 - Elistónia de un caso politica

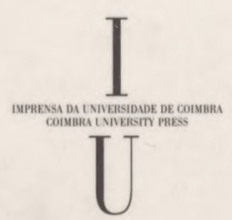

- COIMBRA 2006 



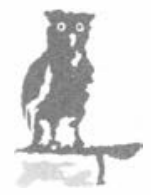

I

$\begin{array}{lllll}V & \text { E } & S & \text { T } & \text { I }\end{array}$

G

A

C

0 
COORDENAÇÃO EDITORIAL

Imprensa da Universidade de Coimbra

\section{CONCEPÇÃO GRÁFICA \\ António Barros}

PrÉ-IMPRESSÃO

António Resende

[Imprensa da Universidade de Coimbra]

EXECUCĀO GRÁFICA
SerSilito - Maia

ILUSTRAÇÃO DA CAPA

Sidónio Pais passeando sózinho no Parque da Pena em Sintra (1918).

ISBN

972-8704-54-2 (IUC)

972-897I-32-X (MPR)

DEPÓSITO LEGAL

240393/06

(C) MARÇo 2006, IMPRENSA dA Universidade DE CoImbra

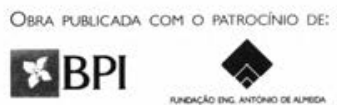

OBRA PUBLICADA COM O APOIO DE

FCT Fundação para a Ciência e a Tecnologia

MINISTERIO DA CIÉNCA, TECNOLOCIA E ENSINO SUPERIOH 
Armando Malheiro da Silva

Sidónio e Sidonismo

Ood. 2. EHistória de um caso politico 


\section{ÍNDICE}

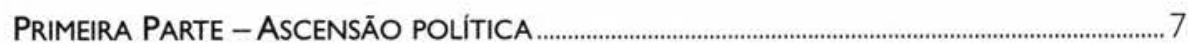

Capitulo I -Ao Princípio a ditadura...........................................................................

No Rescaldo do golpe........................................................................................................9

Reaç̧ões internacionais............................................................................................................... 12

A Prisão de Afonso Costa.......................................................................................................... 17

A Acção da Junta Revolucionária ............................................................................................22

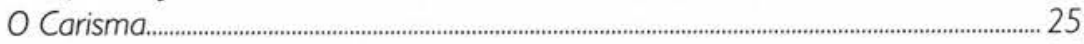

A Formação do 15. ${ }^{\circ}$ Governo.............................................................................................. 28

A Imagem externa.........................................................................................................................36

As Fragilidades do C.E.P. e o 9 de Abril....................................................................51

O Papel estratégico dos Açores ........................................................................................................58

Capítulo 2 - A Consolidação do Poder ..............................................................................61

Forças Armadas e divisões corporativas ............................................................................61

08 de Janeiro....................................................................................................................................64

Viagem triunfal pelo território da República........................................................................65

A Recomposição da base de apoio....................................................................................77

Capítulo 3 - Remodelação e Acção Governativas .............................................................. 89

Trabalho e abastecimentos externos .................................................................................... 89

A Questão social .....................................................................................................................93

O Interior: politica geral e polícias............................................................................................96

A Crise das subsistências ................................................................................................... 108

Política agrícola.................................................................................................................... 115

Política de fomento industrial e comercial...................................................................121

Política financeira................................................................................................................. 123

Política instructo-educativa....................................................................................................... 125

Capítulo 4 -A Legitimação do Poder .............................................................................

Um certo bonapartismo................................................................................................ 131

O P.N.R., partido sidonista................................................................................................ 134

Legislação eleitoral.................................................................................................... 
As Eleições e seus resultados............................................................................................... 161

Capitulo 5 - A República e o Povo ..................................................................................... 179

Actos simbólicos do Presidente eleito .......................................................................... 179

A Proclamação da República Nova ..................................................................................... 182

A Obra da Assistência 5 de Dezembro................................................................................ 188

Segunda Parte - Cerco e QuedA ......................................................................................

Capítulo I - O 16..$^{\circ}$ Governo: génese e problemas ........................................................ 195

Ajustamentos e crispações....................................................................................................195

Presos políticos e cesarismo ...................................................................................................... 199

O Olhar externo ...............................................................................................................................200

A Fome e a greve na C.P.....................................................................................................205

O Escândalo das acções .................................................................................................209

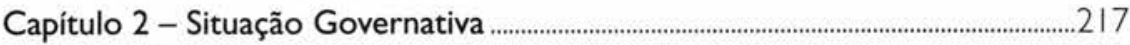

Economia e Finanças .........................................................................................................217

Politica de subsistências e agrícola.........................................................................................219

Políticas de comércio, indústria e trabalho ............................................................................229

Políticas na Justiça e Interior ...................................................................................................233

Política de instrução ................................................................................................................238

Marinha e política colonial ........................................................................................................240

Relações externas e a questão da guerra..............................................................................245

Capítulo 3 - Uma Legislatura atribulada e efémera...........................................................257

Abertura solene..................................................................................................................257

De 15 de Julho a 6 de Agosto..............................................................................................263

Capítulo 4 - O Princípio do fim...............................................................................................273

Agitação operária ..................................................................................................................273

O Cerco oposicionista e o medo à solta ...............................................................................279

Novo périplo pelo país ................................................................................................................281

A Revolta falhada de 12 de Outubro..................................................................................28

A Leva da Morte............................................................................................................................28

Capítulo 5 - O Derradeiro fôlego...........................................................................................291

Novas e últimas alterações no Governo ...........................................................................291

Debate constitucional...............................................................................................................295

Aç̧ão governativa .................................................................................................................298

A Pneumónica ou influenza...........................................................................................................306

O Árduo triunfo dos Aliados e a agudização da crise social ......................................... 313

Confusão no Congresso.................................................................................................................319 
Capítulo 6 - Complot Democrático e morte da República Nova ……........................339

A Atmosfera geral anunciava tragédia.............................................................................339

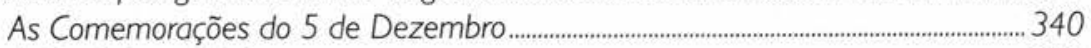

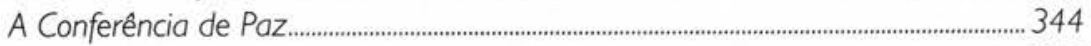

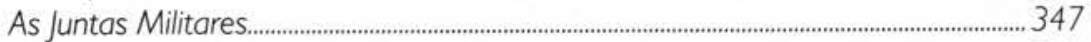

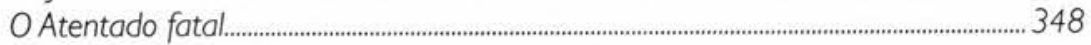

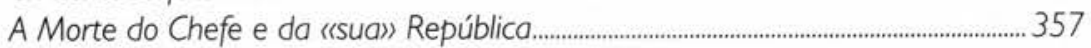

Últimas homenagens e funeral nacional..................................................................................363

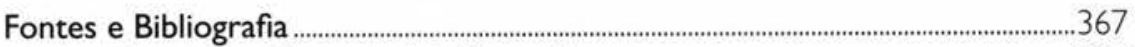

I - Arquivos ou Sistemas de Informação ………………..............................................367

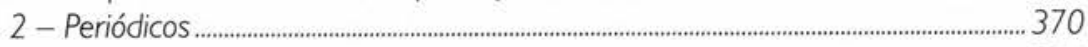

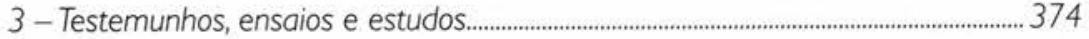

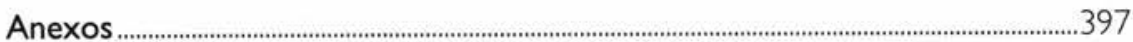

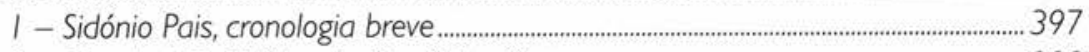

2 - Constituição Política da República Portuguesa.............................................................. 398 



\section{PRIMEIRA PARTE}

\section{Ascensão política}

E no ar de bruma que estremece

(Clarim longínquo matinal!)

O DESEJADO enfim regresse

A Portugal!

À Memória do Presidente-Rei por Fernando PESSOA 



\section{Capitulo I}

\section{Ao Princípio a ditadura...}

\section{No Rescaldo do golpe}

A par do efeito inebriante da adesão popular e da avalancha de felicitações, havia os feridos e os mortos, os estragos em vários edifícios públicos e particulares, a prisão e o castigo para Afonso Costa e seus sequazes, a repartição pelo «bloco» vencedor dos cargos e das posições estratégicas no aparelho do Estado.

Havia, enfim, que gerir a nova situação política, armadilhada por um paradoxo: acabar com o democratismo e com a sua obra nefasta e acabar [com] os odios que dividem a familia portuguesa. Excluir a demagogia (1) e apagar do processo de construção da República a herança da tirania dos democraticos ou da política de facções, de partidos, com o intuito supremo da reconciliação de todos os portugueses e, em especial, dos conservadores e dos indiferentes com o regime fundado em 5 de Outubro. Tarefa paradoxal justificada pela extrema adversidade de uma conjuntura em que avultavam a incerteza em relação ao futuro da Europa e do Mundo dito civilizado, o temor pela independência de Portugal e o pânico das forças burguesas e demoliberais face às notícias vindas de Leste, do Império das estepes, sobre a perturbante vitória do bolchevismo e da sua revolução social. O espectro bolcheviquista irá, de facto, perturbar bastante a índole populista de Sidónio Pais, os seus Governos e as restantes autoridades civis e militares e explica, em parte, a pertinaz repressão dos surtos grevistas até finais de 1918. Um tópico, sem dúvida, pertinente, adiante retomado.

Mas voltando à fase final do golpe dezembrista convém lembrar que a imprensa da capital, nos dias 9, 10 e II, por entre os apelos à calma, o anúncio da normalização da vida urbana e as notícias dos actos e das decisões da Junta Revolucionária vertidas no Diário do Governo, refere as estimativas de feridos e mortos, informando O Século do dia 9 que estes subiam já a 93 (identifica os que foram reconhecidos na Morgue) e aqueles eram 530, de entre os quais uns tinham recebido tratamento no Posto da Misericórdia e outros no Hospital da Estrela. (2)

(1) Cf. PINTO, Jaime Nogueira - Demagogia, in Polis, Enciclopédia Verbo da sociedade e do estado, vol. 2, ob. cit, cols. 66-68

(2) Ver SILVA, Armando Barreiros Malheiro da - Sidónio e sidonismo. História e mito, dissert. cit., vol. 2, p. 6. 
Para além disto, não pôde a imprensa alhear-se da dimensão dos estragos causados tanto por assaltos, como por granadas e daí a enumeração de vários casos, que incluem estabelecimentos comerciais, ${ }^{(3)}$ habitações de nacionais e de estrangeiros, o edifício da Embaixada do Brasil, o do Club Português junto ao Politeama e até o quarto andar do Hotel Avenida Palace todo desvastado por dentro. Dano aparatoso que não afectou, porém, o seu funcionamento, nem impediu que o comandante das forças vitoriosas aí se instalasse, logo que abandonou a tenda montada no acampamento do Parque Eduardo VII, ocupando duas suites até meados de Fevereiro de $1918,{ }^{(4)}$ altura em que mudará, na qualidade já de Presidente da República, para o Anexo do Palácio de Belém.

Uma sucessão, não imediata, de residências oficiais que Rocha Martins, pródigo em detalhes folhetinescos, não explica, mas que esteve relacionada, em primeiro lugar, com o facto de o modesto apartamento de Sidónio Pais na Avenida da República, onde vivia na companhia de, pelo menos, dois dos seus filhos e de Céline Chatry, não reunir, por todos os motivos, as adequadas condições para local de trabalho e de recepção permanente de visitas, inúmeras e variadas, agora que aparecia como o novo homem forte do país; em segundo, Bernardino Machado ficou retido em Belém até à sua partida para o exilio às $14 \mathrm{~h}$ do dia 15 , em comboio especial e na companhia de três oficiais encarregues de o deixarem na fronteira, de onde seguiu para Madrid e só depois para Paris; (5) e, em terceiro e último lugar, o Palácio de Belém ficou vago a partir de então, mas a Sidónio Pais só conviria ocupá-lo na qualidade de Presidente da República, cargo para que foi nomeado em 27 de Dezembro, acabando, entretanto, por aguardar o resultado da sua viagem ao Norte.

Quando ainda se achava no Parque, mas prestes a abandoná-lo para, com os seus parceiros no golpe, tomar conta dos destinos da Pátria, recebeu aí a visita não apenas de curiosos, de amigos, de correligionários - a presença de unionistas desde o início da revolta fora uma constante e não admira, por isso, que o fotógrafo da llustração Portugueza conseguisse para a posteridade o sugestivo retrato de Sidónio e Moura Pinto absorvidos num diálogo muito político - e de centristas, mas também de certas individualidades estrangeiras. Foi o caso do adido militar inglês general N. N. Barnardinston, logo muito comentado como sinal de apoio do Governo britânico aos vencedores e alvo, mais tarde, pelo infatigável Bernardino Machado, mestre na propaganda e na dosagem de mortíferas insinuações políticas, de uma referência crítica no folheto impresso e redigido em forma de carta A Monsieur Lloyd George, Premier Ministre d'Angleterre, (6) um dos seus famosos ataques anti-sidonistas.

(3) Dossier Reclamaçōes e protestos. (Arquivo de Sidónio Pais - Militar. Lente e Político, Subsistema Presidência da República).

(4) Ibidem, Correspondência, carta de 5-2-1918; e sobre o estilo de vida em Belém ver FONTES, Vital - Servidor de reis e de presidentes. Compilação de Rogério Perez. Lisboa: Editora Maŕtimo-Colonial, 1945, p. 106.

(5) Cf. MARQUES, A. H. de Oliveira e COSTA, Fernando Marques da - Bernardino Machado. Lisboa: Montanha, 1978, p. xxx-xxxi).Ver também Mostra nacional Bernardino Machado. 25 Abril a 14 Maio 1995. Catálogo. Vila Nova de Famalicão: Câmara Municipal, 1995, p. 81-83; e ainda a chegada a Paris contada por CHAGAS, João - Diório de .... 1918, vol. 3, ob. cit., p. I-5.

(6) Cf. MACHADO, Bernardino - A Monsieu Lloyd George, Premier Ministre d'Angleterre. S.l.: s.n., 2 Juin 1918 , p. 4; e Idem - No exilio, ob. cit., p. $119-137$ 
Por causa disso sentiu-se o visado na obrigação de, em carta particular de 19 de Junho de 1918, explicar as circunstâncias da visita ao seu amigo, coronel Norton de Matos. (7) $\bigcirc$ general inglês prosseguiu a sua exposição, reconhecendo que, por força das suas obrigações profissionais, manteve contactos estreitos com o novo Presidente do Ministério, Ministro dos Negócios Estrangeiros e da Guerra, no decurso dos quais se convencera das suas boas intenções e lialdade à Causa Aliada. E acrescentou: Estou, como exige o meu dever, em excelentes relações com ele e seu Governo. Faltaria ao meu dever se procedesse de outro modo. ${ }^{\left({ }^{8}\right)}$ Este respeitável e respeitado súbdito de Sua Magestade britânica quis deixar claro o carácter acidental e de pura curiosidade técnico-militar da sua visita ao acampamento do Parque Eduardo VII. No entanto, para os representantes em Portugal dos Governos dos países das Forças Aliadas importava imenso saber se voltava a repetir-se nesse pequeno país ibérico uma profunda alteração política idêntica à verificada, um ano antes, na gigantesca Rússia com imediatas e graves implicações no esforço de guerra contra os Impérios centrais.

A curiosidade do general Bernardiston não podia, pois, ser meramente $a$ do soldado. E garantimos que foi mais a do Adido Militar da Legação da Inglaterra em Lisboa, tendo redigido nessa qualidade um minucioso Report on a visit to bivouacs and trenches in King Edward VIl's Park, Lisbon, after the Revolutionary Movement of $5^{\text {th }}-8^{\text {th }}$ December, 1917 , datado de II de Dezembro, no início do qual refere o convite que lhe fizera o major João Casqueiro, oficial às ordens do general, comandante da base de desembarque em Brest e mencionado adiante nas suas funções de Presidente da Delegação Portuguesa da Commission Internationale de Ravitaillement junto da Legação de Portugal em Londres. Um convite extensivo ao major de Infantaria Swan e tenente Robinson e à familia (mulher e filhos), para visitar as posições ocupadas pelos revoltosos.

O encontro com Sidónio Pais é, aí, relatado nos mesmos termos empregues na carta para Norton de Matos.Após considerações sobre o número, a composição e os aspectos tácticos das forças visitadas no terreno, o autor do relatório registou a dado passo que o Comandante das tropas, durante o passeio guiado com tão ilustres visitantes, teve o ensejo de lhe garantir com a maior ênfase que a Revolução não era monárquica ou pró-alemã tanto na sua origem, como nos seus objectivos. Tratava-se de um movimento puramente republicano, tendo como única meta the removal of an inefficient, despotic and detested regime which had become insupportable. (9) Mais ainda: quer o comité revolucionário, quer o Governo, que se esperava seria formado muito em breve, regiam-se por uma política pró-Aliados, inflexível no respeito pelos compromissos assumidos para com a velha aliada Grã-Bretanha. O major Pais fora, porém, omisso quanto ao envio imediato de reforços, mostrando-se sobretudo muito interessado em saber qual a reacção das autoridades inglesas with regard to the Revolution, but I told him I had no information on the subject. Em conversas cruzadas com alguns oficiais implicados na revolta, o general

(7) Ver SILVA, Armando Barreiros Malheiro da - Sidónio e sidonismo. História e mito, dissert. cit., vol. 2. p. $9-10$.

(8) Memórias, 5. vol. - Documentos avulsos. Dossier. Muito importante. Cartos do general N. N. Bernardiston para o snr. general Norton de Matos; Resposta deste para o general Barnardiston. (Arquivo Norton de Matos).

(9) Foreign Office, Report on a visit to bivouacs and trenches in King Edward VIl's Park, Lisbon, after the Revolutionary Movement of 5th-8th December, 1917, p. 3, FO 371/3369. (Public Record Office). 
Barnardiston pôde constatar que, ao contrário da opinião corrente - difundida célere entre as tropas, causando deserções - de que o golpe tinha por fito suspender o imediato envio de tropas para França, os seus interlocutores declararam-se prontos e desejosos de partir para a frente de batalha.

Manifestação patriótica que o inglês aceitou por válida, mas sem deixar de referir que em sua opinião nunca houve um grande entusiasmo em Portugal pela intervenção no front. Apesar disso os homens, em geral, estavam preparados e dispostos a cumprir o seu dever. Confiava, pois, que esse sentido das responsabilidades permitisse superar a resistência de alguns militares que aderiram ao golpe animados pela expectativa de não se efectuarem mais embarques. E o relator adiantava que os depoimentos colhidos the pareciam sinceros e que o chefe do movimento lhe afirmara a intenção do próximo Governo republicano promover uma política de conciliação com os monárquicos, na esperança de obter a cooperação dos melhores elementos desse partido com vista a garantir o bem-estar e prosperidade do país. ${ }^{(10)}$

Estas tranquilizadoras impressões do general inglês foram reforçadas por despachos diplomáticos emanados de Portugal e de Espanha pelos respectivos chefes de Legação seus compatriotas.

\section{Reacções internacionais}

De Lisboa não tardou a ser expedida para o Ministro Balfour uma circunstanciada e confidencial narrativa dos acontecimentos pelo chefe da Legação em Lisboa Sir Lancelot Carnegie, onde, a dado passo, refere que a imprensa democrática se apressara a classificar o movimento de monárquico e de germanófilo e que o coronel Norton de Matos the enviara já a bordo do Woodnut um memorandum, de que juntava cópia, (11) garantindo que os líderes da revolta estavam combinados com os agentes alemães de Portugal e Espanha. O Presidente Machado adiantara-lhe também essa possibilidade, mas era difícil averiguar a exactidão de tais afirmações, porque ambos eram muito pouco idóneos nessa matéria e não havia até ao momento nada que as justificasse. À guisa de últimas notas, permitia-se ainda chamar a atenção para os seguintes aspectos: a semelhança, em termos programáticos, entre a falhada intentona de 13 de Dezembro de 1916 e o golpe vitorioso de 5/8 de Dezembro de 1917, visto, pois, como um prolongamento daquele; a participação de civis foi pequena, havendo muitos mirones e poucos activistas; a recepção na província dos acontecimentos ocorridos na capital revelava que a população em geral se sentia ferida e estava farta da política até então seguida pelo

12 Partido Democrático e pelos seus militantes - There is no doubt that the country was heartily sick of the late Government and of their leader; ${ }^{(12)}$ mas, apesar de muitos erros

(10) Foreign Office, Report on a visit to bivouacs and trenches in King Edward VIl's Park, Lisbon, after the Revolutionary Movement of 5th-8th December, 1917, p. 4, FO 371/3369. (Public Record Office).

(11) Ibidem, Confidential, n. I Sir L. Carnegie to Mr. Balfour (Received January 3, 1918), n. ${ }^{\circ}$ 106, Lisbon, December 17, 1917. p. 5, FO 371/3369 e Documentos avulsos Dezembro de 1917. (Arquivo de Sidónio Pais - Militar. Lente e Político, Subsistema Presidência da República).

(12) Foreign Office, Confidential, n. ${ }^{\circ}$ I Sir L. Carnegie to Mr. Balfour (Received January 3, 1918), n. ${ }^{\circ} 106$. Lisbon, December 17, 1917, p. 4, FO 371/3369. (Public Record Office). 
cometidos, o anterior Governo e o seu líder tudo fizeram para reforçar e credibilizar a aliança com a Grã-Bretanha, para constituir em pouco tempo e enviar para França, em circunstâncias adversas, um contingente apreciável de tropas e aumentar o prestígio de Portugal no estrangeiro. (13)

Por seu turno, de Madrid, o Ministro Arthur Hardinge remeteu para The Right Honourable Arthur James Balfour um minucioso relato da longa entrevista que tivera no dia anterior com o ex-President of the Portuguese Republic, who is now an exile in Spain and is living at the Palace Hotel in this city. Segundo as suas palavras, Bernardino Machado dissertara bastante sobre a nova situação. Pareceu-lhe confiante de que o novo Governo de Sidónio Pais permaneceria fiel aos Aliados e à República, cujos interesses considerava, aliás, intimamente conexos. Reconheceu, também, que o Ministério democrático de Afonso Costa nem sempre fora sensato e rejeitara sugestões suas para governar de forma mais conciliadora e menos autoritária, agindo de modo bastante preconceituoso para com a Igreja Católica a ponto de não compreender a importante diferença entre - clero secular de índole mais tolerante e as ordens religiosas ultramontanas restabelecidas poucos anos antes da revolução republicana e empenhadas num clericalismo agressivo of the Jesuitic type em todo o país. E aproveitou o ensejo para solicitar uma intervenção do Governo britânico junto das novas autoridades portuguesas, tendo em vista a libertação de algumas destacadas figuras da situação anterior, como o doutor Afonso Costa preso no forte de Elvas em regime de rigorosa detenção. (14)

Na mesma ocasião Aubrey F.E. Bell redigiu um artigo intitulado The Third Portuguese Revolution que viria a ser incluído, por iniciativa do Director dos Serviços de Informação e Propaganda da República Portuguesa nos Países Amigos e Aliados, Francisco Homem Cristo Filho, no número de Fevereiro de 1918 da prestigiada revista londrina The Contemporary Review. (15) Um artigo muito favorável aos autores do golpe e extremamente crítico para com as políticas republicanas adoptadas até essa data. $O$ estado económico e social do país foi pintado com as mais sombrias cores, mas no final o tom tornou-se optimista: o autor, cuja antipatia pelos democráticos the fez dizer, por exemplo, que eles tinham horror à verdadeira democracia, entendia que o regime republicano estava, agora, capaz de atingir uma grande unidade nacional e de mostrar quão infundados eram os receios dos partidários de Afonso Costa. Não tinha dúvidas de que a courageous action of Major Sidonio Paes and his supporters is likely to help to transfer the British alliance from the narrow political sphere to the sphere of real popular sympathy. The British and Portuguese peoples are in the same boat; they are both suffering at home from the effects of the war; they are fighting side by side in France. It is high time that they should recognise each other's good qualities and see their common interests more fully. (16)

(13) Foreign Office, Confidential, n. ${ }^{\circ}$ I Sir L Carnegie to Mr. Balfour (Received January 3, 1918), n. ${ }^{\circ} 106$, Lisbon, December 17, 1917, p. 4, FO 371/3369. (Public Record Office).

(14) Ibidem, n. ${ }^{\circ}$ 614, Madrid, 28th December 1917, FO 371/3369.

(15) Ver BELL, Aubrey F. E. - The Third portuguese revolution. The Contemporary review, London (626) February 1918, p. 200-206.

(16) Cf. BELL, Aubrey F. E. - The Third portuguese revolution, art. cit., p. 206. 
O efeito optimista destes informes, colhidos no terreno, não neutralizaram, de início, as reservas e os temores instalados nos meios oficiais londrinos e até na opinião pública inglesa quanto aos genuínos propósitos dos novos senhores da política portuguesa. $\bigcirc$ factor mais perturbante decorria do apoio imediato dos monárquicos, tidos em Inglaterra como um partido germanófilo, que não ousa proclamar a sua opinião, mas que indirectamente a faz sentir por todas as formas de hostilidade aos aliados e, por isso, o novo Ministro de Portugal em Londres, Augusto de Vasconcelos, observou que As desconfianças que ao principio suscitou o novo governo, confessou-me Sir Ronald (Graham) vieram justamente do apoio desse grupo, que para nós, ingleses, é e continua a ser pro boche.(17)

O que, de facto, estava em jogo não era de somenos importância - a conduta de guerra de Portugal a favor ou contra a causa dos Aliados tinha de ser clarificada com urgência e os rumores surgidos motivavam legítimas apreensões. Não admira, pois, que - Ministro dos Estados Unidos da América, coronel Thomas Birch, (18) amigo pessoal do Presidente Wilson, num primeiro telegrama confidencial com data de 10 de Dezembro, lamentasse ter de relatar que muitos dos membros do partido revolucionário opunham-se à política de guerra do anterior Governo e que o Ministro francês Émile Daeschner lhe dera como certa uma percentagem de $75 \%$ de oficiais revolucionários contrários aos esforços de intervenção no teatro europeu do conflito. Mas no dia 15 , após uma cuidadosa observação dos factos e dos sinais fiáveis, apressava-se a rectificar as reservas do telegrama precedente e a emitir a opinião de que o golpe não resultara de sentimentos ou de propaganda pró-alemã, antes nascera de um impulso contra the Costa Government and the Democratic party, embora não fosse de excluir, entre os revoltosos, uma assinalável maioria de anti-guerristas, o que se traduziria a prazo no adiamento do envio de tropas adicionais para França sem que isso significasse mudança de atitude das novas autoridades em matéria de cooperação com os Aliados. Era, naturalmente, a sua opinião rodeada ainda de cautelas e de juízos algo ambivalentes. $\bigcirc$ desenrolar dos acontecimentos influenciará, porém, positivamente a análise de Birch, deixando-o plena e firmemente convencido da aliadofilia de Sidónio Pais e dos seus Governos. (19) Acrescente-se a isto que o diplomata americano considerava a situação do país crítica, particularmente grave no respeitante à falta dos géneros alimentares de primeira necessidade - ponto delicado que determinaria, aliás, o sucesso ou a queda dos governantes, quaisquer que eles fossem - e à beira da bancarrota: The country, with its finances in a state of complete disorganization is fast approching bankruptcy; there is an increasing deficit in the suplies of necessaries of life. (20)

(17) Cit. por TORRE GÓMEZ. Hipólito de la - Na Encruzilhada da grande guerra. Portugal-Espanha, $1913-$ 1919, ob. cit., p. 202.

(18) Sobre esta e outras personagens evocadas ao longo da nossa narrativa remetemos, de novo, para as notícias prosopográficas in MEDINA, João - Morte e transfiguração de Sidónio Pais, ob. cit., p. 147-221. Sobre Thomas Birch ver p. 167.

(19) Records of the Department of State relating to internal affairs of Portugal, 1910-1926, Political affairs, $705 / 4$ roll, telegramas de 10 de Dezembro e de 15 de Dezembro, e despachos seguintes. (National Archives, Washington).

(20) Ibidem, Political affairs, 705/4 roll, despacho n. ${ }^{\circ} 335,20$ Dezembro de 1917. 
Na Legação da República Francesa a predisposição para se aceitar as alterações políticas verificadas não era a mesma, pautando-se, contudo, os despachos iniciais por um laconismo e uma reserva de hábil prudência, que o evoluir da situação ajudará a quebrar por completo.

Jean Derou no seu estudo sobre as relações franco-portuguesas refere que a uma grande desconfiança inicial sucedeu o reconhecimento de facto a 17 de Dezembro e a apreciação positiva das intenções aliadófilas do Presidente Pais. (2I) Mas ao mesmo tempo reconhece que uma certa dualidade continuará a existir nas relações da França com o novo regime. E noutra passagem alude à apreciação negativa que Daeschner foi fazendo dos actos napoleónicos do Presidente da República e das práticas governativas desenvolvidas, segundo aquele Ministro, ao acaso e sem grande nexo programático. (22)

Em rigor e numa linguagem mais objectiva e não diplomática, poderá dizer-se que as autoridades francesas assumiram, ainda que desfarçando-a para melhor protegerem os exilados democráticos, uma posição hostil e até uma certa antipatia, fomentada pelos actos repressivos dos golpistas e pela campanha intensa da dupla João Chagas e Bernardino Machado em todos os círculos parisienses afectos à linha rigidamente francófila (entenda-se pró III República parlamentarista) do republicanismo português. (23)

Atitude diametralmente oposta da assumida por Mgr. Benito Aloisi Masella, Auditor da Nunciatura de Lisboa, nos telegramas e despachos oficiais enviados para Roma, em cumprimento do seu dever de informar o Vaticano dos acontecimentos mais significativos. Revoluções e golpes de estado eram, claro está, matéria obrigatória que aguçava a natural curiosidade e preocupação da Santa Sé.

Com data de 9 de Dezembro seguiu um telegrama para o Cardeal Gaspari, onde era dito que após due giorni sanguinoso combattimento, movimento militare che diceri anti demagogico ha obbligato Ministero Costa dimettersi e costituito con pieni poteri Giunta rivolusionaria che si propone ristablire giustizia, e costituire governo serio e rispettare precedenti compromissi internazionali. (24) Seguiram-se outros telegramas com as últimas novidades sobre a consolidação do novo movimento revolucionário e uma mensagem ou relatório enviado ao Cardeal Gaspari, Secretário de Estado, com data de I I de Dezembro.Aí Mgr. Masella não consegue conter a sua satisfação pelo cariz assumidamente anti-afonsista do movimento e pelos propósitos anti-demagócios da Junta. ${ }^{(25)}$ E o Auditor da Nunciatura em Lisboa prometeu enviar mais informações e exemplares dos periódicos alusivos aos acontecimentos que, com indisfarçável regozijo, lhe era possível presenciar. Numa sequência apertada de datas, apressou-se a relatar, no relatório de 12 de Dezembro, a destituição do Presidente Bernardino Machado, e, com data de 15, dá conta da formação de um novo Ministério. Masella anexou ao seu relatório de 17 de Dezembro, alusivo

(21) Cf. DEROU, Jean - Les Relations franco-portugaises a l'époque de la première république parlementaire libérale (Octobre 1910 - 28 Mai 1926). Paris: Sorbonne, 1986, p. 162-164. (Archivio Segreto Vaticano).

(22) Ver Ibidem, p. 160 e ss.

(23) Cf.TORRE GÓMEZ, Hipólito de la - Na Encruzilhada da grande guerra. Portugal-Espanha, 1913-1919. ob. cit., p. 202.

(24) Nunziatura Apostolica di Lisbona, 1910-1922, 405 (2). (Archivio Segreto Vaticano).

(25) Ver SILVA, Armando Barreiros Malheiro da - Sidónio e sidonismo. Histório e mito, dissert. cit., vol. 2. p. 17. 
à oposição declarada do Partido Democrático ao novo Governo, pelo menos três periódicos, situados numa perceptível linha de repúdio e de condenação da demagogia democrática. (26)

O acompanhamento da evolução política é testemunhado por relatórios como o de 9 de Janeiro de 1918, intitulado Rivolta della marina contra il governo e redigido num tom que não deixa dúvidas quanto às simpatias de Mgr. Masella pelo Governo de Sidónio Pais. É, aliás, curioso notar a rápida e total adesão do diplomata romano às novas autoridades portuguesas com base, apenas, nas medidas que, contra o non-grato P.R.P., a Junta Revolucionaria tomou logo após o golpe de Dezembro. (27)

A demissão das Juntas de Paróquia, das Comissões Executivas das Câmaras Municipais e dos Governadores Civis per combattere specielmente il partito democratico, a circular do Ministério do Interior de 26 de Dezembro de 1917 impondo as novas directrizes políticas a toda a administração, a viagem do Presidente da República ao norte do país (Porto, Braga,Viana do Castelo, Caminha, Guimarães e Coimbra), a entrevista de Machado Santos ao jornal Opinião, de 16 de Fevereiro de 1918, em que reafirmava a urgência de se reformar a Lei da Separação, a remodelação ministerial de 7 de Março, a posição pública dos monárquicos face à política de Sidónio Pais, as eleições de 28 de Abril e a participação do Centro Católico Português, (28) os resultados eleitorais, a proclamação do Presidente da República na Câmara Municipal, a formação de novo Governo, o projecto de amnistia aos presos políticos... - eis, em síntese, os tópicos focados por Mgr. Masella no seu correio diplomático, podendo-se, talvez, concluir que a perspectiva pró-governamental neles reflectida, desde o início do dezembrismo, secundou, por um lado, as consideraç̃̃es de Bento XV expressas na sua carta ao Cardeal Patriarca, D. António Mendes Belo, de 29 de Abril, (29) e, por outro, facilitou o modo como decorreu o processo negocial conducente ao restabelecimento das relações com a Santa Sé. Mas todos estes tópicos fazem parte de uma sequência narrativa que não pretendemos antecipar...

Entretanto, a imprensa estrangeira e, em especial, a francesa dividiu-se na análise e na divulgação dos factos: se, por um lado, Le Radical de Paris, no número de 9 de Dezembro, lançava a notícia Troubles au Portugal com o significativo sub-título La main de l'Allemagne, e o L'Eveil, de Paris e do mesmo dia, em artigo assinado por Jean Garin-Lhermitte, dava como certa a influência de elementos alemães por detrás dos conspiradores vitoriosos, por outro, o jornal L'Humanité, do referido dia 9, pendia para uma causa de tipo interno como a crise económica - les troubles du Portugal paraissent dus à la situation spéciale créé par la guerre, et non à des causes extérieures - tese acrescida do elemento político - a forte marca unionista na origem e na orientação do golpe - e partilhada, nesses moldes, por Henri Regnault do Le Pays (Paris, II de Dezembro), por Alfred Oulman do Le Petit Bleu (Paris, I I de Dezembro), por Paul Duché do Liberté du Sud-Ouest, de

(26) Ver SILVA, Armando Barreiros Malheiro da - Sidónio e sidonismo. História e mito, dissert. cit., vol. 2. p. $17-18$.

(27) Ver Ibidem, p. 18.

(28) Nunziatura Apostolica di Lisbona, Rapportio n. ${ }^{\circ}$ 1693, Sulle prossime elesioni, 26 Aprile 1918. (Archivio Segreto Vaticano).

(29) Cf. Vida Catholica. Lisboa, 3 (89) 5 de Julho de 1918, p. 641-642. 
Bordéus (I I de Dezembro), por Jean Moro do Petit Niçois, Nice (I I de Dezembro), pelo correspondente do Journal des Débats, Paris (I I de Dezembro), por um reticente Maurice de Waleffe do Journal, Paris (II de Dezembro) ou por Paul Louis, através do seu longo artigo Les Crises Portugaises, saído nas páginas da parisiense Revue Bleue, de 29 de Dezembro. ${ }^{(30)}$

Uma toada predominantemente positiva, que The Morning Post, de Londres ( 10 de Dezembro) puxara para os cabeçalhos de acordo com as impressões do seu correspondente em Lisboa: New Government Pro-Entente. E o refrão espalhou-se pela imprensa italiana: a Idea Nazionale, de Roma (I I de Dezembro) apresentava o movimento como originário no partido unionista e motivado por causas internas; uma lapidar conclusão expressa no título da notícia do L'Avenire d'talia, de Bolonha (I I de Dezembro), I moti dei Portogallo hanno carattere interno; e o jornal II Momento, de Turim (I 4 de Dezembro) preferiu sublinhar II carattere moderato della rivoluzione in Portogallo.

Curiosamente, a imprensa alemã cingiu-se à descrição seca dos factos e à reprodução do conteúdo das proclamações dos vencedores, taxativas quanto ao empenhamento em prol dos Aliados. Idêntico tratamento foi assumido pela Legação alemã em Madrid nos seus despachos para Berlim, omissos quanto a eventuais e comprometedoras manobras secretas de agitação ou de instigações sediciosas no país vizinho. (31)

A leitura da imprensa francesa suscitou à Redacção de A Capital, do dia 10, uma caixa em letras gordas: Depois da Revolução. Os jornaes de Paris entendem que se tratou apenas de substituir um governo, pelo que o nosso exercito continuará a bater-se nas linhas occidentaes. $\mathrm{O}$ autor ou autores da frase não treslera $(\mathrm{m}) \mathrm{o}$ essencial da mensagem dos jornais parisienses...

\section{A Prisão de Afonso Costa}

Pelo abundante caudal de impressões vertidas para a opinião pública dos vários países europeus, sobretudo dos alinhados na beligerância contra os impérios centrais, perpassara o espectro da revolução russa e seu eventual paralelismo com os factos produzidos em Portugal, a par de uma generalizada conviç̧ão de que a tese do ajuste de contas interno era bem mais credível e objectivo que a do complot germânico. Por muita ou pouca simpatia que as diferentes fontes e agentes de informação tivessem pela figura controversa de Afonso Costa, era para este que convergiam os reparos e as alusões, mais ou menos directas, sobre a responsabilidade na génese da atmosfera favorável à revolta.

Desde os primeiros momentos Costa concitou as atenções dos adeptos e dos revoltosos, tendo o diligente revolucionário civil João Rocha, «Corticeiro», logo no dia 6 de Dezembro, em plena incerteza do desfecho da contenda, transmitido a notícia, já

(30) Estes e muitos outros recortes de artigos publicados pela imprensa estrangeira fazem parte de um conjunto reproduzido na íntegra no Anexo Documental da dissertação de Mestrado de GONÇALVES, José António Sequeira - Sidónio Pais e a participação portuguesa na guerra de 19/4-19/8. Dissertação de Mestrado apresentada à Faculdade de Letras da Universidade de Lisboa. Lisboa, 1989, vol. 2, 38, fls. I58- 183.

(31) Portugal, Acten, 1 Juli 1915 - Marz 1920. (Politisches Archiv des Auswärtigen Amts, Portugal). 
atrás reproduzida, de que o dr. Affonso Costa foi preso por elementos revolucionarios em Almeida. Um boato muito apropriado para desmoralizar as forças governamentais e dar especial ardor combativo aos entrincheirados do Parque. Um boato em contradição absoluta com a versão não apenas conhecida, mas reconhecida como verdadeira.

Afonso Costa e a sua comitiva (com elementos daquilo a que os seus adversários denominaram sarcasticamente A Casa Civil, ${ }^{(32)}$ estavam de regresso a Portugal na manhã desse dia, tendo conseguido entrar porVilar Formoso sem problemas e sem que aí ou na Guarda alguém soubesse das últimas ocorrências de Lisboa. Só na estação de Fornos foi recebido no comboio aviso do dr. Vasco Borges, Governador Civil da Guarda, transmitido por telefone para aquela estação, para que fosse aguardado comboio correio em que aquele representante do Governo seguia com ordens do Ministro da Guerra. Havia barulhos em Lisboa e a comitiva, composta pela mulher, cunhado José de Abreu e Ministro dos Negócios Estrangeiros Augusto Soares, contorceu-se de ansiedade. Lembrou-se, por isso, Afonso Costa de telefonar para a estação de Pampilhosa, onde já se encontrava o Governador Civil de Coimbra, dr. António Leitão, pronto a confirmar os escassos informes conhecidos e a sugerir que avançassem até ao seu encontro. $A$ sugestão foi acolhida, o comboio retomou a marcha, parando em todas as estações.

Chegados, finalmente, à Pampilhosa, o dr.António Leitão disse-se portador de ordens, as mais terminantes do Ministro Norton de Matos, para impedir por todos os meios, inclusive a prisão, que o ilustre passageiro seguisse em direç̧ão a Lisboa. As ordens impressionaram bastante Afonso Costa, segundo o relato do seu cunhado José de Abreu, embora reconhecesse a louvável intenção do colega de Ministério de evitar-lhe vexames e, talvez mesmo, salvar-Ihe a vida. ${ }^{(33)}$ Perguntou-se, então, ao Governador Civil se seria possivel chegar a Coimbra, objectivo concretizado, por razões de segurança, algumas horas depois. Uma vez na cidade do Mondego teve, enfim, Afonso Costa ensejo de comunicar por telefone com Norton de Matos e ficar ao corrente dos factos, mas num tom estranhamente optimista: Que era coisa de pouco importância, segundo as informações que possuía e que estava preparando tudo para na manhã seguinte esmagar o movimento. À pergunta sobre quem comandava a sedição foi-lhe respondido que era Sidónio Pais e um outro oficial superior, cujo nome não vem para o caso, visto que, logo no dia seguinte, se soube não ter tido a mínima intervenção no movimento. ${ }^{(34)}$

Uma viagem extenuante, recheada de inesperados contratempos, impunha um descanso possível em Coimbra com o telefone por perto para súbitas e ansiadas notícias.

Na manhã de 7 e no decurso de novo contacto entre Costa e Norton de Matos, este sugeriu a partida para o Porto a fim de não só encorajar os republicanos locais, mas também para evitar que rebentasse algum motim nessa importante cidade nortenha. $\bigcirc$ comboio foi preparado para tomar o rumo sugerido e a comitiva partiu de Coimbra pelas 16 horas, chegando ao Porto, Campanhã, pelas 20 horas. Aí um oficial aguardava-os com a

(32) Cf.MARTINS, Rocha - Memórios sobre Sidonio Paes, ob. cit., p. I 39. Ver também SILVA,Armando Barreiros Malheiro da Silva - Sidónio e sidonismo. História e mito, dissert. cit., vol. 2, p. 889.

(33) Cf. MARQUES, A. H. de Oliveira - Afonso Costa, ob. cit., p. 161.

(34) Cf. Ibidem, p. 161-162. 
acalentadora nova de que o movimento havia sido dominado. E, compreensivelmente, não Ihes foi difícil acreditar no que ouviam. Partiram, pois, para S. Bento e daí um automóvel levou-os ao Hotel do Porto, sede provisória até à almejada confirmação da rendição dos rebeldes. No entanto, à hora do jantar, que começara tranquilamente, um criado

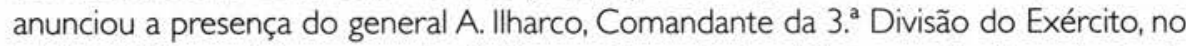
Hotel. Foi de seguida acompanhado à respectiva sala de refeições, sentando-se junto de Afonso Costa para uma breve conversa e saindo pouco depois. ${ }^{(35)}$ Ao findar o jantar entrou na sala o Governador Civil do Porto, dr. Alfredo Coelho de Magalhães, que se abeirou de Afonso Costa e lhe segredou algo que deixou o Presidente do Governo democrático um pouco pálido e, de pronto, mandou servir o café a toda a pressa. Interrogado pelos seus acompanhantes respondeu que o Ministério tinha pedido a demissão. José de Abreu frisa, no seu relato, a perplexidade sentida, não evitando uma azeda crítica à conduta do Ministro da Guerra: este não havia telefonado, não como poderia supor-se e deveria ser, para consultar o seu chefe sobre esse pedido de demissão, mas, na verdade, para que a Afonso Costa fosse comunicado que a demissão havia sido pedida. Foi sob essa dolorosa impressão que partimos para o governo civil. (36) Nessa base de comunicações pôde Afonso Costa estabelecer contacto com o Presidente da República, acedendo favoravelmente às sugestões tácticas que este lhe apresentara, designadamente quanto à viabilidade parlamentar do direito de dissolução e de um Governo unionista de cariz unitário ou nacional!...

A actuação de Bernardino Machado, ensaiando alguns estratagemas anestesiantes ficou já focada nos seus traços essenciais. Urge apenas lançar os olhos pela versão afonsista da conversação havida e do ocorrido nas horas seguintes.

Segundo José de Abreu, Costa insistiu que Norton de Matos devia tê-lo consultado primeiro e que Bernardino não devia ter aceite a demissão sem o ouvir. Estava indignado. Acabada a conversa decidiram regressar ao Hotel. Nas ruas do Porto vazias, não se via ninguém. Recolhidos ao temporário abrigo, ficaram durante algum tempo, em familia, a conversar e a ponderar sobre os próximos passos. Ao contrário do que refere o general Ilharco nas suas Memórias não foi preso pela meia noite, nem Augusto Soares se entregou de motu proprio no Quartel-General da 3. ${ }^{a}$ Divisão. Os habituais lapsos da(s) memória(s)...

No dia 8, pela manhã cedo, apareceram no Hotel uns poucos de amigos dedicados, tendo alguns deles avançado com a mesma sugestão que José de Abreu alvitrara mas o cunhado havia asperamente recusado: saísse do Porto, arranjavam-lhe os meios necessários à fuga. Recusou e decidiu fazer umas visitas na companhia de Augusto Soares. Antes ou pouco após essa saída terá escrito ao Ministro da Guerra num tom cordato, que contraria ou, pelo menos, disfarça a irritação sentida na véspera. Comunicava-lhe estar bem de saúde, a cidade permanecia em sossego e atacando o assunto resumia

(35) Cf.ILHARCO,A. - Memórias.Alguns opontomentos sobre a influencia da política no exército. Porto: Livraria Chardron, de Lélo \& Irmão, Lda, 1926, p. 59-62 e Processo de José Feliciano da Costa Junior, cx. 2074. (Arquivo Histórico Militar).

(36) Cf. MARQUES, A. H. de Oliveira - Afonso Costo, ob. cit., p. 165. 
em poucas linhas o seu intuito: Eu e os meus queremos regressar a Lisboa sem demora mas não desejo sugeitar-me a comentarios ou interrogatorios favoraveis ou desfavoraveis. Diga, pois, por telegrama qual meio de condução devo preferir, a hora e o logar por onde devo entrar, etc. Muitos abraços do seu dedicado amigo // Affonso Costa. (37) Um gesto de elevação que calaria a maledicência dos seus adversários, desejosos de the assacarem todas as mazelas morais.

Marcara posição, manifestando o desejo de se expôr a imprevisíveis riscos: em Lisboa a populaça à solta causou, ao longo desse dia, vários estragos e a sua casa e escritório foram assaltados e o interior desfeito. Retido, porém, no Porto, aí veio, por fim, a ser preso com a familia e com Augusto Soares no Hotel, em circunstâncias algo rocambolescas e vexatórias narradas por José de Abreu. Ficaram à mercê de uma força de Infantaria comandada por um alferes e de um pelotão de Cavalaria 9, que incluía um capitão, possivelmente Alfredo Melo de Carvalho, oficial de irregularissimo comportamento no juízo do general Ilharco, seu comandante na Escola Prática de Cavalaria e aí obrigado a reprimir-lhe, por vezes, os seus desmandos. Esse capitão, que entrara no respectivo piso de pistola engatilhada como se fosse cometer um acto de guerra, ${ }^{\left({ }^{38}\right)}$ será, em breve, nomeado Comissário da Polícia do Porto, há-de incompatibilizar-se, no decurso dessas funções, com o controverso capitão Sollari Allegro e será, no último trimestre de 1918 , alvo de uma sindicância. ${ }^{(39)}$ Trajecto bem ilustrativo da perturbadora instabilidade comportamental que a componente militar introduziu, desde o início, na rede sócio-política de apoio à República Nova.

A Capital. Diário republicano da noite, com data de 9 , domingo, saiu à rua com letras garrafais impressas no topo da primeira página - A Marcha dos Acontecimentos. O novo governo deve ficar constituído esta noite. Prisão do Dr. Affonso Costa no Porto. Esta última notícia era exacta, mas demasiado breve, nada adiantando sobre o seu destino, nem o de Augusto Soares.

Podemos acrescentar, de acordo com os dados recolhidos pela imprensa portuense em geral e pel'O Primeiro de Janeiro em particular, que esses dois ilustres membros do Governo demissionário começaram por ficar detidos no Regimento de Infantaria 6, sendo-Ihes destinados dois quartos, na zona reservada aos oficiais. E aí terão permanecido até ao dia 13, já na qualidade de ex-Ministros, porquanto o respectivo Governo foi formalmente demitido pelo decreto da Junta Revolucionária de 10 de Dezembro, sendo conduzidos para Lisboa juntamente com mais dois prisioneiros - o Comissário Geral da Polícia do Porto Caldeira Scevola e o Inspector da Polícia Rómulo de Oliveira - às primeiras horas da manhã desse dia, no vapor Viana ancorado em Leixões e escoltado por um caça-minas. Foram acompanhados na viagem pelo Chefe do Gabinete

(37) Memórias vol. 5, documentos avulsos, carta de Afonso Costa, Porto 8/12/1917. (Arquivo Norton de Matos).

(38) Cf.MARQUES,A.H. de Oliveira - Afonso Costa, ob. cit., p. 167 e ss. Para um resumo da prisão de Afonso Costa e Augusto Soares ver também a grande imprensa da capital e ainda Um Golpe de estado. A Revolução de 8 de Dezembro, ob. cit., p. 68-73.

(39) Ver SILVA, Armando Barreiros Malheiro da Silva - Sidónio e sidonismo. História e mito, dissert. cit., vol. 2. p. $873-879$. 
do Presidente da República, 1. ${ }^{\circ}$ tenente da Armada Francisco de Aragão e Melo, e ao chegarem ao porto de desembarque receberam a visita, ainda no navio, do capitão Eurico Cameira, encarregue também de representar a Junta nos contactos com o ex-Presidente da República.

Esse oficial, investido já, na prática, das funções de Ajudante do Comandante das forças vencedoras, deslocou-se ao Viana em cumprimento de instruções recebidas, como deixou, aliás, escrito:
Meu Ex. ${ }^{\circ}$ Commandante
Às $4 \mathrm{~h} 15^{\prime}$
Em comformidade com as ordens de V. Ex. ${ }^{a}$ notifiquei ao Ex.. ${ }^{\circ}$ Sr. dr. Bernardino Machado a resolução do Governo que recebeu sem palavra alguma pró ou contra, dizendo que amanhã communicaria o dia da partida e o itinerario. Fui em seguida ao navio Vianna, onde procedi em conformidade com as instrucções de V. Ex. ${ }^{a}$. Quanto ao ponto de o Sr. dr. A Costa e A. Soares me dizerem coisas de interesse nacional sobre a conferencia dos alliados, o primeiro disse-me que the parecia não as dever dizer a mim, e que só as diria ao sr. Ministro dos estrangeiros. Eu julgava necessario que a essa conferencia assistisse o sr. A. Soares, mas como não encontro V. Ex. ${ }^{a}$ não susto a sua partida para E[lvas]. Vae o Capella a acompanhal-o.
V. Ex. ${ }^{\circ}$ resolverá
Subscreve muito attento e obrigado
Eurico Cameira. ${ }^{(40)}$

No canto superior esquerdo e no diametralmente oposto duas breves anotações complementares: Resolver a questão das visitas Dr. Afonso Costa e Dr. Augusto Soares (Esposas); e O sr. dr.A. Costa faz alguns pedidos de que tenho apontamento e que amanhã, digo logo mostrarei a V. Ex // E.C.

Só após essa recepção de chegada é que Augusto Soares seguiu para o Forte da Graça, em Elvas, onde haviam estado alguns dos implicados no 13 de Dezembro, ficando Afonso Costa e os outros dois acompanhantes no Presídio da Trafaria, tendo em conta a conveniência de uma entrevista ou de um memorandum do anterior Presidente do Conselho sobre a reunião da Comissão Inter-Aliados a que assistira. Como se recusara, aliás, a resumi-la ao enviado especial da Junta teria, na bem informada opinião de Brito Camacho, de a fazer, se a não quizer guardar para si, ao Gonçalves Teixeira. Da Trafaria será transferido depois para Elvas e não para Cabo Verde, como ficara decidido em Conselho de Ministros, decisão revogada por influência directa de Brito Camacho, que, em contrapartida, aceitara fosse d'ahi para qualquer outra parte para se não constituir um fóco de conspiração. Em Elvas permanecerá detido, em regime de apertada clausura, até 30 de Março de 1918.

(40) Correspondência, carta de Eurico Cameira, s.d. (Arquivo de Sidónio Pais - Militar. Lente e Político, Subsistema Presidência da República). Ver a narrativa dos factos indicados na carta do capitão Cameira in MARTINS, Rocha - Memorias sobre Sidónio Paes, ob. cit., p. 72. 
A justificação oficial dada para essa prisão assentava na necessidade da instauração de inquéritos a certos actos governamentais suspeitos de ilicitude - Vão fazer-se rapidos inqueritos, sendo os ministros entregues ao Poder judicial, dentro da mais estrita legalidade, zelosamente exigida por Brito Camacho aos militares dezembristas. Mas para lá do proclamado rigor da lei permanecia o imperativo habitual em casos de enfrentamento político - punir com a prisão ou o degredo os principais vencidos.

A lição de experiências anteriores, designadamente a do 14 de Maio, e a delicada circunstância do castigo recair sobre um destacadíssimo líder republicano tornavam qualquer medida exemplar num complicado dilema: a falta de clemência para com tão famoso adversário político chocava e era passível de ser explorada como deplorável acto de vingança, não tardando, por isso, os pedidos de um gesto magnânimo, oriundos de vários lados, incluindo do estrangeiro; e o excesso de clemência praticado com figuras polarizadoras de entusiástica adesão e de extremo antagonismo podia gerar efeitos perniciosos para os vencedores. A adensar o dilema havia o discurso justificativo oficialmente proclamado: a Junta Revolucionária corporizava um movimento animado, essencialmente, pelo objectivo de derrubar um partido e a sua ignominiosa tirania, devolvendo a liberdade, a tolerância, a conciliação e a ordem a uma sociedade violentada pela mais infrene demagogia.

Os novos e eventuais actos de violência eram, assim, justificados com a violência anteriormente praticada pelas actuais vítimas, outrora algozes... E punha-se imediatamente a questão de saber se igual severidade seria extensiva aos monárquicos exilados ou presos - o mais pequeno gesto de complacência constituiria o sinal comprovativo de uma contra-revolução aniquiladora do espírito do 5 de Outubro: Evitei — são palavras de Brito Camacho ao seu amigo e subchefe Augusto de Vasconcelos — sob ameaça de não apoiar o Governo, que amnistiassem o Couceiro, João Coutinho, etc. Na verdade isto teria o peor effeito, sendo para todos os republicanos o signal de pimentismo ressuscitado.

Enfim, mais do que num dilema, a Junta Revolucionária e o Governo por ela nomeado estavam a meter-se num «paiol»...

\section{A Acção da Junta Revolucionária}

De 9 a 12 de Dezembro a Junta figurou impressa nas páginas do Diário do Governo, ditando a lei, anunciando um novo ciclo político-administrativo e agindo rodeada de proeminentes unionistas em solícita atitude de auxilio nas tarefas mais políticas. A atmosfera envolvente, espelhada na imprensa desafecta ao P.R.P.P.D., era um misto de cansaço e de optimismo, chegando o diário A Capital a publicar na primeira página do seu número do dia II um artigo intitulado A Terceira Revolução, onde o recente golpe surgia como um estádio natural e positivo para a concretização plena da República sonhada. ${ }^{(4 I)}$

(41) Cf.A Terceira revolução. O povo portuguez deseja acertar para realisar, em toda a sua expressão fiel, o ideal republicano. A Capital, de II de Dezembro de 1917, p. I.Ver também SILVA, Armando Barreiros Malheiro da - Sidónio e sidonismo. História e mito, dissert. cit., vol. 2, p. 27. 
Em resposta a esse estado de espírito, Machado Santos, jovial e confiante, declarou em entrevista ao jornal A Capital o seguinte: A Junta Revolucionaria e o governo Provisorio não querem exercer nem represalias, nem perseguições, nem vinganças. $O$ que se pretende, asseguro-lh'o, é evitar perturbações. 0 que queremos é assegurar a ordem, evitando-se a todo o custo, que ella seja alterada por quem quer que seja. Eis os nossos propositos. Quem nos attribuir outros não nos fará a justiça que nos é devida. (42) Mas o quixotesco combatente da Rotunda não ficou por aí, proclamando, enfático, que a Junta e o Governo só podiam ter um supremo objectivo: Consolidar a Republica. E era chegada a hora de o fazer: Ella andava tanto em perigo! Salvemo-la com a nossa fé, com a nossa alma, com a nossa infinita dedicação! Foi para isso que se deitou abaixo o governo transacto. Foi para isso que se derrubou o afonsismo!.... (43) Para isso tirava do bolso duas medidas, dois compromissos há muito acrisolados no seu espírito de revolucionário, que haveria finalmente de satisfazer: efectivar a absoluta independência do poder judicial dentro dos limites constitucionais e a concessão para todos os delitos políticos e de opinião de uma amnistia completa. Linhas de acção urgente assumidas na convicção de que não pretendo fazer politica. É que não sou chefe de partido nem o quero ser. É que não organisei nem tento organisar em roda de mim nenhuma corrente politica. ${ }^{(44)}$

A composição militar da Junta Revolucionária significou, desde logo, que o golpe fora urdido e executado por membros do Exército e, em muito menor escala, da Marinha, mas o curriuclum vitae dos seus três elementos remetia, sem dificuldade, para iniludíveis conotações políticas e partidárias.

A presença e a profunda cumplicidade de Machado Santos e dos seus amigos próximos (Carlos da Maia, Lobo Pimentel e Cunha Leal) era por demais significativa, evocando, à uma, o glorioso 5 de Outubro e o malogrado 13 de Dezembro. Sidónio não se limitou a participar activamente no comité nascido no Calhariz e acabou por ficar com os planos conspirativos nos braços e por ser, em caso de êxito, o máximo representante fardado da União Republicana na tenaz urdida contra os democráticos. Por fim, o capitão José Feliciano da Costa Júnior era um jovem desconhecido, havendo quem o apresentasse como unionista filiado ${ }^{(45)}$ e quem sublinhasse a sua independência partidária, explicando o seu ingresso na Junta por escolha dos oficiais concentrados no Parque. Apartidário ou não a política estava bem vincada.

Teófilo Duarte não teve, por conseguinte, dúvidas em acentuar a feição política do movimento e, fazendo valer o seu conhecimento directo de toda a oficialidade, escreveu que dos comandantes das fraç̧ões das tropas rebeldes seis eram republicanos e três monárquicos, dividindo-se os restantes de forma mais ou menos equitativa pelos dois

(42) Cf. Após a victoria. Fala Machado Santos. O que foi a sua acção em Vizeu. O novo governo procurará assegurar a ordem. A Capital, Lisboa, 11 de Dezembro de 1917. p. 2.

${ }^{(43)} \mathrm{Cf}$. Reconstruindo... Consolidar a republica. Eis o que é preciso primeiro que tudo e acima de tudo, diz o sr. Machado Santos. Nem deputado, nem senador, nem chefe de partido. A Capital, 18 de Dezembro de 1917.p. I.

(44) Cf. Ibidem, p. I.

(45) Cf. DUARTE, Teófilo - Sidónio Pais e o seu consulado, ob. cit., p. 159. 
grupos; que os chefes dos civis e quase todos estes exibiam largas tradições de republicanismo e uma folha de serviços preenchida com o 27 de Abril, o I 3 de Dezembro e quantas conspirações enfim se tinham organizado contra os democráticos; (46) que o pessoal telégrafo-postal, precioso auxiliar dos revoltosos, comungava do mesmo ideal; que várias individualidades republicanas e monárquicas ${ }^{(47)}$ se associaram aos anteriores sem modificarem a matriz ideológico-política dominante; que em Viseu os elementos mais categorizados eram republicanos; que o medo de ir morrer a França não constituiu - leit-motiv dos revoltosos, porque Sidónio Pais e Machado Santos estavam isentos de marchar, Feliciano da Costa, assim como todos os restantes, não estava mobilizado salvo os do 33 e dos vinte e seis oficiais implicados no golpe só seis estavam mobilizados. ${ }^{(48)}$

Apesar de suspeitas, as afirmações do Condestável de Sidónio Pais coincidem com a versão veiculada por outras fontes e reforçam a tese de uma primacial motivação interna na base da sublevação de tropas no dealbar desse Dezembro de 1917. Com efeito, os depoimentos mais ou menos coevos são quase unânimes, mesmo quando resvalam para a suposição do complot germânico àcerca da inspiração unionista.

Volvidos seis dias de permanência no Morro, a descida à área urbana onde se localizava a sede do Poder não se fez sem uma parada militar.

Era o dia 10, segunda feira, pelas duas horas de uma explêndida tarde de sol, quando no vasto terreno ocupado pelo acampamento das tropas no alto de Campolide, diante de uma mole imensa de populares apinhados e irrequietos em busca de um bom ângulo de observação, os contingentes da guarnição de Lisboa dispunham-se perfilados em posições marcadas. Artilharia I na Rua Joaquim António de Aguiar, Cavalaria 7 no alto, de costas para a Penitenciária, a infantaria da Guarda Nacional Republicana ficou alinhada ao longo do Quartel de Artilharia I e os cavaleiros da mesma corporação defronte da respectiva entrada. Os outros regimentos concentraram-se na mesma rua perto de Artilharia I e um batalhão de marinheiros, que haviam constituído a chama da resistência governamental, compareceram desarmados, em sinal de castigo, ${ }^{(49)}$ com a sua banda à frente e instalaram-se no alto do Outeiro, por cima do alto de Campolide. A azáfama era enorme, as ordenanças mexiam-se e cruzavam-se como formigas transmitindo ordens, os toques de clarins sucediam-se numa cadência de aviso, automóveis e carruagens com familias de oficiais e diversas individualidades apareciam no recinto a tempo da função que se anunciava.

Pelas 15 horas soaram de novo os clarins, mas em uníssono e para avisar o começo da parada. Uma das baterias deu uma salva de 21 tiros, tocaram cornetas e clarins em

(46) Cf. DUARTE, Teófilo - Sidónio Pais e o seu consulado, ob. cit., p. 159.

(47) Entre as figuras republicanas o autor cita Miguel de Abreu e Cruz Azevedo e no rol dos monárquicos António Bernardino de Sousa Ferreira,Vasconcelos e Cameira (Cf.Ibidem, p. I60). Deve rectificar-se, porém, o atributo dado a Eurico Cameira, porque os dados disponíveis apontam-no apenas como militar presidencialista e católico.

(48) Cf. Ibidem, p. 160-161.

(49) $O$ mal-estar que esta medida causou nas praças do batalhão escolhido para estar presente na parada aparece referido, por exemplo, em Um Golpe de estado. A Revolução de 8 de Dezembro, ob. cit., p. 53-54. 
continência, ouviu-se o hino nacional executado por todas as bandas presentes e os soldados apresentaram armas. Foi, então, que do Quartel de Artilharia I saíram Sidónio Pais e Machado Santos, seguidos pelo seu estado maior, em passo marcial para fazerem a revista às tropas, mas rompendo a custo por entre a multidão que deles se aproximava. No fim da revista recolheram ao Quartel no meio de novas aclamações e ao som da salva da bateria. Enquanto isto as forças desfilaram pela rua Joaquim António de Aguiar e pela Avenida da Liberdade, seguindo para os quartéis depois de passarem em continência ao obelisco da Praça dos Restauradores. ${ }^{(50)}$

\section{O Carisma}

Terminava, assim, essa imponente parada militar, a primeira de outras organizadas até ao final de 1918 e que contarão com a presença de um Sidónio Pais envergando a farda cinza dos combatentes da Grande Guerra, ornada com as cinco estrelas de Comandante em Chefe das Forças Armadas. Em público e em privado, durante doze meses, terá o cuidado de associar as suas poses de estadista à sua condição de militar, que nunca abjurou.

Pouquíssimas vezes pôde ser fotografado ou filmado sem farda - vários documentários cinematográficos se fizeram para memorar os factos ocorridos, mas só um ou outro subsiste - e nessas raras ocasiões o acto não foi deixado ao acaso, o acto cobriu-se inevitavelmente de algum simbolismo: em 28 de Abril votou de casaca na qualidade de cidadão. À sua volta, como colaboradores próximos, alguns civis - seu filho António, escolhido para Secretário particular, o condiscípulo e ex-funcionário da Legação em Berlim António da Costa Cabral, nomeado Chefe do Protocolo dos Negócios Estrangeiros, e a amiga e respeitada figura do Secretário Geral da Presidência da República, Manuel José Forbes de Bessa; o restantes eram militares — o seu Chefe de Gabinete até Março de 1918 foi o $1^{\circ}$ tenente da Armada Aragão e Melo e os seus auxiliares permanentes foram um capitão (Eurico Cameira), dois alferes fixos (Bernardo de Vasconcelos e Eduardo Ferreira da Silva) e outro alferes como Ajudante de Campo no Ministério da Guerra (Jorge Botelho Moniz) durante dois ou três meses.

Os gestos protocolares, as vestes, os diversos rituais mais ou menos secularizados nunca deixaram de ser importantes na mente e na vida de Sidónio Pais, mesmo quando se insurgiu na sua desabrida oração de sapiência contra o absurdo e o anacronismo de algumas práticas simbólicas, que acatou, aliás, disciplinadamente, ou quando, em S. Bento, no papel de deputado condenou o uso de títulos, de condecorações e de medalhas pelo que tinha de imodesto e de ostensivo. Mas durante um ano de protagonismo político não renunciará (terá mesmo aderido) ao solene e vistoso cerimonial, às estrelas do generalato, à tarja constitucional ou até a um pendão verde com monograma (SP) hasteado no Palácio da Pena durante as suas férias estivais, pormenor majestático observado mordazmente pelo Ministro francês Émile Daeschner. Fá-lo-á certamente

(50) Cf. Um Golpe de estado. A Revolução de 8 de Dezembro, ob. cit., p. 51-52. 
por vaidade (ou por vertigem narcísica do Poder), mas muito por espírito de missão e pelo seu entendimento passional das funções institucionais em que se vira investido através da força das armas e do apoio popular em múltiplas formas, incluindo a eleitoral - expressão moderna e básica da soberania popular que lhe era tão cara.

No perfil psicológico, atrás esmiuçado, a psiconeurose de contornos edipianos e depressivos, a timidez, a falta de auto-estima e a projecção egótica na alteridade, entre outros traços, ajudam a compreender a vincada ambivalência da sua conduta, a imprevisível oscilação de um pólo ao seu extremo. A teatralidade da pose marcial e hierática, fazendo, de pé, continência ou de espada em punho num elegante cavalo castanho, intercalava facilmente com a postura do cidadão/soldado afável e sorridente envolvido pela gente simples e anónima, aplaudido e cumprimentado por velhos, mulheres e crianças, desdobrado em múltiplas visitas e inaugurações, junto de doentes ou provando a sopa dos pobres, numa proximidade algo inversa - e muito mediática como se diria hoje... - à convencional e fria postura do estadista.

À rigidez protocolar juntou, não sem um manifesto controlo racional e propagandístico, a expressão brusca e intensa de uma reacção emocional e calorosa. À obstinada e autoritária intransigência face a uma ideia ou a uma opção sobrevinham os impulsos inibitórios de alguma insegurança, traduzidos na ansiosa busca de opiniões alheias e no forte desejo da conciliação em vez da ruptura. À palavra verbalizada dúbia e baça contrapunha a força persuasiva da voz, (51) do olhar, do sorriso, do gesto intenso, de uma mediana e aprazível figura corporal, irradiando o magnetismo do «iluminado» que em nome de um desígnio especial congrega ao seu redor miríades de vontades. Em suma, um complexo jogo de polaridades contrastadas, subjacente ao processo carismático, gerador de idolatria e de antipatia, porque não há, nem costuma haver unanimidade neste processo. Emergem, assim, os que se afastam ou opõem e os que aderem, se projectam e se prolongam na interacção com um líder dotado de determinadas características e atributos, tidos por sobrenaturais, como definiu MaxWeber, mas, de acordo com a lição dos durandianos, tal só se verifica em contextos de forte tensão mítico-simbólica ou de convocação emocionada do sagrado. Contextos esses imprescindíveis à ocorrência de intensas identificações heroicizadoras.

A liderança carismática pressupõe, portanto, dois elementos — uma personalidade singular mobilizadora e uma adesão específica dos seguidores ao líder - activos e condicionados numa conjuntura tecida por múltiplos factores, designadamente o sócio-cultural e a ressurgência / recorrência mitológica. Tríade decisiva para que se possa falar com rigor de fenómeno carismático e enfrentar o desafio que a conceptualização de carisma nos coloca hoje, uma vez falida, como observou Raúl Martín Arranz, a abordagem unilateral da tradição pós-weberiana centrada apenas no líder e em que o ângulo dos adeptos, dos seguidores, dos liderados é tratado apenas como referente ou consequência da acção daquele: Surge así la precisión de aproximarse una vez más a los trabajos de psicología, pero ya no para referirse limitadamente al individuo-líder (marco en el que se fundó la psicohistoria) y con el que alcanzaríamos sin duda excelentes psicobiografias, sino mayormente con

(51) Cf. BELMIRO - [Soneto catírico]. Século Cómico, de 17 de Dezembro de 1917. 
atención a los colectivos, a la vertiente social de la cuestión; al comportamiento colectivo, en fin, para observar cómo en él se resuelve el liderazgo carismático. ${ }^{(52)}$

O primeiro elemento activo dessa tríade implica a capacidade de alguém transformar em projecto colectivo e geral as necessidades, os valores, as preferências e as aspirações de um conjunto variável de seguidores. Mas se tal sucede é porque esse alguém possui traços congénitos propícios e/ou determinada(s) disfunção(ões) pós-natal(ais). $\bigcirc$ paradigma psicanalítico apenas valoriza, como se sabe, este segundo aspecto, nele fundando todo o esforço interpretativo. Foi, aliás, o que fez Carlos Amaral Dias ao lançar o seu olhar especializado sobre o caso histórico de D. Sebastião, esse rei Encoberto, desaparecido jovem em Alcácer, desejado como esperança de sucessão ameaçada pela morte de toda uma geração de herdeiros, nascido três semanas após a morte do pai, abandonado pela mãe aos quatro meses, entregue à vigilância e ao convívio estreito com a avó D. Catarina, educado por dois homens que lhe procuraram incutir ideias de grandeza marcial e de natureza religiosa e configurado numa modalidade de vida mental dominado pelas fantasias messiâncias de salvação.

Fantasias tipificáveis nos seguintes moldes: as sucessivas percas de objecto afectivo levaram D. Sebastião - ou Sidónio Pais, órfão de pai e envolvido numa vivência edipiana - a idealizar os seus antepassados e os seus feitos, convertendo-os em verdadeiros salvadores dele mesmo e do mundo externo, mas como o objecto idealizável não se coisifica na relação objectal, o que só conduziria à frustração ou ao desapontamento, ele é devolvido ao indivíduo sob a forma de uma identificação, através da qual as qualidades idealizadas do objecto são assimiladas à representação do próprio self, resultando disto uma alteração no comércio objectal. O sentimento de infelicidade é projectado e o indivíduo manifesta profunda simpatia pela dor e pela miséria dos outros. A auto-imagem, por outro lado, adquire, em consequência do processo de identificação descrito, as qualidades e a grandeza do objecto idealizado. Como consequência final, o indivíduo vai procurar activamente fornecer aos outros a salvação inicialmente desejada para ele mesmo. Encontramos assim três características mais significantes nesta evolução: a profunda simpatia pelo sofrimento dos outros - D. Sebastião/Sidónio manifestou-a abundantemente; o sentimento de salvar os outros e aliviá-los do sofrimento - todo o processo do reinado sebástico/da personalização sidonista é uma prova de como o rei/presidente assumiu esta função; o sentimento subjectivo que uma missão especial Ihe tinha sido atribuída, como parte de uma alta chamada espiritual - a prática de D. Sebastião/Sidónio terminada desastrosamente em Alcácer/na Estação do Rossio é disso prova evidente. ${ }^{(53)}$

Pelo exposto, a similitude dos dois casos, segundo o paradigma psicanalítico, ressalta evidente, mas não autoriza qualquer propósito de colagem forçada. Ressalvamos, por isso, as naturais diferenças e a indiscutível singularidade psíquica e histórica de Sidónio

(52) Cf. MARTÍN ARRANZ, Raúl - El Liderazgo carismatico en el contexto de estudo del liderazgo, in ALVAREZ JUNCO, Jose (comp.) - Populismo, coudilaje y discurso demagógico, ob. cit., p. 97.

(53) Cf. DIAS, Carlos Amaral - Contribuição ao estudo das fantasias messiânicas no rei D. Sebastião, art. cit., p. 26. 
Pais. Aspecto crucial que introduz o segundo elemento do processo carismático - a resposta auto-projectiva e auto-identificativa num determinado Ego (o líder) por uma pluralidade heterogénea de cidadãos em circunstâncias concretas (políticas, sócio-culturais, económicas, etc.): os seguidores partem das suas angústias, temores, frustrações e anseios pessoais, grupais ou comunitários, fortemente determinados pela dinâmica conjuntural, para a aceitação emocionada daquilo que querem ou julgam que seja a matriz dos objectivos gerais/colectivos personificados pelo líder. Estabelece-se, desta forma, uma relação de veemente cumplicidade das duas partes, mas também uma potencial fonte de equívocos: a percepção pública e necessariamente esquematizadora do plano ou da missão do líder redunda numa grosseira distorsão dos genuínos objectivos doutrinários e programáticos que substancializam e animam a liderança, além de que esta pode de igual modo emitir sinais ambíguos que acentuam a equivocidade da relação.

No caso em foco, como adiante se explica, a distorsão aconteceu plasmada no equívoco conservador/monárquico e no equívoco católico. $\bigcirc$ projecto democrático e republicano de Sidónio Pais, genericamente fixado durante a fase preparatória do golpe e praticado depois com dúbia fragilidade, será reduzido e pervertido, quanto à sua intencionalidade programática, por monárquicos e por católicos em função dos seus próprios interesses e valores. Um equívoco que justificará outro de sentido oposto, ou seja, a rejeição/oposição total por uma parte significativa do campo republicano.

\section{A Formação do $15 .^{\circ}$ Governo}

Em 9 foi decretada e a 10 de Dezembro saía na I. ${ }^{a}$ série do Diário do Governo a dissolução do Congresso da República, sendo anunciado que no mais curto prazo de tempo, o Govêrno constituído convocará os colégios eleitorais que escolherão os representantes da Soberania Nacional, com poderes para a revisão da Constituição. Mas nem neste, nem nos outros decretos revolucionários, especialmente o da destituição do Presidente da República (assinado a II e publicado a 12), se acha expressa a justificação jurídicoconstitucional evocada alguns dias depois nos telegramas trocados entre Sidónio Pais, enquanto titular dos Negócios Estrangeiros, e o Ministro de Portugal em Londres Teixeira Gomes. ${ }^{(54)}$

Em 19 de Dezembro, Sidónio frisara, por razões desenvolvidas à frente, que a demissão de Bernardino Machado se fizera ao abrigo da Constituição em vigor, artigo $38 .^{\circ}$ sobre a eleição do Presidente da República, parágrafos $2 .^{\circ}$ e $3 .^{\circ}$. Preceituava o $2 .^{\circ}$ que no caso da vacatura da Presidência, por morte ou por qualquer outra causa, as duas Câmaras, reunidas em Congresso da República por direito próprio, procederiam de imediato à eleição do novo Presidente que deveria exercer o cargo durante o resto do período presidencial do substituído. E o $3^{\circ}$ que enquanto não se realizasse a eleição referida no anterior ou quando, por qualquer motivo, houvesse impedimento transitório do exercício das funções presidenciais, os Ministros ficariam conjuntamente investidos na plenitude

(54) Ver MEDINA, João - Manuel Teixeira Gomes e Sidónio Pais, Clio. Lisboa, 2 (1980) p. II 1 - 129. 
do Poder Executivo. (55) Com base nestes preceitos e no disposto no n. ${ }^{\circ} 9$ do art. ${ }^{\circ} 47$ (Das atribuições do Presidente da República) e art.os 48 e 49 (Dos Ministros) foi, entretanto, elaborado e mandado para publicação na folha oficial o decreto 3.70 l da Presidência do Ministério, com data de assinatura e de impressão de 27 de Dezembro, que autorizara - Presidente do Ministério a assumir as funções de Presidente da República. (56)

Percebe-se a preocupação de atenuar o problema da legitimidade posto pelo hábil Bernardino Machado quando se negou a renunciar ao cargo e de evitar a todo o custo a quebra da ordem institucional vigente, reduzindo a ditadura ao minimo possivel - expressão empregue pelo omnipresente Brito Camacho: Quero ver se evito a dissolução das Camaras, reduzindo a ditadura ao minimo possivel. Tenho esperança de o conseguir, mas ainda me não fixei definitivamente a este respeito, á espera d'um inquerito para que forneci as bases. Um objectivo porfiado por Brito Camacho muito à sua maneira...

O diplomata francês Émile Daeschner descreveu o chefe unionista, em despacho para - Ministro Pichon, como um pouco selvagem, dotado de real talento de escrita e detentor, lá no fundo, de sinceros sentimentos francófilos, embora se tivesse oposto ao envio de tropas para França por exclusivas razões de política interior e de partido - il s'est trouvé en cela d'accord avec les conseils prodigués comme vous le savez par le Gouvernement Britannique, mais en opposition absolue avec la politique du parti democrate. (57)

Apesar de ter recusado, pelas razões já conhecidas, a oferta para se instalar de armas e bagagens no Poder feita por um Sidónio ainda muito inseguro, oferta confessada num dos seus discursos da viagem presidencial ao Sul $-O$ partido unionista dentro da lei tudo fez para acabar com esse estado de coisas. Pena foi que ele no seu conjuncto não tivesse tomado parte na revolução ${ }^{(58)}$ - Brito Camacho disfarçou mal o cuidado e o interesse em moldar a seu gosto a evolução rápida e convulsa dos acontecimentos. Para além de ter fixado alguns objectivos programáticos - moralização da vida administrativa, eleições e revisão pontual da Constituição de 1911 - facilmente aceites pelos restantes parceiros do novo bloco, enviou os seus correligionários para junto do chefe da revolta, um dócil membro da mesma familia, e manobrou quanto pôde para travar uma indesejável e perigosa ruptura com os democráticos - Escusado seria dizer-te que os democraticos já conspiram. Não teem athmosphera, mas esperam que a crie o Governo. Nessa medida foi certeira a caricatura satírica de Os Ridiculos, de 19 de Fevereiro de 1918, onde aparece desenhado um diligente criado de mesa, o próprio Camacho, a servir comida camachista (cabecinhas de Camachos) envenada de... politica a dois ilustres comensais postos frente a frente - Sidónio e Machado Santos. E não menos certeira foi, para uma fase seguinte, a caricatura publicada em Junho e intitulada Brincar com o lume...

(55) Cf. Constituição política da república portuguesa. Contendo as alterações constantes da lei $n .{ }^{\circ} 635$, de 28 de Setembro de 1916. Lisboa: Imprensa Nacional, 1916, p. 16.

(56) Cf. Diário do Governo, I Série, 226, 27-12-1917. Suplemento.

(57) Z. Europe, 1840 Portugal, Ambassadeur Français à Lisbonne, n. I 13, 23 Juin 1918. (Archives du Ministère des Affaires Etrangères).Ver SILVA, Armando Barreiros Malheiro da - Sidónio e sidonismo. História e mito, dissert. cit, vol. 2, p. 37-38.

(58) Cf. PAIS, Sidónio - Um Ano de ditadura: discursos e alocuções. Coligidos e ordenados por Feliciano de Carvalho com um estudo politico de João de Castro. Lisboa: [s.n.]. 1924, p. 50. 
Nas cartas que pudemos consultar e que são um pálido reflexo probatório da azáfama caricaturada, o astuto e dúctil líder unionista apressou-se a garantir toda a colaboração ao major-lente, através de vários contactos escritos (evitara aparecer pessoalmente no Parque, coerente com o papel que antes assumira) ${ }^{(59)}$ e tendo versado num deles a eventual ida de Bettencourt Rodrigues para os Negócios Estrangeiros. A pronta receptividade do seu pupilo e protegido levara-o a declarar na carta-relatório remetida a Augusto de Vasconcelos, ainda Ministro em Madrid, que Estou bem com o Sidonio, no entanto, por perspicácia e intuição, pressentira já que elle não é capaz de resolver o problema político que estava posto [entenda-se: direito de dissolução da Câmara e alteração por via eleitoral da maioria partidária no Congresso], e se o não resolver, a revolução foi inutil, e elle, como politico, é homem liquidado. Um surpreendente vaticínio que anuncia antecipadamente o desfecho desta história...

A pressão unionista foi, de facto, grande, mas também já não podia ser maior, porquanto o investimento no golpe fora aberto, por opção consciente de Camacho, a outros parceiros, inexoravelmente dispostos quer a partilhar cadeiras ministeriais e outros lugares, quer a sugerir rotas e soluções drásticas para a remoção dos obstáculos incómodos. A inicial relutância de Sidónio Pais, referida por Rocha Martins e confirmada por José Feliciano da Costa Junior, ${ }^{(60)}$ em aceitar qualquer «pasta» para si - ficaria de fóra a garantir a ordem e o Bettencourt vai governar... ${ }^{(61)}$ - terá sido rapidamente ultrapassada face à recusa de vários camachistas reunidos sob a batuta do chefe pelas 2 h. da manhã no escritório do advogado Emídio Mendes na rua do Ouro. Trata-se, é claro, de um dos muitos episódios da narrativa de Rocha Martins a seguir sempre com o necessário cuidado. $\bigcirc$ prolixo cronista diz-nos que a tentativa feita de organizar um Ministério inteiramente camachista falhara nessa madrugada e que Sidónio, de repente, deliberara orientar melhor a sua vida política. Acrescenta ainda que na tarde desse dia (certamente terça-feira, I I) em jantar no Silva, ao Chiado, com Machado Santos e alguns amigos, o fundador da República se mostrara igualmente indisponível para participar do Governo. Mais firme, contudo, na sua recusa ficara, por ora, Sousa Fernandes, apoiante incondicional de Sidónio. Escusou-se muito, por vários motivos, incluindo, possivelmente, o óbice moral de ter financiado o golpe...

Da versão romanceada de Rocha Martins ressalta a impressão de que o elenco ministerial veladamente imposto por Camacho foi reformulado com enérgica habilidade por um Sidónio decidido subitamente a fazer valer a sua vontade!... Há que desconfiar, porém, de versões demasiado pueris e simplistas e optar, antes, pela indicação conjunta dos dados existentes: a partir do momento em que Sidónio Pais assumiu - e ignoramos porque o fez, embora não seja de excluir a falta de uma alternativa prestigiada e

(59) Cf. MARTINS, Rocha - Memorias sobre Sidonio Paes, ob. cit., p. 59.

(60) Testemunho incluído no artigo Dr. Egas Moniz. Um ano de politica. Para a historica fose politica que vai de dezembro de 1917 até dezembro de 1918. O que se lê do sr. Sidonio Pais, d'A Situação de I de Setembro de 1919, p. I; e a mesma ideia foi, em parte, repisada de um modo mais metafórico por António Ferro nas páginas de $O$ Jornal, de 5 de Dezembro de 1919, cit por LEAL. Ernesto Castro - António Ferro. Espaço político e imaginário social (1918-1919). Lisboa: Ediçōes Cosmos, 1994, p. 243.

(6i) Cf. MARTINS, Rocha - Memórias sobre Sidonio Pais, ob. cit., p. 76. 
disponivel - a urgente tarefa de integrar e ultimar um Ministério provisório, procurou conciliar e gerir da melhor forma as diferentes «sensibilidades» em seu redor. Meteu por isso, na mesma folha oficial os nomes sugeridos e/ou aprovados por Brito Camacho e as escolhas procedentes do influente grupo de Machado Santos, representado pelo Centro 27 de Abril, do algo periférico centrismo, em breve erigido ao estatuto de vanguarda da rede sócio-política da situação dezembrista/sidonista, e dos seus oficiais e alferes, conglomerados numa atitude de certa hostilidade político-partidária, comum, aliás, à de alguns machadistas como José Carlos da Maia. ${ }^{(62)}$

Note-se, a propósito e desde já, a decisiva influência de Teófilo Duarte, de Eurico Cameira e de outros oficiais dezembristas na reintegração de militares confessadamente monárquicos, como os coronéis Silva Ramos e João de Almeida, que protagonizarão, em finais de 1918 e inícios de 1919, a espontânea e informal criação das Juntas Militares com o proclamado fito de defenderem a ordem pública; e ainda na entrada, em Março, para Ministro da Justiça do jovem jurista Martinho Nobre de Melo, amigo pessoal do integralista Hipólito Raposo e do capitãoTeófilo Duarte. Esta notória influência do núcleo militar e ordeiro na situação sidonista foi crescendo na razão inversa do apoio das forças históricas do campo republicano, de uma parte da opinião pública e do movimento operário encabeçado pela U.O.N. ${ }^{(63)}$

Mas voltando à composição do Ministério saído do golpe de $5 / 8$ de Dezembro convém frisar que a distribuição dos nomes pelas «pastas» parece não ter sido motivada apenas pela necessidade da representação numérica das várias componentes - três unionistas (Aresta Branco, Moura Pinto e Santos Viegas), dois centristas (Tamagnini Barbosa e Alfredo de Magalhães), dois republicanos históricos (Machado Santos e Xavier Esteves) e dois revolucionários (Sidónio, impelido pelo desenrolar do golpe a uma posição suprapartidária, e Feliciano da Costa, representante dos oficiais, cadetes, alferes e revolucionários civis). Esta proporcionalidade não foi matematicamente reproduzida no elenco final dos Governadores Civis, mas ainda assim oito em vinte e um eram unionistas, traduzindo um efectivo peso político da União Republicana, que até esteve para ser aumentado se não esbarrasse na frontal oposição de Machado Santos. E a propósito da propalada influência de Camacho e do modo como ocorreu a escolha dos representantes do Governo Central, ${ }^{(64)}$ o coronel Belisário Pimenta, um unionista e militar de Coimbra, conta nas suas já atrás citadas Memórias que Brito Camacho era tido como o protector da nova ordem de coisas e que Moura Pinto fizera uma lista de Governadores Civis na qual figurava o seu nome para Coimbra, mas terá sido o próprio Sidónio Pais que the riscou o nome com um traço a tinta e emendou para Solano de Almeida, capitão. ${ }^{(65)}$

(62) Ver SILVA, Armando Barreiros Malheiro da - Sidónio e sidonismo. História e mito, dissert. cit., vol. 2, p. 855-857.

(63) Ibidem, p. 42.

(64) Sobre a definição jurídico-administrativa, origens e evolução das suas atribuições ver Governos civis. Mais de um século de história. Lisboa: Ministério da Administração Interna, 1994, p. 10-32.

(65) PIMENTA, Belisário - Memórias, 1911-1919, n. 10, Sobre a Revolução de Dezembro, p. 289. (Biblioteca Geral da Universidade de Coimbra). 
Este oficial de Cavalaria, que com o seu esquadrão de Nelas auxiliara Machado Santos e companheiros a secundarem o golpe dezembrista em Viseu, ${ }^{(66)}$ incompatiblizar-se-á com os unionistas, ordenando o encerramento do Centro Republicano Dr. José Falcão, à semelhança do que sucedeu noutros pontos do país, e em resposta a isso o Dr. Sacadura entregou a chave do Centro no Governo Civil. Factos registados com o seguinte comentário: A situação não me parecia segura, eu desconfiava dos seus dirigentes, desde o Sidonio Paes de quem não gostava, até aos seus cadetes, rapaziada brava e sem escrupulos que o cercava e o ajudou a perdê-lo. ${ }^{(67)}$

A interferência pessoal de Sidónio na escolha do Governador Civil de Coimbra repetiu-se, pelo menos, no caso de Aveiro, para onde não hesitou nomear o seu amigo e íntimo colaborador em Berlim, o dr.Vasco de Quevedo, que se revelará aí um dedicado e activo extensor da rede sócio-política do dezembrismo/sidonismo. E o mesmo cunho pessoal verificou-se na escolha de Teófilo Duarte para Governador Geral de CaboVerde ou de Filomeno da Câmara Melo Cabral para Angola.

Por detrás do jogo aparente das proporções numéricas, percebe-se um claro nexo intencional, ainda que desequilibrado. Sidónio Pais ficou com a Presidência de todo o Poder Executivo (Presidência do Ministério e da República) e tomou ainda posse, em cerimónias distintas, da Guerra e dos Negócios Estrangeiros, sobrecarga considerável por serem «pastas»-chave a que correspondiam questões cruciais: a resolução do problema político criado pelo golpe, o reconhecimento internacional das novas forças hegemónicas da República e a conduta de guerra, isto é, manter ou não a presença no front alcançada pelos democráticos. Machado Santos no Ministério do Interior conferiria, em princípio, às próximas eleições a nota de um apartidarismo subliminarmente antipartidário, embora não chegue, devido à remodelação de 7 de Março, a cumprir esse desiderato.

Aresta Branco na Marinha, Santos Viegas nas Finanças e Moura Pinto na Justiça traziam o contributo politécnico e político da União Republicana em matéria de administração naval, de controlo orçamental dramaticamente desregulado desde a episódica proeza do superavit afonsista em 1913, de reorganização judicial e da delicada problemática dos cultos. Frise-se que há muito, e em uníssono com os evolucionistas e a generalidade das forças conservadoras, os unionistas sustentavam a revisão da «intangivel».

O concurso do imberbe Partido Centrista Republicano liderado por Egas Moniz, regressado à política após um interregno voluntário de quase cinco anos, ${ }^{(68)}$ visava, quanto ao modelo político, estruturar numa única organização partidária as correntes republicanas e liberais identificadas com o renovado espírito conservador, sinónimo de reforma e de evolução, de defesa ou conservação da ordem e das melhores energias e tradições nacionais, e, quanto à prática política, revalorizar a agricultura, base da nossa vida crematística ou económica, através de um Ministério próprio, sem esquecer o fomento

(66) Cf. MARTINS, Rocha - Memorias sobre Sidonio Paes, ob. cit., p. 199.

(67) PIMENTA, Belisário - Memórias, 1911 - 1919, n. 10 , Sobre a Revolução de Dezembro, p. 291 e 293-295. (Biblioteca Geral da Universidade de Coimbra).

(68) Ver SILVA,Armando B. Malheiro da - Egas Moniz e a política. Notas avulsas para uma biografia indiscreta. In ob. cit. p. .... 
industrial, comercial e marítimo, a protecção social ao operariado pela regulamentação do trabalho, a garantia da liberdade de cultos, etc. $O$ engenheiro militarTamagnini Barbosa e o lente de Medicina no Porto, Alfredo de Magalhães, foram propostos para corporizarem esta corrente nas pastas das Colónias e da Instrução. Pormenor interessante: o novo Ministro da Instrução representava ainda os interesses do Porto, pela primeira vez hasteados no seio da governação republicana, permanecendo no desempenho do mesmo cargo durante toda a situação dezembrista/sidonista. E do Porto, na qualidade de republicano histórico viera, também, o engenheiro Francisco Xavier Esteves, figura ligada à indústria portuense, que será até ao fim um dos colaboradores indefectíveis de Sidónio Pais e relator do ignorado projecto de Constituição sidonista (ver Anexo 2).

$\mathrm{Na}$ sensivel pasta do Trabalho o capitão Feliciano da Costa sugeria, à partida, uma boa articulação de pontos de vista com a Presidência do Ministério na sensível área das susbsistências e da legislação laboral. O seu desempenho governativo ficará, contudo, aquém da sua propalada inteligência e a efémera carreira de diplomata junto da Santa Sé redundará numa aposta infeliz. ${ }^{(69)}$

Observando, de relance, a estrutura governativa sobressai a continuidade em relação aos últimos Governos de predomínio democrático, com a ligeira alteração de Fomento para Comércio e a não inclusão de Subsecretários adstritos a determinadas «pastas»-chave. A do Trabalho criada pela lei de 16 de Março de 1916 foi mantida. E as práticas associadas à cúpula ou esfera executiva dos diferentes Ministérios não sofreram qualquer modificação. Os titulares continuaram assessorados por um Chefe de Gabinete e um Secretário particular, formando estes com os contínuos o mesmo escudo protector e o mesmo funil para a filtragem dos pedidos, das reclamações e das influências. Na sombra, mas controlando o processo burocrático e através dele o exercício do Poder, estavam os Directores-Gerais naturalmente permeáveis ao jogo clientelar e político-partidário. ${ }^{(70)}$

Convém notar ainda que os sucessivos desaires verificados no combate às distorções da distribuição e da venda dos géneros de primeira necessidade irão determinar a concentração num Ministério novo, designado Subistências e Transportes, dos meios humanos, administrativos e de fiscalização indispensáveis a essa tão complicada e ingrata missão. Por seu turno, a aplicação do programa centrista no capítulo do fomento agrícola motivará o aparecimento de um Ministério exclusivamente dedicado à Agricultura, inovação que não nos parece, contudo, derivar apenas ou sobretudo da pressão organizada da plutocracia agrária e latifundária, mas quando muito do reflexo desses interesses diversos, na rede sócio-política de apoio e a par com outros interesses antagónicos, como os dos sectores mercantil e industrial. ${ }^{(71)}$

(69) Ver SILVA, Armando B. Malheiro da - Os Católicos e a «República Nova» (1917-1918), art. cit., p. 488$-489$.

(70) Ver Ibidem, p. 45-46.

(71) A rede sócio-política gere, absorve ou até acentua a carga conflitual dos in put dos chamados grupos de pressão ou lobbys. Sobre estes ver CAETANO, Marcello - Manual de ciência política e direito constitucional. $6{ }^{\circ}$ edição revista e ampliada por Miguel Galvão Teles. Tomo I. Lisboa: s.n., 1972, p. 404-405. 
Estas inovações surgiram na sequência da remodelação que a saída dos unionistas tomou inevitável e a meio da fase ditatorial, terminada do ponto de vista político-institucional com as eleições de 28 de Abril.

Eis aqui um ponto importante que nos afasta da linha até agora seguida pela moderna historiografia e que consiste em incluir toda a experiência dezembrista/sidonista no conceito operatório de ditadura, o que, como se percebe facilmente, implica um subreptício e subjectivo juízo de valor. Um juízo pejorativo e contrário à intencionalidade histórica (isto é, produzida/vivida, bem ou mal não importa, no seu próprio tempo) dos principais protagonistas da situação política em foco, porque para eles era essencial integrarem-se num quadro de legitimidade popular e legal, mesmo que essa integração sofresse limitações e atropelos quanto aos princípios democráticos professados. Aliás, não há dúvida, como se frisará melhor, que a prolongada ausência de uma Constituição revista ou refeita pelo Parlamento, a dissolução, por decreto de 10 de Janeiro, das Juntas Gerais, das Câmaras Municipais e das Juntas de Paróquia eleitas em Novembro e susbstituídas por Comissões Administrativas nomeadas pelos Governadores Civis, 0 restabelecimento, por decreto de 13 de Abril, da Censura à imprensa (72) ou a declaração de estado de emergência por decreto de 13 de Outubro e mantida até final do ano constituíram factores, na sua maioria gerados pela dinâmica oposicionista, mas que fragilizaram bastante o processo de institucionalização e de legitimação plena da República Nova.

A rematar este naipe de novos organismos convém referir as alterações funcionais introduzidas na Presidência do Ministério e Presidência provisória da República, que, ao contrário da prática anteriormente fixada pelo dispositivo constitucional, tendeu, desde o início, a polarizar não apenas um acervo importante de informação administrativa interna, mas também muita informação procedente dos mais díspares sectores, grupos de interesses e cidadãos existentes na realidade social a que se destinam as decisões operadas no âmbito do sistema do Poder.

Nota-se, assim, uma premeditada aposta no reforço do chamado Poder Executivo com dois pólos hierarquizados, mas não necessariamente bem articulados e harmónicos: de um lado a Presidência ou vértice do Estado que devia coordenar a acção ministerial e que acaba por chamar a si o estudo, a apreciação, a retenção e a resolução de vários casos I dossiers; e do outro, a máquina convencional dos Ministérios com as suas Direcções-Gerais e os restantes Serviços desconcentrados ou não nas diversas áreas administrativas da Metrópole e Ultramar, entregue à rotina pesada e lacunar da gestão quotidiana dos negócios correntes. Uma máquina que o discurso político da época repetidamente elegeu como ponto capital da profunda reforma política há muito reclamada, mas que persistirá desmesurada, anacrónica, inerte e incapaz de acompanhar o sentido inovador ou transformista dos projectos ideológico-políticos. Uma máquina, enfim, que Teófilo Duarte, logo a 18 de Dezembro e atendo-se à urgente transferência pelo Ministério

(72) Cf. FRANCO, Graça - A Censura à imprensa (1820-1974). Lisboa: Tecnicelpa/Universidade Católica Portuguesa e Imprensa Nacional-Casa da Moeda, 1993, p. 57. 
da Guerra de um conjunto de oficiais desafectos, retratou com indisfarçável irritação, desvendando, em traços crus, como ela resistia e neutralizava a cadeia hierárquica estabelecida: V. Exa vive pois n'uma athmosfera d'incerteza e mystificação provocada pela falta d'uma direção unica e energica, que dê ordens e as faça cumprir rapida e integralmente. Desculpe V. Exa estas linhas que apenas têm por fim manifestar-lhe o pezar de vêr iludido, como o Norton a quem todos os chefes de Gabinete e Secretarias, garantiam a adopção de medidas para a repressão do nosso movimento, o homem brioso que ao arriscar-me e aos meus soldados, as cabeças, encontrei ao meu lado, em logar de se acolher a uma precedente e comoda permanencia em casa. Vem esta carta por fim fazer notar apenas uma coisa a V. Ex $x^{a}$ : S. Ex $x^{a}$ o Ministro da Guerra estava convencido de que as transferencias saiam hoje ou amanhã, e foi preciso 3 oficiaes irem á $2 .^{\circ}$ repartição quasi a obrigar a fazerem-se as notas necessarias para aquelle fim. ${ }^{(73)}$

E se o funcionalismo dos Ministérios, por oposição passiva e/ou por inércia natural, cedo se tornou, em certa medida, um obstáculo à acção governativa iniciada em Dezembro, esta foi alvo de uma precoce e severa crítica do titular do Interior, Machado Santos.

Em carta para Sidónio Pais, redigida em meados de Janeiro, manifestou o seu profundo descontentamento pelo modo como a questão dos marinheiros estava a ser tratada, considerou quase nulo o trabalho desenvolvido e pediu abertamente a sua demissão: Como não ha maneira de a gente ponderar devidamente os assuntos que são levados a conselho de ministros, pela aluvião de gente que concorre a eles, julgando-se autorisada a interromper-nos a todo o momento, com grave prejuizo dos interesses nacionaes, aproveito a oportunidade para te dizer, com a rude franqueza que me caracterisa, que estou descontente; muito descontente mesmo, pelo inglorio mez administrativo que já decorreu sob a nossa gerencia, encontrando-se hoje o governo ainda sem plano d'ação de conjunto, tanto no que interessa á politica interna como externa e no que respeita á vida economica, financeira e social do paiz. (...) Hontem, como sempre tem sucedido, tratámos ligeiramente um assunto, com ministros a cabecearem de somno e secretários jovens a interromperem-nos a cada passo, que reputo de muita gravidade. ${ }^{(74)}$ São extractos interessantes de uma carta escrita quase em simultâneo com outra, confidencial, motivada por um forte ataque aos unionistas e em especial às declarações envenenadas de Camacho ${ }^{(75)}$ na sua recente viagem a Coimbra, Porto e Braga. Dois exemplos esclarecedores da conduta pessoal e política de uma das figuras de proa do processo de ascensão e queda de Sidónio Pais...

De fora do elenco governativo dezembrista e da respectiva rede sócio-política ficaram os monárquicos e o movimento católico organizado.

Os católicos mexeram-se no sentido de uma rápida revisão do controverso diploma da separação da Igreja do Estado, subordinando o seu apoio a essa contrapartida

(73) Ver SILVA, Armando Barreiros Malheiro da - Sidonismo e sidónio. Histório e mito, dissert. cit., vol. 2, p. 831.

(74) Ibidem, p. $829-830$

(75) Ver o que sobre este tópico escreveu WHEELER, Douglas L. - História política de Portugal, 1910-1926, 
legislativa, enquanto os monárquicos se limitaram a saudar as anunciadas propostas de tolerância e de convivência político-partidária pelas novas autoridades do Estado republicano. $O$ posterior afastamento dos unionistas e a dificuldade dos sidonistas em assegurarem o controlo partidário em todo o aparelho administrativo do país e ilhas tornarão ainda mais fácil o acesso de monárquicos e de católicos a várias Câmaras Municipais, Administrações do Concelho, Governos Civis, Comandos policiais e militares, além de outras eventuais instâncias intermédias, sem que daí se possam tirar apressadas conclusões sobre a matriz ideológica e doutrinária da República Nova.

No plano dos princípios e dos objectivos constitucionais essa República prefigurou-se, ressalvado o pouco consensual cariz presidencialista, como um Estado republicano de direito, moralizador, habitável, tolerante e consolidado, tal qual os seus arautos o previam e desejaram em Dezembro de 1917. Na prática, porém, tudo parecerá apontar, numa série de sinais concretos, para a rotunda negação desse projecto e as aparências — os equívocos - bastam, muitas das vezes, para comprometer as mais generosas intenções, como se prova com a atribulada experiência sidonista. Ela falhará pela conjugação de múltiplos factores, que ao longo deste estudo são evidenciados.

\section{A Imagem externa}

O gigantismo da empresa, que mal começara, não tardou a ser sentido em pleno nas principais questões a cargo de Sidónio Pais, entregue, doravante, a um ritmo de trabalhos, canseiras e emoções extremas que nunca até aí tinha verdadeiramente experimentado, nem mesmo nas fases de acumulador e de Ministro das Finanças. Ascendera ao Capitólio - como observara, por carta, Machado Santos - e arriscava-se, então, a receber as palmas do triunfo e a beber do fel do infortunio!...

A imagem externa da nova situação política afigurou-se-lhe, como vimos, essencial e daí ter procurado empregar toda a sua simpatia e todos os seus dotes de persuasão junto do general Barnardiston para mandar recados tranquilizadores às altas esferas do Comando Aliado.

Poucos dias depois recebia o Ministro inglês Sir Lancelot Carnegie, tendo este apresentado uma declaração de felicitações e de reconhecimento de facto do Governo de S.M.B. ao novo Governo Provisório de Portugal. Sidónio agradeceu, mas replicou que o adjectivo provisório não constava das comunicações emitidas oficialmente. $\bigcirc$ diplomata inglês justificou o emprego do termo com os factos recentes reveladores de uma situação de transitoriedade: o Presidente da República fora deposto, o Congresso dissolvido pela Junta Revolucionária, a Constituição parecia em vias de liquidação, o Ministério em exercício carecia da indispensável legalidade outorgada por eleições livres e era ainda elementar o rápido restabelecimento de um Poder Legislativo na plenitude dos seus direitos. Sir Carnegie pediu, no entanto, ao seu interlocutor que lhe entregasse por escrito as razões que o levavam a considerar possível um imediato reconhecimento diplomático de jure, não apenas de facto, por parte do Governo inglês. Foi então que Sidónio negou enfaticamente o alegado cariz monárquico e germanófilo do movimento, reafirmando a pureza republicana dos seus objectivos, a exclusiva intenção de derrubar um Governo incapaz e impopular, o propósito claro de organizar eleições para muito breve e a absoluta falsidade dos rumores sobre a predisposição defectista ou anti-guerrista das 
unidades militares implicadas no golpe. (76) E em reforço da aliadofilia do seu Governo solicitou todas as informações disponíveis sobre a recente Conferência Inter-Aliados a que assistiram os drs. Afonso Costa e Artur Soares, ambos de momento presos.

A prisão dessas duas destacadas figuras do democratismo serviu de pretexto a Sir Carnegie para perguntar-lhe se achava sensato e oportuno permitir o regresso a Portugal deTelles deVasconcelos, director do jornal Liberal, monárquico e acusado de germanófilo, contra o qual o diplomata inglês lera, aliás, relatórios e acusações muito desfavoráveis. Sidónio Pais respondeu não possuir dados incriminadores contra esse exilado político e acrescentou em tom confiante que, segundo a sua observação pessoal, não existiam germanófilos em Portugal e que a Alemanha nunca fora muito popular neste país. Uma afirmação pouco convincente para o representante de Sua Magestade.

No final da entrevista, o Presidente do Ministério abordou ainda a delicada e preocupante questão dos abastecimentos, em especial carvão e trigo, bem como o período excepcional de seca que lesara gravemente a agricultura. Uma situação crítica só solúvel, em sua opinião, com o aumento da tonelagem através da preciosa ajuda da velha Aliada: no mínimo eram necessárias sessenta mil toneladas para as necessidades imediatas e a provisão de oitenta a noventa mil toneladas bastaria para dissipar toda a ansiedade. Esperava, para isso, que o Governo inglês pudesse devolver a Portugal alguns dos barcos requisitados à Alemanha e entregues pelas autoridades portuguesas ao abrigo do acordo assinado no ano transacto. Um acordo que lhe merecia algumas reservas: pareceu-lhe não terem sido devidamente previstas e acauteladas futuras carências. A conversa terminou e Sir Carnegie saiu bem impressionado: já conhecia Sidónio Pais, mas mesmo assim sublinhou que ele falava fluentemente o francês (ao contrário da opinião de João Chagas), entendia bem o inglês e a sua visível preocupação com a seca não era exagerada, pois não chovia desde Maio. (77)

Após este primeiro encontro oficial, o diplomata inglês manteve-se atento à actuação de Sidónio Pais nos Estrangeiros e na Guerra. Este, por seu turno, insistiu no delicado ponto do imediato reconhecimento de jure, sendo certo que a Grã-Bretanha e a França, por razões diversas, mas concertadas, haviam já garantido o reconhecimento de facto. (78)

$\mathrm{Na}$ apresentação de cumprimentos de ano novo do Corpo Diplomático acreditado em Lisboa e que decorreu no Palácio de Belém, ${ }^{(79)}$ o titular da «pasta» e, desde 27 de Dezembro, empossado também no cargo de Presidente da República, teve ocasião de explicar que tal acto visara atribuir maior representatividade externa ao Poder Executivo e que nessa linha julgava importante que os países aliados, com os quais Portugal participava activamente tanto em França, como em África, apoiassem a disposição do novo Governo em prosseguir o esforço de guerra, reconhecendo-o a nível diplomático. E se é verdade que o Ministro inglês não se deixou seduzir muito nem pelos argumentos, ${ }^{(80)}$

\footnotetext{
(76) Foreign Office, $n .^{\circ} 108$, Confidential, $18^{\text {th }}$ December 1917. FO 371/3369. (Public Record Office).

(77) Ibidem.

(78) Ver DEROU, Jean - Les Relations franco-portugaises (1910-1926), ob. cit., p. 163.

(79) Cf. llustração Portugueza, de 14 de Janeiro de 1918, p. 23.

(80) Foreign Office, n. ${ }^{\circ}$ 2, Confidential, January 4, 1918, FO 371/3369. (Public Record Office).
} 
nem pela afabilidade do anfitrião, outros colegas, designadamente o americano, empenhar-se-ão junto da respectiva tutela no sentido de apressarem o reconhecimento de jure para antes das eleições, seguindo com atenção a solução dada ao caso espanhol, pois que estava iminente a entrega de credenciais em cerimónia privada do novo Ministro de Espanha em Portugal, D. Alexandre Padilha - acto que ocorrerá a 26 de Fevereiro no Palácio de Belém. ${ }^{(81)}$

Não faltou, aliás, quem visse nisso a clara aposta numa aliança ibérica, que até constava das linhas programáticas do centrismo em formação. Uma suspeita reforçada pela nomeação do doutor Egas Moniz, em substituição de Augusto deVasconcelos, transferido à pressa para Londres para Chefe da Legação de Portugal em Madrid ${ }^{(82)}$ e do capitão Alberto Silva Pais como Adido Militar. Este irmão de Sidónio encarregar-se-á, em finais de 1918, da vigilância dos democráticos acusados de actividades conspirativas, embora seja, ao mesmo tempo, vigiado pelo pessoal da Legação da República Francesa em Espanha por alegados negócios e contactos com capitalistas e industriais monárquicos e germanófilos!...(83)

As reservas iniciais da diplomacia inglesa não passaram despercebidas a Sidónio Pais, que desde o rescaldo do golpe ficou suspenso de uma reacção externa favorável e não perdeu tempo a enviar telegramas às Legações com o teor dos objectivos programáticos da Junta. Cumpria-lhes divulgá-los junto das instâncias oficiais próprias e da imprensa. De qualquer modo tratava-se quase já de uma rotina e a maioria dos diplomatas limitar-se-á a proceder normalmente. Houve, porém, excepções. Em Paris, a atitude de João Chagas não surpreendeu: pediu a demissão antes que os de Lisboa Ihe fizessem essa desfeita. ${ }^{\left({ }^{84}\right)}$ Não sabia, porém, que Brito Camacho se dispusera a interceder junto do Sidónio - aconselheio a que o passasse á disponibilidade.

Em outros pontos estratégicos como Madrid ou Washington não houve surpresas: os respectivos Ministros plenipotenciários encarregaram-se de esclarecer e tranquilizar os meios oficiais e a opinião pública da prossecução de uma política aliadófila e da continuidade do regime. A surpresa viria, porém, de Londres, onde se achava um velho amigo de Camacho, de José Relvas e de Augusto de Vasconcelos, um intelectual snob e moderado, que podia, em princípio, acolher bem a reviravolta dezembrista. Mas não foi isso que sucedeu...

No dia 8 fora recebido na Legação de Portugal um telegrama de Lisboa a comunicar a natureza retintamente republicana do movimento vitorioso. Doze dias depois era a vez de Teixeira Gomes remeter para Lisboa um memorando em que recapitulava o conteúdo de anteriores telegramas e esclarecia ter dado conhecimento de toda essa

(81) Sobre o diplomata espanhol e o modo como foi informando o seu Governo da situação política portuguesa, incluindo os acontecimentos que se seguiram à morte do Presidente Sidónio Pais, ver MEDINA, João - Morte e transfiguração de Sidónio Pais, ob. cit., p. 151-152 e p. 15-79.

(82) Ver MONIZ, Egas - Um Ano de política, ob. cit., p. 91-140.

(83) Z. Europe, 1840 Portugal, Ambassadeur Français à Lisbonne, dossier 5, Secret, Madrid 21 Mai 1918. (Archives du Ministère des Affaires Étrangères).

(84) Cf. CHAGAS, João - Diório, vol. 2 - 1918, ob. cit., p. 337. Ver para o ano de 1918 Diário, vol. 3, ob. cit. 
informação ao Foreign Office. No entanto, a 13, Sidónio voltou a insistir com novo telegrama, pedindo-Ihe transmitisse com urgência impressão fizeram acontecimentos esse Governo e opinião pública e da opinião de V. Exa sobre atitude desse Governo. Peço ainda que me tenha ao corrente. ${ }^{(85)}$ Por detrás deste laconismo oficioso escondia-se o desejo de uma intervenção pronta e entusiástica do representante português junto da imprensa britânica, mas Teixeira Gomes não só reservou a sua opinião sobre os eventos, como também declarou, na resposta enviada a 14, que a imprensa tem-se limitado registar acontecimentos dando apenas relevo às afirmações de serem mantidas compromissos para com Aliados. Quanto à impressão pessoal do elemento oficial consta-me que é penosa por haver ainda pouco tempo que o Dr. Bernardino Machado aqui recebeu por parte do Chefe de Estado e Governo Inglês grandes provas de consideração e simpatia. ${ }^{(86)}$

A resposta não agradou pelo que dizia e sobretudo pelo que omitia. Continuou a troca de telegramas, descrita por João Medina no estudo monográfico que dedicou ao incidente. ${ }^{\left({ }^{87}\right)}$ Em 20 de Dezembro Sidónio Pais fez uma pronta e áspera correcção à última parte da nota emitida por Teixeira Gomes para a imprensa inglesa: Magistratura presidencial não foi subsituida por nenhuma Junta... Aumentava, assim, a pressão de Lisboa para que fossem feitos desmentidos rápidos e vigorosos contra rumores de defectismo, monarquismo e germanofilia. Crescera, também, a desconfiança e o mal-estar, embora o escritor algarvio feito diplomata tivesse, segundo comentário de Camacho, telegrafado aceitando a nova ordem de coisas. Entretanto, no início de Janeiro, foi chamado a conferenciar com o Presidente da República e titular dos Negócios Estrangeiros. No seu regresso passou por Paris, onde teve um demorado encontro com joão Chagas, e em Madrid, muito descansadamente, visitou o Museu de Prado. Por fim, a 17 de Janeiro e nas palavras de Camacho, chegou sem dar cavaco.

O que se desconhecia até agora é que enquanto o Ministro chegava a Lisboa, Sidónio Pais pedira para Londres ao I. ' Secretário e Encarregado de Negócios da Legação, o 2. ${ }^{\circ}$ Conde de Tovar, Pedro Tovar de Lemos, ${ }^{(88)}$ que averiguasse as verdadeiras disposições do Governo inglês. Apesar da delicadeza moral da tarefa, esse funcionário satisfez a incumbência logo no dia 15 e de forma a completar o desfecho que o incidente veio a ter. ${ }^{(89)}$ Não surpreende, aliás, que a minuciosa e indiscreta carta de Tovar tenha constituído uma peça integrante do dossier organizado sobre o Ministro português, a par, entre outros documentos, do auto de inquérito e interrogatório conduzido em 27 de Janeiro no edifício do Hotel Avenida Palace pelo juiz Alfeu Policarpo Ferreira e Cruz. Este

(85) Cf. MEDINA, João - Manuel Teixeira Gomes e Sidónio Pais, art. cit., p. 120.Ver também resumo do incidente em RODRIGUES, Urbano - A Vida romanesca de Teixeira Gomes, ob. cit., p. 137 - 151 e LOPES, Norberto - O Exilado de Bougie. Perfil de Teixeira Gomes. Com um estudo de João de Barros. Lisboa: Parceria António Maria Pereira, 1942, p. 123-126.

(86) Cf. MEDINA, João - Manuel Teixeira Gomes e Sidónio Pais, art. cit., p. 120.

(87) Ver Ibidem, p. $121-122$.

(88) Ver Tovar (Condes de ), in Nobreza de Portugal, vol. 3. Lisboa: Editorial da Enciclopédia Lda, 1960-19189. p. $450-451$.

(89) Ver SILVA, Armando Barreiros Malheiro da - Sidonismo e sidónio. História e mito, dissert. cit., vol. 2, p. 55-56. 
magistrado era o responsável pelo Serviço de Inquérito aos Ministérios e Repartições do Estado e, consequentemente, pela coordenação dos inquéritos à gestão das diferentes «pastas» e à conduta moral dos respectivos titulares. $\left({ }^{(90)}\right.$

$O$ inquérito efectuado culminou na ruptura formalmente declarada em 19 desse mesmo mês, quando Teixeira Gomes foi recebido por Sidónio Pais, recém-chegado da sua viagem ao Norte. Vinha eufórico pelo êxito alcançado e este pormenor ajuda a enquadrar as afirmações que terá proferido no final da conversa com o seu interlocutor: Referiu-se ao novo estado das coisas como ao acontecimento mais notável da nossa História moderna em comparação do qual o 5 de Outubro pouco valia. Disse que já não era unionista, que não tinha partido algum, que a circunstância de haver no Ministério alguns membros unionistas não significava que esse partido ali dominasse e que agora o que havia era um partido nacional. (91) Sidónio não lera ainda a carta de Tovar, mas no seu espírito estava decidida a demissão de Teixeira Gomes sem passagem à disponiblidade. E foi exactamente isto que lhe comunicou após ter censurado a sua mudança de atitude para com os negócios da guerra. Abordaram ainda o assunto da casa da Legação e disse-me que não tinha dúvida em que eu ficasse com ela. ${ }^{(92)}$

Uns dias mais tarde dará parte a Brito Camacho e este a 25, n'A Lucta, contou a Teixeira Gomes que o S. Pais tinha informação de que eu fizera este absurdo: não dissera ao G. I. que fora chamado a Portugal, mas sim que me decidira a vir ver a situação pois achava as disposições destes senhores escuras. Respondi-lhe que nada havia mais fácil de esclarecer: bastava consultar Sir P. Graham ou Sir E. Crowe com quem falei no F. O., para saber que tudo aquilo era mentira. ${ }^{(93)}$ Regressou, de seguida, ao Avenida Palace onde estava hospedado e pelas 2 horas da manhã foi acordado pela presença de três agentes da Polícia de Investigação Criminal acompanhados pelo juiz de instrução Alfeu Cruz, que Ihe perguntaram se tinha algum passaporte ou papel diplomático dado pela Legação inglesa. Respondeu que não e depois de mostrar os papéis que possuía levaram-lhe o passaporte trazido de Londres e uma carta, ${ }^{(94)}$ ordenando-lhe que se considerasse detido no Hotel. No dia 27 foi interrogado, como já dissemos, pelo juiz Alfeu e nesse mesmo dia, sabedor (por Brito Camacho e pelos jornais de 26) das acusações que pesavam contra si, redigiu uma apressada carta ao Ministro dos Negócios Estrangeiros Sidónio Pais pedindo que através desse Ministério elas fossem transmitidas ao Foreign Office, pois estava certo de que ali fornecerão immediatamente $a V$. Ex ${ }^{a}$ a prova cabal de que essas accusações não são verdadeiras. A sua opinião era confirmada, em telegrama

(90) O Diário de Notícias e A Capital de 23 de Janeiro deram destaque às diligências efectuadas pelo juiz de direito Alfeu Cruz no sentido de apurar o fundamento sobre as suspeitas lançadas em torno da fortuna pessoal do doutor Afonso Costa.

(91) Cf.TEIXEIRA-GOMES, Manuel - Londres maravilhosa e outras páginas dispersas, ob. cit., p. 133.

(92) Cf. Ibidem, p. 133.

(93) Cf. Ibidem, p. 133.

(94) Dossier 24 Teixeiro Gomes, tira de papel almaço dentro do ofício-relatório do Dr. Alfeu Cruz, datado de 31-1-1918. (Arquivo de Sidónio Pais - Militar, Lente e Político, Subsistema Presidência da República). 
pessoal, por Sir Eyre Crowe, ${ }^{(95)}$ confirmação que implicitamente coloca Tovar como autor de uma maliciosa intriga e tanto mais grave porque nela assentaram as conclusões parciais do inquérito do juiz de instrução. ${ }^{(96)}$

No entanto e apesar da gravidade indiciada pelos elementos apurados, o magistrado considerou no final do seu ofício-relatório, datado de 31 de Janeiro, desnecessaria a continuação da detenção do Snr. Teixeira Gomes não só pela sua cathegoria, mas tambem pela das pessoas que podem constatar os factos apontados com quem não é de recear que ele comunique, parece-me que the deve ser levantada, embora the não sejam concedidos passaportes, continuando a investigação sem prejuizo do procedimento que os factos verificados venham a justificar. ${ }^{(97)}$ Recomendação seguida e cumprida a 4 de Fevereiro: pelas 7 horas da manhã, o chefe da Polícia informava-o de que estava livre, podendo partir para onde quisesse. Teixeira Gomes mostrou vontade em ir para a Figueira da Foz e só mais tarde é que regressou à sua terra natal, ${ }^{\left({ }^{(9)}\right)}$ «exilando-se» aí até que em Lisboa outros senhores aparecessem a tomar conta do «leme»...

$\mathrm{O}$ incidente ficara encerrado, mas deixara brechas. Desde logo, a necessidade de arranjar um substituto adequado para o lugar que vagara. Talvez Pedro Tovar de Lemos tivesse sonhado com a oportunidade de chefiar a Legação, mas o certo é que a escolha recaiu no experimentado Augusto de Vasconcelos, que dirigia, desde 8 de Agosto de 1914 e pela segunda vez após o 5 de Outubro, a Legação de Portugal em Madrid. Saía de uma posição estratégica, que será assegurada por Egas Moniz, para outra onde se tornava pertinente a defesa e a difusão da imagem externa do novo Governo de Lisboa e da sua proclamada fidelidade à Causa dos Aliados.

Augusto de Vasconcelos era um aliadófilo camachista, tal como Sidónio Pais e todo o «estado maion» da União Republicana, e teve ocasião de o afirmar categoricamente em carta confidencial de 3 de Abril para o seu amigo Norton de Matos, motivada por um incidente estranho que envolveu o ex-Ministro da Guerra, exilado em Londres, o major João Casqueiro e o novo Ministro da Legação portuguesa e teve por base um alegado convite feito pelo referido major ao coronel Norton de Matos para presidir à Delegação Portuguesa da C.I.R., convite que transpirou logo para a imprensa e foi cabalmente desmentido porVasconcelos em ofício de 18 de Maio dirigido ao Secretário de Estado dos Negócios Estrangeiros, Joaquim do Espírito Santo Lima. Mas voltando à carta de 3 de Abril convém sublinhar a passagem em que Vasconcelos deixa claro o seguinte:

Se eu entendo, que não posso nem devo negar o concurso da minha modesta acção a qualquer governo republicano, para o representar no estrangeiro, faço condição

(95) Dossier 24 Teixeira Gomes, telegrama de Sir Eyre Crowe, 8-2-1918. (Arquivo de Sidónio Pais - Militar, Lente e Político, Subsistema Presidência da República; e TEIXEIRA-GOMES, Manuel - Londres marovilhosa e outras páginas dispersas, ob. cit., p. 139.

(96) Dossier 24 Teixeira Gomes, tira de papel almaço dentro do ofício-relatório do Dr. Alfeu Cruz, datado de 31-1-1918. (Arquivo de Sidónio Pais - Militar, Lente e Político, Subsistema Presidência da República).

(97) Dossier 24 Teixeira Gomes, ofício-relatório do Dr. Alfeu Cruz, datado de 31-1-1918 e em 2 fls, papel timbrado do Serviço de Inquérito aos Ministérios e Repartições do Estado. (Arquivo de Sidónio Pais - Militar, Lente e Político, Subsistema Presidência da República).

(98) Cf. MEDINA, João - Manuel Teixeira Gomes e Sidónio Pais, art. cit., p. 124. 
essencial dessa colaboração, a conformidade de pontos de vista no que se refere á politica a seguir. Ora o Governo do Dr. Sidonio Paes deu-me as mesmas instrucções, absolutamente as mesmas, que eu recebera do Governo do Afonso Costa ácerca da orientação geral da nossa politica externa e da politica a seguir com os aliados. É por isso que me revolto contra o desgraçado folheto de Paris, contra a campanha empreendida pelos Dr. Bernardino Machado e João Chagas e contra quaesquer manobras desse genero, que além de serem anti-patrioticas, além de prejudicarem muito mais gravemente o paiz, de que o Governo que pretendem combater, representam uma flagrantissima injustiça e um profundo agravo para aqueles, que estão servindo o novo Governo. Não me fundo em declarações; bem sei que valôr atribuir tantas vezes ás declarações dos politicos. Provo o que avanço com os factos. Foram as instruç̧ões que recebi: são aquelas que todos os dias as vem confirmar; serão as que resultam dos factos, como eles se veem desenrolando. Não é exacto, como se diz, que o Governo queira fazer retirar pouco a pouco o C.E.P. Todos os dias eu tenho solicitado do Foreign Office transportes para enviar mais forças de reforço ao C.E.P.e se essas forças não teem vindo, é porque o governo britanico mais preocupado com a colaboração americana, do que com a nossa, reserva todos os seus transportes disponiveis para a condução das tropas yankees. ${ }^{(99)}$

Os factos disponíveis, que a historiografia tem revelado em pesquisas recentes de entre as quais destacamos a dissertação de José António Sequeira Gonçalves, ${ }^{(100)}$ confirmam a fiabilidade das veementes afirmações de Augusto de Vasconcelos e 0 objectivo principal da sua missão em Londres: garantir ao Governo de Sua Magestade que Portugal não mudava, no essencial, a conduta de guerra anteriormente gizada e solicitar-the os meios indispensáveis para que na prática ela pudesse ser prosseguida. A par disto cabia-the ainda desfazer as reservas e as desconfianças do Foreign Office e de todo o Gabinete, adensadas naturalmente pela forma como se processara a demissão de Teixeira Gomes.

O novo Ministro em Inglaterra, amigo e conviva de Teixeira Gomes, mas de quem este se queixará amargamente nos seus apontamentos por não ter feito o que the prometera sobre a casa em Londres onde haviam ficado a sua mobilia e demais pertences, ${ }^{(101)}$ partiu no dia 14 de Fevereiro só chegando a Londres no dia 10 de Março à noite. E a 15 enviou um longo ofício, à guisa de relatório, para o Presidente da República e titular dos Negócios Estrangeiros, pondo-o a par dos contactos que estabelecera nos meios oficiais logo após a sua chegada. ${ }^{(102)}$

(99) Dossier Questão Vasconcellos-Norton, cópia da carta para Norton de Matos, 3 de Abril (ver Anexo 17-G, 1). (Arquivo de Sidónio Pais - Militar, Lente e Político, Subsistema Presidência da República).

(100) Ver GONÇALVES, José António Sequeira - Sidónio Pais e a participação portuguesa na guerra de $19 / 4$. 1918 , ob. cit., 2 vols.

(101) Cf.TEIXEIRA-GOMES, Manuel - Londres maravilhosa e outras páginas dispersas, ob. cit., p. 140-141. As razões do queixoso foram resumidas em tom apologético por RODRIGUES, Urbano - A Vida romanesca de Teixeira Gomes, ob. cit., p. 144-151.

(102) Ver SILVA, Armando Barreiros Malheiro da - Sidónio e sidonismo. História e mito, dissert. cit., vol. 2 , p. $837-844$. 
No dia II conseguiu ser recebido por um dos Sub-Secretários do Foreign Office Sir Ronald Graham, que se mostrou bastante informado àcerca da política interna portuguesa e desejoso de obter esclarecimento para as dúvidas que os acontecimentos em Portugal the haviam suscitado. Sir Graham intrigara-se com o facto de um Governo republicano precisar do apoio dos monárquicos, que para os ingleses formavam um partido germanófilo. A esta perplexidade Vasconcelos retorquiu que o Governo não se apoiava nos monarquicos, embora estes apoiassem o Governo, que os libertara de violenta pressão, que sobre eles exercia o Governo anterior, que o Governo se apoiava essencialmente na opinião pública e esta era, sem sombra de dúvida, republicana conservadora; e que não Ihe parecia exacto considerar os monárquicos como parte integrante de um partido germanófilo, porque em Portugal não havia nenhum partido germanofilo e eventuais excepções não faziam a regra. Os argumentos aduzidos não demoveram o interlocutor da sua opinião, mas fizeram-no reconhecer que a atitude hostil do Governo britânico estava a mudar porque as autoridades de Lisboa tinham vindo a dar sucessivas provas de confiança. Não escondeu, por isso, curiosidade em conhecer melhor as intenções políticas do Governo português, agora que se consumara a ruptura com os unionistas e se fizera a correcção de trajectória para a constituição de um governo forte, com a estabilidade necessaria para conceber e executar um largo programa de administração, sob a base da eleição presidencial, provavelmente por sufragio directo. Sir Graham gostou do que ouviu, mas perguntou quando é que seriam realizadas as eleições.

Este ponto era crucial: apesar do reatar da confiança e da retoma de um bom ambiente nas relações anglo-lusas, era tradição da política externa britânica só reconhecer Governos legitimados por eleições. Posição reafirmada no dia 12 durante a entrevista com - Ministro do Foreign Office Arthur James Balfour, que foi peremptório: É indispensavel o voto de uma assembleia legislativa, por melhor que seja a nossa bôa vontade de os acolher como definitivamente constituidos. Augusto de Vasconcelos ainda insistiu na pretensão de um reconhecimento de jure imediato que Ihe proporcionaria ser logo acreditado em Inglaterra e invocou a propósito a solução espanhola - entrega de credenciais em audiência privada. Balfour esquivou-se alegando que D. Alexandre Padilla não entregou credenciais, limitando-se a comunicar os termos em que estava acreditado. Esta afirmação colheu Vasconcelos desprevenido, pedindo a Sidónio Pais informações detalhadas sobre o caso. $\mathrm{Na}$ entrevista com Arthur Balfour teve ainda ensejo de desfazer as acusações de germanofilia que os exilados - Bernardino Machado, João Chagas, Alexandre Braga, entre outros - vinham urdindo com êxito, sobretudo em França, contra o Governo do seu país e de aflorar a importante questão dos transportes. Sobre este ponto foi-lhe sugerida uma entrevista com Lord Robert Cecil.

Mas antes dos frutuosos encontros que veio a ter com o Ministro do Bloqueio e com o seu Adjunto, Sir Eyre Crowe, Augusto de Vasconcelos dialogou com Lord Hardinge, Secretário Permanente dos Negócios Estrangeiros e que representava as tendências da Côrte no Ministério. Não admira, por isso, que na conversa havida fosse abordada a questão dos bens do ex-rei D. Manuel, remetida para reapreciação pelas autoridades portuguesas.

Urgente e decisiva para a reabertura dos dossiers mais graves foi, de facto, a entrevista com Lord Cecil e Sir Crowe, a quem Vasconcelos expôs o que se passara com a Comissão de Abastecimento e como nós, cedendo ás exigencias da Comissão inglêsa, 
anulávamos todos os contratos pendentes de fornecimento de trigos, para aceitarmos o que fosse adquirido por intermedio da Comissão. Só que esta não conseguira até ao momento dar execução eficaz ao seu dever e o resultado era a iminente falta total de trigo em Lisboa e no Porto, com os subsequentes riscos de perturbação da ordem pública, que em toda a parte são a consequencia inevitavel da fome. Ora como em Portugal o pão era a base de alimentação popular, se ele faltasse pode-se dizer que ha fome. ${ }^{(103)}$

A problemática dos transportes não esgotou, porém, a conversação com Lord Cecil, que se declarou interessado em saber o que se estava a passar em Portugal e auscultar a opinião de Augusto de Vasconcelos sobre a política espanhola. Entretanto, o Ministro português manifestou a Sir Crowe os seus mais vivos protestos contra a campanha, desenvolvida sobretudo em França, visando descredibilizar o Governo de Sidónio Pais, ao que o interlocutor Ihe respondeu que o Governo inglês nos fizera justiça, não acreditando nessas acusações, mas, acrescentou, os Senhores tem-lhes dado pasto com certas imprudencias, que mais valera evitar. Uma hábil estocada a que Vasconcelos reagiu indagando que imprudências eram essas. E Sir Crowe avançou com dois tipos de factos: sobre certas autoridades administrativas locais o Governo inglês tinha a absoluta certesa de que são agentes alemães, precisando no decurso da conversa tratarem-se de autoridades da Madeira; ${ }^{(104)}$ e chocava-lhes a extrema benevolência com que em Portugal eram tratados os espiões ou suspeitos de espionagem, rematando: Nós, inglezes, enforcamo-los; os franceses fusilam-nos; os senhores limitam-se a expulsá-los, o que Ihes permite continuar em plena actividade malefica. A isto conseguiu Vasconcelos retorquir que essa lenidade das nossas leis não era culpa do actual Governo, sendo uma prática quase consuetudinária, embora reconhecesse a necessidade de uma adequada revisão da lei. Esses argumentos eram, todavia, insuficientes para que se pudessem acusar as autoridades portuguesas de germanófilas.

A rematar esta série de contactos Augusto de Vasconcelos entendeu indispensável, mas apenas por dever protocolar, pedir uma audiência ao Primeiro-Ministro inglês Lloyde George. A realização a 15 de Janeiro de uma reservada Conferência do Comité de Guerra Inter-Aliados em Londres, a que o Ministro de Portugal esteve presente, tornou possível que, durante o almoço oferecido por Lloyde George, trocassem algumas palavras: afirmei mais uma vez os sentimentos que animam o nosso Governo e como ele se referisse favoravelmente á sua acção tive ocasião de prestar a devida homenagem ás qualidades de inteligencia, de decisão, de energia e de reflexão do Chefe de Estado do meu paiz. Nesse almoço tomaram parte personalidades já agora historicas eVasconcelos teve o prazer de conversar com algumas delas. No fim da refeição aproximou-se de Georges Clemenceau para lhe manifestar a sua indignação pelo facto de uma parte da imprensa francesa maltratar sistematicamente o novo Governo português, ao que o célebre político da

(103) Ver SILVA, Armando Barreiros Malheiro da - Sidónio e sidonismo. História e mito, dissert., cit., vol. 2. p. $61-62$.

(104) Na sequência desta indicação o Governador Civil do Funchal Carlos José Barata Pinto Feio, nomeado por decreto de 18 de Dezembro de 1917, mas só tomou posse do cargo a 5 de Fevereiro de 1918, foi chamado a Lisboa a 12 de Março e exonerado.Ver GOMES, Fátima Freitas eVERISSIMO. Nelson - A Madeira e 0 sidonismo. Funchal: Direcção Regional dos Assuntos Culturais, Governo Regional da Madeira, 1983, p. I 37- 139. Estes autores não referem o motivo porque Pinto Feio foi substituído. 
III República e Presidente do Governo desde 1917, respondeu alimentando um breve, mas interessantíssimo diálogo, salpicado de algum cinismo político-diplomático:Meu caro amigo, disse-me, o seu Governo é considerado como germanofilo! Saltei indignado e protestei com toda a energia, contra semelhante injustiça. - Mas é de injustiças, que o Mundo é feito! exclamou, filosofando. - Será, mas é para as refazer, que V. Ex ${ }^{a}$ tem lutado toda a sua vida e nós todos nos associámos contra os boches. - Muito bem; mas só os fortes poderão dissipar a densa atmosfera que os envolve. - Pois com os factos estamos nós provando todos os dias a inanidade da acusação, que não é senão uma invenção de má fé dos nossos adversarios.

A atitude de Clemenceau evidenciava bem a força da campanha de Bernardino Machado e a enorme influência que João Chagas exercia junto da classe política francesa. Uma campanha de que o ex-Presidente da República foi o mentor e o arauto mais saliente, como temos referido, tornando espinhosos e quase inúteis os esforços da propaganda pró-governamental em Paris. ${ }^{(105)}$

Em Londres as coisas correram mais favoráveis para o Ministério de Sidónio Pais, não conseguindo o grupo de Paris que Norton de Matos se empenhasse abertamente na campanha lançada com êxito em França. ${ }^{(106)}$ Quanto a este aspecto o trabalho de Augusto de Vasconcelos pôde surtir rápidos e benéficos efeitos, embora não tenha convencido o Governo inglês a declarar o reconhecimento oficial ou de jure antes de eleições. Obteve, porém, o privilégio de ser o primeiro representante de um Poder não sancionado ainda por voto explícito da Nação a quem era concedida uma audiência real. Aconteceu no dia 20 de Março, ás II horas da manhã, no Buckingham Palace e o Chefe da Legação portuguesa ficou agradavelmente impressionado com a simplicidade protocolar da Côrte de Jorge V, em flagrante contraste com as exigencias pretensiosas da Côrte de Madrid. A conversa decorreu com naturalidade e agrado, percebendo-se que o intuito do Rei consistia em interceder junto do representante do novo Governo português a favor da velha pretensão de D. Manuel de reaver os seus bens. Matéria delicada sobre a qual Augusto de Vasconcelos procurou esclarecer o monarca face às leis vigentes, prometendo, porém, empenhar-se pela entrega daqueles bens que eventualmente ainda não tivessem sido devolvidos.

O Ministro de Portugal em Londres não exagerava quanto à crescente boa vontade das autoridades britânicas e compreende-se, por isso, que a 3 de Abril tenha expedido um telegrama urgente para o M.N.E., nestes termos: Tenho grande satisfação de communicar a V. Exa que Governo Inglez acceita linha de delimitação para sul Angola proposta pelo Governo Portuguez, sob a condição de autorisar Governo da União Sul Africana aproveitor agua dos grandes rapidos rio Cunene que Ihe seja necessaria para irrigação e energia electrica. Suponho que devemos responder imediatamente com a nossa aquiescencia, mediante convenção que nos permita participação nesses beneficios. ${ }^{(107)} \mathrm{O}$ assunto fora tratado com

(105) Dossier Bernardino Machado, I doc. (Arquivo de Sidónio Pais - Militar, Lente e Político, Subsistema Presidência da República).

(106) Ver SILVA, Armando Barreiros Malheiro da - Sidónio e sidonismo. História e mito, dissert. cit., vol. 2. p. 844-846.

(107) Colónias Ocidentais. Volume II - Delimitação do Sul de Angola, 3. ${ }^{\circ}$ piso, arm. 9, maço 21. (Arquivo Histórico do Ministério dos Negócios Estrangeiros). 
insistência pelo Governo de Afonso Costa, mas só agora, sob a gerência de um pretenso Ministério germanófilo, recebia o empurrão inglês para ser resolvido a contento das partes envolvidas. Não tardou, por isso, a resposta de Lisboa, assinada por Sidónio Pais, e na qual se percebe a sua particular atenção aos aspectos do fomento económico e industrial, tanto na Metrópole, como no Ultramar, mas numa base de cooperação que não lesasse os interesses nacionais. ${ }^{(108)}$

Ponderados rapidamente os aspectos delicados do problema, era dada a 19 de Abril resposta para Londres no sentido da aceitação da proposta dos limites do Sul de Angola nos termos estabelecidos, mas devendo Vasconcelos deixar consignado na resposta que entende, por rapido do Cunene a propria cataracta Rua Cana ou alguns dos rapidos a jusante dela até foz rapido em que o rio é limitrophe. ${ }^{(109)}$ Determinação executada através da nota oficial de 22 para o Governo inglês. E a partir de então ficaram fixadas as bases políticas e técnicas de umas negociações que haveriam de culminar em 1920, ano da realização dos trabalhos de delimitação no terreno.

Assim se materializou uma vitória diplomática conseguida no contexto das opções que, perante a Guerra e o seu desfecho, a Grã-Bretanha e os países aliados consideraram indispensáveis para a salvaguarda dos seus interesses estratégicos.

Este notório desanuviamento da política oficial britânica face à situação dezembrista beneficiou ainda, e a par de uma favorável campanha na imprensa inglesa, do contributo de Sir Lancelot Carnegie e de Sir Arthur Hardinge em despachos expedidos após o êxito das viagens do Presidente Sidónio Pais ao Norte e ao Sul do país.

A 19 de Janeiro o Ministro inglês em Lisboa informava o Sr. Balfour que a digressão presidencial tinha atingido os contornos de um plebiscito, tão efusivas e numerosas foram as demonstrações de simpatia e de adesão populares. Entendia, por isso, que o Presidente da República portuguesa começava a merecer o favor do Governo de Sua Magestade não só pela sua reiterada fidelidade aos compromissos assumidos quanto à conduta de guerra, mas também pelo modo como mostrou a sua sinceridade ao aceder prontamente a todos os pedidos britânicos em matéria de cooperação militar quer em França, quer na África Oriental. Sir Carnegie estava optimista sobre as possibilidades de Sidónio Pais se aguentar no Poder depois de ter vencido a revolta da Marinha em 8 de Janeiro e de ter conseguido prender os principais activistas da Carbonária. Estes factos tornavam remotas as possibilidades de um regresso dos democráticos à cúpula do Estado republicano. Mas subsistia um perigo: os monárquicos davam largas à sua excessiva admiração por Sidónio na expectativa de favores políticos e esta atitude podia alienar-lhe o apoio de republicanos moderados que ainda se sentiam próximos dele. (110)

Por seu turno, Sir Arthur Hardinge, Ministro em Madrid e velho amigo de Augusto de Vasconcelos, de partida para Londres, deu conta da conversa que ambos tiveram. Fê-lo num despacho confidencial, com data de 18 de Fevereiro. $E$ aí se lê que discutiram a possibilidade do reconhecimento de jure imediato do Governo português, sendo trazidos

(108) Ver SILVA, Armando Barreiros Malheiro da - Sidónio e sidonismo. História e mito, dissert. cit., vol. 2, p. 64-65.

(109) Colónias Ocidentais. Volume II - Delimitação do Sul de Angola, 3. piso, arm. 9, maço 21, n. ${ }^{\circ} 104$. (Arquivo Histórico do Ministério dos Negócios Estrangeiros).

(110) Foreign Office, n. ${ }^{\circ}$, Confidential, Lisbon, January 19, 1918, FO 371/3369. (Public Record Office). 
à colação vários casos histórico-diplomáticos da América Latina e a inevitável solução espanhola. O recém-nomeado Ministro em Londres jogou todos os trunfos disponíveis para convencer Hardinge da vantagem de uma regularização rápida nas relações anglo-lusas e não foi mal sucedido, a avaliar pelo tipo de considerações de sua lavra que este gravou no despacho: em sua opinião talvez devesse ser atendida uma fórmula excepcional, não aplicável a casos futuros, para serem aceites as credenciais do EnviadoVasconcelos e preservada a sua posição enquanto não fossem efectuadas as eleições para Presidente da República e para o Congresso. Em abono do seu parecer favorável aduzia o facto de se tratar de dois países comprometidos no mesmo combate e as boas referências que possuía àcerca do actual Governo português. Constou-lhe ser o melhor de todos desde a queda do regime monárquico e os seus esforços no sentido de restaurar as liberdades cívicas e neutralizar os excessos dos carbonários grangearam-lhe calorosas manifestações de apoio popular ao longo das suas recentes viagens presidenciais pelo país.A estas impressões juntou ainda uma opinião pessoal muito favorável relativamente aos atributos de Sidónio Pais, que tivera ensejo de conhecer em Lisboa no desempenho das funções de Ministro das Finanças no Gabinete Vasconcelos.

Numa linha idêntica à destes dois diplomatas britânicos posicionou-se o Ministro americano, já sem quaisquer reservas sobre a aliadofilia da política externa seguida por Lisboa. A sua simpatia pela experiência do major matemático cresceu até ao seu brusco e brutal término e os resultados eleitorais, não obstante a taxa elevada de abstenções na eleição dos deputados e menor na do Presidente, convencê-lo-ão de que a maioria do povo português estava com Sidónio Pais e de que este usufruía de uma popularidade não só única, como inquestionável. (III)

O prisma dos franceses tinha de ser diferente, tanto em Paris como em Lisboa.

No Quai d'Orsay eram bem acolhidas as opiniões adversas às iniciativas políticas e aos protagonistas da situação dezembrista/sidonista. João Chagas era ouvido atentamente sobre os tópicos mais díspares: pronunciou-se, por exemplo, sobre $\circ$ Visconde de Alte, Ministro português nos E. U.A., dizendo tratar-se de um excelente funcionário, mas não indicado para tão alto posto. O seu homólogo americano, Thomas Birch, também não escapou às críticas de Duarte Almeida, Cônsul Geral de Portugal em Montagne, Gironde, e amigo de Bernardino Machado. Em sua opinião ele era um bom vivant, mas absolutamente incapaz de se dedicar a trabalhos sérios, como eram os políticos, e daí ter caído no embuste de confiar em Sidónio Pais. (1 12) Amostras eloquentes da sanha anti-sidonista, fértil nos meios oficiais franceses, e que nos permitem conhecer as múltiplas facetas de uma campanha que não se esgotou nos manifestos e folhetos corrosivos de Bernardino Machado e amigos. A versão por eles difundida em solo gaulês não era contrariada pelos despachos de Émile Daeschner, apesar da lucidez de muitas das suas observações e comentários e da extrema prudência das suas comunicações iniciais. É curioso notar que, após a legitimação eleitoral da República Nova e o reconhecimento

(III) Records of the Department of State relating to internal affairs of Portugal, 1910-1926, Political affairs, 705/4 roll, despachos entre 19 de Dezembro de 1917 e 22 de Maio de 1918. (National Archives, Washington)

(112) Z. Europe, 1840 Portugal, Politique intérieur, dossier géneral, 15 Mai 1918. (Archives du Ministère des Affaires Étrangères). 
de jure desta pelo Governo francês, o tom de hostilidade anti-sidonista dos ofícios do Ministro em Lisboa cresceu desassombradamente, parecendo ser a reacção contra um modelo que se assemelhava a certos casos histórico-políticos, como o bonapartismo ou o boulangismo, de má memória para os adeptos e servidores da III República.

O comentário de Clemenceau que tanto indignou Augusto de Vasconcelos ajuda, pois, a compreender os limites da missão de Bettencourt Rodrigues, aceite sem dificuldade pelas autoridades francesas como substituto de João Chagas, mas sem que essa aceitação formal significasse um sincero agrément político. No entanto, o novo Ministro de Portugal em Paris era um unionista francófono e francófilo que já servira no mesmo posto por uns escassos quatro meses, ou seja, o tempo de duração do Governo de Pimenta de Castro.

Por uma carta de Brito Camacho sabe-se que Sidónio Pais pensou nele para os Negócios Estrangeiros, mas os seus atributos pessoais e a necessidade de alguém com perfil especial para remar contra a corrente hostil recomendavam o seu retorno ao país onde completara a sua formação de médico alienista. Além disto era velho amigo do Ministro Pichon, amigo do Presidente Poincaré e possuía na alta política da França as melhores relações. Um bom curriculum para uma árdua missão.

Entre as prioridades que aguardavam Bettencourt Rodrigues tinha de apostar numa contra-ofensiva propagandística e publicitária para rapidamente modificar a atitude da opinião pública e, em especial, a dos meios oficiais da III República.

Compreende-se, pois, que nas suas primeiras comunicações oficiais e particulares remetidas ao Chefe do Estado e titular da pasta dos Estrangeiros tenha destacado as démarches exploratórias junto das autoridades francesas. Fê-lo, por exemplo, em carta de 3 de Fevereiro, escrita poucos dias após a sua chegada a Paris, a 24 de Janeiro, tendo assumido logo a gerência da Legação, mas só quatro dias depois é que começou os seus contactos oficiais. Entrevistou-se primeiramente com o Chefe do Protocolo do Quai d'Orsay, encontrando-se de seguida com o Director dos Negócios Políticos e Comerciais, a quem forneceu todos os esclarecimentos necessários sobre as mudanças políticas operadas em Portugal e colheu a impressão de que esses esclarecimentos cairam em excellente terreno. No dia 30 de Janeiro foi recebido pelo Ministro Pichon, que se mostrou bem informado sobre a situação portuguesa e muito sinceramente animado das melhores disposições para com o actual governo, embora nada adiantasse quanto à apresentação de credenciais ao Presidente Poincaré e não escondesse as dúvidas e apreensões dos primeiros momentos do golpe.A Conferência Inter-Aliados impediu que se concretizasse o encontro com o Presidente do Governo, Georges Clemenceau, mas em compensação o enviado português conseguiu reunir com os responsáveis do jornal Temps, tendo-lhes afirmado que a renovação das assinaturas dependia da atitude futura para com o novo Governo de Lisboa e o argumento parece ter surtido o seu efeito. Também o Matin, que encabeçara uma calumniosa campanha de difamação, mudara de tom, o que attribuo á intervenção da censura sobre a qual tem directa ingerencia o sr. de Margerie, director dos negocios politicos. Sugeriu ainda a necessidade de dispor de uma conta aberta num qualquer Banco para fazer face a imprevistos de propaganda e publicidade junto da opinião pública francesa. E, por fim, não se mostrou muito preocupado com a campanha anti-governamental dos foragidos do precedente governo expulso do poder - Bernardino, João Chagas e Norton de Mattos. 
Bettencourt Rodrigues procurou minorar as proporções dos estragos dessa anti-patriotica e desleal propaganda, sendo muito enganadoras as provas de boa vontade colhidas nas instâncias oficiais. Mais visivel e gratificante era a atitude dos jornais, não obstante persistissem certos «focos» anti-sidonistas. (113) Atrair a imprensa constituiu, por isso, um imperativo de mais fácil e bem sucedida execução. $\bigcirc$ Matin, por exemplo, publicou a entrevista de Paul Strozzi, deslocado a Lisboa a pedido de Homem Cristo Filho, com o chefe do movimento de 5/8 de Dezembro. Sidónio Pais aproveitou o ensejo para explanar, por escrito, os motivos e as linhas programáticas do golpe.(114)

Os termos incisivos e hábeis da sua justificação dedicada aos franceses àcerca do que se estava a passar em Portugal eram um pequeno e, só por si, infrutífero passo para atingir a meta almejada. E a parte mais difícil não consistia tanto em domar a imprensa e a opinião pública, mas sobretudo em conseguir que esta forçasse os governantes a reconsiderarem a sua postura. Era enorme a dificuldade da tarefa e, pelos vistos, Bettencourt Rodrigues não possuía soluções novas na algibeira. Circunstâncias fortuitas, a que foi alheio e até relutante de início, ${ }^{(115)}$ torná-lo-ão, de certo modo, beneficiário de um plano de propaganda inovador, ousado e, em determinados aspectos, pouco ortodoxo.

Sucedeu que em meados de Janeiro, durante a viagem presidencial ao Norte do país, um jovem e controverso jornalista residente em Paris regressara à Pátria para falar com Sidónio Pais, acompanhá-lo nesse périplo nortenho na companhia de Paul Strozzi e oferecer-lhe os seus préstimos na área da informação e da propaganda. Esse moço talentoso e aventureiro, que dera brado como estudante irreverente em Coimbra, nas vésperas da proclamação da República, chamava-se Francisco Homem Cristo Filho ${ }^{(116)}$ e exibia já um curriculum furta-cores - ex-anarquista, nacionalista, modernista, monárquico, ex-director da Ideia Nacional, jornalista, e director da Agência Informativa Fast, que se tornará a principal fonte noticiosa do jornal sidonista A Situação.Ao contrário de seu pai, que na temível folha $O$ de Aveiro não se cansará de vergastar e denunciar as contradições do Snr Sidonio Paes, antigo jacobino, (117) aderiu com entusiasmo à experiência em curso e de motu proprio dispôs-se a servir, collaborar sem reservas de qualquer especie na grande tarefa patriotica de V. Ex .

Conseguiu uma primeira conversa em que expôs a sua disponibilidade, tendo-lhe Sidónio Pais recomendado que falasse com Bettencourt Rodrigues. Por carta de 19 de

(113) Para além das investidas do Temps, agarrado ao manifesto de Bernardino Machado, o jornal L'Humanité parece ter sido um desses «focos», como se depreende de dois artigos publicados em Abril: La Terreur règne au Portugal. Ce que dit un républicain du nouveau régime (7-4-1918); e Les Républicains contre le nouveau régime au Portugal. Ils combattent une politique qui fait le jeu des germanophiles (1 1-4-1918).

(114) Ver SILVA, Armando Barreiros Malheiro da - Sidónio e sidonismo. História e mito, dissert. cit., vol. 2 , p. 69-71.

(115) Ver Ibidem, p. 860-86I.

(116) Sobre Homem Cristo Filho ver BARREIRA, Cecilia - Nacionalismo e modernismo. De Homem Cristo Filho aAlmada Negreiros. Lisboa:Assírio e Alvim, 1981, p. 17-25; e LUSITANO, Maria Alice Oliveira e GONÇALVES, António Augusto - Singular vida de Homem Cristo Filho. Aveiro: Edição dos Autores, 1972.

(117) Cf. CRISTO. Francisco Homem - Uma fotografia. O Snr. Sidonio Pais, reitor da Universidade de Coimbra. Para os defensores da ordem (com 0 grande) lerem... República, Maio de 1918, p. I. 
Janeiro voltou à carga, queixou-se do novo Ministro de Portugal em Paris, do modo como $o$ acolheu por ser monárquico, confiando-lhe apenas uns artigos para imprensa remunerados (o que duplamente me magoou), e da pouca atenção que dispensara às suas propostas inovadoras. A sua ideia era promover não apenas uma obra de defesa política, mas também uma obra de propaganda nacional com todos os meios disponíveis e capazes de ajudarem a enaltecer o esforço de Portugal na Grande Guerra. Uma obra extensiva a todos os países da Europa Aliada, que não devia, por conseguinte, ficar apenas na dependência da Legação de Paris, mas sim do próprio M.N.E.

Embora monárquico, Homem Cristo Filho declarava-se acima de tudo um patriota e nessa qualidade respondia ao repto de Sidónio, quando este proclamava que na escolha dos seus colaboradores só exigia competencia, lealdade e patriotismo.A proposta de Cristo Filho foi formulada em moldes cativantes (118) a que Sidónio Pais não podia resistir e, uns meses mais tarde, ao tomar conhecimento da carta que aquele dirigira a Aires d'Ornelas solicitando a demissão do mandato de delegado no estrangeiro do Partido Monárquico Português, deve ter achado, ilusoriamente, que «o peixe mordera o anzol» e aos poucos os monárquicos acabariam por servir a Pátria dentro da «sua» República...

Aceite imediatamente o plano de aç̧ão proposto, Homem Cristo Filho tomou posse ainda em Janeiro e regressou a Paris para montar e dirigir os Serviços de Informação e de Propaganda nos Paizes Amigos e Alliados, com sede na rue Anatole de la Forge, 9, desencadeando de imediato uma série de iniciativas constantes do relatório de actividades do $1 .{ }^{\circ}$ semestre e elogiadas pelo próprio Bettencourt Rodrigues. (119) A acção deste é também reconhecida, mas de forma partilhada, pelo autor do dito relatório quando aí refere que Bernardino Machado é d'uma actividade notavel e maneja a intriga e a calumnia com rara habilidade, sendo, por isso, um dos elementos com que se deve contar e que nos teriam sido extremamente nocivos se não fôra a energica e activa aç̧ão diplomatica do snr. Dr. Bettencourt Rodrigues e a contra-propaganda que eu tenho dirigido. (120)

A estratégia pensadà e seguida baseou-se numa verba mensal de cinco mil francos, ${ }^{(121)}$ sem que o trabalho pessoal do Director dos Serviços de Informação e Propaganda fosse remunerado, por ser essa a sua vontade expressamente comunicada ao Presidente da República. Dispunha, em contrapartida, de ampla liberdade de movimentos e de concepção, embora tivesse de articular o plano gizado com a actividade da Legação em Paris, mais centrada no desempenho pessoal do dr. Bettencourt Rodrigues e no leque de contactos e relações sociais por ele mantidas na alta política francesa - terreno de difícil disputa ao vedetismo de Chagas, Bernardino e amigos.

(118) Cf. No Teatro Aguia d'Ouro. A Conferencia do snr. Homem Cristo, Filho. O Jornal de Noticias, Porto, 22 de Janeiro de 1918, p. I.

(119) Missão de propaganda incumbida ao Snr.Homem Christo Filho, processo 257, 1918. (Arquivo Histórico do Ministério dos Negócios Estrangeiros).

(120) Direç̧ão dos Serviços de Informação e Propaganda da Republica Portugueza nos Paizes Amigos e Alliados. Relatorio, 1. ${ }^{\circ}$ semestre de 1918, p. 2. (Arquivo de Sidónio Pais - Militar, Lente e Político, Subsistema Presidência da República). Ver SILVA, Armando Barreiros Malheiro da - Sidónio e sidonismo. História e mito. dissert. cit, p. 73-76.

(121) Serviços de Informação e Propaganda da República Portuguesa nos Países Aliados 3. piso, arm. 8, maç. 25, Documento n. IV. (Arquivo Histórico do Ministério dos Negócios Estrangeiros). 


\section{As Fragilidades do C.E.P. e o 9 de Abril}

Por muito levianas e venenosas que fossem (e eram-no de facto) as acusações de germanofilia endereçadas às novas autoridades de Lisboa, não só pareciam credíveis, como até eram reforçadas por certas atitudes que lhes eram atribuídas. As demisões de várias figuras da estrutura de comando do C.E.P., tais como a do general Abel Hipólito (demitido por razões que se prendiam com a sua alegada traição no 13 de Dezembro), ${ }^{(122)}$ a do coronel Roberto Baptista, a dos Adidos Militares coronel Ortigão Peres ${ }^{(123)}$ (em França) e major Frederico Simas (destacado em Londres na C.I.R.), e a do capitão Norberto Guimarães, comandante do dissolvido Corpo de Aviação, ${ }^{(124)}$ entre outros, não tardaram, aliás, a ser exploradas como provas de uma clivagem profunda entre os que dirigiam a intervenção no front e os novos senhores da guerra sentados nas cadeiras do Poder em Lisboa.

A intervenção portuguesa era, em finais de 1917, um facto consumado, mas não era, como já referimos, um projecto consensual. O célebre panfleto anónimo Rol da Desonra, que começou a circular em Lisboa em Setembro desse ano, ${ }^{(125)}$ e o expressivo Fado do Cavanço (126) davam de forma prosaica, mas genuína, a dimensão do sentimento de injustiça ${ }^{(127)}$ e do baixo moral das tropas entrincheiradas na Flandres. É que na guerra acentuavam-se ainda mais as desigualdades (a maioria dos soldados e dos oficiais milicianos tinha a morte ao pé, enquanto muitos profissionais militares estavam tranquilos em suas casas ou recuados, passeando-se tranquilamente por Paris) e a permanência no sector reservado ao C.E.P., prolongava-se indefinidamente, sem que às duas Divisões iniciais chegasse uma terceira, indispensável segundo os peritos para garantir o roulement na frente.

Se parece certo que aos ingleses não convinha o aumento do esforço português, os dados mostram também que, apesar do grandioso plano de Norton de Matos e da sua obstinada confiança na perfeição da obra feita, as limitações estruturais do C.E.P., não permitiram que se convertesse num verdadeiro Corpo Expedicionário. Avultavam as falhas e as resistências de vária ordem, ${ }^{(128)}$ a que sobreveio uma medida drástica e grave: a partir de Setembro de 1917 o Governo inglês deixou de pôr à disposição do Ministério da Guerra quaisquer navios para transporte de tropas entre Lisboa e Brest.

(122) Ver SILVA, Armando Barreiros Malheiro da - Sidónio e sidonismo. História e mito, dissert. cit., vol. 2 , p. $900-906$.

(123) Ver GONÇALVES, José António Sequeira - O Coronel joão Ortigão Peres. Adido militar português em França, in Portugal na grande guerra. Guerristas e antiguerristas. Estudo e documentos. Apresentação de João Medina. Lisboa: Centro de História da Universidade de Lisboa / Instituto Nacional de Investigação Científica, 1986, p. I1-43.

(124) Ver sobre o assunto ALVES, Rui - A Aviação portuguesa na guerra 14-18: vítima da República Nova e do esquecimento. História, Lisboa (88) Fev. 1986, p. 46-67. Estudo comentado criticamente por GONÇALVES, José António Sequeira - Sidónio Pais e a participação portuguesa na guerra de 19/4-1918, vol. 2, ob. cit., Anexo 88.

(125) Ver resumo do seu conteúdo em RAMOS, Rui - A Segunda fundação (1890-1926), in MATTOSO, José - História de Portugal, ob. cit., vol. 6, p. 517-518.

(126) Cf. LEAL, Cunha - Coisas de tempos idos. As Minhas memórias, vol. 2, ob. cit., p. 58.

(127) Dossier Guerra. Assuntos e telegramas diversos, Oficio n. 225,19 de Abril de 1918. (Arquivo de Sidónio Pais - Militar, Lente e Político, Subsistema Presidência da República). 
Sem o concurso da marinha inglesa, Portugal não dispunha de frota suficiente para manter regularmente o envio das tropas previstas. Subitamente, e antes do golpe de 5/8 de Dezembro, caiu de forma vertical e notória o embarque de reforços, agravando-se o mal estar no front. As relações entre o oficialato e as praças tenderam a deteriorar-se mais, como notou Isabel Pestana Marques em estudo recente. (129) E a situação começou a inquietar os ingleses, generalizando-se no respectivo Alto Comando, segundo pôde constatar o general Tomás António Garcia Rosado, a ideia de que Portugal enviara Bons soldados, maus officiaes. Os germes da epidemia insurreccional que grassara infrene ao longo de 1918 eram já bem evidentes em finais do ano anterior. Mas se assim era, o que é que os novos governantes dezembristas podiam ou não fazer para que o descalabro não atingisse em 9 de Abril um paroxismo trágico?

A pergunta impunha-se e a resposta dos especialistas não tardou a coincidir com a dos políticos guerristas: em vez de prosseguir o patriótico empenhamento intervencionista, o novo Governo saído do golpe optara pelo recuo e até mesmo pela deliberada extinção da presença portuguesa no front. O general Ferreira Martins, que no posto de tenente-coronel era Vice-Chefe do Estado Maior do C.E.P., pedindo a exoneração do cargo em 2 de Fevereiro de 1918, embora reconsiderasse e se mantivesse em funções, afirmou, no estudo de grande fôlego que dedicou à participação de Portugal na Grande Guerra, existirem e actuarem na política sidonista duas tendências, devendo-se a uma a anemização do C.E.P. por todas as medidas, individuais ou gerais, que o foram reduzindo e the foram impedindo a renovação e a outra as diligências para obter os tranportes... e se deve, sobretudo, a nomeação do Sr. general Garcia Rosado para comandante do C.E.P., (130) Uma apreciação crítica bem mais equilibrada que as categóricas deduções de Luís Alves de Fraga, estudioso desta temática, para quem Sidónio Pais deu o rosto a uma política destinada a acabar com o envio de tropas para França, deixando estiolar o que por lá estava. (131)

Tem sido possivel manter esta leitura dos factos, porque os historiadores ainda não superaram as premissas viciadas do discurso político esgrimido na época, tendendo a confundir neutralidade com defectismo e germanofilia. Confusão habilmente utilizada pelos anti-sidonistas na sua campanha de descrédito interno e externo, mas inadmissível no plano historiográfico. (132)

Convém, por isso, frisar que após o 5/8 de Dezembro não houve, nem podia haver recuo nos compromissos de beligerância no teatro europeu da guerra, embora Sidónio Pais e muitos dos oficiais que o apoiaram e secundaram em nível governativo representassem uma perspectiva diversa da dos guerristas inflamados. Eles partilhavam as reservas, os medos e as dúvidas sobre a eficácia de uma estrutura e os êxitos de uma

(129) Ver MARQUES, Isabel Pestana - Os Portugueses nas trincheiras. História, Lisboa, nova série, I (2) Nov. 1994, p. 21-26.

(130) MARTINS, Ferreira - Portugal na grande guerra, vol. I. Lisboa: Editorial Ática, 1934, p. 335. Ver também FERREIRA, José Medeiros - O Comportamento politico dos militares, ob. cit., p. 70-71.

(131) Cf. FRAGA, Luís M. Alves de - A Participação de Portugal na grande guerra, in MEDINA, João (dir.) - História contemporAnea de Portugal. Primeira República, tomo 2, ob. cit., p. 41-50.

(132) Cf.WHEELER, Douglas - História política de Portugal de 1910 a 1926, ob. cit., p. 164. 
empresa concretizada à pressa para assegurar o máximo de dividendos político-coloniais no pós-guerra, impondo ao Mundo civilizado um país e um regime carecidos de toda a consideração internacional. Desiderato inflamado pela retórica redutora do patriotismo e do heroismo de antanho - quem não pegasse em armas era, no mínimo, cobarde!... Leia-se, porém, o Resumo histórico dos serviços prestados pelo C.E.P. da autoria do general Garcia Rosado e impresso na Revista Militar, de Junho-Julho de 1919 (133) — um texto política e militarmente «correcto» - para se vislumbrar nas entrelinhas a existência de factores que cunharam o outro lado da «medalha»: as penosas condições de manutenção e sobrevivência quotidiana do C.E.P., propícias ao anti-heroísmo.

Entre Sidónio Pais e Norton de Matos será, pois, inútil procurar uma diferença de grau nas suas convicções ideológico-políticas e patrióticas, mas não custa descobrir, desde o início, uma óbvia divergência de perspectiva quanto às vantagens de Portugal marcar presença na frente europeia a todo o custo, forçando mesmo as reticências inglesas e pondo termo à neutralidade condicionada, tal como a definira Freire de Andrade.

$\mathrm{Na}$ entrevista do Matin e na conversa com Sir Carnegie percebe-se muito bem a discordância de fundo que Sidónio manteve em relação ao processo de entrada no conflito, em coerência, aliás, com os esforços neutralistas desenvolvidos até à última hora na sua missão diplomática de Berlim.Vimos como ele receou bastante as consequências funestas dessa «guerra total» e, por isso, tornou-se muito sensível aos efeitos perversos que já se sentiam duramente no país. Diante da situação consumada e agravada de dia para dia, assumiu uma atitude necessariamente hibrida: continuar até ao fim sem hesitações, mas nos limites acanhados do razoável e em estreita sintonia com os ingleses, de quem dependia, sobretudo no respeitante aos transportes e aos abastecimentos de géneros de primeira necessidade, a busca de soluções concretas. A conduta de guerra sidonista aproximou-se, de facto, muito das (dis)posições inglesas - tanto que até será acusada de eventual subserviência à Grã-Bretanha e de humilhante desrespeito pelo orgulho naciona!! (134) Mas para quem defendera em 2 de Maio de 1914, na carta confidencial ao amigo e mentor Brito Camacho, a necessidade de uma renovação e um fortalecimento da alliança anglo-portugueza resultava natural que, em nome dessa aliança e da amizade mútua entre os dois países, o sacrifício não pendesse apenas para o lado mais fraco...

E se em termos pessoais a perspectiva de Sidónio foi a que descrevemos, em termos da política possível, face às condições existentes no final de 1917, o Governo português para resolver as duas graves dificuldades que se abatiam sobre o C.E.P. - falta de transportes e falta de reforços — ou obtinha, de novo, os transportes retirados pela Grã-Bretanha ou alterava a disposição desse corpo militar para atenuar os efeitos nocivos da situação criada.

Nos contactos logo estabelecidos com o general Barnardiston surgiu a primeira alternativa como a mais lógica e a preferida pelas novas autoridades. Mas as objecções

(133) Cf. ROSADO, Tomás António Garcia - Resumo histórico dos serviços prestados pelo C.E.P. Revista Militar, Lisboa, 71 (6-7) Jun.-Jul. 1919, p. 408-426.

(134) Espólio de Augusto Casimiro, - [Apontamentos avulsos, fl. 4], caixa 26. (Biblioteca Nacional, Espólios) 
levantadas pelo general inglês quanto ao delicado ponto dos transportes destinados ao embarque das tropas americanas, frescas e bem equipadas, permitiram-lhe colocar em cima da mesa o plano Derby sobre o C.E.P.já exposto ao anterior Governo, mas por ele rejeitado. De acordo com tal plano passaria a haver uma só Divisão na frente, integrada num Corpo de Exército Britânico e com uma Divisão em reserva a fornecer reforços. É compreensível que em meados de 1917 um plano deste tipo fosse inaceitável para Afonso Costa e seus pares e o próprio Barnardiston reconhecia que o novo Governo, se aceitasse a proposta tinha de agir com cuidado, porque facilmente o acusariam de antiguerrista. Tinha razão - acusaram-no de pior...

Entre a espada e a parede e após uma intensa troca de esclarecimentos do Ministério da Guerra («pasta» assegurada também por Sidónio Pais) com a dupla Carnegie e Barnardiston, o Governo aceitou a 21 de Janeiro a proposta britânica, (135) mas não evitou que no seio do C.E.P. surgissem reacções negativas. Houve alguns pedidos de demissão e os generais Tamagnini de Abreu e Gomes da Costa não esconderam o seu desagrado por uma solução prática, mas lesiva da autonomia e dos brios nacionalistas das forças portuguesas.

O Comandante do C.E.P. deslocou-se a Lisboa para conversações com Sidónio Pais, apresentando depois ao Comando britânico em França uma contra-proposta que diferia da anterior: uma das Divisões recuaria, mantendo-se, porém, o C.E.P. com o estatuto que possuía. $A$ intenção era a de reduzir as exageradas proporções da estrutura sem the baixar a importância formal. Se fosse aprovada surgia em cena um corpo de exército diverso dos restantes, claro precedente que os britânicos não podiam tolerar. Não demorou, porém, a ser apresentada outra proposta, desta vez pelo novo Chefe do Estado Maior, coronel Sinel de Cordes (em substituição de Roberto Baptista), que durante o golpe estivera com as forças governamentais. Conservava as duas Divisões em linha, mas as respectivas Brigadas seriam postas em profundidade - uma em primeira linha, a segunda em apoio e a terceira de reserva. A sua fraca consistência técnica fez que fosse também rejeitada.

Enquanto as altas chefias, ao ritmo próprio da pesadíssima burocracia militar, se dedicavam a estudar contra-propostas inaceitáveis para os ingleses, o tempo foi passando inexorável...

Esgotadas essas tentativas voltou-se à chamada Convenção de Janeiro de 1918 - assim a designou, embora indevidamente, Augusto Casimiro, ${ }^{(136)}$ um indefectível guerrista e grande admirador de Norton de Matos. Como esclarece Sequeira Gonçalves, não se tratava de uma convenção à semelhança da assinada em 3 de Janeiro de 1917, mas tão só de um acordo que visava conferir maior operacionalidade à estrutura convencionada um

(135) Ver Livro branco sobre a entrada de Portugal na $1 .^{\circ}$ Guerra Mundial, 3. ${ }^{\circ}$ piso, arm. 13 e maço $95,1918$. (Arquivo Histórico do Ministério dos Negócios Estrangeiros). E ver também para todo processo de reestruturação do C.E.P. - 1. ${ }^{a}$ Divisão, 35. Secção, caixa 1 178, dossier 3, C.E.P. - Documentos de 6 de Janeiro a 26 de Novembro de 1918. Documento transcrito na íntegra por GONÇALVES, José António Sequeira - Sidónio Pais e a participação portuguesa na guerra de 1914-1918, dissert. cit., vol. 2-Anexo Documental, anexo 41-1 a 3 , fls. 189 e ss.

(136) Ver CASIMIRO, Augusto - Sidónio Pais: algumas notas sobre a intervençōo de Portugal na grande guerra. Porto: Livraria Chardron, 1919, p. 179 e ss. 
ano antes. Seja como for, a redução do C.E.P. a uma única Divisão, encarregue da defesa da mesma área, significou para Casimiro e outros camaradas de armas o princípio do fim, a morte da intervenção portuguesa e o desastre da batalha do Lys a 9 de Abril. Em abono da sua tese pareciam falar os factos: a 6 de Abril entrou, finalmente, em execução

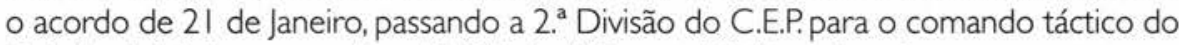
Exército britânico, recuando a I. 'Divisão. A frente, dividida até então por quatro sectores, ficou apenas com três dentro da mesma extensão. As tropas portuguesas estavam exaustas e demasiado vulneráveis à preocupante investida alemã, que se temia, mas não se imaginara para os inícios de Abril. O Comando inglês ordenou, no dia 8 e para execução no dia seguinte, que a Divisão portuguesa fosse retirada da linha da frente e colocada como reserva do seu Corpo de Exército. Tarde de mais... Às $4 \mathrm{~h}$. e $30 \mathrm{~m}$. da madrugada de 9 de Abril rebentava sobre as posições portuguesas, numa frente de 18 $\mathrm{km}$, um intenso e aterrador bombardeamento. (137) Era a batalha dizimadora...

Veremos já como a tragédia decorreu, mas antes importa notar que o acordo de 21 de Janeiro além de não prever a inesperada ofensiva alemã, não estipulava que a Divisão posta na linha da frente ficasse com a mesma área anteriormente ocupada pelo C.E.P. Pelo referido acordo ser-lhe-ia reservada uma única zona dentro do espaço ocupado pelo Corpo de Exército britânico a que ela se ligara, além de que as tropas passavam a rodar entre si (da frente para a retaguarda e vice-versa), aliviando de algum modo a dramática falta de transportes. Os realinhamentos previstos durariam, em condições normais, alguns dias, isto é, se não acontecesse nenhum contratempo... E o atraso verificado no seu arranque não foi, obviamente, da responsabilidade do Governo de Lisboa, que, pela sua parte, ainda decretou a mobilização rápida de algumas companhias e, através das diligências de Augusto de Vasconcelos, foi insistindo com Londres na devolução de alguns barcos ex-alemães. $\mathrm{Na}$ falta da indispensável frota teve de socorrer-se do Pedro Nunes e do Gil Eanes, que, até Abril, só fizeram uma viagem cada um transportando cerca de setecentos homens. E mais não foram desembarcados na frente de guerra, porque entretanto surgiu a epidemia do tifo e as autoridades inglesas e francesas deram instruções no sentido de proibir o trânsito de tropas entre Portugal e França, fossem reforços ou apenas repatriados.

Se o deliberado intuito de Sidónio Pais consistisse, pois, em extinguir o C.E.P. - tese contrariada em absoluto pela documentação disponível — nem precisava de se esforçar, porque o Acaso, parafraseando Braz Burity, ajudá-lo-ia muito...

O atraso no recuo e substituição da I. ${ }^{a}$ Divisão do C.E.P. pela 55. ${ }^{a}$ Divisão britânica tem de ser visto como consequência directa das (in)decisões estratégicas do Comando inglês em interacção, nem sempre harmoniosa, com os interesses tácticos de franceses e de americanos. ${ }^{(138)}$ A desgraça ocorrida a 9 de Abril explica-se, também, pelo facto

(137) Para uma sinopse recente e actualizada do desenrolar da batalha de La Lys ver TELO, António José - A República e as forças armadas, in MEDINA, João (dir.) -História de Portugal, vol. 11, ob. cit. p. 276-279.

(138) Ver, por exemplo, FERRO, Marc - História da primeira guerra mundial, 1914-1918. Lisboa: Edições 70, 1992, p. 309-31 1; GONÇALVES, José António Sequeira - Sidónio Pais e a participação portuguesa na guerra de 1914-1918, ob. cit., vol. I, fl. 32 e ss: e TELO, António José - A República e as forças armadas, in MEDINA, João (dir.) -História de Portugal, vol. 11, ob. cit., p. 278. 
de Hindenburg e Ludendorff, libertos da frente oriental após o início da paz separada com os russos, concentrarem forças e recursos na frente ocidental para um grande e definitivo assalto. A 21 de Março dera-se a primeira ofensiva perto de Saint-Quentin e os alemães, servidos por quatro mil canhões e alinhados em sessenta e cinco Divisões, conseguiram abrir uma brecha que desanimou Douglas Haig, mas não foi suficiente para quebrar a perseverança de Pétain. Os reforços de Foch, enviados a tempo, permitiram segurar a estratégica posição de Amiens. Fez-se uma pausa... Haveria nova réplica, todos o sabiam. Quando?

A 9 de Abril Ludendorf decidiu proceder, de surpresa, a uma segunda fustigação na extremidade norte da frente anglo-portuguesa com vista a isolar o Exército belga e, com ele, uma parte das tropas inglesas, empurrando-os para o mar. As trinta e seis Divisões do príncipe Rupprecht tentaram desesperadamente romper as linhas. A zona parecia-lhes muito vulnerável e no que respeita à situação das tropas portuguesas tinham razão. Nessa madrugada a I. ${ }^{a}$ Divisão já tinha recuado e o seu Comandante, general Gomes da Costa, transitara para a 2. ${ }^{a}$ Divisão, incumbida de todo o sector à espera de uma Divisão britânica, mas, entretanto, o Comando britânico considerou a sua situação delicada e ordenou-the o recuo, ficando todo o sector sob controlo das tropas inglesas. O recuo ia começar quando se deu o ataque alemão. A 2. Divisão foi surpreendida e completamente arrasada. À parte a resistência estóica de muitos combatentes, a brutalidade da investida boche fechou, num instante, eventuais possibilidades de uma «saída» airosa. A I. a Divisão na retaguarda teve de ocupar o lugar dos Batalhões desaparecidos e das centenas de compatriotas mortos a fim de suster o avanço alemão. Sem êxito: as Divisões alemãs conseguiram romper a frente e ocupar todo o sector. No entanto, ao cabo de vários dias de encarniçados combates o objectivo de Rupprecht falha e Ludendorf terá de ensaiar a 27 de Maio uma manobra de diversão, atacando na extremidade oposta dessa frente: houve avanços, mas a resistência manteve-se e a II de Junho deu ordens para suspender a ofensiva. ${ }^{(139)}$

Os Aliados aproximavam-se mais da vitória final, embora à custa de uma aterradora espiral de mortos. E os portugueses tinham acabado de dar o seu amargo tributo - segundo os cálculos de Gomes da Costa a 2. ${ }^{a}$ Divisão perdeu durante quatro horas 7.500 homens, o que correspondia a um terço do total de efectivos nominais. ${ }^{(140)}$

A partir de 9 de Abril o C.E.P. ficou desfeito... para, qual Fénix, renascer das cinzas!... Seria possível? Seria exequível dentro do calendário de uma Guerra que entrara já nas derradeiras ofensivas? A República Nova, como se verá, tentou. Nessa tentativa mudará o Comando, substituindo Tamagnini de Abreu por um soldado-diplomata, Garcia Rosado, e demitindo Gomes da Costa, que não perdoará a desfeita... ${ }^{(141)}$

Mas não nos concentremos apenas no teatro europeu das operações militares.

(139) Ver FERRO, Marc - História da primeira guerra mundial, 1914-1918, ob. cit., p. 312.

(140) Cf. COSTA, Gomes da - O Corpo de exército português na grande guerra.A Batalha do Lys, 9 de Abril de 1918. Porto: Renascença Portuguesa, 1920, p. 176.

(141) Espólio Gomes da Costa, N4 - Carta de Amilcar Motta, s.d., caixa I (Biblioteca Nacional, Espólio),: e Portugal na grande guerra. Sidónio Pais não desmoronou o C.E.P., diz-nos Jorge Botelho Moniz. Diário de Lisboa, de 28 de Novembro de 1924, p. 5. 
Em África, especialmente na colónia de Moçambique, decorriam também campanhas de defesa contra os ataques alemães. $O$ foco de ameaça concreta situava-se no Tanganica alemão e na pequena força de Lettow-Voerbeck, hábil estratega ${ }^{(142)}$ que, com os seus cerca de quatro mil askaris enquadrados por trezentos e cinco oficiais europeus, irá resistindo às ofensivas inglesas e da União Africana sob o comando de lan Smuts. A pressão inglesa sobre os Governos de Lisboa levou à organização de mais duas expedições para além da primeira, que fora enviada no Outono de 1914 em resposta ao ataque alemão do posto fronteiriço Maziua, no Rovuma. A terceira expedição, comandada pelo coronel Sousa Rosa, desembarca em 1917 com um total de 9.786 efectivos que defrontarão sem sucesso a táctica guerrilheira de desgaste conduzida por Lettow-Voerbeck até Setembro de 1918. De Lisboa não foi negado apoio, mas pouco mais havia a fazer com os recursos disponiveis e perante as hábeis e desconcertantes movimentações de um verdadeiro génio militar. ${ }^{(143)}$

E se de África passarmos às ithas portuguesas no Atlântico verificamos aí a ameaça concreta e assustadora da guerra submarina. A situação inquietou Sidónio Pais que numa pequena folha de papel de carta com timbre do Avenida Palace Hotel redigiu, em Janeiro, as seguintes notas:

\begin{abstract}
Madeira
Na Madeira a população está alarmada - a gente remediada foge do Funchal - na cidade constroem-se trincheiras - tudo com receio dos submarinos.

Remedio: 2 peças de 15 do "Almirante Reis» para que se não repita o caso das baterias de terra pelo seu fraco alcance não responderem aos ataques dos submarinos.
\end{abstract}

(No ultimo ataque que durou 30 minutos, um submarino alemão lançou 40 granadas de 15 contra a cidade).

\title{
Açores
}

Tenho de substituir governador civil de Ponta Delgada - convidei Filomeno da Camara - Se ele me disser que aceita eu entendo que se lhe deve alargar os poderes para poder tratar como de potencia a potencia com o almirante americano. ${ }^{(144)}$

A 3 de Dezembro de 1916 um submarino alemão bombardeara a cidade do Funchal gerando o pânico, bem vincado, aliás, na memória dos madeirenses e desde então cresceu em uníssono a reivindicação de melhores condições de defesa para que essa trágica ocorrência não voltasse a repetir-se. Um ano depois o submarino U- 156 voltou a bombardear o Funchal, tendo travado um duelo desigual com dois pequenos navios de patrulha munidos de peças de $47 \mathrm{~mm}$. Pouco antes um outro submarino, o U-I5I,

(142) Cf.TELO,António josé - A República e as forças armadas, in MEDINA, João (dir.) - História de Portugal, vol. 11, ob. cit., p. 287.

(143) Ver Ibidem, p. 292 e ss.

(144) [Apontamentos avulsos, f. ms. s.d.]. (Arquivo de Sidónio Pais - Militar, Lente e Político, Subsistema Presidência da República).

(145) Cf. TELO, António José - Os Açores e o controlo do Atlantico (I898-1948). Porto: Asa, 1993, p. 132 
tinha atacado Cabo Verde, conseguindo entrar facilmente no porto de S. Vicente e afundar dois navios aliados. ${ }^{(145)}$

Ao perigo militar marítimo somava-se a ameaça da fome, provocada pela hegemónica produção da cana-de-açúcar, pela adiada reconversão da agricultura madeirense, pelo limite às importações, pelos ataques dos submarinos aos navios mercantes ${ }^{(146)} \mathrm{e}$ pela especulação e açambarcamento. A fome era, assim, um pesadelo difícil de debelar. Tal como no continente, a questão das subsistências atingiu extrema acutilância como se pode ver pelo estudo de Fátima Freitas Gomes e Nelson Veríssimo que abordaram a vida política, económica e social na Madeira durante o período dezembrista / sidonista. (147) Não conhecemos, porém, abordagens do mesmo tipo para os Açores, nem mesmo para alguma das suas ilhas, embora não faltem estudos temáticos que incluem referências à situação política iniciada em 5/8 de Dezembro de 1917.

\section{O Papel estratégico dos Açores}

Interessa-nos, sobretudo, destacar o aspecto estratégico do arquipélago no contexto da Grande Guerra, temática focada, entre outros, por António José Telo. (148) Pelo apontamento de Sidónio Pais conhecemos a sua intenção em convidar Filomeno da Câmara para Governador Civil de Ponta Delgada, mas isso não passou de uma primeira e efémera ideia. Nessa cidade fora criada uma Base Americana, formalmente aceite pelo 3. ${ }^{\circ}$ Governo de Afonso Costa a 8 de Novembro de 1917, após enviesadas negociações que passaram necessariamente por Londres. ${ }^{(149)}$ Para a comandar foi nomeado o almirante Dunn e decidiu-se instalar uma bateria para defesa do porto, enviar fuzileiros e juntar uma companhia aeronáutica equipada com hidros de patrulha às águas do arquipélago.

A instalação destes meios começou a ser pedida ainda nesse mês de Novembro, mas a resposta foi adiada para quando o Presidente do Governo regressasse da Conferência dos Países Inter-Aliados em Paris, o que equivaleu, na prática, ficar pendente de uma decisão do Governo dezembrista. Entretanto, tinham recomeçado as operações dos submarinos alemães nas ilhas atlânticas, com excepção dos Açores. Era de qualquer forma um sério aviso que vinha reforçar o plano dos americanos para a Base de Ponta Delgada: centro de um considerável conjunto de fuzileiros e meios navais destinado à protecção das populações dos Açores e da Madeira e à abertura de rotas seguras à navegação marítima na área. Esta ideia geral foi desenvolvida num relatório e consubstanciou a proposta apresentada às autoridades portuguesas, que, possivelmente encorajadas pelos ingleses, não a acolheram com agrado, resistindo, sobretudo, à perspectiva de uma excessiva presença de yankees em território nacional.A resposta oficial do Ministério da Guerra assentou, por isso, numa delicada recusa: agradecia o fornecimento de equipamento, mas dispensava uma tão grande força de fuzileiros, preferindo enviar soldados de

(146) Cf. GOMES, Fátima Freitas e VERÍSSIMO, Nelson - A Madeira e o sidonismo, ob. cit., p. 239.

(147) Ver lbidem, p. 55 e ss.

(148) VerTELO, António José - Os Açores e o controlo do Atlântico (1898-1948), ob. cit., p. 103-164.

(149) Ver lbidem, p. 126-131. 
Lisboa caso fosse necessário. A atitude era defensiva e contava com o apoio da Marinha, preocupada com as implicações políticas do assunto. Sugeriu, por isso, que o cruzadorcouraçado Vasco da Gama, sob o comando de Augusto Eduardo Neuparth, fosse para Ponta Delgada. Esse navio esteve, como se verá melhor, implicado na revolta de 8 de Janeiro, e Sidónio Pais pretendeu logo neutralizá-lo, mas sem o tirar do Tejo. (150)

Mas não ficou...

Houve pressões eficazes no sentido de alterar a opção que Sidónio Pais apontara em Janeiro. A alteração deu-se, mas não baseada em argumentos de ordem técnico-militar: o navio era totalmente incapaz de enfrentar submarinos submersos. Em contrapartida, figurava como a mais importante e prestigiada unidade da Marinha portuguesa, servindo bem para Aumentar o prestígio da nossa soberania política no arquipélago - mesmo que fizesse um despezão doido!... Este facto e a análise que o comandante Neuparth se encarregará de fazer ao longo da sua missão de defesa naval dos Açores ilustram o extremo cuidado e desconfiança com que Sidónio Pais e os seus Governos tentarão gerir a presença americana. $\bigcirc$ mais pequeno gesto do almirante Dunn, mesmo que se cingisse a uma ajuda pontual às populações de S. Miguel, suscitava preocupação.

Para se entender a grande susceptibilidade das autoridades continentais e dos seus representantes importa lembrar o caso Orion e a gratidão dos micaelenses para com os americanos por um acto tocante de coragem e de generosidade: o navio de transporte Orion de pavilhão estado unidense defendera, a 4 de Julho de 1917, Ponta Delgada de um ataque submarino.

Não surpreende que no jornal socialista O Protesto de 31 de Outubro de 1917 possa ler-se a seguinte farpa: Somos Orions, somos o que os senhores quizerem, mas temos o orgulho de no momento actual, aos olhos da maior nação do mundo em tudo e especialmente em sentimentos bellos, de sermos classificados de educados, gratos, honrados e almas bem formadas (...) d'alguns particulares comerciantes que fizeram pintar nas taboletas dos seus estabelecimentos o para nós inolvidavel nome Orion. (151) Basta, aliás, a leitura deste periódico ao longo de 1918 para se detectar a maneira provocatória como os paladinos do regionalismo açoreano lançavam sobre Lisboa a sua americanofilia.

Mas se a desconfiança da Marinha e do Governo portugueses era indiscutível, tem interesse sublinhar a forma hábil como Sidónio Pais reagiu às recomendações defensivas de Neuparth: A resposta do Presidente é um modelo de diplomacia. Começa por referir que concorda com as recomendações de Neuparth para melhorar a defesa de Ponta Delgada - que são impraticáveis e, logo, não podem ser executadas, pelo que não há problema em concordar com elas - mas acrescenta: «Sob o ponto de vista internacional, o que convém é darmos às medidas de defesa que adoptarmos todo o carácter de colaboração leal e dedicada com a missão americana, de modo a que não possam parecer inspiradas por desconfiança ou propósito de exclusão contra aqueles nossos aliados. (152)

(150) Ver SILVA, Armando Barreiros Malheiro da - Sidónio e sidonismo. História e mito, dissert. cit., vol. 2 , p. 88 .

(151) Cf. Orion. O Protesto. Orgão e propriedade do Centro Socialista Anthero de Quental, Ponta Delgada, 31 de Outubro de 1917,p. I

(152) Cf.TELO,António José - Os Açores e o controlo do Atlantico (1898-1948), ob. cit., p. 137. 
Uma posição dúplice, a que Sidónio se manteve fiel até ao fim, numa acrobática conciliação das indicações inglesas, do desejo de boa cooperação (pensada já para o pósguerra?) com os americanos e dos direitos de soberania e independência nacionais. Essa táctica, com a ajuda inglesa, deu logo os seus frutos, como refere António José Telo a propósito do relatório alarmista que em Janeiro de 1918 o Cônsul americano em Ponta Delgada enviou para Washington e no qual classificava as novas autoridades locais nomeadas por Lisboa de pró-alemãs, muito especialmente o presidente da Câmara de Ponta Delgada e o comissário da polícia. (153) A Inglaterra não demorou a contrariar esta visão — muitas das autoridades recém-nomeadas tinham-se oposto à participação portuguesa na guerra, mas isso não significava que fossem pró-alemãs - em relatório entregue ao almirante Dunn, que ao desembarcar em Janeiro em Ponta Delgada concordou com os ingleses, notando, sobretudo, uma certa hostilidade aos Aliados no sector militar e naval. Hostilidade que o Governo em Lisboa tentou atenuar e daí a criação do Alto-Comissário para os Açores com poderes de centralização de todas as funções militares, incluindo a defesa marítima assegurada por Neuparth e recomendada no parecer da Comissão nomeada pela Secretaria da Guerra em 17 de Janeiro de 19|8.(154)

A pessoa escolhida para um tal esquema, de algum modo derivado da solução pensada inicialmente para Filomeno da Câmara, nomeado entretanto Governador Geral de Angola, foi o general José Augusto Simas Machado, assumido republicano, comandante de uma Divisão do C.E.P., e visto pelos ingleses como um amigo. (155) Chegou ao local de missão a 13 de Abril e pode dizer-se que se comportou como tal, vigiando, porém, de perto a popularidade de Dunn e sintonizando os interesses do partido regionalista, (156) na medida do possível, com o objectivo táctico de Sidónio Pais: evitar que os democráticos levantassem a cabeça, fomentando a revolta e o descontentamento na população, o que daria uma má imagem aos americanos e afectaria a credibilidade do Governo de Lisboa.

(153) Cf.TELO, António José - Os Açores e o controlo do Atlantico (1898-1948), ob. cit, p. 138.

(154) Dossier Alto Comissario do Governo nos Açores, Parecer sobre a organisação defensiva que, nas actuais circunstancias, mais convem estabelecer no archipelago dos Açores. (Arquivo de Sidónio Pais - Militar, Lente e Político, Subsistema Presidência da República).

(155) Ver TELO, António José - Os Açores e o controlo do Atlântico (1898-1948), ob. cit., p. I4| e ss.

(156) Sobre 0 apoio que os regionalistas e monárquicos deram à experiência dezembrista/sidonista ver CORDEIRO, Carlos - Regionalismo e anti-republicanismo (1910-1918). José Maria Raposo do Amaral. Arquipélago, Ponta Delgada, série História, vol. 2 - Estudos Insulares, 1995, p. 281- 315; e ainda, como depoimento da época, escrito logo após a morte de Sidónio Pais, CORREIA, Ayres Jacome - Os acontecimentos revolucionários de Portugal, a autonomia, a livre administração dos Açores pelos Açoreanos, o descentralismo. Revista Michaelense, Ponta Delgada, 2 (1) Fev. 1919, p. 91-102. 


\section{Capítulo 2}

\section{A Consolidação do Poder}

\section{Forças Armadas e divisões corporativas}

Muito delicada e periclitante se afigurava a situação no território continental, mesmo nos primeiros tempos do golpe dezembrista. As medidas retaliadoras dos vencedores sobre os democráticos, por mais benévolas que fossem, suscitariam sempre motivos de révanche e é preciso ter ainda em conta as clivagens e divisões partidárias nas Forças Armadas.

A Marinha constituía um bastião da influência do P.R.P./P.D. e da Carbonária. O papel dos marinheiros na resistência aos revoltosos do Parque foi, por isso, punida na parada militar do dia 10 de Dezembro, desfilando um Batalhão desarmado - circunstância evocada um mês depois como causa do súbito protesto e revolta. A extinção da Divisão naval chefiada pelo ex-franquista e afonsista ferrenho Leote do Rego foi uma das primeiras medidas tomadas pela Junta Revolucionária. Por seu turno, no Exército procedeu-se também a mexidas pontuais nos Comandos das oito Divisões do território continental e nos Comandos territoriais dos Açores e Madeira que compunham o dispositivo de defesa territorial.

O general llharco nas suas Memórias, atrás citadas, refere de passagem as ordens e contra-ordens de que foi alvo nos dias imediatos ao golpe: o capitão Feliciano da Costa

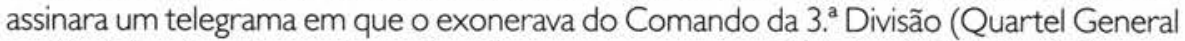
no Porto) e the dava ordem de entrar como preso no Castelo de S. João da Foz; na sequência dessa ordem o general, achando-se, além do mais doente, decidiu entregar o Comando ao coronel mais antigo, mas como, entretanto, lhe foram dirigidos insistentes pedidos do comité revolucionário local (dezembristas do Porto) para que permanecesse no cargo, deixou-se ficar; pouco tempo depois um telegrama do próprio Presidente Sidónio Pais anulava a ordem do capitão Feliciano, mantendo llharco no Comando da $3 .^{\text {a }}$ Divisão; estranhamente, porém, apresentou-se no Porto, alguns dias volvidos, o general Macedo e Brito para assumir o Comando da Divisão; o acto de substituição ocorreu normalmente, mas quando o general llharco ia a retirar do Quartel-General recebeu novo telegrama do presidente Sidonio Paes, ordenando-me que me mantivesse no comando da divisão, devendo o general Macedo e Brito ir assumir o comando da 8. ${ }^{\circ}$, em Braga; (157) nessa mesma altura soube que o capitão Feliciano da Costa tinha chegado ao Porto e

(157) Cf. ILHARCO,A. - Memorias, ob. cit., p. 63. 
andara pelos regimentos a inquirir qual dos dois generais era o mais preferido na Divisão; passados trinta dias, durante os quais o general esteve de cama, foi-lhe oferecido o Comando da 8. ${ }^{a}$ Divisão, que ele rejeitou, sendo, por fim, nomeado Presidente do Júri de Exames para General, o que lhe permitiu permanecer na sua casa do Porto. $O$ caso descrito é muito sugestivo, mas não autoriza extrapolações. Deixa, no entanto, perceber uma óbvia descoordenação inicial que teve a ver com o próprio funcionamento interno da corporação militar e com a inevitável e precipitada subordinação da força armada ao novo Poder político. ${ }^{(158)}$

Segundo António José Telo, o novo regime - a expressão é sua - procedeu logo ao saneamento nas Forças Armadas, aprofundando-o à medida que os contragolpes do P.R.P./P.D. falhavam. Deu-se, assim, o envio de unidades inteiras para África servindo um duplo objectivo: afastar da Metrópole os focos potenciais de revolta e reforçar as expedições militares destinadas a combater o boche. Para preencher as vagas, Sidónio recorreu a pessoas de confiança, reintegrando dezenas de oficiais afastados pelo P.R.P. Outros vieram do exilio disfarçado do C.E.P. para dirigir unidades militares. Muitos dos novos oficiais eram pró-monárquicos, pois estes últimos constituem um dos grandes apoios de Sidónio Pais em toda a primeira fase do seu governo, mas esse apoio não impediu que - Presidente seguisse a típica política de colocações de todos os regimes: os oficiais mais da sua confiança foram concentrados no Corpo de Tropas da Guarnição de Lisboa, criado pelo decreto n. 3.960 de 20 de Março(159) e transformado numa espécie de guarda pretoriana, incumbida, sobretudo, de combater e neutralizar a acção conspirativa dos democráticos, enquanto os oficiais monárquicos eram colocados de preferência no Norte e na província. ${ }^{(160)}$

A Guarda Nacional Republicana foi, também, mexida no seu Comando Geral, entregue agora a um coronel ou general do activo ou do quadro da reserva pelo decreto 4/179 de 29 de Abril (ao contrário do disposto no art. ${ }^{\circ} 6{ }^{\circ}$ da lei de I de Julho de 1913 que dispunha $\mathrm{O}$ comando geral será exercido por um general do quadro activo ou da reserva...), e domada por um intencional aumento de vencimentos de oficiais e praças através do decreto $n{ }^{\circ} 4.284$ de 27 de Abril, equiparados aos oficiais e praças do corpo especial de tropas da guarnição de Lisboa, a que adveio legislação complementar até final de $1918 .^{(161)}$ E quanto à Marinha já atrás referimos a extinção do Corpo de Marinheiros, na sequência da revolta falhada de 8 de Janeiro, tendo sido criado o Comando Central de Defesa Marítima pelo decreto 3.778 de 23 de Janeiro e mandadas embarcar para o Ultramar as praças amotinadas.

Medidas profiláticas para a segurança e estabilidade do Poder, que não podem, contudo, ser vistas como parte integrante de uma estratégia de entrega deliberada das forças militares aos monárquicos!...

(158) Cf. CARRILHO, Maria - Forças Armadas e mudança política em Portugal no séc. XX, ob. cit., p. 205-282 e 476-477.

(159) Cf. Diário do Governo, I série, de 22 de março de 1918, p. 224

(160) Cf.TELO, António José - A República e o exército, in MEDINA, João (dir.) - História contemporânea de Portugal. Primeira República, tomo 2, ob. cit., p. 188-189.

(161) Cf. MATA, Aida Maria Reis da e OLIVEIRA, José Fernando Vieira Lizardo Gomes Coelho de - Intranquilidade e repressão no consulado sidonista. Lisboa, 1981, fls. 26-28. 
A lição dos dados disponíveis suscita-nos, aliás, duas breves notas: o controlo político-partidário da oficialidade não se revelou tarefa fácil para qualquer Governo republicano e os dois Governos dezembristas/sidonistas não foram excepção, embora tenha havido uma acentuada osmose entre a ideologia militar e as bases programáticas do sidonismo; e não é muito viável analisar a reintegração de militares monárquicos de Dezembro de 1917 a Dezembro de 1918 fora do conceito operatório de rede sócio-política, porque se atendermos ao conjunto de casos melhor conhecidos do ponto de vista prosopográfico, verifica-se que o reingresso desses militares deu-se sob o compromisso de honra de servir a República e a Pátria e por sugestão de camaradas próximos do Presidente da República ou ligados à União Republicana, ao Partido Centrista e ao grupo informal de Machado Santos, componentes activas da rede de apoio ao dezembrismo/sidonismo.

O capitão Teófilo Duarte, amigo de gente próxima dos círculos monárquico-integralistas, comprovou-o no seu livro Sidónio Pais e o seu consulado ${ }^{(162)}$ e as curiosas, mas pouco conhecidas, Memórias do coronel de Infantaria Gonçalo Pereira Pimenta de Castro servem também de exemplo ao que afirmamos, descontados os naturais exageros e excessos apologéticos. ${ }^{(163)}$

No seu estilo voluntarista e perseverante, generoso e colérico, Sidónio - sempre ele, em todo o lado... ${ }^{(164)}$ - desdobrava-se em contactos, visitas pelos quartéis e por iniciativas várias tendentes a manter um bom nível de satisfação entre oficiais e praças.

As relações com a Marinha afastaram-se, porém, deste padrão. De acordo com Gonçalo Pimenta de Castro, os marinheiros, desde a revolta no quartel de Alcântara e no Vasco da Gama, mantiveram-se sempre desafectos ao governo de Sidónio Pais. E acrescenta: O meio de Alcântara era péssimo, e os marinheiros juntos eram sempre uma ameaça perigosa e constante.As baterias de artilharia da margem esquerda do Tejo, estavam sempre de prevenção, devido aos navios ancorados no rio. Machado Santos lembrou ao Presidente Sidónio Pais a deslocação do quartel de marinheiros para a ilha de S. Vicente, em Cabo Verde. A medida era eficaz, mas tinha umas certas dificuldades, pois além de ser um castigo para todos os marinheiros, desagradaria a grande número de oficiais e sargentos, que tinham as familias em Lisboa, filhos a educar, etc. Esta medida só irio aumentar a onda dos descontentes. Como era porém urgente tirar os marinheiros de Alcântara, Carlos da Maia propôs que se instalasse o quartel no Alfeite, o que se realizou. (165)

A alegada sugestão de Machado Santos é pouco credível, tanto mais que ele se revelou sempre intransigente na defesa dos interesses corporativos da sua Arma, opondo-se à deportação dos marinheiros revoltosos e pedindo mesmo a demissão do cargo de Ministro do Interior, mas não há dúvida que a neutralização das unidades navais na área crítica do Tejo foi vista como prioritária e a solução do Alfeite ${ }^{(166)}$ obedeceu a esse desiderato, embora, segundo Pimenta de Castro, também não tenha sido aceite pelos marinheiros:

(162) Ver DUARTE, Teófilo - Sidónio Pais e o seu consulado, ob. cit. p. 192-193.

(163) Ver CASTRO. Gonçalo Pereira Pimenta de - As Minhas memórias, vol. 2. Lisboa: Livraria Progredior; Edições Expansão, [1948], p. 34. E ainda SILVA, Armando Barreiros Malheiro da - Sidónio e sidonismo. Histório e mito, dissert cit., vol. 2, p. 94-96.

(164) Cf. DUARTE, Teófilo - Sidónio Pais e o seu consulado, ob. cit., p. 247-249.

(165) Cf. CASTRO, Gonçalo Pereira Pimenta de - As Minhos memórias, vol, 2, ob. cit., p. 52

(166) Ver DUARTE, Teófilo - Sidónio Pais e o seu consulado, ob. cit., p. 236. 
Nos clubs jacobinos, seja-me permitida a designação, eram os marinheiros que mandavam, enquanto que os oficiais e os sargentos deixavam afrouxar cada vez mais a disciplina. Nas fileiras da Armada, aquelas praças que faziam as revoluções tornavam-se maus elementos. Elas, como todas as que cooperam numa revolução, terminada esta, devem ser licenciadas, ou destacadas para vários quartéis. ${ }^{(167)}$ Opinião de um oficial do Exército que não disfarçava a profunda rivalidade corporativa entre esses dois ramos das Forças Armadas...

\section{O 8 de Janeiro}

Opiniões à parte, tenhamos em conta os factos.

$\mathrm{Na}$ noite de 6 de Janeiro cerca de quinhentos marinheiros encerraram-se no seu quartel de Alcântara em manifesto sinal de rebelião, sem que as entidades responsáveis da Marinha, nomeadamente a Fiscalização Naval ou a Majoria Geral da Armada se apressassem a tomar providências. Quem começou a agir, em termos tácticos de vigilância, foi o Governo, avisado logo da revolta, que não estava ainda isolada. Os marinheiros esperavam a adesão da tripulação de vários vapores fundeados perto do cruzador Vasco da Gama, sito na doca seca n. ${ }^{\circ}$ I da Rocha do Conde de Óbidos. A reacção pessoal de Sidónio Pais e dos seus colaboradores directos terá sido rápida e enérgica, ${ }^{(168)}$ contrastando com as hesitações e tibiezas assacadas ao general Pimenta de Castro em circunstâncias anteriores. O próprio Sidónio dirigiu superiormente as operações a partir do improvisado Quartel-General das Necessidades, ${ }^{(169)}$ evitando, contudo, medidas demasiado drásticas causadoras de elevadas vítimas e danos materiais. ${ }^{(170)}$

A fraca resistência dos marinheiros em Alcântara foi compensada na manhã do dia 8, pelas 10 h. 30 m. com a saída do Vasco da Gama da doca onde estava, sendo rebocado para o quadro em frente do Arsenal da Marinha, em posição ofensiva. Das baterias do Castelo de S. Jorge será alvejado por três tiros, cujo disparo Sidónio Pais dirigiu pessoalmente - a rendição foi imediata e a tripulação presa em terra. A revolta terminou, assim, ingloriamente, mas o assunto foi discutido em Conselho de Ministros, causou profundo mal-estar, opondo Machado Santos à linha dura, maioritariamente anti-naval, do Governo, motivou pressões de outros núcleos da rede sócio-política de apoio e saldou-se, por exemplo, no relatório parcial elaborado pelo juiz de Direito Joaquim Crisóstomo da Silveira Junior.(171)

O êxito das forças governamentais foi indiscutível desde quase a primeira hora, mas a revolta constituiu um aviso muito sério, perfeitamente previsível para Brito Camacho. ${ }^{(172)}$ Os democráticos não desarmariam e, sempre que atacassem de novo, as diversas sensibilidades da situação dezembrista/sidonista agitar-se-iam pendularmente

(167) Cf. CASTRO, Gonçalo Pereira Pimenta de - As Minhas memórios, vol. 2, ob. cit., p. 52-53.

(168) Ver a narrativa dos factos em MARTINS, Rocha - Memorias sobre Sidónio Poes, ob. cit., p. 94-98; e DUARTE, Teófilo - Sidónio Pais e o seu consulado, ob. cit., p. 256-258.

(169) Cf. CASTRO, Gonçalo Pereira Pimenta de - As Minhas memórios, vol. 2, ob. cit., p. 45-47.

(170) Dossier Relatorio da Sahida do Vasco da Gama, Relatorio acerca da sahida do cruzadôr Vasco da Gama no dia 8 de Janeiro de 1918 apresentado pelo Juiz de Direito Joaquim Crisostomo da Silveira Junior, encarregado de inquerito dos ultimos acontecimentos politicos, fls. 13-14. (Arquivo de Sidónio Pais - Militar, Lente e Político, Subsistema Presidência da República).

(171) Ver SILVA,Armando Barreiros Malheiro da - Sidónio e sidonismo. Histónia e mito, dissert. cit, vol. 2. p. 98 -99.

(172) Cf. CAMACHO, Brito - Reflexões calmas. A Lucta, de 10 de janeiro de 1918, p. I. 
ou para a firmeza benévola ou para a dureza mais implacável. Os diversos interesses corporativos emergiriam intensos. A opinião pública ficaria, também, à mercê de impulsos contrários e contraditórios, não sendo a posição do Governo de modo algum favorecida por uma contínua instabilidade. Convenceu-se, porém, Sidónio Pais que a fácil vitória obtida sobre a revolta dos marinheiros significava uma tácita adesão do Exército e do Povo de Lisboa ao programa genérico do seu Governo e uma oportunidade de ir um pouco mais além do fixado nos objectivos programáticos iniciais.

A revolta fracassada de 8 de Janeiro e outras circunstâncias avulsas, que nos escapam, funcionaram, provavelmente, de detonadores de uma opção já larvar na mente de Sidónio Pais e partilhada por alguns dos que passaram a rodeá-lo.

Rocha Martins na sua crónica destacou Bettencourt Rodrigues como o mentor da solução presidencialista ${ }^{(173)}$ e confessou-se emissário de Machado Santos junto do chefe evolucionista António José de Almeida com vista a atrair o contributo deste partido histórico para a nova situação. A iniciativa, à qual Sidónio se terá mostrado alheio, falhou, segundo o cronista, por causa dos amigos do líder, alguns dêles, podiam-se citar os nomes, arrastaram o partido evolucionista para o campo contrário.(174) E a avaliar pela documentação do Ministério do Interior referente à actividade dos evolucionistas do Porto, esse partido entrou em oposição ao Governo logo em finais de Janeiro. (175) Indícios claros da manobra de cerco à experiência dezembrista/sidonista, logo empolada por monárquicos e situacionistas, mas reconhecida pelo capitão Cameira em carta particular de 31 de Janeiro, redigida em papel timbrado do célebre Café Martinho: Continuam a circular boatos de intentonas, e, embora eu esteja convencido que será dominada com pulso firme qualquer arruaço que appareça, convem não dormir. Na provincia é mais provavel que haja qualquer coisa, e por isso venho pedir-lhe que, caso haja ahi qualquer anormalidade na guarnição, mais uma vez ponha a sua espada ao serviço da Patria que nós todos tanto amamos e evite, com o seu prestígio e a sua valentia, que o caso passe a mais. N'um caso de revolta aberta contra o Governo deve mesmo tomar o commando e agir. ${ }^{(176)}$

\section{Viagem triunfal pelo território da República}

Não conseguimos, por falta de um diário e de testemunhos fiáveis, reconstituir as conversas, os conselhos, as leituras e as reflexões que Sidónio Pais protagonizou durante um mês de estreia à frente dos destinos da Pátria, mas dispomos de dados suficientes e percorremos, desde as origens, a sua vida para podermos frisar que ele - leitor de Dareste, de Duguit e das crónicas na imprensa sobre a América do Norte e todo o Mundo dito civilizado - em Dezembro de 1917 já não tinha ilusões quanto às sonhadas virtualidades do sistema parlamentar, que, em 191।, desejava ver curado das suas piores fraquezas.

(173) CF. MARTINS, Rocha - Memorias sobre Sidonio Paes, ob. cit., p. 77.

(174) Cf. Ibidem, p. 94.Ver também Conferencia politica. Fala o snr. Machado Santos. A conferencia entre o snr. ministro do interior e o snr. dr. Antonio José de Almeida. Republica, 5 de Fevereiro de 1918, p. I.

(175) Ministério do Interior - Correspondência recebida, maço, 19|8. (Instituto dos Arquivos Nacionais/Torre do Tombo).

(176) Correspondência. (Arquivo de Sidónio Pais - Militar, Lente e Político, Subsistema Presidência da República). 
Entretanto, não podem ser desprezadas as conversas com Egas Moniz, cujas proclamadas tendências parlamentaristas se notam muito pouco ou mesmo nada no primeiro trimestre de 1918, defendendo com os seus amigos, no Jornal da Tarde, o modelo oposto, o que parece ter correspondido a uma jogada táctica para ocupar a centralidade dentro da nova rede sócio-política em detrimento dos unionistas. Uns meses mais tarde, diante do cerco montado pela oposição republicana histórica, Egas Moniz recuará, deixando o Presidente da República Nova isolado no combate: acusá-lo-á de lançar ao abandono o Partido Nacional Republicano, quando era ele, o ilustre clínico, o líder da maioria e o grande responsável pela organização partidária, e pressionará para que fosse interrompida a experiência presidencialista à americana que inicialmente lhe agradara. ${ }^{(177)}$ As debilidades e vicissitudes do P.N.R. não podem, portanto, ser desligadas da actuação político-partidária de Egas Moniz, embora este aspecto tenha sido desprezado pelos investigadores.

Volvidos sete anos de peripécias político-institucionais e partidárias, Sidónio precisava de ganhar coragem e de receber o estímulo necessário para se erguer como porta-voz de uma corrente, ainda e sempre minoritária, mas muito vincada no seio do campo republicano e na opinião pública conservadora - a corrente autoritária e presidencialista. Por exclusão lógica de partes, a solução espalhada, de forma mais ou menos pervertida, no vasto Continente Americano e defendida, mutatis mutandis, duas décadas antes por Déroulède ou por Boulanger afigurou-se-lhe, no dealbar de 1918 , como a solução natural para o problema político, posto já não nos termos do ex-líder Brito Camacho, mas nos do seu conterrâneo Jorge de Castro: se se tirou o poder ao dr.Afonso Costa para o dar ao Camachismo, (...) então todo o tremendo esforço foi perdido. E, embora titubeante, não tardou a erguer o véu do seu pensamento: a nomeação para o cargo de Presidente da República em 27 de Dezembro talvez se inscrevesse já na estratégia de reforço do Executivo - e, nesta medida, autoritária - assumida um mês depois.

A decisão de viajar pelo Norte vincou esta estratégia. E não se reduziu, pois, a uma mera visita protocolar ou a um reencontro nostálgico com a familia e os amigos, se bem que lhe fosse caro dar um abraço à mulher, ao Pedrinho e à $\mathrm{Mi} \mathrm{Si}$ - a quem iria conceder autorização para casar com o finalista de Medicina Mário Cardoso, porque essa era, aliás, a opinião de D. Maria dos Prazeres expressa em carta recente - ou aos cunhados, à mãe e irmãos, ao Luciano Pereira da Silva, ao Henrique de Figueiredo e a tantos outros, todos, em uníssono, desejosos de o felicitarem de viva voz.

A viagem ao Norte não era passeio... Era a busca de um veredicto da entidade vaga e suprema que encimava, desde os recuados tempos juvenis, a sua mundividência política - o Povo. (178) Exactamente o mesmo Povo dos concorridos e esfuziantes comícios da propaganda republicana. $O$ mesmo Povo da inflamada retórica dos oradores

(177) Cf. MONIZ, Egas - Um Ano de política, ob. cit., p. 88. Ver SILVA, Armando B. Malheiro da - Egas Moniz e a política: notas avulsas para uma biografia indiscreta. In Egos Moniz em livre exame, ob. cit., p. 237-31।.

(178) $O$ historiador Damião PERES, referindo-se à viagem ao Norte, teve o cuidado de citar as palavras do próprio Sidónio Pais, registadas pelo jornal O Século, de 19 de janeiro de 1918 , àcerca dos motivos que o levaram a tomar essa iniciativa: (...) afirmou terem-no determinado a essa digressão os incentivos de um fim político, o de tactear a opinião pública e acrescentou: não se pode governar sem o apoio da opinião, nem há força alguma militar que a domine. (Cf. Idem - História de Portugal, suplemento, ob. cit., p. I73). 
de garra que o P.R.P. conseguira concentrar nas suas fileiras. E era esse Povo que urgia ouvir... Era esse populismo imperfeito, porque ideológico e utópico, mas a que faltava o ímpeto plebiscitário, empático e emocional, facilitado pela personificação dos ideais e dos desejos, que se mantinha vivo e mobilizador ao nível do discurso republicano, não obstante as reviravoltas, as traições e as desilusões acumuladas no activo das diferentes facções, que se trucidavam ferozmente em nome de... Qual República?... Os humoristas e caricaturistas coevos, dispersos pela imprensa e pelos cafés, responderam certeiros: República burguesa e snob da cabeça ao tronco, mas popular e pé descalço...

Concebida e anunciada de forma a surtir um bom efeito mediático, a viagem presidencial excedeu as mais optimistas expectativas de acordo com o consensual relato da mais variada imprensa. As fotografias da llustração Portugueza ou da llustração Catolica ajudam a percepcionar a amálgama de rostos, de vestes, de poses, em suma, a amálgama de pessoas diversas concentradas em praças e ruas para verem um homem magro, meão, fardado com discreta elegância, rodeado de notáveis, transportado de carro ou de caleche, hirto e sorridente, de pé ou sentado, irradiando sedução e facilmente tocado e saudado pelos mais efusivos cidadãos. As fotos mostram as elites nas varandas engalanadas dos Paços dos Concelhos, nas casas contíguas, colchas penduradas das janelas à guisa de dia festivo ou de procissão e defronte a mole anónima, curiosa e até surpresa por ter ali tão perto e ao alcance dos sentidos o Presidente - o senhor dos senhores, o chefe dos chefes, o patrão dos patrões, a autoridade máxima para onde convergiam todos os olhares e de onde se esperava brotassem todos os favores. Enfim, de onde se esperava a salvação, a resolução dos problemas, numa fase de tamanhas incertezas, de penosas ausências e de desmedidos sofrimentos.

Tempo de crise, que alguns indicadores estatísticos avulsos configuram na sua crueza: a taxa de crescimento económico de Portugal sofreu, entre 1913 e 1920, uma quebra de $5,9 \%$ contra os 3,3\%, também negativos, do resto da Europa; a população proletária concentrou-se predominantemente em Lisboa e Porto, tendo subido, entre 1910 e 1920 , de $25 \%$ para $38 \%$ na capital e de $25 \%$ para $30 \%$ naquela cidade nortenha; cerca de $70 \%$ do orçamento das familias mais débeis era consumido pelas despesas com alimentação; de 1914 a 1918 o custo de vida tinha aumentado do índice 100 para o índice 293; os preços agrícolas no Continente dispararam desde 1914 (índice 100) para 192,8 em 1917 (300 em 1918 e 400 em 1919!); os salários haviam aumentado, oficialmente, de um índice de 100 em 1914 para 225 em 1917; a crescente escassez de bens essenciais, sobretudo alimentares, anulava o efeito positivo anterior; a tabela oficial da venda do milho pelos camponeses chegou a impôr uns míseros $\$ 95$ centavos quando no mercado paralelo ou negro atingia os $2 \$ 00$; o encargo anual com as despesas de guerra poderia alcançar, em 1918, de 42 a 48.000 contos, segundo cálculos veiculados pela imprensa...

À impressiva eloquência destes números basta somar o espectro real da fome para se rematar o feixe de motivos (não apenas sócio-económicos) que impeliam milhares de pessoas de Norte a Sul do país a ir para a rua, sob sol radiante e chuva intensa, ver, saudar, festejar em preces de auxilio e de mudança o Libertador (livrara a Nação da demagogia), como se lia na prosa eufórica e assanhada da imprensa anti-afonsista.

$A$ viagem cingiu-se a quase uma semana e o comboio impôs-se como o meio de transporte adequado. $O$ percurso seguiu, por isso, a linha do Norte até Viana e os desvios fizeram-se de carro de cavalos e de automóvel. A Beira Interior e Trás-os-Montes 
desviavam-se demasiado de uma rota circunscrita quase só à faixa litoral até culminar na foz do Minho - Lisboa, Coimbra, Porto,Viana do Castelo, Famalicão, Barcelos, Caminha, Braga, Guimarães, Coimbra, Lisboa...

O périplo teve início no dia 12, sábado de manhã. Sidónio Pais saiu a pé do Avenida Palace para a Estação do Rossio, acompanhado pelo Governador Civil de Lisboa, pelo tenente miliciano de Engenharia Henrique Forbes Bessa, um jovem de vinte e três anos filho do Secretário Geral da Presidência da República, pelo capitão Cameira e por mais pessoal do seu Gabinete. No Rossio era aguardado por membros do Governo, por Brito Camacho, pelo general Comandante da I. 'Divisão, pelo Major General da Armada, pelos Comandantes dos Corpos de Guarnição, pela oficialidade de terra e mar, pelo Secretário Geral do Governo Civil, pelo Comandante da Guarda Nacional Republicana, etc. Na comitiva presidencial seguiam os Ministros da Instrução Pública e do Comércio, respectivamante Alfredo de Magalhães e Francisco Xavier Esteves, ambos do Porto, o inseparável capitão Eurico Cameira, o major Balduíno Seabra, o capitão-tenente Sousa Dias, o Chefe de Gabinete 1. ${ }^{\circ}$ tenente da Armada Aragão e Melo, o tenente Aires de Abreu, os alferes Palma e Botelho Moniz, os capitães Alberto da Silva Pais e Bernardino Ferreira, o sr. Carlos Jacques, funcionário dos Correios e Telégrafos, o dr. Fidelino de Figueiredo e Armando Osório de Barros. A imprensa fez-se representar na visita pel'A Lucta e Diário de Noticias (repórter Manuel dos Santos), pela Manhã (Santos Vieira), pelo Diário Nacional (Câmara Lima) e pelo Século (Ferreira Martins), garantindo, assim, uma ampla cobertura jornalística, aspecto nunca descurado até final de 1918 pelo Presidente e pelos seus colaboradores próximos.

capitão Feliciano da Costa, Ministro do Trabalho, com fortes ligações afectivas à cidade invicta, não pôde, por motivo de serviço oficial, integrar a comitiva oficial, instalada num salão atrelado ao rápido do Porto.

No momento da partida foram proferidos vivas à Pátria, à República e ao Presidente Sidónio Pais, correspondidos com o maior entusiasmo. ${ }^{(179)}$ Às $10 \mathrm{~h} .5$ m. chegou ao Entroncamento, de onde foi expedido telegrama de Osório de Barros a comunicar que estavam todos bem; às $10 \mathrm{~h} .5 \mathrm{Im}$. chegada a Santarém e novo telegrama; passagem por Coimbra, registada como tendo sido marcada por uma grandiosa e imponente manifestação ao Chefe do Estado, sendo aclamado por milhares de pessoas. Em Coimbra B houve parada militar com todas as forças da guarnição da cidade. Uma bateria de artilharia deu as salvas. Alguns edificios publicos e camara hastearam a bandeira nacional. ${ }^{(180)} \bigcirc$ telegrama de Osório de Barros expedido da Pampilhosa do Botão enfatizava: Não tenho palavras para exprimir a manifestação de Coimbra. A cidade em pezo ovacionou presidente e governo. A chegada ao Porto pelas $16 \mathrm{~h}$. $30 \mathrm{~m}$. suscitou mensagens ainda mais enfáticas, falando-se de recepção entusiástica e de um concorrido cortejo desde S. Bento até ao Grande Hotel do Porto, na rua de Santa Catarina, para onde convergiram centenas de pessoas. E à noite houve récita de gala oficial no Teatro Sá da Bandeira com a opereta Susi e quando decorria o 1. ${ }^{\circ}$ acto o Chefe do Estado ocupou o camarote. A representação foi logo suspensa, houve aclamação durante 15 minutos e o dr. Sidonio Paes de pé, inclinado

(179) Ver A Viagem presidencial ao Norte. A Lucto, 12 de Janeiro de 1918, p. I.

(180) Cf. Ibidem, p. I. 
sobre o parapeito, conservou um irrepreensivel garbo militar ${ }^{(181)}$ diante de uma assistência cheia de júbilo pela presença do Chefe de Estado. Cerimónias públicas e ovações entusiásticas marcarão todo o programa.

No dia seguinte realizou-se $o$ acto solene da restituição do emblemático edíficio da Bolsa à Associação Comercial do Porto, que O Seculo Cómico caricaturou e parodiou sob o título Viagem triunfal - Sidónio Pais à janela do comboio entrega uma bolsa a um cidadão que a recebe agradecido: No Porto. Comentario ouvido na estação de $S$. Bento - Tudo quanto se lhe fizer é pouco. Sempre é um homem que restitue a bolsa a seu dono...( ${ }^{(82)}$ E no dia 14 foi a visita a Braga e a Guimarães sob intensa chuva: chegada à cidade dos Arcebispos pelas II h. e num período de viva controvérsia por alegadas perseguições das novas autoridades administrativas distritais a vários republicanos de longa data; (183) de tarde a comitiva presidencial dirigiu-se a Guimarães, ao berço da nacionalidade; e regresso ao Porto, de onde partiu, no dia 15 - dia formosissimo de sol - em comboio especial para Viana do Castelo e daí seguiu de carro até Caminha, aproveitando o Presidente da República para visitar a mãe, irmã e irmão António.

O encontro com D. Rita Júlia, já nos seus setenta e dois anos de vida porfiada e sofrida, não teve, por certo, os contornos romanescos que Rocha Martins Ihe deu, (184) mas foi dramática: a viúva do escrivão Sidónio Marrocos Paes, nesse sombrio ano de 1918, haveria de perder dois dos seus rapazes - o malogrado Aureliano, falecido a 29 de Março ${ }^{(185)}$ no Hospital Conde Ferreira e o «seu Sidónio», fugazmente na terra natal a abraçá-la pela última vez e cuja morte lhe foi ocultada para que o choque da notícia não abreviasse o curso da doença que a fulminará a 9 de Março de 1919.(186)

No mesmo dia 15, Sidónio Pais regressou ao Porto, tendo-se realizado à noite e até altas horas da madrugada um baile, no Grande Hotel do Porto, organizado pelas damas da primeira sociedade portuense em honra do Chefe do Estado, e que, segundo O Século de 17 de Janeiro, constituiu uma verdadeira festa chic.

O dia 16 foi dedicado a visitas no Porto e em Gaia: de manhã visita ao Quartel de Artilharia 6, na Serra do Pilar, onde Sidónio Pais tirocinou como tenente artilheiro e de tarde visita à Universidade do Porto, tendo sido acolhido por uma entusiastica manifestação da Academia a que não faltou enorme concurso de gente - tanta que para se fazer ideia do seu numero, basta dizer, quando tudo debandou, a parte ajardinada em volta dos lagos ficou completamente destruida, tendo desaparecido até todas as plantas. ${ }^{(187)}$ No salão nobre o Reitor, professor Gomes Teixeira, famoso matemático a cuja obra Sidónio Pais ligou os seus trabalhos académicos iniciais, saudou o ilustre visitante lembrando e elogiando a sua carreira de académico. A imprensa, empolgada pelo ininterrupto enca-

(181) Cf.Visita do Presidente da República. O Primeiro de Janeiro, 13 de Janeiro de 1918, p. I.

(182) Cf.Viagem triunfal. O Século Comico, Lisboa, 28 de Janeiro de 1918.

(183) Ver, por exemplo, artigo Perseguições. A Manhã, de 18 de janeiro de 1918, p. I.

(184) Ver MARTINS, Rocha - Memorias sobre Sidonio Paes, ob. cit., p. 100-102.

(185) Ver Dossier Fallecimento Aureliano da Silva Paes. (Arquivo de Sidónio Pais - Militar, Lente e Político, Subsistema Presidência da República).

(186) Ver TRIGUEIROS, António Júlio Limpo e SILVA, Armando B. Malheiro - Os Paes de Barcelos, art. cit.., p. 162; e Dossier 100 Correspondencia Particular. (Arquivo de Sidónio Pais - Militar, Lente e Político, Subsistema Presidência da República).

(187) Cf. O Chefe do Estado no Porto. O Século, de 17 de Janeiro de 1918, p. 1. 
deamento de tão calorosas manifestações, considerou que na Universidade do Porto decorrera uma sessão histórica, ampliada em Coimbra, no dia seguinte.

Houve aí uma recepção solene na Sala dos Capêlos, ${ }^{(188)}$ discursos, aplausos, clamores... Depois foi o regresso à Baixa por entre estonteante movimento de milhares de pessoas e no Hotel Avenida uma representação de estudantes solicitou feriados, que the foram concedidos - dias 17 e 18 - seguindo-se, por fim, um banquete de mais de oitenta talheres com a nota elegante de senhoras luxuosamente vestidas e da "grande tenue») dos homens. A rematar houve brindes e mais discursos...

Para além da enorme afluência de gente de todas as classes e condições sócio-profissionais ao longo do trajecto e das paragens presidenciais, importa destacar o sentido global das alocuções e discursos proferidos, de improviso uns, de breve leitura outros, reproduzidos ambos pela imprensa e compilados mais tarde por Feliciano de Carvalho.

A análise desses textos é improfícua do ponto de vista literário e pouco se extrai em nível doutrinário e programático. São peças curtas, que têm sido consideradas como mera expressão da mais elementar demagogia. A sua pobreza ideológico-política não as desvaloriza, porém, como depoimento genuíno e circunstancial de um encontro da maior relevância para o rumo que a situação dezembrista tomou de seguida: a transfiguração política e mítica de Sidónio Pais não se deu com a sua morte, mas com o estreito abraço popular (i89), à maneira de um gigantesco plebiscito. ${ }^{(190)}$ E os discursos proferidos no Norte, mais emotivos e vagos no plano político-institucional que os do Sul, selam o compromisso plebiscitário embebido em profunda afectividade e que como tal foi introjectado e vivido por um Sidónio Pais psicologicamente muito vulnerável à tensão emocional/passional, expressa de forma lapidar em diferentes locais: $O$ esforço da Revolução tem de manter-se custe o que custar!... Ai daquele que levantar um dedo ameaçador! Tenho a meu lado o paiz, tenho a meu lado o afecto da tão generosa e cavalheiresca cidade do Porto. Sinto-me satisfeitissimo com a viagem triunfal e com as manifestações que me teem sido dispensadas e isso dá-me alento para levar a obra empreendida até final, conscio de que terei o apoio de todo o paiz, pois para ele é que trabalho e farei todos os sacrificios, apoiado sempre na opinião publica; ou ainda: Agradeço a confiança que em mim manifestais e afıanço pela minha honra, que o governo respeitará em todo o espírito da revolução que tende a dar ao paiz todas as liberdades e terminar com todas as tiranias. (...) De resto, do lado do governo tenho visto e sentido está também o Povo. As manifestações da cidade de Braga representam uma adesão, que comovidamente agradeço. ${ }^{(191)}$

A par de tão forte carga emotiva há nos discursos mensagens políticas: garantia de republicanismo; reafirmação de aliadofilia e prossecução do esforço de guerra; e apelos à unidade de todos os portugueses de bem, republicanos independentes, monárquicos

(188) Estudantes militares, pasta 22, dois telegramas do Presidente da República para a Universidade de Coimbra. (Arquivo da Universidade de Coimbra).

(189) Cf.Vida pratica. O Século cómico, 4 de Fevereiro de 1918.

(190) Correspondência, carta em duas fls. de papel pautado e timbrado do Governo Civil do Porto/Gabinete do Governador Civil. (Arquivo de Sidónio Pais - Militar, Lente e Político, Subsistema Presidência da República).

(191) Ver SILVA, Armando Barreiros Malheiro da - Sidónio e sidonismo. Histório e mito, dissert. cit., vol. 2. p. $108-109$ e $913-945$. 
e católicos, enfim, todos os que se dispusessem a dar as mãos para realizarem uma obra patriótica e nacional, suprapartidária e, nessa generosa medida, sonhada pelos combatentes da Rotunda em 4/5 de Outubro de 1910.

A apoteose, preparada pelas entidades administrativas, designadamente pela Comissão Administrativa da Câmara Municipal de Lisboa presidida por José Carlos da Maia (substituído algum tempo depois pelo arquitecto Adães Bermudes), atingiu proporções inesperadas no Largo de Camões, defronte da Estação do Rossio. O cortejo presidencial passou pelo Largo do Pelourinho. Sidónio Pais, acompanhado pela sua comitiva, entrou nos Paços do Concelho e, na varanda, saudou de improviso a multidão. (192)

Ainda se sentia o eco da viagem triunfal ao Norte e já ele se apressava a anunciar o desejo de visitar o Sul, afirmando em entrevista ao Diário Nacional que As manifestações foram realmente entusiásticas. (...) As manifestações do norte como as que respeitosamente me fazem nos Teatros de Lisboa são consoladoras. Mas... não bastam! É preciso mais... Mais alguma coisa. É preciso que essas manifestações não fiquem pelas palavras e pelos vivas, que se tradusam num apoio decidido, franco. Unamo-nos se queremos ter uma paz durável, que permita o trabalho.

Para quem the conheça já o perfil psicológico, esta e outras afirmações similares reflectem espontânea e sinceramente outro traço característico da sua personalidade - a acção. Sem negarmos a hábil premeditação que soube pôr nas suas palavras e nos seus actos - outro traço pessoal indiscutível - temos de reconhecer-lhe a entrega total ao processo carismático que o catapultou para as cumeadas da idolatria e o submergiu, ao mesmo tempo, na vaga emocional de um espesso imbróglio de tensões - desde as sócio-políticas, culturais e racionalizadas até às mais difusas, inconscientes e mítico-simbólicas. Sidónio Pais «imolou-se», cada vez mais igual a si próprio, no altar de uma Pátria idealizada, que lhe cumpria regenerar (recriar e retornar mais perfeita), salvar do abismo (da queda e da infelicidade).

Em rodopio constante e em variações cénicas notáveis aparecerá, numa crescente espiral de personalismo, quer ostentando um irrepreensível garbo militar, quer em comovedora atitude assistencial — debruçado sobre o leito dos doentes a ouvir e a confortar o seu sofrimento. Esta atitude correspondeu à resposta que quis/soube dar à vaga epidémica que começara já a varrer o país. Uma atitude de desvelo, de generosidade, de caridade cristã, decisiva no processo de heroicização que, com a morte, fará dele um Mártir e até um Santo no imaginário feminino católico e não só, culminando nesse assomo idolátrico o somatório de equívocos até aí vividos.

No plano estritamente político-partidário o impacte da viagem ao Norte abalou a incipiente rede sócio-política do dezembrismo, tendo Brito Camacho percebido que os seus piores receios e vaticínios não só eram autênticos, como já se estavam a concretizar. Não surpreende, por isso, a pressa que o líder unionista — pessoa pouco dada a viagens fora do eixo Lisboa, Beja e Aljustrel - teve de visitar Braga, Porto e Coimbra, logo nos começos de Fevereiro. Movia-o um impulso de vital sobrevivência política, tanto mais que o centrismo recém-nascido exibia claros propósitos fusionistas com o

(192) Ver SILVA, Armando Barreiros Malheiro da — Sidónio e sidonismo. História e mito, dissert. cit., vol. 2. p. $109-110$. 
unionismo sob a batuta da dupla Sidónio Pais e Egas Moniz. Em contra-corrente e em contra-relógio, dispôs-se, portanto, a visitar amigos e correligionários, bom pretexto para mandar recados às classes conservadoras: garantir-lhes a revisão da lei da Separação e insinuar em termos claros que ao ovacionarem e ao idolatrarem o Presidente da República estavam a consagrar a União Republicana como a maior força organisada da República, ${ }^{(193)}$ porquanto s. ex. ${ }^{\circ}$ era uma criação do unionismo. A astúcia de Camacho urdia a teia de um decisivo confronto...

A imprensa, por seu turno, não perdeu ensejo de ir atiçando a fogueira. Espalhou a notícia de desentendimentos em torno do problema político entre o líder unionista e o seu correligionário, que se desligara, então, publicamente do partido, de acordo com uma pequenina nota de A Lucta. Uma longa conferência entre ambos realizou-se no dia 10 sem resultados específicos. Mas dois dias depois o jornal República, de 12 de Fevereiro, lançava umas perguntas incómodas - Crise no governo? Os unionistas e a eleição presidencial. O snr. Duarte Leite contra o snr. Sidónio Pais? Nos mentideros da política corria já o boato de um choque frontal de posições sobre a eleição presidencial, autónoma e anterior à eleição do Congresso. A União Republicana só aceitaria a escolha do primeiro magistrado da Nação por qualquer sistema desde que ele ficasse consignado na Constituição, revista ou elaborada por Constituintes previamente eleitas. $\bigcirc$ contrário disto encontrará pela frente um completo desacordo dos seus partidários. E este esticar da «corda» não era boato...

Sidónio Pais teria apresentado em Conselho de Ministros uma versão de decreto eleitoral em que se estabelecia um sufrágio mais amplo para a eleição presidencial e mais restrito para o Congresso. Tal projecto bastou para alterar a já difícil contenção unionista. ${ }^{(194)} \mathrm{E}$ a I 3 de Fevereiro o unionista Santos Viegas escreveu uma carta particular ao seu caro Sidonio justificando-se de não poder estar presente no Conselho de Ministros desse mesmo dia, mas não queria deixar de vincar a sua posição sobre a questão política em debate nessa reunião: a Constituição devia ser alterada com um mínimo de presidencialismo, podendo ser aumentada a primeira legislatura para um máximo de 7 a 9 anos; a eleição do Presidente devia ser feita em conjunto com a das Câmaras Legislativas, porque, se aquele fosse eleito sem estas, passava a deter todos os poderes e tornava-se um Dictador eleito o que é contrario a todos os princípios de garantia liberal. Ficava, assim, sublinhada uma perspectiva, comum, aliás, à dos outros camachistas no Governo e um solene aviso.

Efectuou-se, entretanto, a viagem presidencial ao Sul.

Partida no dia 14 da Estação do Rossio em comboio e nos mesmos moldes da viagem anterior. A primeira cidade a visitar era Évora, tendo o comboio presidencial feito paragens obrigatórias em Setil e em Vendas Novas, cuja Estação estava apinhada de povo e uma banda tocava a Portuguesa e quando a composição entrou nas agulhas a assistência manifestou-se, mas menos do que no norte. A recepção na capital do Alto Alentejo foi calorosa, achando-se a cidade toda engalanada. O Presidente da República foi recebido nos Paços do Concelho, na presença do Arcebispo e das pessoas da maior

(193) Ver CAMACHO, Brito - Uma excursão. A Lucta, de 14 de Fevereiro de 1918, p. I.

(194) Cf. Terceiro congresso da União Republicana, ob. cit., p. 24-25. 
representação da cidade e dos concelhos circunvizinhos. D. Augusto Eduardo Nunes, famoso orador sagrado, fez uma alocução em que comparou Sidónio Pais a Napoleão Bonaparte — analogia precoce, que será depois glosada por adeptos e adversários. (195) Mas se a comparação deu brado, o discurso do Presidente proferido no fim do lauto banquete com que foi homenageado agitou a imprensa e todo o leque partidário. ${ }^{(196)}$ A dado passo falou, de modo vago, no partido dos homens de bem para servir a Pátria. Agitação entre os apoiantes, máxima perplexidade e indignação entre a oposição republicana. Partido Único era o título alarmista do artigo saído no jornal República, do dia imediato. ${ }^{(197)}$ Após o choque e a confusão inicial, tentou-se a luz...

Os adeptos do Jornal da Tarde tomarão a seu cargo esclarecer as nebulosas expressões do Presidente, negando categoricamente a intenção de um só partido que excluísse alternativas. E os adversários já não tinham ilusões quanto à determinação de levar por diante o projecto presidencialista.

Mas o que pretendera ao certo dizer Sidónio Pais em Évora e, mais tarde, em Santarém? Num rascunho sem data (parece, contudo, ter sido redigido para a abertura do Congresso em 22 de Julho) e fragmentado, ensaiou ser mais claro. É um texto em bruto, desprovido ainda de arranjos políticos:

Reformar os nossos costumes politicos é de um grande exemplo, o maior que um Governo póde dar na parte que the toca.

Em que sentido deve ser feita essa reforma. Acabar com os partidos? Não [rasurado]! Talvez. Pelo menos transformal-os de maneira que deixem de ser clientellas, mas aggremiações que as mesmas ideias unem, sem sectarismo, mas com verdadeiro espirito de tolerancia.

Um partido de Governo quererá sempre entre nós gosar dos favores do Governo. Ora um Governo não póde faser favores. Um Governo tem de fazer justiça. Cada cargo que provê, deve ser dado ao mais competente, eis tudo. Nenhuma pressão deve ser exercida sobre elle se não é para o obrigar a ser justo.

Na Republica Nova todos são eguaes, toda a collaboração dos portuguezes bem intencionados será bem acceite.

Precisamos de nos unir todos, para num persistente esforço fazermos progredir a nossa querida Patria.

A politica dos Governos sahidos da Revolução foi invariavelmente norteada pela vontade persistente de consolidar a Republica

Hoje como hontem a minha politica é sempre a mesma. Collocado no meio dos partidos um bloco cada vez mais forte se vae formando com gente das direitas e das esquerdas. A onda cresce e ella vae desde as classes mais altamente collocadas até ás camadas profundas da população. Não constitue um partido na verdadeira acepção do termo. A Republica Nova apoia-se no Povo. Ella hoje é inteiramente popular. (...)

(195) Ver a desenvolvida nota de MEDINA, João - Morte e transfiguração de Sidónio Pais, ob. cit., p. 174-175 e $180-182$.

(196) Ver SILVA, Armando Barreiros Malheiro da - Sidónio e sidonismo. História e mito, dissert. cit., vol. 2. p. $112-113$.

(197) Cf. Partido Único. República, de 15 de Fevereiro de 1918. p. I. 
O sectarismo dos partidos é um outro defeito, que conduz facilmente á demagogia quando governam e á revolta quando na opposição.

Esta Revolução fez-se contra a demagogia.Assim procurarei sempre não substituir uma demagogia por outra demagogia.

O Pais não é feudo d'um partido.

Nem a Republica é só para os Republicanos. A Republica Nova é um regimen de liberdade onde todos os cidadãos têm direitos eguaes.

Aceitamos a collaboração de todos os portugueses de bóa vontade, desde que sejam competentes e honestos, e desde que sejam respeitadores da lei e das instituições vigentes.

Respeito pelas crenças religiosas! Respeito pelas doutrinas philosophicas! Liberdade de consciencia!' A separação da Egreja e do Estado, não significa opposição da Egreja ao Estado ou d'este á Egreja.

Porque a maioria do Paiz é de catholicos, não temos o direito de governar contra os livres pensadores, [nem] se póde arrogar o direito de governar contra os catholicos

Se o Poder legislativo deve fazer leis sabias e justas, e o Poder Executivo executa-las com rigor e administrar com honestidade e intelligencia, uma sociedade não póde ser bem conduzida se Ihe falta um Poder judicial que possa proceder com desassombro.

O meu Governo preocupou-se por isso muito com a situação da magistratura, dando-the condições de vida que the garantissem uma vida desafogada e assegurando a independencia plena do poder judicial pela fixação de normas de provimento, collocação e promoção que o libertam por completo das influencias deleterias da politica. ${ }^{(198)}$

Por entre uma conceptualização política confusa e pobre, rompiam alguns laivos de clarificação, patentes também na alocução que proferiu a 29 de Julho ao inaugurar mais uma Cozinha da Assistência 5 de Dezembro em Algés. ${ }^{(199)}$

Percebe-se, pois, que Sidónio Pais tenha rejeitado peremptoriamente os partidos clientelares do figurino rotativista e comparado até o Partido Regenerador com o Partido Democrático. Esse figurino foi desenvolvido até à corrosão total sob a Monarquia Constitucional e perpetuado pelas formações partidárias resultantes da fragmentação do velho P.R.P.. Preferia, pois, um modelo diverso, uma espécie de partido de ideias, que sugeria, afinal, a fase idealista da propaganda republicana. Um partido de ideias, de todos os homens de bem (das direitas e das esquerdas), partido nacional (republicano) que não era um partido único, nem necessariamente a antevisão de unicidades futuras, mas o retorno nostálgico e pragmático ao passado glorioso do P.R.P.. É esta, pelo menos, a nossa leitura das linhas e das entrelinhas do discurso pouco abundante e fragmentado de Sidónio Pais.

(198) Dossier Discursos, s.d., fls. 4,6 e 8]. (Arquivo de Sidónio Pais - Militar, Lente e Político, Subsistema Presidência da República).

(199) Ver PAIS, Sidónio - Um ano de ditadura, ob. cit., p. 75-76. 
De Évora a comitiva, que incluía os Ministros do Comércio e da Marinha, seguiu para Faro e daí, no dia 15, atéVila Real de Santo António, onde o trabalho das fabricas foi paralizado por determinação dos industriais que ofereceram um «copo de água» depois da sessão na Câmara Municipal. Houve discursos e banquetes e recepções efusivas noutras localidades - Loulé, S. Brás de Alportel, Portimão e Praia da Rocha, onde o Presidente da República almoçou até muito tarde, regressando a Lagos pelas 21 h e aí foi recebido nos Paços do Concelho, discursou cerca de quarenta e cinco minutos, visitou a sala do Regimento de Infantaria 33 e a Escola Industrial, onde Ihe foi oferecido chá e bolos. Retirou para Portimão. Ao alvorecer do dia 17 a comitiva preparou-se para deixar o Algarve em direcção a Beja, que se achava já preparada para receber com idêntico entusiasmo e pompa o ilustre visitante. E repetiu-se o programa, com a recepção obrigatória nos Paços do Concelho. Aí Sidónio Pais, num dos seus vários discursos e alocuções, enunciou duas prementes questões que pendiam sobre si e o seu Governo: uma a da Ordem Publica, por toda a gente reclamada, por todos aqueles que do trabalho querem progredir. A outra questão é a solução do problema politico, isto é, realisar o equilibrio politico, para que se estabeleça a paz no paiz. E prosseguiu dizendo: $O$ regimen parlamentar já deu todas as suas provas durante os 80 anos de constitucionalismo monarquico e as provas são negativas. Em pleno seculo $X X$ não é possivel o regimen absoluto tendo-se portanto que optar pelo regime republicano; mas para isso é necessario que o paiz se pronuncie sobre a forma de regimen que deve adoptar: se parlamentar, se presidencialista. $O$ primeiro faliu; 0 segundo é a Ideia Nova. ${ }^{(200)}$ A concluir esclareceu que, em breve, se realizaria a eleição para Presidente da República e depois a das Câmaras com poderes constituintes.

Declarações interessantes, porquanto indicam que no seio do Ministério ditatorial a que presidia, o debate continuava inconclusivo, sendo alguns dos seus membros claramente contra a não simultaneidade dos dois actos eleitorais e contra a manifesta vontade do núcleo formado por Sidónio, centristas e machadistas de autonomizarem e dignificarem a função presidencial.

De regresso a Lisboa, mergulhou na crescente fermentação político-partidária que grassava infrene no seio do Poder. Em nova carta, com data de 19 de Fevereiro, Santos Viegas dava conta da iminente gestação de um Gabinete partidário de cariz centrista caso não houvesse acordo entre Sidónio Pais e Barros Queiroz, representante credenciado do chefe unionista. $O$ ainda Ministro das Finanças, indefectível camachista, demarcava-se de um governo partidario, declarando-se alheio a uma carreira política e portanto a nenhum partido dou a minha expressão effectiva, e por outro lado julgo um erro muito grave para um Governo da Republica, deixar de tomar appoio nos antigos republicanos. Registe-se o pretenso apartidarismo de Viegas e o sentido profundo da sua mensagem: os velhos republicanos não passavam procuração aos novos para tomarem conta da República, apesar dos decantados e ocasionais apelos (de Camacho) à unidade e à substituição da velha guarda por gente nova à cabeça de um partido novo!... Profundas e gravosas incoerências.

As afirmações em Beja soaram naturalmente como provocação, dando mais motivos a aziumados reparos nas páginas de A Lucta, tanto pela pena de Brito Camacho, como

(200) Cf. PAIS, Sidónio - Um ano de ditadura, ob. cit., p. 50. 
por José Barbosa, que em 191 I se distinguira na defesa quase isolada do presidencialismo e vinha agora à colação, chamado pelo seu líder, para condenar réplicas espúrias ou jurídico-constitucionalmente incorrectas do seu modelo americano-brasileiro.Ainda não era o corte formal de relações, mas se tal viesse a suceder, os centristas, com destaque para a dupla Egas Moniz e Tamagnini Barbosa - acusado este por Cunha Leal de desmedida ambição e por Eurico Cameira de inesgotáveis artimanhas, mas definido por Rocha Martins como frio e calmo(201) — dispunham-se a ocupar o lugar vago. Movimentações de bastidores que não têm merecido a necessária atenção e que se nos afiguram cruciais para melhor se entender a rota ziguezagueante da experiência dezembrista e sidonista. Têm sido igualmente desprezados os indícios de notória disponibilidade por parte da Presidência da República para não alienar apoios, tentando manter até certos limites a integridade da rede sócio-política originária. A título de exemplo basta lembrar que a 20 de Fevereiro um novo Conselho de Ministros acordara se procedesse no mais curto prazo à eleição, por sufrágio directo, do Chefe do Estado, elegendo-se simultaneamente os representantes do País, com poderes para elaborarem a Constituição. (202)

Enquanto ia sendo adiada uma indesejável fissura na rede,(203) Sidónio Pais procurou manter acesa a chama incandescente das viagens presidenciais e a 24 de Fevereiro foi subitamente ao Porto, atraído pelo recrudescimento da epidemia do tifo, ou seja, a febre tifóide de tipo abdominal e tifo exantemático, que era endémico entre as comunidades de pescadores e algumas de serranos do interior.(204) Em finais de 1917 eclodira com força em Espinho, propagando-se depois ao Porto, principalmente às suas insalubres «ilhas» e daí afectou outras zonas do Norte do país, falecendo ao todo, em 1918, mil setecentos e vinte e cinco pessoas, mais novecentas e dez de febre tifóide, contra, respectivamente, quarenta e duas e novecentos e oitenta e cinco no ano transacto.

Problema crónico de extrema gravidade, que motivou a pronta nomeação, por decreto n. ${ }^{\circ} 3.861$ de 23 de Fevereiro, do professor da Faculdade de Medicina de Lisboa, Augusto de Almeida Monjardino, para as funções de Comissário do Governo no distrito do Porto, com superintendência e direcção imediata sobre todos os serviços que, directa ou indirectamente, se relacionassem com a debelação da epidemia e o saneamento da cidade invicta. (205) E o novo Presidente da Câmara Municipal, Artur Jorge Guimarães, que acumulava funções com as de Provedor da Misericórdia do Porto, apressou-se a denunciar a grave situação existente numa das suas cartas ao amigo Presidente da República, culpando o Executivo Camarário anterior de dispêndio inútil de dinheiros públicos: Hoje fizemos uma sessão extraordinária para satisfazer aos desejos que tinhas

(201) Cf. MARTINS, Rocha - Brigadeiro João Tamagnini de Sousa Barbosa. Portugal dos nossos dias: Vermelhos, brancos e azuis - Homens de Estado, homens de armas, homens de letras, vol. 3. Lisboa:Vida Mundial Editora, 1948, p. 103.

(202) Cf. PERES, Damião - História de Portugal. Suplemento, ob. cit, p. 175.

(203) Cf.A Situação política. Conjurou-se a crise. Resolveu-se eleger conjuntamente o presidente e as câmaras. O Século, de 20 de Fevereiro de 1918, p. 1.

(204) Cf. MARQUES, A. H. de Oliveira - História da $10^{\circ}$ república portuguesa. As estruturas de base, ob. cit., p. 10-11.

(205) Dossier Epidemias, Ifl. s.d. (Arquivo de Sidónio Pais - Militar, Lente e Político, Subsistema Presidência da República). 
da nossa colaboração. Eu que não tinha ideia de fazer empréstimo algum enquanto aqui estivesse resolvi-me a fazer um de 500 contos que já está autorizado mas destina-se exclusivamente à construção de casas para a gente pobre afım de poder destruir os bairros infectos desta cidade. Se a anterior Camara tivesse tido essa boa orientação já agora a cidade não se veria em tais apuros. Gastaram 2.000 contos para embelezamento destruindo prédios bons e deixando em pé toda essa miséria que é um perigo constante para a cidade e uma vergonha.

A carta data do dia 26 e traduz uma resposta imediata ao impacte da recente visita aos Hospitais de Tifosos ${ }^{(206)}$ e ao apelo de Sidónio para que as autoridades locais colaborassem na erradicação das causas do foco epidémico.

Aliás, para além de sucessivas aberturas de crédito por incumbência legal do Ministério do Interior, não tardou a ser promulgada legislação inovadora, progressista e ilustrativa da faceta não retrógrada, agrária e pejorativamente conservadora com que alguns autores têm estigmatizado a política sidonista. Esta revela-se-nos, afinal, bem mais complexa e contrastada, como mostra a legislação destinada a regulamentar a construção de bairros sociais para operários, à semelhança do que há muito se vinha fazendo nos países mais desenvolvidos, tais como a Inglaterra, a Bélgica, a França ou a Alemanha. O decreto 4.137, de 24 de Abril, foi, segundo Manuel C. Teixeira, ${ }^{(207)}$ particularmente importante, porque através dele era afirmada a vontade do Executivo de assumir igualmente como sua uma iniciativa até aí mais de âmbito municipal e particular como era o caso modelar das colónias operárias de $\mathrm{O}$ Comércio do Porto e de impulsionar a destruição dos bairros insalubres de Lisboa e do Porto, substituídos pela construção de casas baratas para os sectores mais carenciados da população. Os imóveis podiam ser edificados quer pela iniciativa privada, quer por sociedades ou cooperativas, a quem eram concedidos empréstimos com uma reduzida taxa de juro de $4 \%$ pela Caixa Geral de Depósitos, de que foi Administrador o capitão Eurico Cameira(208) e que foi, entretanto, sujeita a uma profunda reorganização, tendo sido criado, por exemplo, um Serviço de Crédito Popular.

No início de Março, Sidónio voltava a sair de Lisboa. Deu um pulo a Santarém e discursou nos Paços do Concelho e na sede do Governo Civil, tendo sido alvo, nas palavras telegráficas do jovem Governador Civil de Lisboa Henrique Forbes de Bessa, de uma Recepção muito boa. S. Ex. ${ }^{a}$ o Senhor Presidente foi cumprimentado na Câmara Municipal onde foi delirantemente aclamado. Neste momento chegou edificio Governo Civil onde the é oferecido almoço de cem talheres. (209)

Das suas palavras transpareciam, agora, apelos à participação cívica e eleitoral dos cidadãos, dando a entender que o rumo para a solução política estava encontrado. Paralelamente às viagens triunfais pelo país, Sidónio Pais comprometera-se noutra «viagem» começada em Dezembro, irreversível, incerta e feita a altíssima velocidade...

(206) Telegramas, Livro 1. (Arquivo de Sidónio Pais - Militar, Lente e Político, Subsistema Presidência da República).

(207) Ver TEIXEIRA, Manuel C. - As Estratégias de habitação em Portugal, I 880-1940. Análise Social, Lisboa 27 (I 15) 1992, p. 76-77.

(208) Este aspecto foi realçado por DUARTE, Teófilo - Sidónio Pais e o seu consulado, ob. cit, p. 207.

(209) Telegramas, Livro 1. ${ }^{\circ}$ (Arquivo de Sidónio Pais - Militar, Lente e Político, Subsistema Presidência da República). 


\section{A Recomposição da base de apoio}

Inflexões de rumo geraram, entretanto, fundas clivagens e estas redundaram, finalmente, em ruptura com os unionistas e na sua dissidência interna, tendo um certo número de membros abandonado a União Republicana por não perfilharem o distanciamento proposto pelo Directório para com a situação dezembrista. ${ }^{(210)}$ Os indefectíveis camachistas cerrarão fileiras em torno do líder, invectivando o Poder de forma dura e corrosiva no seu Congresso de 7 e 8 de Abril e alinhando com os outros dois partidos republicanos no boicote às eleições.

Nessa reunião magna do partido, Brito Camacho fará, aliás, a sua história dos acontecimentos políticos desembocados na crise do momento e das suas relações pessoais com Sidónio Pais, dando também as suas explicações, venenosas, escarninhas e falaciosas, como ele tão bem sabia fazer, do rompimento com o Presidente da República e seu Governo: República presidencialista? Muito bem, como objecto de controvérsia, como problema de direito político a debater com a maior largueza, na mais completa liberdade de pensamento. Mas S. Ex. ${ }^{a}$ queria que aceitassemos o presidencialismo como um dogma; que fôssemos para o desconhecido, para o incerto, levados pela sua mão - um alucinado a dirigir um cego! Renunciou o sr. Sidonio Paes a decretar uma Constituição, a fazer-se eleger Presidente antes de ser eleito o Congresso; mas reclamou o sufragio universal para a sua eleição, elegendo-se o Congresso por sufragio limitado. Estava encontrada a casca da laranja; estava posta a questão irreductivel, o conflicto sem remedio. O sr. Sidonio Paes declarou aberta a crise; a União Republicana deixou de estar representada no Poder.(21I)

O Governo ditatorial, empossado a I I de Dezembro de 1917, sofria, passados quase três meses, uma remodelação que afectava, em primeiro lugar, as «pastas» ocupadas pelos amigos de Brito Camacho. Numa delas - a da Justiça e dos Cultos - Moura Pinto conseguira, não sem atritos e pressões, ultimar a muito reclamada e ansiada revisão da «intangível». Para o seu lugar foi convidado o jovem lente de Direito Martinho Nobre de Melo, amigo íntimo de Teófilo Duarte, visto por alguns autores como porta-voz ou representante da extrema direita integralista e autor, devido à sua formação jurídica, da lei eleitoral - o célebre decreto n. ${ }^{\circ} 3.997$, de 30 de Março de 1918, regulador do acto eleitoral por sufrágio universal em 28 de Abril. Um acto de legitimação abordado adiante no início da conturbada e fugaz fase institucionalizante da experiência sidonista.

Aqui e desde já, importa referir a delicada questão religiosa. Sem dúvida uma das grandes questões da ditadura dezembrista e que não se esgota na Lei da Separação das Igrejas do Estado, de 21 de Abril de 1911.(212)

Os efeitos perversos de uma precipitada aplicação e as resistências que esta, de imediato, suscitou, consubstanciaram um conflito que só foi aplacado após $1918 \mathrm{com}$ as alterações do pastel Moura Pinto, como desdenhosa e intransigentemente Afonso Costa classificou o diploma 3.856 de 23 de Fevereiro de 1918.

(210) Ver PERES, Damião - História de Portugal. Suplemento, ob. cit, p. 176.

(211) Ver Terceiro congresso da união republicana, ob. cit., p. 21 .Ver também artigo de BARBOSA, José - Eleição presidencial. A Lucto, Fevereiro de 1918, p. I.

(212) Ver SILVA, Armando B. Malheiro da - Os católicos e a «República Nova» (1917-1918): da «questão religiosa») à mitologia nacional, art. cit., p. 385-499. 
A revogação dos actos punitivos praticados pelos Governos anteriores não podia deixar de suscitar expectativas favoráveis entre os católicos. A sua imprensa deu, aliás, conta imediata disso mesmo. Logo a 13 de Dezembro de 1917 no Imparcial, órgão dos estudantes católicos de Coimbra, saiu um artigo intitulado A Derrota Demagógica, de regozijo pelo modo como a Junta havia vencido o monstro democrático. Regozijo partilhado pelos jornais A Ordem, de Lisboa, ou a Liberdade, do Porto, mas sem qualquer ressonância nos boletins e revistas ligadas ao Episcopado. Aí a prudência e a contenção foram a regra de oiro, embora se multiplicassem as indicações de que o Governo de Sidónio Pais pretendia mesmo desanuviar o clima de tensão vivido entre Igreja e Estado republicano. Faltava saber como e com que eficácia. Faltava ainda ganhar confiança. E, portanto, para os católicos a interrogação punha-se com acuidade: seria Sidónio de confiança?

Os católicos mexeram-se, ansiosos, na expectativa de uma nova lei. Urgia, pois, pressionar e influenciar o Poder por todos os meios disponíveis. E o malogrado oficial da Armada, conspirador republicano e activo machadista, José Carlos da Maia, não escapou a essa súbita e envolvente pressão católica. Em cinco folhas de papel timbrado da Secretaria da Presidência da República, redigira, à pressa, umas informações úteis sobre as projectadas alterações à lei da Separação. A pedido de um dirigente católico, o «dr. Neto» — o político e economista António Lino Neto(213) — transmitiu ao Presidente da República o descontentamento dos católicos face ao que se sabia das emendas do dr. Moura Pinto, pelo que preferiam o envio da matéria para debate no Parlamento.(214)

O recado data do dia 9 e a 23 do mesmo mês de Fevereiro era publicado o decreto n. 3.856 , assinado a 22,(215) com as referidas alterações à lei de 21 de Abril de $191 \mid$.A apresentação do diploma competiu, de facto, ao Ministro da Justiça e dos Cultos, Alberto de Moura Pinto, não sendo de excluir a alegada interferência de Brito Camacho na redacção do respectivo relatório. Cunha e Costa ${ }^{(216)}$ adiantou este dado para desligar Sidónio Pais das alterações aprovadas e julgadas insuficientes pelos católicos. No entanto, fica claro, à luz das apressadas e esclarecedoras palavras de José Carlos da Maia, que para os republicanos mais transigentes em matéria religiosa era imprescindível seduzir os católicos, por serem uma força que não é para desprezar, como está sendo visto por outros chefes políticos, sem renegarem os fundamentos doutrinários do separatismo.

Para as várias sensibilidades da rede socio-política de apoio era oportuno ganhar rapidamente a confiança dos católicos, antes das eleições e dos debates parlamentares, porque os votos dos católicos faziam falta à consolidação e à legitimação da política aberta pelo 5/8 de Dezembro. Um dos riscos possíveis estava, porém, no método seguido, que classificaremos de ditadura administrativa: impor por decreto medidas

(213) Verbete biográfico in O Grande Livro dos Portugueses. Lisboa, Círculo dos Leitores, 1990, p. 375. Da carta de José Carlos da Maia depreende-se que, em Fevereiro de 1918, Lino Neto e Sidónio Pais estavam ainda longe da amizade pessoal que lhes é atribuída no referido Dicionário.

(214) Ver SILVA, Armando Barreiros Malheiro da - Sidónio e sidonismo. História e mito, dissert. cit., vol. 2. p. $127-128$.

(215) Cf. Decreto 3.856 de 22 de Fevereiro de 1918. Diário do Governo, I série (34) de 23 de Fevereiro de 1918.

(216) Ver COSTA, José Soares da Cunha e - A Egreja catholica e Sidonio Paes. Coimbra: Coimbra Editora, 1921. 
pensadas, discutidas e negociadas nos bastidores do Poder, sem garantia de responderem satisfatoriamente à plenitude dos interesses afectados. Um risco inevitável porque permaneciam intactos os velhos hábitos político-administrativos insidiosamente fixados nas práticas governativas.

Mas debrucemo-nos um pouco sobre o decreto de 22 de Fevereiro, em especial o seu relatório.

A linha geral da doutrina aí expendida não diverge, salvo no republicanismo de fundo, dos textos publicados pelo jornal monárquico e católico O Dia, de 20 de Abril a 24 de Maio de 1911.(217) É, aliás, interessante observar que, a dado passo, o legislador se surpreendeu com a propensão religiosa da República de 5 de Outubro. E, de facto, é por demais sabido que Augusto Comte fundou uma religião, como também é fácil encontrar na oratória política republicana abundantes e fortes alusões a uma espécie de religião da Pátria!...

Enfim e para abreviar: uma República milenarista tinha forçosamente de ser hostil a outros sistemas de crenças, sobretudo se derivassem da matriz judaico-cristã, como é o caso do catolicismo, embebido numa estrutura mítico-simbólica de tipo messiânico. Reduzir ou neutralizar essa hostilidade - propósito declarado no relatório do decreto n. ${ }^{\circ} 3.856$ - à custa, inclusive, de certas auto-restrições ideológicas, não garantia que - republicanismo deixasse de convocar o «cenário» milenarista, mas implicava, sem dúvida, maior permissividade e equivocidade em relação ao «cenário» messiânico da mundividência cristã-católica. E, de facto, o discurso conciliador de Sidónio Pais e da «sua» República Nova permitiu o híbrido entrosamento desses diferentes «cenários» através da transferência, facilitada por circunstâncias dramáticas e especiais (escândalos, guerra, fome, beatificação do Condestável, aparições marianas em Fátima, epidemias...), da carga milenarista e prometeica do reformismo demoliberal, republicano e parlamentar, legitimado pela Constituição de 1911, maçónica e individualista, ${ }^{(218)}$ para um presidencialismo derivado do mesmo tronco jacobino, tendencialmente mais conservador, bastante personalizado e populista, a que a Igreja Católica não regateou uma legitimidade sobrenatural, aceitando Sidónio Pais como um emissário dos insondáveis desígnios da Providência!...

Voltaremos já a este ponto - o equívoco ideológico decorrente da aproximação da República dezembrista/sidonista aos católicos e vice-versa - mas antes fixemo-nos nas alterações à lei da Separação. E quanto a este tópico pode dizer-se que o decreto 3.856 de 22 de Fevereiro deixou explícito, ainda na parte inicial do relatório, o que podia ser alterado. ${ }^{(219)}$

A linguagem é subtil, mas a mensagem evidente: o separatismo mantinha-se em conformidade com o espírito entranhadamente liberal da República; certas cedências em matéria de privilégios e garantias seguiam para debate em instância adequada - 0 Parlamento; e as agressões mais salientes da lei de 1911 sofriam a rasura necessária, pondo termo a uma injustificada repressão da consciência católica. E, neste sentido,

(217) Cf. Decreto 3.856 de 22 de Fevereiro de 1918. Diário do Governo, diploma cit.

(218) Ver CAETANO, Marcelo - História breve das constituições portuguesas. Lisboa: Editorial Verbo, 1968 p. 95-106.

(219) Cf. Decreto 3.856 de 22 de Fevereiro de 1918. Diário do Governo, diploma cit. 
o articulado do novo decreto acabava por dar alguma folga às grilhetas do Estado: reconhecia a falência das controversas comissões culturais, porque eram reduzidas em número e compostas na sua maioria de pessoas indiferentes se não hostis à crença que se propunham manter e assegurar ${ }^{(220)}$ e, em sua substituição, os fiéis ficavam autorizados a reunirem-se livremente, sem prévia licença, para escolherem a corporação que a seu cargo fique tendo a sustentação do culto público,(221) podendo incluir, nos respectivos corpos dirigentes, os ministros da religião em pleno gozo dos seus direitos civis e políticos; as tradicionais agremiações católicas (irmandades, confrarias, etc.) podiam ser incumbidas da sustentação do respectivo culto público, ficando aptas a dispor, por cedência (empréstimo) gratuita e sem encargos do Estado, dos templos e objectos necessários para esse fim; os antigos seminários que ainda não estivessem afectos a serviços do Estado seriam devolvidos à sua original função; quaisquer entidades dirigentes das diversas confissões religiosas podiam fundar estabelecimentos destinados, exclusivamente, ao ensino da teologia e das disciplinas preparatórias; os actos ou omissões previstas pelas prescrições da lei da Separação e pelas leis penais teriam de ser julgados pelos tribunais ordinários, não podendo o Governo, salvo certas excepções, aplicar-Ihes penas disciplinares antes da respectiva sentença transitar em julgado; as pensões eram substituídas por uma subvenção pessoal, anual e vitalícia, a título de reparação e indemnização; cessava o beneplácito em regime de separação (questão polémica à qual O Dia, em 191 , não poupou reparos); e ficava atendido o direito de os eclesiásticos usarem hábitos talares fora dos templos e das cerimónias.

A reformulação das culturais, firmemente condenada em 1911 por Pio $\times$, foi um dos pontos do novo decreto que desiludiu as autoridades eclesiásticas e muitos fiéis, porque ficara aquém do desejado - a sua eliminação pura e simples. A pronta reacção do inflexível Cardeal Patriarca D. António Mendes Belo, deixa entender uma certa insatisfação e expectativa em relação à resposta de Roma face aos últimos gestos de boa vontade do Estado português. Uma reacção curta e prudente, veiculada pela sua circular de 25 de Fevereiro, enviada aos párocos. ${ }^{(222)}$

Ressalvada a indesejável - para os católicos - persistência de um laicismo enformador da nova legislação, as medidas e os gestos político-administrativos do Governo impressionaram bem e representaram um esforço de alguma desideologisação do separatismo legal, acrescido do táctico aliciamento de católicos e de monárquicos para os mais diversos cargos públicos, criados de novo ou deixados vagos pela anterior rede clientelar democrática. ${ }^{(223)}$

Uma característica do processo político desencadeado após 5 de Dezembro de 1917, notada por vários autores, consistiu no cada vez menor apoio expresso do campo republicano, obrigatoriamente compensado pelo apoio de outros campos político-ideológicos.

(220) Cf. Decreto 3.856 de 22 de Fevereiro de 1918. Diário do Governo, diploma cit.

(221) Cf. Ibidem.

(222) Ver SILVA, Armando Barreiros Malheiro da - Sidónio e sidonismo. História e mito, dissert. cit., vol. 2. p. 132.

(223) Ver Ibidem, p. I 32- 133. 
No entanto, é preciso reconhecer e sublinhar que os Governos de Sidónio Pais mantiveram, mas não de modo inequívoco, as fronteiras de um Estado indelevelmente republicano. Para lá de tais limites - efectivamente intangiveis...- terminavam as cedências aos católicos, porque para lá de tais limites ficava a difícil abertura do ensino oficial e particular à temática religiosa, o intolerável regresso das Ordens religiosas, nomeadamente da proscrita Companhia de Jesus (título VI, art 83. ${ }^{\circ}$ ), ou ainda a abdicação completa do Estado ante compromissos difíceis de revogar por respeitarem à administração dos bens arrolados.

Cunha e Costa afiançou que a morte de Sidónio Pais fora o único óbice à satisfação da liberdade de ensino religioso nas escolas particulares. No entanto, Sidónio não podia, em coerência com os seus princípios de livre-pensador mantidos até ao fim da vida, alterar a lógica do regime separatista ou tão pouco arriscar num domínio delicadíssimo como era o instructo-educativo, onde o progressismo da República deixara já algumas perenes marcas. E no tocante aos bens arrolados, o Estado republicano, pelo decreto n. ${ }^{\circ} 4.410$ de 15 de Julho, determinava, apenas, uma mudança na composição das comissões concelhias, em sintonia com similares retoques na Comissão Central, reduzindo-as a três funcionários públicos, libertos, eventualmente, do controlo partidário, mas, inevitavelmente, enredados na teia governamental.

Enfim, a margem de manobra, no sentido da satisfação das reivindicações católicas - entoadas com crescente veemência - foi-se tornando cada vez mais pequena, cingindo-se a matérias de consenso, isto é, aceitáveis para uma República disposta a conviver e a colaborar abertamente com as crenças religiosas: a revisão da lei do Registo Civil, para permitir que os párocos administrassem o sacramento do Baptismo, ou a concordância sobre o envio de missionários para as Colónias - medida que o democrático Norton de Matos, Alto Comissário em Angola de 1921 a 1924, ousará regulamentar por decreto n. ${ }^{\circ} 77$ de 9 de Dezembro de 1921.(224)

Os católicos, como é natural, só poderiam sentir-se plenamente atendidos se a obra republicana fosse profundamente revista. Se a República pretendesse apenas reparar excessos, era óbvia e flagrante a sua insatisfação. Mas também se percebe que thes fosse, mesmo assim, vital o apoio à nova situação política. $\bigcirc$ processo preparatório das eleições presidenciais e legislativas de 28 de Abril (Câmara de Deputados e Senado), oferecer-lhes-á o ensejo para uma expressiva aproximação política dentro de um, cada vez mais vincado, equívoco ideológico.

O espectro do sufrágio universal jogava contra a lógica eleitoral dos partidos da República Velha, porque abria as urnas ao eleitor rural e analfabeto, manipulável pelo clero e pelos monárquicos. A resposta de democráticos, de evolucionistas e de unionistas teve, por isso, o recorte de um cheque-mate: a abstenção. Os republicanos velhos auto-excluíam-se deliberadamente de um processo que ficava sem a sua importante chancela legitimadora. E Sidónio Pais era, assim, condenado a gerir outros apoios, vindos da oposição à República. Apoios equívocos numa situação republicana!...

Apoios envenenados, nomeadamente dos monárquicos...

(224) Sobre o teor e a aplicação do decreto regulamentar da «existência e funcionamento das missões religiosas», veja-se a evocação do próprio MATOS, Norton de - África nossa. 0 que queremos e o que não queremos nas nossas terras de África. Lisboa, Edições Marânus, 1953, p. 94-99. 
Jornais como O Dia de Moreira de Almeida, o Diário Nacional do conselheiro Aires d'Ornelas ou A Ordem de Fernando de Sousa (Nemo), outro ilustre conselheiro do antigo regime, não hesitaram em saudar a Junta Revolucionária e o seu Governo pelos seus intuitos opostos à hegemonia dos democráticos e pela reabertura de um diálogo político, que a prática de intransigente exclusão seguida pelos vários Governos da República, salvo durante o efémero pimentismo, inviabilizara e fora adiando sine die. No fundo, tratou-se da hábil necessidade de gerar pretextos e inimigos para uma redobrada vigilância e para um constante combate em prol da aurora ideal que raiara em 1910. E entre os inimigos estavam os indefectíveis de D. Manuel, os conspiradores capitaneados pelo quixotesco Paiva Couceiro, os jovens integralistas, os legitimistas e uma vaga e imensa mole de classes conservadoras, que englobavam tanto a velha aristocracia fundiária como o campesinato disperso pela vasta ruralidade do país. Esta numerosa massa populacional constituía, aliás, o grande busilis para as elites republicanas: analfabeta e subjugada ao multissecular doutrinamento da Igreja Católica não gozava da plena liberdade ou da indispensável autonomia de consciência para expressar eleitoralmente a sua vontade a favor da República e, nesse sentido, tinha de ser sujeita a uma campanha instructo-educativa e cívica que a reabilitasse aos olhos do Portugal republicano!...

Mas como essa campanha exigia mais que bonitas palavras ou poéticas intenções, o novo regime entrincheirara-se num campo ideológico-político cada vez mais divorciado da realidade social supostamente hostil. Situação paradoxal e insustentável, embora muito difícil de superar, porque qualquer abertura em direcção a essa massa excluída implicava um convite formal à participação de católicos e de monárquicos no xadrez político, com a agravante de que estes, ou melhor, os seus sectores mais militantes e dinâmicos, não apostavam na adesivagem mas na disputa do Poder e até na possibilidade da restauração da Monarquia.Aliás, tanto os periódicos citados e outros similares, como alguns destacados arautos das fileiras monárquicas, não tardaram a marcar bem esse desiderato.

Em entrevista ao jornal A Capital, de 21 de Fevereiro, o ex-republicano e neófito do monarquismo, Cunha e Costa, declarou: Dizer oficialmente aos monarquicos que votem num presidente da Republica equivaleria a recomendar aos republicanos que aclamassem um rei! (225)

Eduardo Burnay, num opúsculo anónimo sob a forma de carta aberta ao sr. Sidonio Paes, inclito e invicto restaurador da ordem, após regozijar-se com a limpeza político-partidária efectuada, pôs várias e delicadas interrogações sobre essa réplica de bonapartismo que despontava, essa republica nova oposta, pelo que se anunciava, à republica que tem estado [que] é uma republica parlamentar e, portanto, a lógica diz que esta não pode ser parlamentar, aliás não haveria novidade. E desde que não é parlamentar ha de ser consular á maneira bonapartiana, ou presidencial á maneira americana. Não ha meio termo. Póde isto efficazmente praticar-se cá? Fazemos a pergunta, mas V. Ex. é que terá de the responder. (226) Na certeza, porém, de que se viesse a falhar, então automatica e reflexamente por si recrescerá a força e o prestigio da causa monarchica, cujo util triumpho só pode vir pela

(225) Esta entrevista foi prontamente comentada e rebatida por GARÇÃO, Mayer-Nas Vésperas da eleição. A Manhã, de 22 de Fevereiro de 1918, p. 1.

(226) Cf. [BURNAY, Eduardo] - Sete annos depois... A Republica nova: carto ao sr. Sidonio Paes, inclito e invicto restaurador da ordem. Lisboa: Lamas Mota \& C.. [19..], p. 84. 
persuasão nacional e não pela fomentação artificial de uma facciosa opposição a qualquer estado de cousas, que o paiz expontanea e indubitavelmente acclame, como a expressão genuina do que the agrada e do que, de momento, quer.(227)

Perspectiva reveladora de um certo determinismo optimista favorável ao regresso da Monarquia, partilhado por Alfredo Pimenta, claro está, à sua peculiar maneira de polemista e de agitador de ideias. Na célebre conferência realizada no salão nobre da Liga Naval Portuguesa, na noite de 26 de Fevereiro, sob a epígrafe A Situação política, esticou o seu estilo desabrido e frontal até ao ponto de afirmar que os monárquicos e todos os conservadores responsáveis exigiam, no imediato, a instauração da ordem acima de qualquer quer outro aspecto, mas não podiam hipotecar as suas convicções ao claro propósito formulado pelo Chefe do Estado nos seus discursos de ingresso puro e simples dos monárquicos na República - Não pode ser! Deante das palavras proclamadas pelo chefe do Estado, devemo-nos manter na maior reserva e na mais firme espectativa. E a conhecida reforma da lei da Separação destruio as ilusões que podessemos ter alimentado.(228) Mais ainda: não se previa que a situação sidonista fosse eterna e quando terminasse ou regressa Afonso Costa ou temos uma Monarquia. (229)

Não havia, pois, ilusões para os integralistas, cépticos quanto às possibilidades de sucesso e de florescimento da experiência presidencialista. Embora se sentissem atraídos pela vertente autoritária e ordeira do sidonismo, repeliam, em contrapartida, o seu subjacente e indelével democratismo. Um dilema que António Sardinha só equacionou pela redução ao absurdo: $O$ presidencialismo é um absurdo por the faltar continuidade. Napoleão, apesar de genial, também caiu. (230) A alternativa passava, pois, inevitavelmente, pelo fim desse estádio transitório de poder pessoal e pela restauração da Monarquia integral.

Estes exemplos mostram que certos sectores do monarquismo estiveram, desde o início, perfeitamente esclarecidos quanto à estratégia integradora proposta por Sidónio Pais, mas tal desengano não impediu que se gerasse o equívoco monárquico e muito menos o colaboracionismo dos realistas, por dever patriótico, no Exército e na Administração. Para Sidónio era por esta ponta - e apenas por ela - que lhe parecia possível desfiar o novelo da cooperação e de uma futura integração no campo republicano. Daí que nos seus discursos tenha repetido, com subtilezas de diplomata, que servir a Pátria impunha uma reconciliação e para esta se efectivar era imperioso apelar a todos os portugueses, independentemente das suas filiações partidárias (monárquica incluída): Eu não desejo saber a que partido pertenceis, apenas sei que sois portugueses. Tenho todavia a certeza que vós, tendo estado ao lado dum partido, desligar-vos-heis para estardes ao lado do governo. Não venho pedir o vosso voto, mas venho pôr á evidencia a consciencia e a gravidade do momento e a obrigação absoluta de defender-mos o bem da Patria. E na base desta postura estava um pressuposto essencial:

(227) Cf. [BURNAY, Eduardo] - Sete annos depois... A Republica nova, ob. cit., p. 90.

(228) Cf. PIMENTA, Alfredo - A Situação politica, ob. cit., p. 41-42.

(229) Cf. Ibidem, p. 44.

(230) Cf. SARDINHA,António, in A Monarquia, de 5 de Julho de 1918, p. 1, cit. por DUARTE, Teófilo - Sidónio Pais e o seu consulado, ob. cit., p. 287. 
A Republica Nova gerada pela Revolução de 5 de Dezembro de 1917 encarna as supremas aspirações da consciencia nacional e firma as suas raizes profundas na alma popular.

Defensora do Povo é defendida por Elle e como Elle invencivel.(231)

Para esta República populista/popular a cooperação com os monárquicos era imprescindível, mas pautava-se por um indesmentível distanciamento doutrinário e dentro dos apertados limites da elementar coerência e do decoro político. Quer isto dizer o seguinte: quando Valentim Fabeiro Portas, Cônsul de Portugal em Tuy, oficiou, a 9 de Abril, para o Ministro dos Negócios Estrangeiros, comunicando que se apresentou neste Consulado o emigrado politico ex-capitão Sr.Jorge Camacho preguntando se tanto ele como outros desejam ir fixar residencia, pois consta-lhe que até á data não foi revogado o decreto de amnistia do governo Pimenta de Castro. Peço $a$ V. Ex. ${ }^{\circ}$ se digne dar-me instruções para poder informar o interessado, o destinatário oficial, ou seja, Sidónio Pais despachou com data de 17 do mesmo mês pela sua própria mão Não podem, repetindo, assim, o teor de uma resposta que apusera num telegrama do dia 6 expedido pelo mesmo Cônsul - Diga-se que não póde entrar. 8-4-18 Sidonio Paes. ${ }^{(232)}$

Em reforço da linha desenhada por esses despachos acha-se o depoimento de António Cabral sobre a audiência que um grupo de delegados da Comissão Eleitoral monárquica obtivera de Sidónio Pais no Avenida Palace, sábado, dia 2 de Fevereiro. Depoimento interessante, a seguir com todas as reservas por se tratar de uma narrativa memorialística legitimadora de uma certa «verdade» histórica.

Segundo António Cabral, Sidónio Pais recebeu a delegação monárquica com requintes de amabilidade, ouvindo atentamente a exposição que aquele, em nome dos seus correligionários, lhe fez, e concluída nestes termos: seria garantida aos monárquicos a liberdade das urnas e poderiam eles usar, sem coacções nem violências, todos os meios legítimos de propaganda eleitoral? A estas questões essenciais a resposta obtida foi francamente afirmativa, tendo acrescentado em palavras quasi meigas, (...) que não podia fazer pedidos, mas só exprimir desejos. Estes, eram de que se realizasse o ingresso dos monarchicos na republica, em pé de egualdade com os republicanos, para o quê, com uma constituição nova, o momento era opportuno. Não haveria abdicação. Fariam os monarchicos uma experiencia, com reserva de que voltariam á lucta, se essa experiencia não desse resultado. $O$ dever patriotico era este. Poderiam continuar as perturbações da ordem: para as evitar, era indispensavel a união de todos os portuguezes. Sem essa união, não se consolidaria o regimen da ordem. Poderia haver, em breve, uma eleição presidencial, directa, e os monarchicos teriam de se manifestar. Se se abstivessem e elle tivesse uma votação ridicula, estaria perdido. Era precisa, pois, a união de todos. Tinha, porem, a certeza - accentuou - de que, na sua missão, havia de triumphar.(233) Aproveitando a referência à realização

(231) Discursos. (Arquivo de Sidónio Pais - Militar, Lente e Político, Subsistema Presidência da República) Ver também DUARTE, Teófilo - Sidónio Pais e o seu consulado, ob. cit., p. 193.

(232) Processo Presos politicos em Portugal. Conspiradores monarquicos). (Arquivo Histórico do Ministério dos Negócios Estrangeiros).

(233) Cf. CABRAL, António - Alexandre Cabral. Memorias politicas. - Homens e factos do meu tempo, ob. cit., p. 302. 
de eleições para breve, os monárquicos terão formulado a hipótese de um plebiscito para que a Nação pudesse escolher o regime político da sua preferência, mas a tal alvitre Sidónio Pais quasi se irritou. Plebiscito?! Não! De modo algum! Voltariam as perturbações. Foi então, a crermos no relato de António Cabral, que a candura monárquica se alterou, ripostando o porta-voz da Comissão com inicisiva firmeza. (234)

Num memorável testemunho, Cabral pretendeu transmitir o dúbio relacionamento de Sidónio com os monárquicos, ${ }^{(235)}$ patente também na postura dos jornais O Dia de Moreira de Almeida, o Diário Nacional de Aires de Dornelas e o órgão integralista Monarquia, (236) e em mais dois episódios ilustrativos, ocorridos nas vésperas das eleições. Um foi o desmentido formal do Visconde do Banho, em artigo publicado no Comercio de Vizeu e reproduzido pela A Capital, de 22 de Abril, acerca do pretendido acordo eleitoral com o Governo: ao contrário do que andava a ser dito, os monárquicos não iriam auxiliar os governamentais a vencerem, limitando-se eles a disputarem as minorias e, como prova cabal deste desmentido, citava o caso de Viseu onde o partido monárquico dispunha de condições para conquistar as maiorias. $\bigcirc$ segundo episódio respeita à tentativa de constituir, na capital, uma lista neutra, a lista da cidade, proposta pelos monárquicos para que se conjugassem os seus votos com os do Governo e para isso a lista não deveria conter nomes em evidência na política monárquica, ou republicana, mas escolher os candidatos entre individualidades de grande prestígio em todos os ramos de actividade e de destaque social.(237)

Uma oferta habilidosa, que o Governo rejeitou, não sem mais algumas convulsões internas. O Ministro da Marinha escreveu, em 25 de Abril, uma carta a Sidónio Pais, de pedido de demissão e de indignada reacção contra a campanha monárquica orquestrada para esse fim e insidiosamente hostil à sua pessoa: As coisas passam-se como se a recusa do governo de incluir nomes monarchicos nas suas listas fosse méramente platonica e apenas se vê que os monarchicos elaboraram uma lista mixta e se propõem pela maioria. Esta é verdade. Esta é a conclusão a que se chega logicamente depois de uma detida analyse dos factos. Sabem os monarchicos muito bem que não podem disputar aos socialistas a minoria e por isso mantêm o seu proposito regressando á ideia fixa da lista que elles impropriamente chamam da cidade. Devo portanto sahir porque dada a caracteristica especial da cidade de Lisboa, muito avançada, e com a sua organisação republicana em poder dos abstencionistas, a minha candidatura não vingará. Enganara-se...

A candidatura governamental acabou por vingar e Sidónio Pais conseguiu demovê-lo do intuito da demissão, mas infere-se de mais este choque ou abalo interno na rede

(234) Cf. CABRAL, António - Alexandre Cabral. Memorias politicas. - Homens e factos do meu tempo, ob. cit. p. 303-304.

(235) Um fragmento autógrafo a lápis de Sidónio Pais ajuda a precisar um pouco melhor os contornos de uma relação inevitável, mas assente em reservas mútuas: Tenho informações - escreveu ele - que ha manejos de allemães combinados com elementos monarchicos. Já pude calcular que elementos serão, como eu tambem calculo sem todavia poder obter provas. $O$ certo é que estes elementos monarchicos estão em ligações politicas com os restantes para a questão das eleições. Esta embrulhada colloca-os numa má situação - e é necessario aproveital-a, o que vou fazer. Dossier 85 Informações. (Arquivo de Sidónio Pais - Militar, Lente e Político, Subsistema Presidência da República).

(236) Ver a análise dos artigos publicados por esses periódicos durante a efémera situação dezembrista/sidonista: DUARTE, Teófilo - Sidónio Pais e o seu consulado, ob. cit,. p. 266-292.

(237) Cit. de O Dia por PERES, Damião - História de Portugal, Suplemento, ob. cit., p. 177. 
sócio-política de apoio à República Nova o efeito auto-destrutivo de uma confluência táctica circunstancial e espinhosa:nem os republicanos, mesmo os desafectos aos partidos ditos históricos, estavam sincera e unanimemente dispostos (Sidónio incluído) a partilhar - Poder com os monárquicos, nem estes pareciam dispostos a perder a ocasião suprema de uma desforra política contra a República. E no meio deste imbróglio de reservas mentais mútuas e de aliança contra-natura, o sidonismo arriscava-se mesmo a «cair por terra» ou a «ser liquidado», segundo os «generosos» vaticínios formulados por Cabral ou por Camacho...

Conscientes da oportunidade renascida, três anos após o Movimento das Espadas de curta e amarga memória, os monárquicos manobraram de várias formas, porque inútil seria imaginá-los como um bloco muito homogéneo e articulado, rumo a metas únicas e bem definidas; e manobraram quanto puderam, culminando a sua militância nos acontecimentos de Dezembro de 1918 e Janeiro de 1919, ou seja, nas auto-proclamadas Juntas Militares (em finais de 19|8), na Monarquia do Norte e na revolta de Monsanto, que não nos propomos analisar neste estudo, mas que urge (re)ver através de um melhor conhecimento das especificidades monárquicas, suas limitações e contingências estratégicas. Não restam, porém, dúvidas que no Norte e, em particular, na região militar do Porto faziam sentido os alertas de Melo de Carvalho, demitido das funções de Comissário Geral da Polícia do Porto, em conflito aberto com Sollari Allegro, nos finais de 1918, e que em carta para o Secretário de Estado do Interior capitão Bernardino Ferreira declarou enfático: Tenho por obrigação avisar-te mais uma vez de que os monarchicos, estão a deitar a mão a isto tudo. Já outro dia, em Lisboa te disse isto mesmo. Hoje acrescentarei que tenho seguras informações de que eles (monarchicos) preparam uma revolução dizem eles, para a fazer estalar ainda este mez.

E ao falarmos de manobras monárquicas e conservadoras ocorre-nos, sem que possamos estabelecer uma óbvia relação causal, a meteórica aparição da Junta de Salvação Pública, cuja existência foi comunicada através de um polémico manifesto de 17 de Março, publicado pelo diário pró-governamental $A$ Vanguarda, que logo também o repudiou perante os veementes protestos suscitados. Ainda hoje se ignora o ou os autores do dito manifesto, mas nos exemplares largamente distribuídos em Lisboa e noutras localidades podia ler-se que Esta Junta é instituída sob os auspícios do Governo de que faz parte o grande republicano e patriota Sidónio Pais, proclamado no glorioso dia 8 de Dezembro de 1917.(238) Excluída, porque de todo inverosímil, a ligação de Sidónio Pais ou dos seus mais próximos colaboradores a um texto orientado para a agitação alarmista e repressiva no país,(239) fica por saber de onde procedeu: do campo monárquico-integralista, do campo católico, de certos sectores do Exército, de alguém mais ou menos isolado ou da própria rede clandestina do P.R.P.IP.D. com o fito ardiloso de embaraçar e de desprestigiar internacionalmente o Governo?

(238) Cit. por FERREIRA, David - Pais, Sidónio Bernardino Cardoso da Silva (1872-1918), in SERRÃO, Joel (dir.) - Dicionário de História de Portugal, vol. 3, ob. cit., p. 283.

(239) Segundo David FERREIRA, o manifesto da proclamada junta de Salvação, a par de profunda emoção causou ainda um estado de alarme e de indignação em todo o país, dado o sentido provocatório e violento do seu conteúdo.Ver lbidem, p. 283. 
Mas apesar da eventual improbabilidade de os monárquicos terem algo a ver com esta aposta desestabilizadora, não há dúvida que a situação dezembrista agitou-os e mobilizou-os para o jogo político e eles movimentaram-se activamente a nível local, sobretudo a norte do Tejo, sem perderem de vista, claro está, as altas esferas do Poder central.É bom, no entanto, que sejamos cautelosos sobre a participação dos monárquicos na governação sidonista.

Nem tudo o que parece é: considerar o almirante Canto e Castro um público e notório monárquico, ou seja, um não adesivo, depois do que sobre ele escreveu, em carta para o irmão atrás focada e transcrita, António da Silva Pais, só pode ser, no mínimo, motivo de perplexidade; e o simples facto de Cunha Leal(240) rotular de antigo monárquico o latifundiário, membro da Comissão Administrativa (241) da Associação Central da Agricultura Portuguesa e agrónomo Eduardo Fernandes de Oliveira, escoIhido e nomeado em 9 de Março para chefiar e organizar de raiz a pasta da Agricultura, preconizada - é bom não esquecê-lo - no programa do Partido Centrista Português, não significa que em 1918 o rótulo continuasse válido. E os casos podiam multiplicar-se... É que também Leote do Rego, Norton de Matos, Egas Moniz e outros destacadas figuras da República após o 5 de Outubro de 1910 atravessaram, antes dessa data, as fileiras monárquicas e essa trajectória foi alterada no seu curriculum político-partidário pela adesão ao republicanismo.

(240) Cf. LEAL, Cunha - Coisas de tempos idos. As Minhas memórios, vol. 2, ob. cit., p. 113.

(241) Composta, em inícios de 1918, pelos seguintes e destacados sócios: José Relvas, Luís da Gama, Joaquim Nunes Mexia, Jorge de Vasconcelos Nunes, António dos Santos Cidrais, Pedro Ferreira dos Santos e Eduardo Fernandes de Oliveira. Ver Boletim da Associação Central da Agricultura Portuguesa, vol. 19, nos I a 12, 1918. 


\section{Capítulo 3}

\section{Remodelação e Acção Governativas}

\section{Trabalho e abastecimentos externos}

A ruptura com os unionistas nos começos de Março tornou inevitável que o Governo ditatorial saído do golpe de 5/8 de Dezembro fosse remodelado.

Para as Finanças transitava o fiel Xavier Esteves, rendido no Comércio pelo major de Engenharia Manuel José Pinto Osório. Para o Interior, «pasta» chave na organização do processo eleitoral e na manutenção da ordem pública, entrou o jovem tenente Henrique Forbes de Bessa, com apenas vinte e três anos de idade (sem dúvida um recorde para a época) e até então Governador Civil de Lisboa, cargo em que foi prontamente substituído por António Miguel de Sousa Fernandes. Na Marinha, outro indefectível do Presidente, Alfredo de Magalhães, assegurou por dois dias a interinidade, sendo substituído pelo machadista José Carlos da Maia que tomou posse no mesmo dia 9 de Março com o amigo de peito Machado Santos, titular de uma nova «pasta» - a das Subsistências e Transportes - criada à revelia de José Feliciano da Costa. Este ficou no Trabalho, mas já sem os Serviços e as atribuições destinadas ao novo Ministério. Uma perda de competências que o contrariou visivelmente. Uns meses mais tarde, aquando do seu efémero e inglório lugar de diplomata junto da Santa Sé, não deixará de mostrar, em carta pessoal para Sidónio Pais, quanto se melindrara: Vejo que os serviços aqui estão montados como pensei fase-lo nas subsistencias que V. Excia entendeu tirar-me para - Machado Santos fazer aquela brilhante figura.

Mas, bem vistas as coisas, a sua prestação na pasta do Trabalho também não foi briIhante, resultando infrutíferas as medidas tomadas face à momentosa complexidade da carestia de vida e do espectro da fome. No entanto, há que reconhecer-lhe, pelo menos, a intenção de reorganizar os seus Serviços, embora pouco tenha feito de concreto, a crermos no relatório que o futuro Secretário de Estado do Trabalho, Henrique Forbes de Bessa, elaborou sobre o estado da «pasta».(242)

Seja como for, devemos destacar, dentro do domínio da gestão interna e pela sua importância estratégica para o fornecimento das matérias primas e dos produtos ali-

(242) Dossier S.E. Trabalho. Arquivo, Relatório do Ministério do Trabalho por Henrique Forbes Bessa, 2 fls. papel azul pautado. (Arquivo de Sidónio Pais - Militar, Lente e Político, Subsistema Presidência da República). 
mentares indispensáveis, a Delegação Portuguesa da C.I.R., (243) presidida até inícios de 1918 pelo major Frederico Simas, que acumulava funções com as de Adido Militar. Para o substituir foi escolhido e nomeado o major João Casqueiro, chefe da base de desembarque em Brest, que numa extensa carta-relatório dirigida tanto ao amigo Feliciano da Costa como ao Ministro, se queixou amargamente da tarefa gigantesca que tinha pela frente: Não the agradeço a minha nomeação para o cargo da presidência da delegação da C.I.R. porque não imagina o raio que me cahiu em caza. Segundo ele, o Serviço achava-se completamente desorganisado por falta de amanuenses que escrevam á machina em portuguez e inglez tudo quanto é preciso, andando a escrita disseminada pelos differentes delegados em livrinhos de bolso, não tem authenticidade legal e da má organisação d'este serviço resulta que às vezes não se sabe os saldos de verbas que nos foram mandadas para pagamentos. Ainda ha dias se pagou duas vezes uma conta de 289 libras o que se deu por falta de escripta competente na secção de fornecimentos de material naval e então na parte de fornecimentos a particulares e caminhos de ferro tudo está um «cahus», não por culpa do delegado respectivo mas por falta d'um amanuense para o auxiliar.(244)

Estas revelações não constam, obviamente, do relatório do seu predecessor, sobre o qual se pronunciou nestes termos: Um outro ponto em que o Feliciano toca é quanto ao grau de honestidade do Simas e que eu já Ihe disse qual a impressão que d'elle tem o major Lucas. Na C.I.R. no animo d'alguns empregados superiores é que elle não era um «business man»; não sei bem a que se referia. Quanto a mim devo dizer que sendo esta Delegação tambem uma casa de commissões não tenho duvida alguma desde que eu tenha os serviços devidamente montados e o conselho administrativo organisado exigir commissões e descontos das casas fornecedoras de material, para ou as deduzir do custo d'esse material ou escriptural-as aqui em conta corrente de que mensalmente darei conta ao Governo. ${ }^{(245)}$ Afinal, tudo acabava por girar, na opinião do major Casqueiro, em torno da falta de pessoal e de organização contabilística, problema de natureza orgânico-funcional extensivo também à tutela em Lisboa: Recinto-me aqui muito tambem de que o Governo não tenha ahi os serviços montados devidamente e que tratasse esse serviço directamente comnosco ${ }^{(246)}$ sem ser por intermedio d'esses directores geraes que ficam sempre nos seus logares emquanto os ministros mudam e que procuram fazer o menos possivel e quem sabe se demoram e não proseguem nem estudam devidamente os assumptos. (247) E em abono desta crítica abundavam os exemplos: Sobre o trigo ou por outra cereaes a vir da America

(243) Dossier 26 Ravitaillement, Relatório do Presidente da Delegação Portuguesa da C.I.R. para o Ministro dos Negócios Estrangeiros do major Frederico Simas, 24 de Janeiro de 1918, 13 fls. dact. (Arquivo de Sidónio Pais - Militar, Lente e Político, Subsistema Presidência da República).

(244) Dossier 26 Ravitoillement, carta do major João Casqueiro para Feliciano da Costa, Ministro do Trabalho, 29 de Fevereiro de 1918 , fl. I. (Arquivo de Sidónio Pais - Militar, Lente e Político, Subsistema Presidência da República).

(245) lbidem, fl. 9.

(246) A deficiência tinha sido, entretanto, colmatada nas folhas do diário oficial através da publicação do decreto 3.810 , de 5 de Fevereiro, que organizava os serviços de aquisição de matérias-primas e de géneros de primeira necessidade precisos para o consumo do país e de normalização dos mercados internos.

(247) Dossier 26 Ravitaillement, carta do major João Casqueiro para Feliciano da Costa, Ministro do Trabalho, 29 de Fevereiro de 1918, fls. 9-10. (Arquivo de Sidónio Pais - Militar, Lente e Político, Subsistema Presidência da República). 
agora, mandei-lhe 3 telegramas que hoje soube pelo Chefe da sua repartição de Gabinete nenhum tinha recebido, quando d'aqui fui informado tinham seguido ao seu destino. Como se explica isto? Não foi ainda até á data aberto o credito para o carregamento do Mormugão.(248)

Atrasos e falhas administrativas graves, para mais num ponto de importância capital - o pão para o paiz. Lembrava, por isso, que nada ha que mais prejudique um governo do que a falta de providencias n'este sentido. Ja ha dias mandei tambem perguntar aonde carregavam as 2.000 toneladas de farinhas a seguir de Gibraltar para Portugal não se comprehendendo que esta farinha esteja em Hespanha e não va pelo caminho de ferro a ser por uma maior vantagem de preço de transporte o que não é crivel por causa dos respectivos seguros do navio, carga alem do transporte. ${ }^{(249)}$ Dando largas ao tom directo e franco que imprimira à missiva, o novo Presidente da Delegação não poupou detalhes significativos sobre o caótico estado burocrático da «máquina» posta às «suas costas»: A C.I.R. com quem estamos em permanente contacto tem milhentos empregados que cada um trata da sua cousa. Aqui na Delegação anda por 2.000 processos que agora, por exemplo, estão a correr - é o registo de toda a correspondencia que entra, são as respostas, a organisação dos processos, contas etc. relativamente a cada um d'elles, são os embarques de material, facturas e sua conferencia - é positivamente de endoidecer e porque nunca estes serviços estiveram montados para o fim para que esta Delegação foi creada anda tudo atrazado, faltas de respostas ás propostas e aos pedidos e muitos dos processos estão truncados e porque não ha tempo senão para atender e mal aos serviços do expediente vulgar, não posso preocupar-me a fundo com as questões importantes a resolver que não se solucionam a meza do meu gabinete mas sim fora d'elle procurando relacionar-me e ouvir todos os magnates do commercio e da finança.(250)

A sua luta seguia, também, num sentido contrário à tendência governamental desenvolvida em Lisboa - esperar que as coisas fossem feitas sem cuidar dos meios necessários. É, aliás, interessante frisar ainda que Casqueiro insiste muito, nesta sua carta-relatório, na incomodidade pessoal que o cargo lhe estava a causar, põe o lugar à disposição e aproveita mesmo a falta de um guarda-livros para dele depender a sua continuidade à frente da Delegação: Fizeram-se o anno passado pagamentos por esta Delegação que andaram por I milhão e quinhentos mil libras, pois não ha um guarda livros nem a escripta montada para este fim e com franqueza n'estas condições não quero continuar pois absolutamente preciso a todo o tempo de comprovar com uma escripta legal e clara toda a minha administração. Se eu não o conseguir já sabe que peço a minha demissão e aqui tem o resultado de me ter tirado de Brest onde estava bem.(25I)

(248) Dossier 26 Ravitaillement, carta do major João Casqueiro para Feliciano da Costa, Ministro do Trabalho, 29 de Fevereiro de 1918, fls. 10. (Arquivo de Sidónio Pais - Militar, Lente e Político, Subsistema Presidência da República).

(249) Ibidem, fl. 10.

(250) Ibidem. Ver SILVA, Armando Barreiros Malheiro da - Sidónio e sidonismo. História e mito, dissert. cit., vol. 2. p. 145.

(251) Dossier 26 Rovitaillement, carta do major João Casqueiro para Feliciano da Costa, Ministro do Trabalho, 29 de Fevereiro de 1918, fl. 5. (Arquivo de Sidónio Pais - Militar, Lente e Político, Subsistema Presidência da República). 
A propósito da chamada questão Augusto de Vasconcelos e Norton de Matos, 0 major Casqueiro parece ter aceite o fardo com muito pouco prazer pessoal, pretendendo livrar-se dele na primeira ocasião possível, que tardava a chegar. O remédio foi, pois, prosseguir num posto tão ingrato, que mais parecia a vida nas trincheiras! Vida de todo desconhecida, como já se disse, para um certo estrato privilegiado da oficialidade.

Nesse seu espinhoso cargo o major Casqueiro mexeu-se em articulação com o Ministro Augusto de Vasconcelos, conseguindo este sensibilizar as autoridades inglesas para a vital questão dos transportes, como se vê pela breve nota manuscrita em papel timbrado da Repartição do Gabinete da Secretaria da Guerra, em 26 de Abril: Acedendo ás instancias do Governo da Republica, o Governo Inglez, que nos tinha já assegurado o fornecimento de cereaes suficientes para as necessidades do Paiz até ás colheitas, acaba de oferecer suprir o nosso deficit de tonelagem comercial encarregando-se do transporte das mercadorias que Ihe sejam indicadas pelo Governo Portuguez, como indispensaveis.(252) Era uma risonha promessa - e como tal se arriscava a continuar... - para quem tinha de gerir, até meados de 1918, a obtenção de grandes quantidades de matérias primas e produtos alimentares procedentes de vários países. ${ }^{(253)}$

Entre a requisição urgente e aflitiva das quantidades necessárias e a sua entrada efectiva no país havia, porém, um imenso «oceano» de dificuldades e de perigos, no topo dos quais aparecia a intensificação dos ataques dos submarinos alemães. Enfim, um rosário de impecilhos e de riscos que levarão Machado Santos, uma vez nas Subsistências e Transportes, a queixar-se do cargo ultra espinhoso, que, por mal dos meus pecados, me vi forçado a assumir. Já lá vamos...

As debilidades estruturais e a condição periférica da economia portuguesa bastavam, se não houvessem mais factores negativos - à cabeça dos quais avulta, sem dúvida, a enorme ineficácia da Administração e dos seus agentes - para reduzir a muito pouco ou até para perverter completamente todos os esforços reorganizativos e os mais generosos voluntarismos, responsáveis, aliás, pelas sucessivas alterações e experimentações introduzidas no sector do abastecimento.

Como bem observou Damião Peres, houve aí, de facto, uma grande e perturbadora oscilação não só nas providências oficiais, como no próprio aparelho organizativo encarregue de as conceber e aplicar: por decreto de 9 de Dezembro concentraram-se poderes no engenheiro agrónomo Cristovão Moniz, para o qual, na qualidade de Director dos Serviços de Subsistência Pública, foi transferida a competência da Administração dos Abastecimentos, criada em I de Junho de 1917 e extinta pelo decreto de 17 de Dezembro; mês e meio depois, pelo decreto de 5 de Fevereiro de 1918, ficou o Ministério do Trabalho, através da Direcção dos Serviços de Subsistência Pública, com a faculdade de comprar e vender todos os géneros básicos e de propor ao Ministério das Finanças a interdição da exportação de produtos mais necessários; volvido um mês, a 9 de Março, a gestão desta área, que incluía também os transportes, passou para um Ministério novo, designado das Subsistências e Transportes; e em 19 de Julho será extinto, concentrando-

(252) Dossier 26 Ravitaillement, meia fl. de papel pautado de carta e timbrado da Secretaria da Guerra. (Arquivo de Sidónio Pais - Militar, Lente e Político, Subsistema Presidência da República).

(253) Ver SILVA, Armando Barreiros Malheiro da - Sidónio e sidonismo. História e mito, dissert. cit., vol. 2. p. 146. 
-se, então, os serviços de abastecimentos numa Direcção Geral das Subsistências, criada no âmbito do Ministério do Interior, mas de vida efémera, porque a 9 de Outubro seria instituída a Secretaria de Estado dos Abastecimentos pelo decreto n. ${ }^{\circ} 4.879$ (e extinta pela lei n. 882 , de 17 de Setembro de 1919).

A par destes sucessivos e infrutíferos ensaios organizativos foi ainda retomada uma iniciativa, que o Governo de José de Castro apresentara em 1915 e o Governo da União Sagrada recuperara, sucumbindo no decurso do debate parlamentar em 1917 como já atrás se viu, a saber: a formação, decretada a 28 de Junho, de um Conselho Económico Nacional, constituído por nove membros, todos de nomeação governamental, com o fim de emitir consultas acerca dos problemas de ordem económica e financeira decorrentes da guerra, mas sobretudo a sua composição - integrava pretensos monárquicos e destacadas figuras do capital como Alfredo da Silva da C.U.F. ou António Cidrais, latifundiário, especulador e deputado governamental - suscitou numerosas críticas. (254)

Não obstante as perceptíveis tensão e clivagem dos diferentes interesses em presença, há que reconhecer a persistência do Governo na busca de soluções propiciadoras da almejada harmonização social e, por outro, a pressão reivindicativa das associações das classes trabalhadoras face à crise geral de subsistências.

\section{A Questão social}

As preocupações e reclamações do movimento operário, expressas e reprimidas antes do 5/8 de Dezembro, ecoaram logo a 9 desse mesmo mês em comício público na Praça dos Restauradores, organizado pela U.O.N. Aí a legítima representante dos sindicatos operários portugueses apresentou à Junta Revolucionária um naipe de exigências sócio-económicas, que servirá de mote e de guia ao processo reivindicativo conduzido nos meses seguintes. ${ }^{(255)}$

Essas reclamações configuravam, de algum modo, o estado da questão social em plena economia de guerra europeia, mas correspondiam, também, a um programa ideológico-político anti-capitalista e às profundas e concretas aspirações que as circunstâncias de crise haviam vincado mais na sociedade portuguesa e a que os Governos não podiam permanecer alheios. Com efeito, a governação dezembrista/sidonista, relativamente, por exemplo, à política agrícola traçada pelo novo Ministério do sector, aceitará e incorporará, como notou Vasco Pulido Valente, ${ }^{(256)}$ as medidas propostas pelo Congresso de Trabalhadores Rurais e pela U.O.N., ainda que introduzindo modificações significativas em algumas delas, como se refere adiante.

(254) Cf. PERES, Damião - História de Portugal. Suplemento, ob. cit., p. 190; e também JESUS, Quirino de - O «Imbroglio» portuguez. O Economista Portuguez, Lisboa, ano 10, 2. série (37) 14 de Julho de 1918, p. 482. Sobre a composição do Conselho ver TELO, António José - O Sidonismo e o movimento operário português, ob. cit., p. 175.

(255) Cf. PEREIRA, José Pacheco - As Lutas operárias contra a carestia de vida em Portugal.A greve geral de novembro de 1918. Porto: Portucalense Editora, 1971, p. 81-82.

(256) VerVALENTE, Vasco Pulido - Estudos sobre Sidónio Pais: agricultura e proletariado agrícola; indústria e sindicatos; comércio externo, in Idem - Estudos sobre a crise nacional. Lisboa: Imprensa Nacional-Casa da Moeda, 1980, p. 254-255. 
Mas antes de nos determos sobre a(s) política(s) seguida(s), convém, por um lado, lembrar que o próprio Sidónio Pais foi confrontado, ainda no Parque Eduardo VII, com a libertação dos sindicalistas, tendo-a aceite de forma relutante e parcial, embora saibamos que em Maio a U.O.N. ( I a Secção-Sul) voltou à carga com a mesma exigência através de uma exposição escrita e assinada por AlexandreVieira; ${ }^{(257)}$ e, por outro, vislumbrar a sua posição pessoal face ao premente dossier social, graças a umas brevíssimas impressões que alinhavou em Janeiro sobre o

\section{Operariado}

Para termos socêgo e podermos trabalhar precisamos de criar um periodo de expectativa entre as classes trabalhadoras. 0 minimo de tempo d'essa expectativa deve ser d'uns 2 anos.

Remédio: Nomear uma comissão em que entrem muitos delegados das associações operarias, para elaborar o codigo do trabalho, começando por codificar a legislação dispersa que temos sobre o trabalho e acabando por propor o novo codigo, olhando ao salario minimo e seguro obrigatorio.(258)

Ingenuidade burguesa ou excesso de confiança nos sinais de apoio que o movimento operário organizado, ao princípio, Ihe manifestou a troco da libertação de sindicalistas presos? Sidónio Pais parece ter acreditado, de início, na possibilidade de uma trégua social ou de um período de expectativa entre as classes trabalhadoras dentro do prazo mínimo de dois anos, através do expediente de uma Comissão responsável pela feitura do código de trabalho é participada por uma ampla representação de sindicalistas.

A intenção inicial surgiu, assim, sob a forma de um aliciamento ao operariado para um compromisso de tranquilidade e de harmonia sociais, que irá, em grande parte, falhar, porque, por um lado, os dois Governos de Sidónio não podiam deixar de prosseguir e até de endurecer a prática repressiva face à temida revolução social e, por outro, a acção sindical organizada não buscava consensos, mas uma resposta cabal e cada vez mais política às suas exigências. E se não falhou totalmente é porque as camadas desfavorecidas e proletarizadas, inclusive nos principais centros urbanos (Lisboa e Porto), achavam-se desligadas das Associações Operárias, sem uma efectiva e radical mobilização reivindicativa e receptivas, por isso, à assistência ou protecção directa do Poder. Uma receptividade que Sidónio Pais e os seus Governos conseguiram agarrar - é um logro ou um mero preconceito erróneo admitir que a sua popularidade se cingiu às classes possidentes e conservadoras - por intermédio de uma dupla estratégia: incorporar várias das reivindicações formuladas pela própria U.O.N., nomeadamente quanto ao aproveitamento dos incultos e ao combate à especulação e aos açambarcadores; e desenvolver, numa linha de indiscutível continuidade, os esforços de reforma dos serviços de assistência e de prestação de socorros públicos, impulsionados após a instauração da República, imprimindo-lhes, porém, uma orientação diversa, que pendia mais para a descentralização administrativa da assistência pública e para o alargamento dos serviços de beneficiência através da criação da Obra de Assistência 5 de Dezembro, que dinamizará a obra social

(257) Dossier 102 União Operaria Nacional, exposição-oficio de 15 de Maio de 1918. (Arquivo de Sidónio Pais - Militar, Lente e Político, Subsistema Presidência da República).

(258) Ibidem. [Apontamentos avulsos, f. ms. s.d.]. 
das cozinhas económicas, designadas também por sopa dos pobres ou sopas do Sidónio. E a par deste tipo de iniciativas há que considerar as acções oficiais e particulares de apoio aos combatentes, feridos e prisioneiros da Grande Guerra, desempenhando nessa área papel decisivo as comissões de distintissimas senhoras.

Mas uma tal estratégia ficava, obviamente, aquém da resposta estrutural à fome, à miséria e aos horrores da hecatombe bélica ainda em curso e que exigia a complementaridade de políticas de grande fôlego e de médio a longo prazo. Políticas relegadas, porém, para plano secundário pelo Estado republicano e burguês, cada vez mais intervencionista e mais empenhado num combate inglório contra os imediatos efeitos negativos repercutidos na sociedade e na economia portuguesas.

As associações operárias, animadas, sobretudo, pela corrente anarco-sindicalista, (259) não deram, de facto, tréguas ao Governo e ao patronato. E a 8 de Janeiro era solucionada a greve do pessoal da Companhia dos Tabacos com aumentos de 10 a 40\%; a 10, greve do pessoal da empresa $\mathrm{Val}$ do Rio, atendido no aumento salarial reclamado; a 13, greve dos operários da construção de carruagens de Lisboa; a 25, a greve dos latoeiros de folha branca, também na capital; a 27, comício dos caixeiros lisbonenses para exigir aos patrões, sob ameaça de greve, aumento de ordenado, denunciando à opinião pública os exagerados e fabulosos lucros que a guerra Ihes tem dado, denúncia aceite pelo próprio patronato reunido na Associação dos Lojistas no dia seguinte; a 2 de Fevereiro, greve do pessoal da Exploração do Porto de Lisboa por aumento salarial; a 10, greve dos trabaIhadores da Companhia dos Carros Eléctricos, resolvida no mesmo dia pela intervenção da Câmara Municipal, disponibilizando os meios financeiros indispensáveis para satisfazer a reclamação salarial apresentada; e a 21, greve do pessoal da Companhia do Gás e Electricidade, serviço de utilidade pública, que o Governo procurou assegurar através do recurso à Armada, mas as negociações não foram interrompidas e algumas pretensões dos grevistas, designadamente a melhoria salarial, mereceram a satisfação desejada. (260)

Em Março parece ter havido uma espécie de interregno no surto grevista, ${ }^{(261)}$ apesar do Conselho Central da U.O.N., logo a 9 desse mês, ter reagido com dureza ao fracasso da audiência concedida pelo Presidente da República a uma comissão de sindicalistas munida de novo caderno reivindicativo, concluindo que nada podem nem devem esperar as classes trabalhadoras de mais esta nova (?) situação política que o operariado acolheu com benévola expectativa. $E$, assim, convida os assalariados, tanto os das indústrias como os das profissões liberais, a ingressarem nas suas associações corporativas para lograrem conquistar o respeito pelos seus direitos e fazer valer as suas reivindicações, pois mais uma vez Ihes deve ter sido demonstrado que os trabalhadores só podem confiar no seu próprio esforço de classe, actuando colectiva e solidariamente fora da acção e influência de qualquer partido político. (262) Insistiam, assim, no lema da união e da pressão concertada contra os

(259) Ver PEREIRA, José Pacheco - As Lutos operárias contra a carestia de vida em Portugal. A Greve geral de Novembro de 1918 , ob. cit., p. 54 e ss.

(260) Cf. PERES, Damião - História de Portugal. Suplemento, ob. cit., p. 190.

(261) Ver, por exemplo, FONSECA, Carlos da - História do movimento operório e das ideios socialistos em Portugal, vol. 1-Cronologia, ob. cit., p. 152.

(262) Cit. in Sidónio Pais e o movimento operário. O Tempo e o Modo, Lisboa, nova série (102) Fev. 1974. p. 12. 
golpes do patronato (contenção salarial, não redução do horário laboral, lock-out, etc.) e o intervencionismo das instâncias repressivas do Poder.

Estreitava-se a via da aproximação, cavava-se a do confronto.

Em Abril são contadas catorze greves e quinze em Maio.(263) A partir de então acentuou-se a hostilidade sindical a que correspondeu uma cada vez maior repressão das forças policiais e militares convocadas directamente pelo Interior ou, na maioria dos casos, pelos Governadores Civis das zonas geográficas socialmente mais agitadas, no uso aliás, de prerrogativa legal anterior e posterior ao sidonismo. E, por isso, só através de

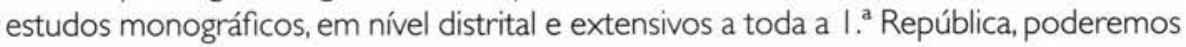
conhecer com mais rigor a orgânica e o uso da força em prol da salvaguarda da ordem pública e da defesa do regime.

Enquanto não se explorar documental e criticamente esta temática, inserindo-a tanto na luta política sem tréguas que opôs os democráticos aos Governos do dezembrismo/ sidonismo, como no combate à agitação social e operária, teremos de relativizar bastante o que tem sido escrito sobre o «terror sidonista», incluindo-se nesta rubrica os actos de violência social e política, em número e qualidade indeterminados, atribuídos a grupos de civis armados, os «lacraus», animados pelo ódio aos democráticos ou possivelmente recrutados pela polícia nas fileiras monárquicas ou até nas sopas dos pobres!...(264)

\section{O Interior: política geral e policias}

O tópico do «terror sidonista» prende-se, na sua vertente institucional, com a actuação do Ministério do Interior, dirigido até 8 de Março pelo contra-almirante Machado Santos, a quem se atribuiu uma relação próxima com certos sectores do operariado e, por consequência, uma política de cedências face ao movimento grevista, substituída pouco depois pela via repressiva. (265)

A profunda simpatia filantrópica e moral do fundador da República ou do próprio Sidónio Pais pela dignificação das condições de vida dos trabalhadores (salários, habitação, instrução, etc.) não excluía o uso da força contra a anarquia. A imposição da ordem era, sobretudo em 1918, entendida como inerente à legítima e à inadiável afirmação da autoridade do Estado e da República. E não surpreendem, por isso, as declarações de Machado Santos reproduzidas em tom crítico pelo jornal monárquico O Dia:

Possivel é que se venha a dar um movimento revolucionario para repôr as coisas no pé em que estavam nos principios de dezembro. Esse movimento será suffocado. $E$ os seus auctores nada lucrando com elle farão com que o governo eneverede pela politica de violencia que a todo o custo pretende evitar, e virá aggravar ainda mais as condições economicas do paiz fazendo com que a vida se torne então de todo insupportavel.

(263) Cf.TELO, António José - O Sidonismo e o movimento operário português, ob. cit., p. 195-196.

(264) Ver MATA, Aida Maria Reis da e OLIVEIRA, José Fernando Vieira Lizardo Gomes Coelho - Intranquilidade e repressão no consulado sidonisto, trab. cit:;ELO, António José - O Sidonismo e o movimento operário português, ob. cit., p. 180-189; e MEDINA, João - Morte e transfiguração de Sidónio Pais, ob. cit., p. 83-143.

(265) Cf.TELO, António José - O Sidonismo e o movimento operário português, ob. cit., p. I56. 
É impossivel voltar atraz. Suppondo que os adversarios do governo tenham força para se impôr ao paiz, a situação que creavam para si proprios era de tal ordem que ao fim de oito dias do seu triumpho baqueariam na praça publica. 0 paiz, meu caro amigo, chegou ao maximo d'anarchia politica e economica. Todos desvairam. Todos estão desvairados, e por mais ferreo que seja o pulso para metter tudo na ordem, a aç̧ão é lenta, muito lenta porque se esbarra com muito interesse illegitimo que se sente ferido, porque se esbarra com muita indolencia, porque se esbarra com muita incompetencia tambem. ${ }^{(266)}$

O uso da violência e da repressão surgia assim como resposta ao apelo de certos sectores da sociedade e como um recurso defensivo e regulador da sobrevivência do regime, tão inevitável, quanto indesejável, e inconfundível, no plano doutrinário e organizacional, com a «máquina» preventiva e repressiva do Estado proto ou mesmo totalitário dos anos vinte e trinta. Propomo-nos, por isso, explorar um pouco mais este ponto, a propósito da reforma geral da Polícia estabelecida através do pacote legislativo, iniciado em 13 de Março de 1918. Mas antes disso convém, de relance, lembrar as directrizes do Ministério do Interior tendo em vista a iminente realização de eleições.

Na opinião suspeita de Teófilo Duarte, o contributo de Machado Santos nesse seu primeiro cargo governativo ficou aquém de todas as metas que tivera em vista - integração dos monárquicos na República, colaboração de unionistas e evolucionistas e expectativa benévola dos democráticos ${ }^{(267)}$ - falhando as principais iniciativas ensaiadas: a circular remetida aos Governadores Civis e divulgada pela imprensa em 12 de Janeiro suscitou os acres comentários do unionismo; o encontro, em 5 de Fevereiro, com António José de Almeida não evitara que o partido se atirasse para as conjuras; e os contactos com os democráticos nunca tinham conseguido desviar estes da via revolucionária por que tinham enveredado. (268) Aquele hagiógrafo sidonista lembrou estes desaires para evidenciar a volubilidade do fundador da República: no Governo falhara a aproximação às direitas e às esquerdas, mas após ter saído das Subsistências remeteu-se a uma atitude de surda hostilidade, defendendo a união de todos os republicanos, como sendo a única solução política a adoptar, esquecendo, assim, que, se isso era bom de dizer, era difíil de realizar, como tivera ocasião de demonstrar na sua passagem pelo Ministério.(269)

Parece-nos, de facto, óbvio que Machado Santos passou, tal como alguns dos seus amigos, nomeadamente Cunha Leal, para uma mal disfarçada oposição mais por despeito ou ressentimento, que por profundas discordâncias doutrinárias e político-institucionais e a prová-lo estão as suas declarações, os seus textos jornalísticos anteriores, uma carta-resposta de Eurico Cameira, ${ }^{(270)}$ datada de 10 de Janeiro de 1921 e até um texto apologético escrito em sua homenagem.(271) Mas quanto às metas falhadas convém,

(266) Cf. O Balanço da Republica. A anarchia! O que diz o sr. Machado Santos. O Día, de 6 de Abril de I9।8, p. I.

(267) Cf. DUARTE, Teófilo - Sidónio Pais e o seu consulado, ob. cit., p. 328.

(268) Cf. Ibidem, p. 328.

(269) Cf. Ibidem, p. 327.

(270) Ver SILVA, Armando Barreiros Malheiro da - Sidónio e sidonismo. História e mito, dissert., vol. 2. p. 894-900.

(271) Ver Ibidem, p. 907-912. 
por exemplo, não esquecer o seu «intransigente» anti-partidarismo, público e notório mal saiu vitorioso da Rotunda no dia 5 de Outubro e jamais superado, nem mesmo nas ocasiões em que se empolgava no apelo patriótico e supra-partidário à unidade nacional.

A este propósito vale a pena recordar os seus comentários negativos, já atrás citados, sobre a forte presença da União Republicana no Governo central e nos Governos Civis. São, pois, facilmente perceptíveis as suas reservas de fundo à actuação e ao valor dos partidos. Reservas mais nitidamente expressas na referida circular e no preâmbulo do decreto de 10 de janeiro que dissolveu todos os chamados corpos administrativos (Juntas Gerais, Câmaras Municipais e Juntas de Freguesia), muitos dos quais tinham assumido uma atitude hostil contra o governo da República Portuguesa, agravada com incitamentos à revolta, determinando a nomeação de Comissões Administrativas de inteira confiança do Governo. E aos seus representantes nos distritos lembrou que o elenco governativo saído da Revolução de Dezembro, é um Governo Nacional de combate à demagogia, que tem a ampará-lo apenas a força moral que se criou à custa dos erros e desmandos dos governos transactos e das agremiações partidárias. Nestes termos qualquer suspeita de que se faça política, exclusivamente ou um jogo dum partido faria com que se diminuísse essa força moral e o próprio concurso da força armada ficaria reduzido à expressão mais simples, impossibilitando a vida do governo e a realização das aspirações nacionais. (272)

A missão fixada impunha, pois, em nome da conservação dessa força moral e do seu revigoramento, que não se exteriorizassem quaisquer sentimentos partidários, devendo as eleições ser preparadas com absoluto espírito de isenção - as forças políticas teriam de ser consideradas por igual e as forças económicas dos diversos distritos protegidas eficazmente. Não podia esquecer-se de modo algum que o governo é republicano, que a sua acção é republicana, mas que é chegado o momento de se assegurar definitivamente a paz pública, fazendo a obra de integração do país na República. Não há que fazer uma política de atraç̧ão. Depurada a República dos seus elementos daninhos, «a política a fazer é de ligação»s. A atmosfera moral que cerca o governo facilita a missão de V. Ex. ${ }^{\circ}$ no seu distrito. (273)

Por imperativo patriótico e graças à favorável atmosfera moral envolvente, todos os partidos - republicanos ou não - deveriam entrar na «barca» dezembrista e isso far-se-ia sem violências, explorando apenas a aprovação unânime que o golpe tivera.

A estratégia governamental definia-se, grosso modo, nestes termos de firme pacificação, que não eram, como temos insistido, estranhos ao corpus ideológico-político do republicanismo, mas contra os quais se opunha naturalmente a lógica eleitoral-caciquista das forças partidárias organizadas e vocacionadas para disputar o acesso e a permanência no Poder. Havia, assim, um diferendo estratégico profundo gerido pelos unionistas com a prudência possível, até ser enunciado pelo próprio Sidónio Pais o corolário lógico do anti-partidarismo subjacente: presidencialismo versus parlamentarismo e reformulação do universo partidário. Afinando pelo mesmo diapasão de Machado Santos, Sidónio conseguira mostrar-se menos vago e gongórico, mais directo e determinado na aplicação

(272) Cf. Uma circular aos governadores civis. Diário de Notícias, de 12 de Janeiro de 1918, p. I.

(273) Cf. Ibidem, p. I. 
da fórmula anunciada como alternativa à República Velha. Esse diferendo era insanável relativamente aos democráticos, porque contra estes se dirigira toda a organização da revolta e sobre os seus principais dirigentes caíra a «espada» dos vencedores, não apenas por vingança política, mas também e essencialmente por reacção auto-defensiva.

Convém evocar, de novo, o caso paradigmático de Afonso Costa, preso no Forte de Elvas em regime de alguma incomunicabilidade até 30 de Março, data em que foi libertado.

Segundo Oliveira Marques, os seus partidários para alijarem responsabilidades, 0 convenceram a sair de Portugal e a não regressar tão cedo. ${ }^{(274)}$ Após umas semanas de permanência em Seia, no seu chalé serrano com a familia e amigos, fixou-se temporariamente em Hendaye, mas não ficou inactivo, dirigindo daí a oposição democrática ao Governo: as suas instruções para Barbosa de Magalhães ou para oTudela das Montanhas ${ }^{(275)}$ são muito curiosas e evidenciam o seu modo pessoal e autocrático de dirigir o P.R.P./P.D. e a sua intransigência moral e política em matéria constitucional e religiosa, embora habilmente se dispusesse a transigir um pouco para sair do gachis em que caimos.

Não era, porém, pessoa para grandes cedências e arrependimentos. Considerava-se vítima da ingratidão dos seus compatriotas, mas, apesar disso, em Julho de 1918 parecia relevar todas as injustiças que tanto o magoavam e admitia retornar ao Poder, logo que o crime de dezembro fosse vingado, e com a seguinte táctica: Quanto á atitude futura na política interna, acho que se deve dar, do nosso lado, um claro testemunho de transigencia e tolerancia para com os outros partidos, não se fazendo nenhuma política partidária, enquanto durar a guerra. Restabelecida a normalidade constitucional, o antigo parlamento reunir-se hia unicamente para votar as alterações á Constituição em que se tivesse acordado e para aprovar rapidamente o orçamento para 1918-1919. Em seguida, proceder-se hia ás eleições geraes do Parlamento que ha de funcionar desde 2 dezembro 1918 a igual dia de 1921. E como o Governo seria mixto, e as eleições, além de livres e honradas, como sempre as fizemos seriam para ninguem suspeitar, talvez não chegasse a ser dissolvido o novo Parlamento, o que muito me consolaria no meio das angustias, que as actuaes e futuras circumstancias da vida nacional me teem causado e hão de continuar a causar. Uma táctica para o curto prazo, concebida no pressuposto do rápido restabelecimento da República Velha, com alguns retoques «cosméticos», e do iminente derrube (violento) da situação dezembrista/sidonista. No entanto, um ano depois o seu ânimo alterara-se por força das circunstâncias internas e externas, ${ }^{(276)}$ comunicando, então, ao Presidente da Câmara dos Deputados, a sua total indisponibilidade para regressar à governação do país: $O$ que se passou comigo desde 1917 convenceu-me infelizmente de que a minha simples presença n'um meio politico como o parlamento serviria de pretexto para que novamente se desencadeassem em torno de mim e apesar dos meus desejos de o evitar as luctas violentas entre republicanos que já varias vezes causaram tanto mal á Nação e ao

(274) Cf. MARQUES, A. H. de Oliveira - Afonso Costo, ob. cit., p. 41.

(275) Dossier 85 Informações. (Arquivo de Sidónio Pais - Militar, Lente e Político, Subsistema Presidência da República).

(276) Cf.FERREIRA, José Medeiros-O Comportamento político dos militares, ob. cit., p. 90-91; e Idem - Portugal na conferência da Paz. Paris, 1919, ob. cit., p. 57-60. 
Regimen. E para que eu continue defendendo a Republica e servindo dedicamente a nossa Patria não careço de retomar a actividade politica.

Sem entrarmos nas razões de tão óbvia mudança de atitude, importa, aqui, frisar, acima de tudo, que Afonso Costa era perigoso para Sidónio Pais e o sidonismo dentro e fora da prisão e que o receio de Brito Camacho, expresso por carta ao seu amigo Augusto de Vasconcelos, de uma eficaz mobilização extra-legal dos democráticos era plenamente justificado e confirmado pelo estreito cerco urdido no segundo semestre de 1918 até culminar no assassínio de Sidónio. Quanto mais conspirassem mais violência governamental suscitavam e quanto mais esta se intensificasse mais legítimo se tornava o recurso à acção conspirativa...

Voltamos, assim, ao dilema formulado por Machado Santos nas declarações atrás citadas e que condicionou bastante a conduta do Governo e, em particular, da «pasta» do Interior em estreita articulação com a Guerra.

A nova situação tinha de ligar o país à República, defendendo-se de quaisquer tentativas hostis e garantindo umas eleições rápidas e limpas, essenciais para a legitimação popular do golpe dezembrista. Justificavam-se, por isso, medidas urgentes no terreno e entre elas era natural a mudança das chefias civis e militares.

Foi, aliás, por aí que a Junta Revolucionária e o seu Governo começaram, mas a realidade global do país impunha outras medidas, bem mais eficazes. Impunha, também, medidas atractivas, que oscilaram entre a abertura e a repressão, como sucedeu no domínio da censura: apesar de abolida logo após o golpe, a portaria I.182 de 28 de Dezembro de 1917 da Direcção Geral de Administração Política e Civil exigia aos indivíduos interessados no reaparecimento de jornais ou na fundação de novos órgãos da imprensa que obtivesse autorização prévia do Ministro do Interior e a portaria n. ${ }^{\circ} 1.199$ de 9 de Janeiro de 1918 autorizava os Governadores Civis a dissolverem desde já todos os centros políticos que, na actual conjuntura, tenham exorbitado dos seus fins legais, concorrendo para a perturbação da ordem (...) e que suspendam por tempo indeterminado todas as publicações periódicas que (...) pretendam perturbar a segurança pública; e não admira, por isso, que nas vésperas do acto eleitoral, em Abril, perante o bloqueio oposicionista com a ameaçadora campanha a favor da abstenção, fosse restabelecida a censura - tópico retomado adiante - pelo decreto n. $^{\circ} 4.082$, de 13 de Abril, embora já surpreenda mais o facto de, nessa altura, ter estado iminente a declaração de estado de sítio.(277)

Se percorrermos a informação disponível do Ministério do Interior percebe-se a necessidade de tais medidas, porque eram vários e profundos os pontos críticos. E, desde logo, verifica-se que não havia apenas uma potencial agitação política, mas uma explosiva agitação social,(278) traduzida em súbitos e dispersos assaltos e roubos de mercadorias, decorrentes do problema da falta de subsistências, que exigiam uma maior e melhor resposta das polícias, da G.N.R. e da Guarda Fiscal.

(277) Dossier Reformas e decretos II. (Arquivo de Sidónio Pais - Militar, Lente e Político, Subsistema Presidência da República).

(278) Para a combater foram, por exemplo, dadas em 13 de Fevereiro ordens terminantes á policia para reprimir todos os atentados contra as pessoas ou propriedades, tendo sido enviada aos jornaes e publicada hontem, 12. uma nota oficiosa sobre o assunto. Ministério do Interior - Correspondência recebida (Segurança Pública), maço 80). (Instituto dos Arquivos Nacionais - Torre do Tombo). 
Mas o estado dessas forças era bastante débil. Os Governadores Civis de Évora e de Viseu informavam o Ministério de Interior, em Janeiro de 1918, que era precária e difícil a situação da policia agravada dia a dia pela demora do pagamento das subvenções, não tendo ainda sido pagos os meses de Outubro, Novembro e Dezembro de 1917.(279) Queixas vulgares e assíduas que explicam a preocupação havida em actualizar salários e subsídios dos agentes de segurança ao longo de 1918. Impunha-se dignificá-los profissionalmente, mas urgia também dotá-los de meios e até de armas para um adequado cumprimento das suas obrigações.

Em Março, o Ministério do Interior remetia à Direcção Geral do Ministério da Guerra um urgentíssimo pedido emanado do Corpo de Polícia Cívica de Lisboa, comandada pelo machadista capitão Francisco Alexandre Lobo Pimentel: precisavam de 250 enxergas e outros tantos cobertores afim de serem distribuídos pelas esquadras e servirem a repouso dos guardas, e tornar menos extenuante o serviço de rigorosas prevenções que Ihe está sendo imposto. (280) E nos inícios de Abril o Governador Civil de Faro, coronel Godofredo do Carmo Neves Barreira, dirigia um ofício ao Director Geral de Administração Política e Civil em que chamava a atenção para os defeitos de um sistema administrativo demasiadamente centralizador e para as difíceis condições operacionais da Polícia Cívica do distrito, não podendo garantir da melhor e mais prestigiante forma o imprescindível princípio da autoridade.(281)

No início do mesmo mês de Abril o Governador Civil de Coimbra, Solano de Almeida, enviava ao Director Geral da Administração Política e Civil um projecto de regulamento do Corpo de Polícia Cívica do respectivo distrito, conforme ao disposto no $\operatorname{art}^{\circ} 21$ do decreto $n .^{\circ} 716$ de 18 de Agosto de 1914 e atendendo à urgência de organizar e melhorar os seus serviços. ${ }^{(282)}$ Foi, porém, mandado arquivar ${ }^{(283)}$ pelo novo Ministro, Henrique Forbes de Bessa, porque estava já em curso nova legislação sobre matéria policial. E o mesmo sucedeu com o projecto remetido pelo Governador Civil de Évora, em cujos considerandos prévios se lê a dado passo: Considerando que o numero de agentes é insuficiente para a segurança publica; Considerando que, com o vencimento de quarenta e oito centavos diarios, sugeitos a descontos, se não pode exigir serviço aturado dos diversos guardas; Considerando que a ultima reforma não satisfaz, no momento actual, ás exigencias do serviço, que as corporações de policia são chamadas a desempenhar.(284)

(279) Ministério do Interior. Livro de correspondência expedida, 1918. (Instituto dos Arquivos Nacionais - Torre do Tombo).

(280) Ibidem.

(281) Ver SILVA, Armando Barreiros Malheiro da Silva - Sidónio e sidonismo. História e mito, dissert. cit.. vol. 2, p. 159.

(282) Ministério do Interior. Correspondência recebida (Segurança Pública), Regulamento do Corpo de Policia Civica do Distrito de Coimbra, em harmonia com o disposto no artigo 21 do Decreto de I de Agosto de 1914. maço 80. (Instituto dos Arquivos Nacionais - Torre do Tombo).

(283) Despacho diferente teve a apresentação de um novo regulamento das serviçais ou criadas de servir do distrito de Coimbra. Ministério do Interior. Correspondência recebida (Segurança Pública), maço 81, caixa 51). (Instituto dos Arquivos Nacionais - Torre do Tombo).

(284) Ministério do Interior. Correspondência recebida (Segurança Pública), Projecto de reforma da Policia Civico do Districto de Évora, maço 79, 1918, caixa 49. (Instituto dos Arquivos Nacionais - Torre do Tombo). 
Por seu turno, o Comando Geral da G.N.R., entregue ao coronel de Artilharia José de Oliveira Duque, informava, em Fevereiro, ser impossível fornecer um posto para Espinho por manifesta exiguidade de efectivos e grande exigência do serviço; noutro ofício, lê-se que o Batalhão n. ${ }^{\circ}$, com sede na cidade do Porto, debatia-se com uma aflitiva carência de efectivos; a falta de equipamento perpassa também por várias comunicações oficiais; e, a par das alterações já referidas ao nível do Comando Geral, não podiam ser descuradas compensações de natureza salarial, bem como a urgente regularização de abonos em atraso: por decreto de 3.805 de 26 de Janeiro o Ministério do Interior abriu um crédito de quarenta e cinco mil escudos para pagamento à Guarda Nacional Republicana dos abonos em dívida por serviços de manutenção de ordem pública, a requisição das autoridades administrativas.

Reorganização operacional e actualização de vencimentos foram, sem dúvida, o leit-motiv da reforma dos serviços da Guarda Fiscal estabelecida pelo decreto n. ${ }^{\circ} 4.177$ de 27 de Abril. No seu preâmbulo esclarece-se que aquela corporação estava incumbida da fiscalização das mais importantes receitas do Estado, as aduaneiras, devendo, por isso, ser dotada de uma organização que permitisse o seu conveniente emprego como força pública juntamente com a resposta às necessidades da mesma fiscalização, desiderato difícil de atingir nas condições mantidas até então: a actual organização centralizou a direcção de todos os seus serviços numa repartição, com graves inconvenientes para a execução dos mesmos serviços, além de que aumentava extraordinariamente o serviço de administração a cargo das companhias da Guarda Fiscal em detrimento da conveniente acção fiscal a exercer pelos respectivos oficiais, que é a sua principal missão na mesma guarda. E daí a imperiosa correcção organizativa dessa alegada disfuncionalidade operacional.

Pelas «pastas» da Guerra e das Finanças correram, pois, as providências possíveis para se colmatarem as carências e as deficiências daquelas duas forças militarizadas, enquanto pelo Interior se tornou inadiável a reorganização das polícias, velha aspiração, segundo notou o Inspector da Polícia de Investigação Criminal de Coimbra Eurico de Campos no preâmbulo do seu próprio projecto, ${ }^{(285)}$ pois que desde 1910 , tanto na imprensa, como no Parlamento, se apregoa constantemente a necessidade de reorganisar os serviços policiais, bem como desde de então, se tem publicado sucessivas reformas, que são logo substituidas por outras, sempre peiores e sem beneficio para o Estado, para os funcionarios, para os serviços e para o publico.(286)

Eurico de Campos referiu-se, sobretudo, ao projecto que o deputado democrático Daniel Rodrigues elaborara, em 1913, com o defeito, porém, de ser um pouco 102 dispendioso, e talvez por isso não foi aprovado. Referiu-se ainda à reorganização dos serviços policiais nos diversos distritos, aquando da governação Bernardino Machado em 1914, e animada pelo saudável princípio de que na polícia, a politica devia ser posta de parte, recrutando quase todos os comissarios de policia, fora dos partidos politicos, entre

(285) Ver CAMPOS, Eurico de - A Reorganisação da policio. Como querem que ela seja e como ela deveria ser. Lousã:Tipografia Lousanense, 1923.

(286) Cf. Ibidem, p.3. 
individuos que, quer como administradores de concelho, quer como comissarios interinos, já haviam dado as suas provas e que eram de fé republicana indiscutivel,(287) mas a iniciativa não teve seguimento porquanto o Governo partidário de Victor Hugo de Azevedo Coutinho contra o disposto na Constituição da Republica anulou as nomeações feitas e de novo entregou a policia nas mãos da politica. $\bigcirc$ mesmo seria praticado, pouco tempo depois, pelo Governo de Pimenta de Castro, em sentido inverso, tendo entregue os cargos que encontrou vagos ao odio politico, começando as perseguições a todos quantos não navegavam nas aguas do pimentismo.(288)

Após o golpe de 5/8 de Dezembro de 1917 não tardou que as autoridades, de novo e por força de circunstâncias político-sociais prementes, se voltassem para a organização policial e logo a 20 de Dezembro de 1917 data o decreto 3.673, da responsabilidade do Ministro do Interior Machado Santos, permitindo que a Direcção da Polícia de Investigação pudesse ser exercida por um oficial do Exército e criando um corpo de polícia preventiva, com um chefe e quarenta agentes dentro da Polícia de Investigação Criminal, ${ }^{(289)}$ para evitar que a população fique à mercê dum bando de desvairados arruaceiros que, acobertados com a autoridade civil e investidos de funções de polícia irregular, perseguiam, vexavam não só os adversários políticos da situação que estava, mas também cidadãos que não se imiscuiam nas lutas partidárias. Mas a curto prazo verificou-se que essa inclusão possuía inconvenientes e isto mesmo é reconhecido no preâmbulo do decreto n. ${ }^{\circ} 3.940$ de 16 de Março, já assinado por Henrique Forbes de Bessa, em șubstituição de Machado Santos a partir de 7 desse mesmo mês.

Para corrigir as falhas detectadas assentava-se no princípio de que a Polícia de Investigação não podia ser confundida com a Polícia Preventiva. Dado o carácter contencioso daquela e porque era necessário dar aos cidadãos e à segurança do Estado as devidas garantias determinava-se a separação dos dois serviços: o Director da Polícia de Investigação devia ser diplomado em direito, enquanto a Polícia Preventiva teria um Chefe da livre escolha do Governo, nomeado em comissão, o qual dentro da verba destinada para as tarefas de prevenção policial podia escolher livremente o pessoal que julgasse indispensável para a boa execução dos serviços a seu cargo, cabendo-lhe, além da nota mensal das despesas, o envio diário ao Ministério do Interior e ao Governo Civil de Lisboa de um relatório sucinto sobre todos os serviços de prevenção realizados; e, em termos de vencimento, o Chefe da Preventiva ficava equiparado ao Director da Polícia de Investigação. Seguir-se-ão diplomas destinados a conceder aumentos na verba prevista para a Polícia Preventiva, o que mostra o acentuado crescimento da sua actividade, prolongada até ao fim da I. ${ }^{a}$ República. Com efeito, aquela que tem sido vista como a antepassada das polícias políticas do Estado Novo por poder instruir processos, pelos seus métodos violentos (sob a direcção de Sollari Alegro, especialmente no norte do país) e por ter a particularidade de estar marcada ideologicamente, ${ }^{(290)}$ foi plenamente integrada no

(287) CAMPOS, Eurico de - A Reorganisação da policia, ob. cit. Lousã:Tipografia Lousanense, 1923, p. 3.

(288) Cf. Ibidem, p. 3.

(289) Cf.TELO.António José - O Sidonismo e o movimento operário português, ob. cit., p. 186.

(290) Afirmações de Fernando ROSAS cit. por SALEMA, Isabel - As Polícias políticas de Sidónio a Caetano. Público, de 24 de Abril de 1997, p. 4. 
aparelho policial gerido pelos Governos pós-sidonistas e reforçada até nos seus objectivos, conquanto prevaleça, de 1922 a 1926, o primado judicial sobre o técnico-policial mais da lavra de militares ou de membros do corpo policial. Magistrados e Inspectores da Polícia/Militares partiam, obviamente, de perspectivas diferentes para os mesmos objectivos.

Basta ler, por exemplo, o citado projecto de Eurico de Campos, um republicano conservador despeitado com a governação sidonista e autor da tese de que foram os monárquicos, designadamente o capitão Sollari Allegro, os mentores do assassínio de Sidónio Pais, (291) para se verificar total sintonia com a reforma sidonista quanto à justificação e aos fins da Polícia Preventiva: no seu art. $65 .^{\circ}$ diz-se que a polícia preventiva e de segurança do Estado, com jurisdição em todo o continente da Republica, tendo por fim a prevenção e a investigação de todos os crimes politicos e sociaes, será dirigida por um director, funccionario directamente subordinado ao Ministerio do Interior; ${ }^{(292)}$ e no restante articulado acham-se disposições ${ }^{(293)}$ que retiram à legislação sidonista qualquer exclusivo da sua alegada especificidade discricionária e ideológica comprovativa de um parentesco directo com a PIDE (Polícia de Vigilância e de Defesa do Estado, 1933-1945).

Deste pressuposto partiu Maria da Conceição Ribeiro no seu estudo sobre A Polícia Política no Estado Novo, embora reconhecendo explicitamente que a orgânica e as funções da Polícia Preventiva fixadas em 1918 foram seguidas, com sucessivas mudanças de designação, pelos Governos posteriores até 1922 e após essa data, com algumas restrições formais, pela Polícia Preventiva e de Segurança do Estado (1922-1926).(294) Isto não a impediu, porém, de afirmar que a I. ${ }^{3}$ República teve de criar organismos de prevenção-repressão política, embora pretendesse sempre policiá-los, limitando as suas competências em benefício da Polícia de Investigação Criminal e o seu arbítrio, em nome de uma submissão mais clara ao Direito, aspecto que se torna evidente em particular depois da reforma de Outubro de 1922. Neste sentido as polícias políticas republicanas - mais uma vez ressalvando o caso, singular, do período sidonista — aparecem-nos, antes de mais, com um carácter de resposta às circunstâncias de forte instabilidade e agitação política e social que se viviam e que propiciaram adaptações de carácter autoritário.(295) Ora, precisamente essa perceptível singularidade do caso sidonista decorreu por inteiro da necessidade de responder a determinadas circunstâncias político-sociais tidas por ameaçadoras do Poder, não se descortinando razões ideológicas especiais e estranhas ao corpus doutrinário republicano, na sua dupla faceta democrática e autoritária. E nem os múltiplos excessos praticados, no Porto, pelo Inspector capitão António Adalberto

(291) Ver CAMPOS, Eurico de - Quem são os assassinos do Dr. Sidonio Pais?: estudo de investigação criminal. Coimbra: Livraria Editora F. França Amado, 1919, p. 30.

(292) Ver Idem - A Reorganisação da policia, ob. cit., p. 30.

(293) Cf. Ibidem, p. 30-31.

(294) Ver RIBEIRO, Maria da Conceição - A Polícia política no Estado Novo, 1926-1945. Dissertação de Mestrodo em História do Século XX, apresentada na Faculdade de Ciências Sociais e Humanas da Universidade Nova de Lisboa. Lisboa: Editorial Estampa, 1995. p. 44-45.

(295) Cf. RIBEIRO, Maria da Conceição - A Policia política no Estodo Novo, 1926-1945, ob. cit., p. 49-50. 
Sollari Allegro, ${ }^{(296)}$ monárquico e presuntivo inspirador da reforma policial sidonista, com a sua rede de informadores (delatores), a constituição de cadastros de organizações e indivíduos ou o recurso contínuo a perseguições e atropelos ao Direito, permitem imprimir-lhe uma marca ideológica distinta, pelo que, com base nos dados disponíveis, não vemos como se possa ressalvar a Polícia Preventiva sidonista das restantes polícias republicanas, fundadas num modelo de Estado que - mesmo se, na prática, acaba por se revelar incapaz de resolver as profundas contradições existentes e de conseguir a almejada pacificação social - se estrutura em torno de princípios demo-liberais e se plasma numa concepção instrumental da polícia política, determinada apenas pelos imperativos da defesa da ordem. (297)

Publicado em suplemento ao Diário do Governo, de 29 de Abril, logo a seguir ao domingo das eleições conjuntas para Presidente da República, Deputados e Senadores, o decreto 4.166 de 27 de Abril, assinado pelo Ministro do Interior Henrique Forbes de Bessa, apareceu justificado apenas pela urgente necessidade de reformar os serviços policiais. (298) Ficava a partir daí estabelecido que todos esses serviços se subordinavam a uma Direcção autónoma do Ministério do Interior, denominada Direcção Geral da Segurança Pública e herdeira de atribuições assumidas até então pela Direcção Geral de Administração Política e Civil, em especial no respeitante à actuação das polícias ou, por exemplo, à recepção das relações periódicas de presos políticos enviadas directamente para o Ministro, por ordem expressa deste quando o titular era Machado Santos. ${ }^{(299)}$

No topo da nova estrutura criada estava o respectivo Director Geral, dependendo directamente do Ministro e exercendo o cargo através de sete Repartições: a do Expediente; a da Polícia de Segurança; a da Polícia de Investigação; a da Polícia Administrativa: a da Polícia Preventiva (de inteira confiança do Governo); a da Polícia de Emigração; e a da Polícia Municipal.Além do Director, a D.G.S.P. ficava composta por um primeiro, um segundo e dois terceiros oficiais, que asseguravam todos os serviços da D.G.S.P. e junto do Director Geral, sob as suas ordens directas, havia um Inspector Geral da Polícia, oficial do Exército, cuja missão seria a de inspeccionar e fiscalizar todos os Corpos de Polícia dos diversos distritos, salvo o de Lisboa, constando as suas atribuições no capítulo II, art. I $3^{\circ}$. À excepção da Polícia Preventiva, todas as nomeações dos funcionários policiais eram de carácter permanente e só seriam afastados dos seus cargos por efeito de promoção ou motivo disciplinar, mas podiam ser transferidos para circunscrições diferentes por conveniência de serviço. $\bigcirc$ território continental e as ilhas adjacentes eram divididos em tantos distritos policiais quantos os administrativos e à frente de cada um deles havia

(296) A actuação do Inspector da Polícia de Segurança do Porto justificava uma aprofundada análise monográfica servida por novas e abundantes fontes documentais. Ver LIMA. Campos - O Reino da traulitânia: 25 dias de reacção monárquica no Porto. Porto: Renascensa Portuguesa, 1919, p. 18 e ss. e ALLEGRO, José Luciano Sollari - Para a história da monarquia do norte, [s. I.]: J.L.S.A., 1988, p. 47-48.

(297) Cf. RIBEIRO, Maria da Conceição - A Polícia política no Estodo Novo. [s. I.]: J.L.S.A., 1988, p. 49.

(298) Ver desenvolvida notícia sobre o diploma na imprensa, nomeadamente O Século:A Reforma da policia. Creação do serviço antropometrico. A policia municipal. O Século, de I de Maio de I9I8, p. I.

(299) Ministério do Interior. Correspondência recebida (Segurança Pública), maço 81, caixa 51 . (Instituto dos Arquivos Nacionais - Torre do Tombo). 
um Comissário Geral de Polícia com superintendência em todos os serviços policiais, ressalvando os distritos de Lisboa e Porto, cujas divisões correspondiam ao seu número de bairros, tendo à frente de cada uma delas um Comissário de Divisão subordinado ao Comissário Geral. Os Comissários podiam ser oficiais do Exército, requisitados em comissão permanente para desempenho de funções policiais. ${ }^{(300)}$

A reforma policial focada incluía ainda a criação de um Montepio da Polícia, junto da D.G.S.P., com carácter obrigatório e com cofre e fundo especiais, administrado por uma comissão de seis membros que exerceriam as suas funções gratuitamente e organizado para estabelecer pensões às familias dos chefes, cabos, agentes e guardas. $\bigcirc$ direito de legar pensões era garantido pelo pagamento de cota mensal de um dia de soldo ou ordenado do posto ou cargo que fosse exercido pelos contribuintes. Dentro do Comissariado da Polícia de Lisboa e Porto era constituída também uma Cooperativa de consumo para todo o pessoal das respectivas corporações. E, na sua parte final, o diploma dispunha, no respeitante aos detidos e presos, que a detenção de qualquer indivíduo considerado suspeito ou criminoso não poderia ir além de oito dias, a contar da data e da hora em que fosse detido, excepção feita para os detidos por crime de sedição, rebelião e alta traição à Pátria e à República que podiam ficar detidos pelo tempo indispensável para a conclusão das investigações. $\bigcirc$ pagamento de fiança e saída em liberdade provisória aplicava-se aos detidos ou presos por agressão, desordem, ofensas à moral pública e transgressão, comprometendo o fiador idóneo a sua pessoa e bens na apresentação do arguido, no dia e horas indicados pela autoridade policial.

As custas e as tabelas de emolumentos e de vencimentos para os diferentes Corpos de Polícia rematam o decreto, sendo perceptível o esforço de valorização salarial com vista a uma melhoria da prestação funcional dos seus agentes. Aliás, outros diplomas serão promulgados até final do ano, versando o crucial reforço de verbas exigidas pelo significativo acréscimo de actividade das várias repartições policiais em geral e da Polícia Preventiva em particular.

Paralela e complementar à importante reforma policial não pode esquecer-se que foi também lançada, pela «pasta» da Justiça, a inevitável reforma judiciária, compreendendo a reforma propriamente dita, a revisão dos Códigos (Penal, do Processo Criminal, Civil e de Processo Civil, Comercial e de Processo Comercial), a Tabela dos Emolumentos e Salários Judiciais e a Lei da Separação(301) — ponto programático imprescindível para qualquer bacharel em Direito feito Ministro da Justiça. Assim, o unionista Moura Pinto levou-a esboçada quando tomou posse, mas deixou-a muito inacabada quando o seu partido rompeu com Sidónio Pais. Ao seu sucessor, igualmente jurista, Martinho Nobre de Melo, coube o ensejo de assinar e publicar na folha oficial uma peça básica dessa reforma, que foi o decreto n. ${ }^{\circ} 4.172$ de 26 de Abril sobre a composição e o funcionamento do Conselho Superior da Magistratura Judicial e a criação do Conselho Superior da Magistratura do Ministério Público. Diploma assente no pressuposto básico, proclamado

(300) Sobre as especificidades das seis Repartições policiais integradas na D.G.S.P. ver SILVA, Armando Barreiros Malheiro da - Sidónio e sidonismo. Histório e mito, dissert. cit., vol. 2, p. I66-170.

(301) Dossier S. E. Justiça, I fl. s.d. e A.P.T.B. - Documentação avulsa, Obra que é urgente fazer pelo Ministério da Justiça, s.d. (Arquivo de Sidónio Pais - Militar, Lente e Político, Subsistema Presidência da República). 
após o golpe pela própria Junta Revolucionária, de que urgia dar uma sólida garantia à independência do Poder Judicial e assim que, para esse fim, era indispensável entregar - Conselho Superior da Magistratura Judicial à própria Magistratura Judicial, ou seja, cabia aos juizes a escolha do seu órgão máximo e colocavam-se desta forma a coberto das interferências do Governo na orgânica, funcionamento e composição da carreira judicial. Constituiu, pois, peça importante de uma reforma que haveria, também, de incluir, pelo decreto 4.250 de 8 de Maio, a criação da Relação de Coimbra, há muito reclamada por uns e rejeitada por outros consoante os seus interesses e conveniências. (302)

Mas voltando ao Interior convém acrescentar que por ali corriam outras matérias pertinentes além da segurança pública ou da preparação do dispositivo eleitoral, cuidadosamente ajustado ao objectivo essencial de ser eliminada qualquer surpresa, ou seja, a eventualidade indesejável de uma derrota nas urnas.

Sobre eleições e lei eleitoral nos ocupamos adiante a propósito da legitimação da República Nova. Aqui resta-nos relembrar, por exemplo, que a assistência pública e o combate aos surtos epidémicos suscitaram providências tomadas através do Ministério do Interior por sua exclusiva incumbência ou em partilha e em comutação com a Presidência do Governo, dada a tradicional simbiose entre estas duas instâncias do Executivo. É, aliás, curioso notar a prevalência desta característica orgânico-funcional numa fase de óbvio reforço do papel presidencial, dotado de maior iniciativa legisladora. ${ }^{(303)}$

Por outro lado, enquanto o Ministério do Interior se mantinha a legislar sobre assistência e saúde, designadamente através do decreto n. ${ }^{\circ} 4.152$ de 23 de Março que aprovava o regulamento geral para os institutos do sexo feminino integrados na Provedoria Central da Assistência de Lisboa, do decreto 4.048 de 23 de Março remodelando os quadros do pessoal efectivo e variável do Posto de Desinfecção Pública de Lisboa ou de sucessivos diplomas de reforço de verba já atrás citados e tendentes a debelar a epidemia do tifo, a Presidência do Ministério e da República evocava o impulso dinamizador e descentralizador da luta contra a pobreza e a fome, ensaiando o controlo parcial de uma área para a qual Machado Santos ultimara, ainda em Fevereiro de 1918, um projecto lei que, entretanto, a sua mudança de «pasta» empurrara para a «gaveta».(304) Pelo decreto 4.031 de 30 de Março de 1918 era, assim, constituída uma comissão encarregue de estabelecer e administrar, na cidade de Lisboa, sopas económicas, com a dotação inicial de $100.000 \$ 00$.

Iniciativa legal brevemente entrosada na Obra de Assistência 5 de Dezembro, em cuja Comissão Angariadora de Donativos tomava parte o alferes Eduardo Ferreira da Silva, Ajudante do Presidente da República, e multiplicada com êxito ao longo do segundo semestre de 1918, perante não apenas o agravamento geral das condições de vida, mas também o novo surto epidémico - o da pneumónica ou gripe espanhola - particularmente agudo no Outono.

(302) Dossier Tribunal da Relação em Coimbra, telegrama de 21-3-1918 e representação de 15-5-1818. (Arquivo de Sidónio Pais - Militar, Lente e Político, Subsistema Presidência da República).

(303) Ver SILVA, Armando Barreiros Malheiro da - Sidónio e sidonismo. História e mito, dissert. cit., vol. 2. p. 172.

(304) Assistencia Publica. Projeto de lei, Fevereiro de 1918. (Arquivo Machado Santos) e SILVA, Armando Barreiros Malheiro da - Sidónio e sidonismo. História e mito, vol. 2, dissert. cit., p. I73-174. 


\section{A Crise das subsistências}

Os surtos epidémicos de 1918 vieram, sem dúvida, tornar insustentável um quadro de vida que o drama das subsistências, intenso desde meados de 1917, convertera em permanente pesadelo, sem soluções eficazes à vista. E o citado transtorno oficial, reflectido na oscilação de medidas e de sucessivas fórmulas orgânico-funcionais, só ajudava a adensar o pessimismo latente.

Compreende-se, porém, essa busca de melhor e maior operacionalidade instituticional e político-administrativa dado que a «máquina» estatal estava muito mal preparada para enfrentar os desafios provocados pela economia de guerra. Se tivermos em conta as críticas de Henrique Forbes de Bessa, no relatório atrás citado e adiante retomado, sobre o caos organizativo, em meados de 1918, do Ministério do Trabalho — criado pela lei de 16 de Março de 1916 ! — não nos surpreendem as dificuldades sentidas até Março de 1918 nesse organismo governamental para fazer face à crise de subsistências inicialmente confinada à sua esfera de acção, nem tão pouco as expectativas postas na criação do Ministério das Subsistências e Transportes, entregue a Machado Santos.

Na sensível e débil área do comércio e distribuição, como há muito notou Vasco Pulido Valente, a guerra estimulara uma tendência que o decreto de 4 de Dezembro de 1917 do Governo Afonso Costa incorporou expressamente ao conceder à Administração dos Abastecimentos o exclusivo da venda do trigo e milho. A novidade residia no facto do Estado tomar sobre si o encargo de assegurar uma parte da actividade económica como único meio de garantir a respectiva disciplina. Era a assunção de um intervencionismo efectivo, tendo como pano de fundo dois fenómenos inusitados e perturbadores: os assaltos nas cidades e a resistência, activa ou passiva, à requisição de alimentos no campo. E o cenário mantinha-se, forçando o novo Governo saído do golpe a enveredar pela mesma via intervencionista, não obstante as críticas que os cultores da ciência económica clássica formularam contra essa orientação ${ }^{(305)}$ e mau grado a disparidade de interesses em jogo, motivando múltiplas queixas, sugestões e apelos.(306)

Impelida para os trilhos do controverso intervencionismo estatal, a governação dezembrista/sidonista jamais deixou de ziguezaguear nessa direcção e logo no início de Fevereiro foi substituída, através do decreto n. ${ }^{\circ} 3.810$ do dia 5 , a antiga Administração dos Abastecimentos, criada em Junho de 1917, pela Direcção dos Serviços da Subsistência Pública, também dependente do Ministério do Trabalho, com o duplo objectivo de organizar os serviços destinados à aquisição de matérias-primas e géneros de primeira necessidade precisos para o consumo do País e normalizar os mercados internos, ou seja, organizar o comércio externo e a distribuição e comércio internos.

No que respeita à primeira vertente e seguindo Vasco Pulido Valente pode dizer-se que houve a preocupação dominante de se conseguir que os aliados ingleses e americanos entregassem os géneros alimentícios e as matérias-primas indispensáveis ao consumo

(305) ver SILVA, Armando Barreiros Malheiro da - Sidónio e sidonismo. História e mito, dissert. cit., vol. 2. p. $175-178$,

(306) Carta de Bernardo Leite de Sousa e Silva, Gaia, 15-7-1918. (Arquivo de Sidónio Pais - Militar, Lente e Político, Subsistema Presidência da República). 
mínimo do país, evitando-se a exportação de produtos que nele escasseassem e, paralelamente, o Estado procurava garantir uma distribuição equitativa das mercadorias importadas. Objectivos que explicam as características essenciais da política adoptada: $a$ progressiva transferência da direcção do comércio externo para os organismos encarregados do abastecimento, acompanhada, como no plano interno, por restrições à iniciativa privada, que $o$ Estado, em determinados sectores, substitui, e a pouca atenção dada a considerações financeiras. ${ }^{(307)}$ Política desenhada por uma sequência de leis que teve 0 seu ponto de partida no citado decreto de 5 de Fevereiro ao atribuir à Direcção dos Serviços da Subsistência Pública um serviço de produtos diversos, exportação e importação; a 16 de Março, o decreto n. ${ }^{\circ}$ 3.936, ao organizar o Ministério das Subsistências e Transportes conferia à Direcção-Geral de Subsistências a faculdade de autorizar ou proibir a entrada ou saída de matérias-primas e de géneros de primeira necessidade e propor ao Ministério das Finanças quaisquer alterações a encargos fiscais que sobre eles incidam; por seu turno, o decreto n. ${ }^{\circ} 3.995$ de 27 de Março estabelecia que as licenças para exportação de produtos fossem passadas exclusivamente pelo Ministério das Subsistências e Transportes, que as comunicaria ao das Finanças, a fim de serem dadas instruções às alfândegas; pela portaria $n .^{\circ} 1.335$ era imposto o mesmo regime às reexportações de produtos coloniais; e com a extinção em Junho do Ministério das Subsistências caberá ao novo Comissário Geral dos Abastecimentos através da Direcção-Geral do Comércio Externo superintender sobre os serviços de exportação e importação de mercadorias necessárias ao abastecimento nacional, podendo adquirir e repartir os maquinismos e matérias-primas que hajam de ser importados, em conjunto, para as indústrias nacionais e autorizar ou proibir a entrada ou saída de mercadorias em geral.

Em jogo continuará a estar, até ao fim do ano e a despeito de nova alteração orgânica com a subida do Comissariado a Ministério dos Abastecimentos, não o aspecto financeiro das trocas internacionais ou o equilibrio da balança de pagamentos, mas sim suprir a constante falta de cereais panificáveis, de algodão e de ferro, ${ }^{(308)}$ como adiante se volta a focar.

Quanto à distribuição e comércio interno, retornamos ao decreto de 5 de Fevereiro que veio fornecer uma primeira matriz burocrática para que a doutrina do decreto de 4 de Dezembro de 1917 pudesse ser concretizada e daí que a Direcção Geral da Subsistência Pública tenha sido apetrechada de um conjunto esclarecedor de atribuições: I. a - estudar as questões do aprovisionamento do país de matérias-primas e de géneros de primeira necessidade; $2{ }^{a}$ - coligir os dados e informações, oficiais ou não, julgados necessários sobre o movimento de mercadorias, cotações, existências, disponibilidades e preços; $3 .^{a}$ - propor ao Ministério do Trabalho os manifestos da produção, existências e disponibilidades; $4{ }^{\mathrm{a}}$ - executar imediatamente as providências do Ministério do Trabalho destinadas à aquisição de matérias-primas e de géneros de primeira necessidade imprescindíveis ao consumo público e à normalização dos mercados internos; 5 . $^{\mathrm{a}}$ - cuidar do armazenamento das matérias-primas e géneros de primeira necessidade; e $6 .{ }^{a}$ - vender

(307) Cf. VALENTE, Vasco Pulido - Estudos sobre Sidónio Pais: comércio e distribuição em 1918, in Idem - Estudos sobre a crise nacional, ob. cit., p. 289.

(308) Cf. Ibidem, p. 290 e ss. 
as matérias-primas e géneros adquiridos. E, para além destas funções, havia ainda um conjunto de serviços orgânicos que reflectiam as preocupações dominantes e se repartiam pelos seguintes sectores: serviço de cereais e produtos panificáveis; serviço de géneros alimentícios; serviço de carnes, peixe, leite e produtos derivados; e, em último lugar, o serviço de produtos diversos, exportação e importação.(309)

Com essa estrutura visava-se ainda uma actuação centralizada, ou seja, que as instruções dos órgãos centrais fossem cumpridas em todo o país, restabelecendo-se para o efeito as delegações distritais e concelhias, dissolvidas pelo Governo da União Sagrada em Setembro de 1916.(310) Pretendia-se, afinal, que o Estado acorresse às carências regionais momentâneas mais graves, adquirindo num sítio para vender noutro ou no estrangeiro para vender em Portugal, sem assumir, porém, o peso total da distribuição.

Entre os lugares de mais aguda escassez avultavam os centros urbanos com Lisboa à frente, mas havia também a preocupação de fazer o equilibrio entre o campo e as cidades, denunciada pelo restabelecimento das comissões locais. $\bigcirc$ diploma citado esboçava, assim, uma estratégia, ainda que predominantemente normalizadora, reforçada um mês após ser criado, em paralelo com o Ministério da Agricultura, o Ministério das Subsistências e Transportes, dotado de três Direcções Gerais: Transportes Marítimos, Transportes Terrestres e Subsistências, que absorvia o pessoal da extinta Direcção Geral da Subsistência Pública.

$\mathrm{Na}$ opinião de Vasco Pulido Valente, a reforma institucional operada traduzia um esforço de autonomia, de centralização e de alargamento de poderes, preparatória da política que passava a concentrar cada vez mais no Estado a distribuição dos principais géneros alimentares. Com efeito, o novo organismo governamental via aumentada a sua faculdade de intervenção, podendo requisitar as matérias-primas, os géneros de primeira necessidade ou quaisquer outros indispensáveis à economia nacional e que se achassem em território da República; autorizar a venda ao público dos géneros para a alimentação; e adoptar as medidas indispensáveis para prevenir ou remediar o agravamento de qualquer crise de subsistências e artigos de primeira necessidade. ${ }^{(3 \mid 1)} \mathrm{A}$ restante estrutura, nomeadamente as comissões regionais, funcionando em nível distrital e concelhia, mantinha-se intacta e à frente de todo o aparelho ministerial era colocado, como temos referido, Machado Santos, destacada figura da nova situação política e do próprio regime republicano.

Alguns dias após ter tomado posse, em carta para o Ministro de Portugal em Londres, dominada pelo urgente tema do transporte de trigo, negociado naturalmente através da Delegação da C.R.I., atrás referida, Machado Santos dissertou sobre transportes e tonelagem, sobre a questão do racionamento e resumiu as suas medidas e os seus projectos, traçando um curioso retrato político-administrativo e social do país e ao qual tinha de atender na condição de governante:

(309) Cf.VALENTE, Vasco Pulido - Estudos sobre Sidónio Pais: comércio e distribuição em 1918, in Idem - Estudos sobre a crise nacional, ob. cit., p. 303

(310) Cf. Ibidem, p. 303.

(311) Cf. lbidem, p. 304. 
Sou ministro d'um paiz que se formou rapinando os mouros, que se engrandeceu rapinando a India, que passou depois a rapinar o Brazil e que quando não teve mais mouros para rapinar, nem indios, nem brazileiros, se passou a rapinar a si proprio. A guerra, meu querido amigo, tem sido uma mina para o português explorar o seu compatriota.

Tipo unico de pão! Racionamento! É tudo muito bonito... para os outros.

O tipo unico de pão, facil de estabelecer n'um paiz que não produz cereaes, como a Inglaterra, é impossivel estabelcer em Portugal. As populações do Norte, comem milho, as do sul trigo, e como só comem pão, com o cheiro de qualquer coisa a que chamam "conduto», não pode fixar-lhes uma quantidade. $\mathrm{O}$ milho e o trigo que produzimos, bastaria para o nosso consumo se pudessemos estabelecer o tipo unico de pão, mas aos inconvenientes apontados ha que juntar o da escacês de material ferroviario que não nos permite levar o trigo para o norte e o milho para o sul.

Para meter a casa em ordem estou tratando de ver se consigo que os meus colegas no ministerio me deixem organisar os celeiros municipaes, sendo o governo o comprador de toda a colheita de trigo, milho e centeio. Se conseguir isto, com as providencias já tomadas para uma intensificação da producção espero não ter necessidade de importar trigo no futuro ano cerealifero.

E se vós me conseguirdes ahi, as 30.000 toneladas em vapores, espero conseguir o equilibrio da nossa balança economica, equilibrio que se manterá depois da guerra.

Apezar de tudo, não ponho de banda a idéa do racionamento, mas como fazel-o para a carne, para o assucar e talves para o arroz, em Lisboa, Porto e Coimbra.

E se conseguir realisar esse racionamento nas 3 cidades, somente, realisei o maximo, com um trabalho d'Hercules.

Tomei conta do meu ministerio tendo 3 dias de pão. O que se devia ter feito, ha mezes, arrancando aos produtores pelos preços oficiaes o que elles tinham nos seus celeiros, não se fez. E eu vi-me forçado a arranjar a farinha por todo o preço, pois que se Ihes não pagar o que querem, fazem tocar os sinos a rebate e levantam as populações, com o pretexto de que as vamos esfomear para servir Lisboa.

Emfim, uma situação horrivel.

Para completar o lindo quadro, a desastrada solução dada á crize, com a substituição de autoridades, que eram unionistas, e nos conselhos cerealiferos.

Até agosto terei de passar pelas forcas caudinas. Felismente, conto não legar ao meu sucessor na pasta qualquer coiza que se aproxime das dificuldades com que tenho estado a arcar.

E a incompetencia?

Se podesseis fazer idea do cáos em que encontrei tudo, da indolencia dos funcionarios e da estupidez, e cupidez do meio, avaliareis melhor do sacrificio que faço estando no governo por amor de minha cabeça e da dos meus amigos, tendo de sancionar atos impoliticos e de me solidarisar com um sistema governativo que ainda não teve um vislumbre de orientação.

Nem a habitual e sempre ambígua mordiscadela no Governo, a que indiscutivelmente pertencia, pôde faltar nestes comentários privados - nítido reflexo de uma personalidade complexa, marcada por um idealismo voluntarista de difícil apreciação. Se para 
uns era, incontestavelmente, o revolucionário destemido, idealista e generoso, afivelou, para outros, a imagem de fraco administrador. Rótulo apressado que pretendia, talvez, significar a sua eventual incapacidade de dirigir quotidianamente a burocracia do Estado e a sua espontânea impaciência face ao formalismo, rigidez e lentidão dos processos usados pela Administração, traços que não Ihe retiravam, porém, lucidez e energia para o estudo e implementação de ousadas soluções administrativas.

Bastante impulsivo e influenciável pelos seus amigos, o fundador da República projectou-se indelevelmente nos textos e nas entrevistas que concedeu, no pequeno pacote legislativo que teve ensejo de formalizar e até no acervo de telegramas, conservados em seu poder, produzidos no decurso da sua função governativa nas Subsistências, definindo aí um estilo. Vale, por isso, a pena um golpe de vista pelas ordens, recados e comunicações várias que manteve com Governadores Civis, Governadores Gerais das colónias, chefes das Legações portuguesas, empresários, associações comerciais e outras entidades durante o seu curtíssimo desempenho ministerial.

Em 12 de Março, ordenava ao Administrador do Concelho de Moura que remetesse imediatamente para o Barreiro os vinte wagons de farinha da fabrica de Amaraleja que foi apreendida pela administração dos abastecimentos. Empregue a força se preciso fôr para executar esta ordem.

Ao Ministro de Portugal em Madrid solicitava, com data de 13, que obtivesse autorização do Governo espanhol para que se possam adquirir na região de Salamanca cinco milhões de centeio que me informam não ter consumo em Espanha peço mais que Vxia me informe telegraficamente resultado. Nesse mesmo dia ao Director dos Caminhos de Ferro do Sul e Sueste e ao Director da Companhia Portuguesa dos Caminhos de Ferro determinava que desse as suas ordens imediatas e terminantes para que seja informado o Director Geral das Subsistencias de todas as remessas de feijão que sejam despachadas em wagons completos, das estações a que sejam destinadas e dos seus consignatarios. Ainda a 13 de Março o Director Geral das Subsistências, João Francisco da Silva, pedia ao Director da Alfândega tomasse nota de que a Associação Central d'Agricultura Portuguesa, fica encarregada da distribuição do referido adubo, ou seja, da porção de nitrato de soda descarregado dos navios ex-alemães à ordem do Ministro do Trabalho, extinta Comissão de Susbsistências. E de novo a I 3 expedia ao Governador Civil de Viseu telegrama nestes precisos termos Acabo receber o seguinte telegrama dirigido meu chefe Gabinete: Repilo ameaças V. Ex. ${ }^{\circ}$ que não me intimidam . Lamento se sirva seu cargo para ameaças. OAdministrador // Artur Leitão // Não percebendo como essa creatura é ainda administrador Castro Daire espero proceda com a energia que o caso requere em harmonia meu ultimo telegrama.

Sem data precisa emitiu circular para todos os Governadores Civis, indicando expressamente que ordenassem a suspensão transações cereaes seu distrito a não ser por Ministerio Subsistencias. Outra circular, esta para as Comissões de Subsistências dos distritos de Portalegre, Évora e Beja ordenava que mobilizassem toda a farinha e trigo existentes distrito e que não seja necessario consumo local e envie rapidamente Barreiro á ordem ministerio subsistencias.

Ao Director da Companhia Caminho de Ferro Beira Alta, sedeada na Figueira da Foz, comunicava informação recebida do Governador Civil da Guarda de que existiam 200 wagons batata que está apodrecendo estações Fornos e Vila Franca e exigia determinasse 
que essa batata siga imediatamente Lisboa para o que Ihe devem fornecer material pequena velocidade.

Ao Governador Geral de Moçambique, em 22 de Março, determinava que vapores África Moçambique que carreguem o mais possível milho para Lisboa e idêntica ordem ao homólogo de Angola tendo em vista o vapor Zaire.

Para o Governador Civil de Leiria a mensagem era de outro tipo: Seu distrito tem muito milho açambarcado. Se V.xia tivesse procedido ao arrolamento como Ihe determinei como ministro do interior e como the indiquei ainda meu ultimo telegrama circular $V$.xia veria que Ihe não faltava cereal distrito. Ordene busca armazens reviste cisternas e obrigue a pôr á venda o milho que está oculto.

Em mensagem urgentíssima para o Director Alfândega do Porto, datada de 22 de Março, pedia o informasse hoje mesmo das quantidades feijão exportado para França e em especial o que foi exportado por intermedio adido naval francês. A 26, num desenvolvido telegrama para o Governador Civil de Faro, era este autorizado a permutar farinha por peixe fresco ou salgado: digo-the que Algarve enriquecido pela guerra tem sido uma verdadeira sanguesuga do Alentejo e comprando trigo e farinha por todo o preço infringiu a lei e fez encarecer enormemente o custo do pão não só para o publico mas, tambem para - Estado porque é este quem garante o preço do pão de segunda em Lisboa. O seu distrito tem maneira de se abastecer de Ayamonte. Auctoriso-o portanto a consentir na permuta de farinha por peixe fresco ou salgado, responsabilisando $V$.xia para que o valor da exportação do peixe não exceda o da importancia da farinha para o que se torna necessario que V.xia de acordo com comissões de subsistencias ou com as camaras municipaes monte um serviço de fiscalisação sobretudo em Vila Real.

Ao Secretário Geral do Governo Civil de Coimbra mandava-se proteger nesse mesmo dia de 27 de Março contra vandalismos populares o predio que existe na Castanheira da freguezia de S. Silvestre pertencente ao dr. Malva do Vale.

Mais para Norte seguia novo telegrama, mais precisamente para o Governo Civil do Porto, pedindo informação urgente se desesseis wagons com assucar que foram enviados pela Sociedade Assucar Colonial para o Porto chegaram ahi quaes as casas a que foi distribuido e preço a que está sendo vendido ao publico. Em 2 de Abril autorizava o Governador Civil de Vila Real a requisitar generos aos comerciantes gananciosos pelos preços tabela e autoriso tambem a que os meta na cadeia. E no mesmo dia para o Governador Civil de Viseu recomendava estrita observância de ordens anteriores acerca contribuição irregular e iniqua que administração conselho Vizeu lança sobre milho em transito. Se conselho deseja milho que o adquira nos outros conselhos distritos das disponibilidades que estes tenham.

Por circular de 5 de Abril a todos os Governadores Civis do Continente chamava-se a atenção para o disposto na portaria n..$^{\circ}$ I.284 de 3 de Março, que dispunha o seguinte: Manda o Governo da Republica Portuguesa, pelo Ministerio das Subsistencias e Transportes, que todo o açucar existente nas alfandegas, entrepostos, fabricas, armazens, particulares, depositos, mercearias ou em qualquer outro estabelecimento de comercio, seja manifestado no praso de dois dias nas cidades de Lisboa e Porto e de quatro dias nas restantes localidades do territorio continental da Republica. Os manifestos devem ser feitos em papel comum e entregues em Lisboa no Ministerio das Subsistencias e Transportes, na seç̧ão do açucar, e no resto do paiz aos presidentes das comissões administrativas das camaras municipaes que os remeterá imediatamente á Direcção Geral das Subsistencias. Os detentores de açucar 
que não derem cumprimento ao disposto nesta portaria incorrem na pena de apreensão das quantidades não manifestadas e serão processados por desobediencia.

Com destino aos ferroviários do Entrocamento pedia ao Administrador do Concelho da Barquinha lhes comunicasse que Governo garante os aumentos de salarios pedidos e que companhia concedeu atendendo á situação economica do paiz. E no mesmo dia 9 recomendava ao Governador Civil do Porto promovesse fiscalização rigorosa do açucar evitando açambarcamentos mantenha rigorosamente preços fixados pelo ministerio apoie-se de preferencia na camara visto comissão subsistencia não me inspirar confiança.

Ao Governador Geral de Moçambique pedia sirva-se V.xia de ordenar embarque nos três primeiros vapores que viessem para Lisboa as 1.320 toneladas de arroz descascado adquiridas pelo Governo a Gomes \& Irmão.

Próximo telegrama incidia já de novo sobre território continental e ia para o Governador Civil da Guarda:Preço centeio carissimo e como V.xia me informou pessoalmente que seu distrito não precisava de cereal algum eu agurado que $V$.xia me envie os arrolamentos que ordenei para poder avaliar da situação economica do seu distrito.

E, de novo, no além-mar recomendava ao Governandor Civil do Funchal a leitura Diario de Noticiais Funchal numero 13235 de nove corrente, anuncio vende-se terceira columna primeira pagina para avaliar fome seu distrito, insistindo uns dias depois com outro recado: Madeira ficou com toda carga vapores Loanda Beira alem disso proibe exportação da banana se houvesse fome Madeira não teriam vindo para Lisboa quinze contos de banana de contrabando.

De retorno ao continente esclarecia o Governador Civil de Santarém de que Este ministerio só passa guia de transito quando tem quasi a certeza de generos não fazerem falta consumo local. E ao Governador de Viana do Castelo pedia-lhe auxiliasse seu colega de Braga na importação farinha exotica e trigo, mimoseando-o noutro telegrama, este de 26 de Abril, com rasgado elogio: Para regularisar serviço destribuição de cereaes e generos primeira necessidade publicou-se uma portaria determinando que o transito dos mesmos só pudesse fazer-se com guias d'este ministerio passadas a pedido das camaras ou das autoridades administrativas afim de evitar que os particulares abuzassem como estavam fazendo. $V^{a}{ }^{a}$ Ex. ${ }^{a}$ que foi dos governadores civis um dos poucos que soube compreender a sua missão saberá dar as suas instruções de forma a cumprir-se integralmente a deliberação governativa. Pedido de guia de transito que $V$.xia envie ministerio será imediatamente satisfeito.

À Casa Tait \& C. a do Porto era dada resposta ao apelo de V.xia a Sua Excelencia o Senhor Presidente da Republica, informando que se mantem deliberação tomada quanto ao transporte dos vinhos licorosos do Douro não havendo pois motivo para receio. Até ao fim do corrente ano devem estar exportadas todas as disponibilidades existentes. (3।2)

Do exposto sobressai facilmente a ciclópica e inglória azáfama destinada a controlar o circuito de distribuição em todo o território nacional e, ao mesmo tempo, as enormes e sucessivas resistências opostas a esse controlo, impedindo/bloqueando o trânsito de produtos ou simulando carências inexistentes para satisfação de interesses económicos locais, enfim, uma sucessão de inevitáveis cenas do esconde-esconde estimuladas pela possibilidade de altos lucros e pelo aguilhão repressivo dos organismos oficiais.

(312) Copiador de telegramas do Ministério de Subsistências e Transportes, fls. inumeradas. (Arquivo de Machado Santos). 
Neste quadro se inseriu, pois, concebido e aplicado por Machado Santos, o projecto radical de um aparelho distribuidor capaz de transformar as relações tradicionais em vários sectores da economia. $E$ de um tal projecto emanou naturalmente o famoso decreto n. 4.125 de 20 de Abril que instituiu os celeiros municipais. No seu artigo $2{ }^{\circ}$ definiam-se estas unidades como organismos destinados a auxiliar a Repartição de Cereais e Panificação na aquisição, armazenagem e distribuição pelo país de todo o centeio, milho e trigo das futuras colheitas e das farinhas desses cereais, assim como de todo o centeio, milho, trigo e farinhas exóticas importadas pelo Estado, precisando no $\S$ único do mesmo artigo que os celeiros podiam ser destinados à armazenagem e à distribuição de quaisquer produtos de que as Câmaras Municipais julgassem necessário assegurar-se para manutenção dos seus munícipes.

Ficava, assim, delineada para estes organismos uma função só aparentemente reguladora, porquanto eles se vocacionavam para um verdadeiro exclusivo de distribuição, pretendendo-se com este regime alcançar dois objectivos distintos: reduzir ao mínimo a especulação típica dos períodos de crise, proibindo-se para isso a venda directa do produtor ao consumidor e pondo-se o Estado no lugar dos intermediários e outros agentes comerciais; e proceder a uma distribuição mais justa dos géneros disponíveis entre cidades e campo, servindo a rede dos celeiros tanto para garantir que as cidades recebessem a produção do campo, como para permitir que o campo obtivesse o que era importado através de algumas cidades. Esteve, porém, este regime longe de ser consensual, «chovendo» logo críticas inspiradas na desconfiança suscitada geralmente pela Administração pública e pelos interesses ameaçados dos produtores. ${ }^{(313)}$

\section{Política agrícola}

Em estreita relação com a questão das subsistências e da carestia da vida andaram também outras políticas, a saber: a agrária e a industrial — ambas com fortes implicações na questão social.

Sobre a primeira convém, antes de mais, relembrar a tese de alguns autores, designadamente António José Telo, de que o sidonismo dá sobejas provas de considerar [a Agricultura como] o sector económico fundamental, com especial relevo para a cultura cerealifera, tendo sido, aliás, um proprietário alentejano o principal financiador do golpe de Sidónio. Em Março de 1918 cria-se o até aí inexistente Ministério da Agricultura, à frente do qual é colocado o latifundiário Fernandes de Oliveira, numa atitude muito louvada pelas associações agrícolas. ${ }^{(314)}$ Uma importância reconhecida pelos factos, mas que precisa de ser burilada em alguns detalhes. Insistimos, por isso, na observação, já atrás feita, de que o apoio financeiro do unionista António Miguel de Sousa Fernandes ao golpe dezembrista não trouxe por si só o apoio da grande lavoura, nem condicionou de imediato e ideologicamente (em sentido retrógrado ou não progressivo) a política agrária a seguir.

(313) Ver sobre este assunto VALENTE,Vasco Pulido - Estudos sobre Sidónio Pais: comércio e distribuição em 1918, in Idem - Estudos sobre a crise nacional, ob. cit., p. 306.

(314) Cf. TELO, António José - A Busca frustrada do desenvolvimento, in REIS, António - Portugal contemporâneo, vol. 3, ob. cit., p. 148. 
É preciso ter em conta outros factores e o programa do centrismo progressista conservador não é, por certo, dos menores. E depois há o contexto de economia de guerra agravando imenso a crónica insuficiência por parte da agricultura portuguesa no abastecimento do país, sendo tradicionalmente importadas grandes quantidades de géneros alimentares, como, por exemplo, cereais, arroz, grão e açúcar. Com a guerra e a subsequente redução do comércio externo, a carência tornou-se endémica e a crise agrícola por demais evidente.

Como notouVasco PulidoValente, desde 1914, o Governo foi-se sentindo obrigado a travar, pelo recurso a medidas legais, as tendências altistas, ao mesmo tempo que a produtividade desceu e os custos aumentaram regularmente devido, sobretudo, à escassez e encarecimento dos adubos químicos e à subida dos salários. ${ }^{(315)}$ Condições concretas a que podemos somar, em 1917, mais um ano de colheitas desastrosas mesmo para o nível médio entre 1913 e 1919, não sendo já possível contar com os fornecimentos externos. Desenhava-se, deste modo, uma situação agrícola insustentável do ponto de vista prático, ou seja, quanto ao abastecimento de géneros e do ponto de vista das concepções económicas que ainda valorizavam, num país como Portugal, o papel dinâmico de um sector primário modernizado com a ajuda do próprio Estado.

$\mathrm{Na}$ conjuntura indicada o fomento da produção agrícola impôs-se ao novo Governo dezembrista como a única alternativa viável, embora pudesse haver divergências de fundo acerca dos meios a utilizar. Uma alternativa, aliás, que os sindicatos operários e rurais enxergaram com lucidez, aproximando-se, numa das duas soluções por eles propostas, das conhecidas teorias de colonização interna caras a Oliveira Martins, Basilio Teles e a Ezequiel de Campos, Chefe de Gabinete do Ministro do Comércio (e depois das Finanças) Francisco Xavier Esteves, a saber: o aproveitamento das áreas incultas, tanto privadas, como baldios e terrenos camarários, através da sua entrega obrigatória às associações de trabalhadores. A segunda solução consistia numa ajuda estatal maciça aos produtores.

Pendeu paradoxalmente mais para este esquema, segundo Vasco Pulido Valente, a preferência dos dirigentes proletários manifestada na sua imprensa e nas reuniões da classe rural, designadamente no Congresso dos Trabalhadores Rurais reunido no Teatro de S. Carlos, em Maio de 1918. Circulou aí um discurso coincidente com o dos agricultores-proprietários, que J. Castro, observador do Governo nesse Congresso, sumariou desta forma: a política proposta pelos trabalhadores rurais consistia em intensificar a produção do solo, estabelecendo preços remuneradores à lavoura e em reduzir e até suprimir a importação de cereais, evitando, assim, a drenagem do ouro e o consequente aumento da carestia da vida. (316) Fixada em tais termos, não surpreende que a U.O.N. no seu órgão oficial $O$ Movimento Operário veiculasse uma indisfarçável indignação, nem tão pouco que, mais tarde, tenha reagido contra os decretos $4.812,4.835$ e 4.836 da

(315) Ver dados quantitativos sobre crescente falta de adubos e índices de salários agricolas in VALENTE, Vasco Pulido - Estudos sobre Sidónio Pais: Agricultura e proletariado agrícola; indústria e sindicatos; comércio externo, in Idem - Estudos sobre a crise nacional, ob. cit., p. 244-250.

(316) Cf.VALENTE, Vasco Pulido - Estudos sobre Sidónio Pais: Agricultura e proletariado agrícola; indústria e sindicatos; comércio externo, in Idem - Estudos sobre a crise nacional, ob. cit., p. 252. 
Secretaria de Estado da Agricultura sobre o desdobramento e a cultura dos baldios camarários e o desbravamento de charnecas e incultos de propriedades particulares e a instituição de prémios, alegando não corresponderem às aspirações profundas das classes operárias. ${ }^{(317)}$

O operariado exigia a socialisação dos baldios e terrenos camararios e outras medidas de cariz radical. No entanto, a simples promulgação de tais decretos confirma que a orientação governamental, em particular através do novíssimo Ministério e, após 9 de Maio, Secretaria de Estado da Agricultura, tendeu a incorporar e adaptar o essencial das reivindições do mundo rural e operário. Processo claro que se traduziu, por exemplo, no alargamento dos créditos disponíveis para intensificação da nossa produção agrícola, ${ }^{(318)}$ no fornecimento aos produtores, tanto quanto possível, de máquinas, alfaias, adubos e apoio técnico ou na promoção da cultura intercalar de cereais.

Todavia, a estreiteza das disponibilidades financeiras reduzia imenso a amplitude, brevidade e eficácia da ajuda estatal, pelo que urgiam providências mais decisivas e praticáveis que o novo organismo ministerial para o sector não tardou a implementar: o decreto n. 3.966 de 22 de Março, publicado não pelo Ministério da Agricultura como refere Vasco Pulido Valente, ${ }^{(319)}$ mas pelo das Subsistências e Transportes, eleva os preços do trigo, milho, centeio, cevada, aveia, arroz e fava a colher no ano cerealífero de 1918-1919, explicando-se no preâmbulo que a fixação de um preço remunerador para os cereais que o país produzisse era a única forma prática de animar a lavoura a intensificar a cultura cerealifera e de corrigir, assim, o desequilibrio da balança comercial atribuivel à importação de cereais. Até final do ano novos aumentos serão decretados pelas Subsistências, configurando uma política inflacionista, bem ilustrada através dos índices de alguns preços agrícolas entre 1914 e 1919:(320)

\begin{tabular}{ccccccccc}
\hline Anos & Trigo & Milho & Centeio & Arroz & Feijão & Fava & Grão & Batata \\
\hline 1914 & 100 & 100 & 100 & 100 & 100 & 100 & 100 & 100 \\
1915 & 120 & 114 & 116,6 & 126 & 131 & 111 & 131 & 133,3 \\
1916 & 150 & 157 & 150 & 152 & 138 & 144 & 138 & 166,6 \\
1917 & 260 & 243 & 183,3 & 248 & 177 & 211 & 184 & 200 \\
1918 & 400 & 371 & 333,3 & 426 & 331 & 378 & 331 & 350 \\
1919 & 430 & 471 & 383,3 & 426 & 569 & 433 & 546 & 600 \\
\hline
\end{tabular}

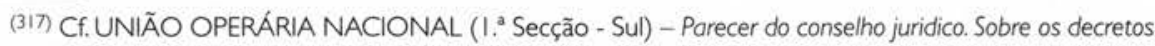
relativos ao desdobramento e cultura dos baldios camararios e ao desbravamento de charnecos e incultos de propriedades particulares e instituição de premios. (Decretos nos 4.812, 4.835 e 4.836). Publicados pela Secretaria de Estado da Agricultura. Lisboa: U.O.N., 1918, p. 2-3.

(318) Cf.VALENTE,Vasco Pulido - Estudos sobre Sidónio Pais. Agricultura e proletariado agrícola; indústria e sindicatos; comércio externo, in Idem - Estudos sobre a crise nocional, ob. cit., p. 258.

(319) Ibidem, p. 255.

(320) Cf. Ibidem, p. 256. Ver também MARQUES, A. H. de Oliveira - História da 1. ^ república portuguesa. As estruturas de base, ob. cit., p. 311-369; e Idem - Portugal. Da Monarquia para a república, in SERRÃO, Joel e MARQUES, A. H. de Oliveira - Nova história de Portugal, vol. II, ob. cit., p. 65-145. 
E, em termos gerais, o índice dos preços agrícolas no Continente fixou-se nestes valores: 1914-100; 1915-114,2; 1916-135,7; 1917-192,8; 1918-300; e 1919-400-o que representa uma subida de 78,6 pontos entre 1915 e 1917 e de 107,2 pontos entre 1917 e 1918 !...

Números elucidativos de um instrumento específico - a política de preços - que provocou, inevitavelmente, um agravamento generalizado das condições de vida das populações urbanas e uma diminuição dos salários, tendo em vista a reanimação do extenso sector primário, de imediato, reflectida no acréscimo de certas produções agrícolas do território continental, com particular incidência nos produtos típicos do Sul, zona do latifúndio. Noutros produtos verificou-se uma diminuição por efeito das especiais condições do ano agrícola, ou por muitos agricultores terem substituído as suas tradicionais culturas por cereais panificáveis, cuja falta era mais gritante, ou por se terem dedicado à pecuária:(321)

\begin{tabular}{lrrr}
\hline \multicolumn{1}{c}{ Produtos } & 1916 & 1917 & \multicolumn{1}{c}{1918} \\
\hline Trigo (1000 litros) & 259.878 & 260.224 & 335.683 \\
Milho (1000 litros) & 351.200 & 332.874 & 314.002 \\
Centeio (1000 litros) & 108.757 & 121.457 & 165.741 \\
Aveia (1000 litros) & 119.636 & 143.302 & 143.996 \\
Cevada (1000 litros) & 46.860 & 55.584 & 55.917 \\
Arroz (toneladas) & 20.599 & 16.779 & 23.261 \\
Fava (1000 litros) & 40.100 & 40.530 & 43.554 \\
Feijão (1000 litros) & 32.848 & 29.834 & 28.817 \\
Batata (toneladas) & 161.179 & 156.017 & 143.372 \\
Vinho (1000 litros) & 413.148 & 404.813 & 393.016 \\
Azeite (1000 litros) & 29.070 & 41.931 & 30.018 \\
\hline
\end{tabular}

A opção estratégica assumida pelos Governos de Sidónio Pais não teve em vista uma política estritamente anti-urbana e anti-desenvolvimentista, mas antes uma política de compromisso táctico imposto pelo curto prazo: despenalizar a vida no campo e fomentar a produção agrícola num gesto claro de sedução à vasta classe agrária que era também

118 uma parte substancial do Portugal profundo (desde o latifundiário do Sul ao pequeno campesinato do Norte), em prejuízo temporário e acentuado da vida nas cidades(322) até ao fim da Grande Guerra, reprimindo com dureza a agitação social e garantindo a contenção salarial enquanto não fosse relançada globalmente toda a economia.

\footnotetext{
(321) Cf.TELO, António José - O Sidonismo e o movimento operário português, ob. cit, p. 173.

(322) VerVALENTE, Vasco Pulido - Estudos sobre Sidónio Pais: Agricultura e proletariado agrícola; indústria e sindicatos; comércio externo, in Idem - Estudos sobre a crise nacional, ob. cit., p. 279 e ss.
} 
No horizonte desta estratégia permanecia a velha e acrisolada meta republicana do progresso e da modernização do país, ${ }^{(323)}$ inserindo-se nela os esforços subsumidos na criação do Ministério da Agricultura e do conjunto de medidas que lhe coube pôr em prática e que são mais adiante apreciadas por se concentrarem, sobretudo, no segundo semestre de 1918.

Fundado pelo mesmo diploma - o decreto 3.902 de 9 de Março - que instituiu o Ministério das Subsistências, só em 26 de Abril é que veio a ser publicado o decreto n. ${ }^{\circ} 4.151$ assinado no dia anterior pelo titular da «pasta» Eduardo Fernandes de Oliveira, considerando-se, então, ter ficado finalmente operacional esse organismo, creado nas mais largas e amplas condições de viabilidade para citarmos as palavras de Ludovico de Menezes nas páginas de $O$ Século.(324)

Os seus fins, estampados logo no início do articulado, são assaz reveladores: 1. ${ }^{\circ}-$ ministrar o ensino da agricultura nos seus diversos graus; $2 .^{\circ}-$ promover e auxiliar o desenvolvimento e melhoramento das indústrias agrícola, florestal e pecuária; $3 .^{\circ}$ - assegurar a higiene e sanidade pecuárias; e $4 .^{\circ}$ - estudar as condições económicas naturais do meio regional e divulgar esse estudo e todos os princípios económicos úteis à agricultura.

Para execução de tão ambicioso desiderato era montada uma «máquina» composta por serviços independentes e autónomos, dotados da máxima capacidade técnicocientífica e da maior operacionalidade no terreno. Ficou, aliás, expressa no diploma a divisão dos serviços do Ministério em internos e externos, compreendendo aqueles a Secretaria Geral, o Conselho Superior de Agricultura e a Repartição de Contabilidade, e os segundos o essencial da intervenção desenhada para o sector e repartida pelas seguintes especializações: Serviços de Instrução Agrícola; Serviços Agrícolas; Serviços Florestais e Aquícolas; Serviços Pecuários; Serviços de Hidráulica Agrícola; Serviços Fisiográficos; Serviços de Economia e Estatística Agrícola; Serviços do Crédito e das Instituições Sociais Agrícolas; e Serviços Comerciais Agrícolas. A cada uma destas áreas funcionais correspondia uma Direcção de Serviço, sedeada em Lisboa, dirigida por um técnico obrigatoriamente com formação agronómica, e implantada a nível nacional através de pessoal técnico subordinado em cada circunscrição, concelho, delegação regional ou posto zootécnico conforme a especificidade dos serviços da respectiva Direcção.

Uma extensa e complexa «máquina», saudada com visível agrado pelos representantes da lavoura nacional. Tal como sucedeu com os funcionários públicos, também os membros ligados à actividade agrícola, antes mesmo da definitiva organização do Ministério, deslocaram-se a Belém para patentearem ao Presidente da República a sua máxima satisfação pela criação desse organismo.A manifestação pública ocorreu na tarde do dia 8 de Abril e, como não podia deixar de ser, foi acompanhada por mensagens e discursos, sendo de destacar o improviso de Sidónio Pais:

(323) Dossier Alvitres, carta de Joaquim C.A. Sequeira, Rio de Janeiro, 12-4-1918. (Arquivo de Sidónio Pais - Militar, Lente e Político, Subsistema Presidência da República).

(324) Cf. MENEZES, Ludovico de - Ministério de Agricultura. Sua organização. O Século, de 5 de Maio de 1918, p. I; O Governo e a Associação da Agricultura. Boletim da Associoção Central da Agricultura Portugueso. Lisboa, 19 (1) Janeiro 1918, p. 2; CIDRAIS,António - O Ministério da Agricultura. Boletim da Associação Central da Agricultura Portuguesa, Lisboa, 19 (3) Março de 1918. p. 81. 
O sr. presidente da Republica disse que era com muito agrado que acabava de ouvir ler a mensagem da lavoura portugueza, não recebendo, porém, o agradecimento que faziam ao governo, visto a sua obra representar apenas um ato de justiça.

Ha muito tempo que a agricultura é considerada a base da nossa economia nacional e um importante esteio em que deve fundar-se o desenvolvimento do paiz. Era, portanto, necessario, mais que em qualquer outra nação, crear-se em Portugal o ministerio exclusivamente da agricultura.

Todos, n'uma vontade unica, dentro da sua esfera de ação e respeitando os legitimos interesses das classes em geral, devem trabalhar para tornar grande e forte 0 nosso paiz.

Por muito que os politicos procurem desvirtuar as intenções puras do movimento de 5 de dezembro, o governo ha de mostrar servir bem a sua Patria que eles tão mal serviram.

A mensagem que the entregam é a confirmação de quanta injustiça se fazia. Emquanto for vivo, hade pugnar pelas liberdades das classes e pela liberdade do povo. ${ }^{(325)}$

Nesse mesmo dia, à noite, foi a vez da Associação Central da Agricultura Portuguesa organizar e oferecer um banquete de homenagem, no salão nobre do Teatro de S. Carlos, ao seu ilustre sócio, destacado dirigente e titular da «pasta», congregando em seu redor cento e oitenta convivas. Nos lugares de honra, além do homenageado estavam o sr. Oliveira Soares, Presidente da Assembleia Geral da dita Associação e, à esquerda deste, o conhecido republicano e proprietário ribatejano José Relvas, que na sua intervenção saudou o primeiro ministro da agricultura portugueza, dizendo que a lavoura, sendo uma das maiores forças nacionaes, deve prestar todo o seu apoio de solidariedade á obra nacional que se pretende realisar em beneficio do paiz, para que se possa dizer de futuro que se fez bem a muita gente sem se fazer mal a ninguem. (326) No fim dos discursos foram levantados vivas entusiasticos ao sr. dr. Sidonio Paes, á Republica, ao sr. dr. Fernandes de Oliveira, á Pátria, á lavoura, etc..

\section{Política de fomento industrial e comercial}

Diverso era o ânimo das classes industrial e comercial, favorecidas, sem dúvida, pela especulação decorrente da situação internacional de guerra, mas atacadas - em especial os comerciantes - pela circunstância ofensiva da sua fortuna proceder directamente da miséria popular. Uma ambivalência projectada nas políticas estatais e, em particular, na linguagem atrás exemplificada do Ministro das Subsistências contra os açambarcadores e traduzida depois em «actos espectaculares» do Chefe dos Serviços de Subsistências, capitão Bernardino Ferreira, e do Inspector Geral da Fiscalização, alferes Jorge Botelho

(325) Cf. Lavoura nacional. Os seus representantes significam ao chefe do Estado grande reconhecimento pela organização do ministerio da agricultura. O Seculo, de 9 de Abril de 1918, p. 1.

(326) Cf. Ministro da Agricultura. O banquete em sua honra oferecido pela Associação Central de Agricultura Portugueza. O Seculo de 9 de Abril de 1918, p. 1. 
Moniz, em meados de 1918, com as suas famosas rusgas e prisões para gáudio e aplauso notório das camadas urbanas esfomeadas. (327)

Perante os fortes condicionalismos externos, reforçados inevitavelmente pelas debilidades estruturais internas, a crescente vocação intervencionista do Estado não encontrou no sector secundário grande campo de manobra. Com efeito, a actuação do sidonismo na indústria é condicionada principalmente pela conjuntura internacional, não havendo tempo de se criar uma política de fundo e de se consolidar uma aliança de classes que a permitisse materializar ${ }^{(328)}$ e a excepção a esta tendência geral concentrou-se nas indústrias mais directamente ligadas à agricultura e viradas para o mercado interno, aproveitando naturalmente a política de fomento agrícola.

A título de exemplo pode apontar-se o caso da indústria corticeira, em crise pela falta de transportes, mas que recebeu facilidades de créditos, de transporte e de armazenagem, assim como a isenção de direitos para a importação de máquinas e prémios diversos; o caso da moagem e dos adubos, beneficiados com significativos aumentos de preços para compensar, relativamente à indústria química, a política de proibição de exportações e facilidades na importação;(329) o caso da pretendida montagem da indústria do ferro; ${ }^{(330)}$ e ainda o pertinente estudo da utilisação das quedas de agua do rio Douro. Sobre esse assunto merece especial destaque o empenho que o Ministro de Portugal em Madrid, Egas Moniz, Ihe votou após saber que o Conselho de Ministros se ocupou do estudo do aproveitamento das quedas de agua do Douro e Tejo, tendo sido publicado, no Diário do Governo de 12 de Março, o decreto n. ${ }^{\circ} 3.915$ que criava junto da Direcção da Hidráulica Agrícola do Ministério do Comércio um serviço temporário de estudos hidráulicos, com o objectivo do reconhecimento dos nossos rios por meio do levantamento da planta das zonas inundadas e do perfil do thalweg, devendo preferir-se os que maior interesse ofereçam sob os pontos de vista da utilização da energia das suas correntes, do aproveitamento das suas águas para a irrigação, e da melhoria das suas condições de navigabilidade, quando a permitam. Congratulou-se muito com o facto e dispôs-se a envidar todos os seus esforços no sentido de ajudar a aproveitar a boa orientação e excelente disposição que a tal respeito ha, neste momento, em Hespanha. (331)

Casos avulsos que não chegaram a integrar uma política consistente para o sector, desde logo repartida e partilhada pelas «pastas» do Comércio, doTrabalho e das Finanças e de que só restam umas escassas peças incipientes. A mais significativa, em termos de planeamento a médio e longo prazo, foi, talvez, o decreto n. ${ }^{\circ} 3.774$ de 19 de Janeiro,

(327) Ver PERES, Damião - História de Portugal. Suplemento, ob. cit., p. 193.

(328) TELO,António José - A Busca frustrada do desenvolvimento, in REIS,António - Portugal contemporáneo, vol. 3, ob. cit., p. 149.

(329) Cf.TELO,António José - O Sidonismo e o movimento operário português, ob. cit., p. 169 e A.P.S.P. - SubSistema Presidência da República, dossier [Fornecimento de Adubos até final de 1918].

(330) Dossier Alvitres, ofício de Fortunato Passos, São Paulo, 8 de maio de 1918. (Arquivo de Sidónio Pais - Militar, Lente e Político, Subsistema Presidência da República).

(331) Dossier Cartas de Egas Moniz, duas Is., 11-3-1918. (Arquivo de Sidónio Pais - Militar, Lente e Político, Subsistema Presidência da República); e Dossier 7 Quedas d'Agua e Questão d'Aguos, Relatorio..., 4 fls. papel timbrado da Legação da República Portuguesa em Madrid. (Arquivo de Sidónio Pais - Militar, Lente e Político, Subsistema Presidência da República). 
publicado pelo Ministério do Trabalho e que ordenava fossem recolhidas todas as informações estatísticas e esclarecimentos complementares sobre a instalação material de todos os estabelecimentos e instituições industriais, do pessoal que empregavam e das suas condições da exploração ou do exercício da indústria. No entanto, a instabilidade política do momento e dos anos seguintes não era muito favorável a projectos de certo

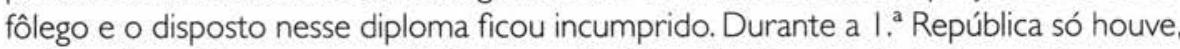
pois, um inquérito, pronto e utilizável — o da Direcção Geral do Trabalho publicado em 1917. Cruzando os seus dados com os do Relatório da Associação Industrial Portuguesa e outras fontes adicionais, Vasco Pulido Valente esboçou os contornos da crise industrial portuguesa particularmente aguda no final do quadriénio de guerra total.

Na prática, Portugal não beneficiou da expansão industrial propiciada pela diminuição da concorrência nos mercados internacionais e da sua quase eliminação nos mercados internos: a dificuldade de transportes reduziu o comércio externo a uma expressão mínima e de 1915 a 1919 o país ficou isolado. Neste contexto, se é certo que as indústrias próprias pouco puderam exportar, ficando cingidas ao fraco consumo nacional, um pequeno punhado delas sempre conseguiu atingir razoável prosperidade, sobretudo, por falta de competição. Mas, em contrapartida, as chamadas indústrias dependentes, muito carecidas de matérias-primas e de combustíveis, foram condenadas a uma difícil sobrevivência. $\bigcirc$ Governo ainda abasteceu com carácter prioritário os segmentos metalúrgicos e químico, beneficiados, assim, pela situação geral. Fora as excepções, concluiu o autor citado os anos de guerra não passam de uma longa crise, que atinge o ponto máximo em 1917 e 1918 (332)

Perante tamanha crise, a governação dezembrista/sidonista só não ficou de todo impotente porque assumiu a um papel rotineiro de regulamentação e de regularização administrativa, vertida nas páginas do Diário do Governo, e de que podemos dar alguns exemplos colhidos, para o primeiro semestre de 1918, nas áreas orgânico-funcionais do Comércio e do Trabalho: o decreto n. 3.734 de 2 de Janeiro definiu o que se devia considerar novo processo industrial e promulgou várias disposições sobre a concessão das respectivas patentes; o n. ${ }^{\circ} 4.036$ de 28 de Março aprovou o regulamento para o emprego de betão armado; e a portaria n. ${ }^{\circ}$ I.319 esclareceu a significação do n. 3 do artigo $4 .^{\circ}$ da lei . $^{\circ} 296$ reguladora do tempo de trabalho diário nos estabelecimentos industriais.

Mas maior determinação e eficácia foi revelada, segundo os dados disponíveis, na repressão da luta sindical, saldada numa expressiva baixa do número global de greves em analogia com os anos anteriores e seguintes. A partir de meados de 1918 a agitação operária mesclou-se bastante com o alarmismo provocado pela vaga da revolução social e do bolchevismo, o que, se ainda lhe adicionarmos o cerco dos republicanos históricos, explica, em larga medida, o reconhecido aparato repressivo das forças militares e policiais às ordens do Governo sidonista e das suas autoridades administrativas.

(332) Cf.VALENTE,Vasco Pulido - VALENTE,Vasco Pulido - Estudos sobre Sidónio Pais: Agricultura e proletariado agrícola; indústria e sindicatos; comércio externo, in Idem - Estudos sobre a crise nacional, ob. cit., p. 268. 


\section{Politica financeira}

No plano financeiro, o Governo ditatorial nomeado pela Junta Revolucionária herdou e manteve, por um lado, os compromissos de financiamento externo acordados por Afonso Costa com a Inglaterra e, por outro, assinou um novo contrato com o Banco de Portugal, considerado de carácter excepcional, mas mantido em vigor até ao fim da l. ${ }^{\text {a }}$ República, pelo qual os empréstimos anteriores eram unificados num único de 150.000 contos até 1919, seguido de mais 60.000 contos por cada ano de guerra, não podendo, porém, a conta corrente do Estado exceder 20.000 contos. O crédito seria garantido por títulos de dívida fundada com juros de $1 \%$, quando o juro normal andava pelos $5,5 \%$, - que significava que a partir de então o aumento da circulação fiduciária para cobrir dívidas do Estado deixava de ter relação com as reservas metálicas do Banco, passando a depender apenas da eventual moderação governamental. Em contrapartida, o Banco de Portugal era beneficiado com uma maior liberdade nas operações, a manutenção das reservas em títulos pagáveis em ouro no estrangeiro e o aumento da participação nos lucros próprios em detrimento do Estado.

Estas novas facilidades de crédito interno foram empregues de forma liberal pela Administração, subindo a dívida flutuante de 210.535 contos em 1917 para 311.166 contos em 1918; e a circulação fiduciária saltou dos 193.131 contos para os 273.834 contos, destinando-se o aumento de $41 \%$ na íntegra a cobrir o crescimento da dívida fundada do Estado pelo novo contrato. Para compensar esta debilidade contribuiu a ligeira valorização do escudo - a libra de $7 \$ 93$ em 1917 passou para os $7 \$ 12$ em 1918 - devida, essencialmente, à continuação do financiamento externo, às melhorias verificadas na balança comercial e a um certo acréscimo da confiança política que refreou a fuga de capitais. ${ }^{(333)}$

Segundo Oliveira Marques, com a política severa e austera de manejo dos dinheiros públicos, advogada por Afonso Costa, o orçamento para 1913-19/4 reduziu as despesas em mais de 1500000 libras: $€ 14161$ 000. Esta tendência para a redução manteve-se até 1917-1918, quando o derradeiro orçamento daquele político registou apenas 11633 milhares de libras-ouro. $O$ golpe dezembrista, o deficiente manejo da coisa pública, a vontade de multiplicar reformas e outras razões ainda fizeram aumentar as despesas nas propostas orçamentais de 1918-1919 e 1919-1920.(334) Um aumento inegável explicado pelo Secretário de Estado interino, Joaquim Mendes do Amaral, no relatório que entregou, em Junho, ao Presidente da República sobre o estado da economia e das finanças do país:

(333) TELO,António José - A Busca frustrada do desenvolvimento, in REIS, António - Portugal contemporaneo, vol. 3, ob. cit., p. 148.

(334) CF.MARQUES,A.H. de Oliveira - Portugal da monarquia para a república, in SERRÃO, Joel e MARQUES, A. H. de Oliveira (dir.) - Nova história Portugal, vol. I I, ob. cit., p. 243. Confrontar estes dados com quadros das Contos públicas in MATA, Eugénia e VALÉRIO, Nuno - História económico de Portugal, ob. cit., p. 262-274. E ver ainda SILVA, Armando Barreiros Malheiro da - Sidónio e sidonismo. História e mito, dissert. cit., vol. 2, p. 197. 
Quanto á situação financeira do Paiz veio este Governo encontra-la num estado verdadeiramente deploravel. É triste constata-lo mas é forçoso dizê-lo.

É evidente que ainda mesmo que Portugal não tivesse tomado uma participação efectiva na guerra europeia não deixariamos de sentir a inevitavel perturbação no equilibrio ja bastante instavel das nossas finanças. O que ja não se pode declarar tão evidente é que o Paiz não tivesse imediatamente beneficiado de uma maneira relativa da sua entrada na guerra e que sobre isso lhe tivessem faltado com um plano financeiro de guerra que logo desde o principio se impunha que fosse estabelecido e cumprido com todo o rigor que as circunstancias permitissem. E porque assim se não fez tem o Paiz que constatar hoje que em materia de finanças se verificou apenas desde o começo da guerra um efectivo aumento das despesas publicas como egualmente se verificaria uma efetiva diminuição das receitas se não fossem algumas medidas ja decretadas por este Governo.

As despezas geraes do Estado tanto ordinarias como extraordinarias tiveram no ano economico findo um enorme agravamento proveniente não só do aumento do vencimento aos funcionarios publicos, exigido pela crescente carestia da vida mas ainda o que proveio do alargamento e intensificação de varios serviços.

Com respeito ás receitas publicas facil se torna compreender que tendo diminuido enormemente o trafego internacional maritimo e terrestre enormemente baixou a cifra das receitas alfandegarias. É certo porem que tendo-se intensificado consideravelmente a actividade comercial e industrial do paiz de algum modo se avolumou a massa tributada, e assim aumentaram os réditos provenientes dos impostos directos, de registo e de sêllo sem ter havido alteração nas taxas dos primeiros e apenas com o aumento muito recente de $50 \%$ nos segundos.

As propostas financeiras que o Governo apresentará ao Parlamento propondo-se modificar a atual situação não podem evidentemente distanciar-se das normas seguidas hoje por todos os paizes em Guerra.

Dum modo geral pode afirmar-se que não sendo suficiente para fazer face aos encargos crescentes da administração publica o aumento de receita proveniente do crescimento da massa global tributavel se torna indispensavel a alteração de algumas das taxas das diferentes contribuições e impostos porque incontestavelmente as que hoje vigoram estão em manifesta desproporção com as percentagens de lucro auferidas pelo comercio e pela maior parte das industrias e ainda pela valorisação da propriedade. ${ }^{(335)}$

Bases genéricas de uma orientação que se reflectirá, de imediato, na aprovação da proposta de Orçamento Geral das receitas e despesas do Estado para o ano de 1918-1919, publicada sob a forma de decreto n. ${ }^{\circ} 4.661$ de 11 de Julho, e ainda em duas medidas controversas sobre os cambiais e os lucros de guerra, explicadas mais adiante.

(335) Dossier S. E. Finanças, Relatório de Joaquim Mendes do Amaral. (Arquivo de Sidónio Pais - Militar, Lente e Político, Subsistema Presidência da República). 


\section{Política instructo-educativa}

A rematar esta panorâmica da governação ditatorial desenvolvida até à fase de legitimação eleitoral, impõe-se, por fim, notar que a muito discreta obra legislativa das «pastas» da Marinha e dos Negócios Estrangeiros contrasta, por exemplo, com a das Colónias, desenvolvida e continuada, a partir de 15 de Maio, por Alexandre Botelho de Vasconcelos e Sá dentro, porém, da mesma linha reformista. Uma linha análoga, afinal, à traçada pelos Ministérios da Agricultura e da Instrução Pública, cujos titulares protagonizaram, nesses cargos, uma rara continuidade governativa.

No relatório de 6 de Fevereiro, enviado pelo Chefe de Gabinete do Ministro, Fidelino de Figueiredo, para o Presidente do Ministério e da República, em cumprimento do ofício deste de 23 de Dezembro de 1917, sobre o estado dos serviços do Ministério da Instrução Pública, deparamos quer com uma sugestiva descrição das precárias condições físicas e técnico-burocráticas em que esse organismo da Administração funcionava — longe de ser a excepção, era antes a regra geral - quer com um apanhado das iniciativas da Comissão de Propaganda de Portugal no Estrangeiro e do Esforço Militar Português, que funcionava na intimidade do gabinete do ministro e sobre a qual pendiam suspeitas de compadrio e de malbaratamento dos dinheiros públicos.

No que concerne às condições operacionais do Ministério até então existentes, os termos empregues são por demais impressivos:

O Ministerio funciona nalgumas dependências do Ministério do Interior, sem acomodações para os vários serviços. Em cada repartição as secretárias, os processos e mais papelada atropelam-se confusamente, por falta de espaço e porque mesmo essa exígua instalação é tão extravagante - corredores, escadas, cubículos e desvãos e um grande salão - que gera a confusão. $O$ gabinete do secretario geral é no último andar, mas a secretaria geral, de que êle é o chefe, funciona no andar nobre, no salão, em algumas pequenas mezas que gravitam em torno da mesa grande do Conselho Superior de Instrução Pública. É nesta meza que trabalha o Conselho, em meio de empregados que trabalham ouvindo o matraquear da máquina de escrever e apenas separado do recanto dos secretários por um biombo baixo. Não pode, pois, haver nas sessões do Conselho Superior de Instrução Pública, ordem e tranquilidade e menos ainda discrição e confiança para tratar matérias confidenciais, porque toda a gente ouve o que se trata nelas. Não ha uma sala, um pequeno espaço para a biblioteca do Ministerio. Havendo sido dispersa, por ordem do $1 .^{\circ}$ Ministro da Instrução, da Republica, a biblioteca do Conselho Superior de Instrução Pública - que naturalmente deveria constituir o núcleo inicial da futura biblioteca do novo Ministério, nucleo já importante pois continha muitos milhares de volumes - póde dizer-se que ainda hoje se está creando uma livraria e esta pequena livraria está arrumada numa parede da Repartição de Sanidade Escolar, que a cede por favor, porque para ela mesma é a casa insuficiente. Não ha nas repartições pedagógicas e secções pedagogicas livrarias privativas, sequer quaesquer livros de informação especial sobre educação e - ensino nos vários países. As repartições, ordinariamente, escassa iniciativa técnica tomam; limitam-se á burocracia administrativa. 
Os corredores foram aproveitados para arquivo e escusado é dizer que tanto este extranho arquivo disseminado pelos corredores como o do sotão estão longe de serem modelares.

As observações iniciais do mau funcionamento do Ministério recomendavam a substituição dos Chefes de Repartição, com vista a uma profunda alteração de condutas e de resultados práticos:

Desta primeira observação nasceu-nos o convencimento de ser útil substituir os chefes das repartições de comissão; para os substituir escolhemos pessoas de perfeita idoneidade moral e intelectual, bem identificadas com os nossos propósitos.

Esses novos chefes, de posse dos seus serviços ha poucos dias, ainda não poderam inteirar-se miudamente do funcionamento das suas repartições, mas já nos transmitiram algumas impressões.

O Chefe da $1{ }^{\circ}$ Repartição de Instrução Primaria, que é uma repartição pedagogica, verifica que ali nunca se fez pedagogia, chegando-se a deixar esquecidos os proprios relatorios dos Inspectores escolares e directores das Escolas Normais e a não as exigir a quem deixava de os remeter, como Ihes cumpria.A parte burocrática não the merece reparos.

As informações do Chefe da Repartição de Instrução Secundária reproduzimo-las integralmente:

(...) a) Que os serviços desta repartição decorriam tumultuariamente, o que se verifica pelo extraordinario atrazo e desorganisação, em que se encontram, quer pelo que respeita ao serviço do cadastro quer aos restantes serviços. Isto mesmo é confirmado pela numerosa correspondencia solicitando resolução imediata de assuntos pendentes ha muito, e para que haviam sido enviadas segundas e terceiras vias havendo até processos, em que faltam elementos, alguns dos quais importantes, tais como reclamações, notas de serviços, etc.

(...) É uma certeza já averiguada que para a Repartição de Instrução Secundaria havia liceus enteados e liceus apadrinhados e que os processos corriam velozes ou emperravam conforme a situação politica dos pretendentes. Da mesma lei se extraíam interpretações diversas, nomeadamente da lei que regula as transferencias dos professores, nem sempre aplicada e quando aplicada, interpretada diversamente. Os atrazos dos serviços nesta repartição da instrução secundaria tem acarretado importantes prejuizos materiais a professores, de que todos se queixam a cada momento num côro de protestos que impressiona. Como se póde exigir a um professor serenidade e bom humor; indispensaveis ao exercicio do seu mistér? Seria interessante e tristemente elucidativo narrar alguns casos das aventuras e vexações e prejuizos determinados pela exigencia dum atestado de fé republicana provada «por actos e factos».

A Inspecção das Escolas Moveis, como organismo predominante politico na origem e no funcionamento deverá ser objecto da especial atenção dos suplicantes, se tal sindicancia houver de ser ordenada. ${ }^{(336)}$

(336) Dossier S.E. Instrução, [Relatório do Ministro da Instrução Pública, Alfredo de Magalhães, 2-2-1918], 16 fls. dactiloscritas em papel timbrado do Gabinete do Ministro. (Arquivo de Sidónio Pais - Militar, Lente e Político, Subsistema Presidência da República). 
Se estes extractos não pecarem por exagero, constata-se a frívola incoerência e inépcia da elite republicana, lançada em sinceras e entusiásticas campanhas reformistas, nomeadamente no estratégico e acarinhado sector instructo-educativo, dotado de Ministério próprio desde 1913 (saído do Interior), mas descurando com frequência a exequibilidade prática das mesmas. Afinal, a deficiente e obsoleta logística burocrática e humana da Instrução Pública herdada de um passado tão ásperamente criticado pelos propagandistas republicanos mantinha-se, em 1917, intacta!...

Em plena fase pós-revolucionária, fortemente partidarizada, a que sucedeu a eufórica aposta política da participação na Grande Guerra, não surpreendem os favoritismos detectados, nem a irregular actuação da Comissão de Propaganda de Portugal na Guerra. É, no entanto, muito curioso e por demais significativo, relativamente à caracterização do perfil mental dos republicanos portugueses, que tenha sido um histórico, figura comprometida com os anos de luta anti-dinástica do P.R.P., do respectivo ideário e inicialmente próxima de Afonso Costa, a subscrever, na qualidade de novo Ministro, a denúncia severa de uma obra governativa alegadamente medíocre e de uma conduta político-partidária reprovável tal qual a estilizou o seu jovem, talentoso e conservador Chefe de Gabinete. E mais curiosas e interessantes são ainda, sem dúvida, as palavras iniciais de um outro relatório, este àcerca da actividade do Ministério desde II de Dezembro de 1917 a 15 de Julho de 1918 :

Nas ideas geraes, que nortearam a revolução de 5 de Dezembro estava implicito tambem certo pensamento sobre materia de educação e ensino; havia que apagar da organisação do Ministerio da Instrução e do proprio funcionamento dos varios graus e serviços da educação publica os cunhos fundos do processo de administração a que o movimento de Dezembro veiu pôr termo. O ministerio, longe de fomentar, proteger e honrar a cultura do espirito, d'ela se havia desinteressado, limitando-se á simples administração burocratica, que raramente exerceu com isenta imparcialidade; não era um organismo creado para os professores e homens de estudo, mas uma entidade creada fóra deles e contra eles. ${ }^{(337)}$

Descontados os excessos de auto-elogio e de indisfarçável imodéstia, típicos das elites intelectual e política da conjuntura em foco, temos de reconhecer que Alfredo de Magalhães e Fidelino de Figueiredo, seu íntimo colaborador, agiram animados por um ambicioso projecto de reformas, tanto no plano educativo como no plano cultural e artístico, com destaque aí para o importante pacote legislativo sobre Bibliotecas e Arquivos ou ainda o decreto n..$^{\circ} 4.114$ de 17 de Abril, que envolveu em parceria o Ministério da Justiça e regulou a criação da propriedade intelectual, designadamente a literária.

Seguindo de perto o teor do segundo relatório, parece-nos oportuno realçar os pontos altos do programa de acção aí enunciado.

(337) Dossier S. E. Instrução, Relatorio do Ministerio da Instrução Pública ( I I de Dezembro de 1917-15 de Julho de 1918) por Alfredo de Magalhães. (Arquivo de Sidónio Pais - Militar, Lente e Político, Subsistema Presidência da República). 
A revisão geral de todos os ramos e serviços do ensino público constituiu um irresistível desiderato para a nova equipa ministerial, temperado, porém, por uma acentuada dose de realismo, que permitiu escolher comissões especializadas de competencias ilustres dotadas da máxima eficácia e evitar, assim, a velha idea de reformar radicalmente, processo perigoso que tem sempre os graves inconvenientes de quebrar as tradições, de desaproveitar o treino e a experiencia, e de criar um periodo transitorio fundamente perturbador. ${ }^{(338)}$ Do trabalho dessas comissões resultaram novas bases de uma reforma global do sistema: A organisação tecnica e administrativa do ensino universitario, secundario masculino, do secundario feminino, do tecnico comercial e industrial e comercial, do agricola, do primario, do artistico, do dentario, das bibliotecas e arquivos, e da educação popular, foi nitidamente delineada sobre bases novas, sem estreitesas economicas que a não tornassem esteril, sem excessivas prodigalidades que a tornassem utopica, antes sempre com plena consideração das possibilidades do tesouro. (339) A reforma, delineada, tal como a do Governo Provisório, e concebida em fecunda ditadura, foi sujeita a um plano de execução prática sempre de acordo com o Chefe do Estado, iniciado pelo ensino universitário e que teve no respectivo estatuto, contido no decreto n. ${ }^{\circ} 4.554$ de 6 de Julho, uma decisiva pedra de toque. (340) No ensino secundário público e particular, considerado o grau da maior importancia porque abrange o mais longo curriculo escolar e porque tem um objectivo de formação psicologica que o póde tornar poderósamente influente ou lamentavelmente deleterio e visto tratar-se do único grau de ensino público que a República ainda não tinha reformado, à parte o episódico regulamento n. ${ }^{\circ} 3.091$, estavam previstas e em curso profundas modificações. ${ }^{(341)}$

Quanto ao ensino primário, o Ministro confessou-se inspirado por um ambicioso projecto em que predominava a orientação de executar a reforma inteligente de 1911 . mas não poude realizar mais do que a aspiração anciósamente urgente de toda a classe do professorado, a sua centralisação, o regresso á directa administração do Estado, e a efectivação da lei do ensino normal, e a transformação das antigas escolas normaes em escolas primarias superiores, tipo escolar que entre nós pela primeira vez se põe á experiencia. (342) As controversas escolas móveis, acusadas de acção mais política que pedagógica e de descarado controlo partidário pelo P.R.P./P.D., foram suprimidas, subordinando-as á inspecção dos circulos escolares e uniformisando o processo de escolha dos professores, com o das escolas fixas, como mais convinha ao ensino e era aspiração geral dos diplomados das escolas normaes. ${ }^{(343)}$ As inspecções escolares de circunscrição foram restabelecidas sem menor agravamento de despeza.

(338) Dossier S. E. Instrução, Relatorio do Ministerio da Instrução Pública ( I I de Dezembro de 1917-15 de Julho de 1918) , fl. [2]. (Arquivo de Sidónio Pais - Militar, Lente e Político, Subsistema Presidência da República). Sobre a reforma universitária, ver também GOMES, Joaquim Ferreira - A Universidade de Coimbra durante a primeira república (1910-1926), ob. cit., p. 300.

(339) Ibidem, fl. [3].

(340) Ibidem, fl. [3]; Sobre a composição da comissão do ensino universitário ver GOMES, Joaquim Ferreira - A Universidade de Coimbra durante a primeira república (1910-1926), ob. cit., p. 301-308.

(341) Ibidem, fls. [4-5].

(342) Ibidem, fl. [5].

(343) Ibidem, fl. [6]. 
No respeitante aos poderosos organismos auxiliares da educação, do ensino e da investigação cientifica - as bibliotecas e os arquivos - não tardaram a ser implementadas providências várias, nomeadamente nos dois principais estabelecimentos culturais do país - a Biblioteca Nacional e o Arquivo Nacional.

Na elaboração da proposta orçamental para o exercício de 1918-1919 e ao invés do que era habito administrativo corrente, esse orçamento não reduz a despeza, antes a agrava sensivelmente, porque o Ministro deseja cumprir as normas da verdade e exatidão, que a atual situação governativa introduziu na administração, e porque reconhece ser impossivel promover quaesquer progressos no ensino sem transcender os limites estreitos do atual orçamento. ${ }^{(344)} \mathrm{E}$, por último, surge a enumeração condensada de mais algumas iniciativas que completavam o programa reformista do Ministério:

Julga o Ministro que efectivando o restante trabalho das comissões, exceptuando os que respeitam a graus de ensino transferidos a outros Ministerios, Colonial, Tecnico e Agricola, organisando todo um sistema de educação popular, creando museus regionaes, multiplicando as bibliotecas populares e moveis, creando um organismo propulsor da cultura espiritual, a projectada Junta Promotora de Investigações Cientificas, ativando as construções escolares e honrando a atividade intelectual não desperdiçou o curto momento em que ás suas atribuições executivas excepcionalmente acresceram faculdades legislativas e que delineou a feição geral do edificio bem nacional e republicano. ${ }^{(345)}$

Um edifício nacional e republicano projectado com esperança, mas sem garantias nenhumas de concretização prática.

(344) Dossier S. E. Finanças, Relatorio do Ministerio da Instrução Pública (I I de Dezembro de 1917-15 de Julho de 1918), fl. [6]. (Arquivo de Sidónio Pais - Militar, Lente e Político, Subsistema Presidência da República).

(345) Ibidem, fls. [6-7]. A fechar o relatório foi incluída uma exaustiva lista «das providencias legislativas adoptodas pelo Ministerio da Instrução». 



\section{Capítulo 4}

\section{A Legitimação do Poder}

\section{Um certo bonapartismo...}

Sidónio Pais proclamou em Beja, a 17 de Fevereiro, pela primeira vez e no seu habitual estilo geométrico e pragmático, a «sua» Ideia Nova, contraposta claramente ao regimen parlamentar, que tinha dado durante oitenta anos todas as suas provas e elas eram negativas. Concentrado no difícil e pendente problema político, surgiu então, em público, a propor a consensual renovação do regime no singular, ou seja, através de uma nova Ideia (e não de várias idéas novas, processos novos) ${ }^{(346)}$ galvanizadora das energias nacionais,

Para Sidónio, a premente pacificação do país exigia a manutenção firme da ordem pública, e o equilibrio político seria atingível, a curto prazo, no plano político-institucional ou, se se preferir, mexendo nalgumas regras do jogo constitucional — de cima para baixo. Mas pouco depois, numas alocuções do mês de Março, mostrou não descurar o sentido inverso, incitando à necessária formação de um partido, o dos homens de bem para bem servir a Patria. A Ideia Nova conjugava-se desta forma com um partido novo, que logo soou a partido único, ostensivamente utópico...

No topo das prioridades não estava, pois, a definição e o desenvolvimento doutrinário de um programa, mas a remodelação institucional do regime e o ajuste de contas interno entre as facções republicanas. A acidental vitória da força armada em Dezembro de 1917 e as entusiásticas manifestações populares de Janeiro/Fevereiro de 1918 dirigidas ao homem, ao responsável por essa vitória e ao governante que detinha as rédeas do Poder ajudaram a definir uma situação onde se viriam rapidamente a misturar vários ingredientes activos - a forte personalização (culto da personalidade) de um protagonista político, a exclusão de um partido até aí dominante, a ênfase populista e ordeira (Povo e Ordem), o descrédito da actividade político-partidária e a sobrevalorização do interesse nacional. Uma mistura pouco original com nítidos traços bonapartistas, que não tardaram a ser vislumbrados, proclamados à opinião pública, denunciados com subtil intencionalidade ${ }^{(347)}$ e perpetuados pela vulgar expressão consulado sidonista.

(346) Cf. VERDADES, João [pseudónimo de MARTINS,Tito Gonçalves] - Idéas novas, processos novos! Prefácio

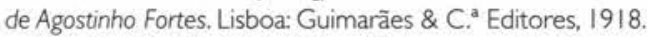

(347) Ver CAMACHO, Brito - É bom recordar. A Lucta, II de Setembro; Grande Mestra. Ibidem, 13 de Setembro; e Um crime. Ibidem, 19 de Setembro de 1918. 
Com as reservas que as analogias históricas ou historicizantes nos merecem, reconhecemos, porém, serem apelativas certas coincidências:

o golpe de estado do general Napoleão Bonaparte, em 1798 (o 18 de Brumário), surgiu, na autorizada leitura de Jean Tulard, com um cariz anti-parlamentar, contra o complot neo-jacobino e para restabelecer a ordem ameaçada por um regime de assembleia (pretexto retomado, mais tarde, por Luís-Napoleão III: Mon nom est le gage du pouvoir fort et stable, de la bonne administration), ${ }^{(348)}$ numa França votada à anarquia, à bancarrota e à dissolução dos costumes;

a origem militar do golpe tornou logo suspeita aos olhos dos jacobinos a emergente ditadura ou consulado de três cônsules, em que o primeiro (Bonaparte) se sobrepôs aos restantes (Roger Ducos e Sieyès), concentrando em suas mãos os mais amplos poderes e atraindo sobre si as duras críticas da esquerda jacobina e da direita monárquica (tirano e déspota para uma, usurpador para a outra);

Bonaparte declarou-se de imediato acima dos partidos, proferindo a frase célebre Ni bonnets rouges, ni talons rouges, je suis national (reforçada pelas palavras de seu irmão Lucien: Le gouvernement ne veut plus, ne connait plus de partis, et ne voit en France que des Français), e recusou constituir um partido próprio, agarrando-se à noção de um governo de salvação pública;(349)

instaurada de maneira ilegítima (golpe militar) e, em breve, repressiva, a ditadura «romana» napoleónica buscou a indispensável legitimidade através do sucesso (saneamento financeiro, reformas administrativas, concordata com a Santa Sé em | 802 e pacificação exterior) e do recurso ao referendo para aprovação de uma nova constituição, embora na prática se tratasse, afinal, de aprovar um homem e daí que o referendo se tenha tornado num plebiscito por sufrágio universal; o plebiscito foi manipulado e fraudulento, sabendo-se hoje que Louis Bonaparte, Ministro do Interior, arredondou os números finais de modo a dar a impressão de um grande élan nacional em torno do Salvador,

o empenho plebiscitário mostrou que Bonaparte percebeu a pertinência da legitimação popular de um Poder conquistado pela força e a fragilidade moderna da ditadura à sombra dos ideais da Revolução Francesa;

a autoridade napoleónica revestiu um cariz carismático qui l'apparente à notre moderne culte de la personnalité, ${ }^{(350)}$ servido por eficazes meios de informação e de propaganda (Napoléon a compris l'importance de la presse alors naissante, pour un dictateur); ${ }^{(351)}$ e a metamorfose da ditadura na fórmula monárquico-imperial, após o segundo casamento de Napoleão com a austríaca Maria Luísa, da familia dos Habsbourg, não lhe assegurou, contudo, o efeito perene da legitimidade hereditária, porque

(348) Cf. TULARD, Jean - Les dictatures de l'époque libérale: Napoleón ler, in Dictatures et légitimité. Paris: P.U.F., 1982, p. 177.

(349) Cf. Ibidem, p. 177.

(350) Cf. Ibidem, p. 184

(351) Cf. Ibidem, p. 185. 
Le régime impérial s'est incarné dans un homme; cet homme abattu, son régime ne peut lui survivre, ou seja, a sua verdadeira legitimidade era do tipo moderno, dependia exclusivamente de si próprio e da vontade popular e nunca do princípio teocrático exercido ao longo dos séculos por uma mesma familia coroada. (352)

Desconhecemos por inteiro se Sidónio Pais alguma vez reconheceu estar a imitar Napoleão I ou se decidiu deliberadamente fazê-lo, porque das suas palavras orais e escritas nada consta sobre essa eventual identificação mimética.Também não sabemos o impacte que essa marcante figura histórica teve no seu imaginário. Limitamo-nos, por isso, a constatar que alguns dos seus actos políticos se assemelham aos do primeiro Bonaparte e ao fenómeno ideológico-político centrado no general Boulanger.

As semelhanças mais óbvias com o bonapartismo(353) são as seguintes:

tal como Bonaparte, Sidónio começou por servir a República e seus notáveis; o desprestígio de alguns deles, a crise do regime e a ideia da Pátria em perigo levaram-no a chefiar um golpe de estado, de que resultou uma Junta de três membros, sendo ele o Presidente;

governou em ditadura temporária até obter a indispensável legitimidade democrática e submeteu a sufrágio universal (presidenciais e legislativas) a solução presidencialista plasmada na sua candidatura sem rivais e configurada na lei eleitoral de 30 de Março, limitadora da função constitucional do novo Congresso; a oposição republicana histórica insurgiu-se contra essa solução e recorreu à abstenção;

e a personalização do cargo presidencial, acompanhada de uma personificação das aspirações de salvação pública, alimentou um processo carismático e hagiográfico vulgarizado pelas expressões Sidónio na lenda ou mito de Sidónio. ${ }^{(354)}$

Em relação ao movimento boulangista, surgido de forma meteórica no tableau político

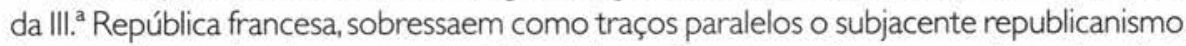
democrático, antiparlamentar e presidencialista, a faceta populista, a vocação nacionalista e suprapartidária do Exército, o apoio táctico dos monárquicos e uma bem sucedida contra-ofensiva dos republicanos parlamentaristas. (355)

Entre Bonaparte e Boulanger situou-se cronológica e politicamente Napoleão III, o príncipe-presidente, que possui, em termos historiográficos, uma curiosa afinidade com Sidónio Pais: o seu regime de cerca de dezoito anos foi definido pelos historiadores

(352) Cf.TULARD, Jean - Les dictatures de l'époque libérale: Napoleón ler, ob. cit., p. 184.

(353) Cf. GONÇALVES, José Pedro - Introdução. In O Presidencialismo português. Textos de Sidónio Pais, Oliveira Salazar, Marcello Caetano e uma introdução. Lisboa: Iniciativas Editoriais, 197I. p. 4.

(354) Numa acepção idêntica de lenda e de mito se posicionou TULARD, Jean com o seu clássico estudo Le Mythe de Napoléon. Paris: Librairie Armand Colin, 1971.

(355) Ver GARRIGUES, Jean - Le Boulangisme. Paris: P.U.F., I992, p. 33-62. 
republicanos como a mais negra das ditaduras e após a II Guerra Mundial, sobretudo na historiografia anglo-saxónica, estabeleceu-se uma tentadora associação entre bonapartismo e fascismo, ${ }^{(356)}$ sendo Napoleão III erguido à categoria de protofascista e de antepassado de Mussolini.

Eleito Presidente da República em 1848, explorou o conflito político com a Assembleia legislativa em torno da preparação de novas eleições gerais previstas para Maio de 1852, de molde a concretizar as suas ambições imperiais, e antecipou-se ao veredicto do sufrágio através do sangrento golpe de estado (militar) de 2 de Dezembro de |85| e da severa repressão que se the seguiu. Envolto em severas críticas e tingido de uma generalizada reprovação moral, o Segundo Império, instaurado formalmente um ano depois e mantido até à derrota de Sedan em 1870, não cabe, segundo Alain Plessis, em classificações redutoras, que ou the acentuam a faceta ditatorial, ou o invertem à maneira revisionista de, por exemplo, um Philippe Vigier (em 1979) - Napoleão III, para este autor, fora l'equisse d'un libéral avancé. A fechar a sua excelente comunicação Napoléon III, un dictateur?. Plessis concluiu que o balanço global do Segundo Império foi, em rigor, largamente positivo para a democracia. Marcado pelo progresso da instrução e pela democratização de uma sociedade rural, liberta, em parte, da influência dos notáveis, o reinado napoleónico traduziu um conseguido esforço para adaptar a vida política francesa à prática regular e natural, embora ainda falsificada, do sufrágio universal, combinado, a partir de 1860, com uma dose crescente de liberdade e até de parlamentarismo: Ainsi a-t-il contribué à l'association de la liberté et de la démocratie politique, deux principes jugés jusque-là incompatibles par la classe politique. (357)

A brevíssima experiência dezembrista/sidonista teve um fim tão precoce e os seus curtos meses de vida decorreram num clima tão excepcional, que ficaremos, certamente, sem saber ou até sem conseguir prever se poderia contribuir, a seu modo, no seu espaço e no seu tempo, para associar de modo positivo a ordem à liberdade e o antiparlamentarismo à democracia, termos, então, antagónicos no pensamento político europeu (ocidental). $\bigcirc$ pouco que é possível descortinar deriva necessariamente do processo de legitimação do regime.

\section{O P.N.R., partido sidonista}

Há que voltar, pois, aos tópicos de partida - as eleições e o partido - para seguirmos e compreendermos o sentido institucional e os fins políticos da tentativa, feita em 1918, de refundar a República. E continuamos a insistir neste aspecto porque, de facto, nas intenções e no discurso dos dezembristas esteve sempre bem patente o sonho de imitar e de superar o 5 de Outubro.

A saída dos unionistas do $15 .^{\circ}$ Governo comprometeu a inevitável realização de eleições - fonte de legitimidade - à luz do sistema representativo fixado pelo quadro constitucional vigente desde 191 | e, por consequência, deixou espaço aberto à ascensão

(356) Para uma súmula actualizada destes conceitos ver RIFF, M. A. - Dictionary of modern political ideologies. Manchester: Manchester University Press, 1987, p. 33-34 e 89-107.

(357) Cf. PLESSIS, Alain - Napoléon III, un dictateur?, in Dictatures et légitimité, ob. cit,, p. 214. 
do recente e pequeno Partido Centrista Republicano. A reforma dos partidos proposta de forma vaga por Sidónio Pais (rascunho atrás transcrito) não significava eliminar o mecanismo partidário da representação democrática, mas apenas limitá-lo pela rígida aplicação do clássico princípio da separação de poderes que o regime presidencialista americano, designado também por constitucional puro republicano, ilustrava desde 1789.(358)

A presença de um Poder Executivo dotado de legitimidade eleitoral própria e autónomo do Legislativo e do Judicial não excluía a existência de partidos, mas sujeitava-a a certas regras, diversas das impostas pelos partidos de tipo clientelar ou de quadros tradicionais, na classificação de Maurice Duverger.(359) Regras mais consentâneas com os chamados partidos de massas, cuja estrutura terá sido inventada pelos partidos socialistas no início do séc. $X X$, transposta sob formas diferentes para os partidos comunistas e fascistas e também imitada por certos partidos conservadores e liberais, que assimilavam, assim, um modelo baseado em adesões directas dos cidadãos anónimos e na criação de clubes ou secções locais destinadas a dar educação cívica às massas populares, tendo em vista o exercício pleno dos seus direitos. ${ }^{(360)}$ O velho P.R.P., enquanto partido frente, seguira, grosso modo, este modelo antes de conquistar o Poder, dando depois origem a três partidos de Governo, na expressão de Sidónio Pais, desejosos de gosar dos favores do Governo. Ora um Governo - acrescentou em tom judicioso - não póde faser favores. Um Governo tem de fazer justiça. Cada cargo que provê, deve ser dado ao mais competente.

A esfera governativa implicava, para Sidónio, um forte impulso moralizador e o concurso individual dos melhores, dos mais capazes (das competências), ficando a esfera legislativa ou parlamentar franqueada à actividade partidária (de aggremiações que as mesmas ideias unem, sem sectarismos, mas com verdadeiro espirito de tolerancia). Em outros testemunhos avulsos do seu pensamento político-institucional, enfatizou ainda a participação de todos — dos homens de bem, das direitas e das esquerdas, da família portuguesa - para bem servir a Pátria e a República. E se, por um lado, incitou à formação de um partido nacional, por outro, sugeriu a todos os cidadãos que se desligassem dos seus partidos para se porem ao lado do Governo.

De um modo muito ambíguo, declarou-se, tal como fizera um século antes Napoleão Bonaparte, acima dos partidos, mas ao mesmo tempo estimulou o aparecimento formal de um partido de apoio ao Governo que permitisse derrotar as oposições em disputa pela maioria na Câmara dos Deputados. Uma notória duplicidade, imposta, é certo, pelo cariz bonapartista da função presidencial, mas negativa para a estabilização e a consolidação do processo político: Sidónio Pais assumiu a legitimidade do Poder Executivo em moldes demasiado pessoais e exclusivistas que irremediavelmente o afastaram da legitimidade partidária, ou seja, da delicada trajectória do Partido Nacional Republicano, entregue a uma liderança fraca (Egas Moniz acumulou funções de líder

(358) Ver BERNSTEIN, Richard B., RICE, Kym S. - Are we to be a nation? The Making of the constitution. Cambridge/London: Harvard University Press, 1987; e LACORNE, Denis - L'Invention de la république. Le Modèle américain. Paris: Hachette, 1991.

(359) Cf. DUVERGER, Maurice - Os Grandes sistemas políticos. I - Instituições políticas e direito constitucional. Coimbra: Livraria Almedina, 1985, p. 73.

(360) Cf. Ibidem, p. 74. 
partidário e de Ministro Plenipotenciário em Madrid), (361) incapaz, por isso, de unir e de dinamizar a respectiva rede sócio-política de apoio, bem como de gerir o desafio da metamorfose de partido de Governo em partido frente, partido de massas ou partido nacional, dominante mas não único. Um partido das direitas concorrente com as esquerdas, pois quer Egas Moniz, quer o próprio Sidónio, pareciam pender para um sistema partidário competitivo, ${ }^{(362)}$ embora claudicassem ambos na sua concretização: 0 lente médico acudiu às crises mais como estadista (em cargos oficiais) do que como líder partidário à altura de um genuíno partido de massas e o lente matemático enleou-se no processo carismático, substituindo-se à função aglutinadora e mobilizadora do partido governamental, expondo-se perigosamente...

Orápido fracasso do P.N.R., unanimemente reconhecido, derivou, em grande medida, da sua génese e evolução imediata. Ele não foi um partido novo (e inovador), mas a mera continuação de um recentíssimo e débil partido existente, herdando-lhe tudo e acrescentando-lhe quase nada. Com efeito, do centrismo, já atrás oportunamente focado, herdou o programa, a estrutura e os filiados.

Em I de Abril, logo após a publicação da lei eleitoral de 30 de Março, a directoria do Grémio 8 de Dezembro reuniu, presidido pelo dr. Roberto Mendes de Carvalho, secretariado por Domingos da Cunha Barbosa e Damião Marques Moura e estando presentes os srs. Barbosa de Melo, Germano Aires de Carvalho e Francisco Alves Ferreira, para se pronunciar sobre uma pertinente moção - Esclarecida nitidamente a questão política - inspirada na posição que os órgãos centrais do Partido Centrista se dispunham a assumir. ${ }^{(363)}$

Cerrar fileiras em torno do Governo, reafirmando o seu impoluto republicanismo, era não só a exigência fulcral do momento político, mas também essencial à fusão partidária em curso. E em 6 de Abril reunia o Grémio Centrista de Lisboa numa espécie de assembleia magna do P.C.R., representado pelas suas Comissões Central, Organizadora e Política, Presidentes das Comissões Paroquiais de Lisboa e delegados dos Centros de Lisboa e Porto, delegados do partido no Norte, etc.. Sob a presidência de Egas Moniz, secretariado pelos drs. João Paula Ramos, do Grémio do Porto, e Justino de Campos, Presidente da Comissão Municipal Centrista de Lisboa, começaram os trabalhos, tendo o líder, no seu discurso de abertura, colocado o P.C.R. ao serviço da causa séria e patriotica do Governo republicano do sr. Sidonio Paes e formulado votos para que os deputados eleitos discutam e aprovem a formula constitucional mais apropriada aos altos interesses do país. Mas no imediato impunha-se, sobretudo, uma resposta cabal e firme aos inimigos do Governo e essa resposta tinha um nome - Partido Nacional Republicano.

A fusão, num só partido, de todos os elementos que apoiavam a aç̧ão e os objectivos do Governo, constituía um facto político da maior importância e significado. E os amigos da situação e da República ao fundirem-se numa só corrente partidária pretendiam

(361) Ver MONIZ, Egas - Um ano de política, ob. cit, p. 87-90.

(362) Cf. LIPSET. Seymour Martin - Consenso e conflito. Ensaios de sociologia política. Lisboa: Gradiva, 1992. p. 166-167.

(363) Ver SILVA, Armando Barreiros Malheiro da - Sidónio e sidonismo. História e mito, dissert. cit., vol. 2 , p. 229 
pôr de lado principios, ideias, e tendencias especiaes, para só pensarem nos principios, nas ideias e nas tendencias que devem orientar todos aqueles que abominando a demagogia, que pretendeu transformar o país numa anxovia do Limoeiro, só tem diante dos olhos o bem comum e os altos interesses da Nação, para os servirem dedicadamente, para fazer com que eles se imponham a todos os interesses particulares, venham eles d'onde vierem, seja quem for que os patrocine. (364) Atitude moral e política, proclamadamente patriótica, animada pelo lema de uma República não para as facções, mas para a Nação inteira e fundada nas mesmas bases programáticas do P.C.R. Não é, pois, exacto afirmar-se que o P.N.R. não teve programa, nem estatutos ou que a sua base doutrinária deve ser procurada nos discursos de Sidónio Pais e na prática ministerial. (365)

Esses discursos eram demasiado pobres e lacónicos para servirem de programa teórico-prático, e a obra do Governo revelou claramente a influência de programas anteriores, nomeadamente do programa centrista. Não hesitamos, por isso, em afirmar que uma parte importante dos tópicos eleitos como prioridades da acção governativa e insistências discursivas da propaganda saíram directamente do património centrista, intrínseco, aliás, à rede sócio-política de apoio a essa experiência político-institucional.

Quanto à estrutura organizativa também não é possível descobrir novidades: basta ler a coluna publicada no Jornal da Tarde, de Março até às vésperas das eleições, para se notar uma mudança quase só de nome, prosseguindo debaixo da nova designação o registo da composição dos Grémios, das Comissões Distritais, Municipais e Paroquais, herdadas e integradas na pretensa nova organização partidária e das sucessivas adesões individuais que, por carta, iam chegando à sede do partido. Temos, assim, um Directório nacional composto por membros efectivos e susbtitutos, predominando nos dois grupos os Ministros e os titulares de altos cargos na Administração. Passou, aliás, por esta característica a substancial diferença entre o P.N.R. e o P.C.R. - aquele era um partido de Governo, anunciado, porém, com fins mais elevados, mais patrióticos e mais aglutinantes, que logo se esfumaram na prática. O legado indelével do rotativismo monárquico, a pequenez do centrismo e a pressa em constituir os corpos directivos e em compor listas para a Câmara dos Deputados e para o Senado levaram à governamentalização imediata de toda a estrutura desde o Directório do partido à representação no Congresso.

O Directório efectivo era constituído por Egas Moniz (Ministro em Madrid), Francisco Xavier Esteves (Ministro das Finanças), Alfredo de Magalhães (Ministro da Instrução), João Tamagnini Barbosa (Ministro das Colónias), Feliciano da Costa (Ministro do TrabaIho), Machado Santos (Ministro das Subsistências), António Miguel de Sousa Fernandes (Governador Civil de Lisboa), Manuel Forbes Bessa (antigo Secretário da Presidência da República) e Alexandre de Vasconcelos e Sá (capitão de mar e guerra). Entre os substitutos deparamos com Fernandes de Oliveira (Ministro da Agricultura), Alberto de Castro Osório (Juíz da Relação de Lisboa), João Pinheiro (advogado), Carlos de Oliveira (comerciante), António Bernardino Ferreira (capitão de Artilharia), Severino

(364) Cf. Politica nova. Joarnal da Tarde, de 8 de Abril de 1918, p. I.

(365) Cf. LEAL, Ernesto Castro - Partidos e grupos políticos na I república, in MEDINA, João - História de Portugal, vol. 10 - A República, ob. cit., p. 305. 
da Silva (médico), António Cidrais (proprietário de Elvas), Zeferino Falcão (Presidente da Câmara Municipal de Lisboa) e Arnaud Furtado (comerciante).

Era, pois, esta a cúpula do P.N.R., que sabemos ter reunido diariamente até finais de Abril num acentuado esforço de complemento organizativo, tanto mais urgente quanto era sabido que o P.C.R., com poucos meses de vida enfrentava dificuldades para se implantar em Lisboa - espaço político privilegiado - sendo minúscula a sua presença na província. Ora, a disputa de eleições contra partidos devidamente posicionados no terreno, em especial o P.R.P./P.D., dotado de uma bem oleada «máquina» eleitoral, não se compadecia com debilidades de logística e de acção. E em estreita articulação com o Directório começaram a funcionar as Comissões distrital e municipal de Lisboa. Aquela era presidida pelo dr. Castro Lopes (Delegado da Procuradoria da República em Lisboa), vice-presidida pelo dr. Francisco dos Santos Rompana (médico), composta pelos vogais Mário de Mesquita (professor), dr. Eduardo Sarmento (advogado), Raul Machado Lopes de Barros (funcionário público e Administrador do Concelho de Almada), Pio Lopes Pinto (oficial da Administração Naval), António José de Abreu Castelo Branco (funcionário público e proprietário), dr. Duarte de Melo Ponces de Carvalho (médico da Armada), Baltazar Alves Diniz (comerciante-tesoureiro) e pelos secretários dr.José Novais Soares de Medeiros (médico da Armada) e João de Deus Azevedo (empregado da Companhia dos Tabacos e proprietário). Na Municipal, formada por doze membros, destacavam-se - Presidente, dr. Justino de Campos (Administrador do 1. Bairro de Lisboa), oVice-Presidente dr. Francisco Alberto de Oliveira (médico) e o Tesoureiro António Salvador Costa (capitalista). Ambas reuniam na sede do partido, que era cumulativamente a base do Gremio Centrista e do Directório, na rua Belver, 3, 1.ªndar.

Através da herança centrista, formada, na origem, por ex-evolucionistas, o P.N.R. assimilou, do ponto de vista formal, o modelo típico do P.R.P. com os seus Grémios cívicos e escolares, as comissões municipais e as paroquiais, empenhadas numa forte mobilização das massas populares. O modelo passou aos partidos republicanos surgidos em 1911 e ao P.C.R., mas as características que mais os aproximavam dos modernos partidos de massas foram bastante esbatidas pela carga burguesa e clientelar (comum aos partidos de quadros ou de notáveis) particularmente vincada, no caso do P.R.P.P.P., com o acesso e a permanência no Poder. Significa isto que, por exemplo, a Comissão Escolar Republicano-Centrista da Graça, a Comissão Política (paroquial) de Campo Grande, o Grémio centrista do Porto ou a Comissão Paroquial de Castro Laboreiro (Melgaço) deviam entregar-se a uma aç̧ão de propaganda e de penetração nos eleitorados locais conforme o estabelecido para a estrutura e objectivos específicos dos grémios centristas das freguesias: fazer propaganda política e cívica e, ao mesmo tempo, instituir e custear, na sede, uma Escola Primária destinada, sobretudo, aos adultos analfabetos. Na prática, porém, este dispositivo propagandístico funcionou mal, reduzindo-se a uma malha de canais de transmissão ao centro político quer das habituais recomendações de ministeriáveis, de candidatos a cargos públicos, etc., quer de pedidos relacionados com os interesses próprios da vida administrativa local. Este aspecto aparece, aliás, bem ilustrado por uma carta de Egas Moniz para Sidónio Pais, com data de 13 de Julho, onde se lê: Só depois de sair do Palacio me lembrei dum pedido que desejava fazer aV. Ex. ${ }^{a}$ e por que muito me interesso, pois importa fundamentalmente á vida regular do gremio do P.N.R. no 
Porto. Desejava que V. Ex. ${ }^{a}$ desse o seu placet ao decreto do sr. Secretario de Estado da Justiça sobre o desdobramento da Conservatoria do Registo Civil do Porto. (366)

Além deste testemunho epistolográfico, conhecemos outros que ajudam a definir, ao de leve, a liderança de Egas Moniz, eivada dos tiques e dos hábitos do clássico chefe de partido e mesclada com as suas funções diplomáticas em Madrid.

Uma carta do monárquico João de Azevedo Coutinho, escrita em Badajoz, a 23 de Março, mostra como os favores e a defesa dos interesses particulares não se cingiam aos correligionários políticos, mas extensivos a amigos pessoais, mesmo que estes fossem antigos emigrados couceiristas. ${ }^{(367)}$ Alguns dias antes, o próprio Egas Moniz escrevera a Sidónio Pais dando-lhe conta de vários assuntos importantes para o país e para as relações luso-espanholas, referindo a dado passo: A crise, com o aumento das duas pastas e a entrada do Machado, parece-me muito bem resolvida. Vejo que decidiram adoptar o sufragio eleitoral universal para as duas eleições, presidencial e legislativa. É um critério, em qualquer caso preferivel á constituição do eleitorado nas condições em que está. (368)

Nessa altura, as suas conhecidas reservas acerca do presidencialismo não existiam, e a forma que tinha de influenciar o Poder para que fossem adoptadas as medidas, em sua opinião, mais convenientes, era através dos amigos postos no Governo e à frente do P.N.R., como foi o caso do dr. João Henriques Pinheiro, arauto retardatário do parlamentarismo nas páginas do Jornal da Tarde, de 23 de Outubro a 8 de Novembro, ou ao redor do Presidente e do contacto directo, por carta, com este. ${ }^{(369)}$

A abertura dos trabalhos parlamentares obrigou Egas Moniz a deixar Madrid e a regressar à política doméstica, submersa, aliás, por uma densa atmosfera conspirativa contra o Governo. Em circunstâncias de crise tornou-se ainda mais imprescindível para Sidónio Pais, a ponto de intervir, por exemplo, activamente, na remodelação de 8 de Outubro: Como lembrança, e para a hipótese de não acederem ao convite de V. Ex. ${ }^{a}$ as pessoas do Porto, tomo a liberdade de recordar a V. Ex. ${ }^{a}$ mais os seguintes nomes: Dr. Jorge Couceiro da Costa, juiz do Tribunal do Comercio do Porto, juiz distinctissimo e antigo partidario, e o do dr. Affonso de Melo que é amigo pessoal de V. Ex. ${ }^{a}$ e poderia mesmo dar um bom ministro do Comercio. O Jorge Couceiro poderia ser convidado pelo telefone. ${ }^{(370)}$

Estes dados avulsos e outros que venham a ser conhecidos ajudarão, certamente, a enquadrar e a desmontar melhor a célebre carta de 9 de Agosto, que Egas Moniz reproduziu integralmente no livro Um ano de politica a partir de cópia fiel do original enviado a Sidónio Pais. Documento, sem dúvida, importante que confirma o mal-estar patente nas hostes situacionistas face à contra-ofensiva da oposição republicana congregada num bloco que o P.N.R., cada vez mais vulnerável ao apoio dos monárquicos e dos católicos, se revelou incapaz de desfazer.É, por isso, muito curioso que nessa carta Egas Moniz tenha escrito o seguinte:

(366) Dossier Cartas de Egas Moniz, carta de 13-7-1918. (Arquivo de Sidónio Pais - Militar, Lente e Político, Subsistema Presidência da República).

(367) Ibidem, carta de João de Azevedo Coutinho para Egas Moniz, 23-3-1918.

(368) Ibidem, carta de 11-3-1918.

(369) Ibidem, dossier 106 Espionagem em Espanha e Subsistências, carta de Egas Moniz de 20-6-1918.

(370) Ibidem, dossier Cartas de Egas Moniz, carta de 8-10-1918. 
Eu nunca cultivei clientelas e detesto o caciquismo. Umas e outro tenho sempre combatido e,já agora, não mudarei de rumo. Quero os partidos formados em programas e tinha-o e foi publicado o do já agora velho partido centrista: mas não concebo que, em egualdade de condições, se prefiram estranhos, por vezes adversários do regime, a correligionários na distribuição de favores.

Tenho a impressão, senhor Presidente, de que ou conseguimos uma vigorosa agremiação partidária que sirva de base ao actual sistema politico ou a situação baqueará a breve trecho. Não ha prestígio que resista á desorganização das forças amigas e estas, sem a acção disciplinadora dum partido, não passa do platonismo dos aplausos que mesmo assim irão pouco a pouco diminuindo.(371)

Deduz-se destas palavras e das que se thes seguem o manifesto desinteresse do Presidente da República pela vida partidária, o que era, em certa medida, exacto e decorria do modo como ele assumira o cargo, e deduz-se também que Egas Moniz pretendia ver o P.N.R. e a respectiva maioria parlamentar perfeitamente sintonizados com o Governo, acusando Sidónio de preferir que o P.N.R. se estiole á falta de estímulo que o desenvolva, ${ }^{(372)}$ como se fosse ele o verdadeiro líder e genuíno dinamizador do partido. Não era obviamente tal e a sua candidatura à Presidência da República surgiu de forma tácita sem concorrentes, sem uma apresentação formal e sem explícitos contornos partidários, embora Sidónio Pais precisasse do compromisso solene dos futuros parlamentares constituintes do P.N.R. para que assegurassem a fórmula presidencialista na nova Constituição!

Palavras e cumplicidades tecidas por uma prática equívoca que disfarça mal o governamentalismo caciquista tão enfaticamente rejeitado por Egas Moniz e contradiz o proclamado apartidarismo da Republica Nova presidencialista, resumido por Quirino de Jesus nas páginas de $O$ Economista Portuguez à luz da vulgata, então conhecida, do constitucionalismo americano e brasileiro: o Congresso legisla, o Presidente executa pelos seus Ministros, o Governo é formado e modificado como o Presidente entender melhor e é, assim, impossivel, salvo com a difficil cumplicidade do Presidente, um partido unico dominar indefinidamente por cima dos restantes, com todos os direitos exclusivistas da maioria parlamentar. $\left({ }^{373)}\right.$

Como se vê, as contradições do projecto político-partidário e político-institucional da República Nova ressaltam dos testemunhos dos seus principais protagonistas e mais evidentes se tornam à medida que vamos confrontando e cerzindo a múltipla e dispersa informação factual existente.

140 Prosseguindo, pois, nesta via e antes de passarmos à análise ligeira do decreto 3.997 de 30 de Março, da campanha eleitoral e dos resultados obtidos, não podemos deixar de lembrar que a lista completa dos candidatos governamentais ao Congresso e dos concorrentes a uma parte dos lugares do Senado (representação partidária por províncias) foi reproduzida na íntegra pelo recém-nascido jornal A Situação. Diário repu-

(371) Cf. MONIZ, Egas - Um ano de politica, ob. cit, p. 145.

(372) Cf. Ibidem, p. 146.

(373) Cf. JESUS, Quirino de - A Republica nova. O Economista Portuguez, art. cit., p. 266. 
blicano da manhã, fundado por iniciativa do próprio Sidónio Pais e dirigido pelo jovem e seu directo colaborador Jorge Botelho Moniz, ${ }^{(374)}$ para conhecimento dos adeptos e muito oportuna lembrança aos eleitores, a quem, aliás, a imprensa pró-governamental recomendava a distribuição das listas com os nomes dos candidatos pelos respectivos círculos eleitorais legalmente fixados. Listas enviadas, nas vésperas do acto eleitoral, a diversos membros da rede sócio-política e das comissões e núcleos do partido em todo - país e aí disponíveis para os potenciais eleitores. ${ }^{(375)}$

Embora, em rigor, desconheçamos como ocorreu a escolha de todos estes candidatos ao Congresso é possível, a partir de alguns casos, advinhar a intervenção directa que nela tiveram, além do Presidente da República, os líderes dos vários núcleos - centrista, machadista e jovens militares - da rede sócio-politica de apoio ao dezembrismo, excluídos, obviamente, os unionistas. Uma carta do irmão António, candidato a senador pelo Algarve, para Sidónio Pais exemplifica, aliás, muito bem a maneira e os critérios de elaboração rápida das listas: Todos os meus me acompanham com a mais viva satisfação nestas felicitações, fazendo nós os mais ardentes votos para que tenhas as maiores felicidades no desempenho do alto cargo que a nação te conferiu. Escrevi ha dias ao Alberto em resposta a uma carta em que ele me dava a noticia de teres incluído o meu nome numa lista de candidatos a senadores. Pelas notícias das eleições que os jornaes trazem já vi que o facto é consumado e que efectivamente fui eleito pelo Algarve que eu muito pouco conheço e onde quasi ninguem me conhece. Mas o que não tem remedio remediado está e eu partirei daqui quando entenderes que é necessário partir, mas se os cargos de senador e de comandante dum caça-minas são incompativeis terei de ser exonerado antes. (376)

Não sabemos se escolhas consumadas como a de António Pais foram a regra, mas parece-nos evidente um padrão ou perfil-tipo sócio-profissional do parlamentar republicano herdado de actos eleitorais anteriores. Com efeito, para deputados e senadores reaparecem-nos os grandes grupos sócio-profissionais com apetência e vocação de Poder: os militares atingem $25 \%$, os advogados $23 \%$, os médicos $16 \%$, os professores $6 \%$, os engenheiros e os magistrados $5 \%$, e os proprietários $6 \%$. Em contraponto a este bloco dominante estão os comerciantes com $3 \%$, os funcionários públicos com $1 \%$ e os contabilistas com $0,7 \%$. A ilustrar o pendor governamentalista temos os $7 \%$ de candidatos que exerciam à data funções de Ministro, mais $3 \%$ de diplomatas e de Governadores Civis, 0,7\% de Presidentes da Câmara e Altos Comissários e 5\% de antigos Deputados, Senadores e Ministros.

Estes dados, ao configurarem o segmento da elite intelectual e burguesa que foi possível recrutar na rede sócio-política de apoio ao dezembrismo para o exercício, em nome da Nação, do Poder Legislativo, permitem-nos, também, ensaiar uma aproximação à base social do P.N.R., a fim de percebermos se a rede sócio-política e a elite parla-

(374) Ver sobre o assunto DUARTE, Teófilo - Sidónio Pais e o seu consulado, ob. cit., p. 326-327; e ainda MEDINA, João - Morte e transfiguração de Sidónio Pais, ob. cit., p. 153-156.

(375) Ver SILVA, Armando Barreiros Malheiro da - Sidónio e sidonismo. História e mito, dissert. cit., vol. 2 , p. 236-242.

(376) Dossier Cartas do Alberto e do António, carta de António da Silva Pais, I-5-19|8. (Arquivo de Sidónio Pais - Militar, Lente e Político, Subsistema Presidência da República). 
mentar do partido estariam socio-profissionalmente identificadas com a sua base de apoio. E o que verificamos, partindo apenas das listas de adesões ao P.C.R. e ao P.N.R., de inícios de Março a finais de Abril (após as eleições deixaram de ser publicadas as filiações no partido), representadas no gráfico junto, é que a percentagem de comerciantes residentes em Lisboa e fora da capital somada à dos empregados comerciais, à dos funcionários públicos, à dos operários e à dos trabalhadores por conta própria (despachantes, banqueiros, alfaiates, sapateiros, artistas plásticos, etc.) revela serem essas as profissões que mais aderentes (com os de Lisboa sempre muito acima dos do Porto e província) forneceram ao partido nesse período. No entanto, estes estratos profissionais não colheram uma representação significativa no Congresso, sendo ultrapassados pelos militares, advogados, médicos, professores, engenheiros, magistrados e proprietários, alguns destes colocados abaixo das profissões dominantes e até dos industriais, dos funcionários de escritório e dos estudantes.

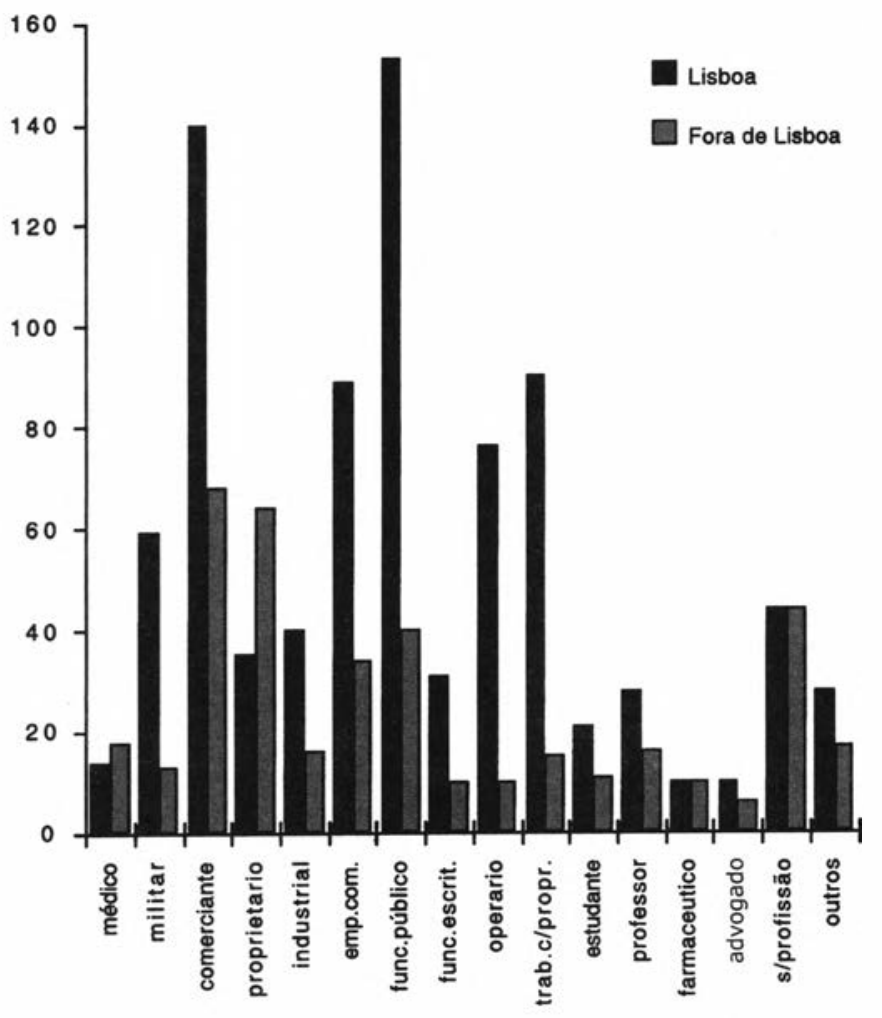

Filiados no Partido Nacional Republicano (P.N.R.)

Uma óbvia razão para a assimetria verificada é a hibridez dos partidos sucedâneos do P.R.P. que deste receberam a vocação frentista, graças à qual penetraram em camadas 
urbanas socialmente mais desfavorecidas e penalizadas, com destaque para as chamadas classes trabalhadoras (do comércio à indústria), e ao mesmo tempo não deixaram de ser partidos de quadros burgueses, mantendo-se, assim, fiéis à matriz liberal, democrática e positivista, postuladora da harmonia do capital com o trabalho. A escolha dos mais capazes para defenderem a Pátria (os militares), dos mais instruídos e educados e dos melhor preparados para esgrimirem a linguagem jurídica do Poder não oferecia dúvidas, nem hesitações e, deste modo, ia sendo negada, por exemplo, aos trabalhadores autodidactas, tão acarinhados pela propaganda republicana, a plena maioridade política demagogicamente prometida.

Convém ainda notar um detalhe muito significativo: a grande adesão de funcionários públicos, beneficiados pelo Governo com o aumento das subvenções fixado no decreto 4.056 de 6 de Abril, denuncia outra velha faceta partidária associada à crise do parlamentarismo - a motivação clientelar tendente a condicionar bastante o sistema de Poder.É, por isso, curiosa a oscilação hesitante e perturbadora - e como tal definida por Egas Moniz na carta, de 9 de Agosto, a Sidónio Pais — entre um caciquismo julgado indispensável na fase do lançamento e da consolidação do partido e uma vincada recusa em ceder à pressão das clientelas. Todavia, esta tendência sobrepôs-se, facilmente, à sua oposta - a anti-clientelar — atrofiando, logo à nascença, a nova aposta partidária e condenando-a a um irremediável desaire...

As observações feitas não esgotam a exploração dos dados disponíveis sobre o P.N.R., mas ajudam a aprofundar um pouco mais o conhecimento que dele podemos ter e do projecto político-institucional subjacente, o qual, segundo circulou pela imprensa, foi vasado numa espécie de plataforma que vinculava os candidatos nacionais republicanos ao presidencialismo à outrance defendido pelo Governo.(377)

\section{Legislação eleitoral}

Um projecto que teve na lei eleitoral de 30 de Março a pedra de toque e, como vimos referindo, o pomo da discórdia não só com os unionistas, mas necessariamente com os outros partidos republicanos, por pretender alterar ditatorialmente a fórmula parlamentarista consagrada na Constituição de 191।.A introdução de matéria constitucional num diploma regulador das eleições e antes dela ser discutida no fórum próprio teve, logo, o efeito de um inaudito atentado à legalidade democrática vigente. Assim o entenderam os unionistas e saíram do $15 .^{\circ}$ Governo em discordância aberta com o Presidente e com os cadetes, os machadistas e os centristas. Estes, pelo contrário, não se opuseram, de início, nem à experimentação do presidencialismo à americana, nem tão pouco ao processo de o instaurar, esforçando-se mesmo por disfarçar ou atenuar a efectiva imposição ditatorial desse figurino minoritário e do sufrágio universal masculino - outro ponto controverso por conferir à ruralidade, considerada pela elite republicana nas mãos de monárquicos e de clericais, um peso eleitoral que vinha limitar o voto urbano, alegadamente mais esclarecido, democrático e progressista.

(377) Cf. Notícias políticas. O Jornal de Notícios, de 18 de Abril de 1918 . 
Em jogo não estavam tanto os princípios, mas os resultados.

A engenharia eleitoral praticada desde o período do rotativismo monárquico até à banalização do abuso e da fraude consistia, afinal, na alavanca indispensável para garantir o acesso e a permanência no Poder - alavanca manobrada pela lei.

A célebre lei eleitoral de 1901 que ficou conhecida pelo sugestivo epíteto de ignóbil porcaria ao dividir o continente e ilhas adjacentes em vinte e seis círculos, correspondendo cada qual a um distrito, salvo Porto, Coimbra, Viseu e Lisboa, divididos em dois, visou claramente afogar os votos urbanos de provável tendência republicana ou ultraliberal nos votos rurais governamentalizáveis. Ao invés, os decretos de 14 de Março e de 5 de Abril de 1911 , já atrás focados, pendiam para um relativo alargamento do sufrágio, concedido a todos os portugueses maiores de 21 anos alfabetizados e chefes de familia há mais de um ano, e uma solução mista (escrutínio de listas de três nomes para eleição de quatro em quase toda a Metrópole, sistema uninominal por maioria relativa nas colónias e método de representação proporcional de Hondt nos círculos de Lisboa e Porto), desenhando, na opinião de Oliveira Marques, um meio-termo na história eleitoral portuguesa, ${ }^{(378)}$ que o código eleitoral de 1913 não tardou a desequilibrar. Esta lei, concebida e promulgada pelos democráticos no contexto histórico-político já atrás esboçado, restringiu o universo de eleitores, excluindo do acto eleitoral vastas massas analfabetas do campo, permeáveis ao controlo dos caciques clericais, monárquicos e conservadores.

Tratou-se, segundo Fernando Farelo Lopes, da instauração da ditadura do P.R.P./P.D., herdeiro de uma dupla estrutura organizativa e clientelar (a republicana e a dos extintos partidos rotativos, em especial o regenerador), ${ }^{(379)}$ envolta na pretensa democraticidade de um parlamentarismo avançado em que o controlo hegemónico de um partido era tido por progressivo e incomparavelmente mais aceitável que o exercício pessoal do Poder Executivo. E se é verdade que no Congresso democrático de Outubro de 1914, na Figueira da Foz, foi preconizada a diminuição dos precários poderes do Presidente da República, bem como a supressão do Senado e subsequente redução do Legislativo a uma só Câmara, e que os acontecimentos de 1915 anularam quaisquer veleidades presidencialistas, João Tello de Magalhães Collaço, na sua conferência Da Vida pública portuguesa publicada em livro em 1926, observou que, paralelamente, se instalara uma profunda crise da Autoridade, a vacancia do Parlamento e a falta de outros elementos permanentes de opinião publica, advindo daí o estímulo para a Presidência da República persistir na busca da Autoridade perdida. ${ }^{(380)}$ Foi, pois, no meio desta crescente tensão que surgiu a lei de II de Janeiro de 1915 elaborada, pelo Governo democrático deVítor

(378) Ver MARQUES, A. H. de Oliveira - Portugal da monarquia para a república, in SERRÃO, Joel e MARQUES, A. H. de Oliveira - Nova história de Portugal, vol. II, ob. cit., p. 417; Idem - História da 1. ${ }^{\circ}$ república portuguesa. As estruturas de base, ob. cit. p. 589-643; e ALMEIDA. Pedro Tavares de - Eleições e caciquismo no Portugal oitocentista (1868-1890), ob. cit., p. 33-96.

(379) Ver LOPES, Fernando Farelo - A I. a república: da «ditadura» democrática à violação das regras do jogo. Risco, Lisboa (1) Primavera 1985, p. 122-126; Idem-Poder político e caciquismo na 1. ${ }^{\circ}$ república portuguesa, ob. cit., p. 35-40.

(380) Cf. COLLAÇO, João Tello de Magalhães - Da vida pública portuguesa. vol. 2 - Conservadores e radicais. Lisboa: Edição do Autor, 1926, p. $102-103$. 
Hugo de Azevedo Coutinho e que foi promulgado o decreto de 24 de Fevereiro, na sequência do Movimento das Espadas e da nomeação do Governo do general Pimenta de Castro com o fim expresso de preparar eleições.

A lei do Governo Azevedo Coutinho diminuiu o número de círculos, ampliando a sua área, eliminou o método proporcional em Lisboa e Porto e quase não mexeu na representação das minorias, o que logo se disse ser um expediente dos afonsistas para assegurarem uma confortável maioria no Congresso. Por seu turno, o decreto do Governo Pimenta de Castro, segundo Farelo Lopes, veio reforçar ainda mais o perceptível impulso centralista: os círculos coincidiam, nas duas eleições (para a Câmara dos Deputados e para o Senado), com os distritos administrativos, à excepção dos de Lisboa e Porto, subdivididos em dois círculos cada; a extensão dos círculos e a perda de autonomia eleitoral dessas duas grandes cidades e principais bastiões democráticos reeditava os objectivos da lei de 1901 (a ignóbil porcaria) e, concretamente, relegava o P.R.P./P.D. para as minorias no Congresso.

A queda do pimentismo alterou, porém, esta perspectiva e o Governo de José de Castro expediu para a folha oficial a lei $n .^{\circ} 314$ de 1 de Junho de 1915, decalcada sobre os princípios metodológicos de 1911 e de 1913, nomeadamente a exclusão dos analfabetos. Diferenciava-se pelas seguintes alterações: concessão do voto aos militares no activo; redução dos círculos da Metrópole de 51 para 43 (39 no continente e 4 nas ilhas adjacentes) e os das colónias de II para 8; criação de 27 círculos de três deputados, I I círculos de quatro deputados, I de dois deputados (Angra do Heroísmo) e I de um deputado (Horta), mantendo o sistema da lista incompleta (dois nomes para um conjunto de três deputados, três nomes para quatro deputados e seis nomes para oito deputados) a fim de permitir a representação de minorias em todos os círculos salvo nos de dois e um deputados; e subida do corpo eleitoral, na Metrópole, para os 471.557 recenseados face aos mesmos 617.201 cidadãos do censo de 1911 , a que, em rigor, deveriam ser acrescentados alguns milhares derivados do aumento demográfico ocorrido desde então. (381) Refira-se, a propósito, que de 1911 a 1925 a percentagem da população recenseada para totais de população masculina maior de 21 anos só cresceu de forma significativa duas vezes: nas constituintes organizadas pelo Governo Provisório da República com 57,5\% e em 1918 com $58 \%$. Nas restantes, os valores são os seguintes: $26,3 \%$ em $1913,31,2 \%$ em 1915, 33, I\% em 1919, 19,3\% em 1921, 19,3\% em 1922 e $20,1 \%$ em 1925.

A lei eleitoral de I de Junho de 1915 teve a particularidade interessante de vigorar, quase sem alterações, até ao fim da I. ${ }^{a}$ República, o que significa que o decreto ditatorial de 30 de Março de 1918 foi redigido aproveitando grande parte das disposições fixadas naquele diploma. E se é certo que o Governo dezembrista introduziu algumas novidades, estas acham-se inscritas em legislação avulsa que antecedeu o decreto 3.997 - toda ela procedente do Ministério do Interior, chefiado por Henrique Forbes de Bessa.

(381) Cf. MARQUES, A. H. de Oliveira - Portugal da monarquia para a república, in SERRÃO, Joel e MARQUES, A. H. de Oliveira - Nova história de Portugal, vol. 11, ob. cit., p. 417-418.Ver também LOPES, Fernando Farelo Idem - Poder político e caciquismo na $1 .{ }^{\circ}$ república portuguesa, ob. cit., p. 85 e ss. 
O decreto n. ${ }^{\circ} 3.907$ de II de Março estabelecia o sufrágio, principiando pela declaração enfática e formal de que realiza uma aspiração do antigo partido republicano português, em cujo programa, elaborado em 11 de Janeiro de 1891, pelos Srs. Azevedo e Silva, Bernardino Pinheiro, Francisco Homem Cristo, Jacinto Nunes, Manuel de Arriaga e Teófilo Braga, expressamente se consignava, entre as liberdades políticas ou de garantias, o sufrágio universal. Em consonância com tão solene aspiração, determinava que os eleitores dos cargos políticos seriam os cidadãos portugueses do sexo masculino maiores de 21 anos no gozo dos seus direitos civis e políticos, soubessem ou não ler e escrever e residentes no território nacional há mais de seis meses.

Sobre a polémica inclusão dos analfabetos, teve o legislador o cuidado de refutar os argumentos aduzidos contra esse princípio, ${ }^{(382)}$ assim como deixou claro que o sufrágio abrangia a eleição do Presidente da República, da Câmara dos Deputados e do Senado. Ficaram, também, equiparados aos cidadãos maiores de idade os menores emancipados e os diplomados com algum curso superior em qualquer Universidade, Escola ou Academia nacional ou estrangeira; não podiam exercer o direito de voto as praças de pré do Exército e da Armada; e não podiam ser eleitores os alienados, interditos por sentença em julgado, os falidos por sentença em julgado, os pronunciados por despacho em julgado e os condenados como vadios dentro do prazo de cinco anos. Em cada concelho era nomeada uma Comissão de Recenseamento presidida pelo respectivo Presidente da Câmara Municipal.Além dos cidadãos inscritos no recenseamento, devidamente alterado e ampliado, estendia-se o direito de voto a todos quantos se apresentassem munidos de um certificado de eleitor gratuitamente passado, no prazo de três dias, pelo Presidente da Câmara Municipal, desde que os interessados o requeressem (até oito dias antes da eleição) e fizessem prova de terem entretanto atingido a maioridade, de residência há mais de seis meses e de se acharem equiparados aos cidadãos com maioridade legal.

Dúvidas suscitadas pela expressão secretário da Camara, usada no artigo $4 .^{\circ}$ do decreto n. ${ }^{\circ}$ 3.907, obrigaram o Governo a esclarecer pela portaria n. 1.261 de 18 de Março que essa expressão correspondia ao Chefe da Secretaria mencionado no artigo 13. da lei de 7 de Agosto de 1913. E como mais dúvidas surgissem no decurso da leitura e da interpretação do diploma sobre o sufrágio universal, e desta vez a propósito da contagem do prazo de quinze dias estipulado pelo artigo $5^{\circ}$, entendeu o Governo necessário desfazê-las pelo decreto n. ${ }^{\circ} 3.977$ de 26 de Março.

Com data de 30 de Março era, finalmente, mandado publicar o diploma regulador do acto eleitoral, que tem de há muito suscitado inevitáveis inferências histórico-políticas, porquanto foi estigmatizado pela suposta marca dos integralistas através do Ministro da Justiça, o lente de Direito Martinho Nobre de Melo. Convém, pois, retomar este aspecto, sem pretendermos repetir tudo o que para trás foi ficando dito sobre as ligações desse jurista ao Integralismo Lusitano e ao núcleo militar de jovens oficiais e cadetes, designadamente ao capitão Teófilo Duarte.

(382) Cf. Decreto n. 3.907, de II de Março. Diário do Governo, Março de 1918; e REPÚBLICA PORTUGUESA - Sufrágio universal. Decreto n. 3.907 e diplomas subsequentes de carácter eleitoral. Lisboa: Imprensa Nacional, 1918, p. 4-5. 
Nobre de Melo justificou, nas entrevistas que concedeu no fim da vida, ${ }^{\left({ }^{383}\right)}$ a sua interferência na redacção do diploma eleitoral porque havia pressa em publicá-lo e ele dispunha de preparação jurídica adequada para a tarefa. Não sofre, aliás, contestação este depoimento, confirmado por uma entrevista concedida ao Século de 3 de Abril.(384) O Presidente da República e o Governo tinham urgência na sua imediata feitura, mas a delicadeza do assunto aconselhava o útil contributo do jovem titular da Justiça. E este incumbiu-se não só da redacção da lei, mas até da sua defesa pública. Não o fez, porém, sózinho, tendo pedido ajuda ao integralista Hipólito Raposo, que reafirmou essa mútua amizade Nas Folhas do meu cadastro. ${ }^{(385)} \mathrm{O}$ depoimento é sobejamente conhecido, como conhecida é, também, a tese aí expressa de que coube ao Integralismo Lusitano o destino de inspirar doutrina e colaborar em alguns diplomas de renovação política que por terem sido promulgados e divulgados na imprensa, são já bastante conhecidos para que haja de aqui the fazer mais larga referencia. Chegado a este ponto o autor remete para a obra de Teófilo Duarte ${ }^{(386)}$ e acrescenta: Não é, porém, conhecido um projecto de Constituição Política, elaborado no sobressalto desses dias [Fevereiro] em longas sessões, e cujo original, entregue a Sidónio Pais e por êle aceite com entusiasmo, julgo ter-se perdido para sempre, se é que não foi abafado por cautela... Na verdade, modificando nêle um só artigo e substituindo pelo monarca a pessoa do presidente, já poderia chamar-se o Rei e pôr em vigor a Constituição. (387)

Palavras que empolam manifestamente o real contributo de Hipólito Raposo na confecção da lei eleitoral, prestado, aliás como o próprio Teófilo Duarte reconheceu, a título particular. Refutamos, por isso, a tese da directa e forte influência integralista na obra do sidonismo. Os novos dados descobertos apontam, ao invés, para uma aproximação esporádica e pouco relevante. E podemos acrescentar não ter sido encontrado no Arquivo Pessoal de Sidónio Pais o dito projecto de Constituição, que, a crermos nas palavras de Hipólito Raposo, diferia forçosamente do projecto elaborado pela respectiva Comissão constituinte da nova Câmara de Deputados, a não ser que o principal modelo seguido por ela — o Projecto de Estatuto Nacional de Machado Santos ${ }^{(388)}$ — tivesse servido igualmente de inspiração aos moços do Pelicano!...

Essa alegada influência dos integralistas nos pilares da República Nova aparece taxativamente afirmada por António José Telo a propósito da composição da segunda Câmara do Congresso: Este senado, que nunca chegaria a funcionar na forma pretendida, é no entanto bastante elucidativo da base de apoio do Sidonismo e da doutrina que está por detrás da lei 3977. Comecemos por notar que este embrião de organização corporativa

(383) Cf. MEDINA, João - Morte e transfiguração de Sidónio Pais, ob. cit., p. 171.

(384) Ver O Decreto eleitoral. Presidencialismo ou parlamentarismo? A questão política do dia tratada pelo sr. ministro da justiça. O Século, de 3 de Abril de 1918, p. 1. No dia da assinatura desse diploma, tanto o Diário de Notícias como O Seculo, numa prática que lhes era habitual, deram grande cobertura noticiosa à nova lei, reproduzindo excertos. Ver A Lei eleitoral sae hoje no Diario do Governo. N'ela se consignam as atribuições do presidente da republica e a duração minima do seu mandato. O Século, 30 de Março de 1918, p. 1-2.

${ }^{(385)}$ Cf. RAPOSO, Hipólito - Follhos do meu cadastro. Vol. 1 (191 I-1925). Lisboa: Edições Gama, 1945, p. 39 e ss.

(386) Cf. DUARTE, Teófilo - Sidónio Pais e o seu consulado, ob. cit., p. 127 e 288.

(387) Cf. RAPOSO, Hipólito - Fölhas do meu cadastro. Vol. I (1911 - 1925), ob. cit., p. 36-37.

(388) Cf. SANTOS, Machado - A Ordem publica e o 14 de Maio, ob. cit., p. $104-116$. 
se devia aos Integralistas, e, mais concretamente, ao seu principal dirigente, António Sardinha, que participa na redacção da lei (juntamente com Nobre de Melo e Hipólito Raposo).(389) E o mesmo autor não hesitou em considerar que, embora aparecesse com o modesto $e$ apagado nome de lei eleitoral $n .^{\circ} 3977$, era para todos os efeitos uma nova Constituição, com profundas modificações em relação à de 1911 e que inspiraria enormemente a futura Constituição de 1933.(390)

Manda, contudo, o rigor que se tenha presente o texto fundamental, reproduzido em Anexo, e se leia o projecto de Machado Santos, saído a lume em 1916, no seu

Art. 28. ${ }^{\circ}$ O Senado é constituido por 95 senadores eleitos na proporção que segue:

6 Pelo professorado do ensino superior.

6 Pelo professorado do ensino medio e especial.

3 Pelo professorado do ensino primario.

5 Pelas academias, sociedades e institutos de arte e ciencias.

6 Pelas associações de profissões liberaes

6 Pelas associações industriaes.

6 Pelas associações agricolas.

6 Pelas associações comerciaes.

10 Pelas associações operarias.

6 Pelo clero de todas as confissões religiosas.

6 Pelas vereações municipaes do continente e ilhas adjacentes.

2 Pela oficialidade da marinha mercante.

3 Pela oficialidade do Exercito.

3 Pela oficialidade da Armada.

16 Pelas provincias ultramarinas.

5 Pelas colonias portuguêsas estabelecidas em paizes estrangeiros. (391)

Deparamos com o mesmo princípio de representação especializada ou organização corporativa de que os integralistas têem recebido o «exclusivo» da autoria, o que é, no mínimo, estranho: Egas Moniz em I91 I propô-lo, Marnoco e Sousa, citando Léon Duguit, apresentou-o, em 1913, como tendência científica muito promissora ${ }^{(392)}$ e Machado Santos inscreveu-o no seu estatuto de Constituição ideal, não se percebendo porque é que só António Sardinha e Hipólito Raposo eram capazes de o formular. Mas admitamos que o fizeram, com a entusiástica anuência e parceria do Ministro da Justiça: a versão subiu à Presidência da República e aí Sidónio Pais leu-a, certamente, com muita atenção, não deixando passar matéria sensível que o indispusesse com os seus parceiros centristas e machadistas, núcleos basilares da rede sócio-política de apoio. E se não opôs objecções de fundo é porque a composição proposta para o Senado era, afinal, pacífica

(389) Cf.TELO,António José - O Sidonismo e o movimento operário português, ob. cit., p. 151 .

(390) Cf. Ibidem, p. 150.

(391) Cf. SANTOS, Machado - A Ordem publica e o 14 de Maio, ob. cit., p. 110.

(392) Cf. SOUSA, José Ferreira Marnoco e - Constituição politica da republica portuguêsa. Commentario. Coimbra, 1913, p. 323-324. 
para esses núcleos. Volvidos seis anos já não se achava nas condições que o levaram a exprimir tais reservas, dispondo-se, por isso, a aceitar essa fórmula, dentro, todavia, da matriz positivista, cientista e nacionalista do republicanismo da sua geração de 90. (393) $^{(3)}$

Se entrarmos, agora, no decreto propriamente dito, convém referir que ele foi dividido em dois títulos: Titulo I - Da representação nacional; e Título II - Das eleições. No primeiro, reduzido a dois brevíssimos artigos, estabelece-se que a Câmara dos Deputados se compunha de 155 membros, eleitos pelo sufrágio directo dos cidadãos eleitores e que - Senado compreendia 77 membros, distribuídos pela forma seguinte:

5 por cada uma das províncias do Minho,Trás-os-Montes, Douro, Estremadura,Alentejo e Algarve

9 pelas Beiras, divididas em Beira Alta, Beira Central e Beira Baixa com

3 representantes cada

2 pelas Ilhas Adjacentes

1 por cada uma das províncias ultramarinas

28 por seis categorias profissionais

1. ${ }^{a}$ Agricultura [elege 10]

2. Indústrias (inclui transportes, a caça e a pesca e as extracções mineiras) [5]

3. ${ }^{\circ}$ Comércio [4]

4. ${ }^{\circ}$ Serviços públicos [3]

5. ${ }^{a}$ Profissões liberais [3]

6. ${ }^{\circ}$ Artes e sciências [3]

No segundo Título, desenvolvido ao longo de oito capítulos (subdivididos em secções) rematados pelas habituais Disposições transitórias, acha-se todo o dispositivo regulamentar que inclui o disposto nos precedentes decretos n. 3.907 e 3.977, bem como na lei $n .{ }^{\circ}$ 314 de I de Junho de 1915, de onde procedia, aliás, o número de círculos adoptado.(394) Dispensamo-nos, por isso, de esmiuçar as disposições mais técnicas ou as que não sofreram alteração, designadamente todo o aparato jurídico-processual relativo à prática, ao controlo e à validação do acto eleitoral, para apenas destacarmos o teor essencial dos capítulos 5, 6,7 e das Disposições finais.

Embora não estivesse prevista para o curto prazo a eleição dos corpos administrativos $^{(395)}$ - as Juntas ou Comissões Distritais, as Câmaras Municipais e as Juntas de Paróquia — dissolvidos no início de Janeiro de 1918, ficava já regulada pelas disposições relativas à eleição dos deputados em tudo o que lhe fosse aplicável, acrescidas de mais algumas normas complementares. ${ }^{(396)}$

(393) Cf. REPÚBLICA PORTUGUESA - Sufrágio universal, ob. cit., p. 10-11.

(394) Ver representação cartográfica Mapa 22 - Circulos eleitorais, 1915-1925 in MARQUES,A.H. de Oliveira - Portugal da monarquia para a república, in SERRÃO, Joel e MARQUES, A. H. de Oliveira - Nova história de Portugal, vol. 11, ob. cit., p. 419.

(395) Ver nota explicativa em LOPES, Fernando Farelo-Poder político e caciquismo na 1. ${ }^{\circ}$ república portuguesa, ob. cit., p. 99-100.

(396) Ver REPÚBLICA PORTUGUESA - Sufrágio universal, ob. cit., p. 40-41. E ainda SILVA,Armando Barreiros Malheiro da - Sidónio e sidonismo. História e mito, dissert. cit., vol. 2, p. 254-355. 
Quanto à eleição do Presidente da República, a primeira novidade aparecia inscrita no artigo $116^{\circ}$ : seria directa, uninominal e regulada, também, pelas disposições da eleição de deputados em tudo o que se the aplicasse, mais um conjunto de disposições específicas, agrupadas em mais sete artigos. No $117 .^{\circ}$ determinava-se que se lavrassem actas das operações efectuadas, assinadas e rubricadas pelas respectivas mesas, mencionando-se nelas a constituição das mesas e das comissões, o parecer daquelas e destas, os contra-pareceres dos portadores das actas, os protestos e reclamações dos candidatos ou seus representantes, os nomes dos presumidos eleitos, o número de votos de cada lista, assim como quaisquer ocorrências dignas de menção. No artigo 1 I $8 .^{\circ}$ indicavase o destino das actas, que deviam seguir, junto com os originais, cadernos, papéis da Assembleia Primária e de Apuramento, para a Comissão Central de Apuramento da Eleição do Presidente da República, constituída pelo Presidente do Tribunal da Relação de Lisboa (presidente da Comissão), pelo Ajudante do Procurador da República junto do Tribunal da Relação de Lisboa, pelo Director Geral da Administração Política e Civil do Ministério do Interior (servindo ambos de secretários) e por quatro funcionários públicos nomeados pelo Ministro do Interior (dois para escrutinadores e dois para suplentes). No artigo I 19. diz-se que após a imediata conclusão do apuramento final seria feita a proclamação do cidadão mais votado para Presidente da Repúbllica e lavrada a competente acta das operações realizadas, devidamente assinada e rubricada por todos os membros da Comissão. No artigo $120 .^{\circ}$ diz-se ainda que a acta original do apuramento ficaria arquivada no Ministério do Interior, enviando-se cópias aos Presidentes da Câmara dos Deputados e do Senado e seguindo-se as mais formalidades determinadas na Constituição de 1911. E os três últimos artigos - 121. a $123 .^{\circ}$ - configuravam inevitavelmente matéria constitucional - passível de controvérsia - porque era aí fixado o seguinte: a duração mínima do mandato presidencial seria de quatro anos, embora coubesse às primeiras Câmaras eleitas fixar definitivamente o período do referido mandato; o Presidente da República era o Chefe da Força Armada da Terra e Mar, cabendo-lhe privativamente empregá-la conforme fosse conveniente à segurança interna e defesa externa da Nação; e ao Presidente da República competia nomear e demitir livremente os seus Ministros ou Secretários de Estados (art. ${ }^{\circ}$ 123, evocado nos diplomas de nomeação e exoneração).

Sobre a eleição do Senado sabemos já que este abrangia uma dupla representação: provincial e especializada ou corporativa.

A eleição dos senadores provinciais seria feita por sufrágio das Câmaras Municipais (controladas, desde Janeiro, pelo Governo) correspondentes a cada província e da seguinte maneira: até cinco dias antes da data marcada para a eleição cada uma das Câmaras do continente e ilhas teria de eleger, em sessão secreta e voto igualmente secreto, um delegado que a representasse na referida eleição. Os delegados municipais, assim designados, reunir-se-iam no dia previamente fixado, em sala das sessões da Junta Distrital com sede na capital da respectiva província, escolhendo de entre eles a mesa e procedendo, por voto secreto, à eleição dos senadores. Seriam considerados eleitos os nomes mais votados e do facto teria de ser lavrada acta com os requisitos formais comuns. Nas províncias ultramarinas verificar-se-ia o mesmo processo eleitoral através das respectivas Câmaras Municipais. Estas disposições viriam, porém, a ser alteradas pela portaria 1.308 de 17 de Abril no seu artigo $7 .^{\circ}:$ 1. ${ }^{\circ}$ Nas próximas eleições de Presidente 
da República, Deputados e Senadores, que se realizarão no mesmo dia; $\S 3 .^{\circ}$ Cada eleitor apresentará uma, duas ou três listas, conforme concorra a uma, duas ou três eleições; e pelo artigo 9.: A eleição dos Senadores pelas provincias e ithas adjacentes será feita por sufrágio directo com a distribuição constante do quadro anexo ao citado decreto de 30 de Março.

Para os senadores eleitos pelas categorias profissionais a lei discriminava, dentro de cada uma, o número atribuído às diferentes organizações que a compunham. Assim, para a Agricultura a influente Associação Central da Agricultura Portuguesa elegia três senadores, a Liga Agrária do Norte dois, a Associação dos Proprietários e Agricultores do Norte de Portugal um e os Sindicatos e Associações Agrícolas do continente quatro, reunindo-se os sócios das três primeiras em assembleia geral e nos termos dos seus estatutos, e os das associações sindicais ${ }^{(397)}$ numa assembleia formada, em Lisboa, por todos os delegados vindos dos diversos pontos do país e regida pela forma disposta para a eleição dos senadores provinciais. Os procedimentos eleitorais indicados eram extensivos para as restantes categorias. Na Indústria, a Associação Industrial Portuguesa de Lisboa elegia um senador, a Associação Industrial Portuense um e todos os Sindicatos e Associações Operárias, legalmente reconhecidas, elegiam três. No Comércio, a Associação Comercial de Lisboa elegia um, a Associação Comercial e o Centro Comercial do Porto elegiam conjuntamente um, a Associação dos Lojistas de Lisboa e a dos Lojistas do Porto elegiam um, e outro por todos os Sindicatos e restantes Associações Comerciais do continente. (398) Nos Serviços Públicos, os Directores Gerais e Chefes de Serviço internos dos Ministérios elegiam um e os restantes funcionários de secretaria elegiam dois. (399) Para a categoria das Profissões Liberais, a Associação dos Advogados de Lisboa elegia um, a Associação dos Médicos Portugueses elegia um e a Associação de Engenheiros Civis Portugueses elegia outro. Finalmente, para as Artes e Ciências, as Universidades do Porto, Coimbra e Lisboa elegiam um, os Liceus Centrais e Nacionais do continente elegiam um, as Escolas de Belas Artes de Lisboa e Porto, Escolas de Música do Conservatório e de Arte de Representar e a Sociedade Nacional de Belas Artes elegiam um. $\left.{ }^{400}\right)$

De modo a tornar possível todo este esquema eleitoral, o Ministério do Trabalho era obrigado a enviar ao Ministério do Interior, até trinta dias antes da data designada para a eleição, uma relação de todas as associações de classe do continente aprovadas pelo Governo e discriminadas por categorias, contendo a indicação da sua sede, denominação, capital social e número de associados. E no prazo de trinta dias o Interior tinha de organizar essa relação das associações com direito a delegação, ordenadas pelas respectivas categorias profissionais. Eventuais reclamações surgidas após a afixação pública das relações deviam ser feitas ao Juiz de Direito da respectiva comarca, o qual teria de pronunciar-se no prazo de cinco dias. Percorridos todos os trâmites legais, as

(397) Cf. REPÚBLICA PORTUGUESA - Sufrágio universal, ob. cit., p. 45.

(398) A eleição do senador pela Associação Comercial do Porto e Centro Comercial da mesma cidade devia seguir o prescrito no $\S 2 .^{\circ}$ do artigo $137 .^{\circ}$ e a eleição dos senadores pela Associação Comercial de Lisboa e pelos Sindicatos consta dos $\S 1 .^{\circ}$ e $3 .^{\circ}$ (Cf. REPÚBLICA PORTUGUESA - Sufrágio universal, ob. cit., p. 46).

(399) Cf. Ibidem, p. 46.

(400) Sobre a realização do acto eleitoral dispunham os artigos $145 .^{\circ}, 146^{\circ}$ e $147 .^{\circ}$ (Cf. Ibidem, p. 47-48). 
relações seriam publicadas no Diário do Governo, convocando as associações de classe para a eleição dos respectivos delegados, designando os edifícios onde estes deviam reunir-se e nomeando os fiscais do Governo que teriam de assistir a cada assembleia e que nunca poderiam intervir nas operações eleitorais, tão somente velar pela observância das leis. ${ }^{(401)}$

Nas chamadas Disposições transitórias, contidas em doze artigos, ${ }^{(402)}$ sobressaem logo os dois primeiros: o art. ${ }^{\circ}$ | estabelecia que o Presidente da República assumirá o exercício das suas funções no dia seguinte ao da sua proclamação; e 0 art. ${ }^{\circ} 2$ determinava que as primeiras eleições a realizar seriam feitas pelo recenseamento elaborado conforme o disposto no decreto de 11 de Março de 1918 e as primeiras Câmaras eleitas teriam competência para rever a Constituição Política da República Portuguesa, funcionando como Câmaras ordinárias uma vez concluída essa revisão e sendo de quatro anos o seu mandato a contar da data da eleição.

A rematar o diploma eram publicados o Quadro dos prazos para as operações do recenseamento eleitoral referido no artigo 19. do presente decreto, o Quadro da divisão dos círculos, o Quadro da divisão das províncias e os Prazos para a classificação e determinação das Associações de Classe com direito de voto, todos datados e assinados pelo Ministro do Interior, Henrique Forbes de Bessa. ${ }^{(403)}$

Com a chancela do Presidente da República e do mesmo Ministro (acompanhada num dos diplomas pela assinatura dos restantes membros do Governo) foram enviados para a folha oficial mais dois decretos e duas portarias, a última com data de 17 de Abril. $O$ decreto 4.023 de 2 de Abril fixava o dia 28 desse mesmo mês para a realização das eleições do Presidente da República, Deputados e Senadores; o decreto 4.072 de 6 de Abril adaptava à nova legislação eleitoral o disposto no artigo $47 .^{\circ}$ da lei n.. 3 de 3 de Julho de 1913 e definia o formato das listas para a eleição de Senadores e Deputados $(20 \times 15 \mathrm{~cm})$ e presidencial $(15 \times 10 \mathrm{~cm})$; a portaria n. ${ }^{\circ} 1.301$ de 12 de Abril aclarava dúvidas suscitadas pelo $\S$ único do artigo $4 .^{\circ}$ do decreto 3.997 e artigo $2 .^{\circ}$ das Disposições Transitórias sobre se os sargentos e equiparados de terra e mar podiam ou não exercer o direito de voto, precisando que o disposto no segundo não restringia o direito expresso no primeiro; e a portaria n..$^{\circ} 1.308$ de 17 de Abril, mais extensa, destinava-se igualmente a aclarar mais dúvidas e a completar outras disposições em ordem a garantir a genuinidade do sufrágio e maior facilidade no concurso às eleições. ${ }^{(404)}$

Por detrás da irrefragável legalidade contida em todo este pacote legislativo e na «máquina» administrativa accionada para esse fim não é, contudo, difícil descobrir os habituais artifícios de engenharia eleiçoeira — herdados muitos deles da legislação anterior, criados outros para essa ocasião, como, por exemplo, a redução do prazo de campanha eleitoral dos 40 dias fixados inicialmente para menos de trinta ou a manipulação governamental de um recenseamento muito apressado, visando todos, afinal, um objectivo tão subliminar, quanto crucial: garantir a vitória do Chefe do Estado e do Governo.

(401) Cf. REPÚBLICA PORTUGUESA - Sufrágio universal, ob. cit., p. 49.

(402) Cf. Ibidem, p. 57-59.

(403) Cf. REPÚBLICA PORTUGUESA - Sufrágio universal, ob. cit., p. 60-67.

(404) Cf. Ibidem, p. 69 e ver p. 69-71. 


\section{Campanha eleitoral}

Uma vitória que o jogo democrático impunha fosse conquistada de forma lisa, pacífica e na mais ampla liberdade. A propaganda na imprensa e a realização de um conjunto variado de actos públicos constituíam, assim, os principais meios legítimos para a disputa eleitoral, não devendo o Governo viciar as regras em detrimento dos seus opositores. Mas a tradição há muito repetida fazia com que os governantes proclamassem a «limpeza» do acto e as oposições apontassem um rol de ilegalidades.

Que sucedeu desta vez? É o que vamos tentar perceber...

Ao Governo ditatorial convinham duas coisas essenciais, tendo em vista uma legitimidade reforçada: grande transparência e enorme afluência de eleitores. E para isso não podia prescindir de uma opinião pública favorável e devidamente informada. Acontecia, porém, que as divisões cavadas no campo republicano não tendiam a diminuir, antes a agravar-se visivelmente, não mostrando as autoridades, por sua vez, grande flexibilidade na busca do desejável consenso. $\bigcirc$ decreto eleitoral representava, aliás, a consumação da discórdia entre as diversas forças republicanas em presença - a governamental e a oposição. Esta rejeitava o sufrágio universal directo quer na eleição presidencial, quer na do Congresso. Impunha-o aquela de modo peremptório e irreversível. No entanto, uma postura tão inflexível precisava de ser explicada e atenuada nos seus contornos mais ásperos e chocantes.

Foi isso precisamente que Martinho Nobre de Melo, Ministro da Justiça e autor do diploma, teve em vista ao deixar-se entrevistar sobre a questão política do dia, ou seja, a opção entre presidencialismo e parlamentarismo, que a recente lei parecia ter decidido a favor do primeiro contra o segundo.

O disposto nos artigos $121^{\circ}, 122^{\circ}$ e $123 .^{\circ}$ não deixava, aliás, dúvidas quanto ao pendor presidencialista do decreto, mas Nobre de Melo, recorrendo aos dotes sofísticos da sua arte, ousou tornear a lógica e as evidências, afirmando que $O$ decreto eleitoral contrariamente ao que se fez correr, não instituiu o presidencialismo, e nem sequer o insinua como fórma de governo, ${ }^{(405)}$ limitando-se apenas a conferir ao Presidente da República algumas atribuições imprescindiveis no desempenho imediato do seu cargo e na manutenção da ordem interna e defesa externa da Nação. O Ministro negava que o disposto sobre a função presidencial de Comandante das Forças Armadas, à semelhança do preceituado nas legislações brasileira e americana, fosse matéria constitucional, porque não é matéria constitucional a organização da força publica, e isto em nenhum paiz; e retorquia, a propósito da disposição relativa à livre nomeação e exoneração dos Ministros, tratar-se de disposição semelhante á que vigorava na Carta Constitucional e, no entanto, a monarquia era parlamentar. Pretendia, pois, sossegar os espíritos, alvoroçados ante a manobra presidencialista do decreto, afiançando que o Governo não estava a impor nada e que esperava tranquilamente o veredicto das Câmaras, como lhes competia a tal respeito, decidindo-se mesmo pelo parlamentarismo, em que estávamos, se o acharem excelente. $\mathrm{E}$ o recado não ficava por aqui: interessava acrescentar, numa hábil tentativa de conquista

(405) Ver interpretação contrária por CAETANO, Marcelo - Constituições portuguesas, ob. cit., p. 107. 
dos indecisos e dos cépticos, que estava aberto o pleito. E não é o governo que pretende decidil-o. Façam-se as eleições livremente. Publiquem-se todos os jornaes, abram-se os centros todos. Ouçam-se todas as vozes. Venham todos os tribunos, preguem, não a revolta, mas o voto! Deixemos todos que fale a nação! (406) Apelava, assim, ao voto livre e plural, ao mesmo tempo que se confessava abertamente presidencialista: É mister — declarava — garantir a ordem, como é mister tornar os poderes independentes, porque só a independencia gera a harmonia. Prestigiemos, pois, o parlamento, libertando-o das mesquinhas querelas dos «faits divers», fazendo-o pairar na atmosfera alta e serena da elaboração das leis. E prestigiemos, de egual passo, o executivo, para que ele possa, emfim, agir e executar, sem peias, sem «a casca de laranja») de hora a hora para o escorregão do costume... A partir deste cenário ideal de debate amplo e franco, lançou um forte ataque à argumentação dos parlamentaristas, citando, a dado passo, o ex-deputado democrático e professor de Direito Vieira da Rocha que teria dito: a Constituição de $191 \mid$ l é um abôrto! Nem parlamentar nem presidencialista e sim uma fórma republicana incaracterística, que o mesmo significava taxar de inútil a defesa de um parlamentarismo que nunca chegara verdadeiramente a existir!...

Esta importante entrevista de Martinho Nobre de Melo dava o mote para a campanha eleitoral. A questão política era, de facto, a questão do dia, uma questão para todos incontornável. E diante dela os adeptos da «situação» não tinham apenas de dourar a pilula presidencialista, mas também de combater um abstencionismo que se perfilava ameaçador.

O Jornal da Tarde e A Situação - o Tempo de Simão Laboreiro(407) só surgirá nos finais de 1918 - formaram a vanguarda das hostes governamentais no combate contra a «frente» democrático-evolucionista, engrossada pelos unionistas. Estes, no seu $3 .^{\circ}$ Congresso de 7 e 8 de Abril, haviam recusado a moção moderada de Fonseca Chaves favorável à participação eleitoral do partido e mimoseada, aliás, por Brito Camacho com os seus habituais piropos sarcásticos, ${ }^{(408)}$ e aprovaram a moção sancionada pelo líder e subscrita pelo ex-Ministro da Justiça Moura Pinto. Moção particularmente dura, denunciadora das eventuais vantagens e utilidades pessoais, que desde a viagem presidencial ao Norte do País pareciam reger a conduta do sr. Sidónio Pais, e terminante quanto à opção abstencionista. ${ }^{409)}$

As acusações formuladas por Moura Pinto foram habilmente corroboradas por Brito Camacho, que conseguia, apesar de algumas baixas importantes, segurar em torno de si o partido e mobilizar alguns militantes, em especial o reputado presidencialista José Barbosa, para o combate nas páginas de A Lucta — sem tréguas até ao lance final... - contra a República Nova.

(406) Cf. O Decreto eleitoral. Presidencialismo ou parlamentarismo? A Questão política do dia tratada pelo sr. ministro da justiça. O Século de 3 de Abril de 1918, p. 1.

(407) Ver MEDINA, João - Morte e transfiguração de Sidónio Pais, ob. cit., p. 156.

${ }^{(408)}$ Cf. Discurso proferido pelo «leaden» da União Republicana na segunda sessão, in Terceiro Congresso da União Republicana, ob. cit., p. 26-31.

(409) Cf. Terceiro congresso da Uniäo Republicana, ob. cit., p. 25. Ver SILVA, Armando Barreiros Malheiro da - Sidónio e sidonismo. Histório e mito, dissert. cit, vol. 2, p. 260-261. 
De parceria táctica ocasional com a Manhã de Mayer Garção, a República ou o Norte, publicado no Porto, o órgão unionista apostou forte na campanha abstencionista, na denúncia de um falso presidencialismo - Barbosa classificá-lo-á de presidentismo ou mero poder pessoal — e na exploração da mais ínfima falha do Governo, fomentando, assim, a atmosfera de conspiração sintetizada pelo próprio Brito Camacho, em Novembro de 1918 , ao findar uma carta para Augusto de Vasconcelos: É voz geral que se conspira á bruta, e toda a gente acredita que isto não pode durar.

A abstenção surgiu não apenas como atitude cívica de repúdio e de pressão pedagógica sobre o Governo, mas como arma, fundada na mesma base deslegitimadora, visando quer a eleição do Congresso, quer a do Presidente. Pôde, por isso, Magalhães Lima declarar ao jornal de Mayer Garção o seguinte: Não só não apresento o meu nome ao sufragio popular que vai realizar-se no dia 28 do corrente, como tambem me confesso e afirmo absolutamente abstencionista. Não posso sancionar, com o meu voto, mesmo de oposição, a legitimidade de uma situação politica pouco lisongeira aos sentimentos republicanos. - EV. Ex. ${ }^{a}$ crê que o povo acompanhará essa orientação abstencionista? - Sem duvida alguma. Todos os dias recebo a esse respeito absolutas afirmações. O povo de Lisboa e das principais cidades do país abster-se-ha de ir ás urnas, o que será o mais eloquente protesto contra a actual situação. ${ }^{410}$ Sem grandes rodeios, o golpe anunciado não tardaria a ser desferido como xeque-mate ao Governo e seus adeptos: não indo ás urnas o Povo oposicionista isolava os governantes, comprometendo-os interna e externamente. Alto risco que só corria quem quisesse perder o jogo logo ali. Quem quisesse prolongá-lo, mesmo sacrificando trunfos, tinha de contra-atacar...

Impunha-se, por isso, uma reaç̧ão concertada e intensa, cometida tacticamente pelos periódicos governamentais, cada qual com o seu estilo e as suas prioridades, mas ambos ressentindo-se da perigosa ofensiva dos adversários. ${ }^{(411)}$

Era iniludível a explícita defesa de um figurino político-institucional que os cidadãos eleitores teriam ensejo de plebiscitar, antes mesmo de ser definido pelos representantes da Nação à velha maneira jacobina e liberal. Não se tratando, porém, de uma estratégia cómoda, A Situação, o jornal dos novos, como fora publicamente apresentado, não hesitou em divulgar, a 7 de Junho, uma nota do Governo de desmentido formal: Será o Congresso que fará a Constituição, não tendo o sr. dr. Sidonio Paes tenção de apresentar qualquer proposta visto serem as camaras que de direito devem proceder á revisão constitucional.(412) Mas maior incomodidade causava a abstenção, liminarmente repudiada: A Abstenção eleitoral significa uma fraqueza. A campanha difamatoria, sem bases nem argumentos, representa a ultima esperança dos maus republicanos. $E$ os moços bateram-se diariamente pela difícil sustentação das posições governamentais, aproveitando todos os pretextos para alvejarem a oposição republicana histórica.

(410) Cf. Pela abstenção. $\bigcirc$ que diz o austero republicano dr. Magalhães Lima. A Manhã, de 4 de Abril de 1918, p. I.

(4i1) Ver SILVA, Armando Barreiros Malheiro da - Sidónio e sidonismo. História e mito, dissert. cit., vol. 2, p. $262-265$.

(412) [Sem título]. A Situação, de 7 de Junho de 1918, p. I. 
No entanto, por muito certeira que fosse a imprensa pró-governamental, secundada pelos principais periódicos noticiosos de Lisboa e Porto, prontos a saudarem e a louvarem os intuitos ordeiros e reformistas do Governo, este travava um combate de vitória incerta em que os adversários dispunham de redes e de antigas cumplicidades, tanto na capital como fora dela, aptas a desferirem uma irreparável humilhação através do escandaloso retrato das assembleias de voto vazias ou fechadas por falta de comparência das respectivas mesas.

O efeito perturbador da abstenção não pode, portanto, ser menosprezado e deve ser visto dentro da acentuada derrapagem governamental para a repressão, cada vez mais dura e aparatosa, e para a viciação das condições eleitorais. Os exemplos falam por si: no início de Março a greve dos Caixeiros ficou envolta em alguma perturbação bombista na capital, tendo Sidónio Pais, acompanhado pelos oficiais às suas ordens, percorrido de automóvel, durante a tarde, as ruas de Lisboa, procedimento ousado e populista que terá de repetir com frequência até ao fim da vida; a 23 desse mês, Brito Camacho deslocou-se ao Porto para proferir uma conferência sobre parlamentarismo e presidencialismo, mas as autoridades e os situacionistas locais boicotaram o evento; $\mathrm{e}$ a vigilância policial recrudesceu perante a multiplicação de focos dispersos de agitação anarco-sindical e política.

A libertação de Afonso Costa, a constante reafirmação oficial da mais estrita defesa da legalidade democrática, a amnistia de 9 de Maio ou a espectaculosa libertação de presos no Porto em 18 desse mês, comprovam o outro lado de uma complexa ambivalência política, que não pode desligar-se dos contrastes da personalidade de Sidónio Pais: a sua índole generosa e afectiva, o seu apurado sentido moral, a sua natural prudência e os seus princípios liberais e democráticos impeliam-no para práticas legalistas, moderadas e tolerantes, mas a sua neurastenia atávica e o forte instinto de sobrevivência política instigavam atitudes contraditórias e impulsivas de inabalável dureza, de incontida comoção ou de desvairada coragem. Percebe-se, assim, que se tenha tornado cúmplice e responsável pela faceta repressiva que a República Nova por razões de auto-defesa (não estamos perante um regime deliberada e assumidamente violento e repressor, mas tão só ante uma modalidade conjuntural da República outubrista) foi exibindo até final com acentuada nitidez.

O restabelecimento da censura ${ }^{(4 \mid 3)}$ a dezasseis dias das eleições, através do decreto n. ${ }^{\circ} 4.082$ de 13 de Abril, ilustra bem essa prática dúbia e contraditória: recurso aos expedientes criticados nos democráticos e, em simultâneo, a máxima preocupação em usar uma cobertura legal, inclusivé a mesma que aqueles haviam criado para si próprios.

Sintomas de uma certa má-consciência (extensiva a todos os republicanos no Poder) que não passaram despercebidos ao Chefe da Legação da França em Lisboa.

Émile Daeschner, em despacho para o Ministro Pichon, datado de 23 de Junho, procedeu a uma detida análise do regime da censura e suas sucessivas modificações, começando por notar que em Portugal a liberdade de imprensa nunca existiu a não 
ser de uma maneira teórica, inclusive em tempo de paz. Todos os Governos até esse momento tinham-se reservado o direito de apreender os jornais considerados perigosos. Com efeito, o Governo Provisório da República, embora tenha decretado o princípio da liberdade de imprensa viu-se obrigado, em breve, a adoptar medidas restrictivas e - $3 .^{\circ}$ Governo Constitucional de Duarte Leite, pela lei de 9 de Julho de 1912 , decidira que podiam ser apreendidos todos os jornais ou obras impressas contendo ultrajes às instituições ou provocações capazes de porem em perigo a segurança do Estado. Algum tempo mais tarde, com a entrada de Portugal na Grande Guerra, as autoridades de então dotaram-se de novas armas contra a imprensa, e a 28 de Março de 1916 foi votada no Parlamento uma lei que estabelecia o regime da censura para os jornais e impressos periódicos, e conferia à Comissões de Censura a faculdade de eliminar toda a informação capaz de alarmar o espírito público e de causar prejuízo, fosse ao Estado na sua segurança interna ou externa e nas suas relações com as potências estrangeiras, fosse aos preparativos militares. Ficavam, assim, essas Comissões dotadas de extensos poderes, usados de forma pouco criteriosa e eficaz, concitando, por isso, protestos unânimes até que, em 6 de Setembro de 1917, a lei n. ${ }^{\circ} 815$ procurou controlar meIhor a actuação das Comissões de Censura, impedindo-as de cortarem para além das informações prejudiciais à defesa nacional, militar ou económica e às operações de guerra ou as que contivessem propaganda contra a guerra. Mas estas modificações, na opinião do Ministro Daeschner, não passaram de letra morta e os cortes continuaram a ser aplicados aos artigos potencialmente incómodos para o Governo na sua política interna.

Deu-se, então, o 5/8 de Dezembro de 1917 e um dos primeiros actos da Junta Revolucionária consistiu na abolição das restrições à liberdade de imprensa e, por consequência, toda a censura. Mas essas disposições não prevaleceram muito tempo e a 13 de Abril eram repostas, por decreto, a lei de 28 de Março de 1916 e a de 9 de Julho de 1912. Foram imediatas as críticas dos adversários, justificadas pelo facto de tal reposição significar um endurecimento maior que a prática havida nas vésperas do golpe dezembrista. Houve, com efeito, um agravamento face à lei de Março de 1916, porquanto as Comissões de Censura, dependentes até aí do Ministério do Interior, passaram a ser compostas unicamente por militares e anexadas ao Ministério da Guerra, exercendo, nas palavras de Daeschner, as suas funções avec une sévérité qui provoqua les protestations aussi bien des journaux d'opposition que des feuilles amies du Gouvernement. (414)

Entretanto, o coro de protestos e o incómodo efeito causado na opinião pública mais esclarecida levaram o $16 .^{\circ}$ Governo, legitimado pelas eleições, a introduzir, dans un sens libéral, nova modificação mediante o decreto n. 4.436 de 17 de Junho, ${ }^{(415)}$ que determina a criação de Comissões Especiais de Censura postas a funcionar junto dos Governos Civis e sujeitas às seguintes regras: só podiam eliminar as notícias prejudiciais à defesa nacional, militar ou económica e às operações de guerra, e às que difundissem

(414) Z. Europe, 1840 Portugal, Ambassadeur Français à Lisbonne, carton 530, dossier 1, 23 Juin 1918. (Archives du Ministère des Affaires Etrangères).

(415) Ver FRANCO, Graça - A Censura d imprensa (1820-1974), ob. cit., p. 57-58. 
propaganda contra a guerra. ${ }^{(416)}$ Quase um mês depois, pelo decreto n. ${ }^{\circ} 4.601$ de 12 de Julho, regulou os vencimentos dos censores e outra matéria menor, pouco ou nada influindo, porém, na modificação de uma prática censória ambígua e arbitrária: segundo Graça Franco o decreto de 17 de Junho, apesar da sua clareza, não foi cumprido ou por manifesto excesso de zelo ou por haver uma dupla lei, isto é, o governo não diz o que pretende cortar, mas indica aos seus funcionários que o façam; ou ainda, face ao crescendo de subversão do país, que levara mesmo à constituição de diversas juntas militares, os ditos funcionários optaram por decidir o que devia ou não ser cortado. ${ }^{(417)}$

Nas condições de alta tensão política que antecederam as eleições e se agravaram logo em Maio, com a descoberta e a sufocação, no Porto, de mais um importante complot democrático, ${ }^{(4 \mid 8)}$ e a par do realinhamento atacante dos partidos abstencionistas, que, apesar disso, aparecerão a fiscalizar, em alguns círculos, o acto eleitoral, decorreu a campanha dos partidos e forças concorrentes, na sua maioria posicionados entre o centro e a extrema-direita, salvo o Partido Socialista de Agostinho da Silva, Nunes da Silva Júnior, José de Almeida, Eduardo Cardoso, António Abrantes e Oliveira e César Nogueira, todos eles membros do seu Conselho Central. Os socialistas foram às urnas, sobretudo em Lisboa e Porto, arrecadando 4.643 votos e elegendo para a Câmara dos Deputados por São Tomé o candidato João de Castro na lista da Liga Africana, ${ }^{(419)}$ votado também no círculo 27 de Lisboa com 696 votos. É de assinalar que a imprensa fez-se eco de alguns problemas que os socialistas tiveram de enfrentar. Sabe-se, por exemplo, que no próprio dia das eleições uma delegação do Conselho Central do partido procurou entrevistar-se com o Ministro do Interior para protestar contra a prisão, nas vésperas do acto eleitoral, do correligionário António Maria Abranches.

No outro extremo do leque partidário estavam os monárquicos, que mostrarão possuir uma boa capacidade de manobra e de penetração eleitoral em círculos interiores do Norte, Centro e Sul - Trás-os-Montes, Beiras, Alto Alentejo e Algarve - conseguindo vencer as maiorias em alguns casos como Arganil ou Vila Real, o que, sete anos volvidos sobre a implantação da República, se não significava um generalizado e sólido sentimento monárquico no país era, sem dúvida, sintomático do divórcio, agravado com o tempo, entre os republicanos e o Portugal profundo. Note-se ainda que nas listas monárquicas cabiam algumas tendências desavindas, como os manuelistas e os integralistas, constituíndo estes a vanguarda doutrinária e aguerrida do movimento monárquico.

Enquanto isto, os católicos do Centro Católico Português, fundado em Braga a 8 de Agosto de 1917 e estruturado em três regiões representadas na Direcção Nacional de

(416) Z. Europe, 1840 Portugal, Ambassadeur Français à Lisbonne, carton 530, dossier 1. 23 Juin 1918 e n. ${ }^{\circ}$ 56, 15-4-1918. (Archives du Ministère des Affaires Etrangères).

(417) Cf. FRANCO, Graça - A Censura à imprensa (1820-1974), ob. cit., p. 59.

(418) Ver ALMEIDA, João Ferreira de, PAIS, João Machado e CABRAL, Manuel Villaverde - Materiais para a história do advento do fascismo em Portugal. Análise Social. Lisboa: 15:58 (1979) p. 403-404.

(419) Cf. NOGUEIRA, César - Socialista. Partido, in SERRÃO, Joel (dir.) - Dicionário de história de Portugal, vol. 4, ob. cit., p. 17: ver também Idem - Notas para a história do socialismo em Portugal, vol. 2 (1895-1925). Lisboa: Portugália Editora, 1966, p. 44-45 e ss. 
tipo colegial, a Comissão Central, composta por Alberto Pinheiro Torres, Diogo Pacheco de Amorim e Fernando de Sousa (Nemo), dispuseram-se, também, a agarrar essa excelente oportunidade para se afirmarem como organização partidária e, sobretudo, para defenderem e pressionarem em prol dos seus interesses e princípios de natureza confessional. ${ }^{(420)}$

Sucedâneo da União Católica, o C.C.P., com a «benção» dos Bispos, ${ }^{(421)}$ constituiu-se nos moldes de uma organização político-religiosa capaz de intervir política e eleitoralmente em defesa das reivindicações católicas, marcando, assim, o início de uma estratégia nova pautada pela inédita apresentação, em Portugal, de católicos deputados, isto é, representantes próprios da Igreja no Parlamento e não apenas deputados católicos. As condições pareciam propiciar essa viragem e isso mesmo foi inferido do honroso segundo lugar que a candidatura de Diogo Pacheco de Amorim obteve por Braga nas eleições suplementares de 15 de Junho de 1917. No entanto, subsistiam graves limitações e dificuldades, especialmente o tradicional enfeudamento à oposição monárquica, que obstava a uma actuação político-eleitoral autónoma ${ }^{(422)}$ e mais consentânea com a subjacente doutrina do ralliement de Leão XIII. Num esforço nítido de demarcação e de afirmação exclusiva dos seus objectivos programáticos, os católicos do C.C.P., embora apresentando candidatos a deputado por alguns círculos - Pinheiro Torres por Braga, Braga da Cruz porVila Nova de Gaia, Francisco Veloso porViana do Castelo, José Nosolini Leão por Penafiel, Francisco Perfeito de Magalhães por Lamego, José da Cunha Matos por Gouveia, Luís Ferreira porViseu, José de Almeida Correia por Leiria, Joaquim Isidro dos Reis por Tomar, Diogo Pacheco de Amorim por Covilhã, Alberto Diniz da Fonseca por Arganil, António Lino Neto, rotulado de «independente», por Portalegre e Conde de Silves por Silves - e a senadores pelas províncias do Minho, de Trás-osMontes e do Algarve, respectivamente Padre António José da Silva Gonçalves, José de Azevedo Menezes e Domingos Pinto Coelho, estabeleceram contactos e acordos com os centristas/nacionalistas de Egas Moniz por forma a apoiarem os governamentais no seu intuito de assegurarem as maiorias contra as oposições concorrentes.

$\mathrm{Na}$ imprensa católica, o C.C.P. apressou-se a divulgar o sentido dessa entente com - Governo, sem abdicar, porém, de uma conduta própria, a saber: dar o voto a Sidónio Pais para a Presidência da República; facilitar ao Governo a consecução da maioria que permitisse a sua acção em prol da boa administração dos negocios publicos, da manutenção da ordem e da defeza contra a demagogia sectaria; fornecer-lhe todo o apoio nas

${ }^{(420)}$ Ver CRUZ, Manuel Braga da - As Origens da democracia cristã e o salazarismo, ob. cit., p. 263-276.

(421) Ver SILVA, Armando B. Mallheiro da Silva - Os Católicos e a «República Nova» (1917-1918): da «questão religiosa» à mitologia nacional, art. cit., p. 461-466.

(422) Esse desiderato só virá a ser alcançado através da «notável direcção» do futuro Presidente do C.C.P." Lino Neto, durante a fase da reestruturação organizativa, da autonomização centrista e da consolidação política, tal como a designa Manuel Braga da CRUZ: nesse segundo período «a actuação do C.C.P. pautar-se-á, efectivamente, pelo desvinculamento da oposição monárquica e mais conservadora, e pela crescente cooperação crítica com os governos republicanos» (Cf. Idem - As Origens da democracia cristã e o salazarismo, ob. cit., p. 265). Até lá prevaleceu a ambiguidade, patente, por exemplo, nos complicados «arranjos» das candidaturas, encaradas com preocupação pelos monárquicos (ver lbidem, p. 273). 
questões de ordem publica, de carácter internacional, de defesa do Poder Executivo contra as intromissões abusivas do Parlamento; e formular as reivindicações essenciais dos católicos para as próximas eleições, em torno das quais deviam agir os candidatos propostos. Dentro destes parâmetros os católicos aceitavam «ligar-se» à maioria governamental, deixando a disputa das minorias aos monárquicos e aos socialistas, com a garantia de poderem assumir no Congresso a sua diferença.

As expectativas dos católicos eram legítimas e excessivas, superando bastante o que a República Nova lhes podia dar, mas, tal como os monárquicos, a mútua conveniência numa aproximação táctica era bem maior que as subjacentes divergências ideológicas e doutrinárias.

Para o Governo era imprescindível «agarran» as forças ditas conservadoras e pô-las a participar no processo político, exigência envenenada pelo abstencionismo republicano: não tardarão, por isso, os católicos e, sobretudo, os monárquicos a reclamarem e a comportarem-se como se fossem o grande ou o único esteio da situação sidonista, corroborando a desconfiança dos partidos republicanos históricos e intimidando os republicanos apoiantes do Governo, entre os quais se erguerão vozes no sentido de um reentendimento com aqueles, o que significava recuar na experiência presidencialista e aceitar um compromisso semi-parlamentarista, previsto claramente por Augusto de Vasconcelos em carta para Egas Moniz, de 17 de Março: É preciso convencer o Sidonio, de que em França e em Inglaterra monarquico português e germanofilo são sinonimos! Por mais que se faça, esta conviç̧ão não se Ihes arranca com a mesma facilidade com que se extrae um molar. E que por isso ele tem que se aproximar dos republicanos, embora com sacrificio de algumas das suas idéas. É esse o dever de todo o homem de Estado, que tem que sacrificar os seus ideaes ás possibilidades praticas, que são imperativas. O Egas é que pode dizer-Iho; se eu tho disser julgar-se-á que é em pro da União. E não é. Sei ver as cousas friamente, muito mais quando estou cá fora daquela fermentação. $E$ estou certo que não me engano.

A rigidez moral, o desvazio messiânico e a alegada falta de um assumido maquiavelismo político tornaram Sidónio Pais incapaz de alterar ou de disfarçar a estratégia de enfrentamento com os democráticos, ficando cada vez mais vulnerável às pressões do núcleo militar da rede, secundado por oficiais apodados de monárquicos propensos a soluções pretorianas, ordeiras e pró-presidencialistas. Por efeito da pressão conspirativa democrática e de uma agitação social crescente foi-se adensando um grave conflito interno que muito contribuiu para a implosão do sidonismo e se estendeu, pelo menos, até ao desfecho da aventura de Monsanto.

Esta evocação ligeira do estertor sidonista não surge, aqui, deslocada. Ela tem muito a ver com o ponto alto e apoteótico da legitimação e da consagração político-institucional da República Nova, porquanto as eleições de 28 de Abril — não nos cansamos de repeti-lo - se possibilitaram, por um lado, a validação de jure de uma situação de facto, marcaram, por outro, o início do confronto final e definitivo com a oposição republicana e, em especial, com os democráticos apostados abertamente na via conspirativa e favorecidos, a partir de determinada altura, pelo desassossego e pelo oportunismo político dos monárquicos/integralistas, infiltrados nas célebres Juntas Militares e implicados no confuso enredo de que elas foram protagonistas pouco antes e logo após a morte violenta de Sidónio Pais. 


\section{As Eleições e seus resultados}

O dia 28 de Abril foi um domingo repleto de sol e de temperatura amena. O Século de 29 de Abril refere que o dia esteve magnifico e, por isso, mais convidativo ao descanso e ao passeio pelos arredores que à afluência massiva às urnas.

O início do acto eleitoral estava previsto para as 9 horas. Em cada Assembleia devia haver todo o material necessário ao acto ${ }^{(423)}$ e três urnas — uma para a eleição do Presidente da República, ao centro a da eleição dos Deputados e a última para Senadores. Não se esperavam, segundo o mesmo periódico, surpresas: a abstenção de democráticos, evolucionistas e unionistas, presentes em várias secções de voto a cumprirem a função fiscalizadora, limitou o universo de eleitores aos partidários do Governo, cujos candidatos disputavam as maiorias, enquanto monárquicos e socialistas ficavam com as minorias, de modo que, se nenhum acontecimento poude perturbar o ato eleitoral, um facto inesperado deu motivo a que nenhuma das assembleas pudesse começar o seu funcionamento á hora regulamentar. Foi o caso que, tendo consignado a lei, ultimamente decretada, que os cargos de presidentes e vice-presidentes das mencionadas assembleas seriam exercidos por vereadores da ultima vereação camararia, estes, na sua quasi totatlidade, republicanos democraticos, unionistas e evolucionistas, não apareceram a constituir as mesas. ${ }^{(424)}$ O repórter anónimo atribuiu a essa disposição legal o que sucedeu em várias mesas: os lugares vagos foram preenchidos ad hoc, segundo o disposto na mesma lei, por indivíduos escolhidos entre si e, por isso, a votação só pôde ser iniciada por volta das II horas, terminando depois das 14 e das 15 horas.

À luz destas notas avulsas merece, igualmente, registo a comparência de militares em largo número nas assembleias eleitorais e o significativo flash do momento em que Sidónio Pais se dirigiu ao seu local de voto - eram cerca de $12 \mathrm{~h} 30 \mathrm{~m}$ quando entrou, acompanhado dos seus Ajudantes, na 3. ${ }^{\text {a }}$ Secção de Belém, a funcionar nos claustros da Casa Pia, depositou o voto e recebeu uma carinhosa manifestação pelos eleitores presentes. Apareceu, em público, vestido de calça escura, casaca preta, camisa de colarinho erguido, gravata e cartola pretas, ostentando, segundo Rocha Martins, um luto recente pela morte do irmão Aureliano, ${ }^{(425)}$ leitura plausível, mas politicamente irrelevante.Apareceu sem farda, significando com tal gesto a sua qualidade de cidadão no uso pleno dos seus direitos numa República de cidadãos, livre e ordeira, popular e nacionalista.

As fotografias e os despachos oficiosos sobre a forma ordeira como estariam a decorrer as eleições não retratam e até disfarçam o clima de grande tensão que envolveu o acto eleitoral à conta, sobretudo, do aguilhão abstencionista e da sabotagem antigovernamental. É que a suave explicação dada pelo repórter de O Século acabou, de algum modo, desmentida pelos diversos casos que o mesmo periódico registou na sua edição de 30 de Abril.

Mas antes de passarmos em revista esses casos de umas eleições ordeiras, embora muito menos tranquilas do que transparece na imprensa noticiosa de âmbito nacional,

\footnotetext{
(423) Eleições de 1918, Lisboa, cx. 215. (Arquivo Histórico-Parlamentar).

(424) Cf. Notas do acto eleitoral. O Seculo, de 29 de Abril de 1918, p. I.

(425) Cf. MARTINS, Rocha - Memorias sobre Sidonio Paes, ob. cit., p. I55- 157.
} 
há que realçar uma evidência que só os jornais afectos ao Governo procuraram atenuar com parangonas triunfalistas tanto mais enfáticas, quanto mais agudo e grave era o efeito de uma abstenção indesmentível, que, aliás, Sidónio Pais mostrou recear imenso, confessando que se nenhuma oposição comparecesse às urnas estava perdido. $E$ daí a tácita aliança com os católicos e o contracto bi-lateral com os monárquicos (estes obrigavam-se a disputar apenas as minorias).

O Jornal da Tarde do dia 30 divulgou, com alguma discrição, os primeiros resultados, sob a epígrafe OActo Eleitoral. É enorme a votação do governo. Por todo o país ha entusiasmo pela vitoria governamental e pela extraordinaria votação que obteve o sr. Presidente da Republica e no número seguinte em letras garrafais e numa tira de texto ocupando o espaço das suas habituais sete colunas proclamava: O Povo Portuguez Confirmou o Triunfo da Revolução. Em Portugal havia um problema a resolver: quem ficaria á frente dos destinos do país - se a demagogia que nos atirava para o abismo, se a grande alma que pulsou em 5 de dezembro, e encarna na figura gloriosa do sr. dr. Sidonio Pais. O povo portugues, pela boca das urnas, fez a escolha, entusiasticamente, dando ao governo da revolução a confirmação de um mandato que Ihe entregara na Rotunda. O povo português salvou a Patria e a Republica, e mostrou que é digno de gloriosos destinos. O dia de ontem ficará, na historia da Republica, como uma data de glorias imorredouras. ${ }^{(426)}$

Por seu turno, A Situação de 29 apareceu com o retrato oficial de Sidónio Pais, fardado, sentado e de perfil, e com palavras de idêntico ufanismo: Triunfou a Republica Nova! Os velhos partidos da Republica deram hontem a sua grande batalha. Simplesmente, julgaram lutar contra um Governo, e quem apareceu foi - uma população inteira. Perderam! O povo executou-os como réus de crime comum. Foi uma batalha! Viva a Patria! Viva a Republica. ${ }^{(427)}$ E esse cariz ufano manteve-se nos números imediatos. No de I de Maio lê-se que: A vitória do governo sobre os abstencionistas é retumbante. A votação do sr. $d r$. Sidonio Paes excede as mais favoraveis espectativas. ${ }^{(428)}$ Mensagem de vitória reforçada dois dias depois: A Votação do Sr. Dr. Sidonio Paes Para Presidente da Republica Está em Meio Milhão de Votos! Em 880.000 eleitores alcança esta formidavel maioria. É necessario frisar porém que n'este recenseamento estavam incluidos os trabalhadores em França e Inglaterra, forças mobilisadas, falecidos depois do recenseamento, ausentes dos concelhos à data das eleições, desertores, homisiados, etc. Sem jogos malabares de numeros, que deixamos para os abstencionistas, nós apresentamos a verdade e perguntamos altivos: Quem duvida ainda do nosso triunfo?.(429) Mensagem, também, de contra-ataque. Prende, por isso, a atenção, no fundo da mesma página, uma fotogravura com a expressão Se Votas Morres, ${ }^{(430)}$ ilustrativa da alegada acção da demagogia e do modo como teria sido feita a campanha abstencionista. Ao lado, a duas colunas e sob a epígrafe AAbstenção... , o jornal dos moços, imitando a imprensa oposicionista, extraiu dos grandes jornais noticiosos os casos demonstrativos já não de uma abstenção gigantesca, mas sim de uma afluência colossal.

(426) Cf. O Povo Portuguez. Jornal da Tarde, 29 de Abril de 1918, p. I.

(427) Cf. Triunfou a Republica Nova! A Situação, de 29 de Abril de 1918, p. I.

(428) Cf. As Eleições em todo o Paiz. A Situação, de I de Maio de 1918, p. 2.

(429) Cf. A Votação do sr. dr. Sidonio Paes. A Situação, de 3 de Maio de 19।8, p. I.

(430) Cf. A Acção da Demagogia. A Situação, de 3 de Maio de 1918, p. I. 
Num tom bem mais sereno, pacífico e imparcial O Século, de 29 de Abril, ao comentar os resultados ainda não definitivos obtidos em Lisboa para as eleições por comparação com as últimas de deputados realizadas em 13 de Junho de 1915 através de sufrágio restrito, verificou que tinham, então, votado 23.964 e em 28 de Abril de 1918, também nos dois círculos de Lisboa e com um universo maior de recenseados - 59.950 eleitores - o número de eleitores atingira os 20.542, menos 3.422 eleitores, donde se conclue que $a$ eleição de hontem foi menos concorrida que $a$ anterior. Pelas noticias que temos recebido de varios pontos do paiz, verifica-se que egualmente na provincia se registou um aumento sensivel de abstenções. Feito o apuramento final, o número de abstenções teria ascendido a 30. 108. Aumento significativo, que a imprensa antigovernamental haveria de acentuar em termos de resultados nacionais, convertendo-o em pesada derrota para - Governo. (431) $^{2}$

Impressões iniludíveis que só um extenso e minucioso confronto com todas as actas de apuramento permitirá confirmar em pleno. Tarefa gigantesca que até agora nenhuma equipa de investigadores assumiu para as eleições realizadas de 191 I a 1925(432) —os dados divulgados por Oliveira Marques ${ }^{(433)}$ foram colhidos apenas na imprensa à luz do pressuposto, válido em geral, de que ela reproduz dados oficiais, prescindindo, por isso, da documentação oficial do Arquivo-Histórico Parlamentar da Assembleia da República. E no respeitante à eleição de 1918 , o facto de não terem concorrido os partidos republicanos históricos foi evocado como pretexto para a omitir nos quadros gerais de evolução eleitoral que esse autor elaborou e que Fernando Farelo Lopes reproduziu no seu estudo.(434)

O rigor da análise a fazer exige, pois, que se cruzem os resultados da imprensa com os oficiais, embora estes padeçam de uma grave limitação formal: nenhuma das actas de apuramento preenchidas ${ }^{(435)}$ contém o número de recenseados, pelo que estes constam sómente dos novos cadernos de recenseamento geralmente arquivados junto das actas, mas organizados às parcelas, sem numeração sequencial e com inúmeros erros no registo e na contagem das descargas - intencionais uns, acidentais outros. Além disso, não conseguimos localizar, no citado Arquivo, a maioria das actas da eleição presidencial, o que nos impediu de confirmar o número de votos em Sidónio Pais que tem vindo a ser divulgado e reproduzido sem contestação, embora os dados recolhidos no Gabinete da Presidência da República possibilitem uma primeira e importante verificação.

A complexidade do tratamento sistemático e exaustivo de tão ampla e confusa informação não nos permite, aqui, avançar com vistosas clarificações, mas apesar de tudo ousamos esboçar uma estimativa provisória e parcial para a abstenção da eleição

(431) Cf. Eleições e numeros. O Norte, de 3 de Maio de 1918, p. I e SILVA, Armando Barreiros Malheiro da - Sidónio e sidonismo. História e mito, vol. 2, dissert. cit., p. 276.

(432) Ver MENEZES, Luis Manuel Machado - As Eleições legislativas de 1921 e 1925 no arquipélago dos Açores. S.l.: Secretaria Regional da Educação e Cultura/Direç̧ão Regional dos Assuntos Culturais, 1992.

(433) Cf. MARQUES, A. H. de Oliveira - História da 1. ${ }^{\circ}$ república portuguesa. As Estruturas de base, ob. cit., p. 616-644; e ldem - Portugal da monarquia para a república, in SERRÃO, Joel e MARQUES, A. H. de Oliveira - Nova história de Portugal, ob. cit., p. 412-429.

(434) Cf. LOPES, Fernando Farelo - Poder politico e caciquismo na 1. ${ }^{\circ}$ república portuguesa, ob. cit., p. 143 - 160.

(435) Consultámos todas as existentes para os 51 círculos eleitorais, o que equivaleu a abrir e a verificar o conteúdo de cerca de duzentas grossas caixas metálicas!... 
dos deputados e dos senadores provinciais, reexaminar o caso paradigmático de Lisboa, onde, segundo Damião Peres, a percentagem dos votantes teria sido apenas de $36 \%$, ${ }^{436)}$ e ilustrar, na medida do possível, as condições anómalas que polvilharam toda a votação, incluindo a dos senadores reservados às categorias profissionais fixadas no decreto de 30 de Março.

À Presidência da República foram chegando, por telegrama, telefone e carta, dias antes da eleição e na sequência desta, informações avulsas que ajudam, pelo menos, a colorir alguns aspectos do processo eleitoral, designadamente as condições da propaganda e os arranjos político-eleitorais efectuados. Assim, o Governador Civil de Ponta Delgada em 22 de Abril telegrafou ao Presidente da República para lhe participar que dera indicações aos candidatos governamentais - um senador e dois deputados - de que seriam aceites pelo partido regional se satisfeitas certas contrapartidas e eventuais substituições de nomes, assunto focado em nota manuscrita a tinta na segunda folha do mesmo telegrama: O Diretorio telegrafou indicando candidatos, mas n'esse telegrama já concedia a faculdade para o Governador alterar qualquer nome como melhor julgasse conveniente. ${ }^{(437)}$ Esta nota confirma, aliás, o interesse do Governo e do P.N.R. em alinharem, nos Açores, com o poderoso Partido Regionalista do monárquico José Maria Raposo do Amaral, mantendo uma postura que Machado Santos, enquanto Ministro do Interior, vincara com absoluta nitidez. ${ }^{(438)}$

De um candidato governamental, Alberto Madureira, irmão de Joaquim Madureira ou Braz Burity, que apresentara candidatura por Bragança, foi recebido um telegrama com data de 17 de Abril, no qual vinha inscrita a seguinte mensagem:Informam-me minha candidatura por Bragança é combatida por elementos de prestigio na republica afirmando eu não pertenço novo partido republica nova. Junto de V. Ex. ${ }^{a}$ protesto contra esses processos caluniosos e uma vez mais manifesto meu leal apoio ao governo e inteira sulidariadade $V$. Ex. ${ }^{a}(439)$

E no próprio dia 28 de Abril Um verdadeiro Portuguez, pseudónimo de um adepto do Governo, adversário confesso dos democráticos, partidário de uma ditadura militar e auto-investido no papel de fiscal do acto eleitoral na sua área geográfica, forneceu, em papel de carta pautado, sem data, nem local (possivelmente Lisboa), ao Presidente da República um retrato curioso do que afiançou ter aí observado:

Acabo de vesitar assembleias eleitoraes e fiquei assombrado do que vi e ouvi!...

Propositadamente não cumpriram o seu dever as autoridades obrigadas por lei a emanciparem os antigos recenseamentos dos vicios democraticos. Os secretarios de Finanças que primeiramente não tinham tempo para nada, calaram-se depois, e se

(436) Cf. PERES, Damião - História de Portugal. Suplemento, ob. cit., p. 179.

(437) Dossier Eleições, telegrama de 22-4-1918. (Arquivo de Sidónio Pais - Militar, Lente e Político, Subsistema Presidência da República).

(438) Ver CORDEIRO, Carlos - Regionalismo e anti-republicanismo (1910-1918): José Maria Raposo do Amaral. Ponta Delgada: Universidade dos Açores, 1995, p. 305-312; e SILVA, Armando Barreiros Malheiro da - Sidónio e sidonismo. História e mito, dissert cit., vol. 2, p. 278.

(439) Dossier Eleições, Telegrama de 17-4-1918. (Arquivo de Sidónio Pais-Militar, Lente e Político, Subsistema Presidência da República). 
deram alguma nota foi de tal modo viciada que o resultado foi ficar o recenseamento com mais votação democratica e unionista.

Na freguesia da Sé nem um dos que requereram foi inscripto tendo ficado tudo em poder do presidente da junta de Parochia. A um deles ouvi contar isto, acrescentando que se tinha queixado ao Presidente da Comissao de Recenseamento Dr. Mourão que nada providenciou.

Parece que tudo isto obedeceu as indicações de Belchior de Figueiredo e socios que assim fizeram uma revolução surda e de maos efeitos moraes.

As votações tem de ser pequenas e se as urnas fossem concorridas pelos democraticos eles venciam pela certa.

Isto esta indisciplinado e as actuaes auctoridades e serventuarios tem mais medo da vingança democratica do que da dos conservadores e assim o resultado é o que se esta vendo.

Portugal só com uma ditadura militar pode entar na estrada legal.

Sinto nao poder findar com o meu nome mas já por experiencia propria sei os precalços que tal franqueza causa e assim só afirmarei ser

Um verdadeiro Portuguez. ${ }^{(440)}$

Interessante miniatura pintada por um adepto, metida e esquecida entre papéis mais sérios e credíveis, tais como os telegramas dos Governos Civis com resultados e ocorrências.

De Viana do Castelo, o Governador Civil Aires de Abreu, eufórico, participava ao Presidente da República, em I de Maio (aniversário de Sidónio Pais), que a votação presidencial no distrito atingira uns redondos 15.833 votos e explicava que o número só não foi maior porque havia muitos eleitores ausentes no front, em África e elevada percentagem de desertores. Fora essas abstenções insignificantes declarava ter-se registado o maior triunfo do prestigio do governo. Viva o Dr. Sidonio Paes. Viva a Republica Nova. ${ }^{(441)}$

Mais comedido, o colega de Faro limitou-se a participar, também a I de Maio, que a votação presidencial no distrito fora de 13.763.

Nesse mesmo dia o colega deVila Real, dr. Ramiro Augusto de Figueiredo, em incontidos assomos de ira contra o candidato monárquico eleito, reagia ao que acabara de ler nos jornais: José de Azevedo Castelo Branco, amigo pessoal de Eurico Cameira, ${ }^{(442)}$ difundira pela imprensa um telegrama declarando se vitima ele o despejado traficante que faltando canalhamente ao acordo feito levou a maioria e se preparava para levar tambem a minoria que levaria não sendo auxilio dos republicanos termina dizendo sua vida correr grave perigo tumultos. Desminto formalmente esse embusteiro pela minha honra garanto V. Ex. ${ }^{o}$ não houve ameaças nem esboço sequer alteração ordem. Ex.mo coronel Ramos que aqui veío poderá informar devidamente. ${ }^{(443)}$ Uns dias depois - a 5 de Maio - despachou, finalmente, os resultados oficiais e definitivos do apuramento pelo círculo $n$. $^{\circ}$ : José

(440) Dossier Eleições, carta s.d. [Lisboa]. (Arquivo de Sidónio Pais - Militar, Lente e Político, Subsistema Presidência da República).

(441) Ibidem, telegrama do Governador Civil de Viana do Castelo, 1-5-1918

(442) Ibidem, dossier Cartas, carta s.d.

(443) Ibidem, telegrama do Governador Civil de Vila Real, I-5-1918. 
Azevedo Castelo Branco 8.917 e Camilo Castelo Branco com 8.825, ambos monárquicos; o governamental joão Baptista Araújo com 1.417; pelo círculo n. 6 (Chaves) o capitão Eurico Cameira obtivera I I.622 e o dr. Carlos Alberto Barbosa II.484 votos contra os 7.763 do monárquico Lobo d'Ávila; e para o Senado haviam sido eleitos os quatro candidatos governamentais pela província de Trás-os-Montes e o $2 .^{\circ}$ Conde de Mangualde e senhor do conhecido Solar de Mateus (Vila Real), Fernando de Almeida Cardoso e Albuquerque, monárquico.(444)

Exceptuadas estas singularidades, a restante documentação reunida no dossier Eleições consiste em telegramas de felicitações - umas largas dezenas em toada de geral triunfalismo e de mimética consagração, quebrada, aqui e além, pelo registo dos resultados parciais ou completos de determinados círculos. ${ }^{(445)}$

A votação ocorrida ficou envolta até hoje em cifras difusas e sujeitas a rijos antagonismos: os adeptos procuraram empolá-las e os adversários tentaram diminuí-las nos seus contornos de concludente vitória.

Pelo meio acha-se, talvez, o necessário ponto de equilibrio: numa população de 6.032.991 indivíduos (segundo o Censo de 1920) e para um universo eleitoral de 880.000 recenseados maiores de 21 anos, analfabetos incluídos (adoptamos o valor fornecido pel'O Seculo e não os arredondados 900.000 de Oliveira Marques), ${ }^{(446)}$ a votação presidencial no continente, ilhas e colónias, teria sido, conforme corre publicado, de $513.958,{ }^{(447)}$ o que perfaz uns $58,4 \%$ relativamente ao número de recenseados, mas se nos ativermos ao valor de 473.789, anotado numa folha dactiloscrita com o cômputo parcial de resultados apurados pelo Ministério do Interior e revistos no Gabinete da Presidência da República ${ }^{(448)}$ até 3 de Maio e ainda sem os votos da Horta e das colónias, a percentagem baixa para os 53,8\%. (Ver tabela na página seguinte).

No Arquivo Histórico-Parlamentar conseguimos encontrar apenas a acta da votação obtida em Moçambique - 618 votos - e na Índia - 50 - que somados aos 473.789 eleva o resultado para os 474.457 votos. Um resultado parcial que difere dos 468.275 votos, também parcelares, proclamados oficialmente pela Comissão Central de Apuramento em edital de 8 de Maio, mas a apontarem já para o relativo desafogo da eleição presidencial, que foi menos penalizada pela abstenção que a do Congresso.

No entanto, quem vê resultados não vê as diferentes motivações e condutas eleitorais que atrás deles se escondem, cobertas pela poeira do tempo. Convém, por isso, desafiar a tendência do esquecimento, selectivo sempre e voluntário tantas vezes, seguindo com o olhar a malha de círculos eleitorais desfiada na imprensa noticiosa mais credível e

(444) Ver Nobreza de Portugal, vol. 2, ob. cit., p. 717-718.

(445) Dossier Eleições, telegramas de felicitações.Ver também SILVA,Armando Barreiros Malheiro da - Sidónio e sidonismo. História e mito, dissert. cit., vol. 2, p. 281-283. (Arquivo de Sidónio Pais - Militar, Lente e Político, Subsistema Presidência da República).

(446) Cf. MARQUES, A. H. de Oliveira - História da 1. ${ }^{\circ}$ república portuguesa. As Estruturas de base, ob. cit., p. 6I0; e Idem - Portugal da monarquia para a república, in SERRÃO, Joel e MARQUES, A. H. de Oliveira - Nova história de Portugal, ob. cit., p. 422.

(447) Cf. PERES, Damião - Histório de Portugal. Suplemento, ob. cit., p. 179.

(448) Dossier Eleições, I fl. dactiloscrita com anotações ms., s.d. (Arquivo de Sidónio Pais - Militar, Lente e Político, Subsistema Presidência da República). 


$\begin{array}{lc}\text { Angra } & 9.185 \\ \text { Aveiro } & 35.528 \\ \text { Beja } & 5.930 \\ \text { Braga } & 51.199 \\ \text { Bragança } & 20.000 \\ \text { Castelo Branco } & 25.000 \\ \text { Coimbra } & 29.000 \\ \text { Évora } & 8.555 \\ \text { Faro } & 13.763 \\ \text { Funchal } & 17.852 \\ \text { Guarda } & 15.000 \\ \text { Leiria } & 18.369 \\ \text { Lisboa } & 50.000 \\ \text { Ponta Delgada } & 5.000 \\ \text { Portalegre } & 12.888 \\ \text { Porto } & 48.000 \\ \text { Santarem } & 25.000 \\ \text { Viana do Castelo } & 15.833 \\ \text { Vila Real } & 27.687 \\ \text { Viseu } & 40.000 \\ & (449) \\ & \end{array}$

circunspecta. Itinerário irregular e incompleto, que um punhado de casos extraídos da documentação oficial permite conhecer com mais algum detalhe e precisão.

Indo de Norte para Sul partamos de Braga, onde todas as assembleias da cidade tinham sido apuradas em 30 de Abril à excepção das de S.Victor, porque aí se registara cerca das 19 horas um conflito motivado pela entrada de um grupo de populares na sala da Escola Primária onde decorrera a votação: foi disparado um tiro que atingira Manuel Clemente Barbosa (a bala entrou pelo abdómen e saiu pelas costas), estimado negociante e proprietário e membro da Mesa, sendo presos, na sequência desse atentado, cinco operários, alguns socialistas, fugindo outros.

Em Sabrosa, círculo 5 de Vila Real, o acto fora muito concorrido e nesse concelho, como nos restantes dessa circunscrição eleitoral, as candidaturas monárquicas su-

(449) Estes dados parciais foram fornecidos para publicação ao jornal A Situação, que os reproduziu aumentando o valor de Ponta Delgada de 5.000 votos para 12.500 e mantendo o número inicial de 21.293 incritos na cópia procedente da Presidência da República, sem ter em conta a posterior subtração de 5.460 votos. Estas discrepâncias explicam que o total publicado seja de 486.749 contra os 473.789 do original conservado no Dossier Eleições. (Arquivo de Sidónio Pais - Militar, Lente e Político, Subsistema Presidência da República). 
plantaram as governamentais em consequência - noticiava $O$ Seculo - do alegado rompimento do Governador Civil com os independentes e os monárquicos, mas por ele explicado como ignóbil traição de José de Azevedo Castelo Branco, no acima citado, telegrama para o Presidente da República.

Em Chaves, na urna para a eleição presidencial, apareceram 50 listas abertas que, depois de dúvidas levantadas, a Mesa decidiu incluir na contagem, embora não conferissem com as descargas.

Em Montalegre terá havido apenas abstenção por parte dos democráticos e dos evolucionistas, enquanto os católicos votaram nas listas governamentais.

Em Murça constou só terem concorrido os amigos do Governo, abstendo-se evolucionistas, democráticos e unionistas, mas em Boticas alguns antigos democráticos deram nas vistas por deitarem listas na urna do Presidente da República.

Em contraste com tal atitude surgiram as 1.000 abstenções em Miranda do Douro e as 1.988 do Vimioso, onde mesmo assim Sidónio Pais conseguiu arrecadar 500 e 611 votos respectivamente.

Número mais elevado - 757 — obteve em Freixo de Espada-à-Cinta, onde a votação para senadores e deputados foi também expressiva, havendo grande regozijo pela vitoria governamental sobre a oposição que recomendava abstenção.

Descendo para o litoral duriense, mais precisamente na Póvoa de Varzim, a eleição foi fiscalizada e uma maioria de recenseados concorreu à urna.

No concelho da Vila da Feira, círculo 14 de Oliveira de Azeméis, a abstenção terá sido completa de democráticos, evolucionistas e camachistas e em Arouca as assembleias funcionaram concorridíssimas, o sossêgo e a legalidade completas, presumindo-se a vitória da lista governamental.

Em Vouzela não houve luta nas assembleias e a fiscalização foi assumida por democráticos e socialistas.

Rumando do litoral para a Beira interior salta logo a notícia de que em Cinfães houve uma enorme votação nas listas do Governo, mas no concelho de Figueira de Castelo Rodrigo, distrito e círculo 17 da Guarda, subiram bastante as abstenções, ultrapassando o milhar. Todavia não tão altas como as ocorridas em Cantanhede, onde só foram às urnas $1 / 5$ dos eleitores recenseados.

Valores mais baixos, embora confirmando a tendência abstencionista, reportam-se a Coimbra, em cujas assembleias urbanas a abstenção, comparada com as eleições de 1915, aumentou cerca de 200 votos e em Santa Cruz, na urna presidencial, D. Manuel II teve um voto e o dr. Afonso Costa outro.

Mais para Sul, em Castelo Branco, Cunha Leal e Miguel Crespo asseguraram as maiorias sem problemas, disputando o monárquico João Trigueiros Frazão as minorias e os católicos drs. José Ribeiro Cardoso e Domingos Pacheco de Amorim, sintonizados com a maioria, cumpriram uma boa prestação.

$\mathrm{Na}$ Covilhã os candidatos socialistas Adolfo Ferreira da Silva e José Ramalho conseguiram 125 e 122 votos cada.

No Fundão as urnas foram pouco concorridas, em Peniche a assembleia da vila não constituiu Mesa por falta de eleitores e em Mira, de 1.978 recenseados só votaram 350 nas listas governamentais e monárquicas. Mas, em contrapartida, Leiria registou um grande triunfo governamental com intensa afluência às urnas e na melhor ordem. 
Em Figueiró dos Vinhos entraram 502 votos, tendo vencido as listas governamentais e católicas patrocinadas por unionistas e evolucionistas, sem o que a urna ficaria deserta.

Deserta ficou, de facto, a assembleia de Passos, em Alvaiázere, não aparecendo ninguém para constituir Mesa. E o mesmo sucedeu no Cartaxo por falta de comparência do Presidente da Mesa com os cadernos e mais documentos necessários ao acto.

Situação bem diversa ocorreu no Sardoal, onde mais de 300 indivíduos se apresentaram para votar, o que não puderam fazer por não constarem do caderno de recenseamento. Notório e suspeito empenho em votar, que não teve paralelo em Grândola - aí o acto eleitoral realizou-se no meio de geral indiferença, tendo só entrado na urna 17 listas!

Em Alcáçovas, Évora, a indiferença teve outro nome - não chegou a aparecer número suficiente de eleitores para a constituição da Mesa. E o mesmo ocorreu nas assembleias de Corte de Pinto e Sant'Ana de Cambes, em Mértola.

Noutras localidades alentejanas as Mesas constituíram-se, mas as abstenções subiram bastante, registando-se, também, o inverso, ou seja, na freguesia de S. Salvador de Beja concorreram centos de eleitores não se realizando a eleição por um incidente ocorrido na mesa de assembleia.

Por fim, no Algarve, mais precisamente na freguesia de Alte, concelho de Loulé, mal o Presidente da Assembleia entrou na sala onde devia realizar-se a eleição grande multidão de povo prorompeu sempre que se pretendia iniciar os trabalhos não havendo quem se prestasse a fazer parte da mesa. Uma atitude obstrucionista que em Silves assumiu outros contornos: o povo republicano de Silves acordou na abstenção absoluta mas compareceu ao acto eleitoral para fiscalisação. Os elementos do Governo e monarquicos não compareceram faltando o presidente da assembleia eleitoral e respectivos cadernos. Os republicanos constituíram a mesa lavrando actas de não eleição, decorrendo tudo na melhor ordem.

A esta resenha intencionalmente impressionista podemos ainda juntar a exposição de alguns casos ou incidentes lavrados nas actas oficiais e noutras fontes institucionais, escolhidos sem outro intuito que não seja o de permitir caracterizar um pouco mais a atmosfera e o modo como se processou o acto legitimador da República Nova.

Seguindo a mesma trajectória principiamos no círculo n. 3 de Braga, onde o candidato independente Guilherme Lopes de Azevedo, major de Infantaria e Governador Civil do Porto entre 26 de Janeiro e 27 de Março de 1918, protestou contra a validade da eleição para deputados nesse círculo, argumentando que entre o Governador Civil de Braga, bacharel José Féria Dórdio Teotónio, e o Centro Católico da mesma cidade fora realizado um acordo, na semana anterior à data das eleições, para fazer vingar a eleição dos três candidatos da lista governamental e do católico indicado pelo referido Centro. Ao abrigo de tal acordo ousou, convertido em centro político nas palavras do reclamante, exercer toda a sua influência sobre os párocos e os párocos sobre os fiéis de molde a ser eleita a lista combinada e em detrimento da candidatura independente. Informações recebidas e cuja veracidade poderia ser apurada por inquérito oficial, em duas freguesias do concelho da Póvoa de Lanhoso os párocos, na missa dominical do próprio dia das eleições, recomendaram aos assistentes que não votassem no nome do signatário do protesto. 
Às portas de todas as assembleias da cidade de Braga, enquanto durou a votação, estiveram padres passando e trocando listas sem que as autoridades procurassem obstar a tais abusos, proibidos pelo artigo 50 da lei eleitoral. Soube, também, o signatário que na véspera e no próprio dia 28 haviam sido distribuídos, na feira deVila Verde, milhares de exemplares de um pasquim de que juntava cópia e no qual se dizia ser o candidato independente mação da Loja Luz e Progresso, pretendendo-se com essas falsas acusações desviar votos n'um meio essencialmente religioso. Esse pasquim conservou-se afixado nas paredes da cidade durante todo o dia 28 perante a passividade dos agentes policiais, quando Ihes competia agir de acordo com o disposto nos artigos 180 e 189 da lei eleitoral.

Prosseguindo nas suas alegações, o signatário mais informa que na ante-véspera da eleição foi chamado ao Governo Civil de Braga o Secretário da Administração do concelho deVila Verde, Avelino Peixoto, influente eleitoral de grande valor n'aquele concelho e amigo do signatario e aí intimado a não trabalhar a favor da referida candidatura, do que resultou o desvio da votação, não só desse influente, mas de outros, que lhe estavam ligados, e que receiaram comprometer o Avelino Peixoto se votassem no signatario.

Com o mesmo intuito de se prejudicar a eleição do candidato independente fora dissolvida a Comissão Municipal de Amares, na semana anterior ao acto eleitoral, e demitido o Administrador do Concelho sem que para tais procedimentos fosse apresentada qualquer justificação plausível. Além destas manobras preparatórias havia a registar atitudes ilícitas praticadas durante o processo eleitoral.

$\mathrm{Na}$ freguesia da Lage, concelho de Vila Verde, não tendo terminado a eleição, as urnas não foram lacradas, nem tão pouco fechadas em cofre, negligência grave que deu azo, de noite, à entrada na sala de um grupo de indivíduos capitaneado pelo padre de nome Pandilha, representante da autoridade naquela assembleia, que se entreteve a lançar nas urnas de deputados e de senadores uma grande quantidade de listas a favor dos candidatos governamentais e católico. E nessa mesma freguesia, assim como na da Loureira não se apresentaram a votar, embora fossem descarregadas nos cadernos umas dezenas de eleitores. ${ }^{(450)}$ Junto ao protesto o signatário anexou vários documentos (declarações de testemunhas, uma carta de Avelino Peixoto e outras provas) em reforço da sua pretensão, que acabou arquivada nos maços da Comissão Geral de Apuramento.

Para o que se terá passado na cidade do Porto temos o breve e suspeito depoimento epistolográfico do Presidente da Câmara Municipal, Artur Jorge Guimarães, que ousou até extrapolar as suas impressões para todo o país: Esta eleição presidente da República tem um valor especial porque foi certamente por todo o paiz uma coisa seria como foi aqui

170 e ninguém pediu votos. Os que foram às urnas foram expontaneamente, não havia maquina eleitoral montada e aqui até muita gente deixou de votar por não ter listas. É isto que tenho respondido aquêles que queriam vêr uma votação maior. Grande foi ela atendendo ao feitio dos portuguezes e ás condições das eleições.

$\mathrm{Na}$ Escola de Sexo Feminino de Oliveira do Conde, círculo 15 deViseu, compareceu, pelas nove horas, o cidadão José Rodrigues para presidir à respectiva mesa eleitoral e aí esperou até às I I horas, mas não houve número suficiente de eleitores, pelo que o

(450) Eleições legislativas de 1918, cx. 169. (Arquivo Histórico-Parlamentar). 
dito Presidente, em vista do disposto no artigo $42{ }^{\circ}$ da lei eleitoral, foi forçado a mandar lavrar um auto de não eleição. ${ }^{(451)}$

Não muito longe, no concelho de Trancoso, círculo n. ${ }^{\circ} 18$ de Gouveia, os dois candidatos monárquicos, José Pereira dos Santos Cabral, advogado, e Francisco de Assis Teixeira de Magalhães e Meneses, proprietário, protestaram contra a forma atrabiliária e ilegal como se efectuou essa eleição em todas as assembleias eleitorais do dito concelho e anexaram provas documentais dos atropelos cometidos: a falta de ressalvas em rasuras feitas nas descargas dos cadernos eleitorais; a coexistência nos mesmos cadernos de rubricas do mesmo escrutinador com caligrafia a tinta aparentemente diferentes, o que deixava supor não terem sido feitas pela mesma mão e na mesma data; a falsificação das descargas em todos os cadernos eleitorais, pois que em todas as assembleias do alludido concelho votou efectivamente apenas uma insignificantissima parte do eleitorado; e essas descargas foram praticadas em alguns cadernos com tal precipitação e zelo que até as próprias linhas em branco chegaram a receber a respectiva nota de descarga!... ${ }^{(452)}$

Em relação ao círculo 24 de Alcobaça temos notícia do não funcionamento de uma ou outra Assembleia eleitoral: na freguesia de Amoreira, concelho de Óbidos, fez-se auto de não eleição, onde se diz que tendo-se esperado até às II horas e não aparecendo eleitores em número suficiente para compor a Mesa, não teve o previsto acto eleitoral;e numa assembleia primária do concelho de Alcobaça, o cidadão nomeado seu presidente, Jacinto Coelho Amaral defendeu-se da acusação formulada por dezanove eleitores de que ele abandonara o local da eleição para que a mesma se não realizasse, alegando o acusado que esteve efetivamente das noves ás dez no local designado para se proceder á eleição; considerando que se não mais se demorou foi porque desconhecia que deveria demorar-se mais tempo o que alias é constatado não só pelo representante da autoridade mas tambem pelo cidadão Antonio de Alcantara Costa, que com aquele assinou a declaração do presidente da meza. ${ }^{(453)}$.

A obstrução eleitoral por falta de comparência dos portadores das actas e de mais documentos indispensáveis à eleição ocorreu na sede do concelho de Alcanena, círculo 25 de Santarém, enquanto na Chamusca, três eleitores subscreveram um protesto por não terem sido cumpridas as formalidades fixadas pelo decreto eleitoral, designadamente a fixação dos cadernos do respectivo recenseamento, ao que a Mesa da respectiva assembleia retorquiu, sacudindo eventuais responsabilidades: se tal falta se deu —o que não estava provado - ela nada tinha a ver com o acto eleitoral em curso pois constituía um procedimento anterior ao qual a Mesa era de todo alheia. ${ }^{(454)}$.

llegalidades de outro tipo foram evocadas numa moção-protesto subscrita pelo professor Manuel Domingos Godinho na sala das sessões eleitorais da sede do círculo 26 de Tomar, com data de 5 de Maio. Segundo ele, nas eleições de 28 de Abril foram distribuídas listas ás portas das assembleias eleitorais; noutros locais de votação do con-

(451) Eleições legislativas de 1918, cx. 195. (Arquivo Histórico-Parlamentar).

(452) Ver SILVA, Armando Barreiros Malheiro da - Sidónio e sidonismo. História e mito, dissert. cit., vol. 2. p. 288-289.

(453) Eleiçōes legislativas de 1918, c×.210. (Arquivo Histórico-Parlamentar).

(454) Ibidem, cx. 211. 
celho de Tomar, nomeadamente na Assembleia de Ferreira, homens pagos ao serviço do Governo, dos monárquicos e dos católicos, abusando da inconsciencia do eleitorado analfabeto, trocaram listas o que constitui um crime grave e não respeitaram as limitações do eleitor analfabeto, que precisa muito mais tempo para se informar dos nomes dos candidatos e da sua orientação no parlamento do que os letrados, e que, na maioria das assembleias primarias deste circulo eleitoral, elas Ihe foram distribuidas no proprio dia, á porta e algumas nas salas eleitorais; e as descargas eleitorais de algumas assembleias primárias não estavam em harmonia com o número de listas entradas. Propunha, a rematar o seu protesto, que nas assembleias onde houve qualquer irregularidade fosse anulado e repetido o acto eleitoral com os mesmos membros da Mesa e novos cadernos eleitorais e que as oposições, todos os cidadãos, exerçam uma vigilancia rigorosamente moralisadora. ${ }^{(455)}$

Em Lisboa, círculo 28 ( $3 .^{\circ}$ e $4 .^{\circ}$ bairros), o candidato monárquico António de Sousa Horta Sarmento Osório foi eleito deputado, mas viu a sua inelegibilidade invocada perante a 2. ${ }^{a}$ Comissão de verificação de poderes por um outro candidato do mesmo círculo baseado no facto de pertencer ao Conselho Fiscal da Companhia dos Caminhos-de-Ferro Portugueses e ser essa Companhia subsidiada pelo Estado. $O$ visado procurou, contudo, mostrar ao longo de uma extensa exposição que a C.P. não era subsidiada do Estado e que, face à lei em vigor, não se verificava a imputável incompatibilidade para efeitos do exercício das funções de deputados e senadores.

Mais para Sul, em Ervedal e em Figueira de Barros, concelho de Avis, círculo n. ${ }^{\circ} 33$ de Elvas, catorze cidadãos eleitores da 2. ${ }^{a}$ Assembleia protestaram contra o facto de se não ter constituído Mesa no dia 28 de Abril, obstando a que, pelo menos, duzentos eleitores não exercessem um direito constitucional. Com efeito, foi lavrado auto de não eleição quando se achavam na sala cincoenta eleitores, número mais que suficiente para se formar Mesa, e cerca de quinze minutos antes das onze horas, ou seja, dentro das duas horas de tolerância prescrita por lei. Tratara-se, pois, de um premeditado impedimento do acto eleitoral e que o cidadão José Pais de Vasconcelos Abranches já levava na algibeira a cópia do mesmo auto para rapidamente ser redigido e assinado.(456)

Por seu turno, em Mértola, círculo 36 de Beja, não se efectuou o acto eleitoral nas assembleias primárias de Sant'Ana de Cambas e da Corte Pinto, o mesmo sucedendo nas freguesias de S. Matias, S. Salvador e S. João Baptista, que compunham a Assembleia do Salvador da cidade de Beja.

Para a eleição de senadores pela província do Algarve havia a registar, conforme consta do protesto apresentado por Marcelino António Maria Franco, mandatário do candidato católico Domingos Pinto Coelho, uma série de irregularidades: na freguesia de Estoi não se cumpriu o envio da terceira cópia da acta para o Presidente da Câmara Municipal do respectivo concelho segundo o disposto no $\S 3 .^{\circ}$ do artigo 77 do decreto eleitoral, além de que a própria acta foi completamente viciada por conter rasuras sem ressalvas e estar escrita com letra e tinta diferentes na parte relativa às votações de cada um dos candidatos; na assembleia da Comissão Provincial de Apuramento apareceram maços contendo actas e documentos mal lacrados e abertos ou sem rubricas; alguns

(455) Eleições legislativas de 1918, cx.213. (Arquivo Histórico-Parlamentar).

(456) Ibidem, cx. 226. 
desses documentos chegaram à posse da dita Comissão pela mão de polícias, que as trouxeram das Repartições do Governo Civil de Faro; a acta da Assembleia da Luz do concelho de Tavira foi lavrada posteriormente ao acto eleitoral e reduzida a votação do reclamante em quatrocentos e dois votos; e apurou-se a votação no candidato Eduardo dos Santos, quando tal não devia fazer-se por ele ser juiz do Tribunal da Relação de Lisboa que abarcava a província eleitoral do Algarve. Ponderando sobre os argumentos expedidos, a Comissão de Verificação de Poderes, de cinco membros, reunida em 16 de Julho, considerou-os juridicamente improcedentes, validando a eleição.

Do Ultramar chegaram também protestos e anomalias eleitorais.

No círculo 46 de Moçambique ocorreu a interrupção dos trabalhos eleitorais para que os eleitores pudessem ir almoçar, retomando o acto depois da refeição, o que levantou suspeitas de irregularidade e motivou protesto formal. A eleição ficou por realizar na Assembleia de Chinde. No círculo 48 de S. Tomé e Princípe quem protestou foi o candidato Carlos Frederico de Sousa e Almeida contra o facto de ter sido proclamado eleito deputado João Monteiro de Castro, socialista da Liga Africana, porque: I. $^{\circ}$ - o candidato eleito residia em Lisboa na rua Filipe Folque e, por isso, devia ter apresentado a sua declaração de candidatura a deputado perante o Secretário Geral do Ministério das Colónias e não ao Juiz de Direito da I. ${ }^{a}$ vara da Comarca de S. Tomé e Príncipe, como foi feito sem estar devidamente instruída; $2^{\circ}$ - a certidão de nascimento incluída junto da declaração de candidatura correspondia a um original de assento paroquial não assinado pelo respectivo pároco; e $3 .^{\circ}$ - que o signatário do protesto obteve maior votação que o candidato proclamado eleito e instruira a sua candidatura de acordo com as disposições legais. Finalmente, no círculo $n .^{\circ} 50$ de Macau era a elegibilidade do candidato dr. Carlos de Melo Leitão para senador posta em causa no protesto do advogado e eleitor António Júlio Guimarães Lobato pelo motivo de ser tabelião privativo de notas na sede da referida comarca de Macau. ${ }^{(457)}$

Fraudes e incidentes eleitorais que seria interessante comparar com ocorrências similares lavradas oficialmente e relativas às restantes eleições da I. ${ }^{a}$ República. Exame comparativo, que se algum dia vier a ser feito poderá, talvez, confirmar a trivialidade do recurso a velhos expedientes no arranjo dos resultados finais. Um recurso tão trivial e tão geralmente aceite como inevitável, embora muito censurado para consumo da opinião pública e das elites pensantes, que ninguém se atrevia, afinal, a convertê-lo em base necessária e suficiente da anulação desses processos eleitorais sujeitos à tradicional prática da chapelada que Júlio Dinis consagrou como sugestivo tópico literário do romance oitocentista na sua célebre Morgadinha dos Canaviais. ${ }^{(458)}$

Irregularidades e abstencionismo à parte, a consumação de um acto eleitoral, pela primeira vez duplo, isto é, presidencial e legislativo, garantia à situação o indispensável reconhecimento internacional de jure que, a pedido do Governo ditatorial, os Chefes de Legação nas principais capitais europeias e no Novo Mundo bem se esforçaram por alcançar logo após o golpe dezembrista, mas sem sombra de êxito.

(457) Eleições legislativas de 1918, × .244. (Arquivo Histórico-Parlamentar).

(458) Cf. DINIS, Júlio - A Morgadinha dos Canaviais. Crónica da aldeia. Porto: Livraria Civilização, 1970. p. $366-384$. 
Volvidos uns meses, o almejado aval da comunidade política internacional estava, finalmente, assegurado e com ele a República Nova entrava num estádio incipiente de institucionalização legitimada, imperfeita e incompleta, mas inscrita no primado democrático da soberania popular expressa em votos. À luz desse princípio os resultados eleitorais vinham selar a metamorfose da ditadura para um regime legítimo, mas ainda sem Constituição aprovada pela Assembleia Constituinte, sem um Congresso a funcionar no pleno gozo das suas atribuições legislativas e até sem as normais garantias de um Estado de direito por efeito da promulgação da lei do estado de sítio na sequência da revolta falhada do 12 de Outubro. Limitações suficientes na época para que logo se falasse de ditadura: o próprio Sidónio antes do dia 22 de Julho, data da abertura solene do Congresso da República Nova, admitiu estar ainda em ditadura e João Telo de Magalhães Colaço classificou, num pequeno volume de 1926, o arranque de Sidonio Pais, em 1918, como uma longa ditadura, ${ }^{(459)}$ situada à margem de um novo dispositivo constitucional. No entanto, este óbice é, em rigor, insuficiente para retirar capacidade legitimadora à função eleitoral.

Urge, pois, atender aos resultados oficiais da eleição para a Câmara dos Deputados e para o Senado, ${ }^{(460)}$ tanto na sua representação provincial, como na especializada. $E$ quanto aos senadores eleitos pelas categorias profissionais atrás especificadas convém referir, desde já, que os respectivos actos eleitorais não foram concluídos antes de 6 de Maio, como se verifica pelas actas de eleição enviadas à Comissão de Verificação de Poderes do novo Congresso.

Pela Agricultura deviam ser eleitos dez senadores e, de facto, há registo de que a Associação Central da Agricultura Portuguesa, a Liga Agrária do Norte, a Associação dos Proprietários e Agricultores do Norte de Portugal e os Sindicatos e demais Associações do sector se reuniram, com um número muito expressivo de sócios e de delegados, para esse efeito, exprimindo, sem dúvida, a adesão dos associados à situação política vigente.

A Associação Central convocou, pela segunda vez, para o dia 5 de Maio, os seus associados a fim de, em assembleia geral, cumprir a eleição de três senadores, o que foi possível por se achar presente um grande número de sócios e de acordo com a seguinte formalidade: constituída a Mesa, cuja presidência era assumida pelo Presidente da Assembleia Geral da dita Associação, procedeu-se a duas chamadas dos sócios inscritos e à medida que os sócios iam votando efectuou-se a competente descarga nos cadernos. No fim da votação verificou-se terem entrado nas urnas 172 listas distribuídas deste modo: José António de Oliveira Soares com 164 votos; Luís Xavier da Gama com 130 votos; Dr. Pedro Ferreira dos Santos com 167 votos; Joaquim de Xavier de Figueiredo e Melo Oriol Pena com 45 votos; José Relvas com I voto; Gonçalo Pereira da Silva de Sousa e Menezes, Conde de Bertiandos, com I voto; e Dr. Artur Cambôa Rivara com I voto. E face aos resultados obitos ficaram eleitos os três primeiros. A estes três senadores apurados há ainda que somar os dois que a Liga Agrária do Norte, reunida em

${ }^{(459)}$ Cf. COLAÇO, João Telo de Magalhães - Da Vida pública portuguêsa. Vol. 2 - Conservadores e radicais, ob. cit., p. 101.

(460) Eleições Legislativas de 1918, cxs. 168-244. (Arquivo Histórico-Parlamentar). 
assembleia geral extraordinária de 29 de Abril, escolheu com o concurso de oitenta e três associados, a saber: D. José Freire de Serpa Leitão Pimentel e Dr. Júlio de Campos Melo e Matos (ambos com 83 votos). E a estes eleitos há que juntar o da Associação dos Proprietários do Norte: os seus associados, em número de duzentos e catorze e reunidos em 6 de Maio, votaram para seu representante o proprietário e agricultor José Novais da Cunha. Por fim, os delegados dos Sindicatos e das Associações Agrícolas do continente reunidos em 5 de Maio, na cidade de Lisboa, sob a presidência do Conde de Bertiandos, eleito por unanimidade para esse fim, escolheram os seus quatro senadores: dr. Alberto Carlos de Magalhães e Menezes (Sindicato de Braga), Luís Caetano Pereira da Costa Luz ou Visconde de Coruche (Sindicato de Montemor-o-Novo), dr.Afonso de Melo Pinto Veloso (Sindicatos de Cabanas, Tondela e Oliveira do Hospital,Vila de Tazem e Carregal do Sal) e dr.Tiago César Moreira Sales (Sindicatos da Lourinhã e Alenquer). Mas a eleição não foi pacífica: António Pires Martinho de Brito, delegado do Sindicato de Abrunheira, apresentou um protesto contra a admissão à votação de delegados nomeados por telegrama, procedimento taxativamente contrário às disposições legais em vigor; e Marcos Adriano da Silva Bentes, delegado dos Sindicatos de Beja, Moura e Almodovar, reclamou contra a proclamação dos quatro referidos senadores porque, sendo condição essencial para ser eleito o ter estado presente no acto da eleição tomando parte na assembleia dos respectivos delegados (artigo 133. da lei eleitoral), os candidatos dr.Alberto Magalhães e Menezes eVisconde de Coruche não constavam da acta da mesma eleição, não provaram terem sido eleitos delegados por voto secreto de qualquer Sindicato ou Associação Agrícola e não apresentaram documentos bastantes para provar que os seus pretensos Sindicatos ou Associações tinham o capital mínimo de $3.000 \$ 00$ ou a totalidade mínima de 1.000 sócios (artigo 134. ${ }^{\circ}$ ). E, tal como outros protestos, também este não foi julgado atendivel pela Comissão de Verificação, embora o nome de Alberto Carlos de Magalhães e Menezes não conste da lista definitiva de senadores.

À Indústria cabiam por lei cinco senadores: um pela Associação Industrial Portuguesa, que, em assembleia geral de 28 de Abril, estando presentes sessenta e dois sócios, elegeu por unanimidade Alfredo da Silva, Director da dita Associação e Administrador da C.U.F., o qual prometeu considerar-se, entrando no Parlamento, simplesmente um representante da classe industrial; outro pela Associação Industrial Portuense; e três pelos Sindicatos e Associações de Classe. Mas, à excepção da primeira, as restantes associações alhearam-se, porventura à maneira de boicote, do processo eleitoral, ficando por preencher quatro lugares.

No Comércio, com direito a quatro senadores, conhecemos apenas a participação das Associações Comerciais de Lojistas de Lisboa e do Porto, que, em 5 de Maio, através dos seus treze delegados reunidos em Lisboa, elegeram, com o mesmo número de votos (seis), Bernardo Guimarães e João José da Costa, ambos de Lisboa, sendo este último eleito senador por sorteio. Os restantes organismos associativos do sector não terão votado os seus representantes no Senado, por razões que não conhecemos em pormenor, não sendo, também, de excluir os propósitos de boicote político.

Uma atitude diferente da assumida pelo pessoal dos Serviços Públicos, que podia eleger três senadores: um, representando os Directores Gerais e Chefes de Serviço, tendo a escolha recaído no dr. Carneiro de Moura, condiscípulo e amigo de Sidónio Pais; 
e dois pelos funcionários públicos, que, em número de duzentos e cinco, escolheram Guilherme Martins Alves (com 127 votos) e Francisco Nogueira de Brito (com 123).

As Associações de advogados, de médicos e de engenheiros civis portugueses colaboraram também na eleição da componente especializada do Senado. Os advogados, em número de quarenta, reuniram, a 28 de Abril, tendo eleito por unanimidade de votos o sócio efectivo António Augusto Cerqueira. Os médicos, presentes na sede da sua Associação em número de cinquenta, conferiram maior votação ao colega Ricardo Jorge. $E$ foram bastantes os engenheiros civis reunidos, a 28 de Abril, na sede da sua Associação, elegendo, também por unanimidade, João da Costa Couraça. De 380 sócios inscritos compareceram 224, ou seja, $59 \%$. Esta forte adesão de uma florescente classe inerente ao desenvolvimento tecnológico e capitalista do país e intimamente ligada à cultura positivista e politécnica subsumida na ideologia republicana, não nos parece nada despicienda ou trivial.

Igualmente significativa foi a participação das Universidades, dos Liceus e das diversas Escolas de Belas Artes (Artes Visuais, Música e Teatro), congregadas todas na categoria das Artes e Ciências e com direito a elegerem três senadores. Em Coimbra, no dia 29 de Março, sob a presidência do Reitor doutor Joaquim Mendes dos Remédios, reuniram, no Salão Nobre do Senado, os delegados dos três Senados universitários, faltando apenas o professor José Alberto dos Reis por motivo de doença e o mais votado foi o professor da Universidade de Lisboa, José Maria de QueirozVeloso. Antes da votação o Reitor Mendes dos Remédios fez votos para que houvessem novas ocasiões e ensejos de aproximação das três Universidades e manifestou o desejo de que todas comungassem nas mesmas aspirações de desenvolvimento e progresso, estreitando-se cada vez mais, entre os seus professores, os laços de camaradagem. Concluída a eleição, o professor Queiroz Veloso agradeceu a alta prova de consideração e estima que lhe acabavam de dar os seus colegas e afirmou que no Parlamento poria ao serviço do ensino das três Universidades todas as suas faculdades de trabalho, não se poupando a esforços no desempenho dessa missão. Por seu turno, vinte e sete delegados dos vinte e oito Liceus do continente reuniramse a 5 de Maio, na sala dos Conselhos Escolares do Liceu Passos Manuel, em Lisboa, a fim de procederem à eleição do senador representante da classe do professorado do ensino secundário no Congresso da República e a escolha recaiu sobre o professor do Liceu Central da Guarda, José Joaquim Ferreira. Um terceiro e último senador foi eleito, nesse mesmo dia 5 de Maio, no Salão do Conservatório de Lisboa, onde pelas 13 horas se reuniram os delegados da Escola de Belas Artes de Lisboa (João António Piloto, Henrique Lopes de Mendonça e José Alexandre Soares), da Escola de Belas Artes (José Marques da Silva, Antero de Figueiredo e João Augusto Ribeiro), da Escola da Arte de Representar (Augusto de Castro Sampaio Corte-Real,António Pinheiro e Júlio Dantas), da Escola de Música ou Conservatório de Lisboa (Francisco Jorge de Sousa Baía, Augusto de Oliveira Machado e Tomaz Vaz de Borba) e da Sociedade Nacional de Belas Artes (Arnaldo Redondo Adães Bermudes, Rosendo Carvalheira e José Malhôa), tendo eleito por dez votos Júlio Dantas.

Partindo de todos os dados expostos e tendo, naturalmente, em conta o estado confuso, as lacunas e as diversas falhas de registo de que enfermam as actas oficiais enviadas para as Comissões Centrais de Apuramento, é possível apresentar um quadro global para o Congresso da República, que difere do quadro de 0 Seculo de 22 de Ja- 
neiro de 1922, reproduzido por Douglas Wheeler. A diferença assenta na base heurística empregue: esses quadros citados incluem apenas o número de deputados e senadores oficialmente registados com votação expressa e identificados partidariamente com base em informações da imprensa respectiva, enquanto os nossos dados procedem directamente das fontes oficiais. Note-se, também, que nem para a Câmara dos Deputados, nem para o Senado terão sido preenchidos os lugares fixados pela lei eleitoral, o que, em parte, se entende face ao impedimento legal de os eleitos deputados ou senadores não poderem acumular essas funções com as de titulares de cargos governativos.

\section{Congresso da República}

3. Legislatura - 15 de Julho de 1918 a 20 de Fevereiro de 1919

\begin{tabular}{|l|c|c|}
\hline Partidos e Corporações & Câmara de Deputados & Senado \\
\hline P.N.R. & 100 & 32 \\
Monárquicos & 41 & 9 \\
Católicos & 4 & 1 \\
Socialistas & 1 & 0 \\
Independentes & 4 & 0 \\
Entidades profissionais e corporativas & 0 & 17 \\
\hline Total & $150[155]$ & $59[77]$ \\
\hline
\end{tabular}

FONTES:A Política no Congresso da República. O Seculo, 29-1-1922, p. I e dados oficiais A.H.P. - Eleições de 1918.

A distribuição dos eleitos pelos seus agrupamentos partidários e político-ideológicos permitiu-nos precisar um pouco mais o indefinido grupo dos independentes, composto por quatro deputados (um dos quais, Pedro Joaquim Fazenda, ex-centrista confesso, próximo de Egas Moniz e do P.N.R.) e não pelos cinco do quadro de Douglas Wheeler, ${ }^{(461)}$ que omite o socialista eleito por S. Tomé e Princípe, além de outras imprecisões, ${ }^{(462)}$ e nenhum senador, ao contrário dos dois que figuram no quadro de O Seculo e de Wheeler. Quanto ao total de deputados governamentais só conseguimos identificar cem contra os cento e doze de $O$ Seculo e os cento e oito de Wheeler, embora o inverso se verifique com o total de monárquicos, maior no nosso quadro (quarenta e um) que os trinta e sete estimados por Wheeler e os trinta e cinco de O Seculo. Se considerarmos Lino Neto um católico governamental o número de católicos eleitos fica em quatro ( $O$ Seculo coincide, neste valor, connosco) e não nos cinco de Wheeler.

(461) Cf.WHEELER, Douglas - História política de Portugal, de 1910 a 1926, ob. cit., p. 163.

(462) No referido quadro aparece a indicação de cinco deputados católicos, quando só foram eleitos quatro e a de vinte e oito senadores pelas categorias profissionais, quando a lei estipulou apenas vinte e quatro. 
E se passarmos aos senadores da representação provincial há total concordância no número de governamentais, mas discrepância nos monárquicos (nove contra os dez de $O$ Seculo e de Wheeler) e nos independentes, porque não conseguimos identificar os dois inscritos nos quadros em confronto. Em contrapartida, podemos afirmar que a parte «especializada» do Senado ficou apenas com dezassete representantes em vez dos vinte e quatro previstos na lei eleitoral.

Mas se é importante corrigir e determinar, com o máximo rigor possível, a cifra dos eleitos, em eleições marcadas pelo espectro da abstenção, a quantidade dos não votantes reveste grande significação política. Convém, por isso, avançar com algumas estimativas, ainda que parcelares e imperfeitas. Assentam, porém, numa base oficial documentada.

Para o universo de 880.000 recenseados a abstenção pode ter rondado, em relação à Câmara dos Deputados, os 61,18 \% com 38,82\% de votantes; e em relação ao Senado houve apenas $33,3 \%$ de votantes e $66,7 \%$ de abstenções. Números gerais, a que juntamos, para rematar esta síntese, a estimativa alcançada para Lisboa, círculos 27 e 28 , por ser a maior e mais populosa cidade do país:

\begin{tabular}{|c|c|c|}
\hline Lisboa (cidade) & $\begin{array}{c}\text { Votantes/Abstenções } \\
\text { Com base nas actas eleitorais }\end{array}$ & $\begin{array}{l}\text { Votantes/Abstenções } \\
\text { Com base nas descargas }\end{array}$ \\
\hline Círculo 27 & $\begin{array}{l}\text { Votos Senado }-3.590^{(463)} \\
\text { Abstenções - } 75,94 \% \\
\text { Votos Deputados - 3.990(464) } \\
\text { Abstenções - } 73,26 \%\end{array}$ & $\begin{array}{l}\text { Votos Senado - 3.353(465) } \\
\text { Abstenções - 77.53\% } \\
\text { Votos Deputados - 3.785 } \\
\text { Abstenções - 74,6\% }\end{array}$ \\
\hline Círculo 28 & $\begin{array}{l}\text { Votos Senado - I.551 } \\
\text { Abstenções - } 82.76 \% \\
\text { Votos Deputados - } 2.140 \\
\text { Abstenções }-73,26 \%\end{array}$ & $\begin{array}{l}\text { Votos Senado - } 1.937 \\
\text { Abstenções - } 78,47 \% \\
\text { Votos Deputados - } 2.181 \\
\text { Abstenções - } 75,76 \%\end{array}$ \\
\hline
\end{tabular}

FONTE: Eleições de 1918. (Arquivo Histórico-Parlamentar).

(465) Faltam cadernos com descargas. 


\section{Capítulo 5}

\section{A República e o Povo}

\section{Actos simbólicos do Presidente eleito}

Aliviado e estimulado por uma votação pessoal muito menos ferida de abstencionismo que a votação legislativa, Sidónio Pais não alterou a sua conduta anterior, apenas a reforçou, tornando cada vez mais irreversível e vincado o seu trajecto de líder carismático, tal como atrás ficou delineado e tal como o próprio o sintetizou numa frase proferida em 5 de Agosto: A política do povo tem de ser guiada pela razão mas aquela que não escutar também a palpitação dos corações não pode conduzir á felicidade. ${ }^{(466)}$ Continuará, assim, idêntico a si mesmo, na substância e na forma.

Em reforço da representação simbólica e da dignidade do alto cargo de Presidente da República ou Chefe do Estado, assinara na véspera das eleições e na qualidade de Ministro da Guerra o decreto n. 4.178 de 27 de Abril, que vinha colmatar uma lacuna na legislação vigente sobre qual devia ser o uniforme do supremo magistrado da Nação:

Artigo $1 .^{\circ}$ - O uniforme do Presidente da República será o que se acha estabelecido para os oficiais generais.

Artigo $2 .^{\circ}$ - O distintivo da categoria será representado por estrêlas de ouro do padrão da figura 21 do pano de uniformes para o exército, de 1911, apostas pela forma seguinte:

a) No casaco, seis estrelas no canhão acima do silvado, formando triângulo, e três, sobrepostas no silvado da gola, colocadas horizontalmente a cada lado;

b) Nas dragonas, três estrêlas dispostas como é indicado na figura I35 do mesmo plano;

c) No dólman de campanha, uma estrêla na gola a cada lado e seis nos canhões em triängulo;

d) Na pelissa, seis estrêlas nos canhões, em triângulo;

e) Nas presilhas da gola do capote e da capa, uma estrêla;

j) No barrete, uma estrêla.

(466) Cf. PAIS, Sidónio - Um ano de ditadura, ob. cit., p. 78. 
Um uniforme pensado, naturalmente, para um Presidente da República militar, desenhado, por isso mesmo, à sua exacta medida e à medida da necessidade prática de fixar bem a hierarquia e a sua respectiva figuração emblemática, tendo em conta que Sidónio Pais era major, patente demasiado baixa para a alta função de Comandante em Chefe das Forças de Terra e Mar. Devia, por isso, apresentar-se em público nessa qualidade e na de titular máximo do Poder Executivo, legitimado directamente pela Nação. Uma apresentação pública baseada num reforço simbólico da dignidade do Estado e a que não foi estranha a componente militar, sobreposta, pela primeira vez desde 1911 , à civilista. Com efeito, o novo Chefe do Estado eleito não só era um militar de carreira, como se fez rodear desde o golpe dezembrista de oficiais fardados, que ficavam, por isso, naturalmente abrangidos pelas alterações formais (no uniforme e distintivos) decorrentes desse reforço simbólico: a portaria n. ${ }^{\circ} 1.348$ de 7 de Maio determinava que os oficiais às ordens, os ajudantes de campo e os oficiais em serviço do Presidente da República passavam a usar como distintivo, cordões e agulhetas douradas pendentes do ombro direito.

Como corolário lógico desta mudança de imagem ficou, na mesma altura, estabelecida pelo decreto $n .^{\circ} 4.233$ a reorganização da Secretaria da Presidência nestes moldes: mantinha-se um Secretário Geral como Chefe da mesma e com os Adjuntos julgados necessários; para o Serviço de Expediente eram criados dois terceiros oficiais destacados do quadro do pessoal dos Ministérios, lugares providos pelo Ministro das Finanças mediante proposta do Secretário Geral; este se não fosse funcionário público teria o vencimento fixado no artigo $5 .^{\circ}$ do decreto de 4 de Junho de 1913 e, no caso de o ser, receberia os vencimentos da categoria ou soldo e gratificação de patente, acrescidos da diferença até à importância fixada no mesmo decreto; os restantes funcionários receberiam os vencimentos que lhe competissem, segundo as suas categorias ou patentes, pelos Ministérios respectivos; junto do Presidente da República prestariam serviço dois Oficiais às Ordens e dois Ajudantes de Campo; e para abonos ao pessoal de Secretaria e demais pessoal seria fixada no orçamento do Ministério das Finanças a quantia de 6.000\$00.

A estes diplomas transfiguradores da anterior imagem do Chefe do Estado republicano, adaptando-a a um figurino de presidencialismo (norte e sul) americano em tons de consulado napoleónico, juntam-se os decretos 4.223, 4.224 e 4.225 de 8 de Maio de pendor humanitário e conciliador, estabelecendo a amnistia geral, a concessão de indulto aos presos e a reintegração no Exército de quatro ex-segundos sargentos de Artilharia e de três ex-soldados da Guarda Fiscal.

Nos considerandos do primeiro desses diplomas lê-se que os sentimentos humanitários não podem ser estranhos às instituições inteligentemente organizadas nem aos espíritos profundamente patrióticas e que o Presidente da República, eleito pela vontade nacional, não deseja perder o ensejo de mostrar à Nação os sentimentos de altruismo que a ela o prendem. Justificação bastante para promulgar e conceder uma amnistia geral e completa, aplicável a todos os crimes de natureza ou carácter político; aos crimes de reuniões criminosas, sedição ou assuada; aos delitos por uso e porte de arma proibida; aos crimes por abuso de autoridade, de que não tivesse resultado ofensa corporal; a todos os delitos cometidos pela imprensa, incluindo as transgressões da respectiva lei e em que não houvesse parte particular acusadora; a todas as transgressões das leis de Separação do Estado e das Igrejas; aos crimes de falência meramente culposa; e aos 
crimes de ameaças, quando não houvesse parte acusadora; e aos de ultraje à moral pública. ${ }^{(467)}$

No brevíssimo preâmbulo do decreto 4.224 , concedendo o indulto aos que o requeressem, no todo ou em parte, no prazo de trinta dias se estivessem no continente e de noventa se no ultramar, voltava a ser sublinhada a expressão humanitária e magnânima do mais alto representante do Estado: o Presidente da República Portuguesa deseja atenuar a sorte de muitos desgraçados que nas cadeias ou no degredo sofrem as consequências dos seus erros, e assim dar mais uma pública demonstração dos sentimentos de generosidade que devem honrar o Governo duma República. ${ }^{(468)}$

Este pacote legislativo precedeu, muito oportunamente, a cerimónia de proclamação do Presidente da República marcada para a quinta-feira dia 9 de Maio, feriado nacional pelo decreto n. ${ }^{\circ} 4.222$ do dia anterior, e foi ainda acompanhado pela afixação, num dos pilares da arcada do Ministério do Interior, do edital da Comissão Central de Apuramento Final da Eleição do Presidente da República, presidida pelo juiz José Maria de Sousa Andrade, no qual se declarava que tendo-se procedido ao apuramento final da eleição do Presidente da Republica, pelos círculos do continente se verificou estar eleito com quatrocentos e sessenta e oito mil duzentos e setenta e cinco votos o cidadão doutor Sidonio Bernardino Cardoso da Silva Paes, que foi em seguida proclamado Presidente da República.

Antes mesmo de se cumprirem vinte e quatro horas sobre a divulgação oficial do veredicto incompleto das urnas, realizou-se, em sessão solene dos Paços do Concelho, uma cerimónia que o jornal A Situação não hesitou em classificar de suprema consagração do mais alto magistrado de Portugal, acrescentando: Hora de Paz e Perdão é esta que deverá abrir o coração de todos os bons portuguezes n'uma sincera esperança e n'um grande anceio de Ordem, Trabalho e Justiça, saudando no Chefe do Estado a sua melhor garantia e com eles bradamos: Viva a Patria rejuvenescida! Viva a Republica Nova! Viva o sr. dr. Sidonio Paes. ${ }^{(469)}$ Uma mensagem apropriada à cerimónia e ao seu espaço - deliberadamente o mesmo da entusiástica e promissora proclamação da República em 5 de Outubro de 1910.

Cerca de oito anos mais tarde, num acto refundador do mesmo projecto, repetiamse os rituais de uma consagração com algumas significativas mudanças: a República que voltava a ser proclamada no Salão Nobre e da simbólica varanda da Câmara Municipal de Lisboa tinha um rosto e um protoganista visivel, votado nas urnas e por esse meio investido, simultaneamente, como Chefe do Estado republicano e como Chefe de um dos três Poderes - o Executivo - autónomos entre si. Já não era a «velha» República colegial, parlamentar e emanada da acção revolucionária de um partido, mas uma nuance desse regime em que avultava o elemento pessoal adstrito ao desempenho da actividade governativa e de certas funções de representação nacional. Para uns era o elemento que faltava, sem o qual o sonho de Outubro ficaria irremediavelmente desfeito; mas para outros era a perversão de uma Ideia pura e sublime traída pela ambição desmedida do poder pessoal e pela sedição monárquica. Não havia, pois, consenso no

(467) Cf. Diário do Governo, 1. Série (100) 9 de Maio de 1918, p. 1-2.

(468) Cf. Diário do Governo, I. Série (100) 9 de Maio de 1918, p. 2.

(469) Cf. A Proclamação. A Situação, de 8 de Maio de 1918, p. I. 
campo republicano, o que à partida limitava bastante a força e o êxito dessa República Nova proclamada com pompa, circunstância e muito povo na Praça do Município.

A Paz e Perdão, a concórdia e a harmonia entre todos os portugueses não eram palavras vãs, antes a lúcida percepção de uma necessidade incontornável, já evocada e anunciada em Dezembro de 1917 e, desde então, porfiada com maior ou menor intransigência de todas as partes, assim parecendo manter-se não obstante os repetidos protestos de fidelidade republicana, de respeito pela vontade popular e de acrisolado patriotismo. E no dia da sua proclamação como primeiro Presidente da República eleito por sufrágio universal, Sidónio Pais não deixou, obviamente, de insisitir nesse tópico fundamental. Fê-lo, porém, de maneira a irritar ainda mais os seus figadais adversários. Fê-lo com grande solenidade e com invulgar aparato festivo e militar, a que não faltou sequer a presença emblemática (bandeiras) e protocolar (representantes militares e diplomáticos) dos Aliados.

\section{A Proclamação da República Nova}

De acordo com o relato da imprensa, Lisboa amanhecera, então, toda embandeirada: Era bem um dia de festa, a que nem faltou um sol luminoso, e essa temperatura morna, acariciadora, que nos torna mais apetitoso comer fruto colhido em pomar de eleição. ${ }^{(470)}$ Todos os edifícios públicos estavam profusamente embandeirados e o mesmo espectáculo de jubilosas cores espalhava-se pela cidade inteira:

Era uma apoteose de tons, onde sobressaiam esplendidamente, em plena luz, as côres das nações aliadas, enlaçadas como para a vitoria, unidas, confundidas, como para fazerem juntas a grande jornada da paz futura. Da Baixa à Alta, pelas grandes arterias, ou nos bairros pobres, pelas ruas humildes, essa policromia quasi fantastica continuava interminavelmente, como n'um imenso arraial. Em quasi todas as casas se desenrolava triunfalmente, como aza ao vento, um farrapo glorioso - glorioso pelo que invocava das virtudes de uma patria e da historia e dos feitos de um povo.

Nunca vimos uma tal profusão de bandeiras, nem, sob galas tão espontaneas, tão manifesto e claro ar de festa. Lisboa aparecia como «kermesse» colossal, e era-o bem, com as suas bandeiras soltas ao vento, por centenares de ruas e de praças, mais para o longe e para o largo, mais para deante sempre, por mais que se estendesse o passeio...(471)

Nessa kermesse colossal cedo se juntou o povoléu, cedo as tropas da Guarnição de Lisboa começaram a percorrer as ruas em direç̧ão à Baixa, muito aprumadas, limpas e vistosas, os arreios dos cavalos reluzentes e a disciplina geral merecedora de empolgados elogios.

(470) Cf. Lisboa inteira aclama, em delirio, o Chefe do Estado. Uma jornada triunfal atravez da cidade. Mais de duzentas mil pessoas consagram o novo Presidente, envolvendo nas suas saudações as tropas da guarnição. A Situação, de 10 de Maio de 1918, p. I.

(47I) Ibidem, p. I. 
Ultimavam-se, na rua, nos quartéis e nos Paços do Concelho, os preparativos da cerimónia prevista para o início da tarde: às 14 horas o cortejo saiu do Palácio de Belém, rodeado de milhares de pessoas aclamavam Sua Ex ${ }^{\circ}$, que vestia o novo uniforme e defronte estava formado com as suas lanças, de flâmulas ao vento, o Regimento de Cavalaria 7 , que, desde a sua afamada participação no golpe dezembrista, acompanhava sempre o Presidente Sidónio Pais, marcando garbosa presença em imponentes cerimónias políticas e militares. $\mathrm{Na}$ cauda do cortejo, formou, pois, essa unidade e seguiu vistosamente, enquanto na frente se dispunham em fila os automóveis com diversas autoridades - 0 Comandante da Polícia, os Ministros das Subsistências, da Agricultura, do Interior, das Colónias, da Marinha, do Comércio, das Finanças, do Interior e da Justiça - o landau com o capitão Eurico Cameira e os alferes Ferreira da Silva e Rui da Cunha, seguido de outro landau com os alferes Bernardo de Albuquerque e Botelho Moniz e atrás vinha, finalmente, o landau que transportava o Presidente da República eleito e a seu lado o Secretário Geral da Presidência da República, dr. Manuel Forbes de Bessa, mais os dois Oficiais Superiores às Ordens, um do Exército e outro da Marinha. No couce os restantes tres esquadroes de cavalaria 7.

trajecto do cortejo fez-se pela Junqueira e pelo Altinho, sendo Sidónio Pais saudado e aclamado por populares apinhados ao longo dos passeios ou debruçados nas janelas e varandas do casario. No landau aberto, de peito feito a descoberto e sem grande protecção pessoal, Sidónio retribuía constantemente com continências e acenos as ovações, as palmas, os vivas entoados e assim chegou, pelo Largo de Camões e pela rua do Arsenal, à Praça do Município ou do Pelourinho, coberta de gente desde o meio-dia:

\section{- É ele! É ele! Ahi vem o Presidente!}

Era, na verdade, o sr. Presidnete da Republica que chegava. $O$ que se passou, n'esse momento, é deslumbrador de entusiasmo. N'um arranco unico, como á voz d'um comandante, toda essa gente rompe em palmas, loucamente, febrilmente. $E$ ́ uma manifestação espantosa, nunca vista, verdadeira apoteose de heroes, autentica consagração de deuses! (472) $^{(4)}$

O relato a quente do repórter entusiasta e apologeta visou transmitir a atmosfera emocional que envolveu o acto solene que se desenrolava ao ritmo cadenciado da marcha e ao som compassado dos clarins. No landau, Sidónio Pais palido, comovido, surpreendido, tenta, em vão, apear-se, mas não ha força que feche o dique áquela avalanche humana. Os cordões da policia são rotos a empurrão, facilimamente - e a policia, impotente para conter os populares, deixa dar largas aquela onda de entusiasmo - que remedio! Passados alguns minutos, finalmente, o sr. Presidente da Republica avança, a passo firme, em direcção á porta da Camara Municipal.(473)

\footnotetext{
${ }^{(472)}$ Cf. Lisboa inteira aclama, em delirio, o Chefe do Estado, art., cit., p. I.

(473) Ibidem, p. I.
} 
À porta da Câmara surgiram todos os membros da Comissão Administrativa, tendo à frente o estandarte da cidade que era empunhado pelo irmão de Machado Santos, Augusto Machado Santos. No átrio formavam, em duas alas, dando a direita a Sidónio Pais, os alunos da Escola da Armada que mal aquele entrou fizeram logo a continência. Mais além, pela escadaria coberta com uma grande passadeira de veludo vermelho, de um lado e do outro, os bombeiros municipais estavam em uniforme de gala e perfilados em guarda de honra.

Sidónio Pais entrou vagarosa e solenemente no edifício da Câmara, seguido pelos Ministros, Ajudantes e mais comitiva. Reboaram, como lá fora, as aclamações, intensas e prolongadas, a que ele agradeceu fazendo a continência. Pelo lanço esquerdo da escadaria foi direito ao Salão Nobre, onde o aguardavam largo número de oficiais generais, individualidades diversas, os Adidos Militares da Inglaterra, da França, da Itália e de outros países Aliados e neutros, que the apresentaram cumprimentos entre as palmas da assistência. O Salão fora engalanado com frescas plantas e o busto da República estava enlaçado, do lado direito, na bandeira verde e rubra. Em segundos ficou repleto. Os Vereadores ocuparam os seus lugares na larga mesa, cedendo o centro da mesma ao Presidente da República, que, de cabeça descoberta, tinha à sua direita o general Barnardiston e os edis à esquerda. Em voz pausada e grave começou a ser lida a acta do apuramento eleitoral (incompleto), irrompendo, no fim da leitura, as palmas e as aclamações ao novo Presidente da República. Fez-se, entretanto, silêncio para o protagonista do acto de proclamação usar da palavra.

Não fez um discurso longo, mas cuidou, no seu habitual estilo geométrico e incisivo, de ajeitar a mensagem ao importante momento de consagração da legitimidade obtida no meio de rijas hostilidades e de temíveis incertezas. Não admira, por isso, que tenha principiado por enfatizar a votação recebida das mãos do Povo Português, detentor supremo da soberania nacional, menosprezando o alcance e o efeito da abstenção, que nunca teria sido tão reduzida e tão insignificante apesar de 3 agrupamentos partidarios a terem resolvido e d'ela terem feito em larga escala a propaganda, bem mais facil e susceptivel de ser coroada de sucesso do que a de chamar os eleitores ás urnas. ${ }^{(474)}$ Em resposta aos seus adversários proclamou a «limpeza» das eleições, a ordem, a liberdade, a legalidade e a honestidade que haviam envolvido a solene expressão da vontade popular. Dirigindo-se ainda à oposição republicana «histórica» evocou a significação e a espontaneidade dos votos recebidos para concluir Debalde se fez durante os ultimos cinco meses uma campanha anti-patriotica e anti-republicana, tendo por base a dupla calunia de apresentar aos olhos dos aliados e aos olhos da Nação o governo saido da Revolução como hostil aos aliados e contrario ás actuais instituições. Em vão, porém, se urdira tal campanha, porque A calunia, a intriga, a conspiração cairam deante da força invencivel da verdade. ${ }^{(475)}$ Esses intentos denegridores e conspirativos fracassaram por obra e graça do Povo: na sua extraordinaria clarividencia, no seu infalivel espirito de justiça e na sua nunca desmentida sinceridade o Povo repudiou todas essas calunias, julgou, sentenciou e coroou assim, com o

(474) Cf. PAIS, Sidónio - Um ano de ditadura, ob. cit., p. 56.

(475) Ibidem, p. 57. 
seu espirituoso aplauso, a obra da Revolução. Com estas palavras, Sidónio Pais preludiava a intensa exortação populista do seu discurso, uma constante, aliás, nas suas alocuções até ao fim da vida:

Povo Português! Sinto-me orgulhoso de ser o teu Presidente eleito e procurarei, quanto em minhas forças caiba, corresponder á confiança que em mim depositaste, sendo o teu amigo de todas as horas e interpretando o teu sentir e a tua vontade soberana, unica a que me curvarei, e a quem ninguem poderá desobedecer sem passar por cima de mim.

Nenhum odio, nenhuma inimisade pessoal, nenhum sentimento rancoroso encontra éco no meu coração, só tenho a aspiração veemente de conciliar todos os nossos interesses legitimos. Poderei errar, mas apenas me demonstrem o erro estou pronto a emenda-lo sem resentimentos nem vaidades, sem teimosias ininteligentemente, sem intransigencias tiranisantes.

Todo o povo portuguez pode contar em mim um amigo, pronto a defender a sua justiça, ainda que seja o meu maior inimigo.

Nenhumas perseguições fiz, tomei somente as medidas indispensaveis para assegurar a ordem publica que á minha guarda estava confiada.

Povo Portuguez! Ao assumir o exercicio da Suprema Magistratura da Nação as minhas primeiras saudações vão para as forças de terra e mar que heroicamente se bateram ao lado dos nossos aliados contra o inimigo comum pela causa da Liberdade, do Direito e da Independencia dos Povos.

Essas forças são a tua emanação, são o teu sangue. Saudando-as abraço-te a ti, a todo o Povo Portuguez, no teu grande desejo de Justiça tão ardentemente manifestado na expontaneidade com que abraçaste a causa dos aliados. ${ }^{(476)}$

E prosseguindo a toada crescente até ao clímax final, apressou-se a anunciar o início de uma nova era de Liberdade, de Tolerância e de Respeito pelas crenças religiosas e pelas convicções politicas, acrescentando que só n'uma tal atmosfera que a nação poderá prosperar. Ela precisa duma base estavel que não poderia encontrar-se senão na união espiritual de muitas almas. Essa união é hoje um facto e a força de atracções d'ela emanada alargará o seu ambito e intensificará a sua potencia. Um grande ideal nacional popularisa este movimento. ${ }^{(477)}$

O ideal de Dezembro plasmado no ressurgimento da Pátria não só triunfara, como era mais do que uma esperança, uma consoladora certesa, que exigia e convocava a união imperiosa de todos os portugueses. Este vibrante e premeditado apelo à unidade nacional terminou com uma empolgante promessa de garantido efeito emocional na generalizada exaltação patriótica quase mística e ardente: Aqui vos afirmo solenemente pela minha honra que defenderei até á minha última gota de sangue a sagrada causa da Patria e da Republica que é tambem a causa do Povo Portuguez. Viva a Patria! Viva a Republica Nova!.

(476) Cf. PAIS, Sidónio - Um ano de ditadura, ob. cit., p. 58.

(477) Ibidem, p. 59 
Concluíra em apoteose como convinha, por entre vivas, palmas e uma intensa corrente eufórica que não tardou a extravasar para a Praça do Município ou do Pelourinho, onde esse tão acrisolado e aclamado Povo se apinhava em delírio. E da célebre varanda, lugar certo do ritual sagrado da litúrgica proclamação republicana, proferiu, agitando, segundo o relato impresso, o seu boné na mão trémula, duas curtas, mas enfáticas frases: Povo de Lisboa! Tu és o digno representante de Portugal e a ti está confiada a guarda sagrada da Patria e da Republica. // Viva a Patria! Viva a Republica Nova! Vivam os aliados! (478)

Terminara a cerimónia, mas estavam ainda longe do seu termo os festejos, que se não bastavam para apagar as horas inefáveis vividas em 5 de Outubro de 1910, deviam igualá-las em brilho, em entusiasmo e em evocação para o futuro.

Eram 15 h e 45 m. Ladeado pelo dr. Zeferino Falcão e por Forbes de Bessa, saiu da Câmara saudando militarmente a multidão que o ovacionava e dirigiu-se ao landau, onde de pé, hierático e afável, repetia a saudação até partir para os Restauradores, a fim de cumprir a parte militar do programa. $O$ cortejo seguiu pela rua do Ouro, vagarosamente e por entre duas contínuas e compactas alas de multidão, contida por cordões de polícia armada. Das varandas e das janelas ouviam-se, também, as palmas, as aclamações e caíam flores. Um percurso curto, que demorou imenso a ser feito. E quando, finalmente, o recém-proclamado Presidente da República chegou aos Restauradores, um mar de gente o aguardava, ansiosa por o saudar, enquanto junto ao obelisco se concentrara grande número de oficiais a cavalo. Era ali que Sidónio Pais ia abandonar o landau e montar o seu cavalo Alter castanho, desembainhando a sua espada. N'essa altura, um novo delirio de saudações estrepitou. O nome do chefe do Estado saía de todas as bocas, e, por momentos, impedido de avançar, sua excelencia agradecia, n'um movimento da espada. ${ }^{(479)}$ Sob os ameaços de chuva, fez-se, por fim, a galope, indo à frente dois oficiais e atrás os seus Ajudantes, e subiu uma Avenida da Liberdade repleta de gente até ao topo da Rotunda, onde seria passada a revista às tropas, prontas a desfilarem em parada e sobrevoadas por dois aeroplanos. A revista decorreu já sob chuva miudinha a chuva lisboeta... Embora! A parada militar nem por isso perdeu o seu brilho - nas palavras do diligente repórter de $A$ Situação, que acrescenta: Os soldados mantiveram o seu garbo e uma estrita disciplina. ${ }^{(480)}$ $\mathrm{O}$ seu aspecto agradou à multidão $\mathrm{e}$ às autoridades, sendo no dia seguinte determinado pelo Presidente da República ao coronel Eduardo Sarmento um louvor ao Corpo das Tropas da Guarnição de Lisboa, sob seu Comando, pelo brilhantismo da sua apresentação. Mais que um louvor, era um sinal claro a todas as Forças Armadas...

Passada a revista às tropas, Sidónio Pais voltou a descer a Avenida a cavalo e regressou aos Restauradores, onde com todo o seu Estado-Maior e na companhia da muito atenta Missão Militar inglesa aguardou o desfile. A intenção de bem impressionar os Aliados numa fase crítica da nossa participação militar no front esteve, por certo, na origem da organização dessa parada e desfile, repetindo o ritual de 10 de Dezembro de 1917.

(478) Cf. PAIS, Sidónio - Um ano de ditadura, ob. cit., p. 59.

(479) Cf. Lisboa inteira aclama, em delirio, o Chefe do Estado, art., cit., p. 2.

(480) Ibidem, p. 2. 
O dia 9 da proclamação presidencial(ista) teve o seu pôr de sol num jantar, no Palácio de Belém, a que assistiu todo o Ministério, o Comandante do Corpo de Tropas da Guarnição de Lisboa e o pessoal militar em serviço na Presidência da República, tendo sido, no final, trocados diferentes brindes. Nessa ocasião, o Presidente Sidónio Pais brindou pelo sr. Machado Santos, o fundador da Republica, pela marinha portuguesa, pelos seus colegas do ministerio, pelos novos da Republica, etc. Rumou, de seguida, ao Coliseu dos Recreios para assistir a uma récita de gala e ao entrar na sala a multidão que por completo a enchia, ergueu-se n'uma enorme manifestação, que durante cêrca de dez minutos se prolongou. Como de costume, distinguiram-se as senhoras. ${ }^{(481)}$ Daí passou ao Teatro de S. Carlos, onde também Ihe foi feita uma outra grandiosa manifestação, pelos academicos e assistencia.

. Os momentos de apoteose haveriam de repetir-se no Domingo, dia I2, com a triunfal consagração do ídolo Sidónio Pais durante a impressiva tourada de gala. ${ }^{(482)}$ Rodeado aí por tanta gente, imobilizado por essa mole efusiva, Sidónio teve de se lhe dirigir numa brevíssima alocução, onde a pedra basilar da sua retórica político-populista ressurgia inevitavelmente: Como Chefe do Estado entendo que sou chefe de todos os portugueses e que, como fui eleito pelo Povo, que pelo Povo e para o Povo devo viver. É de resto entre o Povo que me sinto bem. Por ele me sacrificarei e darei o meu sangue e a minha vida. ${ }^{(483)}$ E esse domingo lindo. Glorious day! só haveria de terminar, nas palavras de Alfredo de Magalhães, Á noite em S. Carlos a Manon com Tito Schipa. Domingo cheio! E a athmosphera impregnada do suave perfume d'uma alegria sadia e consoladora que nos parecia já impossivel....

processo carismático protagonizado por Sidónio Pais não se fechou nele (figura galvanizadora), antes convocou, a priori, a motivação emocional e pragmática da(s) população(ões) e interagiu, em permanência, com múltiplas variáveis conjunturais. Pode-se, assim, ir contextualizando uma heroicização anterior à sagração e morte do Herói e confrontá-la com os claros-escuros de uma factividade muito pouco linear.

Enquanto Sidónio percorria as ruas de Lisboa no meio de vivas e de hinos e de um delírio idólatra, noutros recantos da capital reagia-se, mais ou menos em surdina, com acirrada hostilidade a esse ostensivo triunfo e no Porto, por exemplo, estavam ainda acesas as brasas do recente confronto entre conspiradores democráticos e as chamadas forças da ordem fiéis ao Governo, que, em nome e em defesa deste vigiavam, perseguiam e prendiam. Enquanto Sidónio se expunha e atraía cada vez mais sobre si intensas manifestações de identificação carismática, estimulando também sentimentos adversos de detracção e de repulsa, a «sua» República Nova ressentia-se positiva e negativamente desse processo e desenvolvia-se à mercê de inumeráveis contingências - internas, externas e outras...

(481) Cf. Lisboa inteira aclama, em delirio, o Chefe do Estado, art. cit., p. 2

(482) Ver MARTINS, Rocha - Memorias sobre Sidonio Paes, ob. cit., p. I61-162.

(483) Cf. PAIS, Sidónio - Um ano de ditodura, ob. cit., p. 60. 


\section{A Obra da Assistência 5 de Dezembro}

Anterior aos focados momentos de apoteose e consagração do poder pessoal e institucional de Sidónio Pais e do sidonismo, mas inscrita na mesma matriz, a Obra de Assistência 5 de Dezembro foi formalmente criada em alternativa ao abandonado projecto de Machado Santos sobre Assistência Pública e desenvolvida a par da concentração na Secretaria de Estado do Trabalho dos Serviços de Previdência Social, que passavam a ter, também, aquela vertente assistencial.

O alferes Eduardo Ferreira da Silva, destacado cooperador dessa iniciativa semi-oficial, em entrevista ao jornal A Situação, contou ter ela nascido de uma forma muito simples e espontânea: Uma noite, o sr. Presidente convidou para uma reunião todos os seus cooperadores e, mostrando-lhes o empenho e a simpatia com que acolheria qualquer instituição que surgisse no sentido de proporcionar ás classes mais directamente feridas pela miseria um pouco de bem estar que a guerra, com as suas tremendas consequencias, thes roubara, lançou os fundamentos da Obra de Assistencia 5 de Dezembro. ${ }^{(484)} \mathrm{A}$ escolha do nome filiou-se nos objectivos propulsores do golpe, que, segundo Ferreira da Silva, não se limitara a alterar a nossa maneira de ser politica. Veiu, para realisar uma obra bem mais grandiosa, dar á crise nacional uma solução tanto quanto possivel rapida e perfeita. Já vê, pois, que crismando a «Assistencia» com a data da Revolução, não tivemos em vista o mais comesinho intuito politico. ${ }^{(485)}$ Visava, assim, identificar a Revolução e seus mentores com acções concretas para a resolução de problemas candentes e graves, e nessa medida, o programa previsto extravasava a mera fundação de sopas para os pobres, porque se isso já era muito ainda não era tudo. E nós desejamos fazer o mais possivel, visto que a situação não se resolve com paliativos. Logo que, em todas as freguezias de Lisboa, a sopa aos pobres seja distribuida com a amplitude necessaria, iniciaremos a guerra á miseria doirada, que é, porventura a mais tragica, creando cozinhas economicas que forneçam, pelo minimo, sopa e o chamado "prato do meio». Assim, tiraremos a essa assistencia o caracter de esmola. Outras coisas de grande monta tencionamos fazer, como seja a proteç̧ão aos velhinhos desamparados e ás crianças abandonadas. Emfim, é o combate metodico e porfiado á fome.(486)

Um combate travado noutros pontos do país, como Porto eViana do Castelo, onde já estavam a funcionar sopas administradas por Comissões nascidas por impulso dos respectivos Governadores Civis e em ligação com senhoras e cavalheiros representativos das forças vivas locais, naturalmente concordantes com a política do Governo. Este concedera a essas duas iniciativas $50.000 \$ 00$ e $6.000 \$ 00$ respectivamente. Na Moita e em Aveiro temo-los tambem — referiu Ferreira da Silva — mas estas devidas á louvavel iniciativa particular. Dentro em breve, graças aos esforços do ilustre governador civil da Guarda, alferes sr. Costa Pereira, que fez parte da comissão central, uma outra, dentro

(484) Cf. O que é a Obra da Assistencia 5 de Dezembro. Como nasceu e com o que conta. A recita de hoje no Eden-Teatro. A Situação, de 5 de Junho de 1918, p. 2.

(485) Cf. Ibidem, p. 2.

(486) Cf. Ibidem, p. 2. 
em pouco, se fundará ali, não tendo o governo fixado ainda a importancia do subsidio a conceder-Ihe. ${ }^{(487)}$

Pela mesma entrevista é-nos ainda revelado algo mais sobre a estrutura de um organismo o menos burocrático possível e muito descentralizado. No seu topo começou por haver apenas uma Comissão Central composta pelo capitão António Bernardino Ferreira, o capitão José António Ramos, o tenente José Pedro Dias Gomes Mariares, o deputado Mário de Mesquita, o alferes Jorge Henrique de Almeida Costa Pereira, o aspirante João Batista Lopes de Loução Rebordão de Cavalaria 7 e o alferes entrevistado - gente, como se vê, da entourage do Chefe do Estado. A breve trecho, porém, foi reconhecida a necessidade de subdivir esse núcleo inicial, sendo criadas três Secções ou Sub-Comissões: a da Organização e Administração entregue ao capitão Ferreira e ao tenente Mariares; a da Propaganda confiada ao capitão Ramos e deputado Mário de Mesquita; e a Angariadora de Donativos da responsabilidade do aspirante João Rebordão e alferes Ferreira da Silva.

Em paralelo, funcionavam as Comissões de âmbito distrital, surgidas primeiramente, além de Lisboa, no Porto, em Viana do Castelo, em Vila Real e Guarda, sendo as duas primeiras reforçadas com dotações, respectivamente, de $250.000 \$ 00$ e $125.000 \$ 00$ por decreto n. ${ }^{\circ} 4.609$ de 10 de Julho. Foi, então, determinado, também por lei, a criação de Comissões nas capitais de distrito e ilhas adjacentes onde ainda não existissem, procurando-se alargar a sua acção a todo o território nacional. E, muito embora o intuito primordial da instituição dessa obra social fosse o estabelecimento de sopas económicas, deviam essas Comissões instituir ou substituir estabelecimentos de assistência, nomeadamente creches e asilos, como ficou estabelecido pelo citado decreto n. ${ }^{\circ} 4.609$.

A ideia voluntarista, e logo cunhada de demagógica, de erradicação imediata da mendicidade atravessou o discurso oficial de mistura com a filosofia assistencial seguida pelos Governos republicanos anteriores, designadamente a preocupação, mais ou menos acentuada, com a justa distribuição dos socorros públicos. A substancial diferença com a política de Assistência precedente residia, sobretudo, na autonomia organizacional da Obra de Assistência 5 de Dezembro, que operou independente e em complementaridade com a Direcção Geral de Assistência Pública de Saúde e dos Hospitais Civis de Lisboa integrada, por decreto n. ${ }^{\circ} 4.641$ de 13 de Julho, no Ministério do Trabalho.

Mas nos alvores de Junho só a Secção Angariadora de Donativos parecia estar a funcionar em pleno e dispunha de sede provisória, na rua Luciano Cordeiro, 13, 2. $\mathrm{B}$, residencia de um dedicado amigo nosso, o sr. Bernardino de Melo e Castro, para onde devia ser dirigida toda a correspondência. E a propósito deste importante detalhe organizativo o entrevistado referiu que, na mesma noite em que ficou acordada a cedência do apartamento para esse fim, como ele se queixasse da falta de tempo para dar conta da feitura e da expedição de todo o correio algumas senhoras que estavam presentes ofereceram-se gentilmente para esse importante serviço. (...) É com elas que nós contamos. E á grandeza inexgotavel do coração da mulher portugueza que nós confiamos uma parte do exito da nossa empreza. Ela não nos regateará o seu valiosissimo prestimo. ${ }^{(488)}$

\footnotetext{
${ }^{(487)}$ Cf. O que é a Obra da Assistencia 5 de Dezembro, art., cit., p. 2.

(488) Cf. Ibidem, p. 2.
} 
Com a pronta colaboração das senhoras da melhor sociedade lisboeta e a boa adesão do público em geral, essa Sub-Comissão tinha prevista uma série de festas de angariação de fundos a levar a cabo nos Teatros de Lisboa e a primeira estava já marcada para o dia seguinte - 5 de Junho - no Éden Teatro com o concurso do grande tenor italiano Tito Schipa, que juntamente com a soprano Cacilda Ortigão, o maestro Pedro Blanch e os violinistas Francisco Benetó e Nicolino Milano aceitaram de bom grado participar na iniciativa. Um generoso apoio partilhado, também, pelos mais distintos artistas dramáticos convidados para abrilhantarem o espectáculo.(489)

Essa festa constituiu, de facto, o grande lançamento da Obra de Assistência 5 de Dezembro, da qual Sidónio Pais foi mais que o Presidente Honorário, identificando-se por inteiro com os seus altruísticos e elevados fins sociais, que Ihe haveriam, aliás, de reforçar o atributo da bondade, da magnanimidade e da sentimental dedicação aos miseráveis e injustiçados - um atributo mais para a sua imagem de Chefe corajoso e inteligente. Nesse esforço, simultaneamente, de filantropismo sincero e de hábil propaganda, o cativante apelo ao auxilio feminino foi tarefa assumida por Sidónio com natural facilidade. Os seus dotes inatos de irresistível sedutor facilitaram uma entrega a que as senhoras de Lisboa e de outras localidades se tinham habituado, respondendo afirmativamente a obras como a do Século e a festas como a de Caridade a favor dos Sanatórios para Empregados Tuberculosos dos Caminhos de Ferro do Estado(490) e a da Flor ou peditório do obolo da piedade (...) Para os Heroes, Filhos do Povo! em meados de Abril.

Festas de caridade mista - cristã e cívica - o que não deixa de ser assaz curioso do ponto de vista mítico-simbólico, porque eram iniciativas aparentemente laicas, patrocinadas pelo Estado e não sob a égide tradicional da Igreja Católica, mas em que as senhoras nelas participantes agiam como fervorosas católicas animadas pelos valores e pelas convicções doutrinárias (e políticas) recebidas desde o berço. Aliás, o caso da $5 .{ }^{a}$ Condessa de Ficalho, D. Maria Josefa de Melo, (491) com as suas cartas transbordantes de uma adoração passional e mística por um «Ele» sempre maiúsculo, e o das anónimas e apaixonadas adoradoras do Presidente que lhe enviavam santinhos benzidos ou até postais de nu artístico e sensual são paradigmátios da postura que, a par da impressionante explosão de pedidos de ajuda e de esmola formulados em carta por gente simples, muito contribuiu para a heroicização e a santificação de Sidónio dentro dos cânones messiânico-católicos decantados por labaredas de paixão naturalmente humana.

O venturoso encontro de D. Maria de Melo com Sidónio Pais terá ocorrido, segundo a mesma confessou em entrevista ao Diario de Lisboa, em meados de Janeiro de 1918: Conheci o sr. Sidonio Pais, quando ele voltou do Porto. Já era presidente. E evitando uma pregunta: - Só tratei com ele de assuntos de caridade. Admirei-o intensamente como

(489) Dossier Obra de Assistência 5 de Dezembro, duas circulares. (Arquivo de Sidónio Pais - Militar, Lente e Político, Subsistema Presidência da República).

(490) Cf. Festa de caridade. O Eco Teatral e Cinematografico, de Abril de 1918, p. I.

(491) Ver Nobreza de Portugal, vol. 2, ob. cit., p. 597. 
portuguesa. (492) Por essa altura, mais precisamente a 8 de Fevereiro, já dava a cara em iniciativas de assistência às vitimas da guerra ${ }^{(493)}$ e daí em diante a sua empenhada militância nas acções de filantropia e benemerência predispô-la a colaborar estreitamente com as entidades públicas. A sua adesão à Obra de Assistência sidonista foi, pois, imediata e teve o seu momento alto na enternecedora Festa das Crianças em Sintra: - Oh! em Cintra - recordou a Condessa na entrevista de Artur Portela — não pode, não poderá nunca calcular como êle estava alegre. Atulhou o seu automovel de crianças, beijou-as, deuIhes brinquedos. Tinha para cada uma delas um sorriso: era êle que escolhia as fazendas, os modelos para os fatos. E tinha tanta atenção por estas coisas, como se tratasse dum assunto de Estado. ${ }^{(494)}$ E desfiando um pouco mais o novelo das suas evocações intensamente vividas e sentidas, D. Maria de Melo explicou o significado de uns cravos cor de rosa sobre um piano de cauda tapado com rica colgadura de veludo roxo, com recame de ouro e prata, outro retrato de Sidónio - uma das várias recordações suas que povoavam o Palácio Encantado: Recordam um facto, um pequeno incidente. Quando passou o primeiro aniversario do 5 de Dezembro, lembrei-me de enviar ao sr. presidente um ramo de cravos. Hesitei, hesitei muito. Ele estava muito triste, nesse dia. Contrariedades, movimentos... À noite falei-lhe, na recita de gala de S. Luis... Dei-lhe os cravos... Eram côr de rosa, tal qual como estes que aqui estão... Ele está sempre cheio de flôres em minha casa, ${ }^{(495)} \mathrm{Da}$ boca da Condessa desprenderam-se, em cachos de ternura, mais alguns exemplos da grandeza de alma do Presidente e da alegria imensa que ele sentia a contactar com a miséria confortada e agradecida.

Não há dúvida que o acto, várias vezes repetido, da inauguração das sopas da Obra de Assistência 5 de Dezembro constituiu um meio de promoção natural da mensagem que Sidónio Pais entendia ser urgente passar para a opinião pública - no meio das duras consequências económicas vincadas pela continuação da guerra era vital que se sentisse e se acreditasse na generosa vontade do Governo em combater com firmeza a fome. Perante uma fustigação de males de difícil ou mesmo impossível solução imediata, era crucial agarrar a confiança do Povo pela alardeada capacidade governamental de devolver a fartura e a prosperidade ao quotidiano dos cidadãos.

Nas alocuções conhecidas que proferiu em Junho, Agosto e Setembro ao inaugurar novas sopas e, em finais do Verão, quando deflagrava infrene a epidemia da pneumónica ou gripe espanhola, a par de um tifo exantemático ou tabardilho ${ }^{(496)}$ persistente no

(492) CF. PORTELA, Artur - Memorias de outros tempos. O Palacio encantado da condessa de Ficalho. As obras de caridade de Sidonio Paes. Bernardino Machado e Mayer Garção. A historia de um ramo de cravos côr de rosa. Uma festa em Sintra e um Natal feliz para os pobres. Diário de Lisboa, de 15 de Dezembro de 1921, p. 3.

${ }^{(493)} \mathrm{Cf}$. Asistencia às vitimas da guerra. Jornal da Tarde, de 8 de Fevereiro de 1918, p. I.

(494) Cf. PORTELA, Artur - Memorias de outros tempos. O Palacio encantado da condessa de Ficalho, art. cit., p. 3.

(495) Cf. Ibidem, p. 3.

(496) O termo aparece inscrito numa brochura técnico-sanitária de JORGE, Ricardo - Tifo exantemático ou tabardilho. Relatórios apresentados ao Conselho Superior de Higiene. Lisboa: Imprensa Nacional, 1918, in Dossier Epidemias. (Arquivo de Sidónio Pais - Militar, Lente e Político, Subsistema Presidência da República). 
Porto, em Amarante, em Vila Real ou em Aveiro, Sidónio insistiu bastante nesses tópicos essenciais, sem esquecer a recomendação prática de que a ajuda se destinava só a quem dela realmente carecesse.

No Beato, por exemplo, a 24 de Junho terá dito: Esta Obra já hoje destribue perto de 6.000 sopas diarias e empenho-me porque ela venha a ser uma Grande Obra, para o que hei-de fazer todos os esforços que estiverem ao meu alcance, pois que o farei para bem do povo portuguez, no meio do qual, para me sentir feliz, necessito saber que ninguem morre de fome.AAssistencia Publica é hoje uma das funções mais nobres e que corresponde a um dos mais imperiosos deveres dos poderes publicos; mas, só àqueles que não podem obter os meios necessários ao seu trabalho, ela deve valer, em Sacavém, no mesmo dia, reafirmou que $E$ ́ principalmente no meio do povo que eu me sinto bem. É n'ele que eu busco a inspiração para as minhas acções, visto que, se a minha inteligencia pode errar, ele é que nunca se engana e na maneira como por ele sou recebido encontro a aprovação ou desaprovação dos actos que pratico; em Algés, a 29 de Julho, na inauguração de outra Cozinha da Assistência 5 de Dezembro, dissertou quase exclusivamente sobre o problema político e as relações do P.N.R. e o Governo; a 4 de Agosto, em nova inauguração, desta vez na vila de Sintra, explicou que a Assistência 5 de Dezembro foi criada em moldes novos, livres das peias burocráticas, e para ela tenho concorrido com o meu melhor esforço, esperando que ela seja, dentro em breve, a maior obra de Assistencia Portugueza. Frizo contudo que essa obra tem de ser altamente moralisadora e isso só se consegue fazendo uma selecção dos assistidos. (...) Por isso, não me canso de recomendar o maximo cuidado na organisação metodica d'esta obra. Acabemos com a mendicidade. Pedir, não é digno; mas tambem não ha direito de se deixar morrer alguem de fome. É justo que os ricos repartam um pouco do seu superfluo com os necessitados, mas deve-se escolher bem os que precisam, porque, repito, toda a gente tem a obrigação moral de trabalhar, e na inauguração da sopa de Chelas concluiu com a exortação A obra da Assistencia é a obra do 5 de Dezembro, portanto, povo, auxiliai essa obra, contribuí para que ela se engrandeça, que dela deveis colher bons fructos. ${ }^{(497)}$

Extractos que caracterizam, do ponto de vista mental e ideológico-político, o insofismável republicanismo da geração de Sidónio Pais, mas mais do que isto confirmam a intensificação de uma retórica populista numa variedade de locais e de ocasiões solenes e à medida que se acentuavam os sinais de descoordenação e, sobretudo, de impotência governativa face à crise galopante e insuperável. 


\section{SEGUNDA PARTE}

\section{Cerco e Queda}

Metade príncipe, metade condottiere, seduziu, passou como um relâmpago e não deixou vestígios, porque a força que um mo mento o ergueu até ao alto, se não era fictícia, desapareceu ao primeiro sôpro

Memórias (vol. 3) de Raul BRANDÃO 



\section{Capítulo I}

\section{O 16. Governo: génese e problemas}

\section{Ajustamentos e crispações}

Dentro do clássico formalismo político-institucional vigente, a uma governação ditatorial teria de suceder uma governação estável e legitimada pelas urnas, não surpreendendo, por isso, que o $15^{\circ}$ Governo nomeado pela Junta Revolucionária fosse substituído pelo $16 .^{\circ}$ da I. ${ }^{a}$ República, primeiro e único do $4 .^{\circ}$ mandato presidencial. Nem surpreendem tão pouco as inevitáveis alterações formais provocadas pela eleição directa do Presidente da República, simultaneamente Chefe do Estado e do Executivo.

A surpresa inusitada prende-se apenas com o modo atribulado como se processou a recomposição ministerial. Ela aconteceu em duas fases: a primeira foi determinada pela exoneração de Sidónio Pais das pastas da Guerra e dos Negócios Estrangeiros que acumulara até assumir a plena investidura no cargo de Presidente, cujo exercício desaconselhava essa sobrecarga de funções ministeriais; e a segunda só teve início a 15 de Maio, quando foi finalmente organizado e empossado o novo Governo.

Nesse intervalo de tempo, foram nomeados interinos para as «pastas» da Guerra e dos Negócios Estrangeiros o Ministro das Colónias João Tamagnini de Sousa Barbosa e - Ministro das Finanças Francisco Xavier Esteves, respectivamente. O Ministro da Instrução Alfredo de Magalhães, por motivos que desconhecemos em detalhe, encontrava-se demissionário. Ele próprio o afirma em carta de 12 de Maio para o seu amigo Antero de Figueiredo: Hoje ou amanhã será solucionada a crise. Desde que depuz a pasta nas mãos do Presidente não tornei a Belem, razão por que tenho tudo suspenso, tudo menos a obstinada ideia de conseguir para o Porto, esteja eu ou não dentro do Ministerio, uma organisação escolar condigna da sua importancia e dos seus recursos. ${ }^{(498)}$ Que pressões, intrigas ou divergências terão determinado atitude tão dura a ponto de se afastar da solene cerimónia de proclamação?

Uma atitude similar e coincidente com a do irascível capitão Feliciano da Costa, que ostensivamente fez questão de estar ausente dos Paços do Concelho e, no seu estilo frontal e desabrido, frisou-o por escrito ao «seu» Presidente. Nessa curiosíssima carta queixou-se de não ter sido nomeado para nenhuma das duas interinidades - ele,

(498) Ver SILVA, Armando Barreiros Malheiro da - Sidónio e sidonismo. História e mito, dissert. cit., vol. 2, p. 858-859. 
membro da Junta Revolucionária!... - e da forma ingrata como foi demitido do Trabalho - nem uma palavra me chegou do momento em que era exonerado depois de ter servido com zelo e acendrado patriotismo. Ferido no seu orgulho próprio e incompatível com quase todas as figuras predominantes da rede sócio-política de apoio ao sidonismo, em particular com os ex-centristas tratados desdenhosamente por aqueles que souberam embrenhar-se-Ihe nas saias e mostrar a doblez de caracter, Feliciano da Costa Junior declinou, com mal disfarçadas irritação e arrogância, o lugar de Governador Geral de Angola posto à sua disposição para o compensar e, porventura, o afastar do centro do Poder. Mas as suas palavras e modos desabridos parecem ter sido acolhidas com benévola paciência por Sidónio Pais, que voltará a acenar-lhe com um novo posto - a Legação em Roma - aceite sem polémica, embora por muito pouco tempo.

Por seu turno, o Ministro do Comércio, major de Engenharia Manuel José Pinto Osório, logo após a sua exoneração, não escondeu e até se prontificou a explicar em entrevista ao Primeiro de Janeiro, ${ }^{(499)}$ extractada pel'A Capital, a sua profunda incompatibilidade com o ex-colega Machado Santos a pretexto da controversa reforma ferroviária, descrita mais adiante. (500)

Três casos flagrantes da instabilidade endógena à rede da República Nova, ameaçada, também, pelos seus adversários irredutíveis.

O jornal monárquico A Pátria, do Porto, no seu número de 5 de Maio, estampava frases alarmistas sobre uma conjura descoberta, um complot prontamente desfeito, um plano sanguinário evitado e punido com firmeza: Apreensão de bombas e prisões I O Porto, sede presidencial da República Velha / Diligências policiais a cargo do capitão Allegro / Implicados vários indivíduos civis e militares. ${ }^{(501)} \mathrm{E}$ a essa revolta se referiu Rocha Martins com alguma profusão de dados, designadamente quanto ao excesso de zelo do capitão Solari Allegro ${ }^{(502)}$ — hábil a apanhar presuntivos conspiradores, a fazê-los falar e a prendê-los.

A 15 de Maio era definitivamente enterrado o Governo ditatorial dezembrista e nascia um Executivo vincadamente sidonista, entendido como resultante directo e expressão clara de um quadro político-institucional presidencialista em que Sidónio Pais fundia em si os papéis de Presidente da República, de Presidente do Governo e de catalisador das forças político-partidárias imbricadas no pretendido reordenamento do campo republicano. Mas convém esclarecer que um novo Governo não significou, neste caso, um Governo novo.

Houve, sobretudo, ajustamentos de forma e de estrutura dentro de uma continuidade, que - já o referimos - vinha de antes do golpe dezembrista com certas e inevitáveis diferenças de estilo entretanto operadas. Ajustamentos impostos pela aplicação dos

(499) Ver As Reformas ferro-viarias. Entrevista com o ex-ministro do commercio. O Primeiro de janeiro, de 18 de Maio de 1918, p. 1.

(500) Cf. Coisas de politica. Como o sr. Pinto Osorio explica a sua incompatibilidade com o sr. Machado Santos. A Capital, de 19 de Maio de 1918, p. I.Ver SILVA,Armando Barreiros Malheiro da - Sidónio e sidonismo. História e mito, dissert. cit., vol. 2, p. 314-315.

(501) Cf. ALMEIDA, João Ferreira de, PAIS, José Machado e CABRAL, Manuel Villaverde - Materiais para a história do advento do fascismo em Portugal, art. cit., p. 403.

(502) Cf. MARTINS, Rocha - Memorias sobre Sidonio Paes, ob. cit., p. I54. 
artigos $122^{\circ}$ e $123 .^{\circ}$ da lei eleitoral de 30 de Março, sem implicações directas no elenco de Governadores Civis, alterado após a saída dos unionistas e pontualmente ao longo da governação dezembrista/sidonista consoante a especificidade de cada caso.

Começando pelas modificações verificadas sublinhemos isto: caiu a figura do Presidente do Conselho, caindo, também, com ela o até então habitual e regular funcionamento do Ministério em Conselho. A máxima responsabilidade governativa tornava-se, à luz dos modelos presidencialistas brasileiro e norte-americano, unipessoal - o Presidente da República não era, pois, um primo inter pares, mas o supremo titular do Executivo que escolhia, nomeava e demitia os seus colaboradores, consequentemente convertidos (ou reduzidos) de Ministros em Secretários de Estado (ou do Chefe do Estado).

Mantinham-se, porém, os organismos ou «pastas» existentes e alguns dos seus titulares, a saber: Francisco Xavier Esteves nas Finanças; José Carlos da Maia na Marinha; José Alfredo Mendes de Magalhães na Instrução; Eduardo Fernandes de Oliveira na Agricultura; e António Maria de Azevedo Santos nas Subsistências e Transportes. Outros trocaram de «pasta»: João Tamagnini de Sousa Barbosa, anterior Ministro das Colónias, transitou para a importante Secretaria de Estado do Interior; e o jovem Henrique Forbes de Bessa passou do Interior para o Trabalho. Estreias foram três: o Juiz da Relação de Lisboa, dr.Alberto Osório de Castro - irmão da escritora e propagandista democrática D. Ana de Castro Osório( ${ }^{(503)}$ - rendeu Martinho Nobre de Melo, nomeado, entretanto, para a vaga de João de Menezes no Supremo Tribunal Administrativo, na Justiça, sendo considerado pelo Diario de Notícias, um espírito brilhante, de finissimo trato, e tambem um notavel literato; ${ }^{(504)}$ na Guerra subiu de posto o coronel de Artilharia Amilcar de Castro Abreu e Mota, Chefe de Gabinete do anterior titular, apresentado pelo mesmo periódico como um dos mais ilustres oficiais da sua arma e um dedicado e valioso cooperador do sr. Presidente da Republica quando este sobraçava a pasta da guerra; ${ }^{(505)}$ para os Negócios Estrangeiros a escolha recaiu num alto funcionário da «casa» (Director Geral no Ministério) e antigo aprendiz de jornalista nas Novidades do mestre Emídio Navarro (e daí,talvez, a fama de monárquico, sobreposta, quando convinha, à de adesivo), chamado Joaquim do Espírito Santo Lima e com fama de ser um finissimo diplomata, em que depositam as mais fundamentadas esperanças os seus amigos; ${ }^{(506)}$ no Comércio, um militar substituía outro, diferindo entre si na patente e na natureza das Armas, porque o capitão Joaquim Mendes do Amaral (irmão do monárquico João do Amaral) ${ }^{(507)}$ era de Artilharia (em vez de major de Engenharia), professor da Escola de Guerra e com qualidades de trabalho e de inteligencia notaveis, sendo já, quando estudante, o primeiro do seu curso; ${ }^{(508)}$ e, por fim, nas Colónias um ex-centrista cedia o lugar a outro proeminente ex-centrista, amigo e colaborador de Egas Moniz, o médico naval Alexandre José Botelho de Vasconcelos e Sá, um dos mais competentes coloniais do nosso tempo, tem já a sua responsabilidade ligada a quase todos os assuntos da sua pasta, que ele tem versado, com

(503) Ver MARTINS, Rocha - Memorias sobre Sidonio Paes, ob. cit, p. 166.

(504) Cf. A Organização do novo gabinete. Diário de Notícias, de 16 de Maio de 1918, p. I.

(505) Cf. Ibidem, p. I.

(506) Cf. Ibidem, p. I.

(507) Cf. MARTINS, Rocha - Memorias sobre Sidonio Paes, ob. cit., p. 162.

(508) Cf. A Organização do novo gabinete, art. cit., p. I. 
excepcional brilho no Parlamento. Apaixonado, fanatico mesmo, por tudo quanto interessa o desenvolvimento das nossas colonias, que ele conhece profundamente. ${ }^{(509)}$

As posses decorreram no próprio dia 15, de acordo com a praxe habitual (posse dada ao nomeado e apresentação feita pelo cessante, louvor público à acção desenvolvida até aí, $(510)$ cumprimentos do pessoal e amigos, discursos, etc.) e pelo fim da tarde, sob a presidência do Chefe do Estado, reuniram-se, no Palácio de Belém, sede oficial do Executivo, todos os Secretários de Estado, ocupando-se de vários assuntos de carácter económico e político. A reunião foi muito demorada. Prolongou-se até às 4 horas da madrugada, à semelhança dos primeiros Conselhos de Ministros realizados após o golpe de Dezembro. Dessa longa reunião transpiraram para a opinião pública duas mensagens essenciais: ficara assente a política geral a seguir, idêntica, aliás, nos seus traços fundamentais à que já vinha sendo aplicada e haviam sido apreciadas as questões mais importantes nesse momento, merecedoras de especial atenção - a das subsistências e os transportes de géneros coloniais - porquanto delas dependia - era a convicção generalizada - a sobrevivência dos Governos, a ordem e a harmonia sociais.

Um rápido golpe de vista pelo elenco governativo exposto e sujeito até ao final de 1918 a duas súbitas remodelações, provocadas, sobretudo, por choques e rupturas verificadas no seio da rede sócio-política de apoio, confirma, além do notório predomínio dos ex-centristas de Egas Moniz, alguns deles cada vez mais indefectíveis sidonistas (presidencialistas), e da presença de sete (oito com o Chefe do Estado) militares contra cinco civis, a absoluta inconsistência de quaisquer avaliações ligeiras feitas só a partir do curriculum da maioria dos Secretários de Estados ou por comparação com o elenco anterior, porque, salvo o caso do Comércio ou o do Trabalho, dirigidos por figuras sem perfil específico, as restantes «pastas» ficaram nas mãos de profissionais e de especialistas nas respectivas áreas, alguns em continuidade de funções.

Uma avaliação séria da governação dezembrista/sidonista implica, ao invés, a análise de uma pluralidade de aspectos, incluindo, claro está, a produção legislativa conseguida em condições de instabilidade e de curta durabilidade comuns às dos Governos anteriores da I. ${ }^{a}$ República. E para essa análise há que ter necessariamente em conta, por um lado, as crónicas fragilidades, a par e passo sugeridas, da dita rede sócio-política de apoio e, por outro, o desempenho global de Sidónio Pais, agora mais disponível para representar o Governo nos contactos directos com todas as forças vivas da sociedade e para imprimir uma direcção coerente e forte.

No entanto, o que a documentação permite averiguar é que Sidónio não dirigiu com «pulso de ferro» os seus Secretários de Estado, antes aguentou os seus arrufos, as suas ameaças de demissão e as suas mais diversas pressões (feitas em nome de interesses próprios e alheios) e esperou deles o melhor contributo possível em circunstâncias históricas tão adversas que até os aparentemente mais reputados, como Machado Santos, ou os mais qualificados na sua área, como Alfredo de Magalhães e Eduardo de Oliveira, não se livraram de graves percalços, como teremos ainda ocasião de mostrar.

(509) Cf. A Organização do novo gabinete, art. cit., p. I.

(510) Ibidem. 
Sidónio acompanhou de perto algumas questões sensíveis, leu e reviu toda a legislação de fôlego produzida e seguiu diariamente, com a máxima atenção, o caudal noticioso nacional e estrangeiro, mas esse indiscutível e meritório esforço não chegava, afinal, para suprir certas limitações básicas: faltou-Ihe, de facto, na «algibeira» o tal plano d'acção de conjuncto reclamado por Machado Santos em Janeiro; e não soube, nem pôde conciliar o seu carismático voluntarismo, consumido ingloriamente a apagar fogos logo reacesos, com uma planificação cuidada e inovadora da actividade político-administrativa. Em circunstâncias excepcionais que exigiam soluções extraordinárias, entregou-se todo, num frenesim impotente, à conquista do amor do Povo, misturando razão e coração nos lances mais diversos.

\section{Presos políticos e cesarismo}

O episódio da soltura no Porto de alguns presos sujeitos a maus tratos pela polícia de Sollari Allegro encheu as primeiras páginas dos jornais, dominou as conversas de rua e de café e dividiu as opiniões - monárquicos e democráticos, por razões diferentes, não esconderam o seu desagrado - embora a tónica dominante fosse a da surpresa e a do aplauso pelo gesto intempestivo do Presidente. (511)

A ida, na noite de 16 de Maio, de Sidónio Pais à capital do Norte, ocorreu na sequência do rescaldo das averiguações e das prisões em número incerto relativas à falhada conspiração democrática e tinha em vista, segundo noticiaram os periódicos, a observação in loco do plano de saneamento em curso lançado contra a epidemia do tifo dois meses atrás. Este ponto ficou, porém, secundarizado depois do sucedido no dia 18 , aquando da visita às antigas cocheiras do Paço Episcopal, convertidas pelos democráticos de Afonso Costa em complemento prisional do Aljube. Ali, alguns de entre os numerosos detidos queixaram-se de maus tratos e mostraram sinais visíveis e chocantes de agressão, ao que o Presidente da República, num movimento rápido e brusco, pegou no braço de um dos presos e levando-o até ao portão, terá gritado: Vá... Saia... Está livre... Saia...; e, perante o espanto das autoridades que o acompanhavam, exclamou: Saiam... Estão todos livres... Dou a todos a liberdade.... Ao seu lado estava o novo Secretário de Estado do Interior, Tamagnini Barbosa, prontamente incumbido de inquirir e de castigar os guardas culpados pelas alegadas agressões, tendo a imprensa especulado, a partir deste gesto, eventuais divergências pessoais com Sidónio, que se ficaram pelo boato.

Inspector e o Sub-Inspector da Polícia, confrontados com uma atitude condenatória do seu desempenho nesses cargos, pediram logo a demissão, mas em vez de exonerados foram louvados por portaria do Diário do Governo. E prosseguiu o envio de presos para as colónias como medida punitiva e profilática: o decreto n. ${ }^{\circ} 4.978$ de 31 de Outubro determinou a abertura de crédito para pagar o transporte efectuado pela Empresa Nacional de Navegação nos meses de Março, Abril e Maio.

A intenção de Sidónio Pais, tal como ele se viu obrigado a explicá-la ao jornal A Situação, ${ }^{(512)}$ visava apenas formular um aviso, uma recomendação para que as autoridades

(511) Ver SILVA, Armando B. Malheiro da - Sidónio e sidonismo. História e mito, dissert. cit., vol. 2, p. 321.

(512) Cf. PAIS, Sidónio - Um ano de ditadura, ob. cit., p. 60-63. 
não exorbitassem das suas funções e se mantivessem no escrupuloso cumprimento da legalidade. Deviam ser eficazes e duras com os desordeiros e os prevaricadores, mas agindo sempre a coberto da lei e com um sentido magnânimo da justiça: $O$ que eu vi no Porto é horrivel! O que eu vi no Porto não se descreve. É um espectaculo que nunca se me apagará da memória. Que me deixei levar por impulsos emotivos - diz-se - e que um Chefe de Estado deve fazer calar o coração, porque ha alguma coisa mais que a bondade, é a Justiça. Sim, o Chefe do Estado tem de ser acima de tudo: - a lei. Mas tambem não o façamos rigidamente: - a estatua. A bondade é tambem por vezes uma forma de Justiça e para se fazer Justiça, pode ser necessario perdoar. ${ }^{(5 / 3)}$ E na mesma entrevista evocou a dado passo a natureza presidencialista da República Nova para justificar o seu acto - eu como Chefe do Estado, n'uma Republica Presidencialista, tinha ainda a faculdade de demitir imediatamente o Secretario do Interior e nomear outro que concordasse com o meu ponto de vista ${ }^{(514)}$ - o que caiu mal entre os seus críticos. Estes viram logo em tais palavras a afirmação anticonstitucional de um modelo ainda não aprovado pelos constituintes eleitos e a expressão de um intolerável cesarismo ou até uma réplica burlesca do Kaiser.

A Liga Nacional da Mocidade Republicana, cujo Directório se compunha de João Camoesas, Teófilo Junior, Lopes Cardoso, Fernando de Abreu e Nobrega Quental, não tardou, aliás, a imprimir e a divulgar um manifesto ao país, aprovado por aclamação na assembleia magna realizada no Centro Tomás Cabreira a 23 de Maio e em que esse episódio não foi esquecido.(515) Este e outros acres juízos expressos pelos adversários denotam a incomodidade causada pelo impulsivo gesto com os presos do Porto e a contínua incapacidade governamental de amaciar o ânimo oposicionista.

\section{O Olhar externo}

Claro que os afonsistas, os camachistas e os almeidistas estavam visivelmente irritados com o sr. Sidonio Paes não só por esses supostos ímpetos de cesarismo anti-republicano, mas porque, apesar de todas as fraquezas e deslizes, a República Nova averbava algumas vitórias e a principal chegara a 16 de Maio sob a forma do reconhecimento de jure pelas diversas potências.

Sir Lancelot Carneggie deslocara-se nesse mesmo dia à Secretaria de Estado dos Negócios Estrangeiros para entregar uma nota do seu Governo em que reconhecia formalmente a solução política referendada nas urnas. E, além dessa, levava outra prenda de grande valor politico-diplomático, a saber: a elevação da representação dos dois países à categoria de Embaixada. Não a formalizou, então, mas a 27 desse mês era mandada publicar a seguinte nota: Em vista da antiga aliança entre a Gran-Bretanha e Portugal, e do facto das forças britanicas e portuguesas se acharem combatendo lado a lado como camaradas de armas, o Governo de Sua Majestade deseja acreditar um Embaixador em Portugal. Sua Majestade o Rei da Gran-Bretanha e Irlanda está pronta a receber um Representante

(513) Cf. PAIS, Sidónio - Um ano de ditadura, ob. cit., p. 61-62.

(514) Cf. Ibidem, p. 61.

(515) Ver SILVA, Armando Barreiros Malheiro da - Sidónio e sidonismo. História e mito, dissert. cit., vol. 2, p. $322-323$. 
Diplomático Português com a categoria de Embaixador na Corte de St. James. É intenção do Governo de Sua Majestade que esta alteração se efectue por ocasião da proxima mudança do Representante de Sua Majestade em Lisboa. (516) Proposta aceite sem hesitações por Portugal logo a 28.(517) E se ainda houvessem dúvidas sobre a amizade luso-britânica, a nota da Legação inglesa vinha desfazê-las por completo.

Dúvidas também não podia haver quanto à atitude do representante norte-americano e do seu país face à situação sidonista. No próprio dia da proclamação presidencial(ista) Thomas Birch, em despacho para Washington, emitia uma opinião favorável e optimista: o consenso geral indicava, segundo ele, que o Presidente Sidónio Pais possuía o sincero e emotivo apoio da grande maioria do Povo português and that he has a unique oppotunity for doing some real constructive work. That his popularity is on the increase cannot be doubted after the imposing and enthusiastic demonstration of today. ${ }^{(518)}$

$\mathrm{O}$ amigo pessoal do Presidente Wilson e Ministro americano em Lisboa expediu estas palavras em 9 de Maio e continuará até ao fim da experiência sidonista a reforçar as suas impressões, as mais favoráveis, minimizando os casos problemáticos que foram surgindo e a resposta repressiva das autoridades. Assim, para Birch, a demissão de Machado Santos, no início de Junho, não teve efeitos negativos na situação política; o Exército achava-se melhor organizado; os membros dos «velhos» partidos não desistiam de derrubar o novo Governo, mas sem sucesso; e o movimento revolucionário de 12 e 13 de Outubro teve alguma gravidade, particularmente em Coimbra, mas a resposta governamental foi rápida e eficaz, as cadeias voltaram a encher-se, falando-se de cerca de 2.000 presos em todo o país, e não havia dúvida que Sidónio Pais e o seu Governo alcançaram uma grande vitória e, por consequência, a sua força não cessava de aumentar, notando-se que o apoio dos monárquicos era ainda mais entusiástico. ${ }^{(519)}$ Embora suspeitos, os despachos pró-sidonistas de Birch não andam longe do verosímil ao colocarem-nos perante um regime que, nos derradeiros meses de 1918 , conseguia ser simultânea e intensamente popular e impopular, amado por uns e detestado por outros.

Para as autoridades francesas, como temos frisado, o dezembrismo/sidonismo foi uma situação tolerada com visível desagrado. A França, como potência Aliada, definira desde o início o seu alinhamento pela posição inglesa e enfileirou logo com a Inglaterra, os Estados Unidos, a Espanha, o Brasil, a Argentina, o Uruguai, a Noruega, a Holanda, a Bélgica, Cuba e a China no reconhecimento formal da República Nova. No entanto, o seu Ministro em Lisboa, fino conhecedor da elite política republicana, entreteve-se a narrar os bastidores do Poder, pondo em relevo, ao contrário de Thomas Birch, as intrigas, as incoerências, as mazelas e as previsões mais pessimistas — em suma, o lado negro da situação.

(516) Cf. CARVALHO, Henrique Martins de - Colecções de tratados, convenções e outros actos públicos internacionais relativos a Portugal, vol. 2 (1917-1919). Lisboa: Academia Internacional de Cultura Portuguesa, 1971. p. 114.

(517) Cf. Ibidem, p. 115

(518) Records of the Department of State relating to internal affairs of Portugal, 1910-1926. Political affairs, 705/4 roll, despacho de 8 Maio, 1918. (National Archives, Washington)

(519) Ibidem, despachos entre 10 de Junho e 15 de Dezembro. 
Antes da posse do $16{ }^{\circ}$ Governo, Émile Daeschner informou Stephen Pichon da crise ministerial patente em 9 de Maio e a 16 do mesmo mês dava conta do novo elenco governativo, notando que ele se ressentia já da concepção constitucional a consagrar pelas Câmaras recentemente eleitas, porquanto os Secretários de Estado substituíam os antigos Ministros responsáveis perante o Parlamento e ficavam na dependência do Presidente da República que os nomeia e os demite livremente - Comme je l'ai indiqué sous le numéro précédent, c'est avant tout un Conseil de fonctionnaires à l'exception de $M$. Machado Santos dont M. Sidonio Paes a réussi à s'assurer le concours pour le moment. ${ }^{(520)}$ Nos despachos seguintes, retomados mais adiante, Daeschner não perdeu ensejo de anotar tudo o que lhe pareciam ser as derrapagens não republicanas e anti-democráticas da experiência sidonista.

Contra a indesmentível hostilidade veiculada pelos canais diplomáticos e oficiais franceses prosseguiu, em Paris, a acção de Bettencourt Rodrigues e de Francisco Homem Cristo Filho, com particular incidência na imprensa. Não admira, pois, que o periódico L'Opinion. Journal de la semaine, de 8 Junho de 1918, sob o algo enigmático título Légende d'Orient: histoire d'Occident tenha publicado cenas heróicas da história de um homem que se fez amar pelo povo ou que a prestigiada Revue de Paris, de I de Setembro, incluísse um artigo acerca de Portugal por René Milan, peça de propaganda turística, cultural e política de um pequeno país que se batia com bravura junto com os Aliados. No mesmo número da citada revista um desenvolvido artigo da série Les Vagabonds de la Gloire, intitulado Flandres et Portugal, glosava esse recorrente tema da bravura e da lealdade portuguesas.

Dois exemplos, pois, entre outros, da pressão e do controlo exercidos sobre a imprensa estrangeira pela Direcção dos Serviços de Informação e Propaganda da República Portuguesa nos Países Amigos e Aliados. No seus relatórios trimestrais de Junho a Dezembro, Homem Cristo Filho teve, aliás, ensejo de enfatizar, quanto pôde, os resultados obtidos na linha já atrás exposta com detalhe ${ }^{(521)}$ e onde avultava também a realização de conferências destinadas a tornar pública e indiscutível a posição portuguesa na causa comum contra a Alemanha.

Na América do Norte e do Sul, mais precisamente nos Estados Unidos, no Brasil e na Argentina, a Agência Fast de Homem Cristo Filho tinha correspondentes aos quais enviava semanalmente informes pormenorizados do que ia ocorrendo em Portugal. Este trabalho sistemático explica, por exemplo, que o New York Herald de 26 de Julho tenha feito elogiosas alusões a Portugal, que o jornal La Nación de Buenos Ayres tenha reproduzido, em números sucessivos, notícias escolhidas de política externa portuguesa ou que a canadiana Revue Populaire publicasse um texto de divulgação sobre Portugal. Ajuda ainda a compreender como, por exemplo, em Cuba, o incipiente presidencialismo sidonista tenha obtido eco, pelo menos, em dois periódicos de Habana.

(520) Z. Europe, 1840 Portugal, Ambassadeur Français à Lisbonne, ${ }^{\circ}{ }^{\circ} 88$, Lisbonne 16 Maio. (Archives du Ministère des Affaires Etrangères).

(521) Ver SILVA, Armando Barreiros Malheiro da - Sidónio e sidonismo. História e mito, vol. 2, dissert. cit., p. 325-327. 
No rol das potências que reconheceram a República Nova ainda não figurava o Vaticano, pela simples razão que estavam ainda a começar as negociações com vista ao reatamento das relações entre a República e a Igreja Católica. ${ }^{(522)}$ Um processo bem encaminhado e directamente inscrito na chamada questão religiosa atrás referida e aqui, de novo, aflorada na sua vertente político-diplomática. Um processo para o qual Sidónio Pais e os seus Governos não pouparam gestos de manifesta reconciliação. A revisão da lei da Separação, não obstante as insuficiências denunciadas pelos católicos, foi um decisivo passo; e a presença de Sidónio Pais, em 15 de Maio de 1918, na Sé Patriarcal de Lisboa, por alma dos nossos soldados mortos em campanha, uma cortesia muito promissora. A notícia desse invulgar gesto publicada pela revista do Patriarcado de Lisboa Vida Catholica, contém uma expressiva descrição do aspecto grandioso da Catedral e da pose do Chefe do Estado, ladeado pelos seus ajudantes e por alguns membros da Comissão Central de Assistência Religiosa em Campanha. ${ }^{(523)}$

As palavras e as imagens publicadas com significativo destaque pela Illustração Catholica de 15 de Junho de 1918 revelam bem a densidade do acto, do ponto de vista simbólico, captando, num mesmo espaço sagrado, a simbiose da religiosidade católica, apostólica e romana com a religiosidade cívica, patriótica e republicana, assumida e representada, pela primeira vez, ao mais alto nível, ou seja, pelo Presidente da República. E, como é natural, não faltaram logo católicos que viram nesse acto uma cedência ou uma conversão de Sidónio Pais à religião materna e o mesmo disseram e escreveram os seus adversários do campo republicano. A sua presença - ele, um livre pensador assumido - num templo católico obedeceu, porém, a um interesse político imediato de reafirmação da continuidade do esforço de guerra português e de prelúdio às negociações com a Santa Sé - Egas Moniz não se esqueceu, aliás, de lembrar esse facto nas conversações que manteve com Mgr. Francesco Ragonesi, Núncio do Vaticano em Madrid.

De 15 de Maio a finais de Julho acertaram-se os princípios, venceram-se os atritos de última hora e fixaram-se os termos de um acordo que nem o posterior retorno dos democráticos ao Poder haveria de revogar.A 28 de Junho Mgr. Ragonesi enviou um telegrama ao Cardeal Gasparri, no qual deixava claro que o Governo português lhe comunicara a intenção de procedere alla nomina di un suo rappresentante nel Vaticano prima dell'apertura delle Camera legislativa, che sará il giorno 8 Luglio.(524) Quando os deputados começassem a discutir a nova Constituição, que se pretendia presidencialista, os católicos dispunham já de nova garantia política - o restabelecimento das relações diplomáticas - pelo que podiam retribuir, gratos, o seu apoio à política do Presidente da República...

O telegrama de Ragonesi foi enviado a partir de Lisboa, por ocasião da sua visita ao Cardeal Patriarca, ponto-chave da estratégia concebida pelo negociador romano.

(522) Ver sobre este assunto SILVA, Armando B. Malheiro da - Os Católicos e a «República Nova» (1917$-1918)$ : da «questão religiosa» à mitologia nacional, art. cit., p. 463 e ss.

(523) Archivando. As exequias na Sé, «Vida Catholica», Lisboa 3 (66) Maio 1918, p. 569. Ver SILVA, Armando Barreiros Malheiro da - Sidónio e sidonismo. História e mito, dissert. cit., vol. 2, p. 328.

(524) Nunziatura Apostolica di Lisbona, Telegramma de Mgr. Ragonesi, 28 Giugno 1918. (Archivio Segreto, Vaticano). 
O desejo de visitar Portugal, a pretexto da concessão de uma bolsa de estudo para estudantes portugueses, destinava-se a testar o empenho das autoridades portuguesas no restabelecimento das relações: Mgr. Ragonesi propôs-se fazer a visita incógnito, ao que o negociador português retorquiu, em nome do seu Governo, que nada impedia a estada no seu país do representante do Vaticano. Estava dada a prova de confiança que este requeria. ${ }^{(525)}$

Em 2 de Agosto era publicado no Diário do Governo o decreto de nomeação do Enviado Extraordinário e Ministro Plenipotenciário de Portugal junto da Santa Sé, capitão José Feliciano da Costa Júnior. A nomeação era já conhecida, tendo o Osservatore Romano publicado em Julho uma nota sobre o ministro português. Esta antecipação por parte do Vaticano reflecte a celeridade posta na nomeação do novo Núncio em Lisboa e na sua divulgação pelas autoridades eclesiásticas portuguesas. Com efeito, a 29 de Julho, Mgr. Benito Masella, recém empossado nas funções de Encarregado de Negocios, participou oficialmente que as relações diplomaticas entre a S. Sé e a Nação Portugueza foram felizmente reatadas, e que S. E. Rev.ma Mons. Achilles Locatelli, Arcebispo de ThessaIonica foi nomeado Nuncio Apostolico em Portugal.(526) Divulgada e conhecida a escolha pelo Episcopado português, logo começaram a chegar à Nunciatura Apostólica ofícios dos Bispos com expressões de satisfação e laivos de vitória - a vitória do Senhor Omnipotente e Misericordioso ao cabo da luta religiosa que entre nós se desencadeou. ${ }^{(527)}$

Mas se da parte do Vaticano tudo se encaminhava, aparentemente, sem problemas, da parte portuguesa surgiriam dificuldades de ordem económica e pessoais, que retardaram a apresentação das credenciais do capitão Feliciano da Costa, a braços com a urgência de arranjar casa apropriada para sua residência e instalação da chancelaria, tarefa, sem dúvida, dispendiosa. $O$ certo é que esse atraso inquietou a Secretaria de Estado. De acordo com o estabelecido nas negociações, Portugal apresentava primeiro o seu representante junto da Santa Sé e só depois é que Mgr. Locatelli formalizaria a sua presença em Lisboa como Núncio Apostólico, o que só veio a acontecer em Abril de $1919 ! \ldots$.

A 28 de Outubro de 1918, o Cardeal Gasparri enviava um telegrama a Mgr. Masella, pedindo-lhe que indagasse prudentemente junto do Governo português as razões do atraso verificado tanto piri che persona seria afferma che esso deveri a pressioni di Francia e Italia che vorrebero indurre Governo Portoghese a rinunciare alla ripresa relasioni. V. E. procuri sapere con certessa se tali voci hanno fondamento. ${ }^{(528)}$ A resposta do Encarregado de Negócios em Lisboa foi imediata e tranquilizadora quanto a eventuais interferências

(525) Ver SILVA, Armando Barreiros Malheiro da - Sidónio e sidonismo. História e mito, dissert. cit., vol. 2, p. 329-330.

(526) Nunziatura Apostolica di Lisbona, Posizione XIV, Corrispondenze coll'Episcopato sulla nomina e sull arrivo del nuovo Nunzio Apostolico S. E. Mgr.Achille Locatelli, 29 de Julho de 1918. (Archivio Segreto, Vaticano).

(527) Ver SILVA, Armando B. Malheiro da - Os Católicos e a «República Nova» (1917-1918): da «questão religiosa» à mitologia nacional, art. cit., p. 486.

(528) Nunziatura Apostolica di Lisbona, Posizione XIV, Nomina dei Ministri Feliciano da Costa e Forbes Bessa, Telegramma 28 Ottobre 1918. (Archivio Segreto, Vaticano). 
estrangeiras que ensombrariam o clima de confiança, restaurado havia ainda tão pouco tempo, entre os dois Estados. ${ }^{(529)}$

Estas informações de Mgr. Masella foram desenvolvidas em relatórios posteriores, elaborados a partir de um contacto directo com o novo Secretário de Estado dos Negócios Estrangeiros, Egas Moniz (empossado por ocasião da última recomposição governamental de 8 de Outubro), que lhe assegurara não existirem motivos de outra ordem para além dos financeiros na origem de tal atraso, desfazendo rumores, veiculados na imprensa católica, que davam por certa a recusa do Santo Padre em aceitar as credenciais do Ministro português antes de ser conhecida a posição do novo Parlamento face às reivindicações dos católicos. Rumores que o jornal da Tarde ajudou a desfazer com a notícia de que o Governo da República não recebera nenhumas exigências da Santa Sé sobre eventuais modificações da lei da Separação.

Os verdadeiros motivos do atraso emergem nas duas cartas que conhecemos, enviadas por Feliciano da Costa para o Presidente da República. Num estilo desabrido, não é só a questão financeira e administrativa que nelas emerge, mas outras razões de fundo já explicadas.

Em Roma, Feliciano da Costa não se conformou com os precários meios de subsistência. Pressionou o Governo com sucessivos telegramas e acabou por pedir, de novo, a demissão, sem ter entregue as credenciais, ${ }^{(530)}$ embora fosse recebido, na véspera do seu regresso, pelo Santo Padre que o agraciou com a Ordem de S. Silvestre. (531) A resposta concertada de Egas Moniz e do Presidente da República foi afirmativa e rápida: a 29 de Outubro saía o decreto de exoneração a seu pedido e a I I de Novembro era nomeado para o mesmo posto o antigo Secretário Geral da Presidência da República e, na ocasião, Presidente do Senado, Manuel Jorge Forbes de Bessa. Mas, como informa Mgr. Masella no seu relatório de 22 de Novembro, mi é stato assicurato il nuovo Ministro non avendo ancora pronto l'uniforme solo potrá partire per Roma verso il 15 del prosimo mese. ${ }^{(532)} \mathrm{Em}$ Janeiro de 1919, permanecia ainda em Lisboa, retido pelos trágicos acontecimentos de Dezembro e por ter partido, entretanto, um braço.

Do exposto pode inferir-se que a instalação e o funcionamento das Legações de Portugal e do Vaticano sofreram vicissitudes decorrentes, por um lado, da crise sócioeconómica, sanitária e política com que o Governo sidonista se debatia e, por outro, do desacerto da escolha de Feliciano da Costa para Ministro Plenipotenciário. Forbes Bessa possuía, sem dúvida, melhor perfil para o cargo, tendo sido aceite prontamente por Sua Santidade, como noticiou L'Osservatore Romano, de II de Novembro. ${ }^{(533)}$

(529) Ver SILVA, Armando Barreiros Malheiro da - Sidónio e sidonismo. História e mito, dissert. cit., vol. 2. p. 331 .

(530) Informação colhida em CASTRO, José de - Portugal em Roma, vol. 2. Lisboa, União Gráfica, 1939. p. 363 .

(531) Cf. O sr. Feliciano da Costa. Jornal da Tarde, de 21 de Novembro de 1918, p. 2.

(532) Nunziatura Apostolica di Lisbona, Rapporto n. 1778 , Sul nuovo Ministro del Portogallo presso la S. Sede, 22 Novembre 1918. (Archivio Segreto, Vaticano).

(533) Cf. Informazioni e ultimi dispacci. L'Osservatore Romano, Roma, I I Novembre 1918. 


\section{A Fome e a greve na C.P.}

Em nome do Povo - sempre ele!... - os democráticos acusavam o Governo de incúria e incompetência criminosas e denunciava a carestia de vida galopante, ${ }^{(534)}$ a falta permanente dos bens de primeira necessidade e a escandalosa mancha de corrupção e de imoralidade a cobrir os novos senhores, esses mesmos que haviam ousado acusar e julgar com arrogante severidade o Governo da União Sagrada e o último de Afonso Costa. A oposição ajustava, assim, as suas contas e expunha os pretensos culpados a um descontentamento popular que desejava ver ateado o mais possível.

O alvo central das críticas era o Ministério das Subsistências e Transportes de Machado Santos e, após a demissão deste, do interinato de Eduardo Fernandes de Oliveira, Secretário de Estado da Agricultura com os seus directos colaboradores. Condenava-se uma política, gizada por um e prosseguida pelo outro, cujos traços essenciais ficaram já atrás indicados, com destaque para a aproveitável criação dos celeiros municipais, bem como para o estilo de uma actuação ministerial patente na série de telegramas de que só ficaram por referir os expedidos entre I de Maio e 4 de Junho.(535)

Durante esse período, Machado Santos manteve-se fiel ao seu impulso voluntarista para pressionar as autoridades locais a cumprirem com empenho e firmeza as disposições legislativas, despachos e circulares emanadas de Lisboa, para responder aos protestos da opinião pública contra a imoral ganância dos especuladores e para, enfim, colidir de frente com os diversos interesses escalonados na sociedade e até na própria estrutura da Administração. A já mencionada incompatibilidade com o ex-Ministro do Comércio emergiu, tanto quanto se infere da citada entrevista do major Pinto Osório, da exorbitante tendência do irrequieto Fundador da República para legislar e para regulamentar a golpes de obsessiva e utópica fúria reformadora numa esfera que só transitoriamente justificara a criação desse novo Ministério e que exigia estreita cooperação com o Comércio e a Agricultura. Um conflito de contornos pessoais a servir de prenúncio ao incidente político-ferroviário que tornou irreversível a demissão de Machado Santos, sem que Sidónio Pais conseguisse, dessa vez, evitá-la como seria seu desejo e intenção.

Enfrentando com dureza o conflito laboral nos Caminhos de Ferro, Machado Santos não estava a trair as conhecidas simpatias e ligações ao movimento operário, apenas confirmava a sua postura de revolucionário romântico, filantrópico e autoritário, que ora condenava greves, ora mandava prender patrões e administradores - a plutocracia, como ele gostava de dizer.

$O$ incidente na C.P., assaz ilustrativo de um tal perfil, foi despoletado um mês antes aquando da publicação em Diário do Governo da controversa reforma ferroviária, condenada, como vimos atrás, pelo ex-Ministro do Comércio, major Pinto Osório, por revestir o carácter de ingerência das Subsistências e Transportes na esfera de competência administrativa do Comércio.

(534) Dossier Imprensa, Folhetos, Folhas Volantes, etc., A Fome, s.d. (Arquivo de Sidónio Pais - Militar, Lente e Político, Subsistema Presidência da República).

(535) Ver SILVA, Armando Barreiros Malheiro da - Sidónio e sidonismo. História e mito, dissert. cit., vol. 2. p. $340-344$. 
Sem entrarmos numa detida análise, convém, no entanto, referir que a dita reforma assentava em dois extensos diplomas - o decreto n. ${ }^{\circ} 4.205$ de 4 de Maio estabelecendo o Regulamento dos caminhos de ferro do continente da República Portuguesa e o decreto n. ${ }^{\circ}$ 4.206, da mesma data, fixando as bases da Organização da Direcção Geral dos Transportes Terrestres - e que ambos acabavam por constituir um apertado instrumento de intervenção e controlo do Governo e, em particular, da Direcção Geral dos Transportes Terrestres, à frente da qual se encontrava o jovem engenheiro militar e machadista Cunha Leal.

A leitura do Regulamento é elucidativa dessa tendência, mas o segundo decreto, que vinha desenvolver e ampliar matéria disposta no decreto n. 3.936 de 16 de Março de 1918, deixa-a claramente explicitada logo na abertura do seu articulado: essa Direcção Geral superintendia, sob a autoridade do Ministro das Subsistências e Transportes, em toda a viação terrestre portuguesa, competindo-lhe, em especial, o estudo, a construção e a gerência dos Caminhos de Ferro do Estado; o exame e aprovação dos projectos de Caminhos de Ferro, concedidos a companhias, empresas ou particulares, e a fiscalização da construção dos mesmos; a fiscalização da gerência de todos os Caminhos de Ferro do continente da República portuguesa; e a mobilização de todos os meios de transporte, quando necessário. Para o cumprimento destes objectivos a estrutura criada era munida de uma Secretaria, de uma Repartição de Contabilidade, de uma Direcção dos Caminhos de Ferro do Minho e Douro, de outra Direcção para os Caminhos de Ferro do Sul e Sueste e uma Direcção da Fiscalização para toda a rede ferroviária do Estado. Anexa à Direcção Geral funcionava ainda uma Junta Consultiva dos Caminhos de Ferro. E no respeitante ao Director Geral, propriamente dito, verifica-se que as suas competências, distribuídas por dezanove pontos, conferiam-lhe uma lata capacidade de intervenção, aliás, invulgar no sector e daí as reacções negativas surgidas, designadamente da parte da Administração e Direcção Geral da C.P., dominada, conforme a voz corrente, pelos unionistas.

Na versão de Cunha Leal - um dos intervenientes no conflito - Machado Santos lá ia deitando remendos em tão avariada situação, umas vezes com acerto, outras com desacerto. Em dada altura, recorreu ao meu concurso para submeter as empresas ferroviárias a uma disciplina mais eficaz, reorganizando, com essa finalidade, os serviços estatais de fiscalização segundo os moldes de França. A oposição dos interessados foi clamorosa; e a Administração da C.P., a propósito de qualquer reclamação do seu pessoal, curou, à capucha, não de o acalmar, mas, sim, de o excitar. Pediu o Secretário de Estado o meu modo de ver para se atamancar o problema. Eu tomara já contacto com alguns dos reclamantes com peso nas suas resoluções e chegara à convicção de que, servindo-se deles e indo instalar-me na Estação do Entroncamento, me seria possivel restabelecer o funcionamento dos comboios, desde que os Corpos Gerentes da C.P. não entravassem os nossos esforços!(536)

Referia-se implicitamente à greve dos ferroviários, instigada, segundo esta versão, pelos ditos Corpos Gerentes da Companhia. Em face da opinião emitida pelo seu colaborador, Machado Santos não hesitou ordenar ao Chefe da Polícia de Lisboa e seu

(536) Cf. LEAL, Cunha - Coisas de tempos idos. As Minhas memórias, vol. 2 - Na periferia do tufão. De 1 de Janeiro de 1917 a 28 de Maio de 1926, ob. cit., p. 87-88. 
amigo pessoal, capitão Lobo Pimentel, que, às 16 horas do dia 7 ou 8 de Junho - já não posso precisar - fosse prender todos os Administradores da C.P., ocasionalmente reunidos nesse momento em Conselho, conduzindo-os, para o efeito, em camionette e tratando-os com toda a deferência. Essa detenção deveria manter-se até que fosse restabelecida por mim a normalidade do serviço ferroviário. Um procedimento algo bizarro, narrado por Cunha Leal com muita naturalidade, mas os visados é que não acharam graça à ideia e como foram alertados antes da execução da ordem como um bando de pardais assustados, esvoaçaram, in acto, até ao Palacio do Presidente invocando o seu patrocínio. ${ }^{(537)} \mathrm{E}$, pelos vistos, com êxito...

Sidónio Pais recebeu-os, ouviu-os e desautorizou Machado Santos, ordenando a Lobo Pimentel que não efectuasse a operação concebida pelo seu Secretário de Estado, a quem comunicou, posteriormente, a sua decisão. Era o suficiente para melindrar o susceptível Machado Santos, que, de imediato, apresentou o seu irrevogável pedido de demissão, aceite inevitavelmente por Sidónio Pais. Uma demissão oficializada a 9 de Junho e que arrastou, também, a do indefectível machadista e capitão de Mar e Guerra José Carlos da Maia, exonerado a 27 de Junho, ${ }^{(538)}$ sendo substituído, interinamente até 7 de Setembro, pelo Secretário de Estado da Instrução Alfredo de Magalhães.

Na versão de Rocha Martins, cuja ligação pessoal a Machado Santos é bem conhecida, a narrativa tomou cores mais suaves: na origem da greve dos ferroviários teria estado a reivindicação da revisão do regulamento decretado em Maio, o Conselho de Administração conferenciou em Belém com Sidónio Pais e nos bastidores dizia-se que os ferroviários impunham a demissão de Cunha Leal e dos outros funcionários; propunha-se ao fundador da república a revisão do regulamento. Preferiu que se abrisse a crise. Na sombra tinham-no indisposto com o chefe de estado e quando exigiu a demissão dos delegados do govêrno junto dos Caminhos de Ferro - todos camachistas - e lha recusaram, o inevitável surgiu. Ele acusava-os de cúmplices no movimento contra os seus desígnios. Era mais um republicano a afastar-se de Sidonio.(539)

Duas versões diferentes que incidem sobre ângulos opostos do caso.

Cunha Leal, denotando alguns lapsos e imprecisões cronológicas, não colocou como causa próxima o clausulado do Regulamento estabelecido pelo decreto n. ${ }^{\circ} 4.205$, mas sim a decisão de prender temporariamente o Conselho de Administração da C.P.. Ao contrário, Rocha Martins enfatizou uma cláusula desse diploma - a da indemnização ao público pelo desvio dos géneros nos comboios - como o grande pomo da discórdia.

Qual deles o mais exacto? É difícil sabê-lo, porque cada um juntou o seu contributo pessoal para a verdade e esta exige, pelo menos, que tenhamos em conta o seguinte: em Abril surgiu um primeiro atrito nas relações da equipa das Subsistências com o Conselho de Administração da C.P. a propósito do aumento em 40 a 50\% da sobretaxa nas tarifas concedida por motivos de guerra; ${ }^{(540)}$ os dois diplomas de 4 de Maio provocaram uma viva contestação entre as pessoas ligadas aos Caminhos-de-Ferro e na opinião pública

(537) Cf. LEAL, Cunha - Coisas de tempos idos. As Minhas memórias, vol. 2 , ob. cit., p. 88.

(538) Cf. Ibidem, p. 88.

(539) Cf. MARTINS, Rocha - Memorias sobre Sidonio Paes, ob. cit., p. 187-188.

(540) Dossier 56 Caminhos de Ferro, ofício da Direcção Geral dos Transportes Terrestres, 6 de Abril de 1918 , 4 fls. dactiloscritas. (Arquivo de Sidónio Pais - Militar, Lente e Político, Subsistema Presidência da República). 
em geral, sendo certo que o pessoal ferroviário exigiu a suspensão do decreto n. ${ }^{\circ} 4.205$ e da parte sob fiscalização do Governo contida no n. ${ }^{\circ} 4.206$;(54I) deflagrada a greve por esse e por outros motivos, o Secretário de Estado das Subsistências e Transportes taxou-a logo de acto criminoso e injustificado, impondo, através do Director Geral da C.P., Ferreira de Lima, uma circular(542) que intimava o pessoal a regressar ao trabalho e considerava os desobedientes demitidos devendo, caso habitem edificios da Companhia deixal-os devolutos no prazo das vinte e quatro horas consecutivas, intimação, ao que se sabe, recusada ou, pelo menos, mal acolhida pela Administração da C.P.; e, por último, convém lembrar que Sidónio Pais fora membro do Conselho de Administração dos Caminhos-de-Ferro Portugueses, em 1911 , sendo, naturalmente, sensível à contestação gerada por esses decretos, além de que acompanhou de perto o evoluir da situação, como se deduz de uma comunicação manuscrita (pelo punho, parece-nos, de Eurico Cameira) com as exigências e os actos de sabotagem do pessoal em greve. ${ }^{(543)}$

A demissão de Machado Santos representou, sem dúvida, uma baixa política importante no Governo sidonista, não só porque, apesar de todos os seus excessos de estilo, a linha traçada nas Subsistências correspondera, pelo menos, a um esforço de moralização simpática à generalidade dos cidadãos, indignados com os fabulosos e chocantes lucros dos açambarcadores, mas também pela vantajosa presença do núcleo machadista na rede sócio-política de apoio.(544) Entre os analistas coevos, nos quais incluímos o Ministro francês Daeschner, generalizara-se a convicção de que Machado Santos era um factor de «desordem» ou de perturbação política, com tendência, se remetido à oposição, para as conspiratas permanentes. Não era uma convicção errónea, mas nem sempre ficou demonstrada. Com efeito, era improvável que o almirante renegasse completamente as suas responsabilidades e afinidades com a situação dezembrista, embora a sua posterior conduta no Senado viesse confirmar um afastamento crítico e incoerente, habilmente mistificado para a História pelo seu devotado amigo Cunha Leal.(545)

\section{O Escândalo das aç̧ões}

A saída de Machado Santos e, por arrastamento, a de José Carlos da Maia, enfraqueceu a imagem pública do recém-nascido Governo da República Nova, com a agravante de ocorrer logo a seguir ao escândalo das acções que levara também à demissão do Secretário de Estado das Finanças e destacado dirigente do P.N.R., Francisco Xavier Esteves, exonerado, na 2. ${ }^{\text {a }}$ série do Diário do Governo, de I de Junho.

(541) Dossier 56 Caminhos de Ferro, Bases em que ficou assente a solução da greve dos ferroviários do Sul e Sueste, fl. [3]. (Arquivo de Sidónio Pais - Militar, Lente e Político, Subsistema Presidência da República).

(542) Copiador de telegramas do Ministério de Subsistências e Transportes, fls. inum. (Arquivo de Machado Santos)

(543) Ver SILVA, Armando Barreiros Malheiro da - Sidónio e sidonismo. História e mito, dissert. cit., vol. 2. p. 348.

(544) Cf. Machado Santos. A manifestação de ontem fez-se com todo o entusiasmo. Jornal da Tarde, II de Junho de 1918, p. I.

(545) Cf. LEAL, Cunha - Coisas de tempos idos. As Minhas memórias, vol. 2 - Na periferia do tufão. De I de Janeiro de 1917 a 28 de Maio de 1926, ob. cit., p. 108. 
Na crónica de Rocha Martins o sucedido aparece condensado em poucas linhas:

Em volta da compra de 33.500 acções do caminho de ferro adquiridas pelo ministro das finanças Xavier Esteves, com o fim de resgatar as linhas, levantara-se um clamor intenso. Via-se já a brecha por onde os conspiradores pretendiam entrar.

Subiam as objurgatórias, as invectivas, as frases contundentes porque se negociara êsse papel a $90 \$ 000$ réis cada acção, quando se poderia obter mais barato. A aquisição fizera-se por intermédio do sr. Ricardo Malheiro, do Banco Comercial do Pôrto, que tudo venderia em Espanha no caso de recusa do govêrno português, e tivera a auxiliá-lo o sr. Anselmo Vieira. Seria desvantajosa para o país a passagem daquele grande número de acções para o estrangeiro e o ministro não hesitára.Agora acusavam-no; tôda a imprensa o atacava; os jornais monárquicos acaudilhavam os demagógicos, dava-se fóros de escândalo ao facto que Machado Santos considerava, com a sua honradez, como uma operação honesta. Era nomeada logo uma comissão de inquérito da qual fazia parte o dr. João Ulrich, governador do Banco Ultramarino, cujo contrato com o estado ia ser reformado estando a estudar o caso uma comissão à qual pertenciam os dois negociadores da venda das acções. E era isto o que o Dia salientava, enrolando no ruído, em tôda a ância de batalha, os que se chegavam a essa operação.

Só o ministro das subsistências se atrevia a defender o colega demitido emquanto não chegava a sua vez de cair também entre fúrias inimigas. ${ }^{(546)}$

Essa Comissão de Inquérito foi, efectivamente, nomeada por portaria de 4 de Junho e composta, entre outros, pelo vogal João Henrique Ulrich, que, por carta ao Presidente da República e ofício ao Secretário de Estado das Finanças interino, a acumular com o Comércio, capitão Joaquim Mendes do Amaral, comunicou a recusa de tal nomeação devido aos seus estreitos contactos com o meio financeiro. ${ }^{(547)}$ A recusa foi atendida por portaria de 6 de Junho e a Comissão ficou formada pelos seguintes membros: Alfredo Augusto Lisboa de Lima, Jorge de Vasconcelos Nunes, Alberto Aureliano da Silveira da Costa Santos, Manuel M. A. da Silva Bruschy e José de Almada. No decurso das suas diligências a Comissão pôde ouvir, a 28 de Junho, Anselmo Augusto Vieira e receber o seu depoimento escrito com data de 29 , através do qual tentaremos reconstituir o caso, mas importa, desde já, assinalar que ela não chegou a conclusões precisas a não ser para considerar perfeitamente defensável a idea do Govêrno naquela aquisição. ${ }^{(548)}$

Segundo o depoimento de Anselmo Vieira - um monárquico, crítico em relação ao sidonismo, ${ }^{(549)}$ mas claro defensor da honorabilidade de Xavier Esteves e da razoabilidade da compra das acções pelo Governo - foi em Abril de 1917 que teve a ideia de fundar uma empresa com suficiente capital voltada para a indústria dos transportes terrestres e marítimos e, ao mesmo tempo, base de um Trust do cacau com ligações ao Brasil e à Venezuela.

(546) Cf. MARTINS, Rocha - Memorias sobre Sidonio Paes, ob. cit., p. 187.

(547) Dossier 56 Cominhos de Ferro, carta e ofício de João Henrique Ulrich, 6 de Junho. (Arquivo de Sidónio Pais - Militar, Lente e Político. Subsistema Presidência da República).

${ }^{(548)}$ Cf. Decreto n. 4.727 de 30 de Julho de 1918.

(549) Ver VIEIRA, Anselmo - A Crise nacional. Lisboa: J. Rodrigues \& C... 1926. p. 408 e ss. 
O projecto surgira como resposta patriótica á situação dificil em que se encontra Portugal, e que mais grave será ainda, quando se liquidarem os encargos impostos pela Guerra e como oportunidade de se valorizar o esplendido porto de Lisboa por forma a poder fazer-se d'esta cidade a Hamburgo do Occidente, concentrando aqui, tanto quanto possivel, uma boa parte do movimento commercial dos mercados da America. ${ }^{(550)}$ Exposto a algumas pessoas interessadas nesses assuntos recebeu benévolo acolhimento, embora se reconhecesse ser um plano bastante audacioso, que por isso mesmo deveria encontrar, a par de dificuldades na sua execução, sorrisos compassivos de criaturas timoratas, sempre propensas ao desanimo, e tambem sempre mergulhadas na crença de que os pequenos povos não podem abalançar-se á pratica de grandes emprehendimentos, ainda mesmo quando reunam, como Portugal, um extraordinario conjuncto de condições naturaes, que legitimem e facilitem audazes tentativas. ${ }^{(551)}$ Esse estímulo inicial permitiu explorar melhor a ideia e considerar necessária a criação de uma importante companhia de navegação que ligasse Portugal regular e semanalmente aos mercados americanos e que conseguisse obter uma forte posição, absolutamente preponderante, nas linhas férreas da Península. Partiram, aliás, deste aspecto as diligências encetadas no sentido da compra de acções e obrigações das companhias de Norte e Leste, Salamanca e Beira Alta. A feliz congregação de capitais portugueses, americanos e espanhóis para esse fim possibilitou que se passasse aos dominios da pratica, estabelecendo, então, Anselmo Vieira contactos com os sócios da Casa Amaral através do sr.Arnaldo Machado Fernandes para tratar directa e confidencialmente da compra do lote de acções, propriedade d'essa firma.(552)

As negociações, entretanto, prosseguiram nessa e noutras direcções em busca de uma sólida plataforma de investimento nacional e estrangeiro que possibilitasse a execução do projecto. Mas a dado momento uma individualidade das mais cotadas na banca portugueza, gerente de uma solida casa bancaria, discutindo os pormenores do plano, fez notar que, a prosseguirem os trabalhos com a orientação que se Ihes dera inicialmente, havia o risco de outhorgar á Hespanha interferencia nas linhas ferreas portuguezas. ${ }^{(553)}$

A observação calou fundo no espírito de Anselmo Vieira, que desde logo pensou em abandonar a parte do projecto respeitante a linhas ferreas, continuando, comtudo, a trabalhar pela organisação do «TRUST» do cacau e comunicou, em Fevereiro de 1918, a decisão aos seus colaboradores na execução da empresa, que procuraram demovê-lo desse propósito. Todavia, Anselmo Vieira resistiu aos argumentos aduzidos, retorquindo deste jeito: Estou de accordo com o seu criterio, disse-the mais de uma vez, e vejo que teem razão os amigos que me aconselham a continuar n'estes trabalhos, mas conheço bem o meio em que vivo, a atmosphera que se respira n'este paiz, e sei perfeitamente que, quaesquer que fossem os beneficos resultados que a execução do meu primitivo plano desse á economia nacional, nem assim se evitaria uma pavorosa campanha, em que eu seria varado provavelmente com o epitheto de Miguel de Vasconcellos dos Caminhos-de-Ferro. E assim

(550) Dossier 56 Caminhos de Ferro, Cópia do depoimento de Anselmo Augusto Vieira perante a Comissão de Inquérito sobre a compra das acçōes da C.C.F.P., fl. I. (Arquivo de Sidónio Pais - Militar, Lente e Político, Subsistema Presidência da República).

(551) Ibidem, fls. I-2.

(552) Ibidem, fls. 2-3.

(553) Ibidem, fl. 4. 
tornou-se firme e inabalavel a minha resolução de não tratar mais do assumpto.(554) Estava já animado destes intuitos quando, numa passagem por Madrid, em Março de 1918, que não teve a ver directamente com as acções dos Caminhos-de-Ferro, encontrou, acidentalmente, no Palácio Hotel, o sr. Ricardo Malheiro, Director do Banco Comercial do Porto: passearam juntos, trocando, naturalmente, impressões sobre os motivos que nos levaram a Hespanha e no decurso da conversa aquele comunicou estar ali para se ultimar a venda, por 30 milhões de pesetas, de todo o papel da Companhia de Salamanca, propriedade do Banco Commercial do Porto. Foi então que informei o Snr. Ricardo Malheiro, de todos os trabalhos, que eu realisara, para a organisação da empreza, a que me refiro na primeira parte d'esta exposição, e bem assim dos motivos e melindres, que me levaram a desistir de effectuar uma parte d'esse plano.(555)

Depois desse acidental encontro outro se verificou, de novo em Madrid, por iniciativa de Ricardo Malheiro, tendo este solicitado, então, a Anselmo Vieira a cedência a favor do Banco Comercial do Porto da opção para a compra de acções da Companhia de Caminhos-de-Ferro Portugueses, pois assim a operação que ele estava fazendo tornavase-Ihe mais fácil: Expliquei depois ao Snr. Ricardo Malheiro - prossegue Vieira - que não havia nenhuma opção por escripto, mas apenas a promessa feita pela casa Amaral a um amigo meu, o Snr.Arnaldo Machado Fernandes, de que as acções não seriam vendidas sem que elle fosse ouvido, e que, no tocante ao lote de acções pertencentes ao Snr. Marques de Valle Flôr, havia a affirmação de um intermediario de que ellas se obteriam, logo que isso fosse necessario. ${ }^{(556)}$

Na sequência dessa segunda conversa, Ricardo Malheiro insistiu com o seu interlocutor para que este conseguisse a compra em opção de todas as acções em favor do Banco Comercial do Porto, tendo Anselmo Vieira prometido tratar do assunto junto de Machado Fernandes após o seu regresso a Lisboa, o que fez. Graças aos contactos que ajudou a estabelecer, o Banco Comercial acabou por comprar as acções à Firma Amaral e ao Marquês de Vale Flor, ficando na posse de 33.500 acções dos Caminhos de Ferro Portugueses a fim de ultimar a operação pendente em Espanha. ${ }^{(557)}$ Operação suspensa pelo súbito interesse do Governo de evitar que os vizinhos detivessem uma posição preponderante na exploração ferroviária nacional.

Mas como foi que se estabeleceram, entretanto, as negociações entre o Governo e o Banco Comercial do Porto para aquisição das referidas acções? Anselmo Vieira, no depoimento que estamos a seguir, declara desconhecer esse processo: Estive sempre na convicção de que as acções, que o Banco Commercial do Porto adquirira por compra em opção, iam para Hespanha, como o Snr. Ricardo Malheiro declarava, afirmando até que tinha comprador firme para esse papel, e que as acções seriam pagas por um pouco mais de 200 pesetas cada uma. Fui absolutamente estranho á operação realisada entre o Governo e o Banco Commercial do Porto, como o prova a respectiva correspondencia existente

(554) Dossier 56 Caminhos de Ferro, Cópia do depoimento de Anselmo Augusto Vieira perante a Comissão de Inquérito sobre a compra das acções da C.C.F.P., fl. 4. (Arquivo de Sidónio Pais - Militar, Lente e Político, Subsistema Presidência da República).

(555) Ibidem, fl. 5.

(556) Ibidem, fl. 6.

(557) Ibidem, fls. 7-8. 
no Ministerio das Finanças. A transacção foi directamente tratada e effectivada pelas duas partes, sem a cooperação, que eu saiba de qualquer intermediario.(558)

Embora alheado da negociação directa entre as partes interessadas, o inquirido reservou a resposta ao último quesito do questionário formulado pela Comissão — se sei de algum facto de onde possa conhecer ou concluir que o Snr. Xavier Esteves procedeu, n'esta operação com o intuito de qualquer interesse pessoal inconfessavel, ou menos digno e honesto ${ }^{(559)}$ - para confirmar a opinião ouvida a mais de uma pessoa respeitável do Porto de que o Secretário de Estado das Finanças podia errar, mas era incapaz de cometer conscientemente um acto desonesto, e para sancionar, do ponto de vista técnico-financeiro, a forma como se operou a intervenção governamental.(560)

O Secretário de Estado das Finanças teria agido de boa-fé e com a maior correcção moral, mas raiando a precipitação e a ingenuidade, na medida em que se envolveu numa operação com nítidos contornos especulativos quer pelo valor nominal das acções mantido pelo Banco Comercial do Porto, quer pela ameaça da sua venda a banqueiros espanhóis. ${ }^{(561)}$

No entanto, este aspecto não foi o único determinante para a compra das acções, a crermos no relatório confidencial que Xavier Esteves escreveu, sete dias após a sua exoneração oficial assinada por Sidónio Pais sob pressão do visado e ante as proporções de grave escândalo que o caso tomara.

São vinte folhas manuscritas na frente e em papel quadriculado, cujo conteúdo não cabe aqui esmiuçar e, por isso, cingir-nos-emos ao essencial. E desde logo a revelação interessante, que abre o relatório, de ter sido o Banco Comercial do Porto quem, a 4 de Maio, propôs ao Ministério das Finanças do $15^{\circ}$ Governo o negócio das acções a $90 \$ 00$ cada. Num dos dias seguintes à recepção da proposta, o Ministro, ou seja, Xavier Esteves, levou-a ao conhecimento do Presidente da República, que entendeu merecer o assunto cuidadoso exame, mas pareceu-lhe conveniente a compra das acções e pedindo a cotação d'ellas, tendo em vista os estudos feitos sobre o resgate das linhas da Companhia e as já antigas reclamações dos accionistas do $2 .^{\circ}$ grau, sem esquecer ainda que, paralelamente, a Secretaria de Estado das Colónias desencadeara o resgate da controversa concessão da Ambaca em vigor desde 25 de Setembro de 1885.(562)

Estudos e reclamações que Xavier Esteves acompanhara de perto, mas no relatório confessa que não poude, no momento informar se a proposta do Banco oferecia ou não vantagens para o Estado. Releguei-a então á Secretaria geral do Ministerio, para ser informada. A informação indicava como vantajosa a aquisição dos titulos e acrescentava que a cotação

(558) Dossier 56 Caminhos-de-Ferro, Cópia do depoimento de Anselmo Augusto Vieira perante a Comissão de Inquérito sobre a compra das acções da C.C.F.P., fl. 7. (Arquivo de Sidónio Pais - Militar, Lente e Político, Subsistema Presidência da República).

(559) lbidem, fl. 8.

(\$60) Ibidem, fls. I0-II.

(561) Ver CAMACHO, Brito - O Inquérito. A Lucta, 30 de Setembro; I de Outubro; 2 de Outubro; 8 de Outubro; 11 de Outubro; e 12 de Outubro de 1918.

(562) Dossier 56 Caminhos-de-Ferro, Cópia do depoimento de Anselmo Augusto Vieira perante a Comissão de Inquérito sobre a compra das acções da C.C.F.P.. (Arquivo de Sidónio Pais - Militar, Lente e Político, Subsistema Presidência da República). 
da bolsa era de 50 a 52 escudos. Mandei responder ao Banco que havia grande differença entre o preço e a cotação de bolsa, e que, se o assumpto podia ser mais demoradamente estudado, nenhum compromisso do Estado ficaria tomado, quanto a qualquer transação. ${ }^{(563)} \mathrm{A}$ resposta do Banco chegou com data de 18 de Maio: mantinha inflexível o preço, porque oferecia um lote representativo da maioria do capital e aos preços inferiores da bolsa só se adquiriam pequenos lotes. A resposta foi imediatamente comunidada ao Presidente da República e nesse intervalo de tempo que durou esta correspondencia, foi o assumpto estudado e relacionado com o plano financeiro que é preciso executar para que o paiz possa solver os encargos que Ihe acarretou a guerra, sem prejuizo do seu desenvolvimento economico autonomo e da integridade do seu patrimonio colonial.(564) Gorada a tentativa junto do Banco para uma baixa do preço por acção e dado o entendimento de que a compra dessas acções afastaria de todo o perigo possivel de chegarem hespanhoes a preponderar na C.P. e o resgate viria a afastar todos os estrangeiros d'essa preponderancia, além de contribuir para a execução de um ambicioso plano financeiro de liquidação da pesada dívida à Grã-Bretanha e de apoio ao desenvolvimento global (agrícola, comercial e industrial) do país no pós-guerra, Xavier Esteves não hesitou em manifestar-se definitivamente favorável à operação de resgate, com a qual, aliás, se mostraram concordantes, em Conselho de Gabinete de 15 de Maio, os colegas do Comércio, das Colónias e das Subsistências, conhecedores, pela imprensa, dos propósitos de capitalistas espanhóis de pretenderem valores portugueses, designadamente acções da CP.

A operação seria, pois, iniciada com essa compra e prosseguida pela aquisição de novas acções na Bolsa em pequenos lotes ou à sua cotação, que poderia andar à média de 60 a $70 \$ 00$, e pela compra de obrigações de $2 .^{\circ}$ grau através do Banco de Portugal, que possuía relações com os estabelecimentos estrangeiros na posse de tais acções ou capazes de as obterem:

Com este modo de ver, exposto ao Sr. Presidente da Republica nos dias correntes entre 20 e 23 de maio, concordou Sua Ex. ${ }^{a}$, autorizando a compra das 33.500 acções que deram entrada no cofre da fazenda publica alguns dias depois.

A campanha que, ao ser conhecida a operação, se levantou na imprensa contra o governo, envolve ataques politicos e insinuações contra a honra das pessoas que n'ella tinham maiores ou menores responsabilidades, pelas situações que ocupavam; atingiu-se o secretario de finanças, atingiu-se o governo, atingiu-se o Sr. Presidente da Republica.

Na exposição anterior, ficam esclarecidos os fundamentos da operação e traçado o plano que o Governo pensava levar a cabo não deviam ser revelados os seus detalhes antes de o Estado estar seguro de poder completa-lo; talvez o debate politico começado tenha posto de sobreaviso muitas pessoas que possuem titulos dos Caminhos-de-Ferro, e talvez, recomeçando, se prejudique muito a sua realisação.

(563) Relatório Confidencial de Francisco Xavier Esteves, Lisboa, 8 de Junho de 1918, fls. [1-2]. (Arquivo de Sidónio Pais - Militar, Lente e Político, Subsistema Presidência da República).

(564) Ibidem, fls. [2-5 e 12-14]. 
Sobre a honorabilidade pessoal, que se pôz em discussão, eu só lamento que a vida que alguns homens teem levado desde muitos annos atraz, perseguidos no tempo da monarchia e perseguidos no tempo da republica, não seja affirmação sufficiente do seu caracter; e que depois de fazerem carreiras quasi de stoicismo, quando o seu concurso aparece para uma obra util a fazer, sejam considerados como ambiciosos que se apoderam de poder para desbaratar os dinheiros publicos em proveito de amigos e proprio.

Desejo que n'este particular se saiba que não precisei de vir ao poder para ter a minha independencia e que não a conquistei senão por um trabalho aturado e inalterado durante 33 annos. ${ }^{(565)}$

Uma impressiva nota de mágoa e de desagravo num documento indispensável a quem tivesse de inquirir e ajuizar a correcção do acto praticado.

Xavier Esteves saía visivelmente agastado com a campanha que sobre ele desabara, mas não consta ter colidido com o Presidente da República, revelando-se, pelo trabatho feito na Comissão Revisora da Constituição (ver Anexo 2) um firme defensor do presidencialismo.Transferiu, assim, a sua lealdade à República Nova da frente governativa para a esfera parlamentar, deixando nas Finanças um plano de fundo e um Orçamento Geral para 1918-1919 por ultimar.

Deixava a «pasta» entregue a um colega — o do Comércio — sem a sua experiência, nem o seu prestígio de velho republicano e de pessoa ligada às questões económicas. O capitão Mendes do Amaral ficara ainda com o pesado encargo de acumular a titularidade das duas Secretarias de Estado, solução mantida até 8 de Outubro e para a qual a explicação óbvia, válida também no caso da Marinha, radica na inconveniência política de uma remodelação cerca de quinze dias após a posse do Governo.

(565) Dossier 56 Caminhos-de-Ferro, Relatório Confidencial de Francisco Xavier Esteves, Lisboa, 8 de Junho de 1918, fl. [20]. (Arquivo de Sidónio Pais - Militar, Lente e Político, Subsistema Presidência da República). 



\section{Capítulo 2}

\section{Situação Governativa}

\section{Economia e Finanças}

Já atrás caracterizámos, nas suas linhas gerais, a política económico-financeira adoptada, mas não podemos deixar de tecer, aqui, umas brevíssimas notas sobre a produção legislativa publicada até Outubro. Assim, convém destacar:

a extinção do direito de encarte aos funcionários públicos, criado pela lei n. ${ }^{\circ} 6$ de 5 de Julho de 1913, e aumento do imposto de rendimento sobre os vencimentos desses funcionários;

a regulação da constituição das sociedades anónimas por decreto n. ${ }^{\circ} 4.556$ de 9 de Julho, rectificado pelo decreto com o mesmo número e a mesma data, publicado sob a chancela da Secretaria de Estado do Comércio;(566)

a reorganização dos Serviços Aduaneiros de Lisboa e Porto com base na reforma publicada em 27 de Maio de 191 I, ajustando-a à conveniência de acomodar a lei às necessidades sempre variáveis do comércio e da indústria, nas suas relações com as alfandegas (decreto n. ${ }^{\circ} 4.560$ de 8 de Julho de 1918);

a decisão de decretar imediatamente, em diploma especial, o Orçamento Geral do Estado de 1918-1919 por força de circunstâncias excepcionais que se prendiam com o atraso no funcionamento pleno do Congresso, incumbido, além da necessária aprovação desse Orçamento, de outros assuntos importantíssimos a tratar, como sejam o da Constituição Política da República Portuguesa e o da apreciação da obra do Govêrno neste curto, mas intensivo, período de reorganização nacional, e dêsse facto, seguramente, advirá um retardamento excessivo na publicação daquele diploma, extremamente prejudicial para o bom e regular andamento dos serviços públicos; ${ }^{(567)}$

a reorganização dos serviços da Caixa Geral de Depósitos, atrás focada; a permanência em vigor do decreto de 16 de Julho de 1896 que regulava a contribuição industrial até ser completamente refundido esse diploma (nova tabela estabelecida, pelo decreto n. ${ }^{\circ} 4.699$ de 14 de Julho, com o propósito de criar

(566) Cf.TELO, António José - O Sidonismo e o movimento operário português, ob. cit., p. 178.

(567) Cf. Diário do Governo, I série (158) 15 de Julho de 1918, p. 1366 e ss. 
urgentemente mais novas receitas para o Estado a fim de fazer face ao crescente aumento das despesas públicas derivadas do estado de guerra);

a abertura de vários créditos especiais para ocorrer a pagamentos urgentes de diversos sectores da Administração;

a concessão de vantagens e garantias, através do decreto n. ${ }^{\circ} 4.745$ de 20 de Agosto, a todas as fábricas existentes ou que viessem a fundar-se com o intuito de desenvolver indústrias de aplicação da cortiça, esmerando-se sobretudo no fabrico dos produtos de maior valor comercial;

a reorganização, pelo decreto n. 4.796 de 31 de Agosto, da estrutura e quadro de pessoal do Laboratório de Ensaios e Serviços de Contrastaria de Lisboa, criado pelo decreto de 27 de Maio de 1911 e modificado pelo artigo $99^{\circ}$ da lei n. 85 de 26 de Julho de 1913 e pelo $42 .^{\circ}$ da lei n. ${ }^{\circ} 403$ de 31 de Agosto de 1915;

a regulamentação disciplinar da Guarda Fiscal fixada pelo decreto n. ${ }^{\circ} 4.894$ de 3 de Setembro, mas por ter saído com inexactidões - ocorrência persistente na legislação promulgada durante o $2 .^{\circ}$ semestre de 1918 - foi republicado em 19 de Outubro;

a criação e organização de uma Cantina de consumo na Guarda Fiscal com sucursais em todas as unidades em qualquer ponto do país e destinada a libertar do pequeno negociante as praças da Guarda com familia e diminuto vencimento;(568)

a regulação da compra e venda de cambiais por decreto n. ${ }^{\circ} 4.825$ de II de Setembro; e

a igualmente polémica criação, através do decreto n. ${ }^{\circ} 4.841$ de 23 de Setembro, de um imposto sobre os lucros excepcionais derivados do estado de guerra.

Estes dois últimos diplomas foram suspensos e revogados pelo decreto n. ${ }^{\circ} 4.864$ de 3 de Outubro: o primeiro (sobre os cambiais) previa o pagamento obrigatório de parte dos direitos devidos ao Estado em ouro de modo a colmatar a aflitiva falta de divisas, geralmente compensada pelos empréstimos ingleses; o segundo (sobre lucros de guerra) estabelecia novos impostos com incidência nos lucros de 1918 que excedessem os do ano anterior desde que não tivessem sido obtidos na venda de produtos tabelados, sendo o pagamento feito de acordo com a proporção de $25 \%$ entre 5 e 10 contos de excesso, de $50 \%$ entre 10 e 50 contos e de $80 \%$ acima de 50 contos. Uma forte campanha na imprensa a dar voz ao descontentamento do comércio e da indústria surtiu efeito imediato, tendo o Governo recuado na aplicação dessas medidas. ${ }^{(569)}$

Um recuo ilustrativo do voluntarismo e da precipitação com que certas medidas foram concebidas e apresentadas pelas Secretarias de Estado, das falhas e das limitações na respectiva supervisão exercida pelo Presidente da República e na apressada cedência tanto a campanhas movidas pela imprensa, como à pressão de certos grupos sócioeconómicos.

(568) Cf. Diário do Governo, I Série (241) 7 de Novembro de 1918.

(569) Cf.TELO, António José - O Sidonismo e o movimento operário português, ob. cit., p. 176- 177. 
Características negativas de uma governação que não pode, porém, ser rotulada de totalmente anómala e alheia ao modelo de Governo republicano, porquanto, apesar de vários erros e lacunas, o dezembrismo/sidonismo derivou — há que repeti-lo e sublinhá-lo - da matriz ideológico-política da 1. ${ }^{a}$ República, sofreu a clara influência das propostas governativas (programa político-administrativo) de unionistas, de machadistas e de ex-centristas, nomeadamente na aposta conservadora de um desenvolvimento económico misto (agrícola e industrial), de um forte apelo à moralização da vida pública, de uma reacção ordeira à instabilidade demagógica e de um reformismo instructo-educativo quer em geral, quer na vertente do chamado ensino técnico, e geriu os efeitos do estado de guerra em circunstâncias de excepção perturbadoras de qualquer acção governativa por mais esclarecida e equilibrada que ela fosse.

\section{Política de subsistências e agrícola}

Basta voltarmos à política gizada pelo Ministério ou Secretaria de Estado das Subsistências eTransportes e prosseguida, primeiramente, pela Direcção-Geral das Subsistências eTransportes da Secretaria de Estado do Interior, depois pelo Comissariado-Geral dos Abastecimentos e, finalmente, pela Secretaria de Estado dos Abastecimentos, para se captar, com nitidez, a indiscutível vulnerabilidade interna do $16 .^{\circ}$ Governo chefiado por um líder carismático, conciliador e sem um plano homogéneo e novo, antes um plano eclético, evocativo do halo reformista do Governo Provisório e dependente do contributo de certos núcleos iniciais da rede, como o machadista e o ex-centrista, e a irreversível tendência, vinda de trás, para um acentuado intervencionismo estatal plurisectorial que implicava, necessariamente, a articulação do comércio e distribuição com a agricultura, a indústria e a actividade comercial interna e externa.

Uma vez consumada a demissão de Machado Santos, a escolha do substituto interino recaiu no Secretário de Estado da Agricultura. Uma escolha compreensível e paradoxal: se, por um lado, o escolhido era o responsável pela aplicação da política de subida dos preços agrícolas, já atrás explicada, com óbvias implicações no sistema de distribuição e consumo dos géneros, ${ }^{(570)}$ por outro, representava interesses particulares em jogo — os da lavoura, classe produtora, acusada de especulação fraudulenta.

Nomeado interinamente a 9 de Junho, Fernandes de Oliveira será exonerado a 15 de Julho e durante esse curto período subscreveu, pelo decreto n. ${ }^{\circ} 4.389$ de II de Junho, a suspensão do polémico regulamento dos Caminhos-de-Ferro e do título ll e capítulos iii a viii, xi e xii do título iii do decreto n. ${ }^{\circ} 4.206$ sobre a organização da Direcção-Geral dos Transportes Terrestres, satisfazendo, assim, as reclamações da Administração e dos dirigentes sindicais da C.P. P.. Para além desta medida apaziguadora, subscreveu outros diplomas importantes, de entre os quais o decreto $n .^{\circ} 4.635$ de 13 de Julho estabelecendo a alteração das sobretaxas vigentes de exportação; o n. 4.636 da mesma data obrigando os detentores, negociantes, lavradores, produtores ou possuidores de azeite

(570) Dossier Secretaria de Estado da Agricultura, Carta Aberta..., s. d. (Arquivo de Sidónio Pais - Militar, Lente e Político, Subsistema Presidência da República). 
a manifestar as existências em seu poder perante o regedor da paróquia onde tiverem o azeite armazenado; o n. ${ }^{\circ} 4.637$ da mesma data modificando a organização e o funcionamento dos celeiros municipais; o n. ${ }^{\circ} 4.638$, também dessa data, fixando o regime comercial dos cereais, da moagem e da panificação e regulando o abastecimento de pão no país; ou a portaria n. ${ }^{\circ} 1.433$ de 3 Julho determinando se procedesse ao manifesto da gazolina existente no país a fim de se acudir às necessidades de todos aqueles que dêste combustivel hajam precisão.

Amostras significativas de uma acção governativa feita contra «ventos e marés» e sob uma tremenda pressão hostil de interesses divergentes. Não admira, por isso, que Eduardo Fernandes de Oliveira, em carta particular de 4 de Julho, voltasse a insistir junto do Presidente da República para nomear um Secretário de Estado das Subsistências e Transportes efectivo. (571)

Após tanta insistência, a pretensão acabou por ser atendida, mas através da inusitada extinção dessa Secretaria de Estado.Talvez para não dar azo a uma remodelação precoce e atendendo, certamente, à inconveniência, provada com a actuação de Machado Santos no domínio dos transportes, de apagar a vocação transitória ou efémera dessa «pasta», optou-se pela descontinuidade institucional,(572) ou seja, pelo modo de vincar o cariz plurisectorial da questão das subsistências mediante a fragmentação dos serviços e sua distribuição por sectores diversos: o decreto n. ${ }^{\circ} 4.639$ de 4 de Julho extinguia a Secretaria de Estado das Subsistências e Transportes, todo o pessoal passava provisoriamente à situação de adido e fica à disposição do Governo para ser chamado ao serviço quando se julgar necessário, a Direcção-Geral das Subsistências transitava para a Secretaria de Estado do Interior, sendo, para esse efeito, subdividida em Serviço dos Abastecimentos e em Serviços das Exportações, a Direcção-Geral dos Transportes Marítimos transitava para a Secretaria de Estado das Colónias e a Direcção-Geral de Transportes Terrestres era integrada na Secretaria de Estado do Comércio. É, portanto, sob a tutela do Interior, das Colónias e do Comércio que até 22 de Agosto será oficialmente publicada a legislação relativa à acção dessas três Direcções-Gerais.

Entre 15 de Julho e 22 de Agosto o combate às distorções provocadas no abastecimento dos géneros de primeira necessidade ficou a cargo da Secretaria de Estado do Interior de Tamagnini de Sousa Barbosa e dentro das atribuições funcionais do Serviço dos Abastecimentos (ou Subsistências), onde não tardariam a dar nas vistas o capitão António Bernardino Ferreira (Chefe do Serviço) e o alferes Jorge Botelho Moniz (Inspector Geral da Fiscalização) pela forma enérgica como declararam guerra à especulação e às classes productoras. Esta expressão encobria, aliás, a variada gama de especuladores e de açambarcadores criticados pela imprensa e detestados pelo cidadão comum, assaz vulnerável ao desespero face ao imparável custo de vida e à constante falta de géneros.

(571) Dossier Secretaria de Estado da Agricultura, carta de Eduardo Fernandes de Oliveira, 4 de Julho de 1918. (Arquivo de Sidónio Pais - Militar, Lente e Político, Subsistema Presidência da República).Ver SILVA, Armando Barreiros Malheiro da - Sidónio e sidonismo. História e mito, dissert. cit., vol. 2, p. 363-364.

(572) Cf.VALENTE, Vasco Pulido - Estudos sobre Sidónio Pais: comércio e distribuição em 1918, in ob. cit., p. 309 e ss. 
Galeria de Imagens 

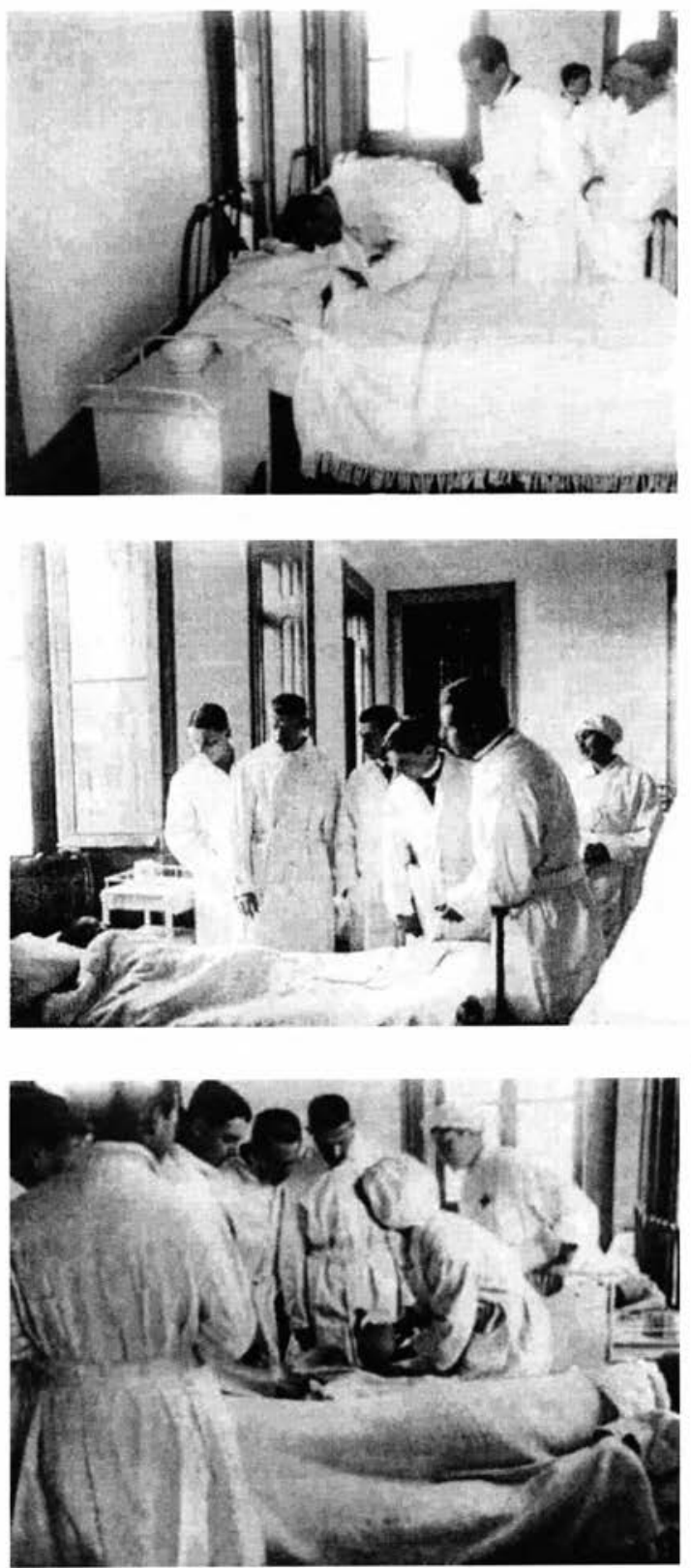

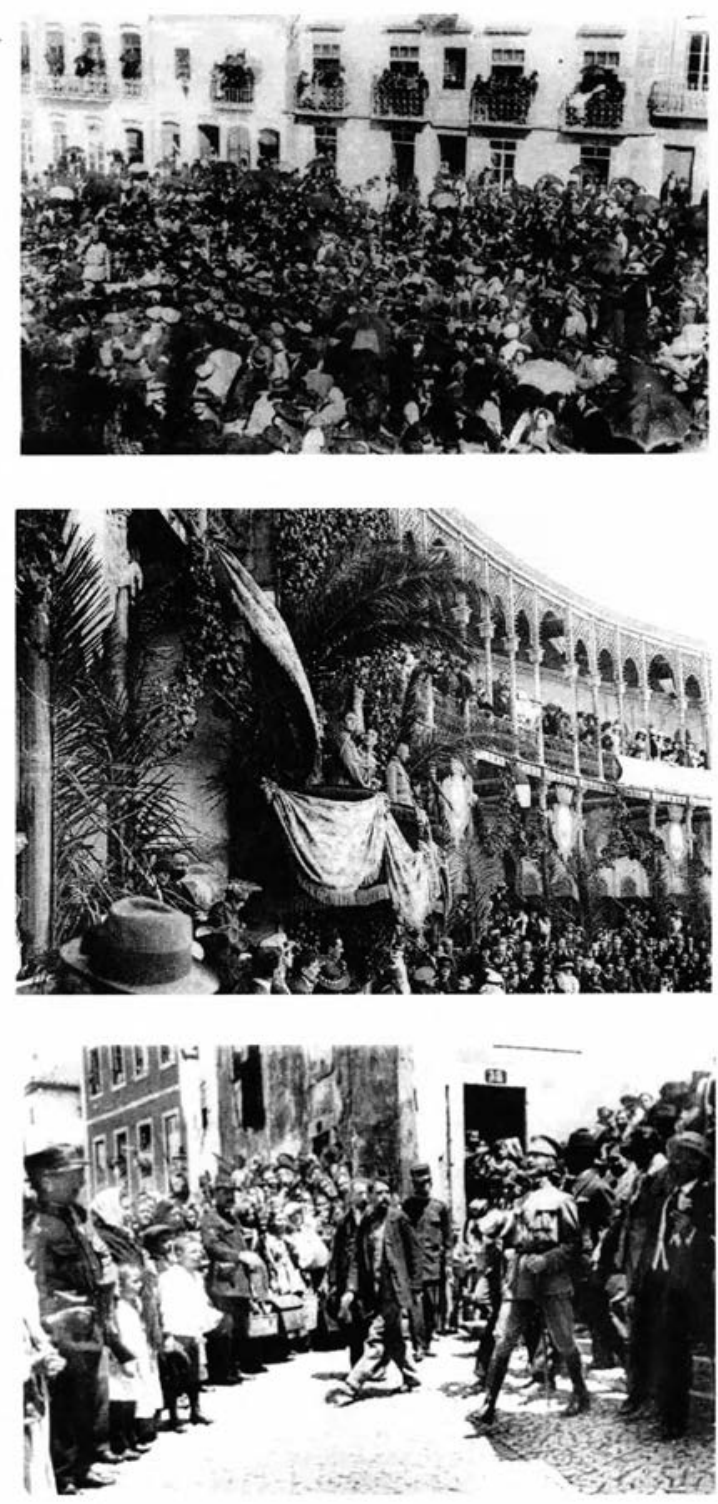

Chegada do Presidente Sidónio Pais a Beja, dia 17 de Fevereiro de 1918 [ Arquivo de Sidónio Pais ]

Primeira tourada de gala em honra do Presidente da República Sidónio Pais realizada na Praça de Touros do Campo Pequeno, a 12 de Maio de 1918. Na tribuna presidencial o Chefe de Estado, de pé, fita a arena [ Arquivo de Sidónio Pais ]

Em S. Cristovão, Lisboa, dia 27 de Maio de 1918, o Presidente da República agradece a manifestação de que era alvo, aquando da inauguração, nesta freguesia, da distribuição da sopa aos pobres pela Obra de Assistência 5 de Dezembro [ Arquivo de Sidónio Pais e O Século de 28 de Maio de 1918, p. 1 ] 

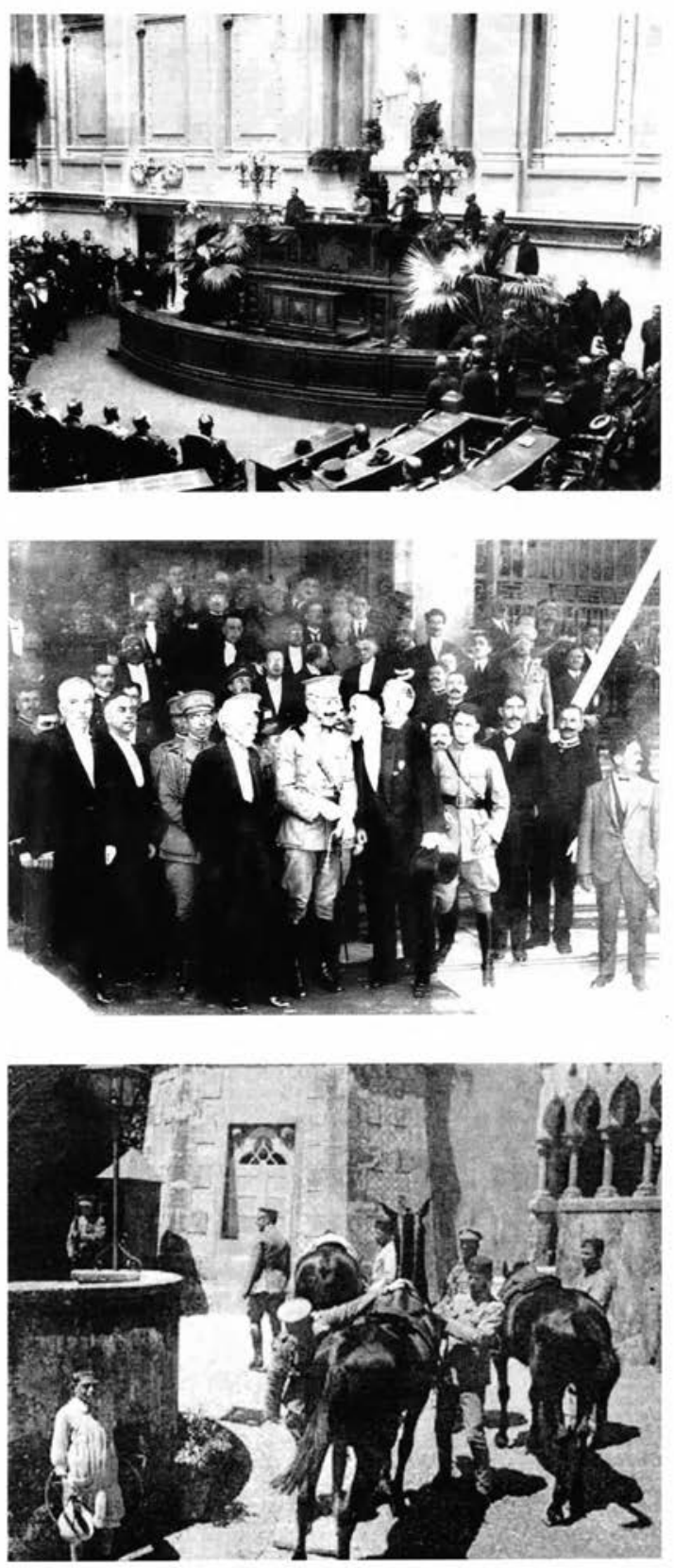

Sidónio Pais, sentado na cadeira da presidência, lê a sua mensagem ao Congresso tendo à esquerda o presidente da Câmara de Deputados [AHP, BEN - 28]

Sidónio Pais abandona o Palácio do Congresso acompanhado pelo presidente da Càmara dos Deputados e pelo deputado António Caetano Egas Moniz [ AHP, BEN - 102]

O Presidente da República chega, após uma cavalgada, ao Palácio da Pena em Sintra [ Setembro de 1918 ] [ Arquivo de Sidónio Pais ] 

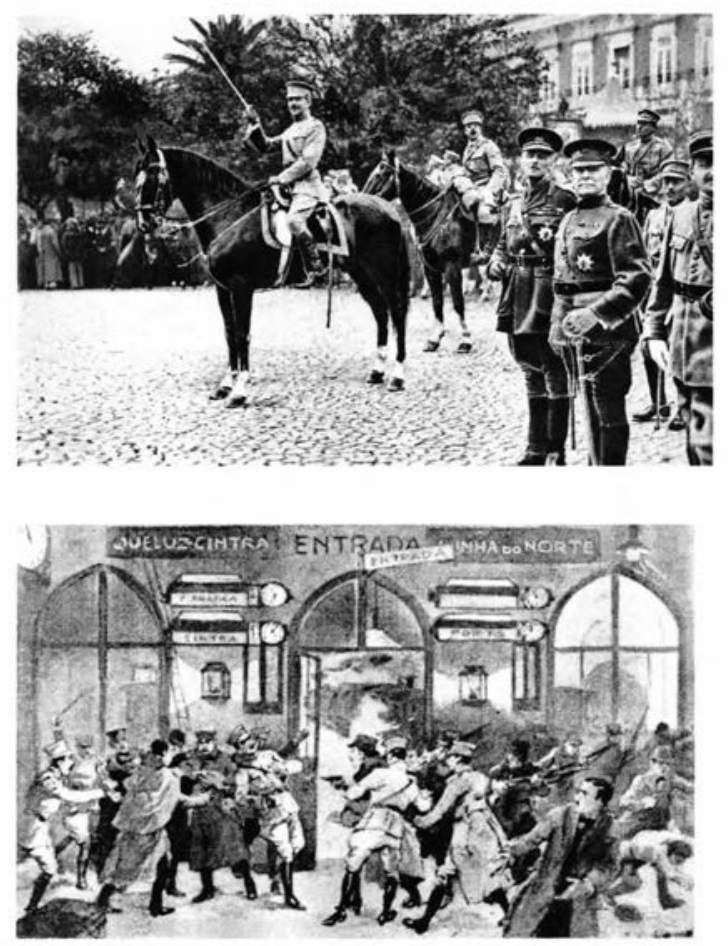

Parada militar comemorativa do 5/8 de Dezembro - 5 de Dezembro de 1918 [ Arquivo de Sidónio Pais ]

Reconstituição do assassínio, na noite de 14 de Dezembro de 1918, do Presidente da República Sidónio Pais, na Estação do Rocio, junto à porta de acesso à plataforma onde estava o combóio para o Porto

[ Arquivo de Sidónio Pais - Formato Postal] 

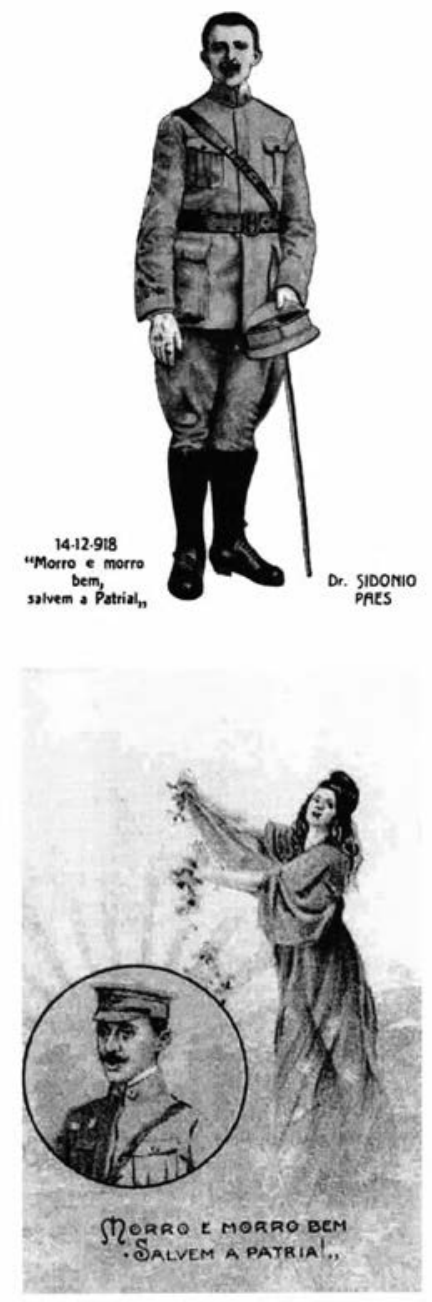

Bilhete postal ilustrado [ Arquivo de Sidónio Pais ]

Bilhete postal ilustrado com a célebre frase inventada por Reinaldo Ferreira [ repórter X] e Belo Redondo jornalista de O Século [Arquivo de Sidónio Pais] 

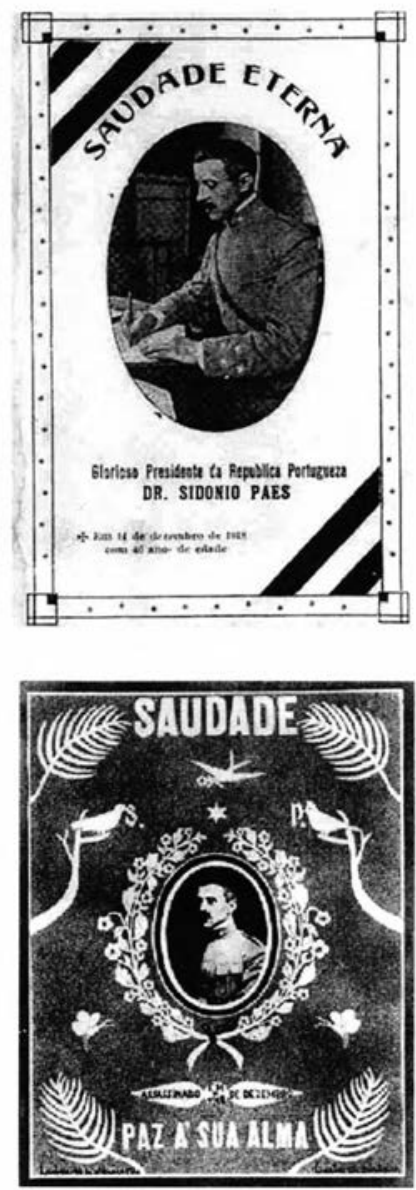

Retratos do Presidente da República Sidónio Pais evocativo da sua morte em 14 de Dezembro de 1918 [ Arquivo de Sidónio Pais ] 

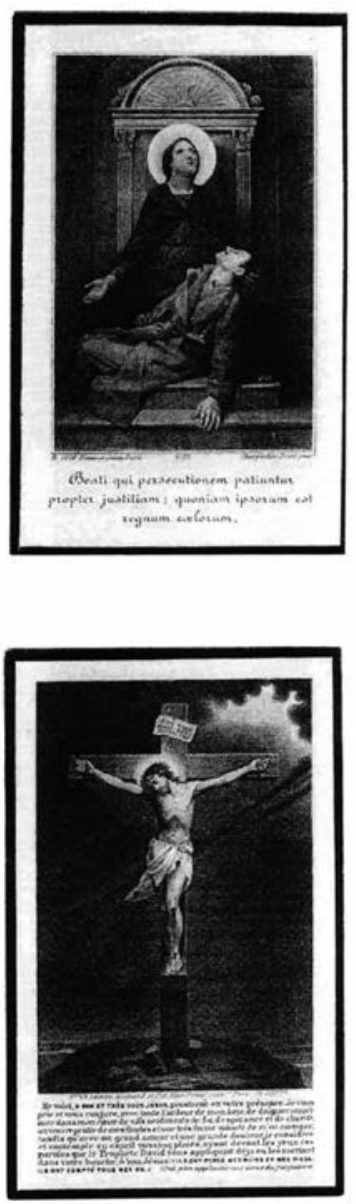

Pagelas ou «santinhos» em memória da alma do Presidente da República Sidónio Pais [ Arquivo de Sidónio Pais ] 
As vozes do descontentamento social e popular não podiam ser desatendidas pelo Poder, que ao ouvi-las e ao querer sossegá-las pendia, inevitavelmente, para medidas de reforço da fiscalização - varejo, apreensão e requisição violenta de géneros. Como observou Vasco Pulido Valente, havia um abismo entre a legislação promulgada e uma acção eficaz sentida na prática: Notou-se - escreve ele no estudo que estamos a seguir - que a própria estrutura do comércio a retalho o protege da fiscalização e que a fraude é necessária à sobrevivência do sistema tal como existe. Assim, quando pretende forçar a execução rigorosa da lei, o Governo depara sempre com a resistência organizada dos interesses lesados e acaba por tolerar o estado de coisas como um mal irremediável. Não é outro o significado visivel das actividades do capitão Bernardino Ferreira e do alferes Botelho Moniz, em meados de Julho. ${ }^{(573)}$ Empenharam-se, pois, na única tentativa séria de reprimir a delinquência económica em Lisboa, arrostando, porém, com um vendaval de protestos, que levaria, em breve, à suspensão da iniciativa ensaiada. Suspensão esclarecedora, aliás, da complexidade dos interesses em jogo.

Bernardino Ferreira e Botelho Moniz começaram por publicar um aviso na imprensa, destinado a encorajar a denúncia através de quaisquer informações quer directas, quer anónimas, remetidas para o Serviço dos Abastecimentos da Secretaria de Estado do Interior, entidade responsável por vários corpos policiais, salvo a Guarda Fiscal dependente das Finanças, implicados, também, na recepção das queixas e na repressão de toda a delinquência económica denunciada. Nos dias seguintes à publicação do aviso, mandaram apreender consideráveis quantidades de géneros, aplicar multas no valor de 4.000 contos e fechar 243 estabelecimentos. Segundo o testemunho da imprensa, de Rocha Martins e Teófilo Duarte, as rusgas efectuadas foram recebidas com aclamações populares, em sentido literal, porque nos bairros pobres batiam-se palmas, a União Operária Nacional em comunicado ao país apoiava publicamente essa acção fiscalizadora e repressiva, interpretando o sentir da classe trabalhadora e de todo o público em geral e até a opinião burguesa, que na imprensa é a opinião do consumidor aprovava quase sem reservas as medidas aplicadas, limitando-se somente a lamentar que continuassem a ser poupados os grandes açambarcadores, a meia dúzia de comerciantes por grosso que fornecem os retalhistas e muitos produtores que também açambarcam, preferindo guardar em casa duas ou três colheitas dos seus produtos para que a escassez promova a alta no preço. ${ }^{(574)}$

Medidas tão excepcionais e tão controversas que provocaram, de imediato, uma forte reacção do comércio a retalho: para pressionar o Governo protestou, primeiro, por intermédio de associações oficiais e recorreu, depois, ao expediente de esconder as existências em lugares seguros e de anular as encomendas ao Estado e aos grossistas. efeito não se fez esperar: houve logo um grande retraimento nas transações e outros interesses mais poderosos manifestaram o seu peso a ponto de Botelho Moniz sentir entraves àquilo que se dizia ser um intolerável excesso de zelo. E porque o Governo

(573) Cf.VALENTE,Vasco Pulido - Estudos sobre Sidónio Pais: comércio e distribuição em 1918 , in ob. cit., p. 317.

(574) Cf. Ibidem, p. 317. 
sidonista era intrinsecamente republicano, ou seja, harmonizador de interesses opostos (com particular atenção ao sentir das classes productoras), suspendeu a solução tripartida encontrada e refreou um pouco esses ímpetos fiscalizadores e repressivos, mantendo- os futuramente dentro de parâmetros razoáveis e aceitáveis, ${ }^{(575)}$ mas sem abandonar a realização de rigorosos varejos, como se infere de um ofício do mesmo Jorge Botelho Moniz, Director-Geral das Subsistências da nova Secretaria de Estado dos Abastecimentos, para o Presidente da República.

Pelo decreto n. ${ }^{\circ} 4.753$ de 22 de Agosto era aprovada e entrava imediatamente em vigor a organização do Comissariado Geral dos Abastecimentos com vista a centralizar e a superintender nos serviços das susbsistências e seus transportes terrestres e marítimos, repartidos pelas Secretarias de Estado do Interior, do Comércio e das Colónias. Mas em parágrafo único desse diploma sublinhava-se que Este comissariado será extinto logo que cessem as causas decorrentes do actual estado de guerra que motivaram a sua instituição.

O Comissariado Geral dos Abastecimentos era criado no âmbito dessas três Secretarias de Estado e subdividido em quatro Direcções-Gerais: a das Subsistências, a do Comércio Externo, a dos Transportes Terrestres e a dos Transportes Marítimos. $O$ Comissariado e as suas $1{ }^{2}{ }^{\mathrm{a}}$ e 2. ${ }^{\mathrm{a}}$ Direç̧ões Gerais eram ainda dotados de Secretarias privativas encarregadas da elaboração e direç̧ão do expediente e bem assim, da aquisição, fiscalização e guarda de todo o respectivo material e mobiliário, sendo a do Comissariado Geral afecta, também, à execução de todo o serviço análogo respeitante ao Conselho Económico Nacional criado por decreto com força de lei n. ${ }^{\circ} 4.497$ de 28 de Junho de 1918. Pretendia-se, deste modo, uma solução de compromisso entre a centralização dos meios e dos seus objectivos e o envolvimento orgânico-funcional das diferentes áreas institucionais relacionadas com o problema do abastecimento, cabendo, por exemplo, a cada uma delas a obrigação de pedir a abertura dos créditos necessários ao adequado funcionamento de toda a estrutura - celeiros, ${ }^{(576)}$ armazéns, depósitos, veículos, fiscalização, etc.

O resultado alcançado ao cabo de mês e meio e não obstante algumas medidas legislativas apreciadas - referimo-nos ao decreto n. ${ }^{\circ} 4.835$ de 23 de Setembro que instituiu prémios para intensificação da produção de cereais panificáveis e restantes géneros alimentícios e $\circ$ decreto $n .^{\circ} 4.836$, da mesma data, regulador dos ditos prémios - foi tido por insatisfatório e, na remodelação de 8 de Outubro, regressou-se ao modelo institucional da Secretaria de Estado.

Se não foi, pois, fácil a vida nas subsistências, o mesmo se pode dizer do esforço de organização, de regulação e de defesa empreendido pela Secretaria de Estado da Agricultura dirigida por Eduardo Fernandes de Oliveira, que, como vimos, não se sentiu muito à vontade a gerir a pesada herança de Machado Santos e, curiosamente, voltará, em Outubro, a pedir ao Presidente da República a sua demissão do cargo por causa

(575) Cf.TELO, António José - O Sidonismo e o movimento operário português, ob. cit., p. 178.

(576) Ver decreto n. 4.857 de 28 de Setembro de 1918 e decreto n. ${ }^{\circ} 4.753$ in Diário do Governo n. 188 de 30 de Agosto de 1918. 
das modificações introduzidas nos artigos $99^{\circ}$ e $10 .^{\circ}(577)$ do citado decreto n..$^{\circ} 4.836$, impresso sob a chancela do Comissariado Geral dos Abastecimentos. ${ }^{(578)}$

A reacção de Fernandes de Oliveira evidencia a extrema delicadeza da sua posição em matéria de comercialização e de abastecimento dos produtos agrícolas, sendo nítido o cuidado em proteger os agricultores, alegando que os preços fixados seriam aplicáveis só em caso de requisição e como instrumento de dissuasão e de contenção da especulação commercial d'aquelles productos. Para além disto, a carta do Secretário de Estado, à semelhança de outros exemplos epistolográficos subscritos por membros da governação dezembrista/sidonista, introduz-nos nos meandros das relações de Sidónio Pais com os seus colaboradores e permite-nos verificar, por um lado, o feitio conciliador do Chefe da República Nova, acentuado pela necessidade de ceder aos pedidos e às pressões dos seus Ministros para não ficar ainda mais sozinho, e, por outro, a liberdade de acção de que os Secretários de Estado gozavam, sob uma coordenação atenta mas flexível.

Não se pode dizer, de modo algum, que o Presidente da República se alheasse da acção desenvolvida por cada um dos membros do seu Governo, tanto mais que os diplomas a promulgar e a publicar na folha oficial eram por ele lidos e anotados, ${ }^{(579)}$ mas em vez de impor directivas detalhadas e rígidas ficou muito à mercê do perfil dos seus colaboradores, da sua maior ou menor capacidade para reformar, inovar e mobilizar, sendo certo que nem todos os sectores se ajustavam facilmente a tais propósitos.

$\mathrm{Na}$ Agricultura impunha-se a árdua implementação de uma vasta estrutura administrativa e técnica com ramificações em todo o país e já atrás descrita.Tão vincado esforço organizativo domina o conteúdo do importantíssimo relatório-programa entregue na Presidência da República por Eduardo Fernandes de Oliveira, datado do mês de Junho, embora ai se desenhem também os objectivos a alcançar a curto e médio prazo através dos diferentes Serviços dessa nova estrutura administrativa e institucional.

Por intermédio da Direcção de Instrução Agrícola pretendia-se reformar o ensino da agricultura nos seus três graus e sobretudo nas vertentes prática e técnico-científica, sem esquecer o chamado ensino domestico feminino e o ensino movel.(580)

Pela Direcção dos Serviços Agrícolas urgia resolver o complexo problema das subsistencias e da alimentação pública, convindo para tanto intensificar a cultura e dar o maior incentivo e auxilio aos lavradores e como tal afigura-se-me - escreve Fernandes de Oliveira - ser de grande alcance as medidas propostas para acquisição de materias primas indispensaveis á preparação de adubos chimicos, á acquisição no estrangeiro, principalmente nos Estados Unidos da America do Norte, de tractores agricolas, em grande

(577) Cf. Diário do Governo, I série (209) 25 de Setembro de 1918, p. 1728.

(578) Dossier Secretaria de Estado da Agricultura, carta de Eduardo Fernandes de Oliveira, 20 de Outubro de 1918. (Arquivo de Sidónio Pais - Militar, Lente e Político, Subsistema Presidência da República).Ver SILVA, Armando Barreiros Malheiro da - Sidónio e sidonismo. História e mito, dissert. cit., vol. 2, p. 367-368.

(579) Ver O Dr.Alfredo de Magalhães fala ao «Notícias de Viana». Notícios de Viana, número especial, 18 de Agosto de 1929, p. inum.

(580) Dossier Secretaria de Estado da Agricultura, Oficio-relatório do Secretário de Estodo da Agricultura, Junho de 1918 , fls. 1-2. (Arquivo de Sidónio Pais - Militar, Lente e Político, Subsistema Presidência da República). 
numero, e com a alfaia indispensavel, cedendo-os por aluguel, aos lavradores, em condições favoraveis e mesmo de protecção. ${ }^{(581)}$ Urgia ainda promover o maior desenvolvimento às Estações Agrícolas de Estudo e de Experimentação Regional, de que dependia o grande adeantamento agricola do paiz, e o melhoramento e criação de postos agrarios de demonstração; organizar o serviço de combate às doenças que atacavam as plantas e devastavam as colheitas mediante um laboratorio de patologia vegetal, devidamente montado e convenientemente dotado, com um grupo de funcionarios especialisados e, adoptando medidas tendentes a garantir a acquisição, quer no paiz quer no estrangeiro, de insecticidas e fungicidas, conseguir-se-ha um dos grandes obstaculos que opõem ao augmento da producção nacional; ${ }^{(52)}$ estimular a cultura do arroz, autorizada em Portugal desde 1915, por forma a salvaguardar a saude pública, a aumentar e baratear as subsistencias e a desenvolver o trabalho nacional; e desenvolver viveiros de arvores de fructa para fomentar a pomicultura nas diversas regiões do paiz que mais se prestam a esse ramo agricola, o fornecimento de sementes seleccionadas, sobretudo de cereais panificaveis, a introdução de novas plantas economicas, a divulgação das praticas de ensilagem, como novos metodos de cultura e de maquinaria aperfeiçoada. ${ }^{(583)}$

Pela $3 .^{a}$ Direcção, encarregue dos serviços da arborização geral do país, da fixação das dunas, da regularização das torrentes e do melhoramento das pastagens nas serras, havia que prover de remedio para que a area florestal do paiz não seja redusida, e, pelo contrario, se favoreça o seu aumento, pois a conflagração europeia tem comprovado, que as nações devem bastarem-se com os seus proprios recursos, ${ }^{(584)}$ objectivo alcançável, na opinião do Secretário de Estado da Agricultura, por, entre outras medidas, uma Lei de Protecção aos Arvoredos e pela criação da Junta de Correcção do Rio Mondego da promulgação da qual depende poder levar-se a effeito a correcção do regimen das aguas daquele importante curso de agua, cujas inundações, quasi annuaes, tantos prejuizos causam á agricultura. ${ }^{(585)}$ Aos Serviços Florestais não incumbiam apenas os trabalhos de arborização, devendo atender igualmente ao regime pastoril das serras portuguesas, pois do melhor aumento das pastagens n'ellas existentes depende em grande parte o desenvolvimento da nossa industria pecuaria, ${ }^{(586)}$ bem como a protecção e desenvolvimento da fauna aquícola dos rios. Não podia ainda ser descurada a criação de uma Escola Profissional para habilitar o pessoal florestal auxiliar (mestres e guardas) e o pessoal jornaleiro empregue na indústria da resinagem. Só para os trabalhos de arborização foi inscrita no Orçamento um aumento de verba de $316.809 \$ 24$

Pela Direcção dos Serviços Pecuários a actividade prevista incidia em quatro domínios específicos: o zootécnico; a sanidade pecuária; a fiscalização dos produtos alimentares de

(581) Dossier Secretaria de Estado da Agricultura, oficio-relatório do Secretário de Estado da Agricultura, Junho de 1918, fl. 2. (Arquivo de Sidónio Pais - Militar, Lente e Político, Subsistema Presidência da República).

(582) Ibidem, fl. 3.

(583) Ibidem, fl. 3.

(584) Ibidem, fl. 4.

(585) Ibidem, fl. 4.

(586) $\mathrm{lbidem}$, fl. 4.

(587) lbidem, fls. 4-7. 
origem animal; e o fomento pecuário.(587) Domínios especializados a exigirem diversas tarefas para as quais o pessoal desses Serviços tinha de dar o seu melhor, nomeadamente no ataque a certas doenças animais, com destaque para o môrmo nos equideos pelo que se torna inadiavel a adopção de medidas, por ventura violentas e dispendiosas, para se conseguir a sua extinç̧ão. Para isso é necessario empregarem-se todos os meios, por mais violentos que sejam, e não regatear os necessarios recursos para que o paiz seja expurgado de tal flagelo, tanto mais tratando-se de uma doença traiçoeira e nimiamente contagiosa, até para a especie humana. ${ }^{(588)}$ E no respeitante à imprescindivel fiscalização dos produtos de origem animal, sobretudo dos leites e seus derivados, muito mais teria de ser feito porque era inadmissivel que a fiscalisação d'esses productos se exerça quasi exclusivamente e mal nas cidades de Lisboa e Porto, merecendo a população do resto do país e, pelo menos, a dos centros populosos de certa importância, os beneficios da fiscalização, empenhada aí, principalmente, em não consentir que se venda como leite completo o desnatado ou aquelle a que se junta agua em grande quantidade, que sejam expostas á venda manteigas com 50 e até $60 \%$ de agua, quando o limite maximo permittido por lei é de $18 \%$, que se vendam carnes e toucinhos avariados, corruptos e até falsificados. ${ }^{(589)}$

Pela Direcção de Hidráulica Agrícola visava-se, principalmente, estudar o regime das águas pluviais, das águas correntes e das subterrâneas e orientar a sua aplicação para fins agrícolas; projectar e executar as obras aconselhadas por esses estudos; aconselhar e dirigir os agricultores que pretendessem melhorar as suas propriedades sob o ponto de vista hidráulico. ${ }^{(590)}$

Pela Direcção dos Serviços Fisiográficos iriam ser iniciados, em 1918, os trabalhos da carta agrológica e agrícola, organizada com um fim utilitário imediato e tendo por base a carta corográfica na escala 1/20.000, incidindo, de início, na região entre o rio Tejo e o Oceano, enquanto o levantamento agrológico e agrícola seria começado numa parte dos concelhos dos Arcos de Valdevez e de Ponte da Barca, que muito interessam os serviços florestaes. O levantamento da zona a irrigar pelas águas captadas na Albufeira de Avis estava também inscrito no programa a curto prazo a fim de proporcionar aos proprietarios dos respectivos terrenos um estudo facil das obras que, por sua conta, tenham de emprehender para utilisar as referidas aguas, a par de outro levantamento considerado urgente - os salgados do Algarve que são pertencentes ao Estado, para em seguida estudar a forma de serem entregues á cultura. ${ }^{(591)}$

Pela Direcção de Economia e Estatística Agrícola estavam em preparação o inquérito geral agrícola e o recenseamento geral dos gados a realizar em 1920, devendo effectuar, para esse fim, antecipadamente, um reconhecimento agricola e pecuario que mostre quais são, no momento presente, as forças productivas e os diversos aspectos da vida economica agricola, que serão depois estudados em monografias especiais. ${ }^{(592)}$

(588) Dossier Secretaria de Estado da Agricultura, oficio-relatório do Secretário de Estado da Agricultura, Junho de 1918 , fl. 6. (Arquivo de Sidónio Pais - Militar, Lente e Político, Subsistema Presidência da República).

(589) Ibidem, fls. 6-7.

(590) Ibidem, fls. 7-9.

(591) Ibidem, fl. 10.

(592) Ibidem, fl. 10. 
Pela Direcção do Crédito e das Instituições Sociais Agrícolas pretendia-se aprofundar um caminho percorrido com êxito nos últimos anos e indispensável para que a lavoura se expandisse e organizasse: Com o fundo inicial de 1.500.000 escudos que o Estado the garantiu, conseguiu-se em pouco mais de 7 annos, distribuir á agricultura do paiz em muitos milhares de emprestimos, a importante verba de escudos $3.344 .508 \$ 81,5$, ao modico juro de 2 e 3 por cento; conseguiu-se a criação de 92 caixas de credito agricola mutuo espalhadas por todos os districtos do paiz; conseguiu-se, finalmente, vencer a prejudicial relutancia do agricultor portuguez ao verdadeiro principio associativo, levando-o pela palpavel compreensão dos factos, e pela fruição de legitimos interesses com proveitosa repercussão na comunidade, á pratica da cooperação e da mutualidade, de onde é licito esperar, com fundados motivos, bem sensivel melhoria na situação economica e profissional das populações do campo. ${ }^{(593)}$ Ao crédito agrícola mútuo ficara-se a dever, segundo o autor do relatório, o desbravamento de muitos incultos, o desenvolvimento e aperfeiçoamento de muitas explorações agricolas, um sensível aumento da produção regional e á sua acção protectora milhares de trabalhadores da terra se acolhem e vivem, contribuindo para o aumento do patrimonio público, livres da usura asfixiante e esterilisadora que abusivamente quinhoava a maior e melhor parte dos fructos da sua incessante labuta, quando os não arrastava á miseria ou os não expulsava da terra e do proprio lar, engrossando prodigamente o exodo dos que, á simples ventura, procuram em terras longinquas os necessarios meios de sustento que na patria thes escasseiam, não obstante 0 arduo trabalho quotidiano. ${ }^{(594)} \mathrm{O}$ crédito agrícola mútuo era, assim, um meio de estancar o flagelo do abandono dos campos e a emigração, problemas candentes que preocupavam os especialistas e para os quais o Secretário de Estado da Agricultura juntava uma ideia - cara também aos integralistas, aos homens da Liga de Acção Nacional ou aos seareiros - que consistia em dar viabilidade imediata ao homestead ou casal de familia inalienavel, e da colonisação agricola interior que o Govêrno tem em projecto, auxiliando a instalação dos casais e dos colonos, provendo ás primeiras necessidades da familia rural, e que é possivel e imediatamente realisavel pelas faculdades que a respectiva legislação the concede.(595)

Por último, era mencionada a Direcção do Comércio Agrícola que criara já um novo Serviço Especial de Informação sobre os géneros agrícolas e seu comércio no país e no estrangeiro. Aliás, esta componente externa estava a ser considerada na campanha de propaganda comercial dirigida aos mercados estrangeiros, consumidores dos nossos productos, campanha essa que mesmo antes de acabar a guerra se deverá começar no Brazil nosso principal mercado importador de vinhos comuns, para o qual se estavam a virar, numa ameaçadora concorrência, italianos e espanhóis. ${ }^{(596)}$ Mas a ameaça não vinha só daí: a nossa exportação de camisaria, ferragens e cutelaria tendo sofrido uma larga concorrencia dos productos Austriacos e Allemães, deverá ser novamente tentada, aproveitando-se a ausencia d'aqueles productos dada a sua origem. Impunha-se, pois, a exploração de todos

(593) Dossier Secretario de Estado da Agricultura, oficio-relatório do Secretário de Estado da Agricultura, Junho de 1918, fl. 10-11. (Arquivo de Sidónio Pais - Militar, Lente e Político, Subsistema Presidência da República).

(594) Ibidem, fls. I1-12.

(595) Ibidem, fl. 12.

(596) Ibidem, fl. 13. 
os mercados possíveis ${ }^{(597)}$ para que, nas circunstâncias então vividas, se concretizasse o tão proclamado desenvolvimento económico em geral e da agricultura portuguesa em particular.

Vasto e ambicioso conjunto de pontos programáticos a desenvolver no sector primário e a que correspondeu a produção legislativa recenseável no segundo semestre de 1918.

Até à remodelação de 8 de Outubro destacam-se alguns diplomas que confirmam o esforço de organização dos Serviços Agrícolas à escala nacional e a implementação de uma política de fomento agrícola. $\bigcirc$ decreto n. ${ }^{\circ} 4.464$ de 22 de Junho dotava a Secretaria de Estado da Agricultura de um quadro de pessoal necessário e próprio, autorizando ainda o trânsito de funcionários provenientes das Secretarias das Finanças e do Trabalho e dispondo sobre horários, provimento, funções, promoções e vencimentos para todo o pessoal colocado nos mais diversos Serviços. E do ponto de vista da organização interna foi promulgado, com data de 14 de Setembro, o decreto n. $^{\circ} 4.815$, criando e regulando a Junta Médica privativa dessa Secretaria de Estado para verificar o estado de saúde dos funcionários, cujo presidente ficava ainda autorizado a desempenhar as funções de Inspector médico escolar, ao mesmo tempo que eram criados médicos escolares em todos os estabelecimentos de ensino médio ou elementar dependentes da Secretaria de Estado da Agricultura. Pelos decretos n. ${ }^{\circ} 4.505$ de 29 de Junho e 4.739, de 19 de Agosto, era atacada a falta de água e a necessidade de avançar com urgentes obras hidráulicas com fins essencialmente agrícolas: o primeiro diploma saiu publicado sob a epígrafe da Presidência da República e assinatura de todos os membros do Governo, embora se destinasse, de facto, a assegurar o equilibrio agrícola entre a produção e o consumo; ${ }^{(598)}$ e o segundo, assinado apenas por Sidónio Pais e Eduardo Fernandes de Oliveira, tendo em conta $a$ excepcional estiagem deste ano, vinha facilitar, do ponto de vista técnico e burocrático, o empreendimento imediato de obras hidráulicas em rios não cadastrados, aplicando-se o disposto nos artigos $1811^{\circ}$ e $183 .^{\circ}$ do decreto n..$^{\circ} 4.249$ de 8 de Maio, ou seja, o cadastro poderia ser feito por troços perfeitamente extremados e independentes de cada rio e por bacias completas de um ou mais dos seus afluentes de diversas ordens. Mas se a água era um bem indispensável, o vinho do Porto era o néctar vital para a economia de uma região e importante para a afirmação da vitivinicultura portuguesa além fronteiras: 0 decreto $n .^{\circ} 4.655$ de 10 de Julho aprovava o regulamento da produção e comércio desse tipo especial de vinhos.

Outro ponto essencial tinha a ver com o ensino agrícola nos seus diferentes níveis: o decreto n. ${ }^{\circ} 4.685$ de 13 de Julho (corrigido e republicado nove dias depois, no Diário do Governo, de 29 de Julho) reorganizava o ensino no Instituto Superior de Agronomia de acordo com o trabalho apresentado por uma comissão nomeada por portaria de 21 de Janeiro de 1918, sendo esse ensino orientado para formar engenheiros agrónomos, engenheiros silvicultores e engenheiros agrónomos ou silvicultores coloniais; o decreto

(597) Dossier Secretaria de Estado da Agricultura, oficio-relatório do Secretário de Estado da Agricultura, Junho de 1918, fls. 13-14. (Arquivo de Sidónio Pais - Militar, Lente e Político, Subsistema Presidência da República). e Ibidem, Dossier 45 Regime Sacarino da Madeira).

(598) Cf. Diário do Governo, 1. Série (144) 30 de Junho de 1918, p. 1029. 
n. ${ }^{\circ} 4.686$, também de 13 de Julho, remodelava a Escola de Medicina Veterinária, denominada nesse diploma Escola Superior de Medicina Veterinária, e aprovava o plano de reorganização do ensino apresentado pelo Conselho Escolar conforme os princípios de modernização pedagógica e técnico-científica definidos pela comissão de ensino agrícola nomeada em 21 de Janeiro; e o decreto n..$^{\circ} 4.831$ de 14 de Setembro visava completar os esforços desenvolvidos no âmbito do ensino professado nas escolas técnicas de agricultura com sede fixa e para isso regulava o ensino agrícola móvel, definido no artigo $1 .^{\circ}$ como um ensino essencialmente prático e ministrado em lições sem carácter erudito, que engenheiros agrónomos e agricultores diplomados ou regentes agrícolas, e também eventualmente engenheiros silvicultores e médicos veterinários realizarão em missões temporárias, de local variável, sob a forma de palestras, demonstrações e exercícios, nos centros rurais e nas propriedades de particulares ou do Estado, dentro duma determinada área, adequadamente às condições locais e aos trabalhos da quadra agricola, e destina-se $a$ difundir entre os agricultores da respectiva região, por meios intuitivos, o conhecimento dos bons processos culturais, zootécnicos e tecnológicos, e irradiado a partir de cinco Escolas Agrícolas Móveis espalhadas de Norte a Sul do país.

Sobre o desenvolvimento dos sindicatos agrícolas e das caixas de crédito agrícola mútuo dois diplomas surgiram para reforçar e melhorar a sua organização: 0 decreto $n^{\circ} 4.562$ de 29 de Junho vinha regular a fiscalização das associações agrícolas no país, continental e insular, dividindo-o em cinco circunscrições; e o decreto n. ${ }^{\circ} 4.684$ de 13 de Julho, devidamente fundamentado, ${ }^{(599)}$ declarava em pleno vigor o artigo $28 .^{\circ}$ e seus parágrafos da lei n..$^{\circ} 215$ de 30 de Junho de 1914 e acrescentava às excepções do $§ 3 .^{\circ}$ do artigo $4 .^{\circ}$ do decreto n. 4.170 de 26 de Abril de 1918 o ponto $4 .^{\circ}$ Os empréstimos mutuados pelas caixas de crédito agrícola mútuo com os respectivos sócios, nos termos da lei n. 215 , de 30 de Junho de 19/4, e de mais legislação especial de crédito agrícola.(600) Leis consensuais que não suscitaram reacções como a da u.o .n ., a propósito do decreto n..$^{\circ} 4.812$ de 19 de Agosto sobre os baldios que autorizava as Câmaras Municipais e Juntas de Freguesia a dividirem imediatamente, no todo ou em parte, os baldios que Ihes pertencessem, desde que a maioria dos vizinhos os requeiram, para os ceder temporariamente ou aforá-los, com o fim de os reduzir a cultura e os agricultores que nos anos de 1918-1919 a 1920-1921 se propusessem cultivar os referidos terrenos receberiam prémios concedidos pela Secretaria de Estado da Agricultura, desde que as culturas efectuadas fossem os cereais - trigo, milho e centeio - e as leguminosas - feijão, fava e grão de bico, e a batata.

A rematar esta ligeira panorâmica sobre as medidas legislativas no âmbito do sector primário, não queremos omitir o decreto n. ${ }^{\circ} 4.829$ de 14 de Setembro que, organizava os Serviços Fiscais da importação, fabricação, preparação e venda dos adubos agrícolas — químicos, orgânicos e mistos - entendidos como as substâncias obtidas pela indústria e destinados a ser encorporadas no solo para favorecer a produção vegetal sob o ponto de vista económico; e o decreto n. ${ }^{\circ} 4.729$ de 7 de Agosto, atendendo às reclamações apre-

(599) Cf. Diário do Governo, I série (161) 20 de Julho de 1918, p. 1432.

${ }^{(600)} \mathrm{Cf}$. Ibidem. 
sentadas ao Govêrno pelos povos de região montanhosa da zona septentrional, da fronteira do Minho e em especial das freguesias de Gavieira, Soajo (ou Massiço da Peneda), Germil, Lindoso, Ermida, Brufe, S. João do Campo, Cabril, da Serra do Gerez, onde não é possível a execução integral do decreto n. ${ }^{\circ} 3.938$, sobre o manifesto de gados nos concelhos limítrofes da raia,(60I) dado ser velho costume nesses sítios os lavradores manterem, durante muitos meses do ano, os seus gados sem pastor, nem guias nos extensos baldios das respectivas Juntas de Paróquia, o que exigia a feitura do manifesto no posto fiscal mais próximo de acordo com certos quesitos e condições.

\section{Políticas de comércio, indústria e trabalho}

Ao contrário do Secretário de Estado da Agricultura, o responsável pela igualmente importante «pasta» do Comércio (e Indústria), capitão Mendes do Amaral, limitou-se a apresentar ao Presidente da República uma folha manuscrita em que condensou a política adoptada para o sector. ${ }^{(602)}$

Neste sucinto relatório-programa emergem apenas três grandes linhas de acção - melhoria e ampliação da rede viária, aproveitamento intensivo da energia hidráulica e cadastração da propriedade rústica e urbana - que não esgotam nem a gestão corrente do sector, nem o pacote de medidas legislativas levadas a cabo até à remodelação de 8 de Outubro. Essas medidas não foram muitas, mas também não houve condições conjunturais e, porventura, o talento necessário para pôr em marcha um plano reformista de fundo. A instabilidade e a inconstância governativas - mal antigo, agravado ao longo

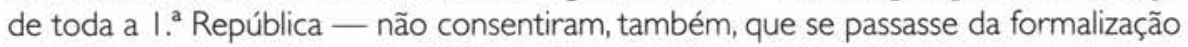
pura, impressa nas páginas do Diário do Governo , à execução prática.

Joaquim Mendes do Amaral manteve-se no Comércio de 15 de Maio a 8 de Outubro de 1918 e durante esses escassos cinco meses pouco pôde fazer para a concretização das reformas idealizadas, a não ser publicá-las na folha oficial. E o seu sucessor, João Alberto Pereira de Azevedo Neves, no Poder por uns efémeros três meses, até nisso teve dificuldades, para além de ser confrontado, como veremos, com o eclodir da crise industrial agravada nas vésperas do Armistício de II de Novembro. ${ }^{(603)}$

Em síntese e à guisa de notas avulsas para uma caracterização genérica, podemos referir que Mendes do Amaral, mais até na qualidade de Secretário de Estado das Finanças interino, prestou-se a colaborar com o nosso Ministro em Londres sobre o delicado ponto dos bens de D. Manuel II, ${ }^{(604)}$ que era de toda a conveniência diplomática esclarecer e equacionar para reforço da confiança do Governo de S. M. Britânica na

(601) Cf. Diário do Governo, I série (180) 17 de Agosto de 1918, p. 1542.

(602) Ver SILVA, Armando Barreiros Malheiro da - Sidónio e sidonismo. História e mito, dissert. cit., vol. 2, p. 378-379.

(603) VerVALENTE, Vasco Pulido - Estudos sobre Sidónio Pais: comércio e distribuição em 1918 , in ob. cit.. p. 274 e ss.

(604) Legação de Portugal em Londres, carta em papel timbrado da Sec. Estado Comércio, Carta de 31 de Agosto para o Ministro de Portugal em Londres. (Arquivo de Augusto de Vasconcelos). 
República Nova. Quanto à produção legislativa mais significativa é de salientar a importante reorganização dos Serviços Postais, Telegráficos, Telefónicos e de Fiscalização das Indústrias Eléctricas promulgada, inicialmente, na versão do decreto n. ${ }^{\circ} 4.602$ de 13 de Julho ${ }^{(605)}$ e retocada, depois, através do decreto n. ${ }^{\circ} 5.001$ de 31 de Outubro. Convém ainda notar que, pelo decreto n. 4.577 de 6 de Julho, o Governo, através da Secretaria de Estado do Comércio, abriu na Secretaria de Estado das Finanças um crédito especial de $30.000 \$ 00$ destinado à construção de vinte casas económicas para habitação de operários na cidade de Viana do Castelo, dando, assim, continuidade e expansão a um plano de construções operárias iniciada, algum tempo antes, no Porto.

Quando o jovem governante Henrique Forbes de Bessa transitou (com os seus colaboradores, designadamente o Chefe de Gabinete Eduardo Sarmento, eleito deputado pelo p.n .r.) para a Secretaria de Estado do Trabalho, substituindo o irascível José Feliciano da Costa e mantendo-se nessas funções até 23 de Dezembro de 1918, pôs-se logo a tentar «arrumar a casa» e desse esforço deu conta num pequeno relatório, redigido em cumprimento das instruções gerais expedidas pela Presidência da República para toda a equipa governativa a fim de integrar os dados mais relevantes na sua mensagem ao Congresso. A abrir esse texto anuncia o propósito de relatar quaes as medidas necessarias a tomar para que o Ministerio do Trabalho possa exercer aquela acção que é de esperar num paiz em que de tal forma avoluma a questão social que dificil se torna achar para o momento uma solução. ${ }^{(606)}$ Posto isto, incide sobre os aspectos organizacionais, observando que, salvo a Repartição de Minas, todos os outros Serviços não passavam de uma aspiração mal definida, e mesmo aquela Repartição achava-se não só desligada dos Serviços Geológicos, erro que na reforma aprovada foi imediatamente emendado, como ainda a precisar de melhor orientação, justificada, a título de exemplo, pelas leis sobre aguas que eram muito incompletas quanto á segurança da sua exploração por parte dos concessionarios. ${ }^{(607)}$

O seu relatório é, afinal, um documento programático e, simultaneamente, um precioso testemunho das alterações orgânico-funcionais que a «pasta» do Trabalho acabara de sofrer, acolhendo Serviços procedentes do Interior e dotando-se dos meios necessários para uma intervenção mais eficaz e apelativa junto do operariado.

Com esse fim foi concebida e promulgada pelo decreto n. ${ }^{\circ} 4.641$ de 13 de Julho (assinado por todos os membros do Governo) a reestruturação da Secretaria de Estado do Trabalho, lendo-se no respectivo preâmbulo os fundamentos dessa tarefa: as diversas alterações introduzidas na primitiva organização do Ministério do Trabalho e Previdência Social pelos decretos n. ${ }^{\circ} 3.51$ I de 5 de Novembro de 1917 e n. 3.902 de 9 de Março de 1918 haviam tornado defeituosa a sua interferência no desenvolvimento das fôrças

(605) Cf. Diário do Governo, I. Série (156) 13 de Julho de 1918, p. 1195 -1196.

(606) Dossier Secretaria de Estado do Trabalho, Relatório do Ministério do Trabalho, 2 fls. papel azul de 25 linhas, s.d. (Arquivo de Sidónio Pais - Militar, Lente e Político, Subsistema Presidência da República).

(607) Ver SILVA, Armando Barreiros Malheiro da - Sidónio e sidonismo. História e mito, dissert. cit., vol. 2 , p. $380-381$. 
produtivas do país, porque, ao passo que deixaram de lhe estar cometidos diversos serviços, outros the eram entregues e não foram convenientemente regulamentados, e, ainda, alguns continuaram a depender de Secretarias de Estado onde a sua permanência nenhuma razão justificava; (608) a dispersão injustificada, por outras «pastas», de algumas funções relativas ao domínio da previdência social, exigia a sua urgente concentração num só organismo: a Assistência Pública tinha de ser considerada, do ponto de vista social, uma instituição de previdência, porque o socorro que presta aos que a ela se acolhem só erróneamente pode ser tomado como manifestação de altruísmo, quando não passa de auxilio a que têm direito todos os que, mais ou menos, contribuem para a sua manutenção; ${ }^{(609)}$ os seguros sociais, convertidos num dos mais importantes ramos da previdência, que muito tem concorrido para o desenvolvimento económico das nações civilizadas; os Serviços de Saúde e os Serviços de Fiscalização do Trabalho constituíam ramos essenciais e indissociáveis da Previdência; os Serviços Geológicos e de Minas eram mantidos e até reforçados nessa Secretaria de Estado, mas devidamente interligados e reestruturados; e, por último, as limitações do Tesouro tinham de condicionar os esforços de reorganização, não permitindo que os encargos duma nova organização da Secretaria de Estado do Trabalho venham avolumar ainda mais despesas públicas, sem se obter a receita necessária ao custeio dessa nova organização. ${ }^{(610)}$

A estrutura ministerial redesenhada distribuía-se por uma Secretaria Geral, junto da qual funcionava a 1 I. ${ }^{2}$ Repartição da Direcção Geral da Contabilidade Pública, e por cinco Direcções Gerais: do Trabalho, da Previdência Social, de Minas e Serviços Geológicos, da Assistência Pública e da Saúde.

Alguns destes Serviços transitaram de outras Secretarias de Estado, a saber: do Interior vinham os Serviços, organismos, arquivos, pessoal e material da Direcção Geral de Assistência Pública e ainda os Serviços sanitários centrais e externos, que manterão a organização, regime e atribuições conferidas pelas leis, decretos e regulamentos de saúde, e bem assim os respectivos arquivos, pessoal e material; (611) das Finanças procediam os Serviços, organismos, arquivos, pessoal e material de fiscalização e funcionamento das companhias e sociedades de seguros; ${ }^{(612)}$ do Comércio vinha a Comissão dos Serviços Geológicos: e o Montepio Geral, criado por lei de 2 de Junho de 1867 e o Montepio Oficial do Professorado Primário referido pela lei n. ${ }^{\circ} 757$ de 3 de Agosto de 1917, embora continuassem a ser regidos pelas mesmas organizações, ficavam, doravante, dependentes da Direcção Geral de Previdência Social para o efeito do mutualismo.

Todas as Direç̧ões Gerais mencionadas subdividiam-se em várias Secções e Repartições, descritas no diploma com os respectivos conteúdos funcionais e sob a designação genérica de Serviços Internos.

(608) Cf. Diário do Governo, I. Série (157) 14 de Julho de 1918, p. 1290.

(609) Cf. Ibidem, p. 1290.

(610) Cf. Ibidem, p. I29I.

(611) Cf. Ibidem, p. 1291.

(612) Cf. Ibidem, p. 1291. 
No capítulo dos Serviços Externos surgiam: a Inspecção do Trabalho, encarregue da fiscalização do trabalho em todas as indústrias e repartida por sete circunscrições industriais do continente e ilhas; a Inspecção de Minas, à qual competia o reconhecimento, a fiscalização e os impostos mineiros e dividida em duas circunscrições mineiras; a Inspecção de Águas, com idênticas atribuições da anterior, mas aplicada ao sector específico das águas minero-medicinais, de mesa e dos sais extraídos dessas mesmas águas; a Inspecção de Pedreiras, tendo a seu cargo a fiscalização dos serviços pedreiros privativos do distrito de Lisboa; o Laboratório Químico-Metalúrgico, vocacionado para os ensaios químicos dos minérios, águas, metais, para os ensaios metalúrgicos e para a metodização dos processos de ensaios a adoptar; e à Inspecção Sanitária do Trabalho cabia uma funcionalidade tripartida: elaborar estudos, pareceres e legislação sobre higiene e doenças profissionais, salubridade e segurança dos lugares de trabalho e a instalação e funcionamento dos estabelecimentos industriais; organizar e dirigir o Museu de Higiene e Segurança Industrial, o Laboratório de Higiene Profissional e a propaganda dos conhecimentos de higiene dos trabalhadores, salubridade e segurança dos lugares de trabalho; e promover inquéritos e estatísticas sobre morbidade e mortalidade operárias e desastres no trabalho. Na dependência da Secretaria de Estado do Trabalho e funcionando junto das suas diferentes Direcções Gerais existiam sete Conselhos e uma Comissão Permanente - o Conselho Superior do Trabalho, o Conselho Superior de Previdência Social, o Conselho Superior de Minas e Serviços Geológicos, o Conselho Nacional de Assistência Pública, o Conselho Superior de Higiene, o Conselho de Seguros, o Conselho de Arbitragem e a Comissão Permanente de Propaganda Mutualista e Social - com carácter consultivo e de estudo. Os quadros de pessoal, os provimentos e promoções, as licenças, as situações de doença e outras, os vencimentos e as aposentações preenchem também o articulado do diploma aqui resumido.

A legislação promulgada e publicada na área orgânico-funcional em foco reflectiu a actividade de toda a estrutura descrita, como podemos mostrar através dos seguintes exemplos: o decreto 4.288 de 9 de Maio reuniu, corrigiu e ampliou a legislação avulsa sobre desastres no trabalho, matéria importante estudada e legislada a partir da $2{ }^{\text {a }}$ Secção da Repartição de Defesa do Trabalho da Direcção Geral do Trabalho; o decreto n. ${ }^{\circ} 4.351$ de 29 de Maio classificou em três classes as indústrias insalubres, incómodas, perigosas e tóxicas, determinando multas para os infractores, matéria tratada no âmbito da I. 'a Secção da Repartição Técnica da Direcção Geral do Trabalho; e o decreto n. ${ }^{\circ} 4.803$ de 10 de Setembro autorizou a Secretaria de Estado do Trabalho a distribuir pelas associações mutualistas mais necessitadas, que socorreram na doença, a quantia de $50 \$ 00$, a sair do Orçamento das despesas excepcionais resultantes da guerra para o ano económico de 1917-1918, matéria da competência especializada da Repartição de Associação Mutualistas e Profissionais da Direcção Geral de Previdência Social. O surto epidémico da pneumónica viria, aliás, a tornar imprescindível e crítica a acção do mutualismo operário. ${ }^{(613)}$

(613) Dossier Secretaria de Estado do Trabalho, telegrama de 28 de Outubro de 1918. (Arquivo de Sidónio Pais - Militar, Lente e Político, Subsistema Presidência da República). 


\section{Políticas na Justiça e Interior}

Passando do Trabalho à Justiça e ao Interior algumas notas se impõem.

Acerca da Justiça há que frisar a continuidade do programa geral esboçado no início da governação dezembrista e atrás referido, uma continuidade indiscutível|(6/4) apesar da «pasta» conhecer quatro titulares durante o período de um ano!

Ao nível estritamente legislativo, alguns diplomas - por certo os mais significativos — bastam para vincar e desenvolver o traço apontado: o decreto n. 4.676 de II de Julho, prontamente divulgado pela Legação dos E.U.A. em Lisboa para Washington com cópia e breves comentários elogiosos, ${ }^{(615)}$ permitia às mulheres munidas de uma carta de formatura em Direito o exercício de advogado, ajudante de Notário e ajudante de Conservador, bem como, em igualdade de habilitações com os homens, as funções de ajudantes de Postos e das Repartições do Registo Civil, lugares de amanuenses e oficiais das Secretarias de Estado e mais Repartições públicas ou dos Corpos Administrativos, ficando dispensadas da apresentação de documentos exigidos para esses cargos concernentes a serviços a que por lei não são obrigadas; ${ }^{(616)}$ o decreto n. $^{\circ} 4.677$ da mesma data regulava os Serviços Notariais; o decreto n. 4.679 de 9 de Julho aumentava em $50 \%$ os preparos judiciais; 0 decreto . $^{\circ} 4.619$ de 13 de Julho (publicado pela primeira vez em 23 de Julho e, de novo, com rectificações em 2 de Agosto) reorganizava e ampliava não só a estrutura, mas sobretudo o princípio do Registo Predial, formulado no artigo $1599^{\circ}$ do regulamento de 20 de Janeiro de 1898; 0 decreto . $^{\circ} 4.805$ de II de Setembro, dadas as circunstâncias económicas difíceis, o dever do Governo de impedir ou atenuar os males da guerra, melhorando, na medida do possível, os serviços públicos e as centenas de presos, novos e velhos, que se achavam inúteis nas cadeias do país, autorizava o aproveitamento do trabalho dos presos de crimes comuns que se acharem cumprindo pena, ainda mesmo os que estão em prisão preventiva, empregando-os em serviços públicos ou de utilidade geral, fora das cadeias, durante o dia, providência esta benéfica para os próprios presos, não só para a sua regeneração, objectivos individual e social da penalidade moderna, mas até para a sua saúde, pelo trabalho ao ar livre, principalmente para os que têm uma origem rural, mal adaptados sempre a aprendizagens industriais; ${ }^{(617)}$ os decretos n.os $4.805,4.806,4.807$ e 4.807, todos de 1 I de Setembro, contêm disposições sobre o Instituto de Medicina Legal de Lisboa, a organização dos seus Serviços e a construção de um edifício para a Morgue de Lisboa, dirigida desde 15 de Dezembro de 1911 pelo professor João Alberto Pereira de Azevedo Neves (em breve, Secretário de Estado do Comércio); e o decreto n. ${ }^{\circ} 4.893$ de 28 de Setembro aprovava o projecto de regulamento do Instituto de Medicina Legal de Lisboa, determinado pelo decreto $n{ }^{\circ} 4.808$ e elaborado pela Direcção do Instituto à luz dos mais modernos conhecimentos existentes sobre esse domínio legal e técnico-científico.

(614) Dossier Secretaria de Estado da Justiça, duas folhas sem titulo. (Arquivo de Sidónio Pais - Militar, Lente e Político, Subsistema Presidência da República).

(615) Records of the Department of State relating to internal affairs of Portugal, 1910-1926, Political affairs, 705/4 roll, 1918, cópia dectiloscrita. (National Archives, Washington),

(616) Cf. Diário do Governo, I série (160) 19 de Julho de 1918, p. 1426.

(617) Cf. Diário do Govêrno, I série (201) 16 de Setembro de 1918, p. 1688. 
Tradicionalmente posta na esfera de intervenção interna do Poder Executivo (no território continental e insular), a «pasta» do Interior detinha competências variadas, que iam do controlo dos Governos Civis e das Administrações do Concelho, das Polícias e outros meios do aparelho político-administrativo e repressivo do Estado até à Assistência Pública (e apoio financeiro e logístico à Obra de Assistência de 5 de Dezembro), passando ainda por outros Serviços, episodicamente concentrados sob sua tutela, como foram os casos, atrás vistos, das Subsistências e do Comissariado Geral dos Abastecimentos, para aí desviados na sequência da extinção da Secretaria de Estado das Subsistências e quando se achava à frente do Interior o capitão Tamagnini Barbosa, discreto, hábil e influente colaborador de Sidónio Pais.

Amplitude e variação que a legislação publicada e a informação recebida e expedida, nesse período, pela Secretaria de Estado do Interior espelha com nitidez quer na vertente institucional, quer ainda nos efeitos directos que a falta de géneros e o espectro da fome tiveram na (des)ordem e (in)segurança públicas. Uma cuidadosa consulta da correspondência oficial, trocada com os representantes distritais e concelhios do Governo e com outras autoridades, tais como as militares (Exército e g .n .r.), permite captar os contornos fácticos e dramáticos desses efeitos. Abundam os exemplos e variam as situações, podendo-se cerzir com elas um retrato policromático do ambiente político-social vivido no $2^{\circ}$ semestre de 1918 e, em especial, até Outubro.

Por telegrama de 31 de Julho, Rosado Fonseca comunicava que, em vista dos assaltos a mercearias de Estremoz por motivo do aumento do preço do pão, ia convocar uma reunião de lavradores a fim de não ser aumentado o preço, mas solicitava providências e a colaboração da autoridade local. No início de Agosto o Governador Civil de Santarém nomeou novos Administradores de Concelho, na sua totalidade militares, e deu conta, pelo mesmo ofício, que a falta de milho tornara-se crítica e permanente em todos os concelhos.

De Fafe, a 2 de Agosto, vinha o apelo, lançado pela respectiva Câmara Municipal, de providências urgentes - envio de wagons - para a Fábrica de Fafe transportar algodão com destino a Lisboa, sob pena de encerrar a sua laboração e ficando sem trabalho seiscentos operários.

Do Governo Civil de Portalegre, com data de 3 de Agosto, chegava a notícia de alguma agitação popular, notada desde há alguns dias, por manifesta discordância com a tabela dos preços de cereais e hontem a convite do administrador do concelho e Presidente da Camara reuniram nos Paços do Concelho para resolverem sobre barateamento de preço pelos lavradores do Concelho. Grande numero de populares se juntaram em frente dos paços do concelho gritando e arrombando a porta da torre do edificio, tocando a rebate e arrombando portas e janellas. Compareceu a Guarda Republicana a quem o povo respondeu com tiros e pedradas. ${ }^{(618)}$

Enquanto isto sucedia no Alto Alentejo, a agitação social no Algarve tinha outros motivos e outros protagonistas: por telegrama de 7 de Agosto, o Governador Civil de Faro sugeria que os donos das fábricas da zona fossem intimados a pagar os salários

(618) Ministério do Interior, Livro de correspondência recebida, liv. 71, Julho-Dezembro de 1918, ofício do Governador Civil de Portalegre. (Instituto dos Arquivos Nacionais - Torre do Tombo). 
aos seus operários visto se terem fechado as portas como protesto contra o último decreto do azeite.

Voltando ao Norte, mais precisamente a Braga, o Governador Civil desse distrito comunicava, em 13 de Agosto, que o Administrador do Concelho de Guimarães the telegrafara dizendo que o povo tentara alterar a ordem pública por causa das subsistências, mas já fora, entretanto, restabelecido o socego absoluto.

As subsistências inspiraram, também, o telegrama do Presidente da Câmara Municipal de Odemira, em que este pedia o envio urgente de fiscais porque o Administrador do Concelho não exercia uma acção energica e moralisadora.

Mas nem todos os fiscais eram desejados da mesma forma: em Aveiro, segundo participação do Governo Civil por telegrama de 16 de Agosto, tinham aparecido, no dia anterior, dois fiscais que procederam violento e arbitrariamente e, por essa razão, pedia que fossem passadas guias de regresso a Lisboa. $O$ Governador Civil de Santarém apressou-se a solicitar o pagamento urgente das despesas com a Polícia Preventiva. Preocupação partilhada igualmente pelo colega do Porto: em 17 pedia envio da importância relativa aos meses de Julho e Agosto destinada à Obra de Assistência 5 de Dezembro e ainda a verba para a Polícia Preventiva, mais 100 caixas de gazolina. DeViseu, no dia seguinte, a novidade era outra: o Governador Civil informava a tutela haver absoluto socego no distrito e ter abandonado o districto por diversos jornaes publicarem a sua exoneração. ${ }^{(619)}$ Novamente do Porto partia a animadora notícia do fim do conflito ferroviário na Linha do Entre-Douro e Minho, estando previsto o restabelecimento do serviço para o dia seguinte - dia 19.

O Alto Comissário dos Açores, general Simas Machado, informava ter nomeado o capitão de Infantaria Miguel de Almeida e o alferes Francisco de Paula para completarem a Comissão de Censura determinada pelo decreto 4.436, propondo noutra comunicação oficial aumentos de ordenados aos empregados das Câmaras Municipais, visto os então auferidos serem exíguos e a situação grave.

De regresso ao continente deparamos com um ofício da mesma data da Secretaria de Estado da Guerra comunicando que o Comandante de Cavalaria 6 dizia não poder fornecer as seis carabinas e respectivos cartuchos ao Governo Civil de Vila Real por ter-se dado a transferência de muitas carabinas para o Regimento de Cavalaria n. ${ }^{\circ} 4$.E a mesma entidade, por ofício, chamava a atenção da Comissão de Censura para umas notícias publicadas sem cortes no jornal O Mundo.

Por seu turno, o Governador Civil de Évora, por ofício de 20 de Agosto, remetia cópia de outro ofício dirigido aos Presidentes das Câmaras Municipais do distrito, informando-os dos resultados da reunião havida com os Presidentes dos Celeiros e Moageiros efectuada naquele Governo Civil.

A Redacção da Justiça de Braga, em 24 de Agosto, pedia providências contra a deliberação do Governador Civil, José Dórdio Teotónio, eleito deputado pelo p.n.r., que proibira a sua publicação.

(619) O Governador Civil em causa era o Dr. Eleutério da Cunha Santa Rita, substituído em 31 de Agosto pelo Bacharel josé Marques Loureiro. Ministério do Interior, Livro de correspondência recebida, liv. 7I, Julho-Dezembro de 1918, telegrama de 18 de Agosto. (Instituto dos Arquivos Nacionais - Torre do Tombo). 
Muito mais exótica, apesar de igualmente significativa, é a nota procedente da Secretaria de Estado dos Negócios Estrangeiros em que se pedia atenção para o facto do súbdito britânico Henry M. Black ter sido levado para o Governo Civil de Lisboa após uma altercação com o seu senhorio, o Almirante Machado Santos.

Da Administração do Concelho de Barcelos saía a confirmação oficial de que a(s) política(s) governamental(ais) para as subsistências esbarrava( $m$ ) num incontornável óbice: ninguém se oferecia voluntariamente para vender ao Estado pelo preço legal qualquer quantidade de azeite. E da Câmara Municipal e Celeiro da Guarda foi enviado, com data de 25 de Agosto, um ofício a pedir a publicação de um decreto que autorizasse os Presidentes da Câmara do país a requisitarem directamente forças do Exército, Guarda Republicana e Polícia Cívica.

A pensar precisamente na Polícia Cívica do Porto, o Governador Civil desse distrito solicitava a substituição dos revólveres daquela Polícia por pistolas farage e o fornecimento de 4.000 cargas. Em vez de armas, o telegrama do Governador Civil de Santarém, de 19 de Agosto alude ao facto de algumas Comissões de Abastecimento terem saldado contas com lucros de alguns milhares de escudos entregues nas Câmaras Municipais como receita, propondo que tais verbas revertessem a favor da Assistência concelhia como a solução mais justa.

Em nome de uma solução mais humanitária e menos degradante, o Juiz de Direito do 1. Juizo de Investigação Criminal de Lisboa, Alberto Magalhães Barros, enviou um ofício ao Comando Geral da g.n.r. com data de 31 de Agosto:

Ex.mo Sr. Comandante da Guarda Nacional Republicana - Lisbôa - Não tendo ontem a guarda do Tribunal prestado auxilio para a condução dos presos ao Limoeiro, tiveram estes de permanecerem até tarde nos calabouços do Tribunal onde se insubordinaram tendo de ser algemados e conduzidos assim pelos oficiaes de diligencias e pessoas das relações dêstes. - O carro celular em que os presos costumavam ser condusidos ha muito que não faz serviço, constando que está em concerto. - É realmente deprimente vêr os presos condusidos no meio de uma escolta, mas peor ainda é o degradante espectaculo de os ver algemados nas ruas da capital. - Para obstar a estes factos venho rogar a V. Ex. ${ }^{\circ}$ se digne por sua parte empregar as necessarias diligencias para que o carro celular seja conduzido diariamente ao Tribunal ou seja dispensado um automovel do Exercito para conduzir os presos ao Limoeiro. E emquanto isto se não levar a efeito, se digne ordenar á guarda do Tribunal que auxilie diariamente a condução dos presos para a cadeia do Limoeiro, como aliás tem sido costume a não ser ontem e há poucos dias em que a Guarda se recusou a prestar auxilio. Saude e Fraternidade. ${ }^{(620)}$

Por falta de suficientes forças da g.n.r. e de automóveis do Exército ou da Justiça, o transporte de presos - tópico pertinente se tivermos em conta a célebre leva de morte de 16 de Outubro, adiante referida - efectuava-se em condições precárias,

(620) Ver SILVA, Armando Barreiros Malheiro da - Sidónio e sidonismo, história e mito, dissert. cit., vol. 2 , p. 389-391. 
agravadas após a intentona militar falhada de $12 / 13$ de Outubro, a que se seguiu uma nova onda de prisões e o transporte de presos pelas ruas da capital, triste espectáculo e flagrante oportunidade para tentativa de libertação de alguns ou de todos os prisioneiros em trânsito, mesmo se acompanhados por número significativo de guardas. $E$ estreitamente relacionado com este aspecto andou outro, mais grave ainda do ponto de vista jurídico-constitucional - a demora da remessa dos presos (comuns e políticos) pelas autoridades administrativas para Juízo. Numa tentativa interessante, mas pouco auspiciosa, de pôr côbro a tal demora e aos seus inconvenientes, o Director Geral da Administração Pública, Carneiro de Moura, expediu para todos os Governos Civis uma circular datada de 7 de Novembro redigida nestes termos:

Tendo ponderado a esta secretaria d'Estado a da Justiça e dos Cultos o facto das auctoridades administrativas demorarem a remessa dos presos para juizo, à sombra do Decreto de 27 de abril do corrente anno, art. 112 , demora que chega a ser de seis a sete dias depois da detenção, facto este de que resultam os inconvenientes de o poder judicial não poder proceder às necessarias diligencias durante esses dias de prisão preventiva dos reus, findos os quaes estes devem ser postos em liberdade ( art. $^{\circ} 10$ de Decreto de 14 de outubro de 1910), queira V. Ex. ${ }^{\circ}$ expedir as necessarias instruções às auctoridades administrativas e policiaes do Distrito a seu cargo no sentido de se evitarem de futuro os inconvenientes resultantes do que fica exposto.

Saude e Fraternidade. ${ }^{(621)}$

Esta circular traz à colação uma faceta já vista a propósito da alegada política repressiva do sidonismo - o chamado «terror sidonista» - política essa ainda hoje tratada, do ponto de vista historiográfico, de forma pouco sólida e insuficientemente documentada. Convém rectificar a abordagem habitual e realçar o papel dos Governadores Civis, a sua margem de acção político-partidária e político-repressiva, desde a escolha das autoridades administrativas inferiores, dos responsáveis pelas Polícias ou das Comissões Especiais de Censura até à ordem de prisão ou à suspensão de periódicos.

A escolha de monárquicos para pontos estratégicos da espinha dorsal da Secretaria do Interior ou, pelo menos, o excesso de zelo no combate directo à(s) oposição(ões), reprimindo, prendendo e sancionando práticas extra-legais de actuação com os presos, mostra ter havido um notório descontrolo, desvio e desencontro entre a legalidade republicana sustentada formalmente pelas instâncias máximas da República Nova e a prática dos seus agentes nos diversos níveis da divisão administrativa territorial, de que os casos polémicos de Alberto Margaride, Melo de Carvalho e Solari Allegro no Porto se tornaram os expoentes da repressão trauliteira. ${ }^{(622)}$

(621) Ministério do Interior, Correspondência recebida (Segurança Pública), maço 82, cx. 52, 1918. (Instituto dos Arquivos Nacionais - Torre do Tombo).

(622) Ver LIMA, Campos - O Reino da traulitânia. 25 dias de reacção monárquica no Porto, ob. cit., p. 7-47 e Dossier Greve de Junho 19/8. Ferroviários, (sub)dossier Governador Civil de Lisboa, duas cartas de Manuel Mateus. (Arquivo de Sidónio Pais - Militar, Lente e Político, Subsistema Presidência da República). 


\section{Política de instrução}

A continuidade pontificou na acção reformista levada a cabo através da equipa responsável pela Secretaria de Estado da Instrução — o professor nortenho Alfredo de Magalhães e os seus directos colaboradores (Fidelino de Figueiredo, Chefe de Gabinete, João de Barros, Secretário Geral, etc.), guiados por um plano de reformas, atrás exposto, a partir de dois extensos relatórios entregues na Presidência da República. Plano vazado numa impressionante torrente legislativa, vasta e ambiciosa, mas a que faltou o tempo para poder ter uma efectiva aplicação prática.

A ilustrar esta observação temos o decreto n. 4.667 de 8 de Maio sobre a Escola Industrial Brotero, de que Sidónio Pais fora o Director desde 1905 até 191 I. Pretendiase com esse diploma fazer cumprir, finalmente, o disposto no artigo $2 .^{\circ}$ da lei $n .^{\circ} 822$ de 8 de Setembro de 1917, habilitando a Comissão Administrativa especial encarregue da construção do novo edifício - velha aspiração a que já nos referimos com detalhe — nomeada por portaria de 28 de Novembro de 1917, a dar execução rápida às obras de que fora incumbida. Eram, claramente, fornecidos os meios para que o velho sonho se concretizasse. Mas ainda não seria dessa vez, nem das seguintes: o novo edifício para a Escola só veio a ser concluído em 1958!...(623)

No mesmo dia 8 de Maio de 1918 foram ainda assinados os decretos n. . $^{\text {s }} 4.666,4668$ e 4.669: o primeiro diploma introduzia ligeiras modificações ao quadro de disciplinas da Escola, fixado no quadro II do decreto de 24 de Dezembro de 1901 e modificado pelo decreto n. ${ }^{\circ} 1.028$ de 5 de Novembro de 1914; o segundo conferia autonomia administrativa a várias escolas de ensino elementar industrial e comercial; e o terceiro estabelecia na Escola Industrial de Brotero, em Coimbra, o curso especial de montador electricista, para o qual Sidónio Pais definira, já em 1910, o conteúdo e a pertinência sócio-profissional. Pelo decreto n. ${ }^{\circ} 4.392$ de 12 de Junho transferia a Escola de Medicina Tropical, o Hospital Colonial, a Escola Colonial, o Instituto das Missões Coloniais e - Museu Colonial, bem como as respectivas verbas já consignadas no Orçamento da Instrução, agravado, aliás, por encargos imprevistos e onerosos, ${ }^{(624)}$ para a dependência directa e exclusiva da Secretaria de Estado das Colónias.

Incidindo especificamente sobre a instrução primária, parece-nos importante destacar o decreto $n .{ }^{\circ} 4.434$ de 15 de Junho estabelecendo e regulando as condições em que deveriam realizar-se, na próxima época, os exames de instrução primária. Pelo decreto n. ${ }^{\circ} 4.642$ de 14 de Julho o Governo ficava autorizado a contrair um empréstimo com a Caixa Geral de Depósitos até à quantia de 5.000 contos, a juro não superior a $5 \%$, amortizável em sessenta anos, para ser aplicado exclusivamente, por expressa vontade do Presidente da República, ${ }^{(625)}$ na criação de escolas primárias com cantinas para

(623) Ver MARTINHO, António Manuel Pelicano Matoso - A Escola Avelar Brotero, 1884-1974, ob. cit., p. 381-4II e 455-457.

(624) Cf. Diário do Governo, I série (129) 13 de Junho de 1918, p. 896.

(625) Cf. O Dr.Alfredo de Magalhães fala ao «Notícias de Viana». Noticias de Viana, número especial, 18 de Agosto de 1929, p. inum. 
alimentação dos alunos, gratuita para os pobres, em todo o país.(626) Desiderato regulado pelo decreto n. ${ }^{\circ} 4.847$ de 23 de Setembro, com o objectivo prático de garantir que o empréstimo contraído fosse estritamente ao fim especial para que foi criado, sendo, por isso, instituído o Fundo das Construções Escolares 5 de Dezembro, dotado com os referidos 5.000 contos, acrescidos das importâncias provenientes de donativos e de legados destinados a construções escolares, dirigido por um conselho autónomo denominado Conselho Central das Construções Escolares 5 de Dezembro, presidido pelo Secretário de Estado da Instrução Pública, e orientado por critérios fixados nesse mesmo diploma. A saúde física e mental das crianças mereceu também a atenção dos legisladores da República Nova e pelo decreto n. ${ }^{\circ} 4.695$ de 14 de Julho eram remodelados os Serviços de Sanidade Escolar, que teriam de ser exercidos por médicos escolares colocados nos estabelecimentos de ensino, à excepção das Universidades.

Sobre o ensino secundário(627) foi promulgada legislação importante, completada no último trimestre de 1918 , a saber: 0 decreto $n .^{\circ} 4.643$ de 13 de Julho que regulava todo o ensino secundário particular, isto é, ministrado fora dos estabelecimentos congéneres do Estado; o decreto $4.50 \mathrm{I}$ de 14 de Julho reformava os serviços desse tipo de ensino, actualizando o vencimento do pessoal dos liceus e atendendo quer às reclamações feitas pelos interessados, quer às recomendações formuladas pela Comissão de Revisão do Ensino Secundário nomeada por portaria de 21 de Janeiro de 1918; e - extenso decreto $n{ }^{\circ} 4.799$ de 8 de Setembro aprovava o regulamento da chamada instrução primária ministrada nos liceus nacionais centrais e nos liceus nacionais, fixando as condições administrativas, financeiras e pedagógicas necessárias ao seu exercício. 0 professorado deste nível de ensino, bem como do primário, era preparado nas Escolas Normais Superiores das Universidades de Coimbra e de Lisboa, que seriam também objecto de diplomas próprios - os decretos n. ${ }^{\circ} 4.649$ de 13 de Julho e o n. ${ }^{\circ} 4.900$ de 5 de Outubro - concebidos para a sua reorganização pedagógica e institucional.

Subindo para o nível superior deparamos com um leque variado de diplomas: 0 decreto n. ${ }^{\circ} 4.697$ de 19 de Julho autorizava a Universidade de Coimbra a levantar na Caixa Geral de Depósitos, até à quantia de $100.000 \$ 00$, um empréstimo destinado à conclusão do campo de jogos e construção de um edifício para instalação da Associação Académica; ${ }^{(628)}$ os decretos $4.647,4.648,4.651$ — os três de 14 de Julho - 4.652 de 12 de Julho, 4.653 de 14 de Julho e 4.874 de 5 de Outubro reorganizam e regulam diversas Faculdades e Cursos Superiores, respectivamente, a Faculdade de Ciências da Universidade de Coimbra, as Faculdades de Direito das Universidades de Coimbra e Lisboa, as Faculdades de Letras dessas duas Universidades, o ensino médico ministrado nas Faculdades de Medicina do Porto, Coimbra e Lisboa e o ensino oficial de Farmácia nas três Universidades do país. E a encimar este conjunto de diplomas regulamentadores sobressai o decreto $n .{ }^{\circ} 4.554$ de 6 de Julho, aprovando e consagrando o estatuto universitário com vista à plena efectivação da autonomia dos institutos de instrução superior. (629)

(626) Cf. Diário do Governo, I série (157) 14 de Julho de 1918, p. 1305.

(627) Ver CARVALHO, Rómulo de - História do Ensino em Portugal, ob. cit., p. 685-686.

(628) Ver GOMES, Joaquim Ferreira - Estudos para a história da Universidade de Coimbra, ob. cit., p. 1 19-120.

(629) Ver Idem - A Universidade de Coimbra durante a primeira república, (1910-1926), ob. cit., p. 303. 
A par da vertente instructo-educativa não foi descurada, como já notamos, a científica e a cultural, sendo de realçar a este nível o decreto n. ${ }^{\circ} 4.888$ de 17 de Setembro que aprovava o regulamento interno da Biblioteca Popular de Lisboa ou o decreto n. ${ }^{\circ} 4.875$ de 5 de Outubro com outro regulamento, este relativo à Biblioteca da Ajuda, erudita e complementar da Biblioteca Nacional; e pelo decreto n. 4.480 de 24 de Junho era aprovado o estatuto e regulamento interno da Academia das Ciências de Lisboa, fixandoThe as condições orgânico-funcionais e financeiras necessárias para que pudesse, com êxito, cultivar e promover o desenvolvimento das ciências e das letras em Portugal.

Toda esta ambiciosa actividade reformista, ligada a uma assumida defesa dos interesses educativos e culturais do Porto, reflectiu, em larga medida, a personalidade e a experiência de Alfredo de Magalhães, republicano «histórico», ex-afonsista e dezembrista que se manteve ao lado de Sidónio Pais de Dezembro de 1917 a Dezembro de 1918 , mas não de uma forma inteiramente pacífica e discreta, pois, como já atrás referimos, ameaçou sair entre finais de Abril e inícios de Maio e voltou a pedir a exoneração, por carta de 13 de Julho, quando já acumulava a «pasta» da Marinha, abandonada por José Carlos da Maia. Sidónio conseguiu, uma vez mais, demovê-lo desse propósito e o professor da Faculdade de Medicina do Porto manteve-se no seu posto até à morte do Presidente.

\section{Marinha e política colonial}

Na Secretaria de Estado da Marinha até 9 de Setembro, data da nomeação do almirante João do Canto e Castro Silva Antunes que Sidónio Pais conhecera em Berlim, a acção de Alfredo de Magalhães reduziu-se a um interinato apagado e regido pela preocupação de evitar o vazio administrativo, dando continuidade à política que o comandante José Carlos da Maia tinha deixado sintetizada num relatório entregue ao Presidente da República e num pequeno pacote legislativo.

Nesse relatório-programa, o amigo e companheiro indefectível de Machado Santos anunciou, logo na abertura, o patriótico engrandecimento da Armada através de uma profunda reorganização interna e da consolidação da estrutura a que fora arrancado, em 5 de Outubro de 1910, o ramo colonial, autonomizado em Ministério próprio (Ministério das Colónias). Reduzida a uma frota pequena e dilacerada por deficiências organizacionais com sérias implicações de natureza laboral(630) e por uma intensa agitação política no seu seio, a Marinha precisava de ser acalmada, arrumada e reformada dentro do espírito reformista geral da governação sidonista, desiderato que José Carlos da Maia, um marinheiro prestigiado, ajudará, ainda que por pouco tempo, a concretizar:

Realisar a disciplina e preparar o pessoal para o exercicio das funções que the são cometidas foi a preocupação incessante do Governo que adoptando providencias varias pode hoje afirmar a sua inteira confiança nas praças de marinha que em

(630) Dossier Secretaria de Estado da Marinha, Exposição da Comissão Delegada, 19 de Fevereiro de 1918. (Arquivo de Sidónio Pais - Militar, Lente e Político, Subsistema Presidência da República). 
diversos pontos se encontram honrando a bandeira da Patria e levantando bem alto o prestigio da Republica.

Para combater os allemães em Moçambique e destinando-se a cooperar com as forças de terra, está prestes a chegar áquella nossa colonia um batalhão de valentes e destemidos marinheiros que vão juntar-se às praças de marinha que lá se encontram promptas a marchar para o campo da honra, comandadas pelos seus oficiaes e sargentos.

Aceitando-se a opinião de alguns oficiaes da Armada muito ilustrados, o Governo descongestionou o antigo quartel de Marinheiros impedindo a aglomeração, inconveniente para a disciplina de praças que melhor foram utilisadas nos diferentes serviços da Armada nomeadamente os de embarque onde a sua eficiencia é maxima.

Passaram os serviços burocraticos referentes ás praças para uma das Repartições da Secretaria de Estado da Marinha, sendo a parte referente á instrucção de recrutas desempenhada por Escolas que successivamente vão sendo instaladas no Alfeite, em Vila do Conde, em Portimão e mais tarde, quando houver possibilidade, na ilha de Porto Santo.

Dotar a Armada com elementos novos possuindo já uma certa preparação e principalmente uma exacta noção da disciplina, eis o objectivo que as Escolas de recrutas foram chamadas a desempenhar e que por certo ha de ser alcançado, dadas as condições que se encontram estabelecidas para o seu funcionamento e a responsabilidade e competencia atribuidas ao primeiro comandante de cada um d'aquelles estabelecimentos.

(..)

Mercê de circunstancias varias que não é oportuno relatar agora, encontra-se devéras reduzido o material naval de que a nação dispõe para a sua defesa e protecção do comercio maritimo, tendo-se mantido ao serviço na sua quase totalidade os barcos particulares que se encontravam mobilisados e que os nossos oficiaes e praças têm sabido utilisar com admiravel pericia e denodado esforço.

Foi augmentada com mais um cruzador a defesa maritima de Moçambique e nos Açores, onde era reduzido o numero dos nossos navios, foi creado o Comando da defesa maritima a cargo de um almirante que tem como navio-chefe o cruzador Vasco da Gama que percorre as ilhas em constante vigilancia.

Foi lançada ao mar a canhoneira Quanza, apromptou-se a Mandowy para qualquer comissão, activaram-se os fabricos do Almirante Reis que breve estará prompto a largar para o mar, continuaram-se os trabalhos em dois destroyers cujo acabamento depende muito da falta de material cuja acquisição está sendo tratada pelas vias diplomaticas, beneficia-se o funcionamento do Arsenal, melhoram-se as condições do respectivo pessoal operario e para coroamento de todos estes esforços está sendo organisada a Junta autonoma(631) que ha de presidir á construção do novo arsenal na margem sul do Tejo já decretada e em via de rapida execução para o que no orçamento foi inscripta a verba respectiva.

(631) Ver decreto n. 4.405 de 8 de Junho de 1918. Diário do Governo, I série (130) 14 de Junho de 1918. p. $901-903$. 
Este melhoramento que representa uma velha aspiração da Armada tem uma importancia muitissimo elevada porque alem de ser a base em que assenta o progresso do nosso material naval, representa uma consideravel melhoria para o nosso operariado que vae colocar-se em condições de poder servir o Estado com maiores comodidades e finalmente vae promover o desenvolvimento das regiões proximas as quaes são por todas as formas naturalmente beneficiadas

(...)

Completando o pensamento reformador e para que elle possa ter utilidade prevista confere ao Secretario de Estado, um dos artigos da organisação, a faculdade de remodelar a instrucção em todas as escolas dependentes da respectiva Secretaria, sendo assim possivel aproveitar os resultados do estudo do Serviço do Estado Maior a quem competem funcções importantes e complexas.

Desta forma o ensino da Escola Naval seria remodelado em termos que obrigassem os segundos tenentes à frequencia de um Curso Complementar de um anno, exigencia que os cursos intensivos fortemente impõem, crear-se-hà a Escola Superior de Marinha que devia preparar os primeiros tenentes e os oficiaes superiores para as complexas funç̧ões do Alto-Comando, seria alterada a organisação das escolas de pilotagem por forma a tornar intenso o trabalho do professor, reorganisavam-se as escolas de aplicação para praças e por ultimo, em obediencia a um dos artigos do decreto que transfere o arsenal para a margem Sul do Tejo, estabelecia-se o internato para os aspirantes de marinha. ${ }^{(632)}$

Na opinião de José Carlos da Maia o êxito da obra gizada seria a consequência lógica do trabalho que a ditadura preparou, ${ }^{(633)}$ retomando, assim, um princípio caro à linha basilista, ${ }^{(634)}$ machadista e autoritária do republicanismo português: a República ideal tinha de assentar numa ditadura progressiva e fecunda, capaz de lançar as bases, os alicerces da política de regeneração republicana e nacional, implicitamente definida por esse machadista no último parágrafo do seu relatório: Com bom material e pessoal bem preparado a Armada saberá cumprir a sua missão. Energia no comando, doçura no trato e firmeza nas resoluções e a Marinha em breve terá bem merecido da Patria.

Sob a influência do mesmo reformismo republicano decorreu, também, a aç̧ão do capitão de Mar e Guerra Alexandre José Botelho de Vasconcelos e Sá na Secretaria de Estado das Colónias, reorganizada por decreto n. ${ }^{\circ} 4.271$ de 8 de Maio, ${ }^{(635)}$ ainda assinado pelo seu antecessor Tamagnini Barbosa.

(632) Dossier Secretaria de Estado da Marinha, [relatório por José Carlos da Maia], s.d., 2 fls. dobradas de papel timbrado da Secretaria de Estado dos Negócios da Marinha, Repartição do Gabinete. (Arquivo de Sidónio Pais - Militar, Lente e Político, Subsistema Presidência da República). Ver SILVA, Armando Barreiros Malheiro da - Sidónio e sidonismo. História e mito, dissert cit., vol. 2, p. 398-400.

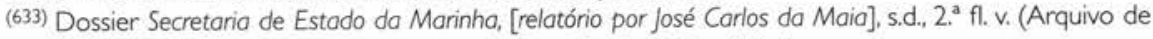
Sidónio Pais - Militar, Lente e Político, Subsistema Presidência da República).

(634) Cf. BURTY, Braz - Ouvindo o mestre. Fala Bazilio Telles. O Jornal, ano I (1) I de Agosto de 1919, p. I.

(635) Cf. Diário do Governo, I série (106) 16 de Maio de 1918, p. 764-765. De acordo com a reorganização efectuada a Secretaria de Estado das Colónias ficava dividida nas seguintes Direcções Gerais e Repartições: Repartição do Gabinete do Ministro; Direcção Geral de Administração Civil; Direcção Geral do Fomento: Direcção Geral Militar; Direcção Geral de Finanças; e Biblioteca e Arquivo Histórico. 
As primeiras folhas do relatório-programa de Vasconcelos e Sá, datado de Junho, foram preenchidas pela descrição de dois assuntos pendentes e delicados que de há muito aguardavam uma solução definitiva. Dois grandes problemas vitaes; para a nossa India, o do Caminho de Ferro e Porto de Mormugão e para a nossa provincia de Angola, o do Caminho de Ferro de Ambaca. (636)

Historiando as duas concessões é aí dito que a de Mormugão foi efectuada em I88। na sequência do tratado de 1879 com a Inglaterra relativo à Índia Britânica; a de Ambaca data de 1885.(637) Dois contratos ruinosos que, na opinião do novo Secretário de Estado, trouxeram complicações bem graves, nunca servindo tais concessões para o fim com que foram feitas, isto é, fomentar-se devidamente as nossas colonias - India e Angola - não obstante os grandes sacrificios pecuniarios do Estado em garantias de juros concedidas, auxilios e facilidades sempre facultadas ás empresas. ${ }^{(638)}$ Um sacrifício considerável que ascendeu a mais do dobro do capital dispendido pelas Companhias na construção dos respectivos caminhos de ferro:

Em 1913 tentou a Companhia do Mormugão distribuir como dividendo suplementar o capital de 180.000 E, acumuladas e capitalisadas, com a anuidade de 5.500 , excesso de $1 \%$ entre os $6 \%$ pagos pelo Estado e os $5 \%$ que a Companhia paga aos seus acionistas. D'ahi um litigio grave, até ha pouco sem solução, embora nos tivessemos comprometido oficiosamente a uma arbitragem como o contracto marca.

Impunha-se desde logo, pelos resultados perniciosos provaveis com a continuação de demoras injustificadas, a efectivação pratica da arbitragem.

A Secretaria de Estado das Colonias só podia conceber uma arbitragem legal, a serio, nos termos do contracto, e que só legislada devidamente se poderia efectivar. E, assim, nessa honesta orientação, ela se preparou e decretou.

O arbitro, representante de Portugal, breve seguirá para Londres, com todos os elementos para defeza dos nossos interesses.

É este o inicio para uma solução que se impõe e se estuda com o objectivo de que, no futuro, o porto de Mormugão e a linha até aos Gates possam, emfim, desempenhar as funções que Ihes competem.

É que não se pode continuar, com uma indiferença que espanta, deixando morrer a nossa India de inanição.

Trabalha-se para que emprezas de navegação toquem no porto de Mormugão e preciso é assegurar para o caminho de ferro, o trafego da India Central.

(636) Dossier Secretaria de Estado das Colónias, Alguns elementos de programa colonial para a mensagem no Parlamento, 12 de Junho de 1918, [7 fls. dactiloscritas], fl. I. (Arquivo de Sidónio Pais - Militar, Lente e Político, Subsistema Presidência da República).

(637) Dossier 14 Questão d'Ambaca (Arquivo de Sidónio Pais - Militar, Lente e Político, Subsistema Presidência da República) e Legação de Portugal em Londres, duas cartas de Alexandre Botelho de Vasconcelos e Sá, 15 de Julho e 22 de Julho de 1918. (Arquivo de Augusto de Vasconcelos).

(638) Dossier Secretaria de Estado das Colónias, Alguns elementos de programa colonial para a mensagem no Parlamento, 12 de Junho de 1918,fl. I. (Arquivo de Sidónio Pais - Militar, Lente e Político, Subsistema Presidência da República). 
A questão de Ambaca é um problema vital para Angola que precisa absolutamente da exploração economica da linha ferrea, concedida a uma Companhia Portugueza, com que o Estado até hoje dispendeu já mais de 22.000 contos de reis.

A empreza que tanto dinheiro tem custado ao Paiz, apresenta-se sem recursos de especie alguma, a não ser os de expedientes inadmissiveis, para renovar e reparar devidamente o material fixo e circulante.

Não podia deixar de ser abordada de frente, com justiça e com energia, pela Secretaria de Estado das Colonias, a questão de Ambaca.

Usou-se do direito de resgate que assistia ao Estado desde 1916, nas precisas condições do contracto de concessão de 1885.

De vez a linha ferrea fica na posse do Estado, que vae emprehender as reparações indispensaveis e poderá, emfim, pensar praticamente na continuação da linha de Malange que se impõe, como medida inadiavel, para a prosperidade de Angola. ${ }^{(639)}$

O recurso ao resgate - sinal claro de um intervencionismo do Estado intensificado em plena I. ${ }^{a}$ República - foi ainda aplicado a outras concessões nas colónias sem ferir, afugentando, as iniciativas honestas de emprehendimentos a patrocinar sempre. ${ }^{(640)}$ Paralelamente achava-se em estudo legislação chamada de «porta aberta» com vista a serem introduzidas as modificações que se imponham a bem da integridade e desenvolvimento futuro das nossas Provincias Ultramarinas. ${ }^{(641)}$

Em relação a Angola pensa-se na solução do seu problema - ocupação, fomento, colonisação - emprehendendo, desde já, como um elemento de valor, em via de completa realisação pratica, o estudo da rede radio-telegrafica para esta provincia, tendo-se já efectivado o contracto para a aquisição da rede considerada de primeira urgencia. A comunicação directa de Angola com S. Tomé e Swakopmund ficará realisada em breve. ${ }^{(642)}$

Para Moçambique faltava aprovar o projecto estudado de instalação da t.s.f.com uma estação no Zumbo que ficaria ligada a outra a estabelecer na fronteira oriental do distrito do Moxico, da província de Angola.

Mas o projecto exigia ainda, segundo Vasconcelos e Sá, uma potente estação de T.S.F. em Lisboa e efectivado este melhoramento pelo Governo, bem como a projectada e combinada estação de 100 kilowatts, pertencendo á rede geral, em Cabo Verde, será então o momento oportuno de na Guiné se estabelecer aT.S.F.(643) Um porfiado e profícuo esforço de ligação regular e directa da Metrópole com as suas províncias da África ocidental e

(639) Dossier Secretaria de Estado das Colónias, Alguns elementos de programa colonial para a mensagem no Parlamento, 12 de Junho de 1918, fls. 1-2. (Arquivo de Sidónio Pais - Militar, Lente e Político. Subsistema Presidência da República).

(640) Sobre o resgate de concessões outorgadas pelo Governo em todas as províncias ultramarinas ver decreto 4.58I-A de I de Julho (Diario do Governo, I série (155) 12 de Julho de $1918,2^{\circ}$ suplemento, p. 1179 D - $1880 \mathrm{D})$, republicado em $3 .^{\circ}$ suplemento do mesmo número da folha oficial.

(641) Dossier Secretaria de Estado das Colónias, Alguns elementos de programa colonial para a mensagem no Parlamento, 12 de Junho de 1918, , fl. 3. (Arquivo de Sidónio Pais - Militar, Lente e Político, Subsistema Presidência da República).

(642) Ibidem, fl. 3.

(643) Ibidem, fl. 3. 
oriental. E se esta era, de facto, uma iniciativa urgente e importante, outras se encadearam no relatório do Secretário de Estado das Colónias. ${ }^{(644)}$

As medidas do plano de acção colonial concebido por Vasconcelos e Sá visavam manter a integridade do nosso dominio ultramarino a que temos um absoluto direito de posse e propriedade pelas descobertas, ocupação e colonisação de mais de quatro seculos, atestando a nossa Historia Militar que as colonias estão bem regadas de sangue portuguez; $\mathrm{e}$ fomentar, com todos os sacrificios, intensivamente, as nossas provincias ultramarinas segundo os preceitos da colonisação moderna, exercendo um esforço financeiro digno das atenções do mundo civilisado que somado ao herculeo esforço bem definido pela nossa intervenção activa na guerra europeia, representa sacrificios de tal ordem a favor da civilisação que serão em verdade argumentos invenciveis á face da Justiça e do Direito, no proximo Congresso da Paz. ${ }^{(645)}$ Palavras totalmente inscritas na concepção colonialista do republicanismo português e facilmente subscritas por um Norton de Matos. ${ }^{(646)}$

\section{Relações externas e a questão da guerra}

Propositadamente deixámos para o fim desta panorâmica geral sobre o programa e as medidas legislativas do $16 .^{\circ}$ Governo e a acção desenvolvida pelas Secretarias de Estado dos Negócios Estrangeiros e, sobretudo, da Guerra em estreita ligação com a Presidência da República, a Legação de Portugal em Londres ou ainda a Legação em Paris, porquanto essa acção obriga, sobretudo, a retomar a questão da conduta de guerra e do c e.e.p. atrás abordada e atrás suspensa após o trágico desfecho da Batalha de La Lys, em 9 de Abril.

Mas antes de retomarmos tão importante questão interessa deixar claro que a política de guerra de qualquer Governo, mesmo em período de confrontação internacional, não se podia esgotar nos pontos relativos à participação militar, devendo reflectir, também, uma concepção geral de defesa.

No relatório-programa do Secretário de Estado Amícar Mota enviado à Presidência da República sobressai claramente esta tendência, tanto mais que, embora não fossem oportunas enquanto durasse a Grande Guerra quaisquer modificações na organização militar, a experiência mostrava que ella necessita de ser revista, para ser convenientemente acomodada ás necessidades da defesa nacional. Impunha-se, pois, um estudo sereno e reflectido capaz de colher ensinamentos seguros para os aperfeiçoamentos a introdusir no organismo militar, ou, porventura imponham modificações radicaes na sua constituição — um estudo só possível, contudo, uma vez garantida a paz e o triunfo da Causa dos Aliados. Só então outros factores haverá a considerar ao emprehender-se uma necessaria

(644) Dossier Secretaria de Estado das Colónios, Alguns elementos de programa colonial para a mensagem no Parlamento, 12 de Junho de 1918, fl. 6. (Arquivo de Sidónio Pais - Militar, Lente e Político, Subsistema Presidência da República).Ver SILVA, Armando Barreiros Malheiro da - Sidónio e sidonismo. Histório e mito, dissert. cit., vol. 2, p. 404-406.

(645) Ibidem, fl. 7. (Arquivo de Sidónio Pais - Militar, Lente e Político, Subsistema Presidência da República).

(646) Ver SILVA, Armando B. Malheiro da e GARCIA, José Luís Lima - Norton de Matos e a oposição à politica colonial de Salazar, art. cit., p. 362-364. 
reorganisação, de ordem interna uns, como sejam os de natureza economica, outros resultantes de acordos internacionaes a estipular ao concluir a guerra. Ainda que fossem dificeis de determinar com rigor os contornos exactos da transformação prevista, ela afigurava-se indispensável:

Para qualquer hypotese porem, é licito prever como aconselhavel uma transformação no nosso organismo militar no sentido de constituir desde o tempo de paz, nucleos permanentes, com solida instrucção e forte enquadramento, conjugando esta medida com outras tendentes ao aproveitamento mais conveniente, em tempo oportuno, de toda a população valida do paiz.

Esta orientação, quando posta em pratica, permitirá melhorar as condições de mobilisação e concentração das forças para uma defesa eficaz do paiz, cuja confıguração, por especial, não pode deixar de ser considerada.

A constituição dos quadros em suficiente quantidade, convenientemente preparados para a sua ardua missão impõe-se pois.

Fixar, porem, esses quadros, seria impossivel como impossivel seria, pelas razões já expostas, fixar o numero e a composição dos nucleos a constituir. Todavia, n'esse sentido, o governo orienta os seus esforços, afim de não faltar aos compromissos tomados para manter em campanha as forças que, na Europa como em Africa, tanto tem dignificado a Patria portuguesa, e de atender á defesa nacional.

Estabelecer um plano e garantir a sua execução independentemente das fluctuações governativas, impõe-se como urgente necessidade. ${ }^{(647)}$

Premissas genéricas a precederem a definição concreta de algumas bases essenciais em que a defesa nacional devia assentar:

Assim, admitindo que o inimigo podia fazer navegar livremente a sua esquadra, e, sob a protecção d'ella operar um desembarque nas nossas costas devemos confessar que isso nos criaria uma situação militar extremamente dificil e critica. Com a organisação defensiva do porto de Lisboa incompleta, e tendo todos os nossos restantes portos em condições de não se puderem defender eficazmente, ficariamos um pouco á mercê do adversario.

Sabemos, todavia, que colocar todos os portos que mais interesse devemos ter em defender, ao abrigo de um ataque, executado á viva força por uma esquadra, exigiria dispendio certamente em desproporção com os nossos recursos financeiros, mas completar a defesa do porto de Lisboa e pôr os outros portos em condições de poderem repelir um ataque efectuado por simples crusadores ou submarinos armados, como alguns d'elles já teem sido alvo, representa um sacrificio a que de maneira alguma nos poderemos eximir.

Devemos, porem, acentuar que as condições de defesa melhorarão, tão depressa estejam executadas algumas das medidas propostas por uma comissão que nomeei, quando ministro da guerra; mas longe se ficará ainda de uma solução satisfactoria,

(647) Dossier Secretaria de Estado da Guerra, [Relatório do Secretário de Estado da Guerra], s.d., I fl. de 35 linhas ms. (p. 1-2]. (Arquivo de Sidónio Pais - Militar, Lente e Político, Subsistema Presidência da República). 
pois que o material de que essa comissão pode dispor, no presente momento, é insuficiente e antiquado.

Pelo que respeita á defesa terrestre e esta recae principalmente na das linhas de Torres Vedras, o material, necessario a essa defesa, em redusido numero, deixa muito a desejar sob o ponto de vista da potencia mobilisada e rapidez de tiro. É muito diminuta a propenção da nossa artilharia pesada movel que tão formidavel desenvolvimento tomou no actual conflicto, onde, depois do celebre obuz alemão de 42 centimetros apareceu o francez de 52 centimetros e em que a peça de 38 centimetros com 45 calibres de comprimento se defronta com o canhão de 120 kilometros de alcance.

É evidente que não iremos adquirir colossos analogos, mas as peças de tiro rapido e obuzes de maior calibre do que aquelles que possuimos, é indispensavel que entrem, nas devidas proporções, na constituição dos nossos parques d'artilharia. Somente d'essa maneira, as tropas de campanha terão o seguro apoio que a artilharia pesada é susceptivel de dar-lhes em determinadas ocasiões.

Importantes verbas se torna, portanto, absolutamente indispensavel dispender com a aquisição do armamento, municiamento e mais material de que o nosso exercito tanto carece, mas só com esse sacrificio poderemos constituir um valor apreciavel no concerto das nações e só com elle as nossas instituições militares poderão rejuvenescer e progredir.(648)

A legislação relativa aos negócios da guerra, entretanto promulgada, ajuda-nos certamente a definir melhor a política de defesa nacional adoptada, uma política, também ela, republicana e sancionada por Sidónio Pais, anterior titular da «pasta», de quem o controverso tenente-coronel Amícar Mota era já um directo e estreito colaborador.

Destacamos, sobretudo, diplomas de reorganização de Serviços do sector. ${ }^{(649)} \mathrm{De}$ natureza diferente é o decreto $n .^{\circ} 4.421$ de 3 de Junho que facultava aos militares do c.e.p., em França, considerados incapazes do serviço activo ou de todo o serviço por efeito de doenças adquiridas ou agravadas em campanha, a possibilidade, querendo, de serem submetidos a nova junta médica.

No âmbito institucional e técnico-operacional parece-nos, pois, oportuno referir a criação e a regulamentação da Secção Fotográfica e Cinematográfica do Exército com o fim de registar, para serem utilizados na projecção fixa e animada, todos os assuntos relativos à educação e preparação do exército, na paz e na guerra, e tudo quanto possa aproveitar à instrução pública, à educação física e à propaganda de Portugal no estrangeiro, quer pela cinematografia de assuntos panorámicos e regionais dos mais interessantes do nosso país, quer pela reprodução de monumentos, obras de arte e documentos oficiais ou históricos que possam interessar às repartições do Estado, estabelecimentos de ensino, arquivos, bibliotecas e museus; ${ }^{(650)}$ a criação e regulamentação interna do Instituto de Reeducação dos Mutilados da Guerra e dos cidadãos atingidos por acidentes do trabalho nas obras e

(648) Dossier Secretaria de Estado da Guerra, [Relatório do Secretário de Estado da Guerra], s.d., [p. 3-4]. (Arquivo de Sidónio Pais - Militar, Lente e Político, Subsistema Presidência da República).

(649) Ibidem, Dossier Reformas e decretos II.

(650) Cf. Decreto n. ${ }^{\circ} 4.214$ de 15 de Abril. Diário do Governo, I série (99) 8 de Maio de 1918, p. 670. 
oficinas do Estado pela portaria n. ${ }^{\circ} 1.398$ de 25 de Maio;(651) a alteração na composição do Comando do Corpo de Tropas da Guarnição de Lisboa e a organização, por decreto n. ${ }^{\circ} 4.705$ de 29 de Junho, do Serviço Automóvel Militar; pelo decreto n. ${ }^{\circ} 4.529$, da mesma data, era reestruturado outro Serviço operacional importante — o Serviço Aeronáutico Militar — que compreendia seis órgãos independentes entre si: a Direcção da Aeronáutica Militar, a Comissão Técnica da Aeronáutica Militar, a Escola Militar de Aviação, a Escola Militar de Aerostação, as Tropas Aeronáuticas e o Parque Militar Aeronáutico; o Hospital Veterinário Militar, que constituía a Escola de Aplicação do Serviço Veterinário e englobava ainda, além da parte hospitalar, as Escolas de Enfermeiros Hípicos e de Siderotecnia, as Oficinas de Fabrico Mecânico de Ferragens e Cravo, as respectivasTropas da especialidade ${ }^{(652)}$ e o Depósito Geral de MaterialVeterinário, foi regulamentado pelo decreto 4.784 de 3 de Agosto; a constituição de cinco Tribunais Militares, com sede em Lisboa, Porto, Coimbra, Funchal e Ponta Delgada, fez-se através do decreto 4.730 de 14 de Agosto; e pelo decreto 4.755 de 28 desse mês era constituída a 9. ${ }^{a}$ Brigada de Caminhos-de-Ferro com o pessoal das Companhias dos Caminhos-de-Ferro de Penafiel à Lixa.

Medidas internas de uma política de defesa fortemente condicionada, como o reconheceu Amícar Mota no seu relatório, pelo esforço de participação no front e em África e quando se entrava numa fase delicada e final da Grande Guerra.

Aspecto importante que envolve e acompanha o processo de reestruturação do c.e.p., cujas tropas, após 9 de Abril, foram concentradas na zona de Samer até 13 de Maio, dia em que, segundo narra Garcia Rosado no já citado Resumo histórico dos serviços prestados pelo c.e.p., em França, duas Brigadas de Infantaria partiram novamente para a frente, indo depois juntar-se-lhes outras unidades, que cooperaram com divisões britanicas nos trabalhos de organização defensiva, contribuindo, se bem que fora da aç̧ão directa, com todos os seus esfórços para a defesa da Flandres, na hora critica em que todos os aliados se reuniam com o mesmo fim. ${ }^{(653)}$ Palavras bonitas e compreensíveis na pena do oficial general incumbido da difícil missão de substituirTamagnini de Abreu no Comando Geral do c e.p., e de negociar com os ingleses o destino a dar a um corpo de tropas, na prática, desfeito e oferecendo um retrato desolador - homens cansados, saturados por uma longa e dura permanência nas trincheiras e ansiosos pelo regresso ao torrão natal.

Voltando a seguir o imprescindível estudo de Sequeira Gonçalves, ${ }^{(654)}$ completado por novos elementos que tivemos ensejo de consultar, convém ter presente que para o Governo britânico a questão do c .e.p., ponderadas as perdas sofridas, a falta de transportes, a impossibilidade de reforços e a ameaça do tifo, só podia ser equacionada de uma

(651) Cf. Diário do Governo. I série (127) II de Junho de 1918, p. 879-881. Republicada in Diário do Governo. I série (147) 3 de Julho de 1918, p. $1062-1064$.

(652) $O$ decreto n. $^{\circ} 4.377$ de 30 de Abril criava junto de cada esquadrão do Hospital Veterinário Militar uma secção de tropas territoriais da especialidade.

(653) Cf. ROSADO,Tomás António Garcia - Resumo histórico dos serviços prestados pelo C.E.P.em França, art. cit., p. 423.

(654) Ver GONÇALVES, José António - Sidónio Pais e a participação portuguesa na guerra de 19/4-1918. vol.. I, dissert. cit., fl. 43 e ss. 
única maneira: aproveitar o que restava e juntá-lo a unidades britânicas. E isto significava não só o fim de um Corpo de Exército autónomo e inteiramente operacional - o grande objectivo de Norton de Matos, alcançado apenas na sua mente de estratega, de colonialista e de visionário - mas principalmente o fim da presença portuguesa na frente europeia. Perspectiva que o Governo de Lisboa, por muito defectista que fosse, não podia aceitar sob pena de reavivar os sentimentos anti-ingleses levados ao rubro pela crise do Ultimatum, bem viva ainda na memória de todos. Não aceitava e tentou mesmo ignorá-la, insistindo, junto do general Barnardiston, no pedido de transportes. A resposta de Londres foi, obviamente, negativa, mas Lisboa replicou que empregaria transportes portugueses e solicitava autorização para o envio de oficiais por terra. A réplica esbarrou num rotundo não inglês, amenizada por Barnardiston da seguinte forma: aconselhou o Governo de Sidónio Pais a ir preparando os reforços em Portugal, evitando-se, assim, inúteis perdas de tempo com a preparação em França quando pudessem ser enviados. A explicação era hábil, mas não impediu novas insistências: as autoridades de Lisboa argumentaram, sem êxito, que essas tropas não eram reforços, mas sim substituições de tropas repatriadas. Voltaram a insistir através do Ministro em Londres com o mesmo resultado: não havia transportes para os portugueses, porque eles eram todos necessários aos americanos.

Sem transportes não havia fuga possível ao problema político colocado pela proposta técnico-militar dos ingleses com vista à agregação das tropas portuguesas às unidades da Grã-Bretanha. Proposta rejeitada ainda pelo general Tamagnini e pelo Governo porque afectaria o moral das tropas, evidenciaria um eventual menosprezo da Inglaterra pelo esforço dos soldados portugueses e seria mal acolhida em Portugal. Não obstante a pertinência dos argumentos expendidos, o Governo de Sua Majestade, pressionado pelo Comando militar em França, chegou mesmo a lançar uma espécie de ultimatum, afirmando que só podia ser feita uma de duas coisas: ou colocar as tropas num sector calmo da zona francesa, ou repatriá-las todas. ${ }^{(655)}$ Para superar o impasse foi marcada uma conferência a realizar em Londres e a que estaria presente o novo Comandante do c.e.p..

A sugestão dessa conferência partiu do Ministério da Guerra britânico e foi comunicada por telegrama do m.n.e. português ao general Garcia Rosado, quando este se achava em Paris a caminho de Londres, onde, como refere no seu relatório de 4 de Setembro - documento de que o jornalista e anti-sidonista Bourbon e Menezes possuiu cópia - se dispunha a discutir com o general Wilson, Chefe do Estado Maior do Exército britânico e com outras autoridades militares, as bases por ele, em princípio, aceites e recomendadas pelo nosso Governo nas suas instruções para a reconstituição do c.e.p., fazendo-se a substituição das forças logo que de Lisbôa o desejassem, embora o mesmo General não se comprometesse a ceder-nos a tonelagem necessaria para tal fim, devendo os homens que viessem para França ser enviados para instrução nas forças aliadas, e sendo o seu enquadramento e instrução combinado entre o referido General e mim, para o que eu deveria ir a Londres logo que fosse possivel.

(655) Cf. GONÇALVES, José António - Sidónio Pais e a participação portuguesa na guerra de 1914-1918, vol.. I, dissert. cit., fl. 44 e ss. 
Era este o objectivo da viagem, mas, até ser cumprido, o alto representante militar português tomou a iniciativa, enquanto esperava pelas suas bagagens, retidas durante três dias em Espanha, de efectuar, entre 22 e 27 de Julho, diversas visitas oficiais em sintonia com o Chefe da Legação portuguesa Bettencourt Rodrigues e acompanhado pelo Chefe de Estado Maior do c.e.p., coronel Sinel de Cordes e pelo coronel Ivens Ferraz.Visitou o Primeiro Ministro Clémenceau, o Chefe do Gabinete do Ministro da Guerra, general Mordacq, o Ministro do Armamento Loucher, o Ministro dos Negócios Estrangeiros Mr. Pichon e o generalíssimo Foch. Na conversa havida com este último foi inquirido qual o effectivo do C.E.P., e tendo-lhe eu dito qual o effectivo approximado existente n'essa data, informando-o de que o meu Governo tinha a intenção de o elevar ao que fôra primitivamente, e de render as forças actualmente presentes em França, fatigadas, e para as quaes se tornava sensivel o clima, rigoroso relativamente a que estavam habituados, perguntou-me se dispunhamos de elementos para essa substituição e como seriam instruidos, tendo-lhe dado as possiveis informações, que, segundo me parece, o satisfizeram. Último encontro oficial antes da partida, a 28, para Boulogne em direcção a Londres, onde foi

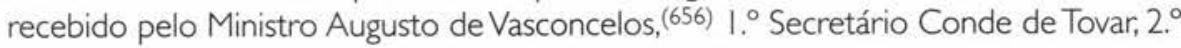
Secretário João Bianchi, major Casqueiro e coronel James.

No dia imediato à sua chegada, o general Garcia Rosado deu início a uma série de contactos e apresentação formal de cumprimentos a vários oficiais ingleses, tendo-lhe um deles - o general Lynden-Bell — solicitado uma reunião informal e preparatória da conferência marcada para o dia seguinte com o marechal Douglas Haig, reunião resumida pelo Comandante do C.E.P. nestes termos:

Não estava eu inteiramente desprevenido acerca do juizo que no alto commando britanico se fazia acerca das nossas tropas; e, entre as informações que eu tinha a tal respeito, tinham o maior valor as que haviam sido dadas pelo nosso Ministro em Londres e de que é um resumo a nota (doc. $n^{\circ}{ }^{\circ}$ I) obtida pelo $2 .^{\circ}$ secretario João Bianchi em que se encontram resumidas as criticas do Brigadeiro General Charles Ker, Chefe da missão britanica junto do C.E.P., o qual, pela propria natureza das suas funções, é de presumir que tenha sido o inspirador da opinião que o alto commando britanico forma das nossas forças. Não foi pois para mim inteiramente surpreza o que se passou na conversação com o General Lynden-Bell e em que tomou uma grande parte, ou talvez melhor, a maior parte um dos sub-secretarios do Ministerio dos Negocios Extrangeiros Sir Ronald Graham. (...) Não posso reproduzir pormenorisadamente tudo o que se passou na conversação bastante longa que tive com o general Lynden-Bell e Sir Ronald Graham. Pretendiam estes que, para melhor aproveitamento das nossas forças, era mais facil aos officiaes inglezes o entenderem-se com os nossos soldados directamente do que por intermedio dos nossos officiaes. Facil foi demonstrar o absurdo de tal asserção e, assim, em breve foi posto a claro que ella se baseiava no conceito existente no Ministerio da guerra e no alto commando acerca das nossas tropas, em resumo formulado, (não se esqueça que se conservava sem caracter official) nos seguintes termos: - Bons soldados, maus officiaes. ${ }^{(657)}$

(656) Cf. MONIZ, Egas - Um ano de política, ob. cit., p. 217-220.

(657) Ver SILVA, Armando Barreiros Malheiro - Sidónio e sidonismo. História e mito, dissert. cit., vol. 2, p. 412 e $969-980$. 
Este era, afinal, o leit-motiv que animava a proposta inglesa de agregação das tropas portuguesas e contra ele o general Garcia Rosado assestou as suas baterias argumentativas, citando factos e vincando ideias que terão provocado um certo recuo dos seus interlocutores. A reunião decorreu em tom cordial e ameno, tendo ficado clara a posição portuguesa, e disso não tardaram a ser conhecidos efeitos directos. Na manhã de 31 de Agosto Garcia Rosado recebeu comunicação de que a entrevista com o marechal Haig teria de ser adiada e que em seu lugar Lord Milner, Ministro da Guerra, desejava falar-lhe às 15 h. $O$ encontro realizou-se e foi dominado pela discussão da polémica proposta inglesa, repetindo e reforçando o general português a argumentação usada na véspera. No final conseguiu que a proposta fosse retirada e, em alternativa, seria entregue no dia 2 de Agosto uma contra-proposta, assegurando-me, expressamente Lord Milner que ella seria acolhida com a maior sympathia. De tudo isto foi imediatamente informado Augusto deVasconcelos, que por telegrama confidencialissimo para o m.n .e. de I de Agosto resumiu o conteúdo da tal conferência preparatória e acrescentou súmula da entrevista que, melindrado pelo facto da Legação não ter sido convidada, em 31, solicitara e obtivera de Sir Ronald Graham do Foreign Office. ${ }^{(658)}$

Folheando, a partir de Junho, a minuciosa agenda do nosso Ministro em Londres, é possível reconstituir as reuniões, os almoços, as deslocações e as visitas que efectuou e os tópicos das principais matérias tratadas.

Em 28 de Junho, sexta-feira, esteve com Lord Hardinge com quem falou do problema colonial de Mormugão, dos bens de D. Manuel II, da elevação da Legação a Embaixada e renovação do tratado da aliança e a reorganização do c.e.p., a tratar, nos seus detalhes técnico-militares, com o general Wilson.

A 4 de Julho almoçou na Câmara de Comércio de Londres e depois encontrou-se com Sir Ronald Graham.

No dia 5 jantou no Palácio de Westminster (jantar oferecido pelo Governo). E três dias depois houve recepção, pelas II h 30 m, em Buckingham Palace.

No dia 9 assinalou uma importante reunião com o general Wilson no War Office, em que terá ficado assente: a) reconstituição do c.e.p., em 2 divisões, uma de combate, outra de reserva b) instrução das forças por enquadramento nas forças inglesas c) combinação definitiva dos detalhes com o general Rosado d) que o general Wilson se empenha pelo transporte mensal de 4 a 5.000 homens. ${ }^{(659)}$ Assunto retomado em II no encontro com Sir Frederic Lewis: Discussão da proposta inglêsa e dos seguintes novos pontos a) transporte de cacau para a America b) transporte do carvão 20000 toneladas mensaes para Portugal c) preço dos fretes para o Governo; d) agencia da Casa Fumese; e) transporte mensal de 4 a 5.000 homens por mes, ida e volta Lisbóa-Brest. Promessas favoraveis. (660)

A 18, encontros com Sir Robert Cecil e Sir Ronald Graham dominados pelo caso do Leonora e pela discussão da política luso-espanhola.

(658) Livro Branco da Primeira Guerra Mundial, 2. ${ }^{\circ}$ Parte, $3 .^{\circ}$ P, A. 13, M. 95 B, 1918, doc. transcrito na íntegra por GONÇALVES, José António - Sidónio Pais e a participação portuguesa na guerra de 1914-1918, dissert. cit., vol. 2, anexo 78 .

(659) Legação de Portugal em Londres, [Agenda 1918, fls, soltas]. (Arquivo de Augusto de Vasconcelos). (660) Ibidem. 
No dia seguinte audiência real às $18 \mathrm{~h}$ e 15 m e pelas $16 \mathrm{~h}$, no War Office, Lord Milner teve ocasião de confirmar as suas combinações anteriores.

Sir Eyre Crowe, no dia 20, garantia, por telefone, ser possível obter o carvão para o Leonora.

A semana de 22 a 28 de Julho foi preenchida com diferentes encontros e almoços: a 22 esteve com o Embaixador de França, tendo sido abordada a demora de correspondência na fronteira; a 23 entrevista com Balfour, às 16 h, durante a qual falaram a) Sobre a nossa representação nas Conferencias internacionaes b) Sobre a politica luso-espanhola. Declarou I - que não é partidario de um tratado de aliança luso espanhola, acha bem tratado de arbitragem II - que não se deve agora fazer tratados de comercio, mas sim acordos de ocasião III - que convém reforçar o nosso exercito e defesas maritimas IV - que o Governo Inglez está pronto a estudar as nossas propostas sobre o assunto. Afirmações interessantes - que se a Espanha tentasse qualquer cousa contra nós era a guerra contra a Inglaterra - que Lloid George nada Ihe disse da carta do Snr. Bernardino Machado;(661) a 26, almoço com Mr. Steed e outras marcações; a 27 conversa com Sir Eyre Crowe sobre política luso-espanhola com uma Afirmação interessante: Lord Grey queria antes da guerra aliar a Peninsula com a Alemanha. Depois da guerra limitou-se á aliança entre Espanha e Portugal. Foreign Office é contrario essa aliança; ${ }^{(662)}$ e a 28, sábado, almoço com Ministro da Suiça às $13 \mathrm{~h} 30 \mathrm{~m}$.

$\mathrm{Na} 2$. $^{\text {. }}$ feira, dia 29, chegada do general Rosado e dos coronéis Sinel de Cordes e Ivens Ferraz; jantar com Conde de Tovar.

No dia seguinte almoço com os generais Rosado e Roldk, durante o qual foi debatida a proposta do Exército inglês para constituição de divisão portuguesa, sendo o tema retomado em conferência na Legação com o Comandante do c.e.p. e pelos coronéis Cordes e Ferraz.

A 31 de Julho Augusto de Vasconcelos foi recebido por Sir Ronald Graham, a quem expressou os mais enérgicos protestos pela alteração verificada quanto à solução proposta para o c.e.p.. A ofensiva parece ter surtido efeito: Graham responsabilizou o alto Comando inglês pela tensão criada.

- general Garcia Rosado elaborou, como ficara combinado, a contra-proposta portuguesa, inspirando-se para tal no acordo de 6 de Janeiro já atrás focado, e ficou a aguardar uma resposta do Ministério da Guerra britânico, enquanto Augusto de Vasconcelos, de 5 a 10 de Agosto, foi agendando vários encontros, mas só num deles - com Sir Graham - aflorou a questão militar, anotando interrogativo: haverá dificuldades na questão dos transportes? Anotou também a conferência de Rosado com o delegado do Estado Maior britânico, sem qualquer indicação acerca do seu conteúdo. $O$ que se passou no Ministério da Guerra, nesse dia 8, di-lo o general português no seu relatório: o general Harrington mostrou-me, particularmente, uma carta de Sir Douglas Haig, da qual disse me seria dada oficialmente communicação escripta, e em que aquelle Marechal, discordando das suggestões contidas na agenda que eu apresentara, porque restabeleciam o

(661) Legação de Portugal em Londres, [Agenda 1918, fls. soltas]. (Arquivo de Augusto de Vasconcelos). (662) Ibidem. 
que nas convenções existentes se encontra estipulado, terminava dizendo que emquanto as tropas portuguezas não estivessem sob o commando de officiaes inglezes não consideraria o C.E.P. como uma formação de primeira linha. $\bigcirc$ Comandante do c e.e. não parece ter sido apanhado de surpresa, e logo alvitrou a passagem de contingentes vindos de Portugal pelos campos de instrução ingleses e propôs que, antes de o apresentar officialmente, elle consultasse o Marechal Haig, emquanto, por meu lado pediria ao meu Governo auctorisação para fazer tal proposta.

Nova pausa, nova espera de reacções...

A carta de Haig não chegará a ser-lhe comunicada oficialmente e a 12 de Agosto recebia carta do general Lynden-Bell informando-o de que o assunto transitara para o âmbito exclusivo do Foreign Office, do qual receberia notícias em breve. Posto logo ao corrente deste facto, Augusto de Vasconcelos encontrou-se nesse mesmo dia, pelas 17 h, com Sir Ronald Graham, tendo registado o seguinte: R. Graham - Contra atitude militares. Confessa que F. O. sustenta nossas opiniões, mas que Alto Comando britanico se Ihes opõe. Nego que seja Alto Comando, um qualquer personagem a quem esteja confiada reorganisação. Calculo que querem levar-me a aceitar proposta negando-me tonelagem. Confia-me que militares desejavam transferir negociação Lisbôa, mas F. O. se opôs. ${ }^{(663)}$ Três dias depois - dia 15 e não 16 como refere Garcia Rosado — jantava no Ritz às 19 h 45 m e conversava com Lord Milner e Lord R. Cecil: Com Lord Wilner; afirmo injustiça atitude militares, necessidade de uma decisão. Promete proxima conferencia e espera encontrar uma formula de conciliação. ${ }^{(664)}$ Uma conversa animadora que teve efeitos positivos imediatos. A 19, segunda feira, Vasconcelos anotou, sem mais comentários, Solução questão c.e.p.

Tratava-se, afinal, do almejado desbloqueamento das negociações - a exigência dos oficiais ingleses no comando das tropas portuguesas fora retirada, os barcos para a sua repatriação e substituição garantidos, e uma proposta aprovada, que retomava os moldes do acordo de Janeiro: uma Divisão à frente, incluída num Corpo de Exército britânico, e outra à retaguarda, de reserva. Proposta logo comunicada pelo Ministro em Londres para o m.n.e., mas estranhamente diversa da que Sir Lancelot Carnegie apresentara formalmente e segundo a qual o general Garcia Rosado havia aceite uma Divisão do c.e.p. numa zona calma da segunda linha e outra Divisão à retaguarda. ${ }^{(665)}$ Discrepância intencional ou fortuita que só veio a ser denunciada oficialmente pelo m.n .e. em 28 de Setembro ${ }^{(666)}$ e, a 10 de Outubro, definitivamente aclarada e rectificada pelo Ministro inglês. Sir Carnegie não tardou a apresentar a primeira versão da proposta, que o Governo português aprovou de imediato, podendo dar, finalmente, início à reorganização do c .e.p., mas - bizarra ironia ou talvez não... - nas vésperas do fim da Guerra!...

(663) Legação de Portugal em Londres, [Agenda 1918, fls. soltas]. (Arquivo de Augusto de Vasconcelos).

(664) Ibidem.

(665) Ver GONÇALVES, José António - Sidónio Pais e a participação portuguesa na guerra de $1914-1918$, dissert. cit., vol. 2, anexo 81 .

(666) Livro Branco da Primeira Guerra Mundial, 2. ${ }^{\circ}$ Parte, $3 .^{\circ}$ P, A. 13, M. 95 B, 1918, doc. transcrito na íntegra por GONÇALVES, José António - Sidónio Pais e a participação portuguesa na guerra de $1914-1918$, dissert. cit., vol. 2, anexo 82 . 
Entretanto, no dia 20 de Agosto, às 12 h, Augusto de Vasconcelos encontrou-se com Sir Graham, tendo discutido o transporte de tropas e a audiência do Rei ao general Rosado. Em 21 de manhã debateu com Sir Lewis a urgente e delicada questão dos transportes, sendo-Ihe garantido que o autónomo e poderoso Ministério da Navegação não poria dificuldades ao transporte das tropas.

$O$ Rei Jorge $V$ recebeu, quinta-feira 22, o general Rosado, precisamente na véspera do seu regresso ao Quartel General do c.e.p., em solo francês, onde tomaria conta do Comando.

Na semana seguinte só um encontro: quinta-feira, dia 29, Sir Eyre Crowe eVasconcelos abordaram o acordo franco-inglês sobre navios, a nota sobre a Espanha e - conclui o Ministro português - O nosso esforço pouco apreciado.

Durante os primeiros quinze dias de Setembro nada de muito especial a assinalar. $E$ só a 27 voltou a haver um encontro com Sir Crowe e um almoço com Tovar e Carlos Bleck à sombra da questão dos transportes. Em 29 de Setembro,Augusto de Vasconcelos partiu para Lisboa, mas manteve-se em contacto epistolográfico com o general Garcia Rosado. (667) A 30 de Outubro desembarcou em Londres. No dia seguinte, encontrou-se logo com Sir Ronald Graham e falaram da Representação na Conferencia de Versailles sobre o armisticio. Embaixada em Lisbôa. Nota sobre as dificuldades para a reorganisação do C.E.P.(668) E os mesmos assuntos, salvo a nota sobre o c.e.p., foram tratados, no dia I de Novembro, com Lord Cecil: Respostas favoraveis sobre o 1. ${ }^{\circ}$ e 2. ${ }^{\circ}$ assegurando sobre a Embaixada quantidade de concorrentes fortemente protegidos e dificuldades que isso suscita ao Governo. (669) A 5 novo encontro com Sir Eyre Crowe que serviu para discutir Futuro das nossas colonias; necessidade de nos apresentarmos ao Congresso da paz com um plano de administração colonial.(670)

A derrota alemã era já uma certeza irreversível e as conversas encetadas nos bastidores diplomáticos reflectiam isso mesmo: na entrevista, efectuada a 7, com Sir Ronald Graham, os assuntos foram Armistício; o que pensa o Governo inglês. Congresso preliminar da paz, em que se discutirá as questões do Presidente Wilson. ${ }^{(671)} \mathrm{E}$ a II, depois de ter anotado a reunião que teve às $16 \mathrm{~h} 30 \mathrm{~m}$ com De Felippi, escreveu na agenda A PAZ.

Duas semanas antes, o Secretário de Estado dos Negócios Estrangeiros, Egas Moniz, regozijou-se pelo sucesso do acordo de reconstituição do c .e.p. e pedia a Sir Lancelot Carnegie todo o seu empenho na execução desse acordo. Quase um mês depois da assinatura do Armistício o general Rosado, em carta para Augusto de Vasconcelos, afirmava: Deu-me muitissimo prazer a sua informação de que no War Office se modificou a opinião acerca do C.E.P.. A intervenção d'este nos ultimos dias da guerra foi quasi nulla; contudo, à data da assignatura do armistício, alem das unidades de artilharia que se mantiveram sempre no front, (...) tres batalhoes da nossa infantaria, estando os restantes 6 batalhões da divisão

(667) Legação de Portugal em Londres, cartas do general Garcia Rosado, 13 de Outubro de 1918 e de 31 de Outubro de 1918. (Arquivo de Augusto de Vasconcelos).

(668) Legação de Portugal em Londres, [Agenda 1918, fls. soltas].

(669) Ibidem.

(670) Ibidem,

(671) Ibidem. 
em marcha nas proximidades de Lille. (...) O moral dos homens, tendo-se modificado da mais favoravel maneira, era excellente, estando eu convencido de que se teriam bem comportado se se lhe exigissem farto esforço. ${ }^{(672)}$ E no próprio dia do Armistício - conclui Sequeira Gonçalves - tropas portuguesas - revoltadas, desorganizadas, extenuadas - encontravam-se ainda na primeira linha, combatendo o inimigo boche, algumas delas talvez ainda sem saber porquê.(673)

Impressões avulsas que servem, talvez, para ilustrar o verso e o reverso do quadro épico pintado pelos guerristas sobre a nossa participação na frente europeia da Guerra de 1914-1918, feita, afinal, de impulsos megalómanos, de reservas pragmáticas, de desaires e de insuperáveis obstáculos, mas mantida até ao fim sem quebra dos compromissos assumidos, sobretudo perante a velha Aliada.

Empresa nada consensual, que dividiu os portugueses opondo entusiastas a cépticos e que, ao mesmo tempo, os vinculou indissoluvelmente à Causa dos Aliados, como se pode ver, aliás, pelo debate crítico dedicado ao tema na nova Câmara dos Deputados e em sessão de I de Agosto, que Norton de Matos rotulou de vergonhosa sessão. Era a sétima após a abertura solene de um Congresso que teve vida curta e atribulada.

(672) Legação de Portugal em Londres, [carta do general Garcia Rosado, 6 de Dezembro de 1918]. (Arquivo de Augusto de Vasconcelos).

${ }^{(673)}$ Cf. GONÇALVES, José António - Sidónio Pais e a participação portuguesa na guerra de $1914-1918$, dissert. cit., vol. I. fl. 46. 



\section{Capítulo 3}

\section{Uma Legislatura atribulada e efémera}

\section{Abertura solene}

Efectuadas em 28 de Abril as eleições para a Presidência da República e para as Câmaras Legislativas, e proclamado o Presidente a 9 de Maio, faz sentido perguntar porque é que o Poder Executivo só convocou a reunião do Congresso para 15 de Julho e a sua abertura solene para 22 ?

Tão acentuado atraso no início dos trabalhos parlamentares foi, então e depois, visto e ainda hoje aceite como um claro sinal de anti-parlamentarismo ou de deliberada intenção de amordaçar e de estiolar a curto prazo o Poder Legislativo, traduzindo, afinal, quer o alegado desvairo cesarista e autocrático de Sidónio Pais, quer a feição autoritária e até proto-fascista da República Nova.

Rocha Martins não considerou relevante a questão, preferindo encadear na sua crónica o episódio revolucionário do rapto do Presidente da República marcado para esse dia 15 de Julho, ${ }^{(674)}$ passando de imediato à descrição da sessão solene do Congresso, na qual o Presidente Sidónio Pais leria a sua mensagem à maneira americana do estado da Nação.

Teófilo Duarte, pelo contrário, sem entrar em detalhes político-institucionais, não hesitou em escrever, ajeitando o mais possível a imagem de Sidónio à de Mussolini e à de Salazar, que após as eleições a situação sidonista caracterizou-se, entre outros aspectos, pelo desrespeito desdenhoso pelas atribuições parlamentares da Camara política, que se procura desvalorizar cada vez mais, mediante a irregularidade e intermitência do seu funcionamento e publicação de medidas governamentais legislativas mesmo durante 0 período das suas funções; e, finalmente, a valorização da Camara Corporativa. ${ }^{(675)}$

A versão, assim estampada, tem convencido alguns historiadores incautos, que se esquecem de consultar e de meditar sobre o livro de Egas Moniz, dirigente do P.N.R. e eleito líder da maioria na Câmara dos Deputados. Um esquecimento significativo, que as benévolas palavras de Carlos Ferrão, anti-sidonista assumido, ajudam, talvez, a frisar: No consulado sidonista [Egas Moniz] assumiu uma desassombrada atitude a favor

(674) Ver MARTINS, Rocha - Memorias sobre Sidonio Paes, ob. cit., p. 1 89- 192.

(675) Cf. DUARTE, Teófilo - Sidónio Pais e o seu consulado, ob. cit., p. 199-200. 
do parlamentarismo contra a experiência de um presidencialismo espúrio cujo epílogo foi a tentativa restauracionista que se seguiu à morte do dr. Sidónio Pais. ${ }^{(676)}$

Já atrás mostrámos claramente que o tão proclamado anti-presidencialismo de Egas Moniz não foi desassombrado, nem tão pouco precoce ou da primeira hora. Foi, isso sim, tardio e eivado de oportunismo táctico para furar o cerco montado pela oposição republicana histórica - acenando aos unionistas e a alguns evolucionistas, irredutíveis na sua recusa de um presidencialismo avant la lettre, com uma solução de compromisso, híbrida e mais consensual - e até, talvez, em consequência de eventuais atritos com Tamagnini Barbosa ${ }^{(677)}$, dentro da frágil e complexa rede sócio-política sidonista. Em Um ano de política o neurocirurgião de Avanca confirma o seu aval inicial ao projecto presidencialista e, para não mentir, cala-se ou foge em relação a aspectos que considerou menores. Nada diz, por exemplo, sobre o demorado começo dos trabalhos parlamentares, embora refira ter-se mantido no seu posto diplomático de Madrid após as eleições, empenhado nas delicadas negociações com Monsenhor Ragonesi,ultimadas em 21 de Junho e, entre outros dossiers pertinentes, no estreitamento das relações luso-espanholas.

Poderia o Parlamento começar sem a sua presença? Não convinha... Sobre as férias parlamentares, ou seja, sobre o controverso interregno dos trabalhos do Parlamento, diz que ele foi apressado pelo receio de uma animada discussão sobre a Constituição, o que até certo ponto seria verdade, mas omite ter sido ele quem, como veremos, propôs em nome da maioria essa interrupção. Porquê? Imposição do Presidente da República ou interesse táctico de Egas Moniz para ganhar tempo?... Mais curioso ainda: no seu livro de memórias omite o projecto de Constituição Política da República Portuguesa, que uma Comissão Revisora eleita pela Câmara elaborou e negociou com Belém, e evoca, apenas, uma das conversas havidas com Sidónio Pais em que este lhe apresentara o projecto que desejaria vêr aprovado. Era um sistema presidencialista com dissolução!.(678) Estava a referirse à versão dactiloscrita e anotada por Eurico Cameira, adiante focada, que antecedeu 0 projecto elaborado pela dita Comissão (verAnexo 2, secção II - do poder executivo), que Egas Moniz ignora.Apagou-o da sua memória ou não chegou a conhecê-lo? Esta segunda hipótese é, no mínimo, surpreendente, porque ele acompanhou e, como se perceberá adiante, até interferiu pela acção de terceiros nos trabalhos da Comissão, para além de ter visto aceite a sua perspectiva: a versão definitiva entregue no Congresso - uma versão, sem dúvida, muito negociada ${ }^{(679)}$ — preconizava um sistema presidencialista sem dissolução!...

Interrogações e perplexidades aqui registadas.

Vamos, na medida do possível, ensaiar uma resposta aproximativa a algumas delas e o ponto de partida é a data oficial do funcionamento do Congresso através de Juntas

(676) Cf. FERRÃ̃, Carlos - A Obro da república, ob. cit., p. 224; e FERREIRA, David - Pais, Sidónio, in SERRÃO, Joel - Dicionário de História de Portugal, vol. 4, ob. cit., p. 523.

(677) Ver MONIZ, Egas - Um ano de política, ob. cit., p. 142; LEAL, Cunha - Coisos de tempos idos. As Minhas memórias, vol. 2, ob. cit., p. 109-11 I; e MARTINS, Marilia Carneiro - Dr. Sidonio Paes. (O Martir da Demagogia). Fascículo n. ${ }^{\circ}$ 2. Lisboa: Editor Augusto Martins, s.d.

(678) Cf. MONIZ, Egas - Um ano de política, ob. cit., p. 143.

(679) Ver Dossier Projecto de Constituição. (Arquivo de Sidónio Pais - Militar, Lente e Político, Subsistema Presidência da República). 
Preparatórias ${ }^{(680)}$ no Senado e na Câmara de Deputados, consagradas aos trabalhos das Comissões de Verificação de Poderes e à fixação do Regimento, que, embora actualizado, se manteve o mesmo da Assembleia Nacional Constituinte de 1911.(681)

O início oficial dos trabalhos parlamentares em cada uma das Câmaras e em sessões comuns do Congresso foi precedido pelo ritual de (con)sagração republicano-estatista decretado em 19 de Julho:

Devendo realizar-se no dia 22 do corrente mês a abertura solene do primeiro Congresso da República depois da Revolução de 5 de Dezembro:

O Govêrno da República Portuguesa decreta, e eu promulgo, para valer como lei, o seguinte:

Artigo $1 .^{\circ}$ É feriado nacional e considerado de grande gala o dia 22 de Julho de 1918.

Art. 2. ${ }^{\circ}$ Ficam revogadas as disposições em contrário.

Determina-se portanto que todas as autoridades, a quem o conhecimento e a execução do presente decreto com fôrça de lei pertencer, o cumpram e façam cumprir e guardar tam inteiramente como nele se contêm. ${ }^{(682)}$

Ritual de (con)sagração cumprido segundo o Programa da sessão solene do Congresso da República Portuguesa, no dia 22 de Julho de 1918, pelas 15 horas, para recepção de $S$. Ex. ${ }^{\circ}$ o Sr. Presidente da República, a saber:

Nesta solenidade será observado o seguinte programa:

1. ${ }^{\circ}$ Uma hora antes da marcada para o acto solene de que trata êste programa, estando reunidos na sala da Camara dos Deputados os membros das duas casas do Parlamento e o Governo, o Sr. Presidente do Congresso, ocupando o lugar da Presidência, secretariado pelo $1 .{ }^{\circ}$ Secretário do Senado e pelo $1 .{ }^{\circ}$ Secretário da Câmara dos Deputados, do Presidente do Senado e dez Senadores, que, juntamente com o Sr. Presidente do Congresso e o Govêrno aguardará no vestíbulo do edifício a chegada de S. Ex. ${ }^{\circ}$ o Sr. Presidente da República, acompanhando-o até à sala das sessões.

2. ${ }^{\circ}$ Abrirá o cortejo, formando duas alas, o pessoal menor da sala das sessões, devidamente uniformizado.

Os Deputados e Senadores tomarão no cortejo lugar imediato ao pessoal menor.

À direita de S. Ex. ${ }^{\circ}$ o Sr. Presidente da República irá o Sr. Presidente do Congresso, e à esquerda o Sr.Presidente do Senado, seguindo na retaguarda a comitiva presidencial, os Secretários de Estado, seus chefes de gabinete, secretários particulares e oficiais de serviço fechando o cortejo.

(680) Ver Decreto n. 4.687 de Diário da Camara dos Deputados, 1918; e Diário do Senado, 1918.

(681) Ver Regimento daAssembleia Nacional Constituinte de 1911. Aprovado em sessão de 4 de Julho de 1911. Lisboa: Imprensa Nacional, 1918 [54 p.]. Foi elaborado por uma Comissão, cujo relator foi Sebastião Baracho e vogais Machado Santos (Senador em 1918), Inocêncio Camacho Rodrigues (Director do Banco de Portugal, idem), Celestino de Almeida (almeidista) e Feio Terenas (Director Geral do Congresso da República, em 1918).

(682) Cf. Diário do Governo. I série (161) 20 de Julho de 1918. 
$3 .{ }^{\circ}$ Ao entrar o cortejo na sala das sessões, e depois de ocuparem os seus lugares os Deputados, Senadores e membros do Govêrno, S. Ex. ${ }^{a}$ o Sr. Presidente da Câmara dos Deputados, lerá a sua saudação ao Congresso, declarando aberta a sessão legislativa.

4. ${ }^{\circ}$ Seguidamente, e encerrada a sessão solene, o cortejo acompanhará S. Ex. ${ }^{\circ} 0$ Sr. Presidente da República até o vestíbulo.

$5 .^{\circ}$ O pessoal menor que fizer parte do cortejo tomará lugar em pé, dum e doutro lado, junto ao estrado da Presidência.

Palácio do Congresso da República, 21 de Julho de 1918. - O Presidente do Congresso. ${ }^{(683)}$

Ritual que evidencia, pelo menos, uma verdadeira encenação do poder, ${ }^{(684)}$ seguido dentro de rígidas medidas de segurança. ${ }^{(685)}$

Na ausência de Émile Daeschner, o Encarregado de Negócios Moullin, em despacho para Paris de 25 de Julho, ocupou-se da descrição sumária e da análise de um acto em que participou integrado no Corpo Diplomático e é interessante notar que as suas palavras iniciais insinuam um certo regresso aos tempos monárquicos: La tradition du discours de la Couronne - escreve Moullin — avait été interrompue par l'avénement de la République. Elle vient d'être reprise par M. Sidonio Paes qui, pour l'ouverture de la session des Chambres, a lu un message présidentiel.(686)

Em vez de um discurso ao estilo americano( ${ }^{(687)}$ o diplomata francês preferiu ver o ressurgimento das práticas da defunta Monarquia e o cortejo presidencial, a recepção à porta do Palácio do Congresso e o protocolo cumprido no seu interior serviram para reforçar essa impressão. Segundo Moullin — vale a pena segui-lo — ao longo do percurso entre o Palácio de Belém e S. Bento, as tropas dispuseram-se em linha e o Presidente da República fez o trajecto no mesmo landau à Daumont usado na anterior cerimónia da proclamação e precedido por vários esquadrões de Cavalaria. A recebê-lo estava o Presidente do Congresso, o velho republicano José Nunes da Ponte, na forma fixada pelo programa acima transcrito. Formado o cortejo no interior do edifício, o Presidente da República foi recebido ao som de A Portuguesa, hino escutado de pé por todos os assistentes, salvo os monárquicos, após o que entrou imediatamente na sala das Sessões, onde tomou lugar na cadeira da presidência da tribuna, tendo à sua esquerda o Presidente do Congresso. Aí, de pé, leu, no meio do mais absoluto silêncio, a sua mensagem, numa voz um pouco trémula e levemente embargada pela emoção. ${ }^{(688)}$

${ }^{(683)}$ Cf. Diário do Congresso. Sessão n. ${ }^{\circ} 24$, em 22 de Julho de 1918.

(684) Cf. RAMOS, Rui - A Segunda fundação, in MATOSO, José (dir) - História de Portugal, ob. cit., vol. 6 , p. 617 .

(685) Cf. Diário do Congresso. Sessão n. 24 em 22 de Julho de 1918.

(686) Z. Europe, 1840 Portugal,Ambassadeur Français à Lisbonne, n. 137,25 Julho 1918 (Z-536-3). (Archives du Ministère des Affaires Etrangères).

(687) Dossier Projecto de Constituição, fl. papel pautado de carta e timbrado do Ministério da Justiça e dos Cultos // Gabinete do Ministro, ms. (Arquivo de Sidónio Pais - Militar, Lente e Político, Subsistema Presidência da República).

${ }^{(688)}$ Z. Europe, 1840 Portugal,Ambassadeur Français à Lisbonne,n. 137,25 Julho 1918 (Z-536-3). (Archives du Ministère des Affaires Etrangères). 
No fim da leitura declarou aberta a sessão e retirou-se com o mesmo cerimonial da chegada. $\bigcirc$ público que assistiu ao acto era restrito, sobressaindo, em largo número, as damas que não se cansaram de aplaudir o Chefe do Estado. No entanto - observa Moullin - o entusiasmo da sala, talvez pela composição seleccionada do público, parece ter sido estimulado por alguns amigos políticos do Governo cuidadosamente distribuídos pelas diferentes tribunas.

Ao invés deste olhar severo e crítico do diplomata francês, Rocha Martins, no seu estilo de escritor, com mascarilha de historiador conforme o juízo crítico de Cunha Leal, não poupou termos garridos para descrever e enfeitar esse momento singular da vida do Parlamento republicano, porque Jámais, durante a republica, se agrupára tam correcta assembléa. ${ }^{(689)}$ Um mornento a que tivera o privilégio de assistir na qualidade de deputado da minoria monárquica, instalada à direita da sala com os integralistas nas últimas cadeiras, tendo ele ficado entre o conde Arrochela, meu íntimo amigo, um grande fidalgo e uma excelente alma e Teles de Vasconcelos, director do Liberal, o periódico no qual eu dera as batalhas à demagogia, jornalista enérgico e conspirador astuto. ${ }^{(690)}$

As galerias estavam atulhadas de mulheres formosas nas suas deslumbrantes toilettes e o hemiciclo repleto de deputados e senadores vestidos a rigor de acordo com a sua categoria profissional: os lentes das Universidades com as suas vestes, os militares com os seus uniformes dragonados, os magistrados com as suas clássicas togas. Cintilavam comendas e dourados e havia uma gravidade e um ar distinto nessa grande sala, onde durante oito anos a singularissimas reuniões de mal vestidos e mal intencionados assistira!...(691) Uma delegação de membros do Congresso fora aguardar o Presidente ao átrio. Sob o grande docel carmezim formaram os contínuos com os seus chapéus armados. Plantas magníficas ornavam a sala dos Passos Perdidos, onde um sexteto tocava o hino nacional à medida que Sidónio Pais se aproximava:

Saira da carruagem à Daumont entre aclamações; passára nas ruas ao som de vivas e de palmas, escoltado pelas cavalarias 2, 4 e 7, levando os sargentos em batedores e o coronel Silva Pereira, que tomára o comando do Corpo de Tropas, pela saída de Sousa Sarmento, à estribeira. Nas tribunas do corpo diplomático instalavam-se os representantes das nações, sentados ainda quando o hino subiu.Alguns deputados monárquicos, regulando a sua atitude pela dos diplomatas, quedavam-se também nas suas cadeiras diante dos republicanos de pé escutando aquela música vinda dum corredor. Foi, então, que da galeria, no meio do silencio, que só os compassos do sexteto perturbavam, uma voz se ergueu clamorosa:

- Levantem-se que se está tocando o hino nacional!

Fôra o médico António de Vasco Fernandes quem assim se nos dirigira. Eu já estava de pé mas, ante a intimação, tive vontade de me sentar num arranco que João Moreira de Almeida evitou. Só quando o chefe do estado apareceu se ergueram os outros deputados monárquicos. É que o protesto, mal cabido, irritára.(692)

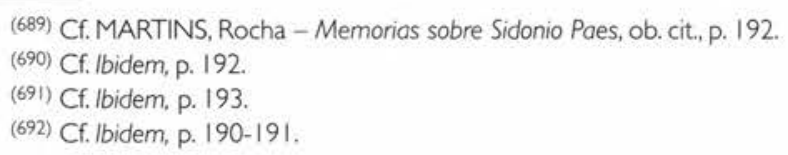


O episódio não escapou a outra testemunha presencial — o machadista Cunha Leal, que o refere e comenta nas suas Memórias vergastando a imaginação febril de Rocha Martins. (693) Confirma, porém, um detalhe fixado pelo publicista: Aquela oração fôra um pretexto para o contacto; nada dizia dos seus planos, iniciava os segrêdos do presidencialismo e Cunha Leal, tomando-me o braço, exclamava: Foi o discurso da corôa!.(694)

A mensagem presidencial lida perante o Congresso à moda de Wilson, ${ }^{(695)}$ embora não tenha obedecido à intenção inicial de condensar as linhas programáticas do $16^{\circ}$ Governo cerzidas a partir dos relatórios fornecidos pelos vários Secretários de Estado, foi clara quanto às prioridades internas e às linhas de força da política externa da República Nova, com uma ou outra falha polémica, designadamente a omissão das relações com - Brasil,(696) logo comentada e criticada pela imprensa.

No seu estilo habitual, Sidónio Pais começou por frisar que Portugal entrara em plena normalidade constitucional - acabara a ditadura - e que até à revisão pelo Congresso da Constituição Política da República Portuguesa mantinham-se em vigor as alterações introduzidas durante a ditadura revolucionária em conformidade com o princípio da separação dos três Poderes - legislativo, executivo e judicial independentes e harmonicos entre si.

Sem grandes subtilezas, Sidónio reconhecia implicitamente que o Executivo se regia já pelo figurino presidencialista americano, antes mesmo de tal ser aprovado pelos deputados e senadores. A matriz populista aparece, a seguir, não só bem vincada, mas também impregnada de um claro utopismo liberal, democrático e progressista (milenarista): Pela parte que me toca, só quem desconhece o meu passado e ignora a persistencia do meu caracter, pode apodar-me de reaccionario. Tão pouco poderia associar-me a uma obra improgressiva. Fui sempre e sou republicano; por isso procurei manter e consolidar a Republica. Justificou, por isso, a necessidade histórica e política da revolução de 5 de Dezembro em termos que denunciam a sua mentalidade de livre-pensador e de republicano da geração nacionalista de 90: A chama que ardia nos corações dos revolucionarios elevava-se até aos Céus, numa inspiração de Justiça, de Verdade e de Beleza, que os inspirava, vaga talvez na forma da realidade, mas firme e definida na intenção mais pura de salvar a Patria e de buscar a felicidade do Povo. Foi para esses elevados fins que o governo conduziu sempre a

(693) Ver LEAL, Cunha - Coisos de tempos idos. As Minhas memórios, vol. 2, ob. cit., p. 93-94.

(694) Cf. MARTINS, Rocha - Memorias sobre Sidonio Paes, ob. cit., p. 195. Trecho confirmado por LEAL, Cunha - Coisas de tempos idos. As Minhos memórias, vol. 2, ob. cit., p. 93.

(695) Uma informação manuscrita na folha de guarda de um livro sobre o Presidente Wilson pelo punho de Luís Maria da Costa de Freitas Branco permitiria postular uma segura admiração de Sidónio Pais pelo seu homólogo americano se na capa do exemplar em causa não estivesse impresso o ano de 1919. Seja como for, impõe-se a transcrição integral dessa nota manuscrita: Este livro que o grande presidente Dr. Sidónio Paes tinha acabádo de ler na ocasião de ser assassinódo, foi-me dado a mim Luiz Maria da Costa de Freitas Branco pelo seu filho e secretário António Paes como recordação daquele que libertou Portugal do jugo jacobino e que manifestou interesse por este livro por mim encontrado nos aposentos do grande presidente, quando, na noite de 15 para 16 de Dezembro de 1918 estive junto do seu cadaver - HALÉVY, Daniel - Le Président Wilson. Étude sur la démocratie américaine. Nouvelle édition revue par l'auteur. Paris: Payot \& Cie, 1919. (Nota: agradecemos ao Sr. Eng. Sidónio de Freitas Branco Paes ter-nos proporcionado a consulta deste curioso exemplar).

(696) Dossier Oferecimentos. (Arquivo de Sidónio Pais - Militar, Lente e Político, Subsistema Presidência da República). 
sua política interna e internacional. Uma política ditatorial que, à exacta semelhança do que sucedera em 1911 - e a analogia é assaz significativa - teria de ser apreciada e ratificada pelo Congresso. E porque cabia aos deputados e senadores a última palavra sobre a obra Ditatorial, Sidónio Pais achou oportuno esclarecer e sublinhar, quanto à política externa seguida, o bom relacionamento mantido e reforçado com a Inglaterra e demais Aliados - a Bélgica, a França, a Itália e os Estados Unidos, exemplo grandioso de poder e elevação aos altos ideais - sem esquecer, entre os países neutros, a Espanha nossa irmã peninsular, e o restabelecimento consumado das relações diplomáticas entre Portugal e a Santa Sé. A terminar teve o cuidado de dirigir, num natural assomo patriótico, a saudação veemente ao Exército e à Marinha portugueza que heroicamente se tem batido e continuará a bater-se em terras de França e nas nossas colonias pela causa sagrada da Patria e da Humanidade, apelando, na sequência desse tão nobre exemplo, à unidade nacional e à entrega de todos à causa da felicidade do povo portuguez.

Palavras serenas na inauguração de uma legislatura que não decorreria calma, para citarmos Damião Peres. ${ }^{(697)}$ Opinião corroborada por Cunha Leal, que foi, naturalmente, mais longe, afirmando que nos primeiros dias de sessão saltaram à vista os antagonismos que debalde o Sidonismo tentava ocultar sob o manto duma aparente homogeneidade.(698) Os factos mostram, porém, que as principais figuras da situação dezembrista/sidonista não procuraram ocultar antagonismos, antes os exibiram, como temos frisado, com fins tácticos nem sempre muito claros.

Se analisarmos com cuidado as actas das sessões da Câmara dos Deputados, do Senado e das sessões conjuntas do Congresso, verifica-se que, apesar de atritos vários ${ }^{(699)}$ e das catilinárias do grupo machadista (Machado Santos no Senado e a dupla Cunha Leal e José Carlos da Maia na Câmara de Deputados) a «abrir fogo» sobre Moniz,Tamagnini e todo o Governo, não foi nesse areópago que a desarmonia das hostes do P.N.R. mais se fez sentir. E se ela foi um facto inevitável, considerando o próprio processo de formação das candidaturas a deputados e senadores atrás focado, muito convirá - repetimo-lo - analisar, entre outros aspectos, as pecularidades da liderança de Egas Moniz, deixadas, até agora, em branco...

\section{De 15 de Julho a 6 de Agosto}

Deixando mais para diante o exame ligeiro da segunda fase da $3 .^{a}$ legislatura (de 15 de Julho de 1918 a 20 de Fevereiro de 1919), condensada apenas nas sessões de Dezembro de 1918, cingimo-nos, aqui, a umas rápidas notas sobre a actividade parlamentar até à sua suspensão em 6 de Agosto.

Nesse dia ocorreu a décima sessão do Senado e, pelas $18 \mathrm{~h}$, a segunda sessão conjunta sob a presidência de Manuel jorge Forbes de Bessa (Presidente do Senado), secretariado por José Féria Dordio Teotónio e José Epifânio Carvalho de Almeida, e estando presentes 122 congressistas. $\mathrm{Na}$ ordem dos trabalhos havia apenas um ponto

(697) Cf. PERES, Damião - História de Portugal. Suplemento, ob. cit., p. 182.

(698) Cf. LEAL, Cunha - Coisos de tempos idos. As Minhas memórias, vol. 2, ob. cit., p. 94.

(699) Ver MARTINS, Rocha - Memorias sobre Sidonio Paes, ob. cit., p. 195-200. 
- a proposta da iniciativa da Câmara dos Deputados sobre o adiamento das reuniões do Congresso.Vários parlamentares pediram a palavra, sendo o primeiro a usá-la o líder da minoria monárquica, conselheiro Aires de Ornelas, que se opôs a esse adiamento, evocando várias razões, nomeadamente a necessidade de se discutir em sessão secreta a conveniência ou não da publicação do Livro branco e da situação de Portugal na guerra. As declarações do conceituado militar africanista e colonialista foram, de imediato, rebatidas pelo Secretário de Estado das Colónias.

Após essa intervenção inesperada, Egas Moniz, em nome da maioria, ergueu-se para explicar os motivos por que tomara a iniciativa de propôr o adiamento e precisar, em termos concretos, a sua proposta: Proponho que a presente legislativa seja adiada para o dia 4 de Novembro do corrente ano - Egas Moniz. Posto isto, explicou:

Foi tomada, Sr. Presidente, de acôrdo com o que manda a Constituição para que a comissão revisora do estatuto fundamental do país possa trabalhar. Nós, como V. Exas sabem muito bem, pertencemos a uma Assembleia Constituinte, e temos de resolver sobbre êsse momentoso assunto, para mim tam importante e fundamental, e mais do que nunca, neste momento, que eu julgo que da boa solução dele dependerá a tranquilidade da familia portuguesa (Apoiados). E nós não podemos entrar na sua discussão sem que alguma cousa, algum material exista para a sua orientação.

Era indispensável, era absolutamente necessário que uma comissão trouxesse, ou logo, ou amanhã, um projecto à Camara que nos sirva de base para a discussão. Não pode êsse projecto ser elaborado de momento, porque esse assunto é fundamentalissimo, o que em primeiro lugar deve prender a atenção das duas Câmaras porque o problema é vital para a nação portuguesa, visto dêle derivar o problema da ordem pública, conforme terei ocasião de demonstrar.

Sr. Presidente: constituída essa comissão, era necessário dar-lhe tempo para trabalhar. Por outro lado, Sr. Presidente foram nomeados doze comissões na Camara dos Deputados e outras doze no Senado para rever toda a legislação publicada desde 5 de Dezembro. Nessas comissões estão empenhados quási todos os Deputados e Senadores. Essa revisão vai ser penosa, longa e trabalhosa, e era impossível que os membros de uma e outra casa do Parlamento pudessem dignamente desempenhar-se das duas funções (Apoiados). Foi por isso que a maioria da Camara dos Deputados tomou a iniciativa deste adiamento, que se impõe, a meu ver, da maneira mais iniludivel dentro do campo restrito de factos que me forçam a esta conclusão.(700)

Senadores e deputados da minoria monárquica contestaram as explicações dadas e insistiram na sua posição de fundo: não ao adiamento, pelo menos, antes de se efectuar a sessão secreta reclamada por Aires de Ornelas e suscitada pelo debate de I de Agosto na Câmara dos Deputados. Alfredo Pimenta sobressaiu pela qualidade da oratória e da argumentação aduzida, tendo mesmo submetido ao voto uma moção sobre a não suspensão dos trabalhos parlamentares, que foi rejeitada pela maioria, contrária, em

(700) Cf. Diário do Congresso. Sessão n. 25 em 6 de Agosto de 1918, p. 9. 
uníssono com os Secretários de Estado presentes (Colónias, Instrução e Interior), à realização da sessão secreta. Jorge Botelho Moniz, respondendo a Pimenta, disse: Não se pode dizer ao público, sabe-o V. Ex. "muito bem, tudo quanto se passa, e a influência que vai produzir sobre o ânimo do povo uma sessão secreta, acerca do que nela se passasse, seria má.Julgar-se-ia que se estava a atacar a Inglaterra e a própria intervenção na guerra quando é possível que amanhã tenhamos que mandar para França novos contigentes. Veja V. Ex. ${ }^{\circ} 0$ estado moral em que se iria colocar o nosso povo.(701) Como se vê, as pouquíssimas vozes da maioria que se fizeram ouvir foram concordantes com a do líder e - assinale-se - ninguém do grupo machadista (só não compareceu José Carlos da Maia) interveio, desta vez, a favor ou contra. ${ }^{702)}$

Desde as primeiras sessões, deparamos com os tons dissonantes do trio Machado Santos, José Carlos Maia e Cunha Leal e com o protesto de solidariedade jornalística formulado pelo director da Voz Pública e deputado da maioria, Joaquim Madureira, a abrir a sessão n. ${ }^{\circ} 2$ de 25 de Julho na Câmara dos Deputados, contra os incidentes ocorridos a 23 - incêndio na sede do jornal A Montanha de Lisboa e suspensão por dois dias do Norte, do Porto. Cunha Leal secundou-o em termos de acusação directa às autoridades e à «pasta» do Interior: um amigo que tinha vindo do Porto, este dizia peremptoria e terminantemente, garantindo o que dizia pela sua palavra honrada, que no Porto se estava fazendo culto do cacete e que todos aqueles que tinham a designação a que se convencionou chamar de República Velha, eram perseguidos e vexados por desordeiros, que evidentemente não podiam achar melhor maneira, em seu critério, de defender a Republica.(703)

Os monárquicos Moreira de Almeida e António Cabral, num gesto de idêntico repúdio da violência gratuita e de quaisquer atentados à liberdade de imprensa, condenaram o sucedido. Da parte do Governo apareceu a fornecer explicações oficiais o Secretário do Interior Tamagnini Barbosa, já forçado nessa Câmara e no Senado, respectivamente por Cunha Leal e por Machado Santos, a assumir, mas com displicência, (704) a resposta, no dia 23, a uma interpelação feita intencionalmente para polemizar em torno do ilogismo presidencialista desse apressado ensaio.(705) Tamagnini agarrou-se a notícias da imprensa para sugerir que o incêndio no edifício d'A Montanha, velho, quase devoluto e em vias de ser demolido, não teve, muito provavelmente, origem criminosa. E quanto ao periódico do Porto, a decisão de apreender os exemplares de um número contendo eventual matéria ofensiva foi do Governador Civil e o encerramento por dois dias terse-ia devido ao facto da chave da sede do Norte ter ficado na esquadra para onde um dos tipógrafos presos a levou, esquecendo-se dela aí quando foi posto em liberdade.

Nessa mesma sessão o Secretário de Estado das Colónias - homem de Outubro de 1910 e de Dezembro de 1917 — fez uma intervenção ideológica de que respigamos o seguinte passo: Sr. Presidente: os revolucionários de 5 de Dezembro são os irmãos de armas

(701) Cf. Diário do Congresso. Sessão n. 25 em 6 de Agosto de 1918, p. 18.

(702) $\mathrm{Na}$ sessão n. ${ }^{\circ} 9$ de 3 de Agosto, na Cãmara dos Deputados, Cunha Leal interveio contra o adiamento.

(703) Cf. Diário da Camara dos Deputados. Sessão n. ${ }^{\circ} 2$, em 25 de julho de 1918.

(704) Cf. Diário do Senado. Sessão n. 4 em 26 de Julho de 1918, p. 13.

(705) Ver LEAL, Cunha - Coisas de tempos idos.As Minhas memórios, vol. 2, ob. cit., p. 85 e ss; e PERES, Damião - História de Portugal. Suplemento, ob. cit., p.183. 
e de ideal dos verdadeiros revolucionários de 5 de Outubro. O seu ideal foi o mesmo: salvar a Pátria pela República. Nós fizemos a República; efectivamos o que eles agora asseguraram realizar praticamente. Todos unidos, os sinceros, havemos de defender a República sonhada em 5 de Outubro e realizada em 5 de Dezembro, com todo o nosso coração, com todo o nosso esforço de homens honestos e enérgicos, mantendo a liberdade verdadeira para todos os portugueses (Apoiados). (706) Aproveitou, também, o ensejo para lamentar que da maioria surgissem críticas ao Governo, quando dela devia partir a sua defesa. Estava, obviamente, a referir-se aos machadistas, a única brecha visível aberta na maioria, não obstante a sua falta de coesão interna e uma liderança frágil.Ao longo das onze sessões realizadas pelos deputados não se vislumbram, de facto, outros focos de divergência explícita e sistemática no seio da maioria para além da protagonizada pelos amigos de Machado Santos.

O que se passou na célebre sessão de I de Agosto sugere a unanimidade da maioria governamental, extensiva aos restantes grupos parlamentares (monárquicos, católicos, independentes e deputado socialista), em torno das críticas formuladas à organização inicial do C.E.P. pelo Secretário de Estado da Guerra, tenente-coronel Amícar Mota, convidado por um deputado da maioria, o oficial do Exército José Augusto de MeloVieira, ${ }^{707)}$ a prestar alguns esclarecimentos. Amícar Mota acedeu e foi mais longe, procedendo a um verdadeiro auto condenatório da política intervencionista de Norton de Matos. Fez afirmações contundentes ${ }^{(708)}$ e leu documentos comprometedores, conseguindo empolgar os ilustres representantes da Nação a ponto de Egas Moniz propôr, no final, uma Comissão de inquérito à organização e funcionamento do C.E.P. votada também favoravelmente pela minoria monárquica e composta pelos tenente coronel Vicente de Freitas, capitães José Cabral Amaral, Ventura Malheiro Reimão, Artur Mendes de Magalhães, José Cruz Azevedo, capitão médico José Maldonado, alferes Pequito Rebelo e pelo advogado católico Alberto Pinheiro Torres.

$\mathrm{Na}$ sessão do dia seguinte - a oitava, de 2 de Agosto - Tamagnini Barbosa trouxe à Câmara um pedido de consulta mais controverso: se ainda se deviam considerar em vigor as autorizações concedidas aos Governos transactos para servirem no interregno parlamentar durante o estado de guerra. E acrescentou: para alguns jurisconsultos, que foram ouvidos, essas autorizações continuavam em vigor, mas o Governo entendia que o Parlamento devia pronunciar-se a esse respeito. Em apoio desta atitude saiu a terreiro Egas Moniz que manifestou a sua concordância e da maioria sobre a vigência das autorizações, esclarecendo, porém, que enquanto o Parlamento funcionar o Poder Executivo, ao contrário do que procediam os Governos anteriores a este, não pode legislar sem trazer aqui as suas medidas para as apoiarmos ou não (Apoiados). Eu entendo que a interpretação a dar é que está em vigor a lei de 2 de Setembro de 1915, com o complemento do decreto

(706) Cf. Diário da Camaro dos Deputodos. Sessão n. ${ }^{\circ}$ 2, em 25 de Julho de 1918.

(707) Candidato pelo P.N.R. juntamente com Fidelino de Figueiredo, pelo círculo eleitoral 39, oferecera-se para ir para o front, onde permaneceu até 1918.

(708) Cf. Diário da Camara dos Deputados. Sessão n. 7 em 1 de Agosto de 1918 - seguimos transcrição fiel dactiloscrita feita por Cruz Azevedo e oferecida ao Capitão Sidónio Bessa Paes, (Arquivo de Sidonio Paes , secção 2, Subsecção Capitão Sidónio Bessa Paes). 
de 12 de Março de 1916, com a restrição, porém, de que enquanto o Parlamento estiver aberto, o Poder Executivo não poderá publicar nenhuma lei sem a trazer aqui, ao contrário da forma por que os Governos Democráticos procediam, legislando várias vezes com o Parlamento aberto. É uso que nós não desejamos (Apoiados). ${ }^{(709)}$ Posição de princípio que não foi, na prática, acatada pelo Governo durante os dois curtos períodos de actividade parlamentar sob a égide da República Nova.

Rotundamente contrário às autorizações pronunciou-se Cunha Leal, que, por se considerar um membro disciplinado da maioria, avisou: sairia da sala das sessões quando fosse feita a votação.

De notar ainda a presença em S. Bento do Secretário de Estado do Comércio e interino das Finanças, capitão Mendes do Amaral, para fornecer explicações sobre parte da obra de que era responsável, nomeadamente o Orçamento de 1918-1919, queixandose a certo passo da sua intervenção de que não encontrara nenhuma medida anterior a 5 de Dezembro de 1917 que pudesse ser considerada um plano financeiro de guerra, facto extraordinário, não compreendendo como é que alguém se pode convencer de que podemos continuar a reger-nos pelas mesmas normas de administração que nos orientavam antes de nos lançarmos no conflito europeu. ${ }^{(710)}$

Incidente de certa gravidade, narrado com algum detalhe por Rocha Martins, sucedeu na décima primeira sessão de 6 de Agosto, a última antes das longas e impropriamente chamadas férias parlamentares.

O capitão Solano de Almeida, dezembrista, protegido de Machado Santos e Governador Civil de Coimbra até 31 de Agosto, data em que será substituído pelo capitão Luís Alberto de Oliveira, fora acusado na sessão anterior de ser monárquico, de que na ocasião das eleições de 28 de Abril fora desleal para com o Governo e de que continuava a sê-lo, acusação feita por um deputado da maioria, o professor Joaquim Faria Correia Monteiro, eleito pelo círculo eleitoral conimbricense. Este virulento ataque era indirectamente dirigido, segundo Rocha Martins, ao fundador da República, mas era o visado que corria a justificar-se. Eu estava a seu lado - conta o cronista do sidonismo - nas cadeiras da frente da Camara, quando ele declarou é preciso desagravar-me duma creatura que não me merece a consideração dum perfeito homem de bem e que além de me agravar na minha honra me afrontou aproveitando a minha ausência. Os protestos subiram de tom e ao dizer que a «monarquia era a única cousa que pode salvar a Pátria» começou o tumulto. Houve cenas de pugilato entre os deputados da maioria e da minoria; as galerias manifestaram-se e, neste momento irromperam os vivas à república a que se retorquiu. Clamou-se sinceramente ante o berreiro com vivas à monarquia.(711)

Por trás deste confronto desprestigiante para a instituição parlamentar, já de si muito mal vista pela opinião pública, distingue-se a persistente incomodidade e intransigência dos republicanos, mesmo os moderados ou ditos conservadores, no convívio político-

(709) Cf. Diário da Camara dos Deputados, Sessão n. 8 em 2 de Agosto de 1918.

(710) Cf. Ibidem.

(711) Cf. MARTINS, Rocha - Memorias sobre Sidonio Paes, ob. cit., p. 200. Confrontar o resumo feito pelo publicista monárquico com o relato oficial no Diário da Câmara dos Deputados. Sessão n. ${ }^{\circ}$ I em 6 de Agosto de 1918. 
-partidário com os monárquicos, que se revelavam, também, cada vez mais irredutíveis nos seus propósitos restauracionistas, ainda que só ousassem manifestá-los plenamente ao sentirem-se ameaçados pelo eventual retorno dos democráticos à esfera do Poder. Uma tensão indesmentível que teve o seu ponto, porventura, mais alto no frustrado e frustrante reinício dos trabalhos parlamentares em 4 de Novembro, tendo, então, ocorrido, nas palavras do Presidente da Mesa da sessão da Câmara dos Deputados António Lino Neto, um acidente nesta Câmara, do qual resultou um retraimento entre a maioria republicana e a minoria monárquica.

Quanto à opinião corrente, que Rocha Martins cinzelou na sua crónica, de que no novo Congresso tudo foi igual ou pior que nas legislaturas anteriores e, ironizando, chegou mesmo a compará-lo a um harmonium; abre, fecha e faz um ruido!,(712) é preciso não esquecer que de 22 de Julho a 16 de Dezembro só houve, no total das duas «casas», cerca de trinta e sete sessões plenárias, todas vespertinas, e que o interregno parlamentar durou cerca de quatro meses, sendo certo que neste período funcionou a Comissão revisora da Constituição (ver Anexo 2) e as Comissões revisoras da obra ditatorial divididas pelas diferentes «pastas» da governação - Trabalho, Interior, Justiça, Negócios Estrangeiros, Instrução Pública e Subsistências.

No caso da primeira Comissão sabemos que deu por concluída a sua tarefa em Dezembro, no meio já da disputa artificial entre parlamentaristas e presidencialistas, mas sobre as outras desconhecemos como e o que terão feito, embora o mais provável é que os seus membros tenham arrastado o trabalho, achando-se longe do seu termo quando ocorreu o assassinato de Sidónio Pais.

Acresce a estas notas o facto de ter sido morosa a eleição das Comissões da Câmara de Deputados e do Senado prescritas pelo Regimento, num total de doze ${ }^{(7 / 3)}$ para cada uma das «casas» do Congresso. A título de exemplo convém referir que a eleição pelos deputados da importante Comissão revisora da Constituição, evocada como pretexto por Egas Moniz para o adiamento dos trabalhos parlamentares, só ocorreu na oitava sessão de 2 de Agosto, tendo ficado composta da seguinte forma: Francisco Xavier Esteves (relator), Amâncio de Alpuim Torresano Moreno, António Celorico Gil, João Henriques Pinheiro, Manuel Pires Bravo Júnior, José Luís dos Santos Moita, Serafim Joaquim de Morais Junior, José de Almeida Correia e António Lino Neto. E a resposta genérica à alegada inoperância do Parlamento sidonista, considerado, aqui, na sua primeira fase de funcionamento, leva-nos ainda a observar que, pelas actas das sessões e pela caixa de moções, requerimentos, pareceres e projectos-lei existente no Arquivo HistóricoParlamentar, foram vários os deputados da maioria, da minoria, independentes e até o socialista João de Castro a proporem leis e a formularem pedidos de esclarecimento e protestos, dentro do padrão normal da vida parlamentar.

Observação extensiva ao que se passou no Senado, onde os debates foram também vivos e apimentados, com destaque para Machado Santos, que logo a 26 de Julho, na

(712) Cf. MARTINS, Rocha - Memorias sobre Sidonio Paes, ob. cit., p. 199.

(713) A saber: comissão de legislação civil e comercial; de legislação criminal; de colónias; de instrução pública; de obras públicas; de guerra; de agricultura; de comércio e indústria; de negócios eclesiásticos; de infracções e faltas; de marinha; de negócios estrangeiros; de estatística; de petições; de recrutamento; e de regimento. 
quarta sessão, entrou em polémica com o Secretário de Estado da Agricultura, seu substituto interino nas Subsistências, expressamente interpelado para que explicasse a razão de ter ordenado uma sindicância à inoperância dos Serviços ${ }^{(7 / 4)}$ — medida julgada pelo interpelante ofensiva por dar a impressão que saíra um gatuno da Secretaria de Estado. E explicasse ainda a política de preços tida por demasiado benéfica para a classe da lavoura representada no Governo por esse Secretário de Estado ou a controversa extinção da Secretaria de Estado das Subsistências. Fê-lo com tal vivacidade e dureza, taxando o procedimento de Fernandes de Oliveira de pouco sério e pouco digno, que este na resposta disse: Sr. Presidente: Vou procurar revestir-me da maior serenidade para responder ao Sr. Machado Santos; e vou procurar ter serenidade porque me vejo forçado a conter-me na resposta que devia dar a S. Ex. ${ }^{\circ}$. Desde que $S$. Ex. ${ }^{\circ}$ disse que o que eu fiz, acabando com - Ministério das Subsistências e ordenando um inquérito, não era sério, nem digno, preciso, Sr. Presidente e meus senhores, de fazer um grande esforço para me conter, principalmente pelo respeito ao lugar que ocupo e ao local onde falo. É efectivamente preciso um grande esforço para não responder à letra a S. Ex. ${ }^{a}(715)$

A este confronto sucedeu-se outro a propósito do contestado Conselho Económico, extinto com a criação do Comissariado Geral dos Abastecimentos: na sessão n. ${ }^{\circ} 10$ de 6 de Agosto. Machado Santos, em mais uma das suas intervenções de fundo, em que se manifestou contra as autorizações ao Governo e o adiamento dos trabalhos parlamentares, glosou o mote da desorientação governativa, patente na extinção da Secretaria de Estado das Subsistências, que o orador gerira com pulso firme e à revelia dos interesses oligárquicos. Foi, então, que o industrial Alfredo da Silva, interrompendo-o, lembrou-lhe que o Conselho Económico propôs um dos seus primeiros decretos para colmatar a falha de Machado Santos de não ter publicado um decreto com força de lei, autorizando - Governo a requisitar os navios nas viagens e fixando os preços dos fretes nos navios, ${ }^{(7 \mid 6)}$ por forma a evitarem-se pedidos exorbitantes de verbas para fretes de navios, como os I.700 contos que a Companhia Nacional de Navegação apresentara a Machado Santos. Este contestou a afirmação de Alfredo da Silva e o incidente ficou por aí...

Compreendendo-se as razões de cariz pessoal e político-administrativo (preconceito populista e social contra os agricultores e as forças oligárquicas em geral, acusadas de enriquecerem à custa da miséria do povo) subjacentes às intempestivas intervenções de Machado Santos, percebe-se facilmente - vem a propósito repeti-lo - que o distanciamento crítico deste e dos seus amigos não se prendeu com divergências de fundo relativamente à concepção ideológico-política do sidonismo, mas com uma maneira muito própria de imaginar a prática administrativa e um juízo muito severo acerca da competência alheia. E quando, após o 12 de Outubro e a instauração do estado de sítio, Machado Santos levantar a sua voz contra as prisões em massa - falará de 10.000 presos... - a suspensão das garantias e a favor de uma amnistia geral, convém não esquecer que os seus princípios altruístas, generosos e democráticos eram perfeitamente compatíveis - há atrás palavras suas que o confirmam - com o exercício enérgico

\footnotetext{
(714) Cf. Diário do Senado. Sessão n. ${ }^{\circ} 4$ em 26 de Julho de 1918, p. 9.

(715) Cf. Ibidem, p. 12.

(716) Cf. Ibidem, p. 14
} 
da autoridade, da ordem, da força necessária... A repressão sidonista não pode, pois, ser, em rigor, condenada a partir das queixas e dos protestos dos machadistas, como alguma historiografia se apressou a fazer.

A fechar este relance pelo primeiro período da 3. ${ }^{a}$ legislatura, tem interesse observar que a posição dissidente assumida por Machado Santos, líder natural da maioria nessa Câmara, enfraqueceu-a bastante face ao bloco monárquico, coeso e aguerrido, deixando-a sem uma liderança única e forte. Por outro lado e a par da presença dos interesses provinciais ou regionais veiculados por senadores eleitos pelos partidos, havia ainda, como factor novo e imponderável, a presença de representantes corporativos, mais ou menos desalinhados das estratégias partidárias, e a voz do católico Domingos Pinto Coelho, não muito ouvida até final e que quando soou tendeu a aproximar-se do «coro» monárquico. Entre os senadores das classes sócio-profissionais merece relevo Carneiro de Moura que, na sessão n. ${ }^{\circ} 2$ de 24 de Julho, entregou para ser agendado e discutido um Projecto da Constituição Política da República, publicado na íntegra em anexo à sessão n. 8 de I de Agosto - um projecto de feição mista, embora mais presidencialista que parlamentarista, e descentralizador, cuja instância básica era a Junta de Freguesia - e na sessão n. ${ }^{\circ} 6$ de 30 de Julho apresentou um projecto de lei sobre a organização administrativa das províncias ultramarinas baseado no princípio essencial de que a administração colonial mais se realiza pela escolha acertada de bons administradores do que pela promulgação de muitas leis que ninguém executa. ${ }^{717}$

Sessões de umVerão quente, abrasador e não nos referimos apenas ao clima, embora este convidasse, de facto, ao êxodo das cidades para a praia ou para os lugares frescos do campo e da montanha.

Fiel aos seus antigos hábitos de veraneante regular, Sidónio Pais sentiu-se no direito e no dever de mudar de ares, sem suspender a frenética e espinhosa actividade de Presidente da República Nova, a braços com iniludíveis problemas internos e com um tenaz e crescente cerco externo. Socorreu-se para tanto de uma prerrogativa de que outros se haviam já lembrado: no seu Projecto de Estatuto Nacional Machado Santos incluiu um $\S$ único ao artigo $15^{\circ}$ relativo à eleição do Presidente da República, em que concede ao Presidente a possibilidade de residir oficialmente n'um palácio do Estado e poderá dispor para seu recreio e lustre das suas elevadas funções, de mais dois prédios do Estado, um no campo e outro á beira-mar. ${ }^{(718)}$

A escolha recaiu numa zona dos arredores da capital, por não ser prudente uma ausência prolongada para fora do centro do Poder; recaiu, enfim, num local parasidíaco e exótico, evocativo de uma atmosfera medievo-romântica e das famosas margens do Reno coroadas de deslumbrantes castelos. Sidónio Pais decidiu, pois, instalar-se no $\mathrm{Pa}$ lácio da Pena, em Sintra, com alguns requintes cesaristas e aristocráticos, ${ }^{(719)}$ mas nem mesmo aí se isolou do povo, nem sequer abandonou as iniciativas de benemerência e de propaganda. Prosseguiu na inauguração das célebres sopas e ajudado pelas senhoras

(717) Cf. Diário do Senado. Sessão n. ${ }^{\circ} 6$ em 30 de Julho de 1918, p. 4 e ss..

(718) Cf. SANTOS, Machado - A Ordem publica e o 14 de Maio, ob. cit., p. 108.

(719) Z. Europe, 1840 Portugal,Ambassadeur Français à Lisbonne, n. 170,7 de Outubro de 1918. (Archives du Ministère des Affaires Etrangères). 
da Obra de Assistência 5 de Dezembro organizou, no Parque da Pena, uma festa para as crianças pobres. ${ }^{(720)}$

Não foram, porém, semanas de absoluto repouso ou de gratificante convívio com indigentes agradecidos. É certo que se descontraiu em exercícios do seu agrado - andou a cavalo pelas redondezas e deu passeios retemperadores na área do Parque. Mas, a crermos no testemunho de Afonso de Bragança, sofreu o peso das questões pendentes sobre si e sobre a «sua» República, designadamente a instabilidade social e política, a ameaça da revolução social ou bolcheviquista.(721)

(720) Ver descrição romanceada de MARTINS, Rocha - Memorias sobre Sidonio Paes, ob. cit., p. 213-215.

(721) Cf. BRAGANÇA,Afonso de - Sidónio Pais, na intimidade. Revisto de Portugal, Lisboa, I (2) 24 de Agosto de 1919 , p. 70-72). 



\section{Capítulo 4}

\section{O Princípio do fim...}

\section{Agitação operária}

A intranquilidade, cada vez maior, do movimento operário organizado, teve causas internas directas, em que avultam o já focado aumento dos preços e a subsequente carestia de vida, assim como causas externas, sendo, sem dúvida, considerável o fascínio — real ou superlativizado — da revolução bolchevique russa, de cujas peripécias e conturbados desenvolvimentos se fez eco a imprensa através de um caudal informativo que ia alimentando a assustada curiosidade das consciências burguesas europeias. Pela mala diplomática circularam, também, alarmantes notícias e comentários sobre tão extraordinários e temidos eventos.

Sidónio Pais sorveu, regular e ansiosamente, ambas as fontes, mas o acesso privilegiado aos despachos e relatórios das Legações puseram-no a par de perspectivas sombrias e hostis à anarquia instalada na Rússia dos sovietes. Referimo-nos aos despachos do Ministro em Petrogrado Jaime Batalha Reis ${ }^{(722)}$ e de outros Chefes e funcionários de Legações portuguesas, tais como Bartolomeu Ferreira, Ministro em Berne, ou Jorge Santos, da Legação em Estocolmo. Este último, desviando-se um pouco do tópico dominante relativo à estratégia dos Aliados face à paz separada da Rússia dos sovietes com a Alemanha, descreveu, em despacho de 6 de Fevereiro, como os acontecimentos vividos no antigo Império dos Romanov foram vividos na Suécia, chamando particular atenção para o problema social.(723)

Por seu turno, o Visconde de Alte, Ministro de Portugal em Washington, dava conta dos gestos cativantes do Presidente Wilson para com o Congresso dos Sovietes Russos, atitude a seguir atentamente, porque, na opinião daquele diplomata, o objectivo prático de Wilson nas effusivas manifestações de sympathia que a todo momento endereça ao povo russo desde a queda do Imperio consiste em preparar terreno para a expansão da influencia politica, financeira e commercial americana na Rússia depois da guerra de modo

(722) Ver SILVA, Joaquim Palminha da - Jaime Batha Reis na Rússia dos sovietes ou dez dias que abalaram um diplomata português, ob. cit., p. $55-183$ e 187 e ss.

(723) Política russa desde a revolução de Março de 1917, 3. ${ }^{\circ}$ P-M I6-A 8, oficio n. 9 A, Legação de Portugal na Suécia, Estocolmo, 6 de Fevereiro de 1918. (Arquivo Histórico do Ministério dos Negócios Estrangeiros) e SILVA, Armando Barreiros Malheiro da - Sidónio e sidonismo. História e mito, vol. 2, dissert. cit., p. 438-439. 
a evitar que este vasto paiz se torne uma dependencia da Allemanha e reservatorio que de futuro the engrandeça a força economica e política. ${ }^{(724)}$ E enquanto Alte decifrava a postura da política externa americana, o nosso Ministro na China, J.V. de Freitas transmitia, por exemplo, em ofício de 26 de Junho, uma comunicação do seu colega russo em Pequim, principe Koudacheff, desafecto aos bolcheviques, na qual insistia que o bolchevismo se estava a tornar cada vez mais odioso à democracia russa e cada vez mais dependente do germanismo triumfante e subjacente. Era a tese do duplo perigo bolchevique - prómilitarismo germânico e anarquia social - que justificava todos os alertas e todos os cuidados. Recebeu, por isso,Vasco de Quevedo, enviado, entretanto, para Madrid tendo em vista o previsível regresso de Egas Moniz, ${ }^{(725)}$ rigorosas instruções da Presidência da República e da Secretaria de Estado dos Negócios Estrangeiros para se manter atento a eventuais manobras de agentes do bolchevismo russo, competindo-lhe pressionar as autoridades espanholas no sentido da adopção de medidas destinadas a evitar a difusão das ideias bolcheviques e a impedir a presença e a actividade de agentes oficiosos dos Sovietes. ${ }^{(726)}$

Mas de todos os diplomatas portugueses que se debruçaram sobre a ameaça bolcheviquista foi, sem dúvida, Batalha Reis o que viveu intensamente o processo revolucionário russo, dando disso conta nos seus despachos e em dois relatórios - um de Junho/Setembro de 1918 e outro de 20 de Agosto.

No primeiro relatório abordou a saída de Petrogrado e da Rússia do corpo diplomático Aliado, bem como as peripécias da viagem de comboio do Ministro português de Petrogrado para a Finlândia, em 28 de Fevereiro, e de Helsingfords, em 5 de Março, para Tammerfors, local onde brancos e vermelhos se batiam com ferocidade, obstruindo a via férrea, retardando e forçando recuos ao comboio até ao retorno forçado à Estação Nicolau de Petrogrado, de onde conseguirá, finalmente, partir em 8 de Abril, por comboio e depois por barco, até à chegada a Newcastle, em 4 de Maio. ${ }^{(727)}$ No segundo relatório versou, sobretudo, a necessidade de intervenção militar dos Aliados na Rússia, sugestão de que não foi o inventor, limitando-se, segundo Joaquim Palminha da Silva, a glosar uma ideia há muito amadurecida pelo embaixador francês Noulens. ${ }^{(728)}$ Tomados globalmente, os dois documentos constituíram um testemunho impressivo de uma realidade distante e confusa, demasiado grave e singular para não deixar de surpreender e de inquietar governantes e opiniões públicas de díspares latitudes.

(724) Política russo desde a revolução de Março de 1917, 3. ${ }^{\circ}$ P-M I6-A 8, oficio A n. ${ }^{\circ}$ 9, Legação de Portugal nos Estados Unidos, Washington, 13 de Março de 1918. (Arquivo Histórico do Ministério dos Negócios Estrangeiros).

(725) Dossier Correspondéncia, Cartas do irmão Alberto da Silva Pais, carta de 23 de Julho de 1918). (Arquivo de Sidónio Pais - Militar, Lente e Político, Subsistema Presidência da República). A pretensão de Vasco de Quevedo, tão veementemente defendida por Alberto Pais, foi atendida e ele ficou como Encarregado de Negócios na Legação de Madrid.

(726) Politica russa desde a revolução de Março de 1917, 3..$^{\circ}$-M 16-A 8, oficio A. 153, de 13 de Dezembro de 1918, cópia para M.N.E. da Legação de Portugal em Madrid. (Arquivo Histórico do Ministério dos Negócios Estrangeiros).

(727) Ver SILVA, Joaquim Palminha da - jaime Batha Reis na Rússia dos sovietes ou dez dias que abalaram um diplomata português, ob. cit., p. 266-277.

(728) Ibidem, p. 307-308. 
Pelo exposto, a traços necessariamente grossos e breves, parece-nos óbvio que o fantasma da revolução russa inquietou as autoridades e a opinião pública portuguesas à medida que a agitação social e política foi vincando e evidenciando certos traços de violência, de sabotagem e de mobilização das massas contra $a$ ordem estabelecida e as instituições do Estado burguês e republicano. Podemos, por isso, notar que a atitude da U.O.N., de início expectante e confiada na libertação de todos os sindicalistas presos antes do golpe dezembrista, e abertamente hostil até à greve geral de Novembro, foi encarada por Sidónio Pais e pelos seus Governos com uma crescente desconfiança e com o iniludível receio de que, por detrás das reclamações contra a carestia, os açambarcadores e a insuficiência dos salários, larvassem perigosos intuitos anarquizantes e revolucionários.

Coerente com os seus valores sócio-económicos e os seus princípios ideológicopolíticos e doutrinários, Sidónio não podia diferenciar-se substancialmente de um Afonso Costa ou até de um Machado Santos ${ }^{(729)}$ diante de surtos grevistas «selvagens» e violentos e, em especial, diante de uma ameaça nova, para a qual países como a França vinham adoptando e preconizando medidas profilácticas e repressivas eficazes. ${ }^{(730)}$ Mas se, por um lado, não hesitou no manejo da força, por outro, soube fragilizar a capacidade de manobra do movimento operário atraindo a si e às iniciativas de carácter assistencial e caritativo as massas urbanas proletarizadas, esfomeadas, pauperizadas e vitimadas pelo tifo e pela pneumónica, maioritariamente alheias à filosofia e à acção anarco-sindicalista das associações operárias.

Temos, assim, uma dupla estratégia sidonista face à questão social: desvelo e atenção aos necessitados passivos e repressão para com os «insurrectos». E dentro desta linha estratégica foram geridas, de modo ora afável e conciliador, ora frio e tenso, as relações com a U.O.N. ${ }^{(731)}$ e com certas associações e federações de classe, como as da indústria da construção civil e os ferroviários, protagonistas de agressivas acções de luta. Em contrapartida, o apoio inicial que a Junta Revolucionária e o Governo subsequente souberam granjear junto do pessoal dos Correios e Telégrafos, permitiu reduzir o impacto dos protestos surgidos a partir de Março a propósito do incumprimento de promessas que continuavam adiadas. ${ }^{(732)}$

Estes exemplos não bastam, porém, para mostrar como decorreu e como foi encarada a agitação operária no segundo semestre de 1918. Para isso convém evocar os dados disponíveis a partir do estudo da imprensa das classes trabalhadoras desde a eleição presidencial.

(729) Cf. PEREIRA, José Pacheco - As Lutos operárias contra a carestia de vida em Portugal.A Greve geral de Novembro de 1918, ob. cit., p. 93.

(730) Cf. DEROU, Jean - Les Relations franco-portugaises (1910-1926), ob. cit., p. 214 e Z. Europe, 1840 Portugal, Ambassadeur Français à Lisbonne, $n^{\circ}$ 191, 5 de Dezembro de 1918. (Archives du Ministère des Affaires Etrangères).

(731) Dossier 102 União Operaria Nacional, oficio n. 247 de 15 de Maio de 1918, 4 fls. ms. (Arquivo de Sidónio Pais - Militar, Lente e Político, Subsistema Presidência da República). Ver também VIEIRA, Alexandre - Em volto da minha profissão. Subsídios para a história do movimento operário no Portugal continental, ob. cit. p. 102-1 12; e Idem - Para a história do sindicalismo em Portugal, ob. cit. p. I19-140.

(732) Dossier Correios e Telégrafos, vários docs., 16 de Março a 2 de Novembro de 1918. (Arquivo de Sidónio Pais - Militar, Lente e Político, Subsistema Presidência da República). 
Seguindo as notas coligidas por António José Telo, começamos pelo registo dos 28 mineiros de S. Pedro da Cova que continuavam, em Abril, presos no Porto para serem julgados como instigadores dos assaltos realisados em Gondomar, em Dezembro do ano findo. ${ }^{733)} \mathrm{E}$ em 14 de Maio esteve iminente um forte embate entre o operariado e as forças policiais, a propósito do comício da construção civil contra a carestia de vida, reunião essa vigiada de perto pela G.N.R. a cavalo, mas que não chegou a intervir. Em finais desse mesmo mês, os manipuladores do tabaco, cuja greve se arrastava há várias semanas com o apoio da União dos Sindicatos Operários, marcaram uma grande concentração na Praça do Comércio, com o objectivo de entregarem as suas reclamações ao Governo, mas na hora marcada a Polícia e a G.N.R. isolaram a Praça e impediram-lhes a entrada: os manifestantes concentraram-se, então, na rua do Ouro e começaram a empurrar o cordão das forças policiais que resistia e o confronto que parecia inevitável foi, in extremis, evitado porque chegou ordem para o cordão se abrir e franquear o acesso dos operários à sede do Poder, onde as suas reclamações seriam imediatamente aceites. $^{(734)}$

Findava um «braço de ferro» para logo começar outro, protagonizado pelos ferroviários (Minho e Douro e Sul e Sueste) e pelo Secretário de Estado das Subsistências e Transportes, que viria, como já focámos, a pedir a sua irrevogável demissão. Esta acção grevista teve várias peripécias, incluindo actos de sabotagem e de violência na Estação das Devezas, ${ }^{(735)}$ e motivou uma resposta governamental com a ocupação militar das Estações e a multiplicação de rusgas e de prisões. ${ }^{(736)}$ A par desta greve, de forte impacte na opinião pública, registaram-se, em Junho, outras paralisações assinaláveis, a saber: os chapeleiros de S. João da Madeira; mineiros e outros trabalhadores da Batalha; douradores e barbeiros de Lisboa; alfaiates do Porto e de Lisboa; trabalhadores rurais dos arredores de Lisboa; tanoeiros do Porto; marceneiros de Lisboa; tipógrafos de um só periódico do Porto; e operários tipógrafos de Lamego. ${ }^{(737)}$ O número decrescerá em Julho, o que é explicado pela mudança táctica da U.O.N. empenhada, desde Maio, na preparação de um movimento geral, a realizar oportunamente, para se reclamar um aumento generalizado de salários e que devia substituir as greves e as reivindicações parciais e pulverizadas. Mas apesar de ser esta a orientação da cúpula dirigente do associativismo operário e da diminuição de conflitos marginais, eles prosseguiram pelo Verão, com destaque para nova paralisação dos ferroviários do Sul e Sueste em 18 de Julho, tendo sido praticados na Estação do Barreiro, para onde prontamente se deslocou o Governador Civil de Lisboa, ${ }^{(738)}$ actos de destruição de material fixo e circulante que obrigou à intervenção

(733) Dossier 102 União Operaria Nacional, oficio n. 247 de 15 de Maio de 1918, fl. 3. (Arquivo de Sidónio Pais - Militar, Lente e Político, Subsistema Presidência da República). O caso aparece narrado de modo diverso por TELO, António José - O Sidonismo e o movimento operário português, ob. cit., p. 202.

(734) Cf.TELO, António José - O Sidonismo e o movimento operário português, ob. cit, p. 203.

(735) Z. Europe, 1840 Portugal, Ambassadeur Français à Lisbonne, $n .{ }^{\circ} \mid 53,24$ de Agosto de 19|8. (Archives du Ministère des Affaires Etrangères).

(736) Dossier Greve de Junho 1918. Ferroviários, sub-dossier Governador Civil de Lisboa, telegramas. (Arquivo de Sidónio Pais - Militar, Lente e Político, Subsistema Presidência da República).

(737) Cf.TELO,António José - O Sidonismo e o movimento operário português, ob. cit., p. 203.

(738) Álbum «Ao Sabor da Maré...». (Arquivo de joaquim Rosado Fernandes). 
da força pública a ponto de suscitar o vivo protesto do Comité Central da Associação de Classe do Pessoal dos Caminhos de Ferro do Sul e Sueste, com sede no Barreiro, enviado ao Presidente da República e datado de 20 de Junho:

Perante a atitude pelo Governo adotada contra a classe ferroviaria do Sul e Sueste prendendo grevistas, violentando-os e cercando e encerrando a Associação cumpre-nos declarár $a V$. Ex. ${ }^{\circ}$ que a classe não acceita a resolução que V. Ex. ${ }^{\circ}$ ontem pretendeu dar ao conflito e que considera rôtas todas as negociações efetuadas com - Governo, cortando desde esta data as relações com V. Ex. ${ }^{a}$.

Declinamos toda e qualquer responsabilidade pelo agravamento do conflito, que apenas cabem inteiramente ao Governo que entrou no caminho da violencia contra uma classe que se tem mantido correta e ordeira.

Se a solução do conflito se não fizer com a urgencia que o caso requer, generalisar-se-ha a outras classes sem que nos caiba a mais leve responsabilidade por esse facto.

Saude e Fraternidade

O Comite Central

P.S. Qualquer comunicação para os representantes da classe, devem ser enviadas para o Sindicato Ferroviario, Rua do Arco Marquez do Alegrete 30 - 2. ${ }^{\circ}$ Lisboa Telefone n. ${ }^{\circ} 2535 .(739)$

O comité dos grevistas acusava o Governo de ter entrado no caminho da violência, mas a verdade é que a estratégia governamental era mais complexa: uso simultâneo da força e do diálogo. Por um lado, as forças da ordem investiam para desmobilizar de diversas formas os activistas, protegendo eventualmente os «amarelos» que furavam as greves e, por outro, ensaiava-se um acordo rápido e pacificador. Assim se explica a apresentação pelo Governo de umas bases para um acordo,(740) que a Associação de Classe em reunião do dia 19 , pelas $10 \mathrm{~h}$, no Barreiro, decidiu aceitar na sua maior parte, ${ }^{(741)}$ embora no dia seguinte, como vimos, declarasse a suspensão do acordo e, após retoma das negociações, viesse a aprová-las definitivamente no dia 23 . Um esquema negocial nem sempre repetido, mas que não deixou por isso de ser paradigmático.

Entre as outras greves ocorridas em Julho podemos destacar a dos engraxadores de Lisboa, a dos litógrafos da Casa Mota também de Lisboa, a dos sapateiros do Porto, a dos alfaiates da Murtosa, a dos tipógrafos de A Lucto em Lisboa, a dos trabalhadores fluviais no Porto, a dos operários das fábricas de Famalicão, a de dois mil tecelões da fábrica RioVizela em Neguelos e a do pessoal dos eléctricos e da água de Coimbra. ${ }^{(742)}$

(739) Dossier 56 Caminhos de Ferro, Bases em que ficou assente a solução da gréve dos ferroviarios do Sul e Sueste e outros docs. (Arquivo de Sidónio Pais - Militar, Lente e Político, Subsistema Presidência da República).

(740) Ibidem, 2 fls. ms.

(741) Ibidem.

(742) Cf.TELO, António José - O Sidonismo e o movimento operário português, ob. cit., p. 203. 
Em finais desse mês houve, na Régua, assaltos populares a estabelecimentos e a armazéns de açambarcadores, o que obrigou à presença do Exército para intervir com dureza, carregando de espada nua e disparando a ponto de fazer feridos e mortos. ${ }^{(743)}$

Relevante foi a vitória alcançada pelo proletariado de Évora - operários da construção e de outros sectores - ao obterem, após paralisação generalizada e manifestação dos grevistas pelas ruas da cidade, a concessão das 8 horas de trabalho contra as $10 \mathrm{~h}$ até então em vigor.

A partir de meados de Setembro a U.O.N. vincou mais a sua mudança táctica, lançando-se na propaganda aberta em prol da greve geral e contrariando, assim, o tom cordato e moderado do comunicado difundido em finais de Junho que dizia estar só em preparação um movimento pacífico tendente a apresentar as reclamações operárias ao Presidente da República e não existiam sovietes nem qualquer movimento sedicioso. ${ }^{(744)}$ Nesse sentido, foi agendada uma série de comícios simultâneos a realizar em 15 de Setembro nas principais cidades, centros industriais e algumas zonas rurais importantes, mas a resposta do Governo traduziu-se na proibição pura e simples dessas manifestações e quando, em alguns sítios, surgiram, apesar do aparato repressivo montado, comícios e até pequenas sessões de propaganda, a reacção governamental nem tardou, nem esmoreceu, impondo a proibição na generalidade dos $\operatorname{casos}^{(745)}$ salvo em poucas localidades como S. João da Madeira e Covilhã.

Face ao sucedido a direcção da U.O.N. recuou e substituiu os quarenta comícios anunciados por sessões de propaganda, realizadas nas sedes dos sindicatos durante os dias seguintes, e, em especial, no dia 20. Por sua vez, o Partido Socialista, procurando ganhar e marcar bem o espaço em disputa com o anarco-sindicalismo, anunciou um comício seu contra a carestia de vida no Parque Eduardo VII em finais de Setembro, mas também esta manifestação socialista será proibida pelo Governo e a proibição acatada sem problemas de maior.

No começo de Outono a imprensa operária e anarquista, como reconhece António José Telo, mudou de tom e passou a apelar — é o caso do jornal A Revolta — à urgente adopção da simpática revolução russa; $A$ Greve ameaçou com uma revolução à russa; a Sementeira avisou que as vitimas da fome também terão o seu dia; $O$ Construtor garantiu estar prestes a chegada da hora da suprema justiça; e O Rebelde prognosticou que o leão popular rugiria em breve. ${ }^{(746)}$ Exemplos de um discurso e de uma campanha instigada pela facção radical e revolucionária do sindicalismo operário, entusiasta da «aurora» soviética e defensora da greve geral.

Mantida esta meta, que acabou por ser fixada para o dia 18 de Novembro, o número de greves até aí foi diminuto:(747) em Agosto registou-se a dos chapeleiros de Lisboa, a dos mecânicos da fábrica Miranda na Granja, a dos mineiros de S. Pedro da

\footnotetext{
(743) Cf.TELO,António José - O Sidonismo e o movimento operário português, ob. cit., p. 204.

(744) Cf. Ibidem, p. 204.

(745) Cf. Ibidem, p. 205.

(746) Cf. Ibidem, p., p. 206

(747) Cf. Ibidem, p. 208 e PEREIRA, José Pacheco - As Lutos operárias contra a carestia de vida em Portugal. A greve geral de Novembro de 1918 , ob. cit., p. 41 .
} 
Cova, a dos leiteiros ambulantes de Coimbra, a dos tecelões de uma fábrica na Covilhã, a dos trabalhadores de madeiras em Portimão e a dos operários da construção civil em Viana do Castelo; em Setembro só terá tido alguma expressão a dos trabalhadores rurais de Almeirim; e em Outubro houve, apenas, as greves dos operários das fábricas Street em Lisboa e a dos funcionários de um banco e de várias casas de finanças, além de uma tentativa frustrada de greve parcial a partir de Beja e na sequência da revolta democrática de 12 e 13.

Era clara e intencional a concentração de esforços para a difícil, mas estratégica preparação da greve geral, animada por intuitos mistos de reivindicação de natureza económica contra o custo de vida e de ajuste de contas com a burguesia, como se podia ler no jornal 0 Construtor de 17 de Novembro e em proclamações e manifestos volantes. (748) E nesta medida, uma tão intensa campanha sindical e revolucionária acabou por se mesclar e ser até aproveitada pela actividade conspirativa do P.R.P./P.D., vinda muito de trás e assente na sua própria rede. Como notou, perspicaz, o Ministro francês Daeschner, os democráticos tinham no Exército, entre sargentos e praças, na Marinha, nos bairros pobres de Lisboa e no Alentejo uma segura e ampla base de apoio a partir da qual puderam ir lançando as suas investidas contra o Poder sidonista ou republicano presidencialista, cuja maior fraqueza ou «calcanhar de Aquiles» foi a sua força, ou seja, a sua necessidade vital de defesa e a forma sistemática e implacável como a exercitou, proclamando-se paladino intransigente da ordem - é que a violência atrai violência e o círculo torna-se vicioso!...

\section{O Cerco oposicionista e o medo à solta}

Insistimos, pois, na tese de que o sidonismo respondeu com a repressão organizada a um cerco de várias frentes, incluindo a interna. Um cerco que não foi só político, beneficiou da crise económico-social e da investida revolucionária do operariado e, para completar o caos, teve ainda uma vertente sanitária e epidémica com a morosa erradicação do tifo e a violenta profusão da bronco-pneumónica, vista, sobretudo pela imprensa católica, como um tremendo «castigo de Deus» (749) que converteu o país, durante o Outono de 1918 , num vasto e desolador sepulcro.

Mas se a conjugação destas várias frentes foi um facto, é também iniludível a forte motivação política pró-democrática do cerco ao Governo sidonista e a organização conspirativa, sucessivamente ultimada para o assalto final e sucessivamente repelida.

A malha de informadores e de delatores, montada pelo Ministério/Secretaria de Estado do Interior e pela Polícia Preventiva em cooperação com a «pasta» da Guerra e com as suas unidades de confiança, como a G.N.R. e o Corpo de Tropas da Guarni-

(748) Z. Europe, 1840 Portugal, Ambassadeur Français à Lisbonne, anexo a n. 191 de 5 de Dezembro de 1918 (Archives du Ministère des Affaires Etrangères). Dossier 92 Manifestos panfletos e proclamações); e Polícia de Segurança do Estado, AN/TT - Propaganda apreendida, 1919-1926. (Arquivo de Sidónio Pais - Militar, Lente e Politico, Subsistema Presidência da República).

(749) Ver, entre 1916 e 1918, jornais, boletins ou revistas de propaganda apostólica diocesana e do catolicismo laico referidos em SILVA, Armando B. Malheiro da - Os Católicos e a «República Nova» (1917-1918): da «questão religiosa» à mitologia nacional, art. cit., p. 419-420. 
ção de Lisboa, permitiu ao $16 .^{\circ}$ Governo, à custa, é certo, de um crescente desgaste da sua imagem em determinados sectores da opinião pública, ir aparando os golpes insurreccionais e só falhando ante o expediente clássico do atentado pessoal contra o protagonista maior da situação.

Não obstante inevitáveis exageros e incontáveis boatos, as informações chegadas à Secretaria da Presidência da República espelham bem a atmosfera conspirativa e a efectiva mobilização da rede sócio-política de apoio ao P.R.P./P.D. e das redes tacticamente conexas do evolucionismo e do camachismo com vista ao derrube da República Novo e do seu Chefe.

Uma intensa mobilização ofensiva(750) ${ }^{(7 u e ~ d o ~ p o n t o ~ d e ~ v i s t a ~ p o l i t o l o ́ g i c o ~ j a ́ ~ a t r a ́ s ~}$ ficou explicitada: a incapacidade endógena de reestruturação do campo republicano, correlacionando as suas forças de um modo diverso do existente até finais de 1917. activou, de novo, os mecanismos habituais de fractura, de exclusão e de oposição em vez da integração, da harmonização e da pacificação da familia republicana, forçando, assim, à derrota e à neutralização de uma das tendências em confronto - a parlamentar intransigente ou a presidencialista conservadora.

Pode, pois, dizer-se que a declaração do estado de sítio pelo decreto n. ${ }^{\circ} 4.891$ de 12 de Outubro e sua renovação por cerca de trinta dias pela lei n. 832 de 13 de Dezembro, correspondeu a uma escalada de tensão e de instabilidade social e política, cindindo o país, nos grandes centros e, particularmente, na capital, em dois - um a favor e outro contra a situação sidonista. De um lado, regorgitavam as intentonas conspirativas de republicanos históricos e também de elementos monárquicos; e do outro as manifestações mais ou menos orquestradas de populares afectos ao Governo que chegarão a assaltar jornais democráticos e até mesmo a invadir e saquear, na sequência do primeiro atentado falhado contra Sidónio Pais, a sede do Grémio Lusitano.

Em tal escalada de tensão e de intranquilidade, os papelinhos, as notas oficiais da Polícia, os rascunhos apressados ou os recados recebidos por via telefónica na Presidência da República ajudam a contar uma ou mais histórias, sincopadas, soltas e a maioria sem datação, convocando algumas delas, para maior inteligibilidade, a documentação oficial do Interior. Histórias que fazem o sentido do medo, da delação intencional e gratuita, da suspeita, do perigo imaginado e do perigo realmente urdido.(751)

Em torno de Sidónio Pais criou-se, deste modo e ao mesmo tempo, uma espécie de «nuvem de fumo» e de escudo preventivo de avisos destinados à segurança da sua pessoa e à da «sua» República presidencialista, cada vez mais ensombrada pelo risco do ataque final e cada vez mais obrigada a defender-se dos potenciais agressores, sendo para o efeito redobradas as medidas de vigilância e de protecção a adoptar na própria sede da Presidência da República — o Palácio de Belém. ${ }^{(752)}$

(750) Ver SILVA, Armando Barreiros Malheiro da - Sidónio e sidonismo. História e mito, vol. 2, dissert. cit., p. 450 .

(751) Ver lbidem, p. 451 - 458.

(752) Dossier Cartas para e notas do capitão Eurico Cameira e de outros Ajudantes do Presidente da República. Instruções..., 5 fls. (Arquivo de Sidónio Pais - Militar, Lente e Político, Subsistema Presidência da República). 


\section{Novo périplo pelo país}

Fácil é, porém, verificar que, por deficiência dos meios práticos disponíveis e por efeito do seu próprio temperamento, Sidónio correu óbvios riscos nas inúmeras ocasiões de contacto directo com a população de Lisboa e província. Embora viajasse e saísse geralmente acompanhado dos seus Ajudantes e ladeado, quando em cortejos presidenciais, por esquadrões de Cavalaria 7, havendo também cordões de Polícia ao longo dos percursos e patrulhamentos sistemáticos, Sidónio expôs-se bastante, andasse de carro aberto, a pé ou a cavalo e foi um alvo relativamente fácil para qualquer atirador homicida.

Mas se isto é notório, tem de reconhecer-se, em paralelo, a existência de um certo esquema de protecção pessoal, perceptível, por exemplo, na sua viagem ao Alto Douro eTrás-os-Montes de 22 a 27 de Setembro, tendo-se incumbido o capitão Cameira ou o alferes Ferreira da Silva de telegrafar para a Secretaria de Estado do Interior, responsável pelo accionamento do dispositivo policial de segurança, nas diversas paragens do périplo: no Pocinho, dia 22, comunicou que S. Ex. ${ }^{\circ}$ chegou bem sendo aclamado no percurso. Parte em comboio especial; de Vila Real, a 25, que S. Ex. ${ }^{\circ} O$ Presidente da Republica pernoitou em Pedras Salgadas e almoçou em Vila Real, visitando o quartel de infantaria 15, seguindo para Bragança; de Mirandela, com a mesma data, que a viagem de S. Ex. ${ }^{a}$ o Presidente da Republica segue sem novidade. Segue para Vila Flor e Pocinho e logo para o Porto onde fica no Grande Hotel; deVila Flor, ainda em 25, o Presidente da República ordenou fosse comunicado pedido de envio urgente para Vila Real e Bragança de 20 sacos de arroz, sabão, bacalhau e petróleo ou carboneto; no Porto, a 26, Cameira transmitiu recado do Presidente, que achava necessário demitir por telegrama os membros da Camara do Porto major Campos e tenente Mota Alves, substituídos por Francisco Pais da Cunha Prelada e alferes Miguel Magalhães Cruz; ainda no Porto o mesmo Cameira, a 27, informava estar tudo bem S. Ex. ${ }^{\circ}$ O Presidente da Republica vai montar em Gaia uma sopa 5 de Dezembro. Segue para Mesão Frio e Régua; e do Governo Civil de Vila Real assegurava-se que - Presidente tivera nessas localidades uma recepção calorosa. ${ }^{753)}$ Defraudada ficou, porém, a expectativa dos brigantinos de poderem receber a honrosa visita do Chefe do Estado, facto de que se lamentou por ofício de 4 de Outubro o Governador Civil. ${ }^{(754)}$

Durante esta viagem, assim telegraficamente esboçada, Sidónio Pais proferiu as suas habituais alocuções, mas na compilação de Feliciano de Carvalho só ficou registo de uma, feita em Santa Marta de Penaguião a 28 de Setembro. Reafirmou aí que o seu unico desejo é fazer a felicidade do povo, só para este é que governava e lamentava não ter sido assim feito pelos Governos da primeira republica, acrescentando: $A$ importancia que até hoje tem ligado ao povo é nula, ou quasi nula, eu tenho o desejo de que tudo isto se modifique: esta é que entendo que é a verdadeira politica. A importancia que até hoje

(753) Ministério do Interior. Livro de correspondência recebida, liv. 71. Julho-Dezembro de 1918, telegramas de 22 a 27 de Setembro de 1918. (Instituto dos Arquivos Nacionais - Torre do Tombo).

(754) Dossier Epidemias, sub-dossierTypho exantematico e hespanhola e encefalite-letargica, Oficio n. ${ }^{\circ} 69$ de 4 de Outubro de 1918. (Arquivo de Sidónio Pais - Militar, Lente e Político, Subsistema Presidência da República). 
se tem ligado ás juntas de freguezia é nula, ou quasi nula, é necessario que tal deixe de acontecer e que em cada freguezia as pessoas capazes façam parte da junta, afim de bem cuidarem dos interesses daqueles que os rodeiam e que constituem a sua freguezia. No dia em que isto suceder e que as juntas, trabalhando para os seus paroquianos, se não esqueçam da unidade que ao mesmo tempo necessita existir entre todas elas por meio de camaras, ter-se-ha modificado esta engrenagem que tão mal tem andado, e a situação do povo portuguez será certamente mais desafogada. É esta a obra que quero fazer porque só bem do povo portuguez quero e paro ele unicamente vivo.

Expressão enfática de um populismo mais passional, romântico e obsessivo que meramente demagógico ou oportunista, cerzida de permeio com um recado directo ao papel dos corpos administrativos locais na defesa dos interesses das populações. Uma defesa pertinente na difícil hora então vivida diante do flagelo epidémico da broncopneumonia de propagação rápida e dizimadora.

A viagem ao Nordeste coincidiu, pois, com a explosão desse surto e com a descoberta e o desmantelamento do chamado complot de Lamego, confirmado pelo Comando da Polícia do Porto, a 28 de Setembro, de forma assaz lacónica: em vista das buscas ter apreendido armamento em Lamego. A imprensa, por seu turno, foi mais pródiga em informes, tendo o jornal monárquico A Pátria, do mesmo dia 28, puxado para cabeçalho os seguintes dizeres: $O$ complot de Lamego / A Polícia consegue descobrir todo o tenebroso plano dos revolucionários civis e militares / Assalto ao quartel de infantaria $n .^{\circ} 9$ / A morte de várias pessoas e familias de Lamego / O incêndio das suas habitações e de várias igrejas; e cuidou de acentuar que a descoberta foi possível como resultado das diligências levadas a cabo pelo ilustre inspector de segurança Sr. Capitão Solari Allegro. ${ }^{(755)}$

E se este caso não passou despercebido, nomeadamente a certa imprensa do Norte, eco bem maior haveriam de ter, no país todo, os incidentes dos dias 12 e 13 - sábado e domingo - de Outubro e a trágica ocorrência do dia 16 que ficou conhecida por Leva da Morte.

\section{A Revolta falhada de 12 de Outubro}

Preparada com naturais dificuldades e pressentida pelo habitual zelo dos informadores, a tentativa de golpe na primeira quinzena de Outubro teve a particularidade de irromper em diversos locais sem aparente articulação entre si, embora Rocha Martins, na sua crónica dos fastos sidonistas, refira, a propósito, que esse era o grande golpe democrático; iam pronunciar-se as cidades onde os conspiradores faziam, desde há muitos meses, a sua obra; combinara-se tudo para a mesma hora. Em Penafiel um aspirante, Magalhães, com o cabo Pereira Lopes e o soldado Pereira da Costa, insubordinara uma pequena fôrça e tomara o telégrafo. Acompanhara-o um capitalista chamado Domingos Valda. (756)

(755) Cf. ALMEIDA, João Ferreira de, PAIS, José Machado e CABRAL, Manuel Villaverde - Materiais para a história do advento do fascismo em Portugal, art. cit., p. 404.

(756) Cf. MARTINS, Rocha - Memorias sobre Sidonio Paes, ob. cit., p. 225. 
De Norte a Sul, de Vila Real a Beja, surgiram focos de perturbação da ordem pública, mas só com alguma gravidade em Coimbra e em Évora, nada se registando de significativo em Lisboa, o que indicia, por um lado, o alto grau de fidelidade ao Governo pelo Corpo de Tropas da Guarnição integrado por oficialidade e praças de confiança, e, por outro, cingir-se a revolta a pontos periféricos a partir dos quais se espalharia o grito geral de insubordinação e de assalto à capital. Em Penafiel foi um grupo de soldados comandados por um aspirante, cujo nome a nota telegráfica recebida na Presidência da República não especifica, que se insubordinou, tomando a Estação do Caminho-de-Ferro e depois houve tiroteio sendo os revoltosos todos presos. ${ }^{(757)}$

Segundo o breve testemunho memorialístico do general Gomes de Sousa, que era, na altura, $02{ }^{\circ}$ comandante do Regimento de Infantaria 35, aquartelado no Mosteiro de Santa Clara, a revolta começou mesmo ali sob a chefia do Comandante, coronel Mourão e com elementos que tinham colaborado no movimento sidonista e alguns milicianos, ${ }^{(758)}$ tendo ligeira repercussão numa guarnição vizinha, pelo que os oficiais tomaram os rumos que quiseram e os soldados seguiram para as suas terras. Foi, então, que Gomes de Sousa recebeu ordem para assumir o Comando do Regimento, onde se dirigiu acompanhado por alguns oficiais e pouco depois chegou lá uma força do Regimento de Infantaria 23, de que só uma parte tinha entrado no movimento, para ocupar o quartel, entretanto abandonado e roubado - as praças na fuga para suas casas tinham levado o que puderam, tudo tinha sido revolvido e por todo o lado se achavam espalhadas armas e munições. Confrontado com tal situação o novo comandante confessa que o rescaldo nada teve de compensador, contando que ao chegar ao quartel encontrou um corneteiro a quem mandou fazer o toque de sargentos, por perceber que alguns por ali andavam e logo compareceu a maioria dos que tinham entrado na insurreição, declinando todos perante ele as suas responsabilidades. Mandou, de seguida, um oficial montado apresentá-los no Quartel General, de onde foram levados para a Penitenciária. Mas o problema ainda não ficara inteiramente resolvido: No Grupo de Administração Militar, quando ali entrava um oficial para assumir o comando, um sargento dava-lhe um tiro atravessando-lhe um pulmão. Não foi pequeno o trabalho para fazer voltar aos seus lugares tudo quanto andava disperso, sobretudo o armamento e munições, que era urgente colocar em lugar seguro porque os insurrectos começavam a afluir ao quartel. Quando já estava presente a maioria, esboçavam-se conflitos com as praças do 23 , tendo um sido desarmado quando pretendia apunhalar uma sentinela daquele Regimento. No estado de desmoralização em que estavam era impossível conservá-los no quartel. Com as devidas precauções deram todos entrada na Penitenciária. ${ }^{(759)}$

Versão lacónica traçada pela óptica castrense e que por isso mesmo contrasta com a policromia narrativa de Rocha Martins, num encadeado de detalhes, de nomes, de peripécias e de conversas havidas, que não cabe, aqui, reproduzir na íntegra. ${ }^{760)}$

(757) Dossier Revolta de 12 de Outubro, fl. inum. ms. em papel da Secretaria da Presidéncia da República. (Arquivo de Sidónio Pais - Militar, Lente e Político, Subsistema Presidência da República).

(758) Cf. SOUSA, Gomes de - Meio século de vida militar, 1888-1938, ob. cit., p. 134.

(759) Cf. Ibidem, p. 135- 136.

(760) Ver MARTINS, Rocha - Memorias sobre Sidonio Paes, ob. cit., p. 225-230. 
Basta salientar que os revoltosos tomaram por algumas horas conta da cidade, dispondo para o efeito da artilharia necessária e prendendo o comandante da respectiva Divisão Militar, general Jaime de Castro, enquanto em Lisboa Sidónio Pais e seus directos colaboradores, incluindo o Secretário de Estado da Guerra e o dos Abastecimentos, (761) tomaram as providências adequadas, mandando marchar forças da Figueira da Foz e aprontando outras — de Aveiro e do Porto - que não chegaram a intervir. Uma nota telegráfica recebida em Belém refere a ocorrência de grande tiroteio entre revoltosos e fiéis em que toma parte importante o esquadrão do 8 (fiel). Os revoltosos ocuparam as estações do caminho de ferro e central telegrafica. ${ }^{(762)}$ A reacção pronta do Governo e a actuação das forças fiéis permitiu sufocar a revolta: A maior parte dos oficiaes e soldados do regimento de infantaria 35 inclusivé o Comandante das tropas revoltosas, Coronel Mourão fugiram; os restantes foram presos. As tropas do grupo de administração militar aquartelado n'aquella cidade foram presas. O comandante da divisão, general Jayme de Castro, tem sob as suas ordens o regimento de infantaria $23,05{ }^{\circ}$ Grupo de metralhadoras, uma bateria de artilharia 2 e um esquadrão de Cavallaria. 0 socego é completo em toda a cidade. Todas as tropas que teem sido mandadas marchar contra os revoltosos teem seguido com grande entusiasmo havendo tantos oferecimentos de oficiaes e soldados que em varias unidades tiveram de ser muitos recusados. (763) Ao reassumir o Comando da Divisão, o general Jaime de Castro telegrafou para o Gabinete da Presidência pedindo envio de algumas forças para prender tropas do $2{ }^{\circ}$ Grupo e o novo Governador Civil de Coimbra apressou-se a informar o Presidente da República que o movimento militar democratico que se deu hontem n'esta cidade foi completamente sufocado, estando assegurada a ordem publica. Filho [Sidónio] de V. Ex. ${ }^{a}$ bem. ${ }^{(764)}$

Findava, assim, uma revolta militar e eclodia outra, muito mais a Sul - em Évora - sendo no decurso de tais sucessos decidida e assinada por todo o Executivo a declaração de estado de sítio. ${ }^{(765)}$

Rocha Martins conta que a insurreição, nessa cidade alentejana, ocorreu na ocasião em que o Governador Civil, major José Marcelino Carrilho, um dedicado amigo de Sidónio Pais, se achava ausente a tratar, em Lisboa, de assuntos do distrito. Era tarde - diz-nos ele. Era de madrugada do dia 13, um domingo frio - pode precisar-se melhor. A soldadesca fora revoltada pelo alferes miliciano Acabado, amigo de Estevão Pimentel, membro do comité revolucionário juntamente com o major de Cavalaria 5 Joaquim José da Conceição e o coronel de Cavalaria Manuel Alves Paias. Os revoltosos apoderaram-se logo de Artilharia de Montanha e com ela conseguiram dominar a cidade, acaudilhados por Infantaria 11. Na Praça do Geraldo tinham sido colocadas de noite grandes caldeiras de vinho e de aguardente que as tropas bebiam com o povoléu armado. Havia também grandes cafeteiras onde se fazia café e os operários, acudindo a um chamamento,

(761) Dossier Reformas e decretos II, sub-dossier Autógrafos. (Arquivo de Sidónio Pais - Militar, Lente e Político, Subsistema Presidência da República).

(762) Ibidem, dossier Revolta de 12 de Outubro, fl. inum. ms. em papel da Secretaria da Presidência da República.

(763) Ibidem.

(764) Ibidem.

(765) Cf. Diário do Governo. I série (223) 12 de Outubro de 1918, p. 1791-1792. 
julgando tratar-se já duma revolta contra a carestia da vida, ou dessa grande anciedade duma revolução à russa, apareciam com enorme gaudio dos conspiradores, pois, em parte alguma tal se conseguira. Tinham-se espalhado proclamações bem urdidas. Já correra sangue. A revolução principiara pelo assassínio do coronel Pereira da Silva, de cavalaria 5, contra o qual se disparara nessa nevoenta madrugada.(766)

Essa morte excitara os ânimos, antecedera novas adesões e causara indignados abandonos, como o dos alferes Ponce e Moura, que saíram do quartel. O Governo Civil foi tomado pelos revoltosos, o Governador Civil substituído por Rebolado Formosinho e o Comandante da Divisão Militar, general Braz Mousinho de Albuquerque, deixou-se prender. DeVendas Novas haviam chegado recrutas que, de imediato, se misturaram com os amotinados - a sargentada aplaudira e o oficial Mendinhos, porque resistira, recebera ordem de prisão. ${ }^{(767)}$ Todos os Regimentos da cidade tinham aderido à revolta. A polícia nada pôde fazer, senão aguardar uma ofensiva das forças leais ao Governo que permitisse restabelecer a ordem. Foi, aliás, o que viria a suceder no dia 14 - uma coluna de tropas do Sul, organizada sem demora, avançou sobre a cidade e desarmou os revoltosos, pertencentes, de acordo com os relatórios dos breves inquéritos mandados efectuar em 16 desse mês, ao 2. ${ }^{\circ}$ Grupo de Artilharia de Montanha, ao Regimento de Cavalaria n. ${ }^{\circ}$, à Companhia de Depósito do 3..$^{\circ}$ Batalhão de Infantaria n. ${ }^{\circ}$ । e ao Batalhão n. 3 da Guarda Nacional Republicana. E, a título ilustrativo, vale a pena determo-nos um pouco mais sobre um deles.

Assim, no Relatório do breve inquérito feito no $2 .^{\circ}$ Grupo de Artilharia de Montanha está escrito que ao toque da alvorada do dia 13 entrou nesse quartel $\mathrm{o}$ alferes miliciano José Domingues Rodrigues Acabado, pertencente a essa unidade, e juntamente com os segundos sargentos Henrique Valentim e Alberto Fernandes Cerqueira foi às casernas para apressar o levantar das praças, obrigando-as a armar e formar, incitandoas e convencendo-as à revolta para salvarem a República. Passados alguns momentos surgiu a Companhia de Depósitos de Infantaria II, acompanhada de um numeroso grupo de civis armados, que penetraram no quartel e juntaram-se às praças do Grupo de Artilharia de Montanha. À frente delas já estava a maioria dos seus sargentos e o aspirante a oficial miliciano Candeias, comandante do piquete de prevenção e que havia, por isso, pernoitado no quartel. Atreladas as peças existentes, os revoltosos saíram em direç̧ão ao Regimento de Cavalaria n. ${ }^{\circ}$ 5. Houve tiroteio, de que resultou a morte do comandante daquele Regimento e, graças ao apoio dos sargentos do 5, conseguiram a adesão das praças. Todas essas forças reunidas ficaram sob comando do tenente coronel Paias e do major Conceição até se gorarem os seus objectivos. Recolheram, então, os soldados ao quartel no dia 14 , entrando por pequenos grupos que se iam desarmando. Pelas $16 \mathrm{~h}$ compareceu no quartel o alferes miliciano José Luís Santos Romão para tomar. o comando. Auxiliado pelo alferes miliciano José Carvalho Pereira fez entrar o Grupo na normalidade.

(766) Cf. MARTINS, Rocha - Memorias sobre Sidonio Paes, ob. cit., p. 234.

(767) Cf. Ibidem, p. 235. 
autor do inquérito no apuramento das responsabilidades concluiu: o alferes Acabado, contava com a coadjuvação e auxilio de 20 segundos sargentos da unidade, na sua quasi totalidade dados como alma ao movimento, e que os cabos e soldados nada sabiam do movimento projectado, sendo a ele incitados e levados de surpresa pelo Alferes Acabado e sargentos na manhã de 13. Impossivel é, num inquerito tão rapido, apurar todas as praças que não entraram no movimento e muito menos as que nele entraram coagidas ou obrigadas pela força, separando-as d'outras que a ele expontaneamente tivessem aderido. ${ }^{(768)}$ Foi, mesmo assim, possivel afiançar que, entre sargentos, cabos e praças, tomaram parte activa trinta e três indivíduos. Solidário com o alferes Acabado esteve o 1. ${ }^{\circ}$ cabo condutor adido n. 95 da 3. ${ }^{\circ}$ bateria do Corpo de Tropas da Guarnição de Lisboa, Manuel Garda Junior. Dezassete segundos sargentos participaram directamente na revolta, ficando de fora três, cujos nomes aparecem também referidos. Sobre o procedimento dos oficiais, o relatório iliba a maioria de envolvimento e cumplicidade.(769)

Para as cadeias, inóspitas e exíguas, não seguiram apenas militares, noticiando a Pátria de 15 de Outubro que tinham sido detidos em Lisboa importantes vultos da oposição republicana e democrática:Visconde da Ribeira Brava, Francisco Correia de Herédia, (770) José Barbosa, (771) Francisco Homem Cristo, ${ }^{(772)}$ dr. JoséTudela, Gonçalves Neves, tenentecoronel Sá Cardoso, ${ }^{773)}$ dr. José de Castro, José do Vale, capitão Francisco Paula Pacheco, Álvaro de Oliveira, dr. Caetano Gonçalves, ${ }^{774)}$ Alfredo Pinto, o ex-Ministro dr. Almeida Ribeiro, José de Sá Marques, dr. Costa Gonçalves, entre outros. Prisões e rusgas que precederam e se seguiram à greve geral de Novembro, dando o mote às intervenções cáusticas de Machado Santos e de Cunha Leal, falando de 10.000 presos, no recomeço dos trabalhos do Congresso em inícios de Dezembro.

(768) Dossier Revolta de 12 de Outubro, 2.. Grupo de Artilharia de Montanha. Relatório do breve inquérito feito no \| G.A.M. sobre o movimento revolucionário de 13 de Outubro de 1918 pelo Comandante pelo major Bernardino Pires Franco, fls. 1-2. (Arquivo de Sidónio Pais - Militar, Lente e Político, Subsistema Presidência da República).

(769) Sobre as investigações levadas a cabo no Regimento de Cavalaria 5, na Companhia de Depósito do $3 .^{\circ}$ Batalhão do Regimento de Infantaria n. ${ }^{\circ}$ II e no Batalhão n. 3 ver SILVA, Armando Barreiros Malheiro da - Sidónio e sidonismo. História e mito, dissert. cit., vol. 2. p. 465-470.

(770) Ver Nobreza de Portugal, vol. 3, ob. cit., p. 214.

(77I) Destacado unionista que se manteve ao lado de Brito Camacho, embora divergisse do líder em matéria político-institucional por defender posições próximas do presidencialismo, que foi preso e este facto logo denunciado pelo jornal A Lucto, que a partir de então publicou várias notas a dar conta da «injusta e humilhante» situação do seu correligionário.

(772) Deve ter sido preso em Aveiro a pretexto de criticar Sidónio Pais e o seu Governo no jornal Povo de Aveiro. Seu filho que, como se sabe, estava em Paris a dirigir a propaganda externa da República Nova apressou-se a enviar um telegrama em francês para o Presidente Sidónio Pais, pedindo-lhe intercedesse para que o regime prisional do pai fosse atenuado. Dossier Telegramas, Telegrama de 24 de Outubro de 1918. (Arquivo de Sidónio Pais - Militar, Lente e Político, Subsistema Presidência da República). Num canto superior foi anotado o seguinte: «Recomendar. Responden»; e a isto Eurico Cameira acrescentou por baixo: «Recomendei e respondi. 4-11-1918).

(773) Sobre a prisão deste conhecido oficial afonsista ver relato da autoria de seu filho: CARDOSO, Sá - Memórias duma época e apontamentos políticos, ob. cit., p. 25-29.

(774) Dossier Revolta de 12 de Outubro, Para Arquivar n. ${ }^{2}$ 2. Carta de Luís da Cunha Gonçalves de 15 de Outubro. (Arquivo de Sidónio Pais - Militar, Lente e Político, Subsistema Presidência da República). 


\section{A Leva da Morte}

Os dias 12 e 13 de Outubro foram assinalados pelos sidonistas no calendário das bernardas vencidas e inscritos a relevo nos anais dos democráticos. Estes, na primeira oportunidade surgida, imprimiram um número único com o título evocativo Doze de Outubro de 1918, onde, sob a epígrafe trivial Salvé! Republica imperecivel, deixaram gravada uma lapidar antinomia de perceptíveis laivos milenaristas:

A Velha República, a República, a deusa do lar da Pátria, o anjo tutelar que se elevára radiosa e bela em 5 de Outubro de 1910 para salvar Portugal amparando o velho heroi de mil-combates, rejuvenescendo o cavaleiro andante da Renascença fôra substituida ardilosamente no Lar sagrado por essa lóbrega e indecente prostituta a que os bandidos, por escarneo, puzeram o nome achincalhante de republica nova! (775)

Sobre esses bandidos da achincalhante República Nova não tardou a pesar a suspeição do crime hediondo e cobarde que a expressão Leva da Morte haveria de condensar, manchando de sangue e estigmatizando a situação, como notou Damião Peres: Fosse como fosse, partindo de ignota origem, a denominação de leva da morte logo ganhou um uso comum e ficou perdurando nos fastos lisboetas como designação dessa tragica coluna. Denominação de uso comum, mas também estandarte - impressionante estandarte repetidamente erguido contra a situação dezembrista por todos os seus adversários políti$\cos$. $(776)$

Versões e explicações opostas alimentaram, de imediato, a opinião pública.

Não faltou quem visse no trágico evento uma intentona policial destinada a exterminar alguns dos presos, (777) conduzidos à noitinha, bem guardados, mas seguindo por ruas estreitas e escuras propícias a ataques de surpresa ou a emboscadas, e quem, pelo contrário, se inclinasse para uma tentativa ousada de libertação dos detidos(778) — hipótese que Damião Peres julgou mais verosímil, pois tinha semelhanças com o ocorrido em 12 de Julho de 1917, quando também eram conduzidos, em custodiada coluna, numerosos grevistas que tinham sido presos após luta armada.(779)

O circunspecto e noticioso Diário de Notícios de 17 de Outubro publicou, em simultâneo, a sua descrição do acontecido e a nota oficiosa distribuída pelo Governo. Seguindo aquele periódico, deparamos com uma força de 207 praças da Polícia, comandada pelos chefes Alves Dias e César Augusto do Couto, que saiu do Governo Civil de Lisboa em direcção ao Cais do Sodré, onde deviam embarcar com destino a vários fortes 150 presos políticos, deslocados em coluna. Esta saíra pelas 21 h, voltando

\footnotetext{
(775) Cf. Salvé! Republica imperecivel. Doze de Outubro de 1918, número único, 1919.

(776) Cf. PERES, Damião - História de Portugal. Suplemento, ob. cit., p. 189.

(777) Cf. LEAL, Cunha - Coisas dos tempos idos. As Minhas memórias, vol. 2, ob. cit., p. I I5-1 16.

(778) Ver MARTINS, Rocha - Memorias sobre Sidonio Paes, ob. cit. p. 243-246.

(779) Cf. PERES, Damião - História de Portugal. Suplemento, ob. cit., p. 189.
} 
pela Rua de Serpa Pinto para a do Ferragial de Baixo, desceu a Calçada que conduzia ao Corpo Santo. Pelo trajecto havia, segundo a notícia do jornal, vários curiosos que paravam nos passeios a ver o desfile ou que acudiam às janelas. Os polícias da frente da coluna intimavam as pessoas a recolherem-se e faziam-no por ordem expressa para evitar qualquer manifestação ou atentado. Ao chegarem, porém, à embocadura da rua de Vítor Cordon ouviu-se o estalar de uma bomba (outras fontes referem antes um tiro) e, de súbito, estabeleceu-se uma enorme confusão, envolvendo-se polícias e presos na mais doida desordem, em meio da qual o tiroteio era ensurdecedor. E o autor da notícia alude, então, às várias versões que corriam céleres e desencontradas acerca do caso: afirmavam uns que o primeiro tiro partira da espingarda de um polícia que ia na vanguarda, feito contra uma gente que teimava em não se retirar de uma janela, e afirmando outros que tais tiros partiram de uns indivíduos que ali esperavam a força e os fizeram para estabelecer a confusão e dar fuga a alguns presos. Também há quem diga que, após o primeiro tiro, o Sr. Visconde da Ribeira Brava, um dos presos que iam na frente, puxara de uma pistola e desfechara contra um guarda, puxando de um punhal um preso que ia junto dele e avançando contra outro polícia. ${ }^{(780)} \mathrm{O}$ certo era, porém, ter-se gerado uma indescritível confusão e uma horrivel desordem, alastradas do Chiado a São Paulo e por todas as imediações do Governo Civil, onde se via gente correndo e fugindo, e se ouviam tiros, descargas, gritos lancinantes de feridos, imprecações, doestos.... (781)

A gravidade do sucedido motivou, de pronto, uma nota oficial, com uma ligeira diferença quanto ao número de guardas da coluna - 240 contra os 207 referidos acima — e de presos - 153 e não 150 - e uma substancial discrepância no respeitante à origem do incidente: Ao voltar da Rua de Serpa Pinto para a Rua do Ferragial de Baixo - lê-se na nota - foi a força atingida por bombas e tiros, que partiram de ambos os lados do cruzamento daquelas ruas e de algumas janelas dos prédios próximos, ao mesmo tempo que alguns presos, de entre estes o visconde da Ribeira Brava, atacavam os guardas e se punham em fuga, matando um daqueles e ferindo muitos outros e os chefes comandantes da guarda avançada e da coluna que conduzia os presos. Imediatamente uma parte da força rompeu fogo contra os grupos assaltantes e vários presos que debandaram, deixando estendidos alguns, ao mesmo tempo que os outros guardas faziam recolher ao Ginásio Clube e à garagem do Governo Civil os presos restantes... (782)

Numa hábil tentativa de superar, ao nível interpretativo, a aceitação pura e simples de uma das hipóteses em confronto - libertação de presos ou liquidação física pela polícia de alguns deles - Manuel Villaverde Cabral preferiu insinuar uma estratégia do bloco social de apoio à ditadura, traduzida num salto qualitativo pela repressão da antiga classe política e dos inimigos de classe, surgindo, então, as primeiras forças de repressão irregulares de trauliteiros, grupos de caceteiros e comparados, por Luís de Magalhães, aos somatenes catalães institucionalizados pela ditadura de Primo de Rivera: A violência desta

(780) Cf. ALMEIDA, João Ferreira de, PAIS, José Machado e CABRAL, Manuel Villaverde - Materiais para a história do advento do fascismo em Portugal, art. cit., p. 406.

(781) Cf. Ibidem, p. 407.

(782) Cf. Ibidem, p. 406. 
repressão atingira foros inéditos ainda sob Sidónio, com a Leva da Morte, em Outubro de 1918, em révanche aberta contra a «Formiga Branca», a polícia secreta de Afonso Costa, e generalizar-se-ia no Porto durante o «reinado» de Paiva Couceiro... (783)

Uma interpretação legítima, que nos parece, contudo, demasiado presa a um modelo teórico pré-estabelecido e fundada em bases documentais (memórias impressas, em concreto as de Cunha Leal, e relatos de imprensa) que urge contrastar com dados de outra natureza e procedência. Preferimos, por isso e a partir de todos os elementos disponíveis, apresentar a Leva da Morte como uma oportunidade que os democráticos aproveitaram para libertarem alguns dos seus correligionários e uma consequência directa do confronto ascensional e irreversivel entre eles e os sidonistas.

Sob o signo político do estado de sítio e da correspondente suspensão das garantias constitucionais, já de si muito limitadas pelo atraso verificado na apresentação e discussão do novo projecto de Constituição Política (ver Anexo 2), decorreram os dois últimos meses de vida do sidonismo - dois meses densos, intranquilos, de enorme tensão social e política, mas também de profundos suspiros de alívio e de esperança perante o fim da Grande Guerra e o início da tão ansiada Paz.

(783) Cf. CABRAL, Manuel Villaverde - A Grande Guerra e o sidonismo (esboço interpretativo), art. cit., p. 385 . 



\section{Capítulo 5}

\section{O Derradeiro fôlego...}

\section{Novas e últimas alterações no Governo}

No dia 5 de Outubro não foram autorizados os habituais festejos comemorativos da instauração da República sob o pretexto da pneumónica, embora o verdadeiro objectivo consistisse, tal como foi referido por certa imprensa, em evitar aglomerações. E a 8, cinco dias antes de ser declarado o estado de sítio na sequência da grande conspiração democrática há muito anunciada, ocorreu a segunda e última remodelação do $166^{\circ}$ Governo. Ela era iminente do ponto de vista orgânico-funcional porque se mantinha a interinidade e a acumulação das «pastas» das Finanças e Comércio no capitão Mendes do Amaral, zurzido pel'A Lucta como uma das vulgares (in)competências do Governo, e se impunham urgentes alterações no delicado e espinhoso sector dos abastecimentos em busca - constante e inglória - de maior operacionalidade dos meios e de melhor concretização dos fins. Estas as razões superficiais para mais uma «revoada» de Ministros, embora a mudança de nomes fosse vista de diferentes modos e para muitos não deixava de significar um sinal evidente de crise nas hostes de apoio ao Executivo.

Rocha Martins explica a remodelação ocorrida de forma algo confusa e imprecisa, ${ }^{(784)}$ mas que, no essencial, parece apontar para eventuais pressões dos ricos, feridos nos seus interesses pelos decretos 4.825 e 4.84 I sobre cambiais e tributação de lucros de guerra, e pela extinção do Conselho Económico, cujas funções passaram a ser absorvidas pela nova Secretaria de Estado dos Abastecimentos.

O pressentimento de borrasca conspirativa veio tornar inadiável a decisão de refrescar o elenco governativo, para o qual entrava, finalmente, Egas Moniz, após nova recusa inicial: chamado a Belém, para entrar no gabinete, recusava-se com a sua teima parlamentarista. Talvêz aceitasse com o título de presidente do conselho. Sidonio fixou-o; estava-se a 8 de Outubro e disse-Ihe: - Dentro em três dias teremos uma grande revolução democrática. Insinuava que o abandonavam, na hora perigosa, quando êle só era preciso para defender o existente e não podia estar a preocupar-se com os detalhes da administração pública. Desde logo o médico se declarara ao seu lado, quisera demonstrar-the que não tentava as aproximações com as esquerdas - com o inimigo - pêcha de que o acusavam. Cedera e o chefe do estado - guardando para os negócios estrangeiros um secretario de estado

(784) Ver MARTINS, Rocha - Memorios sobre Sidonio Paes, ob. cit., p. 221-222. 
parlamentarista, a servir o presidencialismo - dissera-the que arranjasse um ministro do interior e outro da justiça. ${ }^{(785)}$ E nesta breve passagem o prolixo publicista reproduz literalmente o depoimento impresso do próprio Egas Moniz, ${ }^{(786)}$ muito escasso, por seu turno, em explicações de fundo sobre a recomposição ministerial. De concreto deixa apenas vincado o já explícito diferendo com o Presidente da República a propósito da solução presidencialista.

Este era, aliás, o ponto aparente da discórdia captado pelo perspicaz Ministro de França em Lisboa Émile Daeschner. Em ofício para o Ministro Pichon, de II de Outubro, fala incorrectamente de um novo Ministério e abre com a alegada divergência de vistas existentes entre o Presidente da República e o líder da maioria Egas Moniz - aquele não aceitava renunciar às prerrogativas que solicitara às Câmaras, enquanto este recusava entrar num Governo de que não tivesse a presidência e que não fosse responsável perante o Parlamento.Tão viva e forte divergência tinha por pano de fundo o crescente descontentamento geral pelas deploráveis condições de vida e as ameaças cada vez maiores e mais precisas da oposição. A perigosa conjugação destes factores prementes impôs aos dois políticos uma atitude sensata e defensiva, obrigando-os a saírem da sua inicial intransigência e a unirem-se num sentimento de defesa comum. Houve, assim, cedências mútuas: Egas Moniz aceitou entrar para o Governo como mero Secretário de Estado dos Negócios Estrangeiros, mas Sidónio comprometeu-se não reclamar do Congresso, enquanto não se reunisse para rever a Constituição, as prerrogativas presidencialistas prefiguradas na lei eleitoral de Março e a permitir que o controlo parlamentar sobre - Executivo se exercesse mais directamente, exigindo-lhe a prestação de contas dos seus actos. Acordo tácito e verbal entre os dois que só num futuro próximo e após o recomeço dos trabalhos parlamentares mostraria a sua utilidade e eficácia. Até lá ficava a incógnita sobre a conciliação dessas duas tendências opostas - presidencialismo e parlamentarismo.

Uma incógnita que a entrevista do diplomata francês com o novo Secretário de Estado dos Negócios Estrangeiros não permitiu desfazer. Segundo o relato oficial da conversa havida, Egas Moniz mostrou-se particularmente afável para com o representante francês, felicitando-o e felicitando-se das vitórias dos Aliados contra os boches, acrescentando uma nota pessoal: completara os seus estudos clínicos em Paris e como muitos dos seus compatriotas sentia-se filho intelectual da França. Palavras registadas com interesse pelo diplomata gaulês, porque se dizia que Egas Moniz não tinha simpatias muito activas pela Causa dos Aliados.

Passando, depois, em revista o curriculum dos novos titulares de «pastas» e dos que transitaram de umas para outras, observou que o responsável cessante pelo Interior, empossado como Secretário de Estado das Finanças, embora fosse um engenheiro militar de talento assumira, por amizade com Sidónio Pais e Egas Moniz, um lugar muito difícil, car les finances portugaises avec l'augmentation croissante des dépenses sans la création de ressources correspondantes, n'ont été maintenues en équilibre que grâce á des emprunts à court terme et à l'émission de papier monaie. Para o Interior entrara António

(785) Ver MARTINS, Rocha - Memorias sobre Sidonio Paes, ob. cit., p. 222.

(786) Ver MONIZ, Egas - Um ano de política, ob. cit., p. 152. 
Bernardino Ferreira, homem do 5 de Dezembro, considerado enérgico: /l sort du rang et est communément surnommé utamboun» par allusion à son emploi au début de sa carrière militaire. Sobre os outros membros nada opôs de significativo, limitando-se, no fim, a frisar o papel político de Egas Moniz num Ministério a prazo - se ele conseguisse concretizar - objectivo de transformar os Secretários de Estado em Ministros responsáveis perante - Parlamento, não tardaria a verificar-se uma nova recomposição governativa. ${ }^{(787)}$

A preferência parlamentarista de Egas Moniz remonta, se quisermos recuar o suficiente, à célebre carta de 9 de Agosto já comentada ao longo deste estudo e que representa um sinal claro de incomodidade face ao cerco de certas forças contra o Governo. Forças diferentes: os republicanos históricos haviam formado um bloco para derrubar militarmente a situação dezembrista/sidonista e os monárquicos acentuavam a sua irredutibilidade, aceitando a defesa do princípio da ordem, mas combatendo a feição republicana do Governo, incluindo a presidencialista. ${ }^{(788)}$ Para Egas Moniz e alguns dos seus amigos o sidonismo estava perante um dilema letal:morto para os republicanos por ter a colaboração de monárquicos e morto a prazo para estes por ser uma República, ainda que Nova, na qual rejeitaram o ingresso. Para sair desse incómodo dilema parecia inevitável o recuo em direcção à oposição republicana histórica, oferecendo como «cachimbo de paz» algumas cedências em matéria constitucional.

A defesa política de tal recuo era o prenúncio ou o anúncio da possível morte do figurino presidencialista americano que o P.N.R. se comprometera a defender na revisão constitucional. E era-o, sobretudo, pelo facto relevante de aparecer Egas Moniz como protagonista da quebra desse compromisso por razões tácticas e não por razões ideológicas e doutrinárias como inadvertidamente se tem aceite a partir da leitura ingénua das páginas de Um ano de política. $\bigcirc$ líder da maioria governamental tornara-se uma das figuras axiais da rede sócio-política de apoio ao dezembrismo/sidonismo, cuja influência foi, aliás, aumentando à medida que outros núcleos iniciais da rede se afastaram.

Com a saída e o afastamento dos unionistas e dos machadistas da esfera do Poder os ex-centristas, juntamente com os militares dezembristas, ficaram a sustentar O P.N.R. e a experiência encabeçada por Sidónio Pais, que ficou, por isso, mais «encostado à parede». Não só precisava, como, afinal, dependia inteiramente das opções tácticas de Egas Moniz. Mas se tal limitação foi um facto, parece-nos também indiscutível a resistência de Sidónio diante do recuo que o médico de Avanca via como a única escapatória possível a um cheque mate de consequências imprevisíveis. ${ }^{(789)}$ Daí, pois, as intermináveis discussões que terão tido, especialmente a partir da sintomática publicação no Jornal da Tarde, a partir de 26 de Outubro, de uma série de artigos intitulada Presidencialismo. e Parlamentarismo da autoria do deputado governamental João Henriques Pinheiro, amigo de Egas Moniz e autor de um projecto alternativo de Constituição, ${ }^{(790)}$ artigos esses

(787) Z. Europe, 1840 Portugal,Ambassadeur Français à Lisbonne, $n .^{\circ}$ 172, 11 de Outubro de 1918. (Archives du Ministère des Affaires Etrangères).

(788) Ver CAMPOS, Fernando - Presidencialismo. A Monarquia (vésperas das eleições de 28 de Abril).

(789) Cf. MONIZ, Egas - Um ano de política, ob. cit., p. 158-159.

(790) Foi, como se verá adiante, enviado para a Mesa da Câmara dos Deputados na sessão n. ${ }^{\circ} 4$ de 9 de Dezembro de 1918. 
saídos em reforço da publicação do projecto de revisão constitucional, com o mesmo título,(791) de Alberto Machado, outro deputado do P.N.R.

Sobre essas discussões Egas Moniz deixou escrito que Sidónio Pais o chamara um dia para lhe pedir que pusesse termo à campanha jornalística a favor do parlamentarismo: Disse-lhe que os artigos eram assinados e que, havendo dentro do Partido Nacional Republicano correntes nos dois sentidos, as colunas do jornal estavam ás ordens de quem quizesse defender as suas doutrinas, quer numa, quer noutra orientação. (...) Ao dr. Sidónio Pais tinha eu dito tempos antes o procedimento que teria na Camara. Atacaria e votaria contra o projecto de constituição presidencialista que aparecesse. Defenderia um projecto parlamentarista com direito de dissolução. Desde êsse momento em diante começaram as nossas intermináveis discussões, as mais desagradáveis e as mais penosas da minha vida política. ${ }^{(792)}$ Nesse momento ameaçou, pois, votar contra o projecto de constituição presidencialista que aparecesse e o contencioso abeirou-se, segundo o seu testemunho, da ruptura: A solução que achámos na noite de 2 de dezembro surgiu para os dois como a única que podiamos encontrar lógica e honrada. Recolhi tarde a casa. Dormi tranquilamente o sono abençoado das horas despreocupadas. De manhã fui vêr nos jornais a nota em que tinhamos acordado. Apenas a Situação, jornal governamental, e até presidencial, dava a notícia da minha saída do Ministério. Era o bastante. Estava, finalmente, desligado do governo! (793)

Não estava... No dia seguinte o Presidente da República chamou-o a Belém e disse-lhe: $E$ indispensável que fique no Ministério e que vá para a Conferência de Paz. Tenho confiança em si e apêlo para os seus sentimentos patrióticos. ${ }^{(794)}$ Egas ainda tentou justificar a inevitabilidade da demissão, mas Sidónio insistiu com veemência e prontificou-se a rectificar nos melhores termos a notícia da Situação. Mas isto é o que se lê e outra coisa o que se pode inferir: parece ter havido um pacto temporário imposto por imperativos de política externa que explica o silêncio verificado até 14 de Dezembro, na Câmara dos Deputados e Senado, em torno do projecto da Comissão revisora e dos projectos alternativos. $O$ que não precisamos de inferir, por se afigurar demasiado flagrante e óbvia, é a falácia que envolve a ameaça de votar contra o projecto de constituição presidencialista que aparecesse, sobretudo se tivermos em conta que tal projecto (ver Anexo 2) existiu e Egas Moniz não podia desconhecê-lo: fez-se, pois, de desentendido e apresentou-se ao juízo da História como um parlamentarista convicto e assumido, esquecendo, oportunamente, que tinha, afinal, a consciência amarrada a um comprometedor projecto presidencialista elaborado pela Comissão revisora oficial, dado por concluído em início de Setembro, ${ }^{(795)}$ mas só entregue em Dezembro, e executado com o seu conhecimento, ainda que já sem a sua aprovação!...

\footnotetext{
(791) Ver MACHADO, Alberto - Presidencialismo, parlamentarismo. Reflexões sobre um projecto de revisão constitucional. Lisboa: Imprensa Henriquina, 1918.

(792) Cf. MONIZ, Egas - Um ano de politica, ob. cit., p. 156.

(793) Cf. Ibidem, p. 160.

(794) Cf. Ibidem, p. 161.

(795) Cf. Presidencialismo. A Lucto, de 7 de Setembro de 1918, p. I.
} 


\section{Debate constitucional}

Assentemos, até prova em contrário, que Egas Moniz preparou um recuo airoso para ele e incómodo para os presidencialistas, a começar pelo próprio Sidónio Pais. Um recuo concebido através da instauração, no seio da sua maioria parlamentar, de uma corrente parlamentarista mobilizadora do P.N.R. e fragmentadora do bloco oposicionista à situação.

Manobra apreciada com um misto de agrado e de desconfiança pela gente d'A Lucta. É que os plumitivos do Calhariz mantinham a lúcida acidez do seu mentor e quando leram o opúsculo citado de Alfredo Machado e as declarações de João Pinheiro de que a maioria parlamentar votaria um projecto parlamentarista, não perdoaram a estocada: O peor, segundo nos dizem, é que ambos são pessoas sobre as quaes o sr. dr. Egas Moniz exerce uma grande influencia pessoal, e o sr. dr. Egas Moniz tem sempre, em politica, opiniões excessivamente provisórias. ${ }^{(796)}$

Era, pois, pública e notória a volubilidade do conceituado médico, mas os sinais de aproximação lançados pelos seus amigos não podiam ser desprezados. Compreende-se, portanto, o bom acolhimento que o projecto constitucional de Alfredo Machado, decalcado como ele próprio confessou da Constituição de 1911 , mereceu nas páginas do periódico unionista, talvez pela pena de José Barbosa ou do próprio Brito Camacho,(797) uma elogiosa aceitação que significou algo mais: o anúncio de tréguas se... As condições dos camachistas residiam, sobretudo, em matéria constitucional e na recusa do estado de sítio e da política repressiva exercida a torto e a direito, ainda que justificada por impulso de defesa.

Um acordo em torno destes pontos sensíveis facilitaria a reaproximação da União Republicana, mas se tal sucedesse Sidónio perdia de algum modo a face. É, por isso, difícil - não impossível... - imaginar tal cenário e mais difícil ainda se tivermos em conta que Camacho deu passos cautelosos para mais uma vez - era a sua suprema habilidade... - não se comprometer em demasia, nem ficar com a coerência muito beliscada. Com efeito, basta ler os artigos de fundo publicados no órgão oficial do partido unionista, desde finais de Setembro, para se perceber a sua postura.

Em 8 de Outubro José Barbosa, que seria preso na sequência da revolta falhada dos dias 12 e 13, num texto cáustico intitulado Sem gente!, aproveitou a iminente remodelação ministerial para liquidar, em jeito de balanço, a actuação política de Sidónio Pais:

O sr. Sidonio Paes falha em tudo. Falhou na adaptação do presidencialismo, falhou na cooperação militar que prometeu manter na frente ocidental; falhou na resolução dos problemas da administração publica sobre os quaes tomou providencias; falhou na atracção dos monarquicos, que se negaram a ingressar na Republica pela porta que S. Ex. ${ }^{\circ}$ Ihes abriu; falhou na obra de extermínio dos partidos republicanos; na organisação do parlamento que elegeu; falhou na prova dos crimes de que acusou

(796) Cf. Presidencialismo e parlamentarismo. A Lucta, de 19 de Outubro de 1918, p. I.

(797) Série de artigos intitulados Presidencialismo e parlamentarismo, de 19 de Outubro até 2 de Novembro. Num deles - o de 25 de Outubro - aparece reproduzida carta de Alfredo Machado a agradecer os comentários tecidos a propósito do seu trabalho e a aceitar alguns dos reparos feitos. 
os seus inimigos politicos vencidos; falhou na escolha dos seus colaboradores; falhou no conhecimento que simulou dos homens que considerou capazes de aderir ao seu exito; falhou em mil outras coisas e falha agora no que é essencial a qualquer homem responsavel pelo governo de um paiz. ${ }^{(798)}$

De um lado zurzia-se no Chefe da República Nova e nos seus novos Ministros ou Secretários de Estado; e do outro aparecia Brito Camacho, de mansinho, a tomar posição contra a tentativa revolucionária de 12 e 13 de Outubro, alegando que a via revolucionária não ajudava a resolver o problema político, antes o agravava e se os democráticos e evolucionistas se instalassem de novo no Poder a primeira coisa a fazerem era excluir a União Republicana dos seus eventuais acordos governativos. A afirmação é, no mínimo, curiosa porque mostra bem o grau de confiança e de empenhamento com que o partido unionista entrara no bloco abstencionista e oposicionista formado em resposta às eleições de Abril.

Esses sócios de circunstância não tranquilizavam o unionismo e, por isso, ultrapassada a experiência presidencialista convinha a Brito Camacho arranjar outros parceiros que permitissem resolver o problema político falhado quer por Pimenta de Castro, quer por Sidónio Pais, porque não seguiram a solução proposta pela elite do Calhariz. $\bigcirc$ seu chefe insurgia-se contra o uso da força e sugeria, repetindo o que não se cansava de dizer desde o 5 de Dezembro acerca da sua aversão a golpes militares e a esquemas extra-legais de conquista do Poder: era favorável a uma via de consenso e de razoabilidade progressista que podia voltar a ser percorrida com a maioria governamental se esta renunciasse ao «presidentismo» (regime presidencial à medida do Cesar Sidónio). E esta dava, finalmente, sinais de querer fazê-lo: num artigo intitulado Caminho a seguir, Brito Camacho congratulou-se com a posição parlamentarista do líder da maioria governamental e aproveitou para frisar que, embora a Constituição de 1911 estivesse cheia de defeitos e o maior deles todos fosse o de combinar os dois sistemas parlamentarista e presidencialista, viciando um e outro na sua essência, podia ser adoptada com algumas alterações e esse trabalho de revisão demandaria pouco tempo. Num texto seguinte, publicado a 31 de Outubro e intitulado Tudo pode ser, condenou o adiamento do reinício dos trabalhos parlamentares, considerado como uma intolerável sujeição do Parlamento ao Governo.

Tema retomado e desenvolvido a propósito da tumultuosa sessão do dia 4 na Câmara dos Deputados em três artigos com o título A Maquina... impressos na primeira página de A Lucta entre 5 e 7 de Novembro. E no dia 21 era publicado o artigo mais explícito e importante - Actividade política - no qual Camacho relançou o problema político e insistiu na solução que entendia ser a mais consensual e adequada: Para os republicanos portuguezes, o problema é este - Republica presidencialista ou Republica parlamentarista; um Regimen de vontade pessoal ou um Regimen de vontade colectiva - a Nação acima de todos os individuos, e a sua intangivel soberania sendo o substractum de todos os Poderes publicos, independentes e harmonicos entre si.

(798) Cf. BARBOSA, José - Sem gente! A Lucta, de 8 de Outubro de 1918, p. I. 
Posta a questão nestes termos urgia estabelecer uma plataforma de discussão e acordo, assente nos seguintes pontos: República parlamentar com dissolução; reforma eleitoral com base no alargamento do sufrágio; e lista neutra para as eleições administrativas. Com base nisto - acrescentou - pode fazer-se e deve fazer-se uma grande agitação política, tomando a palavra no bom sentido, por forma a não terem razão de ser as tentativas revolucionárias. ${ }^{(799)}$

A plataforma estava, assim, formulada com nitidez, mas adiada por parte da maioria governamental. É, aliás, difícil calcular, por falta de dados, qual a atitude seguinte de Egas Moniz e dos seus amigos, sendo certo que Sidónio Pais considerava o projecto presidencialista elaborado pela Comissão revisora uma base razoável e conciliadora para aproximar as duas correntes ou tendências em conflito. E é possível supor que antes de existirem resultados concretos da Conferência de Paz, talvez o debate dos projectos voltasse a ficar «congelado» por iniciativa do Presidente da República ou do seu Secretário de Estado dos Negócios Estrangeiros ou dos dois. Mas não adianta muito conjecturar, embora Martinho Nobre de Melo na entrevista que concedeu ao semanário Expresso não hesitasse em fazê-lo, dizendo que se Sidónio não tivesse morrido penso que o regime se consolidaria e o facto de o terem morto revela que temiam a consolidação de um regime presidencialista em Portugal.(800)

Importa, porém, considerar estas palavras a uma outra luz. Tomemos para esse fim dados concretos como o da recomendação telegráfica de Londres, em I 5 de Dezembro, dirigida por Egas Moniz ao amigo Vasconcelos e Sá, Secretário de Estado das Colónias, para que fosse imediatamente aceite a antiga constituição com aditamento dissolução. Lembra isto [loão Henriques] Pinheiro. Seria satisfação completa todos parlamentaristas e seria afırmação vantajosa para estrangeiro o conseguimos immediatamente uma constituição.

Constatada a importante inflexão táctica de Egas Moniz, convém avaliar-lhe rapidamente os efeitos na política geral do $16 .^{\circ}$ Governo, que permaneceu inalterável no plano programático, mas foi modificada quanto ao posicionamento ostensivo perceptível desde a saída dos unionistas e vincado a partir das eleições de 28 de Abril.

Tentava-se uma aproximação aos «velhos» republicanos, desfazendo para o exterior, agora que se abeirava a partilha crucial dos despojos de guerra no tableau internacional, quaisquer simpatias ou cumplicidades com os monárquicos estigmatizados de germanófilos nas altas esferas político-diplomáticas francesas e inglesas. E um sinal claro desta postura para os Aliados verem será dado pela prisão do jornalista e deputado monárquico Teles de Vasconcelos, tema polémico discutido no Congresso em Dezembro.(801) Quer isto dizer, à luz da análise sistémica de David Easton e Marcel Merle tal como Nuno Severiano Teixeira a aplicou ao caso paroxístico do Ultimatum inglês, ${ }^{(802)}$ que voltou a ser acentuada — foi-o, de forma clara, na passagem da ditadura para a legitimação da República

(799) Cf. CAMACHO, Brito - Actividade política. A Lucta, de 21 de Novembro de 1918, p. I.

(800) Cf. Martinho Nobre de Melo recorda para o Expresso. Os Tempos de ministro da Justiça de Sidónio Paes e de ministro dos Negócios Estrangeiros de Gomes da Costa, art. cit, p. 9-r.

(801) Cf. MARTINS, Rocha - Memorias sobre Sidonio Paes, ob. cit., p. 263.

(802) Ver TEIXEIRA, Nuno Severiano - O Ultimatum inglês. Política externa e política interna no Portugal de 1890, ob. cit., p. 17-24. 
Nova - a interacção sistema interno e sistema externo na última fase do sidonismo, a opinião estrangeira e os ganhos a obter nas negociações com as potências vencedoras funcionaram como meio natural de pressão e de resolução das questões internas, ou seja, de out put a incidir por retroaç̧ão no sistema interno.

Um discurso feito e validado fora (no exterior, no quadro diplomático internacional) servia, assim, de instrumento de desbloqueio de uma situação interna — do país e, em especial, do campo republicano, mergulhado num impasse que opunha e afastava a República Nova dos republicanos históricos, deixava-a prisioneira do apoio de monárquicos e católicos, além de sujeitá-la a um perigoso confronto interno entre a corrente parlamentarista e a presidencialista. Caíra-se, pois, num impasse que frustrara o objectivo centrista, assimilado pelo P.N.R., da formação de um amplo bloco unitário conservador capaz de integrar a maior parte das sensibilidades da República.

Em Outubro tal desiderato era já só uma miragem, porquanto a popularidade do Presidente da República não bastava para unir a familia republicana, embora, como observou João Bonifácio Serra, o carisma de Sidónio não trouxesse consigo uma alteração completa, revolucionária, do Estado republicano e da sua articulação com a sociedade, ${ }^{(803)}$ e o modelo presidencialista parecia cindi-la a meio sem implicar, contudo, rupturas na prática político-administrativa, retro e prospectivamente considerada.

\section{Acção governativa}

Na remodelação de 8 de Outubro Egas Moniz viu reforçada a sua influência e correu pela opinião pública a ideia de que suplantara o seu putativo rival, o antigo correligionário centrista Tamagnini Barbosa, o qual possuía ligações pessoais e afinidades programáticas com alguns elementos do núcleo militar dos cadetes e dos oficiais dezembristas, nomeadamente o alferes Jorge Botelho Moniz e o capitão de Artilharia José Pinto da Cruz Azevedo (amigo pessoal e conterrâneo de Sidónio Pais), empossado Secretário de Estado dos Abastecimentos.

A alegada rivalidade entre os dois proeminentes políticos, narrada nas Memórias de Cunha Leal e referida, com outra variante (Sidónio versus Tamagnini), por Rocha Martins, ${ }^{(804)}$ carece de uma rigorosa averiguação e enquanto tal não surgir há que reduzi-la a proporções mais comedidas. E para tanto convém referir que Tamagnini Barbosa, na opinião do Ministro francês, aceitou as Finanças em nome da amizade a Sidónio Pais e a Egas Moniz, e que acatou, embora preferisse o incipiente figurino presidencialista, a sugestão deste último para que fosse reposta a Constituição de 1911 , facto implícito na sessão conjunta do Congresso de 16 de Dezembro reunido para eleger Canto e Castro Presidente da República.

Tamagnini Barbosa deixou a importante Secretaria de Estado do Interior para sobraçar a «pasta» ingrata das Finanças, ficando aí coarctado por inultrapassáveis condicionalismos económico-financeiros e pelo plano herdado de seus antecessores.

(803) Cf. SERRA, João Bonifácio - Do 5 de Outubro ao 28 de Maio: a instabilidade permanente, in REIS, António (dir.) - Portugal contemporâneo, ob. cit, p. 59.

(804) Cf. MARTINS, Rocha - Memorias sobre Sidonio Paes, ob. cit., p. 222. 
O lugar vago foi preenchido por outro militar, o capitão de Artilharia António Bernardino de Sousa Ferreira, tido por amigo pessoal de Egas Moniz e por este indicado( ${ }^{(805)}$ para essa missão, embora se deva acrescentar que o indigitado fazia parte da entourage militar de Sidónio, servindo-o na Obra de Assistência de 5 de Dezembro e ao lado de Botelho Moniz na luta quixotesca contra os açambarcadores.

Outro amigo de Egas Moniz, o aveirense e juiz da Relação de Lisboa Jorge Couceiro da Costa, foi para a Justiça e dos Cultos em substituição de outro magistrado da mesma Relação, Alberto Osório de Castro.

Na Secretaria de Estado das Colónias Vasconcelos e Sá, também amigo de Egas Moniz, continuou a exercer o cargo e a continuidade estendeu-se ainda à Marinha, onde já estava o almirante joão do Canto e Castro Silva Antunes empossado em inícios de Setembro, à Instrução Pública de Alfredo de Magalhães, ao Trabalho do jovem Forbes de Bessa e à Agricultura, «pasta» gerida por um Eduardo Fernandes de Oliveira muito pouco à vontade na regulamentação e tabelamento de preços agrícolas na produção e para a comercialização, ameaçando demitir-se, como vimos atrás, por causa dos artigos 9..$^{\circ}$ e $10{ }^{\circ}$ do decreto 4.836.

Estreias no plano ministerial contaram-se quatro: Egas Moniz deixara Madrid para ir para a Câmara defender os princípios que julgava mais convenientes para a nossa política; mas se o presidencialismo triunfasse, não me afastaria. Trabalharia o mais possivel para o melhorar ${ }^{(806)}$ e acabou guindado à esfera governativa e chefe da diplomacia portuguesa, embora afirmasse nunca tivera desejo de sobraçar uma pasta ministerial e sempre tivera pelo Parlamento uma irresistível atracção; ${ }^{(807)}$ outro ilustre professor de Medicina, João Alberto Pereira de Azevedo Neves, tido por monárquico, foi chamado ao Governo para aplicar na Secretaria de Estado do Comércio os seus úteis conhecimentos de especialista em autópsias segundo o reparo satírico de $A$ Lucta; o tenente-coronel de Cavalaria Álvaro de Mendonça, alegadamente monárquico e filho do general Honorato de Mendonça, durante muitos anos Comandante de Cavalaria 4 e Ajudante de Campo de D. Carlos, assumiu a responsabilidade pela Guerra; e o conterrâneo de Sidónio e seu companheiro no Parque Eduardo VII, capitão de Artilharia José João Pinto da Cruz Azevedo, ocupou o ingrato e difícil posto de Secretário de Estado dos Abastecimentos, novo ensaio institucional de coordenar uma área à mercê de incontáveis vicissitudes.

Ao todo este novo elenco governativo somou sete militares e cinco civis, ocupando aqueles os postos mais expressivos da autoridade do Estado ou os mais carecidos, no entendimento de Sidónio e seus colaboradores, dos atributos profissionais e morais inculcados pela formação militar. Nesta medida vislumbra-se, por comparação com os elencos anteriores, uma ligeira militarização no $16 .^{\circ}$ Governo remodelado.

Note-se ainda que a remodelação feita não implicou mudanças nos Governos Civis, verificando-se apenas em Aveiro e em Castelo Branco a substituição dos respectivos Governadores Civis em finais de Outubro.

(805) Ver MARTINS, Rocha - Memorias sobre Sidonio Poes, ob. cit., p. 222; e MONIZ, Egas - Um ano de política, ob. cit., p. 152.

(806) Cf. MONIZ, Egas - Um ano de política, ob. cit., p. 159

(807) Cf. Ibidem, p. 159 
Apesar das críticas dirigidas pela imprensa desafecta à situação, nomeadamente a de que vários Secretários de Estado não exibiam as correspondentes e aconselháveis qualificações técnicas e profissionais e de que alguns deles seriam monárquicos, $016 .^{\circ}$ Governo, remodelado em 8 de Outubro, tinha um núcleo relevante de ex-centristas encabeçados pelo seu ex-líder e líder do P.N.R., conservava em áreas orgânico-funcionais sensiveis e novas, como a Instrução, o Trabalho e a Agricultura, as mesmas equipas e não se desviava, afinal, das políticas anteriormente programadas.

Se, de relance, percorrermos a produção legislativa nas diferentes áreas constata-se, facilmente, a publicação de diplomas previstos nos relatórios-programas atrás focados e esta constatação é comum à generalidade das «pastas», salvo na recém-criada Secretaria de Estado dos Abastecimentos e no combate ao surto epidémico da pneumónica, levado a cabo pela conjugação de esforços do Trabalho, do Interior e da própria Presidência da República, designadamente através da Obra de Assistência de 5 de Dezembro, reforçada a miúdo com meios financeiros de apoio à sua actividade. ${ }^{(808)}$

A Secretaria de Estado da Instrução, como temos salientado, foi a esse propósito modelar, prosseguindo infrene e prolixa a obra reformista gizada após o golpe de Dezembro, promulgando quer ajustamentos da organização interna como a portaria n. ${ }^{\circ}$ 1.568 de 16 de Outubro que dividia, quanto à generalidade do expediente, a Repartição de Instrução Universitária em três Secções, ${ }^{\left({ }^{809}\right)}$ quer novos instrumentos legais para a grande reforma em curso, a saber: no âmbito do ensino secundário saiu na folha oficial o decreto n. 5.002 de 27 de Novembro aprovando os programas do ensino secundário ${ }^{\left({ }^{810}\right)}$ e pelo decreto $n{ }^{\circ} 4.961$ de II de Novembro foi regulamentado o ensino secundário feminino, professado no Liceu Nacional Central de Maria Pia de Lisboa, no Liceu Nacional Central Feminino do Porto, no Liceu Nacional Feminino de Coimbra e nas Escolas de Educação Feminina, e destinado a preparar a mulher para a vida do lar e de educadora de filhos e para todas as situações que não impliquem competência com o homem; ${ }^{(811)}$ para o ensino universitário há a assinalar o decreto n. $^{\circ} 4.945$ de I de Novembro que estabelece e ordena as disciplinas constituintes das diversas secções das Faculdades de Letras das Universidades de Coimbra e Lisboa e o decreto n. 5.046 de 30 de Novembro, que modificou e ampliou o plano organizativo da Faculdade Técnica da Universidade do Porto, dotando-a de capacidade para ministrar um ensino teórico, experimental e profissional aos cursos especiais de engenharia civil, de engenharia de minas, de engenharia mecânica, de engenharia electrotécnica, de engenharia químico-industrial e curso preparatório para a Escola de Guerra; o ensino artístico praticado pelas Escolas de Belas Artes de Lisboa e Porto foi, também, objecto de um diploma reformador - o decreto n. ${ }^{\circ} 5.053$ de 30 de Novembro - tendo em conta as conclusões da Comissão

${ }^{(808)}$ Através da Secretaria de Estado das Finanças, pelo decreto n. 4.931 de 19 de Outubro de 1918 era regulamentado um diploma anterior - o decreto $n .^{\circ} 4.694$ de 12 de Julho-que autorizava a Obra de Assistência 5 de Dezembro a emitir selos cujo rendimento revertia a favor do seu cofre.

(809) Cf. Diário do Governo. I série (232) 25 de Outubro de 1918, p. 1880.

(810) Cf. Diário do Governo.I série (257) 28 de Novembro de 1918,p. 2015-2016 e SÉRGIO,António - Breves anotações pedagógicas à ultima reforma de instrução secundaria. Pela Grei. Lisboa (6) 1919, p. 296.

(811) Cf. Diário do Governo. I série (247) 14 de Novembro de 1918, p. 1930. 
de 21 de Janeiro sobre a remodelação do ensino artístico; ${ }^{(812)}$ e, por fim, a questão do Teatro Nacional de Almeida Garrett foi retomada e atendidas as insistentes reclamações da opinião pública para que fosse reformada a sua organização, dispondo o decreto $n$. 5.052 de 30 de Novembro que seria retirada a concessão à Sociedade que explorava o Teatro (fixada pelo decreto de 4 de Agosto de 1898 e mantida pelo decreto de 12 de Outubro de 1912) a partir de 31 de Julho de 1919, altura em que o Governo deveria ter já uma proposta de reforma do Teatro Nacional elaborada por uma Comissão para o efeito nomeada ${ }^{(813)}$ neste mesmo decreto.

No último trimestre de 1918 o ímpeto reformista, igualmente verificado na Agricultura desde que foi criado o respectivo Ministério/Secretaria de Estado, parece ter perdido fôlego, reduzindo-se a dois diplomas que se encaixam perfeitamente no programa delineado por Fernandes de Oliveira: o decreto n. ${ }^{\circ} 4.908$ de 19 de Outubro que prescrevia a constituição e regulava o funcionamento dos conselhos administrativos dos Postos Agrários nas sub-regiões sedes de região; e o decreto n. ${ }^{\circ} 5.068$ de 30 de Novembro, que fixava a coordenação e unificação dos Serviços de Meteorologia Agrícola criados pela organização da Secretaria de Estado da Agricultura contida no decreto n. ${ }^{\circ} 4.219$ de 8 de Maio.

Ao compulsarmos o Diário do Governo fica a impressão de ter sido cumprida, no plano legislativo, toda a reforma estrutural pensada para o sector agrícola, e a impressão oposta é suscitada pelo pacote legislativo saído da Secretaria de Estado do Comércio sob a superior direcção de Azevedo Neves. São meras impressões extremas que a análise histórica permite rectificar. ${ }^{(814)}$

O legislador reformista confessou o móbil do seu esforço - preparar o futuro imediato do pós-guerra marcado previsivelmente por uma forte concorrência para a qual o país tinha urgentemente de se dotar das condições essenciais. Daí a reforma do ensino técnico industrial e comercial, assim como a reforma e a reorganização dos serviços públicos, como os postais, telegráficos, telefónicos e de fiscalização das indústrias eléctricas. Daí, enfim, os veementes apelos ao contributo de todos o intervenientes no processo produtivo nacional irmanados na defesa do interesse comum. Mas das palavras aos actos costuma ser grande a distância e nesses «anos loucos» era ainda maior, porque a «galinha dos ovos de ouro» nutrida pela economia de guerra, especulativa e socialmente injusta, estava a acabar. Com o fim da Guerra chegou o esboroamento de um mercado artificial que absorvia o trabalho da indústria e com o início da paz desencadeou-se logo o pânico, apesar dos textos tranquilizadores de Bento Carqueja e de Quirino de Jesus nas páginas do Comércio do Porto e do Economista Portuguez respectivamente.

Mas a sensação de ameaça encastelada no horizonte e agravada pela preparação de uma greve geral alegadamente revolucionária tornou-se muito forte entre os patrões e

(812) A precipitação frequente, então, na confecção dos diplomas legislativos fez que este decreto voltasse a ser publicado com correcçōes no Diário do Governo. I série (281) 27 de Dezembro de 1918, p. 2225-2227.

(813) Cf. Diário do Governo. I série (275) 18 de Dezembro de 1918, p. 2186.

(814) Ver SILVA, Armando Barreiros Malheiro da - Sidónio e sidonismo. História e mito, dissert. cit., vol. 2. p. $488-491$. 
a 9 de Dezembro chegou mesmo a constituir-se, em sessão efectuada na Sociedade de Geografia, a Aliança do Comércio e Indústria, reunindo industriais, armazenistas e distribuidores em torno de um programa comum que ao visar, em última instância, a abolição de todas as restrições legisladas durante o período de guerra, de circulação e permuta de produtos, que prejudiquem o livre exercício do comércio e indústria, como meio de contrariar toda a expeculação ou açambarcamento pela aç̧ão da concorrência, ${ }^{\left({ }^{815}\right)}$ exprimia mudança: pode sem dúvida aceitar-se - observou Vasco Pulido Valente - que no programa de acção da Aliança o ano de 1918 depois de ver a maior intervenção estatal na economia, assiste também ao princípio das tendências anárquicas do pós-guerra. ${ }^{(816)}$ No entanto, estes lampejos projectados para o futuro ocorreram num tempo dominado pelas aflições e pelas ilusões do presente: na resposta limitada e imediata às dificuldades mais prementes misturava-se a idealização catártica de um Portugal novo, feliz e próspero.

Regeneração e prosperidade sonhadas no meio das fortes tenazes de uma crise para a qual continuavam a faltar as grandes soluções, fosse na indústria, fosse no comércio interno e externo ${ }^{(817)}$ ou na desconcertada e desconcertante distribuição dos géneros. Tão desconcertada e desconcertante que em cerca de dez meses o Governo teve de ensaiar um quarto arranjo institucional para cumprir os seus proclamados propósitos em nome do Bem Comum: abastecer o público de forma equitativa e dentro dos preços fixados. Mas para isso, como notou Vasco Pulido Valente, era preciso atacar os interesses vitais dos retalhistas, ou seja, da burguesia comercial das cidades, pulverizada por todo o país numa malha de cerca de 70.000 comerciantes independentes, difíceis de controlar a partir de Lisboa. ${ }^{(818)}$

○ 16. Governo sidonista tentou-o, como vimos, através da acção conjugada de Bernardino Ferreira e Botelho Moniz no âmbito da Direcção Geral das Subsistências integrada na Secretaria de Estado do Interior. Fizeram varejos e prisões. Incomodaram o comércio a retalho e este reagiu forçando uma pausa e um recuo governamentais que durou até ser criado o Comissariado Geral dos Abastecimentos e depois a Secretaria de Estado dirigida por um militar e na qual aparece, de novo, Botelho Moniz a desempenhar as funções de Director Geral das Subsistências e animado das mesmas tácticas de pressão sobre os açambarcadores.

A anormalidade, para parafrasearmos Vasco Pulido Valente, ${ }^{(819)}$ ou seja, o desassossego dos retalhistas e dos especuladores em geral renasceu com a presença de Botelho Moniz e de Cruz Azevedo, ambos militares dezembristas, à frente da distribuição dos géneros. Varejos geraes e rigorisissimos voltou a ser a expressão em uso e não apenas circunscrita a Lisboa, mas extensiva a todo o país!...

(815) Cit. porVALENTE,Vasco Pulido - Estudos sobre Sidónio Pais: agricultura e proletariado agrícola; indústria e sindicatos; comércio externo, in Idem - Estudos sobre a crise nacional, ob. cit., p. 276.

(816) Cf. Ibidem, p. 277.

(817) Ver sobre este assunto Ibidem, p. 286-292.

(818) Ver lbidem, p. 314-317.

(819) Cf.Ver lbidem, p. 318. 
Na I. árie do Diário do Governo, pelo decreto n. 4.879 de 9 de Outubro, foi novamente restituído à categoria institucional de Ministério ou Secretaria de Estado o sector excepcional das subsistências, abastecimentos e transportes e na $2{ }^{\text {a }}$ série, com a mesma data, foi nomeado novamente um militar para geri-lo com muito empenho e «mão de ferro» às ordens do Presidente da República. Este último detalhe parece-nos importante: Cruz Azevedo assumiu-se como um indefectível seguidor e um diligente colaborador de Sidónio Pais, não como um concorrente ou um primus inter pares à maneira de Machado Santos. E é também importante sublinhar que, tal como o efémero Ministério das Subsistências e Transportes, a Secretaria de Estado dos Abastecimentos, instituída pelo decreto 4.879 , concentrou, para além dos serviços do anterior e extinto Comissariado Geral dos Abastecimentos, todos os meios orgânico-operacionais dispersos pelas Secretarias de Estado do Interior, Comércio e Colónias a fim de intervir de forma possivelmente mais coordenada e eficaz, impondo-se para tanto a reforma e a regulamentação de tais serviços em diploma especial. ${ }^{820)}$ No decreto da criação ficou ainda estipulado que os vencimentos do Secretário de Estado dos Abastecimentos e as remunerações para os seus secretários seriam idênticas às consignadas nas tabelas orçamentais para a Secretaria de Estado do Comércio e que era desde já autorizada a abertura dos necessários créditos especiais para todas as despesas que se julguem precisas para a completa execução do disposto no presente decreto. ${ }^{(821)}$

Assente nesta base legal e orgânica, a nova Secretaria de Estado entrou, de imediato, em acção quer através da retoma da fiscalização no terreno e à escala nacional da forma acima exposta, quer pela via legislativa, investindo necessariamente na função regulamentadora dos preços dos géneros alimentares e noutras disposições que permitissem racionalizar o consumo: pelo decreto $n .{ }^{\circ} 4.899$ de 16 de Outubro ordenava-se que a partir do dia 19 todas as fábricas de moagem de Lisboa se subordinassem aos diagramas em anexo, fixando os novos tipos de pão na cidade de Lisboa; ${ }^{(822)}$ a distribuição gratuita de senhas e cartas de consumo determinada por não ser justo que o público pague as senhas destinadas à distribuição de géneros, visto nem sempre ser possível garantir o regular abastecimento dos mercados, ${ }^{(823)}$ e a subvenção de $40 \$ 00$ mensais para as Câmaras Municipais de todo o país e Juntas de Freguesia de Lisboa e Porto e de $10 \$ 00$ a cada regedor dos restantes concelhos a fim de aliviar as despesas de distribuição e autenticação das senhas consta do disposto no decreto n..$^{\circ} 4.921$ de 28 de Outubro; as agravadas dificuldades no abastecimento de carnes, na maior parte dos centros populosos do país, justificaram a promulgação do decreto n. 4.950 de 8 de Novembro concebido para atacar a solução do problema, atendendo por um lado, à aquisição económica do gado, e

(820) Parece não ter sido promulgado e à falta deste instrumento legal é difícil reconstituir com todo o detalhe a estrutura orgânica da Secretaria de Estado dos Abastecimentos. No entanto, através de informação indirecta podemos adiantar que ela compreendeu a Direcção Geral dos Abastecimentos, a Direcção Geral das Subsistências, a Direcção Geral dos Transportes Marítimos e a Direcção Geral dos Transportes Terrestres, substituída em Dezembro pela Direcção Geral dos Caminhos de Ferro.

(821) Cf. Diário do Governo. I série (221) 10 de Outubro de 1918.

(822) Matéria retomada e esclarecida através do decreto $n .^{\circ} 4.936$ de 2 de Novembro.

${ }^{(823)}$ Cf. Diário do Governo. I série (235) 29 de Outubro de 1918. 
por outro lado aos preços correspondentes na venda da carne a retalho, de forma que êsse indispensável alimento não fique fora do alcance da maioria dos consumidores, ${ }^{(824)}$ e promovendo a reprodução bovina nacional quer pela restrição da matança do gado, quer pela protecção das fêmeas em idade de reprodução como noutros países proficuamente tem sido legislado.

Não se esgotou, porém, na difícil gestão do abastecimento a actividade legislativa da Secretaria de Estado, merecendo, por fim, destaque outros diplomas: pela Direcção Geral dos Transportes Marítimos o feito do Augusto de Castilho e seu comandante, o malogrado tenente José Botelho de Carvalho Araújo, incansavelmente louvado pela imprensa e saudado pela opinião pública e autoridades, foi apreciado, contribuindo essa Direcção Geral com a quantia de $5.000 \$ 00$ para a subscrição aberta pelas Companhias de Seguros nacionais a fim de ser entregue às familias do glorioso comandante do Augusto de Castilho, primeiro tenente da marinha, José Botelho de Carvalho Araújo; do aspirante Carlos Elói da Mota Freitas; e das praças da armada que pereceram no combate; ${ }^{(825)} \mathrm{e}$, em finais de Novembro, a polémica regulamentação dos Caminhos de Ferro que provocara a queda de Machado Santos saía de novo sob a forma de lei - decreto n. 5.039 de 30 de Novembro ${ }^{(826)}$ - e em moldes mais consentâneos com as reclamações anteriormente suscitadas por certos sectores, designadamente a Administração da C.P., sendo, para o efeito, extinta a Direcção Geral dos Transportes Terrestres e criada a Direcção Geral dos Caminhos-de-Ferro, que passava a ter a seu cargo todos os assuntos relativos aos caminhos de ferro do continente, à excepção dos referentes à Administração dos Caminhos-de-Ferro do Estado reorganizada pelo mesmo diploma.

$\mathrm{Na}$ «pasta» da Justiça e dos Cultos havia uma reforma há muito traçada que os diferentes titulares, todos juristas, não alteraram, convergindo sempre na sua aplicação. Dentro desta linha de continuidade inserem-se alguns decretos publicados entre inícios de Outubro e meados de Dezembro. Mas a reforma prosseguida implicou, também, como era costume, uma inflexão sobre os aspectos orgânico-funcionais endógenos à própria estrutura ministerial e daí o decreto n. ${ }^{\circ} 5.021$ de 29 de Novembro( ${ }^{827)}$ que reorganizou a Secretaria de Estado da Justiça e dos Cultos estabelecendo e regulando, como divisões orgânicas, o Gabinete do Secretário de Estado, a Secretaria Geral (Repartição Central) e a Direcção Geral da Justiça e dos Cultos. Neste diploma acha-se ainda especificado o respectivo quadro de pessoal, as suas atribuições e deveres, o provimento dos cargos, licenças, acção disciplinar, aposentação e vencimentos, as condições de trabalho e funcionamento e a reorganização dos chamados serviços médico-forenses desempenhados por médicos legistas nas comarcas judiciais do continente e ilhas. ${ }^{(828)}$

(824) Cf. Diário do Governo. I série (243) 9 de Novembro de 1918. Este diploma foi rectificado e republicado in Ibidem (248) 15 de Novembro de 1918, p. 1937-1938.

(825) Cf. Decreto n. 4.973 de 15 de Novembro. Diário do Governo. I série (249) 16 de Novembro de 1918 , p. 1941 .

(826) Cf. Diário do Governo. I série (266) 9 de Dezembro de 1918, p. 2121 -2145. Republicado in Ibidem, (278) de 22 de Dezembro de 1918, p. 2191-2215.

(827) Cf. Diário do Governo. I série (26I) 3 de Dezembro de 1918, p. 2047-2048.

(828) Matéria tratada especificamente nos decretos n. 5.023 de 29 de Novembro e n. 5.069 de 22 de Dezembro de 1918. 
Por entre os seus negócios correntes sobressai a delicada questão dos direitos e obrigações de senhorios e arrendatários de prédios urbanos, questão de reconhecida pertinência sócio-económica e traduzida num controlo dos aumentos de renda dentro da crise então vivida. Explica-se, por isso, no preâmbulo do decreto n. ${ }^{\circ} 4.952$ de 9 de Novembro, a conveniência de assegurar a execução do disposto no artigo $45 .^{\circ}$ e seu parágrafo do decreto n. ${ }^{\circ} 4.499$ de 27 de Julho por um conjunto de providências que constituindo a sanção dessas disposições, evitem que elas continuem a ser sofismadas e iludidas práticamente, como estão sendo, em prejuizo dos justos intuitos que as inspiraram, na anormalidade da situação económica e social criada pelo estado de guerra.(829)

Na Marinha e nas Colónias a produção legislativa publicada no último trimestre de 1918 não trouxe novidades e manteve-se, por isso, nos trilhos dos programas atrás focados. Em relação àquela Secretaria de Estado ocorre, apenas, destacar o decreto n. ${ }^{\circ} 5.041$ de 3 de Dezembro, que punha em execução o regulamento orgânico desse organismo governamental na parte concernente ao Conselho General da Armada e à I. Direcção Geral da Armada (Majoria General da Armada) ou ainda a concessão, pelo decreto n. 5.044 de 29 de Novembro, da pensão anual de $1.200 \$ 00$ à viúva do comandante do Augusto de Castilho, morto em combate. E no respeitante à Secretaria de Estado das Colónias, onde se manteve Vasconcelos e Sá, deparamos com medidas administrativas específicas de gestão corrente que vão desde a fixação (decreto n. ${ }^{\circ}$ 4.956 de 7 de Novembro) do horário de trabalho nos estabelecimentos comerciais da cidade da Beira e seus arrabaldes até à autorização concedida ao Banco Nacional Ultramarino para fazer uma nova emissão de notas na sua filial de Lourenço Marques, passando ainda pela regulamentação (decreto n. ${ }^{\circ} 4.959$ de 21 de Outubro) dos Serviços Clínicos e Administrativos do Hospital Colonial de Lisboa, pela abertura de créditos destinados a obras ou a outros fins e pela contagem do tempo de serviço (decreto n. ${ }^{\circ}$ 4.976 de 7 de Novembro) prestado pelos magistrados judiciais e do Ministério Público no cargo de Secretário dos Negócios Indígenas de qualquer província ultramarina. Diplomas menores ou triviais que ocuparam, para o período em foco, todo o «espaço» legislativo, faltando aí as leis anunciadas e exigidas pelo plano de actividades delineado no relatório-programa atrás exposto.

Em estreita dependência da evolução da horrenda guerra, cada vez mais próxima da hora final do Armistício e das suas imediatas consequências, mantiveram-se as políticas externa e de guerra, assim como as iniciativas de reestruturação interna e de definição, por exemplo, de uma política nacional de defesa. Basta, para compreendê-lo, compulsar a legislação produzida, embora se detectem inevitáveis excepções...

No caso da Secretaria de Estado dos Negócios Estrangeiros, sublinhe-se a concessão pelo decreto n. 5.026 de 25 de Outubro, de um subsídio anual à cadeira de língua e literatura portuguesa a criar na Universidade de Londres com o título de Cadeira Camões; e a regra surge, confirmada pelo decreto n. ${ }^{\circ} 4.926$ de 22 de Outubro, que criou uma Comissão incumbida de coligir, examinar e coordenar todas as informações relativas aos bens e interesses privados portugueses existentes em território inimigo ou por ele ocupado e aos do inimigo nos territórios da República portuguesa.

(829) Cf. Diário do Governo. I série (246) 13 de Novembro de 1918, p. 1923-1924. 
Quanto à «pasta» da Guerra repare-se neste encadeamento de disposições legais: o decreto n. ${ }^{\circ} 4.868$ de 5 de Outubro concedia uma pensão complementar a todos os militares mutilados ou estropiados da guerra; o n. ${ }^{\circ} 4.932$ de 31 do mesmo mês levou em conta, para efeitos de apuramento do tempo necessário da rendição do pessoal do C.E.P., o serviço anteriormente prestado em expedições militares no ultramar, estabelecendo a sua equivalência; o $n$. $^{\circ} 5.060$ de 30 de Novembro concedia uma medalha comemorativa aos militares e civis que participaram nas expedições militares da província de Moçambique de 1914 a 1918; e o n..$^{\circ}$.061 de 30 de Novembro concedia uma medalha comemorativa aos militares e civis que integraram o C.E.P.. Nas bordas deste tipo de legislação avultam outros diplomas, tais como o n. ${ }^{\circ} 5.030$ de I de Dezembro, que não só restabelecia as antigas Ordens Militares (Ordens de Cristo e S.Tiago da Espada), mas também remodelava as de Avis e da Torre e Espada, do Valor, Lealdade e Mérito, atendendo a que o actual momento histórico instantemente aconselha e a que a grandiosa epopeia, escrita em letras de fogo e de sangue, da formidável guerra, que felizmente atingiu o seu termo, e que o esfôrço militar português, ao lado dos exércitos aliados, representou um papel dos mais nobres da nossa história e digno de altissimo prémio impunha ao Governo o indeclinável dever de distinguir os seus mais notáveis protagonistas de forma a apontálos e impó-los à consideração dos seus concidadãos; ${ }^{(830)}$ o n. ${ }^{\circ} 5.031$ de 30 de Novembro que aplicava aos oficiais médicos e veterinários do quadro permanente as disposições do decreto com força de lei n. ${ }^{\circ} 3.835$ de 14 de Fevereiro sobre promoções; o n. ${ }^{\circ} 5.032$ da mesma data recompunha, por ser precária a organização das tropas de caminho de ferro, quer se considerem as exigências da mobilização quer as do serviço em tempo de paz, a estrutura e eficácia de uma unidade especial que não comportava, ultrapassadas as contingências da guerra, um elevado contingente de recrutas; e o n. ${ }^{\circ} 5.062$ de I de Dezembro aprovava e mandava executar o regulamento literário ou curricular do Colégio Militar, instituição aí fixada como liceu central, para todos os efeitos de ordem pedagógica, tendo os exames nele feitos a mesma validade que os realizados nos liceus e seguindo-se em tudo os programas do ensino liceal.

\section{A Pneumónica ou influenza}

Mas enquanto uma guerra ia chegando ao fim, inspirando legislação destinada a acautelar o futuro imediato, outra — filha da anterior e incomparavelmente mais mundial — tinha começado célere e medonha, contra um inimigo invisível e implacável, impondo a mobilização de todos e do Governo.

Embora impotente face às dimensões da calamidade e cercado já noutras frentes, o Governo sidonista tentou, com muito voluntarismo e o concurso de especialistas, conjugar verbas, creditadas através da Secretaria de Estado das Finanças, esforços e iniciativas de apoio que envolveram tanto a Presidência da República, como as Secretarias de Estado do Trabalho e do Interior, empenhadas igualmente na prossecução dos seus planos de

(830) Cf. Diário do Governo. 1 série (264) 6 de Dezembro de 1918, p. 2113 . Republicado in Ibidem (280) 24 de Dezembro de 1918, p. 2222-2223. 
aç̧ão e de rotina administrativa. E sob a chancela do Trabalho foi publicado o decreto n. ${ }^{\circ} 4.872$ de 7 de Outubro, ${ }^{(831)}$ criando o lugar de Comissário Geral do Governo com precisos poderes para combater a epidemia de gripe pneumónica.

Para esse alto posto de vanguarda na direcção de tão difícil combate foi nomeado primeiramente João Alberto Pereira de Azevedo Neves, entretanto chamado para a Secretaria de Estado do Comércio, e logo substituído pelo eminente epidemologista Ricardo Jorge, até à data Director Geral de Saúde na Secretaria de Estado do Trabalho e que nesse lugar vinha já enfrentando, desde Maio, a epidemia gripal, assim como vinha dirigindo a campanha sanitária contra o tifo exantemático ou tabardilho. Da sua acção chegaram à Presidência da República alguns testemunhos documentais de que destacamos, a título de exemplo, dois ofícios datados do mês de Setembro que retratam, de forma impressiva, a dramática eclosão e permanência desse surto epidémico e a estratégia adoptada para o debelar, faltando, porém, dramaticamente o dinheiro necessário.(832)

Influenza, ${ }^{(833)}$ gripe espanhola, andaço ibérico, ${ }^{(834)}$ bronco-pneumónica ou simplesmente pneumónica são as designações de uma mesma infecção vírica (de um tipo de vírus mutante isolado em 1933 porW. Smith e colaboradores, o que permitiu a preparação de vacina própria) muito contagiosa, repentina, mal de pouca dura, e ai de nós se assim não fosse, como escreveu Ricardo Jorge, e sob a forma de praga, para o que muito contribuíram as deficiências imunológicas e a fácil actuação de bactérias oportunistas num quadro alimentar e sanitário assaz calamitoso.

Os efeitos patológicos da gripe no homem podem ser explicados do seguinte modo: limita-se aparentemente à camada epitelial e subepitelial do aparelho respiratório e após o seu aparecimento produz-se uma grande inflamação nos tecidos atacados de modo a facilitar o acesso dos anticorpos que interrompem a acção vírica; o vírus gripal causa, assim, lesões nas células epiteliais que podem abrir caminho a infecções bacterianas secundárias geradoras, sobretudo, de complicações pulmonares; e também, mas com menor frequência, surgem complicações em que não intervém nenhum agente secundário, sendo causadas directamente pelo vírus - é o caso pneumonia gripal primária, que irrompe poucas horas após ter-se manifestado a gripe e suscita um prognóstico muito grave ou ainda o caso de uma encefalopatia que afecta geralmente as crianças. ${ }^{(835)}$

A caracterização epidemiológica da infecção vírica gripal permite compreender que ela se tenha tornado subitamente pandémica — por várias vezes ao longo da História, a

(831) Dossier Epidemias, sub-dossier 32 Typho exantematico e hespanhola e encefalite-letargica, Decreto que cria o lugar de Comissário Geral do Governo, original assinado por Sidónio Pais e Secretários de Estado, 2 fls. (Arquivo de Sidónio Pais - Militar, Lente e Político, Subsistema Presidência da República).

(832) Ibidem, Oficio n. 388 do Director Geral de Saúde, 14 de Setembro de 19/8).Ver SILVA,Armando Barreiros Malheiro da - Sidónio e sidonismo. História e mito, dissert. cit., vol. 2, p. 499-501...

(833) Ver ECHEVERRI DÁVILA, Beatriz - La Gripe española. La pandemia de 1918-1919. Madrid: Centro de Investigaciones Sociológicas/Siglo XXI de España Editores, S.A., 1993, p. 4; e Harrinson's principles of internal medicine, 12 ed. New York: Mac Graw-Hill, 1991, p. 696-70.

(834) Expressão empregue pontualmente por Ricardo Jorge.

(835) Dossier Epidemias, sub-dossier 32 Typho exantematico e hespanhola e encefalite-letargica, I fl. s.d. dactiloscrita. (Arquivo de Sidónio Pais - Militar, Lente e Político, Subsistema Presidência da República). 
última das quais entre Maio e Junho de 1889 e $1890^{(836)}$ - com uma primeira notícia segura acerca do seu aparecimento explosivo num acampamento do Exército americano, em Funston, Kansas, a 4 de Março, enquanto em Detroit mil operários da Ford Motor Company ficaram acamados e numa pequena povoação do Kansas dezoito pessoas adoeceram repentinamente, multiplicando-se os incidentes semelhantes por vários pontos dos Estados Unidos. Como a gripe não era aí uma doença de declaração obrigatória as autoridades ignoraram-na, processando-se o envio de tropas americanas para o teatro de operações militares sem qualquer controlo especial sobre uma simples e inofensiva gripe que apresentava sintomas típicos — forte cefaleia, dores musculares e articulares, prostração e febre alta que podia ir aos $40^{\circ}$, podendo ainda ser acompanhada de conjuntivite, catarro, erupções na pele e náuseas - e ao cabo de uma semana o enfermo restabelecia-se, embora uma pequena percentagem de afectados tenha morrido pelo efeito de inesperadas complicações.

Esta primeira onda epidémica americana, difundida pelo contínuo movimento de tropas, estendeu-se rapidamente desde Oriente até à costa Este, coincidindo com a fase das grandes mobilizações das tropas americanas que entravam, finalmente, no conflito contra os Impérios Centrais e iam ajudar os Aliados a travar a última grande ofensiva alemã, tendente a romper as linhas da frente Oeste. Para tanto os E.U.A. deram um contributo significativo de homens e de tal forma que o número de 85.000 combatentes aliados em França passou para 1.200.000. Com este acentuado aumento surgiu logo o registo dos primeiros caos de gripe entre as forças expedicionárias americanas aquarteladas em Bordéus e Brest, dois dos principais portos de desembarque de tropas.

$\bigcirc$ médico americano W. T. Vaughan, que seguiu muito de perto a evolução da epidemia, não hesitou em afirmar que a gripe foi levada para França por essa grande massa de homens vindos da América do Norte. Esta opinião foi, todavia, contrariada por outros autores, para quem a gripe começara na Europa, dado o aparecimento recorrente de pequenos surtos epidémicos desde 1915 entre as tropas acampadas, e houve ainda quem sugerisse que o foco original teve lugar nas estepes centrais do continente asiático, na mesma zona onde se localizou a maioria das pandemias (1847, 1890, 1957 e 1968), exportando-se para França nos primeiros meses de 1918 através dos 200.000 emigrantes chineses postos a trabalhar na retaguarda.

No entanto, para a autora que estamos a seguir, ${ }^{(837)}$ estas teses não suplantam a hipótese, documentalmente apoiada, de que a pandemia teve início no Médio Oeste americano e assim sendo a denominação gripe espanhola - muito generalizada e não apenas em Portugal, único país, segundo Ricardo Jorge, onde a expressão fazia sentido já de que é de Espanha, nossa vizinha, donde recebemos a presente infecção. Mas somos a única nação que o empregamos com propriedade ${ }^{(838)}$ - não tem qualquer fundamento,

(836) Cf.ANDRADE, Helena Rebelo de e PAIXÃO, Maria Teresa - História das grandes pandemias de gripe. Pathos. Monografias de Patologia Geral. Lisboa, 12 (9) Out. 1996, p. 22-23.Ver também MARGOTTA, Roberto - História ilustrada da medicina. Lisboa: Reed International Books Limited/Centralivros Edição e Distribuição Lda, 1996, p. 166-167.

(837) A base deste genérico enquadramento temático é - repetimo-lo - o estudo de ECHEVERRI DÁVILA, Beatriz - La Gripe española. La pandemia de 1918-1919, ob. cit., p. 3-59.

${ }^{(838)}$ Cf. JORGE, Ricardo - A Gripe. Relatório. Lisboa: Imprensa Nacional, 1919, p. II. 
tanto mais que a primeira onda de gripe surgiu no mês de Maio em Espanha, vinda de França e nunca o contrário (a exagerada xenofobia francesa culpou, porém, os operários espanhóis emigrantes em território gaulês), dois meses depois de ter invadido os E.U.A.. Foi, pois, daí e de França que a propagação se fez, atingindo, no mês de Maio, Espanha, Portugal, Itália, Grécia, Albânia, Escócia e norte de África, em Junho alastrou pela Dinamarca e a Noruega, e, em Agosto, pela Holanda e a Suécia.

Manifestando-se por ondas ou vagas, a epidemia teve uma primeira ofensiva, claramente pandémica, a partir de Junho e até Setembro, espalhando-se por quase todo o globo, mas os autores e a análise dos dados disponíveis parecem indicar ter tido poucas consequências sociais ou demográficas, radicando sobretudo o seu interesse no facto de ter sido a precursora da onda do Outono, considerada por M. Burnet como a peor plaga de la historia. ${ }^{\left({ }^{839}\right)}$ Esta praga ou segunda onda surgiu e disseminou-se pouco depois do aparente desaparecimento da anterior e a 22 de Agosto o doutorVaughan, médico das forças expedicionárias americanas, dava conta de um violento recrudescimento da primeira onda epidémica na Europa. Nessa última semana de Agosto explodia a segunda onda epidémica a partir de Freetown, Sierra Leone e, ao mesmo tempo, eram registados os primeiros casos em Boston, assim como há igualmente registo do aparecimento da mesma onda em Portugal.

Mas mais importante que determinar o seu berço urge assinalar a sua gravidade e expansão avassaladora: em Outubro de 1918 todos os continentes, à excepção da Austrália, enterraram milhões de mortos por gripe. $\bigcirc$ vírus, durante a segunda onda, difundiu-se com uma velocidade espantosa e o curioso é que a semana de máxima mortalidade coincidiu em Boston e Bombaim. Cidades tão distantes como Paris, Berlim, New York e Seattle registaram, também, a máxima mortalidade na semana que finalizou a 26 de Outubro; o mesmo sucedeu na Nova Zelândia e na Grã Bretanha, enquanto por esses dias se utilizaram, em Bogotá, os veículos da recolha de lixo para transportar os mortos e em New York eram abertas valas comuns com escavadoras a vapor. As proporções atingidas por esta segunda onda parecem estar reflectidas nos números oficiais de mortos verificados em vários países: em França terão morrido 166.000 pessoas; na Alemanha 225.330; na Grã-Bretanha 228.900; nos E.U.A. 550.000; e na Índia julga-se terem morrido 16 milhões. $O$ seu impacte foi particularmente pesado nas crianças e nos jovens: cerca de $25 \%$ das suas vítimas tinham I 5 anos ou menos e cerca de $45 \%$ estavam entre os 15 e os 35 anos. Ao todo terão morrido vinte milhões, cifra bem maior da causada pela Grande Guerra. ${ }^{(840)}$

Repentina a aparecer e veloz a espalhar-se, a pandemia gripal extinguiu-se pelo Natal de 1918, podendo, então, a maior parte do Mundo congratular-se por ter sobrevivido a uma guerra e a uma moléstia tão atroz. Mas a trégua voltou a ser curta, porque nos inícios do novo ano a gripe reincidiu em amplas zonas da América do Norte e da Europa. Era a terceira e última onda que não foi tão definida, nem tão universal que a anterior,

(839) Cf. BURNET, M. - Historia de las enfermedades infecciosas. Madrid: 1967, p. 299 (cit. por ECHEVERRI DÁVILA, Beatriz - La Gripe española. La pandemia de 1918-1919, ob. cit., p. 27.

(840) Cf. CAMPBELL, John et al. - História do século XX. vol. 2 - 19/4-1918/ Guerra Mundial, ob. cit., p. 167. 
embora apresentasse o mesmo carácter maligno: uma elevada percentagem de complicações pulmonares e uma mortalidade que incidiu, sobretudo, nos jovens adultos. ${ }^{(841)}$

Em Portugal esta onda não teve, porém, o impacte das anteriores, como sugerem os números de mortos conhecidos (dos não mortais a cifra ignora-se, traduzida na fórmula vaga de milhares e milhares): ${ }^{(842)}$ de 381 óbitos em Agosto de 1918, 1270 em Setembro, 31.785 em Outubro - o clímax da epidemia - 18.123 em Novembro e dos 2.216 de Dezembro foi-se passando para os 720 em Janeiro de 1919, 163 em Fevereiro, 135 em Março, recrudescendo em Abril com 401 casos mortais e em Maio com 655. De Julho em diante a epidemia será debelada, ${ }^{(843)}$ mas os estragos demográficos, económicos e afectivos causados na sociedade portuguesa levariam tempo a cicatrizar.

E já que retornamos, inevitavelmente, ao caso português, convém mostrar, de relance, como a influenza, gripe ou pneumónica se espalhou aqui e como é que as autoridades geriram, em circunstâncias quase dantescas, as parcas e fracas medidas sanitárias aplicáveis.

Num detalhado relatório entregue ao Conselho Superior de Higiene, em sessão de 18 de Junho, Ricardo Jorge começou logo por assinalar o momento da chegada do flagelo espanhol ao nosso território, suas vítimas iniciais e diligências oficiais para enfrentá-lo, tardias e ineficazes, porque a indispensável prevenção, mas obviamente impraticável, tinha de ser fronteiriça e nos portos marítimos:

De má nota para os fastos epidemologicos vai este ano corrente; ainda mal entrava de quebrar o tabardilho que de memoria de homem se não alastrara assim entre nós, e já soprava de Espanha a ameaça dum flagelo, o mais contagionante de todos, a querer repetir a ruidosa intrusão de ha 30 anos.

Ainda antes que os periodicos notificassem o rebentar da praga em Madrid, chegara-nos a denuncia de que em Badajoz andava enfermidade suspeita de colera; um distinto medico sanitario da raia ali enviado em missão, desfez o boato já de si nada veraz. A seguir vem á publicidade a deflagração do andaço madrileno que num lapso de não muitos dias rastilha a Espanha inteira, cruzando-a de norte a sul e de leste a oeste.

Na sessão de 28 de maio, ao darmos conta desta irrupção - de que pediramos a 23 e a 27 informação pelo consulado de Madrid - assinalamos o seu caracter influencial, similar aó da pandemia classica de $1889-90$ e da recente dos Estados Unidos (1915-16), mostrando o perigo que corriamos de rolar sobre nós a vaga epidemica que já se espraiava na raia em Badajoz e Ciudad Rodrigo. Hoje sabemos pelas nossas autoridades consulares em Hespanha e pelas sanitarias da fronteira que a molestia se fechou em arco desde Tui no Minho a Aiamonte no Guadiana.

A 31 de maio recomendamos ás delegações de saude que avisassem a sobrevinda de casos da epidemia hispanica que «ameaçava imediatamente os concelhos

(841) Ver ECHEVERRI DÁVILA, Beatriz - La Gripe española. La pandemia de 1918-1919, ob. cit., p. 43-44.

(842) Cf. MARQUES.A. H. de Oliveira - História da 1. ${ }^{\circ}$ República portuguesa. As Estruturas de base, ob. cit., p. 11.

(843) Cf. Ibidem, p. 12. 
da fronteira e os grandes centros)». Não tardaram essas novas, precisamente da zona raiana e das grandes cidades; dão conta dela, em Vila Viçosa por fins de maio, a atacar um quinto da população, trazido o contagio pelos trabalhadores ruraes de retorno de Badajoz e Olivença (2 de Junho); logo após (10 de Agosto) nos logares fronteiriços de Terrugem (Elvas) e Assumar (Arronches); veiu o Porto ( 10 de Junho), onde lavra pelas familias e no Aljube junta 18 casos; emfim Lisboa onde se indicia ( 1 I de Agosto) na prisão de Monsanto (50 casos) e na secção dos mutilados de guerra do Instituto medico-pedagogico da Casa Pia. Foram os seus primeiros rebates conhecidos.Assentou pois arraiaes na peninsula inteira, e agora dificilmente, segundo os seus habitos, deixará de haver canto que escape ás presas do inficionamento. ${ }^{\left({ }^{844}\right)}$

Depois da gripe ter penetrado célere e abrasado todo o território, a questão que se pôs com angustiante impotência foi esta: que fazer? E a resposta foi difícil e vaga.

Para o Comissário Geral do Governo impunha-se reconhecer, no mesmo relatório, que para um contagio difusivo como o gripal, nada ha por ora que precate e defenda. Ha que suporta-lo sem mais, e se já na vida civil as baixas nos elementos activos da industria e do comercio chegam a causar um real prejuizo á vida economica, nos arraiaes de guerra - acervo das baixas póde ser tal que inutilize um exercito transitoriamente para as operações de campanha. Se o virus se permeia até ás trincheiras e acampamentos, ou atravez da Europa central sobre as fileiras alemãs, ou atravez dos Pirineus importado de Espanha, sobre as hostes aliadas, dará que falar nos fastos da guerra. ${ }^{(845)} \mathrm{E}$ mais adiante retoma a questão para se pronunciar, algo reticente, quanto à eficácia do isolamento e da prática massiva de internamentos, ${ }^{(846)}$ que eram, afinal, inevitáveis, como recomendáveis eram certos cuidados básicos. ${ }^{(847)}$ Agasalho hospitalar ou domiciliário, redução dos contactos ao mínimo, supressão dos habituais cumprimentos e reverências - apertos de mão e osculos de cerimonia, gestos que repugnam á higiene e até á cultura, restos como são de passado selvagem - contenção no uso de fármacos prescritos pelo médico, renúncia à auto-medicação e outras medidas cautelares constituíam a «arma» passiva que podia ser empregue à falta da necessária vacina, ou seja, a única maneira de atenuar levemente o ímpeto abrasador da epidemia.

Nas recomendações fixadas pelas entidades competentes condensava-se, pois, o essencial da estratégia possível no combate à praga através de uma crucial campanha

(844) Dossier Epidemias, sub-dossier 32 Typho exantematico e hespanhola e encefalite-letargica, A nova incursão peninsular da Influenza. Relatorio apresentado ao Conselho Superior de Higiene em sessão de 18-6-19/8, fls. 1-2. (Arquivo de Sidónio Pais - Militar, Lente e Político, Subsistema Presidência da República).

(845) Ibidem, fl. 7.

(846) Cf. MARQUES, A. H. de Oliveira - História da 1. ․․ república portuguesa. As Estruturas de base, ob. cit., p. 14.

(847) Dossier Epidemias, sub-dossier 32 Typho exantematico e hespanhola e encefalite-letargica,A nova incursão peninsular da Influenza. Relatorio apresentado ao Conselho Superior de Higiene em sessão de 18-6-1918,fls. 10-13. (Arquivo de Sidónio Pais - Militar, Lente e Político, Subsistema Presidência da República).Ver SILVA, Armando Barreiros Malheiro da - Sidónio e sidonismo. História e mito, dissert. cit., vol. 2, p. 506-507. 
de esclarecimento que devia implicar todas as autoridades administrativas e não-estatais, como as comissões de senhoras, as associações humanitárias, as Misericórdias, a Obra de Assistência de 5 de Dezembro e a Igreja Católica - o Episcopado através dos boletins diocesanos não deixará de lembrar aos párocos os cuidados higiénicos e sanitários que as comunidades à sua «guarda espiritual» deviam conhecer e acatar.

Paróquias eclesiásticas e Juntas de Freguesia ou Paróquias civis, unidades justapostas, mas situadas, do ponto de vista jurisdicional, em níveis diferentes, eram, sem dúvida, uma das bases primaciais da organização social que a mensagem profilática devia atingir e mobilizar, derramando-se pelos cidadãos e, em especial, por essa mole imensa de analfabetos e de gente rude e simples, muito carenciada e assaz vulnerável aos flagelos naturais.

Invocou, por isso, Sidónio Pais directamente a importância política da Junta de Freguesia. Ao mesmo tempo, num dos seus habituais impulsos persuasivos e generosos, sugeriu e incentivou o empenhamento desse corpo administrativo básico na angariação de donativos para apoio a um número cada vez maior de vítimas. Lançou também mão de outras soluções, tal como fizera meses antes com os epidemiados do tifo, apelando ao Exército e às disponíveis senhoras da sociedade lisboeta e das boas familias de província para, em comissões espontâneas de socorro ${ }^{(848)}$ agregadas a uma Comissão Central de Socorros às Vítimas da Epidemia (posta sob a presidência do Presidente da República e cuja Comissão Executiva estava instalada na Secretaria de Estado do Trabalho), dinamizarem a ajuda aos pobres e aos doentes.

O Povo, que não lhe saía da boca (enquanto ideia-força ou tema mítico-utópico), pôde, assim, voltar a vê-lo, num rodopio frenético de preocupação, a distribuir sorrisos, palavras de conforto e subsídios. O Povo, aflito e exangue pela ininterrupta sucessão de desgraças, dirigiu-lhe, enfim, veementes clamores e pedidos de ajuda inadiável, intensificando-se, por força da aflição e da desdita, o processo carismático e mítico-simbólico que as viagens presidenciais do início do ano haviam contribuído para despoletar e que ia além da mera propaganda ou de um exercício de mera persuasão política. ${ }^{849)} \bigcirc$ Chefe do Estado Sidónio Pais adquirira, pois, neste profundo enlace populista, maior protagonismo e impacte emocional, perceptível em diversos e avulsos testemunhos: no dia 4 de Novembro, pelas 16 horas, depois de saudar sorridente a população entusiástica apinhada junto ao portão do quartel de Infantaria 30, à Graça, reuniu aí com os representantes das Juntas de Paróquia do bairro oriental de Lisboa no sentido de acertar com eles a campanha de ajuda em curso; e na Presidência da República não cessaram de chegar telegramas e cartas com mensagens urgentes, desesperadas e de viva gratidão pela atenção dispensada. ${ }^{(850)}$

(848) Dossier Politica, Oficio n. ${ }^{\circ} 626$, de 12 de Dezembro de 1918, I fl. dactiloscrita. (Arquivo de Sidónio Pais - Militar, Lente e Político, Subsistema Presidência da República).

(849) Para uma abordagem correlativa do processo carismático feita, porém, a partir do conceito operatório de persuasão ver SANTO, Paula Espírito - O Processo de persuasão política.Abordagem sistémica da persuasão em referência ao actual sistema político portugués. Lisboa: Instituto Superior de Ciências Sociais e Políticas, 1997.

(850) Ver SILVA, Armando Barreiros Malheiro da - Sidónio e sidonismo. História e mito, dissert. cit., vol. 2 , p. $509-512$. 


\section{O Árduo triunfo dos Aliados e a agudização da crise social}

Diante do flagelo da gripe e da ameaça revolucionária e afonsista ou democrática contra a ordem estabelecida, a actuação dos Governos Civis, Administrações do Concelho, Comissões Administrativas das Câmaras Municipais e Polícias aparece, de algum modo, retratada na correspondência oficial estabelecida com a Secretaria de Estado do Interior, para onde convergiam não só os pedidos de auxilio, de subsídio, de isolamento e de hospitalização dos epidemiados, as medidas tomadas ou a tomar face a situações concretas de insubordinação, desordem e de alteração grave da ordem pública como sucedeu por ocasião da greve geral, mas também uma variedade de assuntos que corriam por aquela «pasta», e vem a propósito lembrar, pela sua importância política, a resposta dada a um pedido do Governo Civil do Porto acerca da pretensão da Câmara Municipal de Santo Tirso em contrair empréstimo com a garantia de um aumento de contribuições directas e indirectas, sendo dito, então, que só o Poder Legislativo tinha competência para se pronunciar a respeito de tal matéria.

Apesar da turbulência social e político-partidária vivida e da anormalidade constitucional vigente (vigorava a Constituição de 191 | , submetida a revisão por um Congresso ainda de férias), é interessante notar o cuidado formal que o Executivo exibiu, por mais de uma vez, ao invocar a tácita separação de Poderes como modo de defesa e de afirmação da legalidade instituída. E esse cuidado estendeu-se ainda à execução e transmissão das providências de carácter repressivo, nomeadamente as prisões feitas - logo após o 12 de Outubro e ao redor de 18 de Novembro - por iniciativa e critério dos representantes distritais e concelhios do Governo, embora lhes coubesse o dever de comunicá-las logo para Lisboa, o que nem sempre sucedeu, porque esteve longe de ser regular e uniforme a actuação das autoridades administrativas.

Mas se houve, de facto, importantes diferenças de estilo, de zelo e de competência no tratamento das grandes questões que lhes cabia enfrentar, como o ataque à expansão da epidemia gripal ou a manutenção da segurança interna, não faltaram, obviamente, reacções comuns e, em especial, quando se impunha a celebração oficial de certas datas e ocasiões solenes.

O Armistício assinado pela Alemanha a I I de Novembro foi, sem dúvida, um desses momentos altos, que logo motivou uma série de telegramas dos Governos Civis e de outras autoridades dirigidos à tutela e à Presidência da República, em sinal de profunda congratulação. Muitos deles foram sucintos e quase protocolares, mas a regra teve excepções: de Évora, a I2, o Governador Civil substituto comunicou que o armistício foi recebido pela população festivamente; e de Angra do Heroísmo a comunicação expedida foi mais eloquente ao referir que houve grande contentamento com armisticio tendo havido grandes manifestações e visitas de todas as entidades oficiais. ${ }^{(851)}$ Mesmo admitindo que essas manifestações tenham sido estimuladas e enquadradas pelas autoridades, corresponderam, sem dúvida, a um natural sentimento colectivo de alívio e de esperança pelo

(851) Ministério do Interior. Repartição Gabinete, Livro de registo da correspondéncia recebida, liv. 7 I. (Instituto dos Arquivos Nacionais - Torre do Tombo). 
fim de tanto sacrifício e de tanta dor. O fim da Guerra era o momento único há muito suspirado, que vinha devolver alguma confiança no futuro, apesar das feridas abertas, das perdas irreparáveis, das incertezas angustiantes... ${ }^{852)}$

É interessante notar que na principal imprensa noticiosa da capital portuguesa - com destaque para O Século - as primeiras páginas cobriam-se de pormenores acerca da assinatura da Paz e dos informes preocupantes sobre o avanço da Revolução bolchevista no antigo II Reich. A vitória dos Aliados ganhava, assim, um sabor amargo e os principais líderes da Entente já tinham na mira um novo adversário, bem mais temível que o imperialismo alemão finalmente vencido, e para combatê-lo formou-se de imediato, na expressão de Marc Ferro, uma cruzada antibolchevista definida claramente por Clemenceau em nota de 23 de Outubro para o seu Ministro dos Negócios Estrangeiros: O bolchevismo tornou-se uma força com a qual se deve contar. Ameaça com o Exército Vermelho, cujos efectivos sonha elevar até um milhão de homens. Procura alargar a todos os territórios da antiga Rússia, em primeiro lugar, e ao resto da Europa a seguir, o regime dos Sovietes. Esta nova e monstruosa forma do imperialismo faz pesar sobre a Europa um perigo tanto mais terrivel quanto é facto que ocorre no preciso momento em que o fim próximo da guerra vai provocar inevitavelmente em cada país uma grave crise económica e social.(853)

Em Portugal, com a sua especificidade ou escala próprias, a hora era de júbilo e de apreensão face ao alarmante expansionismo bolchevista.

Pelo decreto n. $^{\circ} 4.95$ I de II de Novembro, a Secretaria de Estado do Interior, através da sua Direç̧ão Geral de Administração Pública, declarou prontamente, porquanto era conveniente associar por manifestações públicas os sentimentos nacionais ao feliz acontecimento da assinatura do armistício com aAlemanha, o dia 12 como feriado e festa nacional. E nesse dia de festa o Diário do Governo saiu com uma proclamação do Presidente da República e Comandante em Chefe dos Exércitos de Terra e Mar, Sidónio Pais, onde se lia: Nesta hora de grandioso júbilo para as Nações Aliadas saúdo com fervor os Exércitos de Terra e Mar e em especial os heróicos combatentes que nos campos de batalha da França e da África e em diferentes combates navais souberam mais uma vez levantar tam alto o nome de Portugal, e emito um voto de mais profundo respeito e admiração pelos que em prol da Pátria perderam a vida nessas duras pelejas. ${ }^{(854)}$ Palavras de infusão patriótica adequada às circunstâncias e de desfecho airoso para uma participação militar numa Guerra que milhares de portugueses não só não compreenderam, como passaram depressa a julgar profundamente injusta e amarga — um revolto mar de lágrimas, de desespero, de miséria e de fome para muitos e um paraíso para alguns.

$O$ Povo tinha razões para sair à rua vitoriar dias mais felizes. $E$, segundo o relato que Rocha Martins ajeitou no seu estilo habitual, ${ }^{(855)}$ uma multidão dirigiu-se, no próprio dia I I, ao Largo fronteiro do Palácio de Belém para dar vivas aos Aliados e à República

(852) Ver SILVA. Armando Barreiros Malheiro da - Sidónio e sidonismo. Histório e mito, dissert. cit., vol. 2 , p. 513-516.

(853) Cf. FERRO, Marc - História da primeira guerra mundial, 19/4-1918, ob. cit., p. 306.

(854) Cf. Diório do Governo. I série (245) 12 de Novembro de 1918.

(855) Cf. MARTINS, Rocha - Memorias sobre Sidonio Paes, ob. cit., p. 251. 
Nova, tendo Sidónio Pais lido do alto do mirante desse Palácio o telegrama de felicitações enviado pelo rei JorgeV. Um manancial de felicitações de Chefes de Estado e de cidadãos anónimos chegaram céleres a Belém não só por ser da praxe, mas pela relevância da celebração.

A assinatura da Paz representou para o Governo sidonista um trunfo favorável que the permitiria, a breve trecho, fechar o espinhoso dossier das subsistências e dos abastecimentos através da natural regularização dos mercados e da normalização das condições da vida económica e social. Trunfo decisivo no plano interno, porque ajudaria a neutralizar os propósitos conspirativos da oposição republicana e operária. Se a rede de apoio governamental estivesse coesa - e não estava por causa das posições assumidas por Machado Santos e por Egas Moniz com a sua táctica parlamentarista de pacificação republicana - o regime tentaria, porventura, isolar e restringir ainda mais a margem de manobra política do P.R.P./P.D. e de outras forças coligadas com vista a instalar a República Nova presidencialista, doravante hegemónica, no campo republicano, abraçando, para isso, o Povo e cantando-lhe promessas redentoras...

Apesar das fragilidades endógenas que o afectavam, o sidonismo conseguiu, de facto, aproveitar o élan da vitória Aliada, intensificando o tom patriótico das declarações oficiais, as paradas militares, a concessão de subsídios e de esmolas, a difusão das sopas, a sucessão das festas e dos feriados... E tudo isto para travar o assalto revolucionário consubstanciado na greve geral do dia 18.

Alexandre Vieira, destacado dirigente da U.O.N., reconheceu nos seus apontamentos histórico-memorialísticos que o dia 18 de Novembro foi uma data péssima para a realização de um movimento grevista de âmbito geral, já atrás caracterizado nas suas híbridas motivações e finalidades - laborais e políticas. ${ }^{(856)}$

Se era verdade que nunca em Portugal se trabalhara tão intensa e extensamente na preparação de uma greve, não o era menos a constatação de que o momento fixado para tal evento tinha contra si factores iniludíveis: primeiro, porque a pneumónica (terrivel epidemia que dizimou milhares de vidas) grassava de um extremo ao outro do País; segundo, porque vinha de ser firmado o armistício, e como tivesse baixado o preço de alguns artigos que não eram de primeira necessidade, o consumidor, na sua boa fé, supôs que as condições de vida iam melhorar; terceiro, porque a uma consulta feita pelo comité central a 60 organismos sindicais de fora de Lisboa, a quase unanimidade deles se manifestou pela inoportunidade da greve naquela conjuntura, ao contrário do que sustentou a maioria dos representantes dos Sindicatos da Capital.( ${ }^{857)}$ A prudência podia aconselhar a suspensão ou a mudança de data, mas é preciso não esquecer um aspecto referido por Pacheco Pereira e António José Telo, a saber: à corrente anarquista e radical, animada pelo contagiante exemplo soviético, convinha aproveitar a «maré» desse Outono radioso, na convicção revolucionária de que o fim da Guerra era também o fim não apenas dos velhos Impérios e das obsoletas Monarquias, mas da burguesia e do capitalismo.

(856) Ver PEREIRA, José Pacheco - As Lutos operárias contra a carestia de vida em Portugal.A Greve geral de Novembro de 1918, ob. cit., p. 53-58.

(857) Cf.VIEIRA, Alexandre - Para a história do sindicalismo em Portugal, ob. cit., p. I 35. 
Ao Governo sidonista, republicano, burguês e democrático-autoritário, a opção nem sequer se punha: a Ordem contra a Anarquia a todo o custo, o que significava uma redutora leitura da greve programada, vista pura e simplesmente como uma ampla conspiração que envolvia organizações operárias e os tentáculos da rede sócio-política do democratismo. E pelo que ficou já exposto, sobretudo através das informações policiais recebidas na Presidência da República e na Secretaria de Estado do Interior, o perigo conspirativo foi tomado muito a sério.

A crença num duplo assalto — democrático e bolchevista - ao Poder não se reduziu, pois, a um mero exercício de retórica ou de propaganda legitimadora da duríssima repressão usada. ${ }^{(858)}$ Fundou-se num pânico que invadiu os círculos oficiais e concretamente o próprio Sidónio Pais e a sua entourage. Estariam a delirar, mas o delírio era sincero e a esta luz adquirem outra dimensão as notícias que a imprensa governamental pôs a circular: o Jornal da Tarde, de 21 de Novembro, publicou, por exemplo, uma pequena nota intitulada $O$ plano dos bolchevistas portugueses, onde se dizia que Além de uma larga chacina de individualidades em destaque, os bolchevistas portugueses planeavam assaltos aos bancos, casas comerciais, grande propriedade e casas de caridade, onde sabem da existência de valores. Seriam abertas as portas de todas as prisões, dizendo-se que o ministro da guerra do govemo dos «soviets») era um sargento. ${ }^{(859)}$ Interessa-nos pouco dissertar em torno da (in)verosimilhança destas revelações, porque o importante é reconhecer que o pânico então vivido era suficiente para converter qualquer fantasia em realidade.

No seu estilo sóbrio e factualista, Damião Peres ${ }^{(860)}$ destacou o papel dos ferroviários (pessoal de tracção e oficinas) do Sul e Sueste no arranque da greve geral. Cortaram as linhas telegráficas na madrugada de 18 e cometeram vários actos de sabotagem — avarias em locomotivas, descarrilamento de uma delas à entrada da Estação do Pinhal Novo e levantamento de um carril que ocasionou, na madrugada do dia 19, próximo da Estação de Fonte, a uns $30 \mathrm{~km}$ de Setúbal, o descarrilamento do primeiro comboio de passageiros organizado após o início da greve e procedente de Casa Branca, aparatoso desastre ferroviário que só não ocasionou acidentes mortais pela conjugação dum feliz acaso com a cuidadosa atenção dos tripulantes da locomotiva. ${ }^{861)}$

Aos ferroviários juntaram-se os trabalhadores da construção civil, os tipógrafos e outras unidades fabris de Lisboa, designadamente uma parte da indústria do mobiliário, concentrando-se a luta principal do proletariado na margem Sul - Barreiro, Moita e Setúbal. A maioria do proletariado agrícola alentejano ${ }^{(862)}$ e parte do ribatejano, especialmente em Évora, S. Marcos, Redondo, Torre de Coelheiros, Montemor, S.Tiago, Sousel, Vale de S. Tiago, Odemira, Golegã, etc., parte do proletariado algarvio, de Faro, Tavira, 316 Portimão, Silves e Olhão, o proletariado de alguns locais do Norte, tais como os ferroviários do Vale do Vouga, e ainda uma parte do operariado de Ovar e de Gaia aderiram

(858) Cf.TELO,António José - O Sidonismo e o movimento operário português, ob. cit., p. 216.

${ }^{(859)}$ Cf. O Plano dos bolchevistas portugueses. Jornal da Tarde, 21 de Novembro de 1918, p. I.

(860) Cf. PERES, Damião - História de Portugal. Suplemento, ob. cit., p. 195.

(861) Cf. Ibidem, p. 195.

(862) Sobre a conduta dos trabalhadores rurais alentejanos durante a experiência dezembrista/sidonista ver estudo de ROCHA, Francisco Canais e LABAREDAS, Maria Rosalina - Os Trabalhadores rurais do Alentejo e o sidonismo. Lisboa: Ed. I de Outubro, 1982, p. 9-II. 
à paralisação, afirmando, em síntese, António José Telo que as zonas mais afectadas pela greve eram Lisboa, a margem Sul e o Alentejo, enquanto no Norte, dominado pela tendência moderada e com uma organização e tradições de luta muito menores, as adesões eram mínimas. ${ }^{(863)}$ A resposta a esta ofensiva desigual foi imediata e implacável, sobressaindo a actuação do Secretário de Estado dos Abastecimentos Cruz Azevedo - posto em evidência na narrativa de Damião Peres ${ }^{(864)}$ — a quem Sidónio Pais conferira plenos poderes para lidar directamente com os ferroviários grevistas: Tem plenos poderes o Snr. Secretario de Estado dos Abastecimentos para a resolução de todos os assumptos relativos á greve dos Caminhos de ferro do Sul e Sueste, podendo para esse fim requisitar as forças que julgar necessarias e dar a essas forças as instruções que entender. // Paço de Belem, |8-X|-18.(865)

Definitivamente, Sidónio Pais não era Pimenta de Castro e Cruz Azevedo muito menos... Tomou a peito a desmobilização dos ferroviários e, entre várias medidas dissuasoras, invocou as disposições do decreto de 6 de Dezembro de 1910 que interditava as greves dessa natureza e suspendeu, com data de 21 de Novembro, a execução do decreto n. 4.903 de 21 de Outubro de 1918 , reclamada pelos grevistas. Baseou a suspensão nas condições anormaes em que presentemente se encontram alguns dos serviços dos Caminhos de ferro do Estado. ${ }^{(866)}$

A par disto foram efectuadas rusgas e prisões:António JoséTelo refere que ao alvorecer do dia 18 ocorreram rusgas gigantescas em Lisboa e na margem Sul, e registaram-se mais de 300 «prisões preventivas», especialmente entre os comités de greve, conhecidos graças à acção da P.P., enquanto as estações são ocupadas militarmente, as ruas densamente patrulhadas por forças armadas de carabina e no Governo Civil de Lisboa se concentram 1000 polícias armados, prontos para todas as eventualidades. A sede das forças repressivas é instalada no Limoeiro. Os sindicatos são quase todos revistados e vigiados durante todo o dia, revistando-se quem lá entrasse para tratar de qualquer assunto. A construção civil é um dos sectores mais atingidos pelas prisões. Supomos que foi nesta altura que foi encarcerado, talvez por acaso, o primeiro comité da greve geral, passando a funcionar um segundo do qual faziam parte Sousa Neves, António Peixe e Alfredo Marques, presos no dia 20.(867) Ainda segundo o mesmo autor, estas medidas repressivas foram acompanhadas por atitudes demagógicas tendentes a forçar o regresso dos operários ao trabalho. Classificou como tais a decisão que Sidónio Pais tomou no dia 18 - trata-se, aliás, de uma reacção habitual e inscrita no seu perfil psicológico e não uma mera encenação demagógica!... - - de percorrer de carro várias ruas da cidade e a pé o Bairro Alto, incitando os trabalhadores a terminarem a paralisação; e a marcação para o dia 20 de uma imensa parada militar anunciada por um panfleto intitulado Portugueses em que se convidava a população ordeira e patriótica

(863) Cf.TELO, António José - O Sidonismo e o movimento operário português, ob. cit., p. 211.

(864) Cf. PERES, Damião - História de Portugal. Suplemento, ob. cit., p. 195.

(865) Dossier Reformas e decretos II, [Ordem de Serviço] em papel timbrado da Presidéncia da República, Paço de Belem. (Arquivo de Sidónio Pais - Militar, Lente e Político, Subsistema Presidência da República).

(866) Ibidem, Original do decreto de 21 de Novembro, assinado por Sidónio Paes (esta assinatura serviu para gravura da capa deste trabalho).

(867) Cf.TELO, António José - O Sidonismo e o movimento operário português, ob. cit., p. 212. 
a usar um laço verde para significar adesão à política ordeira do Governo. ${ }^{(868)}$ Iniciativa perfeitamente inscrita no populismo republicano estampado nos discursos e nos actos do Presidente Sidónio, que o mesmo é dizer no respectivo processo carismático.

Apesar das medidas enérgicas tomadas com prontidão, o movimento grevista prolongou-se nos seus principais bastiões de resistência — Lisboa, margem Sul e Alentejo - pelo dia 19, mas a partir de 20 e da parada militar intimidatória a greve geral começou a perder rapidamente fôlego, tendo sido os ferroviários do Sul e Sueste os que conseguiram resistir mais tempo, mantendo a circulação paralisada até 25 de Novembro, data em que retomaram a laboração.

Vencida a ameaça, o Governo não desarmou, continuando as prisões e as deportações, ${ }^{(869)}$ as rusgas e as vigilâncias apertadas nos locais de maior risco. A própria segurança do Presidente da República foi reforçada e isto verificou-se, por exemplo, na breve visita a Coimbra por ocasião da abertura solene do novo ano lectivo em 30 de Novembro: a Secretaria de Estado do Interior, pelo Director Geral da Administração Pública, Ricardo Pais Gomes, oficiou a 26 de Novembro à Polícia Cívica de Lisboa para que fosse nomeado um destacamento de quarenta guardas, devidamente comandados, para seguirem para Coimbra e ali permanecerem durante a estada n'aquella cidade de $S$. Excia o Presidente da Republica. Trinta d'esses Guardas deverão seguir para Coimbra no proximo dia 28 , e os dez restantes deverão com o respectivo commandante embarcar no mesmo comboio em que for o Ex. ${ }^{\text {mo }}$ Presidente da Republica. O Commandante d'esta força deverá ser um official subalterno d'essa Policia e aqueles 30 guardas fazer o policiamento da cidade de Coimbra, durante a permanencia ali do Ex. ${ }^{\text {mo }}$ Presidente. ${ }^{\left({ }^{870}\right)}$ A sua presença na «cidade dos doutores» foi motivo de comunicações telegráficas para Lisboa, dando conta da chegada sem novidade e das estrondosas ovações ou estrondosas manifestações com que foi recebido.

Entre a grande manifestação ordeira do dia $20^{(871)}$ e a rápida passagem por Coimbra no final do mês( ${ }^{(872)}$ - momento breve, mas de forte emotividade, a que não faltou, perante a deslumbrada e contraditória complacência de Sidónio, o toque da tradição e do ritual banido pela Revolução do 5 de Outubro com a charamela, os archeiros de calção e meia, os lentes de borla e capelo - decorreram dez dias intensos dominados pela celebração da Paz: recepção oficial, a 23 de Novembro, no cais de desembarque das primeiras tropas do C.E.P.; Te Deum oficial de acção de graças pelo fim da Guerra, a 24, na Basilica da Estrela com a presença do Chefe do Estado; banquete diplomático oferecido, a 25, pelo Secretário de Estado dos Negócios Estrangeiros aos representantes das Nações Aliadas no Palácio das Necessidades; e festa militar em honra dos Aliados no Coliseu dos Recreios no dia $28,{ }^{(873)}$ decretado feriado nacional. E dominados, também,

(868) Cf.TELO.António José - O Sidonismo e o movimento operário português, ob. cit., p. 214.

(869) Ver TELO, António José - O Sidonismo e o movimento operário português, ob. cit., p. 215-216.

(870) A.M.I., A.N.T.T. - Livro de registo de correspondência expedida, Liv. 68.

(871) Cf. Energia e rapidez. Jornal da Tarde, de 26 de Novembro de 1918, p. 1.

(872) Cf. SOARES, António José - Saudades de Coimbra, 1917-1933, ob. cit., Out. e Nov. de 1918.

(873) Dossier 92 Manifestos, Panfletos e Proclamações. (Arquivo de Sidónio Pais - Militar, Lente e Político, Subsistema Presidência da República). 
pela atmosfera conspirativa interna que o estado de sítio e as medidas repressivas, apesar de irem surtindo o seu efeito prático, adensavam cada vez mais.

Por um lado, Sidónio Pais averbava vitórias importantes e a Aclamação da Ordem, a Jornada triunfal ou Um dia historico.A Parada de ontem, para usarmos as epígrafes redondas do Jornal da Tarde, constituiu, mesmo depois de descontados os excessos da imprensa governamental, a prova de que a popularidade do Chefe do Estado - gerada e mantida sob o signo do confronto apaixonado e violento entre sidonistas e os outros - não baixara, cruzara transversalmente a sociedade portuguesa de então e tendera mesmo a ser reforçada através dessas exibições espectaculares e cénicas da Força Armada, da preparação dos festejos comemorativos a celebrar no dia 5 de Dezembro e ainda da prossecução de iniciativas de carácter assistencial e caritativo.

Mas, por outro lado, nos meios intelectuais, jornalísticos e político-partidários a fractura era funda, a começar pela sua própria rede de apoio, e Sidónio estava plenamente consciente disso, tendo declarado, ao discursar no banquete oferecido pela «sua» Universidade de Coimbra, o seguinte: Não posso deixar de fazer aqui, n'este logar, algumas considerações politicas visto que o problema politico continua tendo a magnitude que sempre Ihe atribuí. Tentei resolver esse problema com o movimento de 5 de Dezembro e optei pela revolução visto a evolução se apresentar morosa e tardia. Reconheço que o problema não foi, afinal, inteiramente resolvido, embora continue a crer que o será dentro da Republica Nova.Tem surgido dificuldades de toda a ordem. 05 de Dezembro foi um movimento feito por um grupo de homens alheios a partidos politicos e, por isso, eu tenho hoje a hostilidade declarada das esquerdas ao mesmo tempo que falta o apoio das direitas. ${ }^{(874)}$

Este significativo desabafo, que deixa transparecer as divergências surgidas com os seus principais apoiantes, mereceu a Brito Camacho, em fase de reaproximação a Egas Moniz e seus amigos, um comentário sarcástico e distorcido, em que alude à plataforma de reconciliação formulada em artigo de A Lucta: Em Coimbra, onde se fartou de dizer baboseiras, dando tratos de polé á gramatica, o Cesar declarou que não precisa de esquerdas nem de direitas; governa com o Paiz, e isso lhe basta. Na minha plataforma ninguem pegou - nem o Governo, nem os evolucionistas, nem os democráticos. É voz geral que se conspira á bruta, e toda a gente acredita que isto não pode durar.

\section{Confusão no Congresso}

Embora não se possa tomar à letra a prosa cáustica de Camacho, inquinada de sectarismo partidário e pessoal, ela confirma uma tensão abrasiva que perpassou inclusive as sessões da Câmara dos Deputados e do Senado, reabertas em 3 de Dezembro, depois de uma tentativa frustrada a 4 de Novembro - e não a 24 como se lê em Damião Peres, na cronologia de Fernando de Castro Brandão( ${ }^{(875)}$ e em outras obras

(874) Cf. PAIS, Sidónio - Um ano de ditodura, ob. cit., p. 95.

(875) Ver PERES, Damião - História de Portugal. Suplemento, ob. cit., p. 196; e BRANDÃO, Fernando de Castro - A I República portuguesa. Uma cronologia, ob. cit., p. 126. 
de referência - muito esclarecedora, aliás, sobre o mau relacionamento então vivido entre a minoria monárquica, nervosa e inquieta, e a maioria governamental liderada por Egas Moniz.

que sucedeu explica-se em poucas palavras.

O reinício dos trabalhos parlamentares em ambas as Câmaras estava marcado para esse quarto dia do mês de Novembro, mas a comparência de deputados e de senadores foi reduzida: no Senado só responderam à chamada quinze membros, decidindo o Presidente suspender a sessão, por falta de quórum, até ao dia 2 de Dezembro; e na Câmara dos Deputados o número de presentes à chamada era maior - quarenta e seis deputados - e o Presidente da Mesa eleita para essa sessão, coronel Eduardo de Almeida, decidiu dar início à função. Foi, também, o início da confusão: a chamada havia sido feita antes das 15 h e na ausência de quatro deputados monárquicos, à frente dos quais se evidenciaria Carvalho da Silva. Eles entraram, entretanto, no hemiciclo e, após ser lida a acta, aquele representante monárquico pediu o uso da palavra para protestar contra o começo irregular dos trabalhos, mas foi impedido pela Mesa e por vozes erguidas na bancada da maioria. O próprio líder Egas Moniz atiçou a fogueira dizendo peremptório: quem não respondeu à chamada não tem direito a falar. Carvalho da Silva e Camilo Castelo Branco retorquiram e gesticularam largamente, sendo, porém, abafados pelo ensurdecedor ruído dos parlamentares nacionalistas republicanos. Os deputados da minoria não se calavam e esta atitude foi considerada provocatória e intolerável.Volvidos uns minutos, os deputados da maioria cercaram os quatro monárquicos, firmes no seu obstrucionismo, e foi então que Santos Moita e outros correligionários começaram a empurrá-los para fora da sala, tendo um exaltado atirado com uma cadeira na direcção de Carvalho da Silva, não o acertando por uma nesga. Quando as coisas chegaram a este ponto de confrontação física, a sessão foi suspensa e adiada para os alvores de Dezembro.

A cena não tinha sido edificante, mas era ilustrativa da tendência, representada por Egas Moniz e neste aspecto acolitada pelo grupo de Machado Santos, de viragem táctica à esquerda. Viragem essa que implicava o desprezo público pelo apoio e até por uma normal convivência com os monárquicos.

A aceitação interna e externa do $16^{\circ}$ Governo não se compadecia com tais proximidades. Claro está que os governamentais não podiam vir a terreiro invocar este profundo móbil da sua atitude e os monárquicos não perderam o ensejo de se vitimizarem. No meio da poeira levantada, a maioria parlamentar convocou uma reunião de urgência para o dia seguinte na Secretaria de Estado do Interior, onde estiveram presentes Machado Santos e Cunha Leal: este aproveitou o ensejo para se desligar do P.N.R., enquanto o seu mentor e patrono preferiu embarcar no apelo geral à reconciliação republicana, suficientemente vaga e genérica para conjugar diferentes opções tácticas - a dos presidencialistas intransigentes que aguardavam com o «cacetete» na mão o arrependimento dos demagógicos e seus cúmplices, e os parlamentaristas que se haviam disposto a darem o dito pelo não dito e a cederem o bastante para atraírem a facção moderada da oposição ao sidonismo. A leitura da situação política nesse final de 1918 inclinara-os a pactuarem com o inimigo - a ditadura ou demagogia democráticas - contra o qual fora feito o golpe dezembrista. Grave paradoxo que, como temos frisado, feriu de morte e desde o início a experiência dezembrista/sidonista. 
Num golpe de vista pelo conteúdo das sessões da Câmara dos Deputados e do Senado, desde a sessão preparatória do dia 3 à sessão ordinária de 13 de Dezembro, sexta-feira, véspera do dia em que foi assassinado o Presidente da República Sidónio Pais, é possível salientar alguns tópicos maiores: os contínuos ataques do grupo machadista contra o P.N.R. e o «seu» Governo, caprichando Cunha Leal numa oposição quase sistemática e demolidora; (876) a manobra palaciana de João Henriques Pinheiro e Alfredo Machado, amigos de Egas Moniz, ao apresentarem projectos de Constituição parlamentarista destinados a enfraquecer, dividir e desviar apoios do projecto presidencialista elaborado pela Comissão Revisora (ver Anexo 2); a irredutibilidade dos monárquicos, perceptível nos seus azedos comentários a certas iniciativas do Governo e na discussão gerada por causa da prisão do deputado e correligionário Teles de Vasconcelos, há muito considerado nos círculos oficiais das potências Aliadas como germanófilo e agente da Alemanha; e a discussão das questões políticas correntes fez-se em prejuízo da agenda legislativa que urgia cumprir e do debate de revisão constitucional estranhamente adiado sine die.

$\mathrm{Na}$ Câmara dos Deputados houve, para o período em foco, sete sessões.

Na primeira, efectuada a 3 de Dezembro e presidida pelo católico António Lino Neto, estiveram presentes noventa e um deputados e por proposta de Marcolino Pires foi consagrada à comemoração da vitória dos Aliados, discursando em uníssono os líderes parlamentares. Uma mudança se registara, entretanto, na liderança da maioria devido à nomeação de Egas Moniz, Secretário de Estado dos Negócios Estrangeiros, ficando a substitui-lo à frente dos deputados governamentais o discretíssimo Almeida Pires.

$\mathrm{Na}$ segunda sessão do dia 4 a abertura dos trabalhos foi marcada por uma intervenção do Presidente da Mesa, Lino Neto, acerca do incidente verificado um mês antes, que ele procurou sanar, aprazando uma conferência entre as partes envolvidas em que foram dadas explicações de parte a parte plenamente satisfatórias e com honra para todos, ficando assente que não houve nenhum propósito de ofensas pessoais, pelo que comunicou ter desaparecido por completo o retraimento havido como convinha à continuação do prestígio desta Câmara e à boa marcha dos nossos trabalhos no interesse do país. ${ }^{(877)}$

Volvidos os pontos prévios da sessão, usou da palavra o Secretário de Estado da Guerra, tenente-coronel Álvaro de Mendonça, com o objectivo de esclarecer a Câmara sobre os motivos que levaram o Governo à proclamação do estado de sítio com suspensão total de garantias ${ }^{(878)}$ e ainda sobre os motivos pelos quais se entendia ser necessária a continuação da suspensão de garantias, com ligeiras restrições a indicar. Pedia, por isso, à Câmara que aprovasse a manutenção do estado de sítio até 10 de Janeiro de 1918 sob pretexto de nova tentativa revolucionária para os dias 5 e 8 de Dezembro e de que acabara de ser descoberto outro complot em Lisboa e proximidades. De seguida, falou o colega do Interior, capitão Bernardino Ferreira, para defender e explicar a proposta que entregara na Mesa sobre a prisão de Teles de Vasconcelos: Sendo necessário, por motivos internacionais, a prisão do Deputado António Teles Vasconcelos, cumpro o dever de pedir à

(876) Ver LEAL, Cunha - Coisos dos tempos idos. As Minhas memorias, vol. 2, p. $128-132$.

(877) Cf. Diário da Cámara dos Deputados, Sessão n. ${ }^{\circ} 2,4$ de Dezembro de 1918, p. 4.

(878) Cf. Ibidem, p. 5-6. 
Câmara dos Deputados a devida licença, nos termos do artigo $17 .^{\circ}(879)$ da Constituição Política da República Portuguesa. ${ }^{(880)}$

Em torno das propostas do Governo gerou-se o debate, definindo os monárquicos, através do seu líder Aires de Ornelas, que começou, aliás, por formular um voto de pesar pela morte do deputado João Lúcio, meridianamente a sua posição: não aceitavam que as imunidades parlamentares fossem levantadas ao seu correligionário preso e incitavam o Governo a resolver de vez o problema da ordem e da segurança com medidas seguras e indispensáveis. A maioria governamental não se opôs, a não ser as vozes inevitavelmente discordantes de Cunha Leal e José Carlos da Maia, manifestando-se aquele, tal como Machado Santos no Senado, contra a continuação do estado de sítio, tendo mandado para a Mesa a seguinte moção: A Camara dos Deputados, reconhecendo que falta ao Govêrno a inteligência governativa necessária para evitar novos conflitos politicos e sociais, resolve levantar o estado de sítio, abolir a censura à imprensa, convidar o Govêrno a dar explicações claras sobre a prisão do Deputado Teles de Vasconcelos. (881) Por seu turno, José Vicente de Freitas, membro da Comissão de Inquérito ao C.E.P. nomeada em Agosto, expôs à Câmara as dificuldades surgidas na obtenção de documentos no Arquivo da Secretaria de Estado da Guerra, o que muito complicava e atrasava o seu trabalho, perguntando, por isso, se deviam ou não prossegui-lo. A sessão terminou sem que todo o expediente exposto e discutido fosse votado, estendendo-se, por isso, para as terceira e quarta sessões de 6 e 9 de Dezembro, respectivamente.

A quarta sessão abriu, aliás, com um voto de congratulação pelo malogro do atentado contra a vida do Presidente da República apresentado pelo Presidente da Mesa, que terminou a sua curta alocução dizendo: A Câmara consignando êste voto de congratulação, mostra que a primeira assemblea do país não quer aventuras, mas sim deseja o progresso da nação dentro da ordem (Apoiados), da disciplina e da legalidade (Apoiados). Com esta orientação tem a Câmara procedido e continua a proceder, correspondendo assim ao notável esfôrço do Sr.Presidente da República e com S. Ex. ${ }^{\circ}$ colaborando na salvação da Pátria, numa acertada conjugação de poderes. ${ }^{\left({ }^{82}\right)}$ As intervenções que logo se seguiram acolheram favoravelmente o voto proposto: o Secretário de Estado das Finanças, Tamagnini Barbosa, - líder dos nacionalistas republicanos Almeida Pires, ${ }^{\left({ }^{83}\right)}$ José Carlos da Maia pelo grupo machadista, o líder monárquico, Pinheiro Torres, pela minoria católica e o socialista João de Castro associaram-se todos ao protesto contra o atentado, embora o deputado socialista, em coerência com os seus princípios, fosse o único a acrescentar uma nota dissonante e apresentasse também o mais enérgico e forte protesto contra todos os atentados que dentro da situação política em que actualmente vivemos têm sido cometidos.

(879) Este artigo reza assim: Nenhum Deputado ou Senador poderá ser ou estar preso, durante o periodo das sessões, sem previa leicença da sua Camara, excepto em flagrante delicto a que seja aplicavel pena maior ou equivalente no escala penal.

(880) Cf. Diário da Camara dos Deputados. Sessão n. ${ }^{\circ} 2.4$ de Dezembro de 1918, p. 7.

(881) Cf. Ibidem, p. 13.

${ }^{(882)}$ Cf. Ibidem, Sessão n. ${ }^{\circ} 4,9$ de Dezembro de 1918, p. 4.

(883) Cf. Ibidem, p. 4-5. 
Refiro-me, em especial, àqueles atentados como o do Centro Evolucionista de Lisboa, como o da Rua Serpa Pinto, como o de Alpiarça, como o de Montemor-o-Novo, e, emfim, a todos que se têm praticado não só contra a vida de cidadãos honestos, mas também contra todos os princípios e liberdades dos cidadãos. ${ }^{(884)}$

Na mesma sessão foram depois discutidos os assaltos à Loja Pró-Pátria e, sobretudo, ao Grémio Lusitano - destruído e saqueado na sequência da tentativa falhada de assassínio de Sidónio Pais - tendo Tamagnini Barbosa afastado qualquer responsabilidade directa ou indirecta do Governo pela violência praticada e prometido severo castigo para os culpados. O deputado da maioria Melo Vieira, que na sessão de I de Agosto interpelara Amilcar Mota sobre a participação de Portugal na Grande Guerra, insurgiu-se em termos duros e dramáticos contra a desordem reinante sem que o Governo conseguisse até à data inverter a situação: $O$ Govêrno, sempre que se dá um crime da natureza do que ontem se cometeo, vem ao Parlamento declarar que fará tudo quanto estiver nas suas mãos, para que tal crime se não repita, para que os criminosos sejam rigorosamente castigados. E o que vemos? Os factos repetem-se com uma regularidade que chega a pasmar e dos delinquentes nem um só é castigado! (Apoiados) No Pôrto tem-se praticado os piores atentados contra pessoas e bens e em Lisboa o mesmo está sucedendo, não constando que - Govêrno tenha tomado uma medida que torne absolutamente impossivel factos desta natureza. ${ }^{(885)}$ Este ex-combatente do C.E.P. parecia acusar o Governo de inépcia e/ou de brandura e denunciava, afinal, a violência que se apoderara da rua, exercida por apoiantes da situação e seus adversários, num crescendo intolerável de instabilidade que afectava a vida quotidiana. ${ }^{(886)}$

Palavras de crítica moderada que contrastam, obviamente, com as invectivas virulentas de Cunha Leal, que não hesitou em insinuar, sem rodeios, a responsabilidade do Governo no assalto ao Grémio Lusitano: São crimes sobre crimes os que se sucedem em Portugal, a ponto que a gente já duvida de que se acabe de desfiar de vez o rosário dêsses crimes. À longa série dêles é preciso agora acrescentar o assalto ao Grémio Lusitano. Acto expontâneo, saído duma grande indignação da alma popular? Não. Estou convencido de que houve incitamentos, manobras por detrás da cortina. De facto toda a gente sabe que em Portugal não há o ódio contra a Maçonaria. Quem preparou o assalto? As autoridades, de braço dado com velhos inimigos da Maçonaria? Ao Governo compete averiguá-lo. (887) Mais um ataque cerrado aparado, desta vez, por Maurício Costa em nome da maioria: Não posso de facto acompanhar o Sr. Cunha Leal no seu ataque violento ao Governo e menos nas suas insinuações de que por parte deste haja cumplicidade da tolerância perante uma tal afronta à liberdade.As declarações do Sr. Secretário de Estado das Finanças mostram pelo contrário que o Govêrno, longe de pactuar com os criminosos, está pelo contrário disposto a, intransigentemente, manter, como Ihe cumpre por honra própria e da República, a confiança

(884) Cf. Diário da Camara dos Deputados. Sessão n. ${ }^{\circ} 4,9$ de Dezembro de 1918, p. 6.

(885) Cf. Ibidem, p. 15.

(886) $O$ aspecto da violência e da instabilidade na fase final da República Nova foi oportunamente salientado porWHEELER, Douglas L. - História política de Portugal, 1910-1926, ob. cit., p. 169-170.

(887) Cf. Diário do Camara dos Deputados. Sessão n. ${ }^{\circ}$ 4, 9 de Dezembro de 1918, p. 16. 
que todos nós deste lado da Câmara nêle depositamos (Apoiados).(888) Outro deputado da maioria - João Henriques Pinheiro - pediu, entretanto, a palavra para requerer fosse consultada a Câmara sobre se aprova ou não que se imprimam e distribuam pelos Deputados o relatório e o projecto da Constituição Política - um projecto subscrito também por Amâncio Alpoim e Celorico Gil - e em resposta a esta intervenção falou o deputado Manuel Bravo, membro da Comissão Revisora, para se demarcar da manobra que esses seus colegas da maioria e amigos de Egas Moniz acabavam de protagonizare para esclarecer o atraso verificado na ultimação do respectivo projecto (ver Anexo 2):

Sr.Presidente como faço parte dos membros da comissão revisora da Constituição, tenho a declarar a V. Ex. ${ }^{\circ}$ e à Câmara que o facto de até hoje essa comissão, na sua maioria, não ter apresentado um projecto, não provêm senão de circunstâncias de ordem pessoal da parte de alguns dos seus membros.

Acontece, porém, que tendo uma parte dos membros dessa comissão elaborado um projecto que não está de acordo com a orientação da maioria, entendeu o Sr. João Pinheiro apresentar agora em nome dessa minoria êsse projecto.

O Sr. João Pinheiro representa, neste momento, uma corrente, e eu julgo poder declarar à Câmara que a minha voz representa, neste momento, a corrente oposta. Nestas condições, declaro que a corrente contrária à represetada pelo Sr. João Pinheiro mandou hoje imprimir o projecto da revisão da Constituição para que numa das próximas sessões êle possa ser sujeito à discussão e consequente deliberação da Câmara.

Não posso por emquanto fazer outra declaração, senão a de que, sendo livre a qualquer membro da comissão apresentar o seu parecer pessoal sobre o assunto, 0 Sr. Pinheiro, representando a minoria, não pode pretender que êsse seu trabalho seja o parecer da comissão.(889)

A maioria governamental aparecia, assim, dividida em matéria constitucional e para complicar ainda mais a situação o deputado Alfredo Machado interveio, de seguida, a fim de enviar à Mesa o seu próprio projecto, já atrás citado, e justificar as correcções introduzidas. Por seu turno, Amâncio de Alpoim sentiu-se, também, na obrigação de esclarecer as razões pelas quais subscreveu o projecto de João Pinheiro, de que não conhecemos, aliás, nenhum exemplar, embora fosse aprovada a sua publicação interna para ser sujeito a debate e confrontado com o projecto da corrente maioritária.

Entrando, finalmente, os deputados presentes na ordem do dia, a discussão girou à volta da proposta governamental sobre a prorrogação do estado de sítio, sobressaindo, de novo, Cunha Leal a «disparan» como ferrenho oposicionista, chegando mesmo a arrancar espontâneos apoiados da minoria monárquica nas alusões feitas ao caso Teles de Vasconcelos.

(888) Cf. Diário da Camara dos Deputados. Sessão n. ${ }^{\circ} 4,9$ de Dezembro de 1918, p. 18.

(889) Cf. Ibidem, p. 19. 
Na quinta sessão, do dia 10, o deputado católico Pinheiro Torres, secundado por Maurício Costa, questionou a legitimidade do exercício por parte do Governo das autorizações concedidas pelas leis n. ${ }^{\circ} 373$ e 491 fora dos interregnos parlamentares e, dado tratar-se de um assunto que urgia uma regularização imediata, o deputado governamental avançou com o projecto-lei que consagrava a impossibilidade de exercer tais autorizações com o Parlamento aberto, como vinha sucedendo.

Nessa sessão continuou, durante a ordem do dia, o debate da proposta sobre o estado de sítio, sendo perceptível uma crescente incomodidade nas fileiras da maioria face ao regime de excepção em que se estava a viver: o deputado e jornalista Adelino Mendes, particularmente sensível à garantia expressa no n. ${ }^{\circ} 13$ do artigo $3 .^{\circ}$ da Constituição de 191 | sobre liberdade de pensamento, pediu o fim da censura à imprensa, declarando a dado passo: Ninguém pode dizer nos jornais o que pensa da vida política portuguesa. Os Srs. Ministros são intangíveis. (Apoiados). Ninguém pode censurar os seus actos, e levam o exagêro ao extremo de não permitirem que em jornais portugueses apareçam referências a pessoas e a factos do estrangeiro, que nos jornais estrangeiros vêm narrados com uma largueza que só tem os limites que os jornalistas Ihes fixam. (Apoiados). ${ }^{(890)}$

Não obstante as críticas e as reservas que tão delicado tema suscitara no seio da maioria, a prorrogação do estado de sítio acabou por ser aprovada, enquanto a proposta relativa a Teles de Vasconcelos continuou a transitar pela sexta sessão do dia 12 e pela sétima efectuada a 13 e num clima de maior tensão, porquanto o Secretário de Estado do Interior declarou ter documentos comprometedores que aconselhavam a expulsão do deputado preso - o que viria a acontecer no dia 14 de Dezembro - e a minoria monárquica, pela voz de Aires de Ornelas, solicitou a nomeação urgente de uma comissão de cinco membros com representação de todos os quadrantes do hemiciclo a fim de tomar conhecimento de tudo quanto se referia à situação actual do Sr. Deputado António Teles de Vasconcelos. A proposta foi logo aceite pelo Secretário de Estado do Interior com rasgados elogios às palauras nobres, cheias de patriotismo, cheias de critério, de ombridade e dignidade, como são aquelas que a Camara ouviu num assunto tam grave ao ilustre leader da minoria monárquica, o Sr. Aires de Ornelas (Apoiados). (891) E contestada pelo dissidente da maioria Celorico Gil, que se levantou para afirmar a inutilidade de mais comissões parlamentares e defender que os artigos germanófilos de Teles de Vasconcelos no jornal Liberal eram um insuficiente motivo da sua prisão - tinham sido publicados textos no Dia e na Monarquia vinte mil vezes mais germanófilos, o bastante, nessa ordem de ideias, para meter na cadeia os seus autores.

Foram estes, em traços muito largos, os tópicos que dominaram e fizeram arrastar o debate na Câmara dos Deputados até I 3 de Dezembro, data em que continuava adiada e sem marcação previsível a apreciação dos projectos de revisão constitucional.

Antes de uma visita rápida às seis sessões do Senado vamo-nos deter na análise de tais projectos, incluindo o do senador Cameiro de Moura, já atrás citado, mas com incidência especial no projecto presidencialista elaborado pela Comissão Revisora (ver Anexo 2).

${ }^{(890)}$ Cf. Diário da Câmara dos Deputados. Sessão n. ${ }^{\circ}$, 10 de Dezembro de 1918, p. 9.

(891) Cf. Ibidem. Sessão n. ${ }^{\circ}$. 13 de Dezembro de 1918, p. 12. 
Meses volvidos após a publicação, em Abril, nas páginas do recém-nascido jornal governamental A Situação, da série incompleta de artigos intitulados $O$ Presidencialismo e assinados por um anónimo XX, ${ }^{\left({ }^{892}\right)}$ o Jornal da Tarde, órgão igualmente afecto ao Governo, dava cobertura a uma outra série de textos com o expressivo título Presidencialismo. e Parlamentarismo da autoria de J.P., ou seja, do deputado da maioria João Henriques Pinheiro.

Um pouco antes - em Setembro - era dado à estampa sob a mesma epígrafe Presidencialismo, Parlamentarismo as Reflexões sobre um projecto de revisão constitucional, escritas pelo deputado governamental e bacharel em Matemática, Filosofia Natural e Medicina,Alfredo Machado, que incluíam, em anexo, o projecto propriamente dito. Entre o texto de $X X$ e os de João Pinheiro e Alfredo Machado — todos eles, não é demais frisá-lo, emergentes da mesma área político-partidária — há diferenças de doutrina e de modelo, ínsitas, é certo, ao próprio republicanismo português e já bem patentes, como se tem dito, no debate constitucional de 1911, mas ressurgidas, sobretudo, por motivos tácticos e de política externa.

Nos artigos de A Situação ficou logo claro o propósito originário de fornecer à opinião pública elementos elucidativos do figurino presidencialista que o Governo nomeado pela Junta Revolucionária, saída do 5/8 de Dezembro e presidida por Sidónio Pais, se preparava para implantar antes mesmo da conclusão formal do debate no Congresso eleito a 28 de Abril.

Mais do que iniciar um período vivo de discussão pretendeu-se, numa compreensível luta contra o tempo e sem perder de vista a urgência na legitimação do golpe, preparar a consagração da tendência presidencialista como a alternativa natural, pura e inevitável à República instaurada em 5 de Outubro de 1910, ainda que até aí se mantivesse algo minoritária dentro da familia republicana. Nesse sentido, o autor não perdeu tempo com rodeios e na abertura do primeiro artigo - sub-intitulado À maneira de prefacio — formulou por antecipação o que pretendia demonstrar:

Mas, quanto a nós, se definirmos bem os antecedentes historicos e os precisos termos juridicos desses regimens, adviremos á conclusão de que República parlamentar é coisa que não faz sentido, porque não é ela mais do que a disfarçada reprodução patente da monarquia constitucional.

O presidencialismo, ao inverso, constitue a unica verdadeira fórma da Republica, Republica despida de todos os preconceitos de irresponsabilidade e comodismo inutil do Chefe do Estado, liberta da confusão dos Poderes, que no constitucionalismo monarquico é manifesto e só serve a manter a influencia oculta da Corôa, Republica na qual é enfim possivel a aplicação dos principios fundamentaes da divisão do trabalho e da especialisação de funções.

Como é nossa intenção elucidar o publico sobre todas as virtudes doutrinarias e todas as conveniencias praticas do Presidencialismo, encetaremos a nossa tentativa

(892) Chegou a ser aventada a hipótese do autor dos artigos ter sido o redactor Arnaldo Pereira. 
por estabelecer um método que a todos torne mais facilmente apreensível a nossa exposição e mais claros os nossos comentarios e argumentos. ${ }^{(893)}$

Traçado o plano não faltaram, ainda no intróito, as críticas da praxe aos partidos da República Velha e seus líderes, com destaque para Brito Camacho, e aos parlamentaristas portugueses - aqueles pereceram irremissivelmente esvaziados de ideias e descredibilizados pelo clientelismo e pelas variações oportunísticas inspiradas pelas conveniências políticas de cada momento; e estes eram acusados de falsear e subverter os bons principios republicanos e a pureza das doutrinas, para servirem inconfessaveis interesses de facção, para, amesquinhando, enfraquecendo, desprestigiando o Poder, facilmente o converterem em joguete nas mãos dos mais audazes e mais astutos, assim levando a nação a quasi descrêr da Republica como forma honesta e estavel de governo. ${ }^{(894)}$

Estribada nesta dupla crítica, a argumentação do autor desenvolveu-se em torno dos seguintes tópicos essenciais: a separação clássica (Locke e Montesquieu) dos três Poderes (mais aparente que efectiva) foi encarnada pela República federal norte-americana ${ }^{(895)}$ e suas sucedâneas sul-americanas;, ${ }^{(896)}$ a Revolução Francesa, o bonapartismo e a Monarquia Constitucional de Luís Filipe contribuíram para desvirtuar os princípios republicanos, monarquizando e pervertendo por efeito de certos vícios aristocratizantes aquela que Boulmy designara por democracia absolutamente pura, 'sans mélange', ou seja, a democracia americana, a única que nada tinha das formas politicas mais antigas, porque ela foi, ali, a primeira, a originaria, forma de governo:(897) os abusos do parlamentarismo sentiam-se, com particular incidência, numa grave quebra do primado da Ordem e subsequente desorganização administrativa, governação inábil, atrabiliária, anónima e sem responsabilidade, isto é, a ditadura de muitos em vez da ditadura de um só e a anarquia social; e, por fim, a escolha das competências que deviam participar no Executivo tinha de ser feita fora do Parlamento e da acanhada esfera das clientelas partidárias.

(893) Cf. O Presidencialismo. (À maneira de prefacio). A Situação, 6 de Abril de 1918, p. I.Ver SILVA,Armando Barreiros Malheiro da - Sidónio e sidonismo. História e mito, dissert. cit., vol. 2, p. 531-532.

(894) Cf. Ibidem, p. I.

(895) Ver DUVERGER. Maurice - Os Grandes sistemas políticos, ob. cit., p. 288-329; MOULIN, Richard - Le Présidentialisme et la classification des régimes politiques. Paris: Librairie Générale de Droit et de Jurisprudence, s.d., p. 13-43; Regimenes politicos contemporaneos. Curso de formación politica. Barcelona: Bosch Casa Editorial, 1958, p. 167-183; QUERMONE, Jean-Louis - Les régimes politiques occidentoux, ob. cit., p. 155-162;VIRGALA FORURIA, Eduardo - La Organización interna del poder ejecutivo en los Estados Unidos: el presidente, el gabinete y la presidencia institucionalizada. Revista de Estudios Politicos. Madrid (83) Enero-Marzo 1994, p. 137. 189; e ainda LUCENA, Manuel - Semipresidencialismo: teoria geral e práticas portuguesas (I). Análise Social. Lisboa, 31 (138) 1996, p. 856-860.

(896) Ver CHEVALIER, François - Dictature et légitimité en Amérique latine, particulièrement au XIXe siècle, in Dictatures et légitimité, ob. cit., p. 381-399; e ROUQUIÉ, Alain - Dictatures et légitimité dans les Etats de l'Amérique latine contemporaine, in lbidem, p. 401-414.

(897) Cf. O Presidencialismo. Antecedentes históricos. A Situação, 12 de Abril de 1918, p. I. Para esta visão apologética da democracia americana não se pode esquecer a influência do livro de Alexis de TOCQUEVILLE - Da Democracia na América (Prefácio de João Carlos Espada. Cascais: Principia Publicações Universitárias e Científicas, 2001 . 
Subjacente a tais argumentos não está a semente de uma ideologia nova, mas, sobretudo, o corolário lógico da monocracia sociocrática positivista (versão ortodoxa ou comteana), genuína argamassa a unir os principais elementos da doutrina jurídico-político-presidencialista dentro de contextos histórico-políticos, sócio-económicos e culturais diferentes do norte-americano. ${ }^{(898)}$

Com efeito, o presidencialismo federal brasileiro, formulado teoricamente por Assis Brasil, foi devedor, como observou João Camilo de Oliveira Torres e demonstrou Gilberto Freire nos dois grossos volumes de Ordem e Progresso, ${ }^{\left({ }^{899}\right)}$ da implacável crítica positivista à democracia parlamentar, matrizada, aliás, numa simples e séria questão: poderia o regime parlamentar, sendo uma solução monárquica, funcionar bem numa república? ${ }^{(900)} \bigcirc$ desenvolvimento que a ideia teve no Brasil confirma, afinal, a forte presença dos fundamentos positivistas e politécnicos na democracia autoritária espaIhada pelo continente americano e germinada em pequenos redutos na velha Europa, especialmente nos círculos neo-bonapartistas, boulangistas e linguistas formados sob a III República oportunista e littreana.

$\mathrm{Na}$ formulação e defesa do figurino presidencialista em Portugal, durante as duas primeiras décadas do séc. $X X$, não prevaleceu, pois, a académica descoberta da superioridade teórica da divisão clássica dos três Poderes consubstanciada no modelo norte-americano, mas basicamente a constatação da falência do parlamentarismo, enquanto prolongamento camuflado do constitucionalismo monárquico.

É, aliás, esclarecedor que o autor da série de artigos publicada em A Situação tenha invocado a protecção doutrinária de Oliveira Martins e de Basilio Teles, assumidos adeptos de ditaduras orgânicas, de pendor cesarista e anti-partidocráticas, capazes de refundar a sociedade política portuguesa numa base diversa da liberal mitigada. Muito esclarecedor é ainda o detalhe formal de um indisfarçável decalque do projecto da Comissão Revisora sobre o Projecto de Estatuto Nacional concebido e publicado por Machado Santos em 1916.(901) O fundador da República caldeou para lá do positivismo e do livre pensamento outras influências e matrizes ideológicas — proudhonistas, materialistas e filantrópicas - de modo a projectar um pensamento hibrido e contraditório, que foi oscilando entre um demoliberalismo socializante até um autoritarismo moralizador.

(898) A especificidade do caso norte-americano foi bem sintetizada, entre outros, por LACORNE, Denis - L'Invention de la république. Le Modèle américain. Paris: Hachette, 1991, p. 259-273.

(899) Ver FREIRE, Gilberto - Introdução à história da sociedade patriarcal no Brasil. Ordem e Progresso, 2 tomos. Lisboa: Edição «Livros do Brasil», s.d. O autor escolheu para epígrafe do primeiro tomo esta significativa frase de Auguste COMTE: Le progrès est le développement de l'ordre. E uma síntese recente e bem conseguida do pensamento deste filósofo francês, discípulo de Saint Simon na sua juventude, pode ler-se em BESSA,António Marques - Quem governa? Uma análise histórico-política do tema da elite. Lisboa: Instituto Superior de Ciências Sociais e Políticas, 1993, p. 123-130.

(900) Cf. TORRES, João Camilo de Oliveira - O Presidencialismo no Brosil. Rio de Janeiro: Ediç̧̃es Cruzeiro, 1962, p. 190.Ver também MENEZES, Djacir - Os Positivistas e a república. Revista de Ciência Política. Rio de Janeiro 28 (1) Jan.-Abr. 1985, p. 26-38; FONSECA, Célia Freire D’Aquino - O Brasil de fim de século e a república (1889-1930). Arquivos do Centro Cultural Calouste Gulbenkian,. Paris 34, 1995, p. 691-703; e KELLY, Prado - AsTransformações do presidencialismo brasileiro. Revista Brasileira de Estudos Políticos. Belo Horizonte (7) Nov. 1959, p. 93-128.

(901) Ver SANTOS, Machado - A Ordem publica e o 14 de Maio, ob. cit., p. 104-1 16. 
Esta genérica moldura do projecto de Constituição Política da República Portuguesa, de que foi relator Francisco Xavier Esteves e subscritores Manuel Moniz, Serafim Joaquim de Morais Junior, António Lino Neto e José de Almeida Correia (verAnexo 2), ajuda, sem dúvida, a compreender os contornos e os limites da adaptação à realidade nacional do modelo americano nos revoltos anos dez.

Não deixou de ter alguma razão José Barbosa quando, nas páginas de $A$ Lucta, acusou a imitação americana da República Nova de ensaio presidentista, isto é, de ser mais um exercício pessoal de Poder que um genuíno regime presidencialista: o reforço do papel do Chefe do Estado e do Executivo, legitimado directamente pelo sufrágio universal, foi hiperbolizado pela conduta do Presidente da República Sidónio Pais, quer por força do seu perfil pessoal e carismático, quer por falta de um novo quadro constitucional; e a secundarização dos partidos políticos até 14 de Dezembro foi inegável face aos problemas endógenos do P.N.R., atrás referidos, associados a uma ideia latente de partido nacional e mobilizador (não único, mas unitário) herdada do histórico P.R.P. e algo conflitiva com o bipartidarismo desenvolvido nos E.U.A. e na Grã-Bretanha, porquanto os partidos aí formados eram de quadros, enquanto o P.R.P. inspirava-se num modelo novo de partido frente ou de massas.

Duas importantes limitações que o projecto presidencialista torneou pelo formalismo vago de certas disposições do Título III (ver Anexo 2), neutralizando, pelo silêncio, a crítica de Barbosa e dos parlamentaristas assumidos. E se, finalmente, nos ativermos ao seu articulado ou à sua apresentação formal e abstracta, é possível identificá-lo com as principais características daquilo a que Marcelo Caetano chamou sistema de governo representativo pessoal( ${ }^{(902)}$ e Jean-Louis Quermone régime présidentiel moniste, ${ }^{(903)}$ e com os Títulos I e II do Estatuto Nacional de Machado Santos. Vejamos, pois, a seguinte grelha comparativa:

\section{A - Governo representativo pessoal - presidencialista}

a) exercido por um Chefe do Estado, representante da Nação, através de Ministros ou Secretários de Estado por ele livremente escolhidos e só perante ele responsáveis (ver art. $400^{\circ}$ § único);

b) separação completa entre Executivo e Legislativo (ver art. $6 .^{\circ}$ e $7 .^{\circ}$ );

c) os Ministros não tomam parte nas reuniões da Assembleia Legislativa ou Congresso (ver art. $48 .^{\circ}$ );

d) o Chefe do Estado delinea a política a adoptar (ver art. 40.\%);

e) o Legislativo pode apresentar projectos de lei, mas o Chefe do Executivo possui 0 direito de veto (ver art. $\left.{ }^{\circ} 46 .^{\circ}\right)$;

f) o Chefe do Estado é eleito com mandato temporário (4 anos) por sufrágio directo e reeleito para novo e único mandato seguinte de igual duração (ver art. 53. $\left.{ }^{\circ}\right) ; \mathrm{e}$

(902) Cf. CAETANO, Marcelo - Manual de ciência política e direito constitucional, $6 .{ }^{\circ}$ edição revista e ampliada por Miguel Galvão Teles, tomo I. Lisboa: Coimbra Editora, 1972, p. 368-37I.

(903) Segundo esse autor a particularidade do Chefe do Estado ser cumulativamente Chefe do Executivo. Ver QUERMONE, Jean-Louis - Les Régimes politiques occidentaux, ob. cit., p. 155. 
g) o Chefe do Estado não tem direito de dissolução do Congresso (ver Título III, Seç̧ão II).

B - Orientação republicana unitária e individualista, patente na primazia à enumeração dos direitos e garantias que, segundo a tradição liberal portuguesa, assentam na liberdade, segurança individual e propriedade:

a) na Constituição de 1911 os dois primeiros títulos são: Da forma de governo e do território da Nação Portuguesa e Dos direitos e garantias individuais; e

b) no Estatuto Nacional de Machado Santos os dois primeiros títulos conferem com os indicados na alínea anterior (ver Anexo 2 - Título I e II ipsis verbis);

C - Orientação presidencialista:

a) no Estatuto Nacional de Machado Santos o Titulo III - Da Soberania e dos Poderes do Estado com os artigos $5 .^{\circ}$ e $6 .^{\circ}$ (idênticos a Título III, art. 5..$^{\circ}$ e 6. ${ }^{\circ}$ );

b) no Estatuto Nacional de Machado Santos a Secção I é sobre o Poder Presidencial, a II sobre o Legislativo e a III sobre o Judicial, enquanto no projecto presidencialista (Anexo 2) a Seç̧ão l é do Poder Executivo e a ll do Legislativo, com ligeiras diferenças no articulado, sendo de realçar dois importantes traços comuns: a eleição directa do Presidente da República para mandato de cinco anos e um Senado corporativo ou especializado.

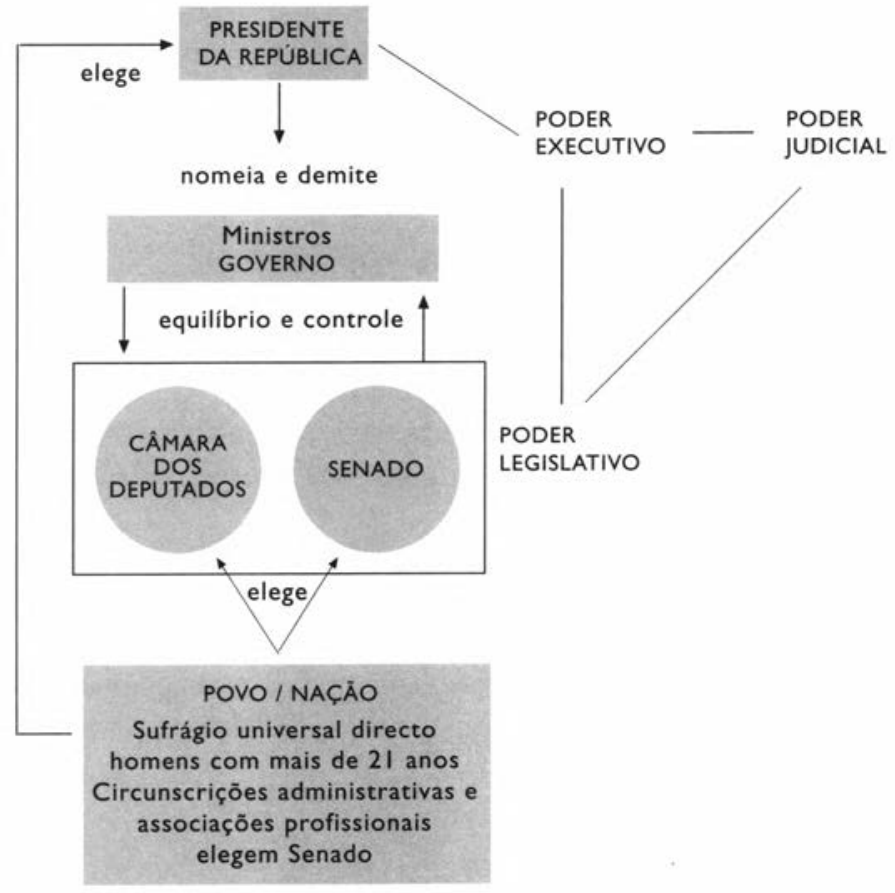

Esta representação gráfica explicita a estrutura interna do projecto presidencialista da Comissão Revisora da Câmara dos Deputados e as diferenças essenciais com o figu- 
rino parlamentarista da Constituição de 1911. Esse projecto - convém frisá-lo - teve, pelo menos, duas versões anteriores, a primeira das quais dactiloscrita e anotada por Eurico Cameira ${ }^{(904)}$ e serviu de guia inicial ao trabalho da Comissão, muito aparado e revisto - a título de exemplo citam-se 0 art. ${ }^{\circ} 5$ I que fixava um mandato presidencial de sete anos e 0 art. 59, 4. ${ }^{\circ}$ e $\S 1 .^{\circ}$ que previa a dissolução da Assembleia Nacional quando entender que assim o exige o bem da Nação, tal como o evocou Egas Moniz no seu livro UmAno de política. Note-se, também, que o projecto da Comissão foi subscrito por Lino Neto e José de Almeida Correia com declarações, parecendo-nos óbvio que aquele deputado católico, entre outras eventuais objecções, tenha-se insurgido contra o art. 83. : É mantida a legislação em vigor que extinguiu e dissolveu em Portugal a Companhia de Jesus, as sociedades nela filiadas, qualquer que seja a sua denominação, e todas as congregações religiosas e ordens monásticas, que jámais serão admitidas em território português (verAnexo 2).

A presença e a conservação desse artigo era suficiente para azedar as relações com os católicos, frustrar as suas expectativas e desfazer o equívoco gerado sobre a alegada disposição do regime para revogar o laicismo instituído a partir do 5 de Outubro. Por último, merece registo um apontamento encontrado no Arquivo de Tamagnini Barbosa sobre A Constituição, que condensa alguns reparos ao projecto de constituição elaborado ainda em vida do malogrado presidente Dr. Sidonio, numa linha de reforço da função presidencial e da eficácia do Executivo e da ampliação e aprofundamento da matéria relativa à defesa nacional. ${ }^{(905)}$

Os excessos do poder pessoal refreados pela primazia fiscalizadora do Parlamento, sendo este, por sua vez, limitado através da faculdade presidencial de dissolução, resumem, afinal, a perspectiva vazada por João Pinheiro nos seus sete artigos publicados no Jornal da Tarde, entre 26 de Outubro e 22 de Novembro, e partilhada por Alfredo Machado no estudo que precede a apresentação do seu projecto constitucional.

Ambos esgrimiram argumentos parecidos e até idênticos, reconhecendo joão Pinheiro, no seu exórdio, certas vantagens teóricas do sistema presidencialista, contrapostas às virtudes formais do parlamentarismo:

À instabilidade dos ministros nos governos parlamentaristas, dificultando a continuidade na administração pública e à circunstancia de ser mais conservadora a forma de governo presidencialista porque lança o peso da responsabilidade sobre uma só pessoa, acrescenta ainda Burgess os seguintes argumentos a favor do presidencialismo:

O governo é eficaz porque uma pessoa entende-se facilmente comsigo mesmo emquanto que duas ou mais passarão um tempo precioso em discussões estereis que teem o inconveniente de evitar uma resolução oportuna.

É poderoso porque um chefe mediocre vale mais do que dois chefes bons, segundo a frase, frequentemente citada, de um dos chefes mais poderosos que o mundo

(904) Constituição Política da República Portuguesa, avulso. (Arquivo de Eurico Cameira).

(905) A Constituição, fl. 2. (Arquivo de Tamagnini Barbosa). 
conheceu. Evitam-se os conflitos entre o poder legislativo e o poder executivo que só entorpecem a administração, mantendo a independencia de um em frente do outro. E não ha nada como atribuir a responsabilidade a uma pessoa só, para garantir «a circunspecção, a reflexão e a atenção imparcial a todos os interesses»).

É curioso observar aqui que Burgess, um dos chefes da escola classica presidencialista, confessa que uma vantagem do parlamentarismo sobre o presidencialismo consiste na ida dos ministros ao Parlamento, informando assim o Poder legislativo sobre todos os assuntos que tenha de regular. «As leis não se iniciam nem se fazem, como no outro sistema, pelos chefes de meio cento de comissões legislativas, isto é, por homens geralmente sem experiência e muitas vezes visionarios»).

A favor do parlamentarismo argumenta-se que neste sistema ha uma maior harmonia nos diferentes actos do governo.

Que os ministros são mais competentes porque são obrigados a uma preparação mais cuidadosa que teem de mostrar ao País atraves do Parlamento. Que um conflito entre o poder legislativo e o poder executivo se resolve facilmente pela demissão do ministro ou do gabinete, ou pela dissolução das camaras, ao passo que no sistema presidencialista o poder legislativo pode entorpecer a administração por diversas formas indirectas, sem que haja remedio eficaz para resolver o conflito. E, finalmente, que no sistema presidencialista não ha forma pratica de efectivar a responsabilidade do Presidente da Republica, a quem são atribuidos amplissimos poderes. ${ }^{\left({ }^{(96)}\right)}$

Argumentos acolhidos e glosados pelos dois parlamentaristas de serviço. No entanto, o argumento principal, o mais enfatizado, foi o da tradição cultural e política do país acrescido da repisada tese de que a sociedade portuguesa não se encontrava em condições de adoptar o regime presidencialista. Exactamente a mesma justificação que, em 191 I, vários publicistas republicanos empregaram, inclusive os que, como Alves da Veiga, ${ }^{(907)}$ aceitavam que o tipo americano ou república representativa traduzia com maior fidelidade o espirito da doutrina democratica. E para acentuar a incompatibilidade natural com esse tipo de regime republicano, Alfredo Machado não poupou a denúncia dos erros cometidos pela governação do Dr. Sidónio Pais, muito pouco exemplar quanto à permanência dos Ministros nos seus postos ao longo de escassos meses, e esmerou-se na enumeração dos maus exemplos dados pelas repúblicas sul-americanas. Todas elas, incluindo a brasileira, enfermavam dos defeitos próprios do presidencialismo, os maiores dos quais eram o excesso de poder pessoal e a tendência para um despotismo incontrolável.

A única república aceitável — a dos Estados Unidos da América — não podia, afinal, servir de termo de comparação, porque a raça anglo-saxonica, é inteiramente diversa da nossa. Esse povo tem os sentimentos de legalidade e de respeito ás autoridades constituidas, de tal modo afinados, que não é dificil com quaesquer constituições assegurar a sua felicidade. ${ }^{(908)}$

(906) Cf. PINHEIRO, João - Presidencialismo. Parlamentarismo. Jornal da Tarde, 26 de Outubro de 1918, p. I.

(907) VerVEIGA, Alves da - Politica nova. Ideias para a reorganização da nacionalidade portugueza, ob. cit., p. 105

(908) Cf. MACHADO, Alfredo - Presidencialismo, parlamentarismo, ob. cit., p. 23-24. 
Ainda assim, muito melhor correriam por lá as coisas se transformassem as instituições num sentido mais harmónico com o sentimento de liberdade. Valia-lhes, e bastante, o princípio federativo, absolutamente impraticável em Portugal, estado unitário e nessa medida tendencialmente parlamentarista. Não surpreende, pois, que Alfredo Machado tenha ido pouco além da matriz constitucional de 1911 , introduzindo no seu projecto o dispositivo da dissolução e a moderna representação de classes no Senado.( ${ }^{(909)}$ Salvo estas alterações de monta, cingiu-se a um arranjo apenas cosmético do texto urdido pelos primeiros constituintes da República. ${ }^{(910)}$

No capítulo quinto do seu opúsculo, Alfredo Machado deu algum destaque ao projecto que Carneiro de Moura, senador representativo do funcionalismo público, apresentara na sessão $n^{\circ} 2$ de 24 de Julho, referindo tratar-se de um projecto egualmente bem estudado e com idéas interessantes, mas cuja principal disposição talvez, a eleição do presidente, não merece ser aprovada. Quer sua ex. ${ }^{\circ}$ - prossegue o deputado da maioria - que a eleição do presidente se faça por sufragio directo de todos os eleitores das freguezias, atenuando um pouco esta unica tendencia presidencialista, com a disposição do seu art. 90, em que preceitua que, quando nenhum dos candidatos obtenha maioria absoluta, o que julgo bem raro realisar-se, competirá ao Congresso, em sessão conjunta, escolher o presidente entre os tres candidatos mais votados, seguindo-se regras estabelecidas no art. seguinte...(11) Uma complicação eleitoral, na opinião de Alfredo Machado, que parecia traduzir uma conciliação dos dois sistemas — presidencialista e parlamentarista propósito louvável que a importancia do problema não admite e no restante sua Ex. ${ }^{a}$ é abertamente parlamentarista, como era de supôr. ${ }^{(912)}$

Carneiro de Moura foi, ao que sabemos, o único senador que se dispôs a contribuir para o debate constitucional numa linha alternativa e de raiz federalista, debate esse que não chegou a ser sequer aflorado ao longo das seis sessões do Senado realizadas em Dezembro.

Na primeira sessão do dia 3, sob a presidência de Zeferino Cândido Falcão Pacheco, o tema forte não pôde deixar de ser o regozijo e a congratulação pela assinatura do Armistício de II de Novembro. A sessão, por alvitre expresso do presidente, devia ser consagrada à celebração da vitória dos Aliados, facto tam memoravel, de interesse tam momentoso para nós e de consequências tais para a Justiça e para a Liberdade dos povos. E neste sentido se pronunciou Egas Moniz, na sua primeira intervenção no Senado e na qualidade de Secretário de Estado dos Negócios Estrangeiros, tendo aproveitado o ensejo para saudar os soldados portugueses e, em especial, as Nações Aliadas. Em uníssono, a maioria, as minorias e as classes sócio-profissionais representadas na Câmara - Carlos Lopes pelo P.N.R., Mário Monteiro pelos monárquicos, Machado Santos dissidente, Pinto Coelho senador católico e Carneiro de Moura pela parte especializada — associaramse à saudação, repetindo, no essencial, o seu regozijo pelo triunfo do direito, da justiça e a libertação dos povos esmagados pelo militarismo traiçoeiro e bárbaro. No entanto, o

\footnotetext{
(909) Ver lbidem, p. 38-39.

(910) Ver Ibidem, p. 41-42.

(911) Cf. Ibidem, p. 33.

(912) Cf. Ibidem, p. 33.
} 
ex-Secretário de Estado das Subsistências aproveitou o ensejo da sua intervenção para desviar habilmente o tema de política externa em foco para o plano interno, alvejando, como vinha sendo a sua prática regular, o Governo sidonista em termos contundentes, contidos no prólogo a um projecto-lei que o Senado rejeitará na sessão de 3 de Dezembro. ${ }^{(913)}$

Esse discurso polémico trouxe a terreiro o senador da maioria Eduardo Faria em defesa do Governo, refutando o ilustre Senador Sr. Machado Santos, homem de bem e dotado de nobilissimos intuitos de generosidade: Permita-me S. Ex. ${ }^{a}$ que the afirme que não tem, mais que eu, intuitos de pacificação da família portuguesa. Mas, permita-me ainda $S$. Ex. ${ }^{\circ}$ que Ihe diga que, neste momento, nem tudo deve ser comiseração. Se o fôr, daremos a impressão que cá dentro tudo são elementos de desordem e perturbações graves. ${ }^{(9 / 4)}$ Num tom muito brando, contrapôs ao quadro negro da repressão arbitrária do Governo a necessidade e legitimidade que este tinha de garantir a justiça e a ordem, mas não conseguiu, nem devia, talvez, imaginar que fosse possível demover Machado Santos da sua ideia fixa: desde 5 de Dezembro que se adiava a pacificação da familia portuguesa e em vez do Governo se empenhar nesse nobre intuito tinha-se limitado a prender gente sem culpa formada. E, em jeito de estocada final, Machado Santos manifestou à Mesa o desejo de interpelar o Governo sobre política geral. Pedido de interpelação provocatório, feito no encerramento dessa primeira sessão senatorial.

$\mathrm{Na}$ segunda sessão, realizada no dia imediato, não houve quorum, estando apenas presentes trinta e quatro senadores, pelo que os trabalhos foram adiados para a sessão n. 3 no dia 9, cujo período de antes da ordem do dia foi dominado pelas intervenções de Machado Santos, Conde de Águeda, Carlos Lopes e Nogueira de Brito.

O primeiro contestou a forma como foi nomeado o novo Secretário de Estado da Marinha que contradizia o sistema representativo vigente - Os Ministros é que assumem as responsabilidades perante o Parlamento e não o Chefe do Estado - e aproveitou para enviar à Mesa três projectos de lei: um sobre a regulamentação do jogo, outro sobre federação e sindicatos operários e um terceiro acerca da estadoalização e municipalização de alguns serviços de utilidade pública, tais como resgate dos caminhos de ferro, a concessão de quedas de água, etc.

O Conde de Águeda mostrou-se mais preocupado com a apresentação dos senadores militares, propondo que não aparecessem fardados na sala das sessões tendo em vista os preceitos da disciplina.

Por seu turno, o senador Carlos Lopes, representante da maioria, verberou o vil atentado contra o Chefe do Estado e propôs que, em regozijo pelo malogro desse acto, a sessão fosse suspensa por um quarto de hora e nomeada uma comissão para ir felicitar - Presidente da República. Proposta aprovada por aclamação, depois do monárquico Mário Monteiro ter sugerido que a mesma fosse aclamada e Machado Santos ter pretendido generalizar o debate, o que a Câmara não consentiu impedindo-o de usar a palavra. A deputação escolhida para ir a Belém ficou composta pelos senadores Castro Lopes, Mário Monteiro, Pinto Coelho e os que a ela se quisessem associar.

(913) Cf. Diário do Senado. Sessão n. ${ }^{\circ}$ em 3 de Dezembro de 1918, p. 8 e 9.

(914) Ibidem, p. 17-18. 
Senador Nogueira de Brito aludiu à celebração do Armistício, tecendo largas considerações sobre a guerra e a paz e esperando que Portugal conseguisse obter as compensações devidas.

Seguiu-se a leitura de várias moções, levantando a de Machado Santos, ${ }^{(915)}$ como não podia deixar de ser, alguma polémica, na medida em que o Presidente da Mesa e do Senado,Zeferino Falcão, considerou que ela tinha duas partes, devendo a segunda originar um projecto de lei. Machado Santos contestou, o Presidente consultou a Câmara e esta pronunciou-se a favor de Zeferino Falcão. É, pois, de salientar que a maioria no Senado, embora carecida de uma liderança forte, foi obstruindo as tentativas de oposicionismo sistemático por parte do fundador da República.

Antes do encerramento da sessão houve ainda diversas intervenções, merecendo especial destaque a de Ribeiro do Amaral por se ter insurgido contra a falta de consideração dos Secretários de Estado para com o Senado, que primavam pela ausência, e contra a forma intolerável como se estava a fazer a censura à imprensa, impedida de publicar nas suas colunas aquilo que em público se diz e o que se diz na Câmara através de cortes extensivos e exagerados. ${ }^{(916)}$ Refira-se, também, que o senador governamental, Severiano José da Silva, corroborou as críticas à censura, lembrou a necessidade de exame e aprovação pelo Parlamento das contas de despesa efectuadas e, por fim, frisou, repetindo embora não estar a fazer oposição, que os transportes terrestres encontravam-se num estado verdadeiramente lamentável.

$\mathrm{Na}$ quarta sessão, do dia II, Machado Santos voltou à carga com a questão dos presos políticos, lendo na Câmara uma carta que lhe fora enviada por um preso político da Penitenciária de Coimbra para que ela pondere bem o que se está passando de tirânico, opressivo e afrontoso para o país e para todos nós. ${ }^{(917)}$ Hoje esse documento serve para confirmar serem imprescindíveis as pesquisas monográficas - já atrás sugeridas - sobre a actuação dos Governos Civis (dos Administradores de Concelho e dos Chefes da Polícia) a fim de que possamos conhecer de forma séria a política repressiva exercida ao longo da efémera experiência dezembrista/sidonista.

Carneiro de Moura interveio para secundar as palavras de Machado Santos, dizendo que $S$. Ex. ${ }^{\circ}$ falou mais pelo coração do que por aquilo que os factos podem conter em si, e fez bem em apelar para o sentimento da $\mathrm{Camara}^{(9 / 8)}$ e não se ficou por aí: juntou a anteriores protestos a sua viva reprovação pela contínua ausência de Secretários de Estado nas sessões do Senado; trouxe novo projecto para que o Governo proceda já à desmobilização, organizando as empreitadas para obras do Estado, para a abertura de canais, para a construção da rêde ferroviária, de estradas, de postos, para o aproveitamento do terrenos incultos, de jazigos carboníferos, de quedas de água, para a instituição do Bem da Familia, para a organização do ensino profissional, para a criação do imposto dos lucros de guerra; ${ }^{(919)}$ e deixou no ar uma nota amarga sobre a situação crítica que, então, se vivia

\footnotetext{
(915) Cf. Diário do Senado. Sessão n. ${ }^{\circ} 3$ em 9 de Dezembro de 1918, p. 8.

(916) Cf. Ibidem, p. 12

(917) Cf. Ibidem, p. 5.

(918) Cf. Ibidem, Sessão n. ${ }^{\circ} 4$ em II de Dezembro de 1918, p. 9.

(919) Cf. Ibidem, p. 10.
} 
no plano interno, exclamando: A desorganização em que temos vivido não pode continuar. Todos legislamos, e já ninguem se entende! Isto é o caos! (920)

Não muito longe desta exclamação andou a breve oratória de Severiano José da Silva, insistindo que ao Poder Legislativo competia avaliar e aprovar as contas do Estado e interpelando o Secretário de Estado das Finanças, ausente, lançou a pergunta: Qual a razão por que, de há seis meses para cá, se não publica a nota do estado da dívida flutuante, com a precisa descriminação, e qual o seu montante?.( ${ }^{(21)}$ Vozes dissonantes, deslizantes para o coro machadista, que forçaram Castro Lopes, senador governamental e líder da maioria na Câmara, a defender, na medida do possível, a indefensável falta de comparência dos Secretários de Estado e reafirmar a condenação dos factos denunciados - prisões ilegais, assaltos e violências que eram para lamentar, sendo de toda a conveniência que $o$ Sr. Secretário de Estado do Interior mande proceder a um inquérito, a fim de se apurar o que há de verdade sobre o assunto. ${ }^{(922)}$ O representante da maioria entendeu, pois, oportuno pedir ao Presidente da Mesa para que empregasse as suas diligências a fim de conseguir a presença no Senado dos membros do Governo.

Na sessão n. ${ }^{\circ} 5$ de 12 de Dezembro nem os senadores apareceram em número suficiente ou não o quiseram fazer, com responsabilidades para Machado Santos segundo afirmou (na sessão seguinte) Castro Lopes - Pois eu devo dizer, porque é uma necessidade, que se ontem não houve sessão foi devido ao Sr. Machado Santos estar a conversar nos corredores com alguns dos seus amigos. Não thes convinha que houvesse sessão(923) - pelo que só na sexta sessão de 13 de Dezembro se concretizaram os veementes apelos feitos, estando presentes, de uma assentada, os Secretários de Estado da Marinha, dos Abastecimentos e das Finanças.

Foi uma sessão sobrecarregada, que abriu com as declarações de voto sobre a proposta, até então em suspenso, de prorrogação do estado de sítio por mais um mês: os monárquicos, por intermédio de Mário Monteiro, declararam-se favoráveis dentro da orientação que a nós próprios nos impusemos de prestar a este Governo todo o nosso apoio em matéria de ordem pública e internacional; ${ }^{(924)}$ Oliveira Santos manifestou-se contra a proposta do Governo porque este não tinha ainda dito no Senado quais os factos que determinavam o prolongamento do estado de sítio e não era, em sua opinião, possível estabelecer-se a paz, a harmonia, o amor na familia portuguesa conservando-se 10.000 presos a ferros da República; ${ }^{(925)}$ Machado Santos não só ratificou estas palavras como acrescentou muitas mais no mesmo sentido; o senador Eduardo Ernesto de Faria, apelando à circunspecção e serenidade, procurou demonstrar a necessidade do estado de sítio, demasiado óbvia face à perturbação interna que desde 10 de Dezembro de $1917 \mathrm{se}$ mantinha de tal forma grave que não faltam ataques à segurança individual, que não faltam ataques à propriedade e urgia, por isso, em nome da liberdade impor a ordem; o católico

\footnotetext{
(920) Cf. Diário do Senado. Sessão n. ${ }^{\circ} 4$ em II de Dezembro de 1918, p. 10.

(921) Cf. Ibidem, p. 10.

(922) Cf. Ibidem, p. II.

(923) Cf. Diário do Senado. Sessão n. ${ }^{\circ}$ 6, em 13 de Dezembro de 1918, p. I1- 12.

(924) Cf. Ibidem, p. 3.

(925) Cf. Ibidem, p. 4.
} 
Pinto Coelho não hesitou em partilhar a mesma perspectiva e entrou em polémica com Machado Santos por causa da última greve ferroviária do Sul e Sueste; ${ }^{(926)}$ e em nome do Governo e na impossibilidade da comparência do colega da Guerra, o Secretário de Estado da Marinha, Canto e Castro, justificou a proposta em discussão com a frustrada tentativa de golpe em Outubro, com a greve geral de Novembro e o recente atentado que Luís Maria Baptista falhara no dia 6 de Dezembro. Não conseguiu, porém, evitar as interpelações de Machado Santos, que à «queima roupa» voltou a perguntar quais os motivos que levaram a encarcerar dez mil homens. Canto e Castro retorquiu: $O$ número não é exacto. Machado Santos respondeu com uma pergunta: Pode V. Ex. ${ }^{\circ}$ dizer-me quantos são os presos politicos? Réplica do camarada de Arma e de posto: Não chega a mil; Só mil estão em Elvas. - contra-atacou Machado Santos - V. Ex. ${ }^{\circ}$ desconhece tudo; não está ao facto do que se passa no país. V. Ex. ${ }^{a}$ não sabe quantas criaturas estão presas: são aos milhares. ${ }^{\left({ }^{(27)}\right)} \mathrm{E}$ desfiou o seu rosário de invectivas anti-governamentais, perante $\circ$ silêncio do futuro Presidente da República. Em seu auxilio vieram CruzAzevedo e Castro Lopes, envolvendo-se este em diálogo vivo e duro com Machado Santos, que, por sua vez, contou ainda com o apoio de Tiago Sales, senador pela Agricultura, que afirmou a intenção de se abster por ser esse o modo mais suave de exprimir o desagrado pelo que se passava.

Os senadores Luís Gama e Pinto Veloso declararam também a sua discordância, insistindo na sensível e chocante situação de muitos presos que se achavam detidos em péssimas condições, sem serem interrogados e que afirmavam estarem injustamente presos. Uma forte e iniludível evidência que Adães Bermudes, sidonista assumido, reconheceu desta forma: Nós não podemos consentir que êste tumultuário estado de cousas permaneça. Por isso, tristemente, declaro que, sem ter as hesitações do orador que me precedeu, darei o meu voto à proposta do Govêrno, pedindo-the apenas, como já foi pedido aqui, que procure ser rápido na averiguação dos factos e justo nas suas decisões para que a punição indispensável não possa recair sobre indivíduos dignos ou inocentes. ${ }^{(928)}$

(926) Cf. Diário do Senado. Sessão n. ${ }^{\circ} 6$, em 13 de Dezembro de 1918, p. 14.

(927) Cf. Ibidem, p. 7.

(928) Cf. Ibidem, p. 19. 



\section{Capítulo 6}

\section{Complot Democrático e morte da República Nova}

\section{A Atmosfera geral anunciava tragédia}

A intranquilidade e a agitação interna foram captadas por Émile Daeschner através da sua habitual perspicácia e verrina anti-sidonista, apressando-se a comunicá-las para Paris em termos que merecem ser recordados.

Com data de 10 de Dezembro e sob a epígrafe festas por ocasião do aniversário do 5 de Dezembro de 1917 começou por observar o contraste entre a modestíssima comemoração do 5 de Outubro e a celebração do 5 de Dezembro - l'anniversaire de la fondation de la "Nouvelle République», autrement dit du Government de M. Sidonio Paes, deu lugar a inúmeros festejos, geralmente mal organizados comme elles le sont en Portugal e inesperados, mas não obstante isso o programa foi cumprido e Sidónio Pais recebeu abundantes aplausos.

A situação era, na opinião do diplomata francês, muito paradoxal: a oposição dos partidos republicanos históricos estava activa e cada dia que passava mais complots eram descobertos, mais prisões efectuadas, as leis de excepção continuavam em vigor, - Parlamento em tais condições não podia cumprir a sua missão e parecia-lhe, por isso, muito difícil que semelhante situação pudesse prolongar-se indefinidamente; mas, por outro lado, não Ihe parecia menos difícil que a popularidade do Presidente da República baixasse, bem pelo contrário: ele tudo fazia para colher as simpatias do Povo, como se vira no recente dia de aniversário do 5 de Dezembro, a pretexto do qual concedera quatro dias de feriado, espectáculos e sopas populares, e se ele continuasse a divertir e a alimentar a população, muito dificilmente os seus adversários, sob estrita vigilância, poderiam derrubar o regime a não ser pelo recurso ao atentado pessoal.(929)

Convém notar que este interessantíssimo comentário de Daeschner está datado de 10 e no dia seguinte H. Martinet, um arquitecto paisagista e Secretário do Comité France-Portugal, organismo afecto ao P.R.P./P.D., dirigiu, em Paris, ao sr. Martet, Chefe do Secretariado do Presidente do Conselho Georges Clemenceau, uma carta em que pedia uma audiência para o Presidente do Conselho de Ministros português Afonso Costa e o ainda Presidente constitucional da República de Portugal Bernardino Machado,

(929) Z. Europe, 1840 Portugal, Ambassadeur Français à Lisbonne, n. ${ }^{\circ}$ 195, 10 de Dezembro de 1918. (Archives du Ministère des Affaires Etrangères). 
alegando, de passagem, saber, pela melhor fonte, que a situação nesse país estava em vias de mudar e que haveria o maior interesse em não deixar comprometer por elementos germanófilos uma situação que poderia ser excelente para a França (ver Anexo 3).

Embora vaga e sucinta, a afirmação é, sem dúvida, comprometedora e a incomodidade sentida pelo destinatário fê-lo, aliás, remeter logo a carta para o Quai d'Orsay. ${ }^{\left({ }^{(30)}\right.}$ E para além disto subsiste ainda uma fortuita e estranha coincidência: enquanto em Lisboa o Ministro francês concluía que a República Nova só seria derrubada através de um atentado pessoal contra o protagonista central do regime, em Paris era pedida uma audiência a Clemenceau em nome das duas principais figuras da República Velha com o pretexto sucinto, mas explícito, de que a situação sidonista ia mudar. E, na verdade, três dias depois mudou...

Martinet não nomeou, é certo, a sua fonte bem colocada, nem adiantou qual o modo da mudança iminente, mas a sua evasiva e o seu silêncio parecem reforçar o sentido geral da sua missiva, que indiscutivelmente coloca os democráticos de Afonso Costa na dianteira do processo conspirativo contra a República Nova e no papel de naturais mentores do homicídio como recurso final.

Deixando um pouco mais para diante a retoma de um tópico tão delicado pela extrema escassez de provas e de dados conclusivos, urge sublinhar o acerto de Daeschner quanto à popularidade de Sidónio Pais, intensa e elevada, apesar da frenética actividade dos seus adversários externos e do recuo táctico dos seus companheiros de barricada.

\section{As Comemorações do 5 de Dezembro}

Os seus últimos quinze dias de vida foram marcados por um aviso grave de que a sua vida corria perigo e, ao mesmo tempo, por uma sucessão de actos públicos e comemorativos de forte carga emotiva e cénica, no meio de efusivas manifestações populares espontâneas, empáticas e profundas, que culminaram, de forma paroxística, dramática e mórbida, no imponente cortejo fúnebre que acompanhou, na tarde chuvosa do sábado, dia 21 de Dezembro, os despojos mortais do Grande Presidente e do Grande Morto do edifício da Câmara Municipal de Lisboa ao Mosteiro dos Jerónimos, Igreja de Santa Maria de Belém. ${ }^{(931)}$

$\mathrm{Na}$ quinta-feira, dia 5 de Dezembro, aniversário da arrancada gloriosa dos bravos soldados do Parque Eduardo VII, principiou uma panóplia de celebrações e de festejos em tom marcial, apoteótico, indulgente ${ }^{(932)}$ e sectário, porquanto vinha cavar mais a distância entre os apologistas da situação e os seus detractores indefectíveis.

As tropas desfilaram pelas Avenidas novas por entre as habituais aclamações e ovações de um indistinto Povo de Lisboa, faminto, epidemiado, mas sempre assíduo às aparições do garboso e quase omnipresente Chefe do Estado - o Maior de Todos e o

(930) A lápis no canto superior direito está escrito o seguinte: Mr. Luoch quelles relations avez vous avec ce Costa? Aucune J.L.

(931) Ver MEDINA, João - Morte e transfiguração de Sidónio Pais, ob. cit., p. 15-72.

(932) Dossier Amnistia e Indulto, e sub-dossier Amnistia 5 de Dezembro. (Arquivo de Sidónio Pais - Militar, Lente e Político, Subsistema Presidência da República). 
Pai dos Pobres. Era dia feriado e de festa nacional por decreto n. ${ }^{\circ} 5.028$ de 4 de Dezembro e o mesmo diploma fixava, no seu artigo $22^{\circ}$, que Será feriado e de festa nacional no corrente ano e nos anos futuros o dia 8 de Dezembro. ${ }^{(933)}$ Rocha Martins não pôde perder a oportunidade de esticar a corda sentimental na descrição de mais uma vistosa parada, escrevendo a dado passo: Depois, no reboar dos vivas, ao som das últimas salvas, subiu a Avenida, foi vêr o Parque, passou de mãos atrás das costas nos logares onde os bons soldados tinham acampado; calcou com a sua bota os torrões sagrados dessa colina de libertação e quedou-se uns instantes, de cabeça baixa, pensativo, sob a chuvinha, na claridade mansa. Aquilo durou um instante; pela última vez o heroi pisaria o seu campo de luta, a terra da sua glória. Depois tornára a montar e vira desfilar as tropas. Se me matarem - dissera êle - ainda que me matem! - saira dos seus lábios a frase ${ }^{(934)}$. Uma dessas frases postas com fervor na sua boca por quem lhe quis guardar o lugar de Herói na História...

À noite, no Palácio de Belém, o Comandante das forças revoltosas de há um ano atrás, confraternizara, em jantar íntimo, com os seus companheiros de armas, saboreando as doces lembranças que o fluir da História entretanto azedara...(935)

Rodeado de gente que o saudava e comprimia, ei-lo no local de recepção dos náufragos do caça-minas Augusto de Castilho, acolhidos como Heróis e condecorados com o aparato que o momento requeria. Rocha Martins pintou e retocou a cena: 0 chefe do estado saudara aqueles bravos; prendera o colar da Torre e Espada ao pescoço do tenente Ferraz; apertara as mãos dos sargentos e marinheiros, por cujas faces as lágrimas corriam; subira para o automóvel ao som dos vivas, das palmas, do hino nacional e quando as fileiras do povo eram mais movediças êle desviara o olhar, voltara a cabeça como para salvar, com o seu silêncio, o gesto dum braço trémulo que o alvejava a revólver. ${ }^{(936)}$

Eram cerca de $12 \mathrm{~h}$ do dia 6, sexta-feira, quando terminou a cerimónia da entrega das condecorações no Comando Central das Defesas Marítimas, em Belém, à beira-rio. O Presidente da República discursara no seu estilo peculiar e concluíra que Hoje existe a mais cordial e completa união entre o exercito e a marinha que constituem uma emanação do povo portuguez e se abraçam num abraço fraternal para defender a Patria e o progresso da Humanidade. Exortava a Força Armada, premira a tecla sensível do patriotismo e dera recados aos descontentes... - mote glosado, mutatis mutandis, na sessão solene realizada nos Paços do Concelho.

Seguido de todos os Secretários de Estado, oficiais superiores da Marinha, Guarda Republicana, Exército e Guarda Fiscal — lê-se nos relatos divulgados pela imprensa diária - dirigiu-se para o seu automóvel descoberto após os cumprimentos de despedida. A banda da Armada tocou o Hino Nacional e a guarda de honra apresentou armas. No exterior do recinto, junto às cancelas, estava muita gente, contida por alguns polícias e sentinelas da Marinha.

(933) A Direcção da Associação de Socorros Mútuos José Maria Latino Coelho de Lisboa dirigiu, com data de 20 de Novembro, um ofício ao Presidente da República em que pedia fosse considerado dia feriado em todo o paiz o dia 8 de Dezembro, por ser o dia em que a Republica Nova ficou restabelecida. // Saude e Fraternidade. Dossier Pedidos. (Arquivo de Sidónio Pais - Militar, Lente e Político, Subsistema Presidência da República).

(934) Cf. MARTINS, Rocha - Memorias sobre Sidonio Paes, ob. cit., p. 278.

(935) Cf. Ibidem, p. 278-279.

(936) Cf. Ibidem, p. 273. 
Entretanto, o automóvel presidencial pôs-se em andamento, atravessando devagar a linha férrea por entre as aclamações da mole humana ali concentrada. Quando passou em frente da segunda cancela, um indivíduo muito novo, de cara rapada, que se achava entre os manifestantes, avançou para o veículo e apontou um revólver, quase à «queima-roupa» e às costas de Sidónio Pais, que ia correspondendo sorridente às saudações recebidas. $O$ gatilho funcionou, mas devido, talvez, a defeito mecânico, a bala não partiu, embora o fulminante tivesse sido picado. Por mais duas vezes foi repetida a tentativa de disparo e só então é que alguém reparou no gesto desse desconhecido, tendo mesmo o próprio Sidónio dito ao seu Ajudante Cameira que Ihe parecia ter visto um homem com um revólver na mão. Este, vendo que falhara por três vezes consecutivas, meteu de imediato o revólver no bolso e começou a dar palmas, fingindo-se um manifestante entusiasta e pacífico. Fora, porém, descoberto e circulava já o grito de alarme. Avisado, o grumete Arnaldo Cruz que se açhava junto e fazia parte da Guarda de Marinheiros lançou-se sobre o moço em simultâneo com o Secretário de Estado dos Abastecimentos Cruz Azevedo, cujo automóvel vinha atrás do de Sidónio Pais. Nessa ocasião, aproximou-se também o Governador Civil António Miguel de Sousa Fernandes que se precipitou sobre o jovem homicida, meteu-lhe as mãos nos bolsos e arrancou um revólver pequeno oxidado, de fabrico espanhol, que continha, como depois se viu, três cartuchos picados. Cercado pelos seus captores, o alucinado - termo usado na imprensa - foi conduzido para o quarto n. ${ }^{\circ} 10$ do Comando Central e seguiu depois para o Governo Civil para identificação e interrogatório, tendo escapado à fúria de alguns manifestantes que chegaram mesmo a esboçar o movimento de o irem arrancar aos captores, mas interveio a tempo o 1. ${ }^{\circ}$ tenente Mesquita Guimarães que correu a tomar conta do visado, gritando que ninguém devia bater num preso. Entretanto, o Chefe de Estado, apesar da confusão gerada, seguiu muito sereno no seu automóvel para o Palácio de Belém no meio de mais vivas e calorosas aclamações.

Luís Maria Baptista - assim se chamava o autor do atentado - logo que ingressou no Governo Civil foi interrogado pelo capitão Lobo Pimentel. E aí se soube que tinha 18 anos, era praticante de piloto, morador na rua de $S$. Julião, $58,5{ }^{\circ}$, filho de José Maria Baptista e de Gertrudes Baptista, sendo o pai comerciante estabelecido com uma mercearia e loja de vinhos, conhecida pela Dispensa do Povo, na Rua dos Fanqueiros, e membro da última vereação democrática na Câmara Municipal de Lisboa. De acordo com informação veiculada por Émile Daeschner, o jovem praticante de piloto pertencia a uma denominada Liga da Mocidade Republicana, associação filiada no P.R.P./P.D., mas na resposta que deu insistiu ter agido sozinho e por motu próprio.

O que pouco depois se passou é sabido: na noite de 8 para 9, grupos de militares e de civis assaltaram e destruíram o mobiliário da sede do Grémio Lusitano e da Loja Pró Pátria, na calçada do Sacramento, porque a Maçonaria foi, desde o início, tida como a autora moral do crime falhado. ${ }^{(937)} \mathrm{A}$ violência e a destruição praticadas mereceram

(937) Ver PERES, Damião - História de Portugal. Suplemento, ob. cit, p. 198. Sobre os resultados do inquérito oficial que o Governo mandou instaurar ver MEDINA, João - Morte e transfiguração de Sidónio Pais, ob. cit., p. 93 e ss. 
unânime reprovação, não faltando quem visse nisso obra dos «lacraus» e da própria Polícia sidonista. $\bigcirc$ certo, porém, é que o ódio aos democráticos, muitos deles activos mações, se mantinha vivo e até mais acirrado que em Dezembro de 1917, quando foram assaltadas e destruído o recheio das casas de Afonso Costa e de Norton de Matos, e de periódicos governamentais como o Mundo. Analogia oportuna, da qual se infere que a sanha antidemocrática e antimaçónica, logo evidenciada, era, afinal, anterior ao sidonismo, mas por este mantida e agravada, porquanto o golpe de 5/8 de Dezembro resultou de uma clivagem profunda no campo republicano, como temos repetidamente focado, e as práticas políticas e partidárias posteriormente adoptadas tornaram mais quimérica a vã reconciliação da familia republicana.

Muitas felicitações, vindas de vários pontos do país e de fora, recebeu Sidónio Pais por ter saído ileso do atentado e os seus inúmeros adeptos católicos viram nesse sucesso o dedo milagreiro da Providência. No entanto, a hierarquia da Igreja Católica não se deixou embalar apenas pela comoção do momento e o Cardeal Patriarca de Lisboa, D. António Mendes Belo, julgou azada a hora para dirigir uma Mensagem congratulatória e para lembrar que os católicos ainda não se podiam sentir plenamente contemplados nas suas legitimas reclamações:

Mas, Senhor Presidente, se o reatamento das relações com a Santa Sé traduz a satisfação de uma das mais imprescindiveis e nobres reclamações da consciencia catholica, é indiscutivel que esse facto, aliás de culminante transcendencia, seria de exito desvalorisado e nullo, se não fosse ou não fôr seguido, sem hesitações nem delongas, de outras providencias, cujo decretamento se mostra apoiado nos mais rigorosos principios da justiça, como são, entre outras, a que reconheça a plena liberdade do culto catholico - a do ensino religioso - a de Associação, nomeadamente pelo que respeita as missões ultramarinas, que constituem o mais alto dever de patriotismo, - e a restituição á Egreja, dos bens moveis e immoveis, de que, pelo Decreto de 20 de Abril de 1911, foi despoticamente esbulhada, taes como - templos, alfaias, residencias episcopaes, seminarios, presbyterios, passaes, inscripções, e quaesquer outros valores, que á Egreja pertenciam por sacratissimo titulo, e ainda a abolição das penas iniquas e perpetuas, que tolhem a religiosos portuguezes o ingresso no seu paiz - a revogação das disposições que prohibem a administração dos sacramentos do baptismo e matrimonio, e os funeraes religiosos, sem a previa apresentação do Boletim ou certidão do registo civil.(938)

Mensagem clara, que não deixa dúvidas quanto à estratégia da Igreja Católica portuguesa, nem quanto à determinação na defesa dos seus interesses, revigorada pelo consenso republicano sobre a inconveniência total em prosseguir as hostilidades contra os católicos e muito especialmente pelo modo como a República Nova se dispusera a corrigir a obra radical da República Velha.

(938) Cf. LISBOA, Cardeal Patriarca de, D. António Mendes Belo-Mensagem. «Vida Catholica», Lisboa, 4 (80) 20 de Dezembro de 1918, p. 224-225. 
A necessidade do voto e do apoio conservador justificou tantas correcções em pouco tempo e acabou por originar o equívoco ideológico que já evidenciámos. Curiosamente, as palavras do Cardeal Patriarca, acima transcritas, indiciam o propósito de obrigar o Poder a definir-se perante os pontos mais delicados da questão religiosa - a liberdade do ensino, a restauração do congregacionismo com o implícito regresso ao país dos Jesuítas e a devolução à Igreja dos bens patrimoniais nacionalizados.

A presença oficial do Presidente da República no solene Te-Deum, na Basilica da Estrela, a 14 de Novembro, e nas solenes Exéquias, realizadas na Igreja da Encarnação, durante a manhã do fatídico dia 14 de Dezembro continuava a ter valor simbólico, mas já poucos dividendos políticos proporcionava. Sidónio Pais tinha que mostrar, na prática, até onde estava disposto a ir, mas a morte física e brusca livrou-o desse próximo exercício. E se eram exactas as informações de Mgr. Masella tudo indicava que ele, embora fosse un incredolo e, secondo la voce comune, viveva mal, se preparava para rever a lei do registo civil e autorizar o envio dos missionários para as colónias, ${ }^{(939)}$ pouco ou nada podendo, no entanto, fazer relativamente aos tais pontos sensíveis, que ameaçavam apagar por completo a obra laicizadora do 5 de Outubro.

No domingo, dia 8 e, pela primeira vez, feriado nacional, Sidónio Pais «banhou-se» num mar de gente que encheu o Jardim Zoológico para assistir a um festival infantil e lanche oferecido às crianças pobres de Lisboa. ${ }^{(940)}$ E na semana seguinte, pelo menos, dois momentosos assuntos terão absorvido a sua atenção: as negociações preparatórias da Conferência da Paz e a situação político-militar no Porto, onde os militares monárquicos se achavam inquietos e a actuação repressiva de Sollari Allegro alvo de contínuos protestos.

\section{A Conferência de Paz}

Sobre o tópico em epígrafe, abordado por José Medeiros Ferreira num estudo monográfico dedicado ao papel de Portugal na Conferência da Paz, ${ }^{(941)}$ começamos por lembrar que Egas Moniz, na qualidade de Secretário de Estado dos Negócios Estrangeiros, integrara uma Comissão encarregada dos estudos preparatórios, nomeada por decreto de 20 de Novembro e composta pelos Secretários de Estado das Colónias Vasconcelos e Sá, das Finanças Tamagnini Barbosa, da Guerra Álvaro César de Mendonça e da Marinha Canto e Castro, bem como pelo general Alfredo Augusto Freire de Andrade, pelo engenheiro unionista António Santos Viegas, pelo Conde de Penha Garcia José Capelo Franco Frazão, ${ }^{(942)}$ por Joaquim Espírito Santo Lima do M.N.E., pelo especialista em Direito Internacional de Coimbra, Álvaro Machado da Costa Vilela, pelo diplomata de carreira Jaime Batalha Reis regressado, entretanto, do seu «calvário» russo, pelo Ministro de Portugal na Argentina Alberto de Oliveira, pelo Comandante do C.E.P.general Garcia

(939) Cf. SILVA, Armando B. Malheiro da - Os Católicos e a «República Nova» (1917-1918): da «questão religiosa») à mitologia nacional, art. cit., p. 481 .

(940) Ver fotografias do evento em PERES, Damião - História de Portugal. Suplemento, p. 198.

(941) Ver FERREIRA, José Medeiros - Portugal na conferência da paz. Paris, 1919, ob. cit., p. 15-30.

(942) Ver Nobreza de Portugal, vol. 3, ob. cit., p. $119-121$. 
Rosado, pelo coronel Eduardo Marques, por Francisco Joaquim Fernandes, por Eduardo Augusto Marques e pelo capitão-tenente Alfredo Botelho de Sousa.

Ao aceitar, nos termos fixados pelo decreto, ${ }^{(943)}$ a representação portuguesa no forum internacional organizado para ajustar o «preço» da Paz, Egas Moniz foi substituído interinamente na Secretaria de Estado dos Negócios Estrangeiros pelo titular da Marinha Canto e Castro e partiu com destino a Londres no dia $5,{ }^{(944)}$ com uma brevíssima passagem por Madrid e chegada a Paris na manhã do dia 8.

O Ministro na capital francesa, Bettencourt Rodrigues, não pôde recebê-los porque tivera de acompanhar o Governo francês na sua entrada solene em Strasbourg, mas deixara uma carta em que explicava as razões da sua saída de Paris e dizia ter elementos para supor que a Bélgica pretendia o alargamento do Congo à custa da costa portuguesa. Na noite desse dia, Egas Moniz embarcou com os seus companheiros delegados para Londres, onde chegou no dia seguinte. $\mathrm{Na}$ gare esperava-os um representante do Ministro dos Negócios Estrangeiros Balfour, além do pessoal da Legação portuguesa, chefiada por Augusto de Vasconcelos. Faltavam dez dias para a realização de eleições gerais e convinha apressar as conversações com o Governo inglês.

No dia 10, Egas Moniz foi recebido por Lord Balfour e desta primeira entrevista, cujo relato foi logo transmitido para Lisboa, deduziu Medeiros Ferreira os objectivos do programa português para a Conferência da Paz: manutenção e aumento das colónias, caso de Moçambique, dívidas de guerra pela Alemanha, reparações e indemnizações, repartição da frota alemã e distribuição do material de guerra. Entre estes pontos houve dois que se revelaram polémicos dada a pronta reacção de Sidónio Pais, por telegrama do dia 12 (e não 13 como refere Medeiros Ferreira), a saber: Egas Moniz ousara expressar o desejo de que seria agradável a Portugal a cedência da colónia alemã do norte de Moçambique; ${ }^{(945)}$ ousara fixar um montante para as indemnizações; e ousara ainda expôr o plano colonial português. Sidónio, em resposta imediata à comunicação telegráfica de Londres, remeteu, com carácter de urgentíssimo, um autêntico testamento em matéria de política externa:(946)

Envio minhas saudações pessoaes e referencia telegrama 358 faço recommendações seguintes: que não representam forma alguma falta confiança Vossa Excellencia mas que sou obrigado fazer em assunto tanta monta para esclarecimento futura orientação.

Rogo primeira oportunidade desfazer impressão deixada sua exposição Lord Balfour relativamente a pretenção de Portugal a qualquer parcella de territorio inimigo. Desejo que se mantenha integralmente minhas instruções expressas. Preferiria que V. Exa não tivesse indicado montante indemnisação. Não compreendi tambem necessidade exposição nosso plano colonial, financeiro e economico. Desejaria ver

\footnotetext{
(943) Cf. MONIZ, Egas - Um ano de política, ob. cit., p. 170.

(944) Cf. Ibidem, p. 172-173 e 177-407.

(945) Cf. MONIZ, Egas - Um ano de política, ob. cit., p. 178-179 e 185.

(946) Cf. FERREIRA, José Medeiros - Portugal na conferência da Paz. Paris, 1919, ob. cit., p. 16.
} 
aclarada por habil sondagem reservas havidas questão material de guerra. Portugal deve apresentar conferencia da Paz atitude modesta e desinteressada. Suas reclamações essenciais são como disse a V. Exa e mais delegados primeiro manutenção integral nosso territorio. Segundo equitativo, conforme é de jutiça, nas reparações e indemnisações em que de forma geral se venha a assentar para os Aliados, sem nenhuma pretenção a territorio novo de que prescinde, e que em caso de oferta será preferivel substituição por outras especies compensações mais uteis. Nomeio desde já plenipotenciario á Conferencia da Paz alem de V. Exa, Conde de Penha Garcia e Engenheiro Santos Viegas, podendo ser ainda nomeados outros se houver logar. Peço dirija convite meu nome conselheiro technico Anselmo Braamcamp. Não esquecer Garcia Rosado, como aqui encarreguei V. Exa Seguem por estes dias Paris, Conde de Penha Garcia, Fernandes, Villela, Botelho Sousa, Eduardo Marques. Espero seguirão tambem mais tres conselheiros technicos para assuntos agricolas, comerciais e industriais. Acho indispensavel que venham Paris como conselheiros technicos Vasconcellos e Batalha Reis. Rogo convide mesmo fim meu nome Bettencourt Rodrigues.

Sidonio Paes. ${ }^{(947)}$

Era óbvia a divergência do Presidente da República e chefe do Governo com o seu Secretário de Estado e responsável pela Delegação, sobretudo em matéria colonial e quanto à postura negocial a adoptar, embora Egas Moniz tenha tido o cuidado de atenuar e de justificar as diferenças no telegrama-resposta com data de 14 e cifrado no mesmo momento em que aí se recebia a notícia da morte do Chefe do Estado.(948)

Para Sidónio Pais o principal fim a atingir era o da distribuição de meios financeiros sob a forma de descontos na dívida de guerra ou do direito a reparações e indemnizações; prescindia de novos territórios coloniais em benefício de compensações mais úteis, que só podiam ser pecuniárias, opção ou preferência que o demarcava por inteiro das prioridades fixadas pelo ex-Ministro da Guerra dos Governos democráticos e estrénuo colonialista, coronel Norton de Matos; e propendia para uma atitude low profile nas negociações, regida por uma perspectiva moral e uma prudência táctica expressas na renúncia a pretensões territoriais coloniais ou outras (o caso de Olivença entraria neste grupo) e no aparente interesse em manter a autonomia e a reserva de planos e de intenções junto das principais potências negociadoras.

Por seu turno, Egas Moniz e mais acentuadamente Afonso Costa, que o substituirá à frente da Delegação portuguesa, entenderam ser necessário aproveitar o ensejo para se obter um leque variado de compensações, desde territoriais a financeiras, mas os magros e frustrantes resultados finais obtidos ${ }^{(949)}$ fazem supor que os ganhos definitivos de Portugal talvez não fossem muito diferentes mantendo a atitude modesta e desinteressada sugerida por Sidónio Pais, com a particularidade, porém, de haver, neste caso, um número muito menor de expectativas passíveis de serem defraudadas.

(947) Telegramas, Telegrama n. ${ }^{\circ}$ 298, de 12 de Dezembro de 1918. Resumido por MONIZ, Egas - Um ano de política, ob. cit., p. 181-182. (Arquivo de Egas Moniz).

(948) Ver MONIZ, Egas - Um ano de política, ob. cit., p. 182-185.

(949) Cf. FERREIRA, José Medeiros - Portugal na conferência da Paz. Paris, 1919, ob. cit., p. 84-85. 


\section{As Juntas Militares}

Tem subsistido, porém, a incógnita sobre a opinião pessoal de Sidónio Pais face ao irrequietismo das denominadas Juntas Militares do Norte e Sul alegadamente dominadas pelos monárquicos.

Rocha Martins deteve-se sobre a agitação dos núcleos de guarnição desenvolvidos sob a designação de Juntas, dizendo que elas tinham larguíssimos intuitos - defeza do brio militar, evitar a politica nas fileiras, combate ao democratismo, quer na sua essência niveladora, inimiga de tôda a hierarquia, base essencial dum bom exército, quer na sua acção prática, em Portugal, como bando organizado para o latrocinio e para o crime ${ }^{(950)}$-. sobre os quais se espalharam boatos e receios infundados. Conta, também, que por influência dos seus colaboradores mais próximos, salvo Eurico Cameira e Bernardo de Albuquerque, Sidónio convencera-se de que precisava de ir ao Porto para liquidar o que já se chamavam os trauliteiros e que desacreditavam a cidade. ${ }^{951)}$

Mais seguro e melhor documentado,Teófilo Duarte não explicou exactamente o que Sidónio ia fazer ao Porto, mas apontou a razão de fundo para o indiscutível nervosismo desses «núcleos de guarnição» manifestado ainda em vida do Presidente: temiam que este se ligasse aos democráticos ou que a sua provável morte significasse o regresso da «demagogia» ao Poder. ${ }^{(952)}$

Raul Rego, no quarto volume da sua História da República, justifica a viagem ao Norte com algumas nuances e metáforas bizarras: Nas juntas militares se estribará a conjura monárquica e nelas pensavam os monárquicos como alavanca poderosa para restaurar o regime apeado em 1910 . As possíveis reacções seriam esganadas aqui e além, como pelos braços desse polvo político-militar. Por causa das juntas e de quezilias no Porto, onde elas já mandavam praticamente, resolve Sidónio ir ao Porto.Tomara o gosto das viagens, do contacto com as populações, vivia do oxigénio das manifestações. Nada o deteve. Nem os conselhos de Solari Allegro, que sabia como o temporal era capaz de rebentar de um momento para o outro; e até uma nuvem de raios e coriscos. Solari Allegro receava o temporal no Norte; mas vai rebentar em Lisboa. A morte de Sidónio surge num momento em que ele se vê entre dois fogos, cothendo os frutos de nunca ter definido uma política. De facto foi um ditador, mas não se definiu nem pela monarquia, nem pela República, embora se dissesse sempre republicano. ${ }^{(953)}$ Por razões demasiado óbvias, o autor citado não se serviu, nem tão pouco alude à revelação sensacional - para usarmos a expressão empregue por Eurico de Campos - de Feliciano da Costa em A Capital de 9 de Janeiro de 1919, segundo a qual o sr. dr. Sidonio Pais, na sua viagem àquela cidade, não só demitiria os monárquicos Solari Allegro e Alberto Margaride dos cargos que ocupavam, respectivamente de comissário de policia e governador civil, como ia dar um golpe na constituição das juntas militares, fazendo várias substituições de comandos. ${ }^{(954)}$

(950) Cf. MARTINS, Rocha - Memorias sobre Sidonio Paes, ob. cit., p. 287.

(951) Cf. Ibidem, p. 291.

(952) Cf. DUARTE, Teófilo - Sidónio Pais e o seu consulado, ob. cit, p. 333-336.

(953) Cf. REGO, Raul - História da república, vol. 4 - Do sidonismo ao 28 de Maio, ob. cit., p. 57-58.

(954) Cf. CAMPOS, Eurico de - Quem são os assassinos do Dr. Sidónio Pais?, ob. cit., p. 16-17. 
Belisário Pimenta, comandante, a partir de 18 de Novembro, do 3. batalhão de Infantaria 35, em Santa Clara, registou nas suas Memórias inéditas a opinião de que 0 Sidónio era pessoa para levar a tarefa ao fim, e embora eu não concordasse com a sua politica, entendo que a intromissão da Junta do Porto não deixava de ser uma intromissão da classe militar, sempre perigosa e poderia trazer como consequencia revoltas - o que era pior. ${ }^{(955)}$

E podíamos desfiar mais alguns alvitres, mas pouco elucidativos, à excepção do depoimento de Feliciano da Costa, reconciliado com Sidónio depois de morto e, também por isso, de credibilidade incerta, sobre a verdadeira motivação dessa infausta tentativa de viagem. De fiável podemos apenas referir que, numa cartinha de 7 de Dezembro, D. Maria dos Prazeres, depois de felicitar o marido pelo aniversário da «revolução» concluída a 8, dia de Nossa Senhora da Conceição, terminou dizendo Cá te esperamos no dia 14. Estou anceosa por te ver e abraçar. Aceita abraços de todos. Infere-se destas curtas palavras que a viagem foi programada com antecedência e que Sidónio iria passar algum tempo com a familia em Coimbra, antes de seguir para o Porto. Ficamos, porém, sem saber o restante programa da deslocação ao Norte.

\section{O Atentado fatal}

Não vamos, pois, insistir mais numa temática para a qual não conseguimos encontrar dados novos e em que a eventual descoberta de novidades, assim como o reexame dos dados conhecidos justificam um estudo monográfico fora já do âmbito deste trabalho. Mas vamos tentar rever o atentado de que Sidónio Pais foi vítima com o único propósito e a única certeza de que não se deve considerá-lo uma questão fechada. Trata-se, pelo contrário, de uma questão aparentemente insolúvel, que, por isso mesmo, terá de ser mantida o mais possível em aberto à espera que novos elementos e novas averiguações possam ir furando o invólucro de mistério que a envolve.

circunspecto Damião Peres, preso aos seus cânones erudito-críticos e positivistas, atribuiu a José Júlio da Costa e ao seu perfil de desequilibrado e de criminoso nato a exclusiva responsabilidade pelo crime. (956) Excluía, pois, como não fundamentada a tese da cumplicidade da Maçonaria, ao contrário da posição de Teófilo Duarte que, em 1942. reproduziu uma carta em francês dirigida ao Adido Militar na Legação de Portugal em Paris, Vasco de Carvalho, pelo chefe de uma organização francesa, encarregado de o ir pondo a par do que se passava na loja Cadet, onde a notícia do segundo atentado produziu surpresa por parecer acto isolado e desinserido da preparação em curso de uma nova tentativa melhor organizada. E o mesmo autor concluiu que Sidónio, como D. Carlos, caía varado pelos tiros disparados das alfurjas maçónicas!(957)

Ideia que se repete, mais tarde, num artigo do suspeitíssimo jornal A Voz, de 14 de Dezembro de 1951, intitulado Quem mandou matar Sidónio Pais? Sabe-se agora quem foi

\footnotetext{
(955) PIMENTA, Belisário - Memórias n. 10 / 3363, p. 316- 317 e ss. (Biblioteca Geral da Universidade).

(956) Cf. PERES, Damião - História de Portugal. Suplemento, ob. cit. p. 200-201.

(957) Cf. DUARTE, Teófilo - Sidónio Pais e o seu consulado, ob. cit, p. 266 e ALLEGRO, José Luciano Sollari - Para a história da monarquia do norte, ob. cit., p. 62-67.
} 
o homem do capote alentejano que fugiu pelo túnel do Rossio, reproduzindo uma entrevista, de fiabilidade não controlada e muito discutível, a um dos quatro homens alegadamente contratados por um oficial superior do Exército, membro da loja maçónica da Rua Eugénio dos Santos, para matarem Sidónio Pais. Não é referido, no artigo, o nome dessa loja e diz-se aí que o informador citou os nomes de quem deu as armas aos dois contratados para o crime e de alguns dos dadores de quantias no peditório feito na Loja da Rua Eugénio dos Santos. Como o Cândido de Oliveira já não vive, não usamos desses nomes, alguns de personalidades importantes na política do tempo, mas já falecidos também. Depoimento muito tardio que $\mathrm{A}$. Cunha Raposo incluiu acriticamente no seu estudo $\mathrm{O}$ mistério do crime de 14 de Dezembro.(958)

Baseado não se sabe em que fontes, o escritor francês Jacques Bainville, muito de raspão, ao tratar da ditadura de Oliveira Salazar Reformador de Portugal, deixou escrito o seguinte: Durante a guerra, um patriota, o presidente da República Sidónio Pais erigiu-se em ditador com o apoio do exército e a simpatia popular, e tentou imediatamente uma obra eficaz de reorganização. Mas foi morto na estação do caminho de ferro de Lisboa por dois homens da carbonária. Portugal caiu novamente num período de desordens, agravado pela agitação comunista.(959)

Nos antípodas desta revelação andou o despeitado Eurico de Campos, prisioneiro por ordem das autoridades sidonistas, que num opúsculo dedicado ao tema escreveu: Se as investigações fôssem despidas de todas as sugestões; se tivessem sido aproveitados todos os elementos e todos os indícios; se não tivessem a preocupação de despistar as investigações e se tivessem sabido interrogar o criminoso, a conclusão verdadeira e fatal das investigações seria esta: fôram os monárquicos, só os monárquicos, que armaram o braço que assassinou o Dr. Sidónio Pais. ${ }^{(960)}$ Para baralhar pistas e desviar as atenções das lojas maçónicas e das alfurjas democráticas não podia arranjar melhor!...

Com o rolar do tempo o mistério foi-se fechando em si mesmo e de tão desencontradas leituras a historiografia, dita científica, apenas reteve a tese do acto isolado, que de algum modo corresponde à prolixa e confusa narrativa de Rocha Martins. ${ }^{(961)}$

Douglas Wheeler, no estilo rigoroso e ponderado de que deu mostras, não hesitou em concluir que o assassínio de Sidónio Pais não foi obra de sociedades secretas, como se disse frequentemente mais tarde, mas o feito de um indivíduo só, um tal José Júlio da Costa, de 24 anos. E num rápido escorço biográfico apresenta o assassino como um jacobino ferrenho até ao sacrifício. Natural de uma pequena vila alentejana, fora educado, pelo pai, no republicanismo radical. Ardente democrático e admirador de Afonso Costa e da União Sagrada, tomou a determinação secreta, conforme escreveu, de matar ou morrer.A sua história, se bem que curta, revela uma vida inteiramente dedicada ao republicanismo na sua tradição jacobina: procurou defender a República como soldado em Timor e em Angola, e reagiu mal quer à recusa do seu alistamento no C.E.P., quer à das autoridades

(958) Cf. RAPOSO, A. Cunha - O Mistério do crime de 14 de Dezembro, in Os Grandes enigmas entre duos guerros. Lisboa: Amigos do Livro, [19..], tomo I, p. 252-254.

(959) Cf. BAINVILLE, Jacques - Os Ditadores. Porto: Livraria Civilização, 1937, p. 268.

(960) Cf. CAMPOS, Eurico de - Quem são os assassinos do Dr. Sidónio Pais?, ob. cit., p. 31.

(961) Cf. MARTINS, Rocha - Memorias sobre Sidonio Paes, ob. cit., p. 301-302. 
francesas quando tentou alistar-se como voluntário estrangeiro. Sabia ler e escrever, tinha força de vontade e era dotado de iniciativas intensamente racionais a ponto de dizer que o seu acto homicida visara restaurar a liberdade e destruir o absolutismo. Pretendera ser mártir e morrer pela República, admitindo que o seu feito poderia lançar o país na guerra civil. Pediu aos seus captores que o matassem, sem ser atendido.(962)

Idêntica perspectiva ressalta do estudo monográfico que João Medina consagrou ao assunto, tendo para o efeito acumulado um acervo razoável de dados impressos e alguns colhidos na própria familia de José Júlio da Costa. Da pesquisa e da análise efectuadas concluiu que o assassinato de Sidónio Pais foi o gesto solitário do exaltado e messiânico criminoso, devendo ainda ser inserido na fase tumultuária que assinala os conturbados derradeiros meses do consulado sidonista e acrescido de um episódio protagonizado por José Júlio, em Garvão, sua terra natal, aquando de uma ocupação de terras que opôs Governo e latifundiários a trabalhadores rurais:

Servindo de medianeiro, José júlio logrou que se estabelecesse um acordo pelo qual os ocupantes saíam das terras, sob condição de não virem a ser molestados pela Guarda Republicana, acordo que teve a benção do governador de Beja, dr. Passarinho, ${ }^{(963)}$ e das autoridades de Lisboa. Uma vez desocupadas as terras e retirados os trabalhadores, as autoridades mudaram de atitude, prenderam os responsáveis e decretaram a sua deportação para África: este rompimento do compromisso assumido levou josé júlio da Costa a jurar que havia de vingar os camponeses traídos. O caso das ocupações do Garvão, que Rocha Martins conta dum modo depreciativo, pesou fortemente no espírito já doentiamente exaltado de José júlio no sentido de o levar a abater a figura na qual divisava não só a traição ao 5 de Outubro mas ao exército aliadófilo e, por fim, aos rurais alentejanos que o próprio nativo do Garvão, apesar da sua discordância como proprietário, pretendera defender junto do Governo. ${ }^{(964)}$

Se admitirmos uma sintomatologia psico-patológica no comportamento de José Júlio da Costa, independentemente das conclusões do relatório sobre o seu estado mental anexo ao processo e feito pelos alienistas Caetano Beirão, Júlio de Matos e José de Matos Sobral Cid, ${ }^{(965)}$ o caso de Garvão, como sugere João Medina, podia evidentemente ter detonado a resolução de matar, assumida fora de qualquer complot ou plano homicida urdido pela emaranhada rede sócio-política do democratismo. Mas uma tal leitura pressupõe, por exemplo, excluir liminarmente a hipótese de ter havido outros potenciais ou efectivos assassinos, o que contraria os dados conhecidos e sobretudo os relatos coevos da imprensa.

(962) Cf.WHEELER, Douglas - História política de Portugal, 1910-1926, ob. cit., p. 171-172.

(963) Este nome não coincide com a lista oficial publicada dos Governadores Civis para este distrito, a saber: Dr. Francisco Manuel Pereira Coelho, até 19-3-1918; Coronel João de Sousa Tavares, de 19-3-1918 a 12-6-1918; e Capitão António Carlos Cortês, de 12-6-1918 a 18-2-1919.

(964) Cf.MEDINA, João - O homem que matou Sidónio Pais. História, Lisboa (10) Agosto 1979, p. 51 .Assunto retomado pelo autor em obras posteriores designadamente Idem - Morte e transfiguração de Sidónio Pais, ob. cit., p. 199-200.

(965) Cf. SILVA, Armando Barreiros Malheiro da - Sidónio e sidonismo. História e mito, vol. 2, dissert. cit., p. 559. 
Embora com diferenças de pormenor, esses relatos mencionam entre dois a diversos tiros, sugerindo, assim, que Sidónio Pais terá sido atingido mortalmente por mais que uma bala e, possivelmente, por mais que um matador. Hipótese que a minuciosa autópsia feita nos Jerónimos, em 17 de Janeiro de 1919, pelo médico-legal Asdrúbal de Aguiar, infirmou de todo: um só projéctil the terá roubado a vida ao alojar-se na região mamária direita onde produziu uma ferida a que se seguiu trajecto atravessando sucessivamente o músculo grande peitoral, o segundo espaço intercostal, a pleura parietal costal, a pleura visceral, o lobo inferior do pulmão, o diafragma e a pleura parietal costal, a cartilagem costal correspondente à $7 .^{\circ}, 8^{\circ}, 9^{\circ}$ e $10^{\circ}$ costelas e os tecidos moles da região do hipocôndrio, tudo do lado direito; em síntese, a causa de morte consistira numa ferida provocada por arma de fogo na região mamária direita com perfuração do pulmão direito, figado e via cava inferior, hemotórax direito e derrame hemático peritonal.(966) Uma lesão deste tipo origina morte quase fulminante e por isso se percebe que Sidónio Pais, com uns escassos minutos de vida, tenha expirado sem dizer nada de inteligível e muito menos a famosa frase, consentânea com a atmosfera messiânica e mítico-simbólica então bem patente, que Belo Redondo e Reinaldo Ferreira inventaram e gravaram nas páginas de O Século: Morro bem! Salvem a Pátria!.

A reconstituição precipitada e comovida do crime fê-la logo a imprensa, com destaque para os grandes jornais noticiosos O Século e o Diário de Notícias.

De acordo com tais relatos, eram cerca de $23 \mathrm{~h} .50 \mathrm{~m}$. quando o Presidente da República chegou, de automóvel, com os seus Ajudantes ao hangar exterior da Estação do Rossio, onde uma companhia da G.N.R. de grande uniforme, com a respectiva banda, fazia a guarda de honra. Ao longo da rampa de acesso ao referido hangar havia cordões de polícia e o mesmo se verificava no salão da Estação, vendo-se, também, nas ruas próximas, numerosos agentes da Polícia Preventiva e Judiciária. Acompanhado pelo capitão Cameira, alferes Bernardo de Albuquerque e Ferreira da Silva, o irmão António da Silva Pais e o filho António, seu Secretário particular, Sidónio Pais encaminhou-se para a gare no meio de aclamações a que agradeceu resolutamente e seguindo sempre á frente da sua comitiva o Chefe de Estado dirigiu-se por meio do cordão de policia para uma das portas centrais que dão ingresso na "(gare», a quinta para quem venha do lado do ascensor. Quando S. Ex. ${ }^{\circ}$ ia a transpôr a referida porta, partiu do seu lado direito uma detonação.(967) Sidónio Pais ter-se-á voltado para esse lado e recuou. Ouviram-se, de seguida, mais dois tiros e o visado cambaleou, caindo redondamente no chão. Na versão de O Século houve um primeiro tiro e Sidónio ficou surpreso e estremeceu, mas só caiu sobre o lado esquerdo ao segundo tiro, correndo logo o capitão Cameira a ampará-lo e tomando-o nos braços de joelhos, beijou-o, beijo a que S. Ex. ${ }^{a}$ agradeceu com o olhar. ${ }^{(968)}$ Socorrido imediatamente, foi transportado pelas pessoas que o acompanhavam, incluindo os seus Ajudantes, e pelo sr.Augusto Ludgero Marques de Abreu até ao automóvel, que partiu

(966) Cf. AGUIAR, Asdrúbal António de - Exames periciois no cadaver do presidente da república dr. Sidonio Paes no vestuario e na arma aggressora. Lisboa: Instituto de Medicina Legal de Lisboa, 1921, p. 43 e 50.

(967) Cf. Gravissimo atentado contra o Presidente da República. Morte do sr. dr. Sidonio Paes. Diório de Noticias, de 15 de Dezembro de 1918, p. 1.

(968) Cf. O Chefe do Estado. O Século, de 15 de Dezembro de 1918, p. I. 
a toda a velocidade para o Hospital de S. José, onde entrou directo no «banco» e aí os médicos Torres Pereira e Damas Móra já nada puderam fazer.

Entretanto, no local do crime, gerara-se a confusão: a Polícia e alguns populares caíram sobre o agressor e ao mesmo tempo sobre um outro indivíduo que estava a conversar junto do criminoso e que, segundo logo se afirmou, foi visto a puxar por um revolver niquelado. Segundo o Diário de Notícias o criminoso caiu logo morto com um tiro pelas costas e o outro individuo foi agarrado pelo continuo da secretaria de Estado dos abastecimentos, sr. Rego, pelos agentes de investigação Custodio das Dores e Cunha, procurando os populares linchá-lo, como acontecera ao criminoso, chegando a ser agredido violentamente, do que the resultaram varios ferimentos. ${ }^{(969)}$

Notícias posteriores, publicadas na segunda página, desfizeram o manifesto equívoco: Parece estar provado que os tiros que mataram o sr. dr. Sidonio Paes foram disparados por José Julio Rodrigues, o preso que se encontra na Escola de Guerra. O homem que disparou o primeiro tiro foi morto. ${ }^{(970)}$ A sua identidade foi depois conhecida: chamava-se Luís Furtado Saraiva, reconhecido mais tarde como notório sidonista e, portanto, erradamente implicado no complot, logo anunciado pelos jornais. O Diário de Noticias chegou mesmo a puxar para sub-título a negro Trata-se de um «complot» de ha muito preparado e no «miolo» da notícia pode ler-se que o assassino parece ter pertencido á Liga da Mocidade Republicana, a que tambem pertencia aquele individuo que ha dias em Belem tentou praticar identico atentado. Por seu turno, das páginas de $O$ Seculo ressaltam as graves consequências da confusão gerada no momento do atentado: estabelecera-se tumulto e pânico indescritiveis, ficando quatro pessoas mortas e várias feridas, entre as quais o irmão da vítima e o filho António.

Baseado no que colhera pela imprensa, o insuspeito Ministro francês Émile Daeschner emitiu para Paris um telegrama com o n. ${ }^{\circ} 189$, desenvolvido depois por despacho de 18 de Dezembro, que pode ser confrontado com a comunicação do pró-sidonista Mons. Benito Aloisi Masella para o Vaticano.

$O$ atentado, segundo Daeschner, ocorrera no dia 14 às $23 \mathrm{~h} .45 \mathrm{~m}$. no momento em que $\circ$ Chefe do Estado penetrava na gare central de Lisboa a fim de tomar o rápido para o Porto com partida marcada às $23 \mathrm{~h} .55 \mathrm{~m}$. Do inquérito policial em curso parecia resultar que vários tiros foram disparados, provavelmente por dois indivíduos, posicionados no meio da multidão e perto das portas de acesso ao cais de embarque. Os primeiros tiros teriam atingido o Presidente no peito, enquanto outras balas, sem dúvida disparadas por um segundo assassino, rasparam a cabeça de Sidónio Pais quando ele se achava já por terra. Transportado imediatamente ao Hospital de S. José sucumbiu durante o trajecto. No local do atentado a confusão foi enorme. Várias pessoas foram mortas ou feridas por coronhadas dos agentes da Polícia. $O$ capitão de corveta António Pais, irmão do Presidente, que o segurava, foi ferido na cabeça por um golpe de sabre. Um indivíduo, tido por um dos autores do atentado, foi imediatamente morto, mas verificou-se depois que estava inocente; o revólver encontrado no seu bolso tinha

(969) Cf. Gravissimo atentado contra o Presidente da República. Morte do sr. dr. Sidonio Paes. Diário de Noticias, de 15 de Dezembro de 1918, p. 1.

(970) Cf. Ibidem, p. 2. 
ainda todos os cartuchos. O principal culpado foi preso, mas só muito a custo pôde ser subtraído ao furor da multidão. Entretanto o seu cúmplice, conseguiu escapar. Quanto ao culpado preso, chamado José Júlio da Costa, parecia ser membro da Liga da Mocidade Republicana, Association affiliée au parti démocratique. Le premier attentat manqué du 6 Décembre, contre M. Sidonio Paes, que je vous ai signalé par ma communication n. ${ }^{\circ}$ 185, avait également comme mentor un membre de la mème Société. On en a généralement conclu à un complot inspiré par le parti démocratique. L'assassinat du Président aurait été décidé depuis longtemps et irrévocablement fixé à l'occasion du voyage à Porto: des complices postés sur divers points devaient mettre le Président dans l'impossibilité d'échapper. ${ }^{\left({ }^{71}\right.}$ ) A Polícia não tinha conseguido ainda estabelecer provas formais do complot, nem sobretudo as suas ramificações. Para o diplomata francês o atentado não foi uma completa surpresa: desde há muito tempo que a política seguida pelo Presidente punha a sua vida em perigo, embora não the tenham faltado os avisos e, no próprio dia da sua morte, fora prevenido do risco que corria.

A morte de Sidónio Pais causou um sentimento de profunda emoção, raiando mesmo a consternação. O povo, por muito ignorante que fosse, ficou com a impressão de ter perdido um amigo, o que não admira porque uma das maiores preocupações do Presidente Pais foi a de conquistar o coração das gentes: grace à son action - escreveu Daeschner - personnelle de nombreuses oeuvres de bienfaisance, des soupes populaires par exemple, avaient été fondées. II s'occupait particulièrement des enfants et ne craignait pas de se mêler à la foule. En de nombreuses occasions, notamment pendant l'épidémie de grippe on l'avait vu se rendre dans les hópitaux et les quartiers ouvriers pour porter des secours. D'autre part la pompe, bien qu'un peu vulgaire, dont il accompagnait diverses cérémonies, plaisait à la population avide de spectacles à effet. Enfin le courage personnel très réel dont il avait fait preuve dans de nombreuses circonstances, qualité extremement rare chez les hommes publics portugais avait fini par imposer même aux indifferents. ${ }^{(972)} \mathrm{E}$ às saudades sinceras que ele deixava no povo havia a acrescentar, para os que eram capazes de raciocinar, o medo do futuro. Sidónio Pais representava, com efeito, o princípio da ordem e era exacto que após a sua entrada em cena a tranquilidade pública não foi gravemente perturbada. O novo Governo parecia disposto a manter a obra herdada, mas perante o transbordar intenso das paixões políticas a sua tarefa revelava-se das mais delicadas e podia, de um momento para o outro, deparar com as maiores dificuldades.

Lacónico e apressado, o coronel Thomas Birch, a quem se imputou outra frase célebre - Grande de mais para paiz tão pequeno ${ }^{(973)}$ — expediu para Washington um telegrama urgente a comunicar que o Presidente Pais tinha sido cobardemente assassinado por um anarquista cerca das $24 \mathrm{~h}$ de 14 de Dezembro na Estação do Caminho de Ferro. E acrescentou: In my judgement assassination is not the result of Bolsheviki activity. ${ }^{(974)}$

(971) Z. Europe, 1840 Portugal, Ambassadeur Français à Lisbonne, n. 199,18 de Dezembro de 1918. (Archives du Ministère des Affaires Etrangères).

(972) Ibidem.

(973) Ver MEDINA, João - Transfiguração e morte de Sidónio Pais, ob. cit., p. 167.

(974) Records of the Department of State relating to internal affairs of Portugal, 1910-1926. Political affairs, 705/4 roll, Telegrama de 15 de Dezembro de 1918. (National Archives, Washington). 
O alegado anarquista fora agarrado no local do crime, agredido e ferido, levado para a Casa do Correio da Estação e daí seguiu de automóvel para a Escola de Guerra, onde começou a ser sujeito a um duro e interminável interrogatório, prosseguido noutros espaços. Num dos bolsos acharam-lhe uma carta para o Grão-Mestre Magalhães Lima e isso bastou para inculpar o velho livre-pensador, maçon, democrata e republicano, de envolvimento no crime. A polícia foi buscá-lo ao Hotel Francfort e conduziu-o ao Governo Civil de Lisboa, ${ }^{(975)}$ onde já se encontrava Brito Camacho, ${ }^{\left({ }^{776}\right)}$ figuras conhecidas no meio de uma vasta leva de detidos conotados com o presumível complot democrático.

Forçado a falar, José júlio da Costa mostrou-se loquaz e orgulhoso da proeza - Bizarro, teatral, melodramatico nas palavras de Rocha Martins. Chamou a si a responsabilidade de um acto cometido para salvar a República. Nos meandros da «confissão» citou nomes de pessoas amigas e conhecidas, imediatamente presas e interrogadas, e reconstituiu os seus passos no dia do crime do Rossio, bem como a sua ida ao Arsenal e ao Hotel Francfort para falar com Magalhães Lima. E num futuro imediato não perdeu ocasião de justificar a sua missão libertadora contra o absolutismo.(977)

Pela súmula do interrogatório a que foi submetido vê-se, pois, que josé Júlio confessou haver cometido o atentado contra a vida do Presidente da República, acrescentando ser democrata e frequentar em Garvão a Barbearia do primo José Joaquim da Silva, onde colocava num prego alocuções à União Sagrada a fim de serem lidas pelos fregueses da loja e falara várias vezes com Francisco Ernesto Goes, por este ser democrático, sobre a situação política, resolvendo ambos entre si o assassinato de Sidónio Pais. Contou ainda como se dispôs a praticar o plano e as providências que tomou, tendo escrito duas cartas - uma para a mãe e outra para a mulher — ao cuidado do dito Goes. Partiu para Lisboa no dia 9 de Dezembro na companhia de Caetano Rosa Dourado, que ignorava em absoluto a intenção da viagem e falou com vários indivíduos democráticos de quem não pôde precisar os nomes por desconhecê-los e os quais eram tambem de opinião que Sua Ex. ${ }^{\circ}$ devia ser assassinado, tendo tambem procurado duas vezes o Ex.mo Sr. Dr. Sebastião Magalhães Lima no Francforte-Hotel, afim de o consultar ácerca do atentado só falando-lhe apenas uma vez e sobre uma manifestação ao Exmo Sr. Wilson, Presidente da Republica dos Estados Unidos daAmerica do Norte, não Ihe fallando na sua intenção por elle se encontrar doente. Na manhã do sábado sangrento foi à Igreja da Encarnação onde - Chefe do Estado comparecera para assistir à missa por alma das vítimas do Augusto de Castilho com o intuito de praticar o crime, mas arrependeu-se por se tratar de uma homenagem aos mortos, rumando, por isso, ao Palácio de Belém com o mesmo intuito. O sistema de segurança, aí montado e já atrás descrito, fê-lo recuar, decidindo, então, executar o plano à noite quando Sidónio Pais embarcasse para o Porto. Como se vê, José Júlio estava a par de todos os movimentos da vítima...

\footnotetext{
(975) Cf. Magalhães LIMA, Sebastião Magalhães - Episódios da minha vida, ob. cit., p. 316-319.

(976) Cf. CAMACHO, Brito - Uma noite, in Idem - Matéria vaga, ob. cit., p. 34-38.

(977) Ver, por exemplo, entrevista de Manuel RIBEIRO inserida em ALBUQUERQUE, António de - Sidónio na lenda, ob. cit., p. 89-95. É de registar, também, o depoimento de Bourbon e MENEZES sancionador do acto homicida no plano político (Cf. Ibidem, p. 100). Ver ainda MARTINS, Rocha - Memorias sobre Sidonio Paes, ob. cit., p. 297-304.
} 
Regressado a Lisboa, procurou no Arsenal de Marinha o amigo António Augusto de Almeida, sargento-ajudante da Armada, para discutir com ele por ser democratico o crime, mas com quem não falou por não se achar no Arsenal, segundo lhe foi dito pelo 1. grumete José Pedro, com quem foi passear até perto das $23 \mathrm{~h}$. Estiveram no Café Suisso, onde ficou o Pedro emquanto elle, Costa, ia ao Hotel Internacional onde estava hospedado, buscar a sua capa, e voltando ao café sahiram ambos, dirigindo-se para a estação de Lisboa Rocio, onde depois da chegada de forças de policia, se separaram, mandando o Pedro para o quartel a aguardar os acontecimentos. Na conversa que manteve com esse grumete sondou-o sobre o eventual apoio da Marinha à revolução que o seu acto iria - estava convencido disso - provocar, indicando mesmo qual devia ser a composição do Governo a constituir na sequência da revolução libertadora (Sidónio libertara a Nação da tirania democrática, Costa libertava a Nação e a República da tirania sidonista - expressão cabal do círculo-vicioso ou bloqueio do sistema político). Sozinho dirigiu-se para junto da porta da gare e aí aguardou a

chegada de Sua Excelencia colocando-se perto da porta que dá ingresso á gare, dando a direita a esta e a esquerda ao lado d'onde vinha Sua Ex. ${ }^{a}$ e quando Sua Ex. ${ }^{\circ}$ se aproximava do local em frente do sitio onde elle, Costa, estava, sacou da algibeira do casaco a sua pistola, e afastando os dois guardas da policia que estavam na frente da ala do povo, e cada para seu lado, avançou para o centro das alas e colocou-se em frente de Sua Excellencia, desfechando-lh'a para o peito, ponto que desejava atingir por ser este o mais certeiro para Lhe produzir a morte, ignorando quantos balas partiram, vendo no entanto que Sua Exc. ${ }^{a}$ ao vêl-o na sua frente se virou um pouco para o seu lado esquerdo, sem que tivesse tempo de evitar o ser atingido, por o attentado ter sido praticado repentinamente, sendo a pistola a mesma que the foi apreendida no acto da captura e que segundo o exame de folhas $1 / 4$ é da marca Browning-Patent-Brevété S.G.D.G. ${ }^{\circ}{ }^{\circ} 643253$ do calibre 32 e que elle, Costa, adquiriu por compra uns tres meses antes por 50\$00.(978)

Interrogados, de seguida, Francisco Ernesto Goes, José Pedro, Dr. Magalhães Lima e José Joaquim da Silva, os seus depoimentos variam em extensão e interesse.

O depoimento do Goes é o mais extenso, tendo confessado haver-lhe sido entregue pelo Costa a proclamação Liberdade e Portugal ou Portugal e Liberdade, em que descrevia a sua vida e fazia apreciações sobre a participação de Portugal na guerra, chamando traidores a Sua Ex. ${ }^{\circ}$ o Sr. Presidente da Republica e membros do Governo, a quem atribuía as responsabilidades no desastre havido na guerra em 9 de Abril ultimo, por não terem enviado tropas de reforço, dizendo serem vendidos ao ouro alemão e que Portugal estava definhado mas ressurgiria de novo e que esse Portugal era elle, Costa, pois que tinha soado a hora da vingança, frase esta frequentemente empregada na alocução ou proclamação.(979)

(978) Doc. avulso, fotocópia cedida ao filho do Dr. Sidónio Pais - Peça dos autos do processo-crime... (Arquivo de Sidónio Pais, Subsecção Afonso Bessa Pais). Súmula dos interrogatórios feitos aos presos josé Júlio da Costa, José Pedro, Dr. Magalhães Lima, Francisco Ernesto Goes e José Joaquim da Silva.Ver SILVA.Armando Barreiros Malheiro da - Sidónio e sidonismo. Histório e mito, vol. 2, dissert. cit., p. 993 e ss.

(979) Ibidem. 
Nas declarações prestadas por josé Pedro ficou confirmado o encontro e o convivio com o Costa na tarde do dia 14 até à hora de chegada do Presidente da República à Estação do Rossio, dizendo ainda que o Costa lhe perguntou o estado em que se encontrava a Marinha e se secundaria o movimento revolucionario, respondendo-the elle, Jose Pedro, affirmativamente, acrescentando-the que talvez mattassem S. Ex. ${ }^{\circ}$ e que talvez fosse n'aquella noite e the afiançara que o Ex.mo Sr. Dr. Magalhães Lima pertencia ao complot do movimento revolucionario dando-the o bilhete a que atraz me refiro mas para elle 0 apresentar ao Ex.mo Sr. Dr. Magalhães Lima, factos que o Costa nega, e pelo que foram acareados como consta do respectivo auto de folhas 131 e em que ambos manteem as suas declarações. ${ }^{(980)}$

Magalhães Lima negou qualquer conhecimento do crime que o Costa praticou, acrescentando que elle o procurou no hotel fallando-lhe apenas uma vez sem que elle the fallasse no atentado, e apesar de o Costa o procurar outras vezes não mais se falaram.

As declarações de José Joaquim da Silva nada adiantaram sobre o crime.

Todos os detidos para interrogação, salvo José Júlio da Costa, foram postos em liberdade. Ficou nas masmorras o confesso assassino, aguardando a conclusão de um processo-crime ${ }^{(981)}$ que merece ser localizado e examinado com particular atenção.

Entretanto e na sequência da informação do médico da Cadeia Nacional de Lisboa, com data de 2 de Março, foi deliberado submeter o prisioneiro a um exame mental que veio a ser feito pelos alienistas Caetano Beirão, Júlio de Matos e Sobral Cid, tendo estes peritos afirmado a dado passo que José Julio da Costa emprega constantemente uma linguagem em que $a$ sonoridade do verbo substitui muitas vezes a imprecisão das ideias; uma vaga phraseologia revolucionaria, com que parece desvanecer-se, cobre, com effeito, a ausencia de conhecimentos exactos de sociologia e historia. Este homem deu-nos a impressão de ser em grande parte o produto, como centenas d'outros da anarchia mental em que se debatem as sociedades actuaes, e um bom exemplar dos descontentes que, na phrase de um philosopho francez, ao sereno cumprimento do dever preferem a tumultuaria reivindicação de direitos. Não é porem um alienado nem o era ao tempo do crime de que é acusado, não podendo por isso beneficiar da irresponsabilidade que 0 art. $42 .^{\circ}$ do C. Penal confere aos alienados. ${ }^{(982)}$ Este parecer tão categórico veio a ser contradito pela evolução posterior do caso, falecendo José Júlio da Costa no Hospital Miguel Bombarda aos 16 de Março de 1946. O seu internamento num Hospital Psiquiátrico por apresentar sintomas de perturbações mentais aconteceu pouco depois de voltar a ser capturado e preso na sequência do 28 de Maio de 1926.

(980) Ver SILVA, Armando Barreiros Malheiro da — Sidónio e sidonismo. História e mito, vol. 2, dissert. cit., p. 993 e ss.

(981) ABC ouve o dr. Paes Rovisco sôbre o assassino de Sidónio Paes. ABC, Lisboa (64) 29 de Setembro de 1921.

(982) Relatório sobre o estado mental de Jose Julio da Costa, em papel timbrado da Delegação da Procuradoria da República do 3. Districto Criminal de Lisboa/Cadeia Nacional/I. Secção. (Arquivo de Sidónio Pais - Militar, Lente e Político - Subsistema D. Maria dos Prazeres Bessa Paes e Filhos). Ver SILVA, Armando Barreiros Malheiro da - Sidónio e sidonismo. História e mito, vol. 2. dissert. cit., p. 997 e ss. 
Para indignação e incoformismo de Rocha Martins, extravasados nas páginas dos seus Fantoches, ${ }^{(983)}$ José Júlio da Costa foi libertado da Cadeia Nacional por um grupo de revolucionários ligados ao 19 de Outubro de 1921 — os dois irmãos Brás e o Midões, que o levou para local seguro no Norte do País, mais precisamente em Nine, perto de Braga, segundo Rocha Martins. E aí, nesse refúgio urdido pelo P.R.P./P.D., de acordo com o mesmo publicista, levou uma boa vida: Refastela-se, goza, bebe, come, é um assassino oficial e mostra-se diante de gente de bem. É um factor de assassínios; é um impulsionador, é um exemplo famoso, é um incitamento vivo; e ao deixá-lo em paz, António Maria da Silva, Presidente de um Ministério democrático, aplaudia-o...

Se tivermos em conta a carta inédita - datada de II de Dezembro e atrás referida (ver Anexo 3) - do arquitecto Martinet a pedir uma audiência urgente para Afonso Costa e Bernardino Machado, confidenciando aí que a situação em Portugal ia mudar muito em breve, as declarações constantes na súmula dos interrogatórios exarados no processo-crime, a libertação de José Júlio no tragicamente célebre 19 de Outubro ou noite sangrenta, a oposição dos alienistas a um diagnóstico de alienação mental e ainda a permanência do Costa em liberdade durante os quase cinco derradeiros anos da I. a República, não perde necessariamente consistência a tese de que o atentado teria partido da iniciativa individual do homicida, mas também não fica de modo algum excluída a probabilidade de ter existido um complot democrático, ${ }^{(984)}$ mais exactamente de se ter mantido em curso, através da dispersa e flexível malha de núcleos da rede sóciopolítica do P.R.P./P.D., a deliberação de abater Sidónio, único meio de mudar a situação, visto terem falhado todas as tentativas de golpe e de insubordinação generalizada.

As duas teses, face aos dados disponíveis - escassos e contraditórios alguns deles - podem não se contrapor e tenderem a aproximar-se, aglutinando até uma terceira possibilidade: 1 . $^{\mathrm{a}}$ - os marinheiros, soldados e civis bombistas afectos ao democratismo teriam tutelado/aproveitado a intenção pessoal e o desequilibrio mental de José Júlio; 2. ${ }^{\text {a }}$ - este ter-se-á anichado nas alfurjas dos democráticos; e 3. ${ }^{\text {- }}$ - algum (alguns) dos dois ou dos vários tiros ouvidos terá (terão) partido de outro atirador saído dessas mesmas alfurjas.

Enfim, nuances hipotéticas em torno de uma questão que permanece enigmática...

\section{A Morte do Chefe e da "sua» República}

Enquanto decorriam as prisões, as manifestações de vingança e os interrogatórios, num ambiente de profunda comoção e perplexidade, as autoridades, os congressistas e os líderes partidários, mal refeitos do abanão sofrido, procuraram reagir por forma a

(983) Cf. Fantoches. Bastidores da política e dos negocios. Lisboa (3) 20 de Janeiro de 1923; (9) 3 de Março de 1923; (21) 26 de Maio de 1923; (37) 15 de Setembro de 1923; (42) 20 de Outubro de 1923; e (48) I de Dezembro de 1923. Ver também nota de MEDINA, João - O Sidonismo ou a Republica fracturada, in Idem - História de Portugal, vol. 11 - A República, ob. cit., p. 73.

(984) Fernando Pessoa apressou-se a negar essa «tese» para defender a Maçonaria.Ver Idem - Da República (1910-1935). Introdução e organização joel Serrão. Recolha de textos Maria Isabel Rocheta e Maria Paula Morão. Lisboa: Ática, 1978, p. 266-267. 
evitar consequências piores, temendo, sobretudo, o eclodir de tumultos, de greves ou de eventual insubordinação de tropas.

Do Exército, porém, o alarme dado não se situou à esquerda, antes à direita: as Juntas Militares reclamaram a continuação da obra do Grande Presidente e a nomeação imediata de um Governo de Ordem.

Logo no domingo, deputados e senadores reuniram na Secretaria de Estado do Interior sob a presidência do Presidente do Senado Zeferino Falcão e tomaram, ao cabo de uma prolongada reunião, diversas deliberações de carácter reservado. Estavam, obviamente, a pensar numa solução rápida para o vazio de Poder criado numa altura delicada quer interna, quer sobretudo externamente. A extrema delicadeza das circunstâncias serviu de pretexto para que de Londres Egas Moniz emitisse, nesse mesmo domingo dia $\rfloor 5$, dois telegramas denunciadores de uma postura táctica contrária à defendida pelo Presidente morto e comprometedora para os adeptos do presidencialismo forjado desde, pelo menos, a publicação da lei eleitoral de 30 de Março:

N. ${ }^{\circ} 60$ Londres, em 15 de Dezembro. 1918

Ministro Colonias [capitão de mar e guerra e médico Alexandre de Vasconcelos e Sá]

Urgentissimo. Confidencial.Acabo receber terrivel noticia. Indispensavel a meu vêr eleição immediata novo Presidente Republica. Lembro-te nome Relvas, Braamcamp, ou qualquer outro que imediatamente tome conta logar. Entendo tambem que podia immediatamente ser aceita antiga constituição com aditamento dissolução. Lembra isto Pinheiro. Seria satisfação completa todos parlamentaristas e seria afirmação vantajosa para estrangeiro o conseguirmos immediatamente uma constituição. Julgo isto muito importante e acabavamos com novas perturbações ao discutir novo projecto constituição. Seria o entrarmos já normalidade.Tu verás o que convem fazer. Dá noticias.

Egas Moniz ${ }^{(985)}$

No dia seguinte, por meio de novo telegrama, solicitou informações sobre a situação política e lançou mais alguns alvitres:

N. ${ }^{\circ} 63$ Londres, em 16 de Dezembro. 1918

Ministro Colonias. Lisboa.

Achava muito conveniente V. Ex. ${ }^{\circ}$ desse ordens Angola para que automoveis militares visitem quanto possivel regiões menos bem ocupados por nós. Consta-me que nossos inimigos chocolateiros daqui tentam apresentar uma carta Angola indicando regiões que ainda não ocupamos. Peço noticias sobre politica interna daccordo com que resolverem. Braamcamp seria optimo Presidente bem como Relvas. Não seria bem visto Presidente militarista. Mande dizer o que poder pois carecemos informações para nos defendermos perguntas que nos fazem. Sigo quintafeira Patria.

Egas Moniz.

(985) Cf. SILVA.Armando B. Malheiro da - Egas Moniz e a política. Notas avulsas para uma biografia indiscreta. In Egas Moniz em livre exame, ob. cit., p. 292-295. 
E do Secretário particular Correia Mendes recebeu no dia 17 a indicação de ter ficado mesmo Governo Presidencia Canto e Castro. Maioria reunida resolve eleger hoje sessão congresso Presidente Republica provisorio; indica nome Nunes da Ponte, Bettencourt Rodrigues, José Relvas e Canto e Castro. Situação gravissima; militares querem dictadura militar e plebiscito nação sobre forma de Governo; para obstar esta questão Tamagnini propoz nome Canto e Castro Presidente da Republica. Notícias satisfatórias e preocupantes que hão-de acompanhar o evoluir agitado e incerto da situação.

A satisfação de Egas Moniz pela solução política adoptada - solução de compromisso que mantinha válida a revisão constitucional prevista no decreto eleitoral de 30 de Março de 1918, cara aos presidencialistas - está bem patente no seguinte telegrama expedido para Correia Mendes também a 17:

Acho acertadissima escolha Canto Castro em quem logo pensei. Receei que não aceitasse. Acceitando dá prova alto patriotismo que mais radica minha admiração suas excelentes qualidades. Diga isto nossos amigos. É a melhor solução tal como daqui vejo politica Portugueza. Julgava indispensavel como solução imediata para evitar plebiscito, demonstrações militares e outras tolices, permanecer actual Ministerio até conclusão paz com Canto Castro presidente da Republica e do Ministerio ou melhor com Presidente Ministerio extranho Ministerio e sem pasta. Indispensavel aprovação rapida constituição a adoptar e depois regular situação politica. Muito confidencial. Entendo que não deve ir agora aí a não ser chamado oficialmente ou dando demissão que hoje peço acompanhando colegas d'aí. Doutra forma seria incorrecção indesculpavel. Peço explique sua frase final telegrama 154. Continue dar-me informações pormenorisadas. Ainda não sei dia partida Paris.

Egas Moniz

De domingo a terça-feira precipitaram-se, em Lisboa, as decisões importantes sob a óbvia pressão, entre outros, de Egas Moniz. No próprio dia 15 o Governo e mais autoridades, reunidas de emergência logo após o atentado,(986) escolheram Canto e Castro para Presidente do Executivo, tendo sido deliberado mandar imprimir no Diário de Governo uma Proclamação deste teor:

Portugueses! No momento gravissimo da nossa história, em que a dentro do País se procurava iniciar um futuro próspero e brilhante para a Terra Portuguesa e em que alêm fronteiras se vão decidir os direitos e os deveres das Nações do mundo inteiro, produziu-se um acto da maior vileza, privando Portugal do seu Chefe llustre!

Nesta ocasião todos os portugueses devem unir-se para defender a Nacionalidade, dando um alto e digno exemplo de civismo.

Barbaramente assassinado Sua Excelência o Senhor Dr. Sidónio Pais, Chefe de Estado, bondoso, ilustrado, justo e querido, é forçoso que nos lembremos da Pátria em perigo e que o bom Povo Português saiba enveredar pelo caminho ditado pelo mais vivo sentimento do dever.

(986) Cf. NETO, Roma - A Morte do Dr. Sidonio Paes e a actual situação política, ob. cit., p. 55-56. 
O Governo da República, nos termos do $\S 3 .^{\circ}$ do artigo 38. da Constituição, investiu-se na plenitude do Poder Executivo, elegeu para seu Presidente o Secretário de Estado da Marinha e interino dos Estrangeiros, Sr. Almirante joão do Canto e Castro Silva Antunes, e resolveu:

1. Manter absolutamente $a$ ordem em todo o País, para o que conta com o patriotismo do Povo e a cooperação de todas as Forças de Terra e Mar.

2. ${ }^{\circ}$ Honrar a memória do grande português e extinto Presidente da República Portuguesa, Senhor Dr. Sidónio Pais.

No Congresso da República, fiel depositário do mandato da Nação, confia o Governo. Ele saberá cumprir o seu dever, dando, como sempre, ao País e ao mundo inteiro, a mais alta demonstração do seu nunca desmentido patriotismo.

Pela Pátria em perigo e pela República honesta e ordeira, todos nós, portugueses, temos de pugnar sem violências, mas com a inquebrantável energia que se impõe.

O Govêrno conta com o Paí!! (987)

Homenagem sentida à memória do Chefe llustre e demonstração de firmeza na manutenção da ordem, indispensável nesse transe. Inevitáveis apelos ao patriotismo do Povo, à cooperação do Exército e da Marinha e ao concurso espontâneo e destemido de todos para pugnar sem violências em prol da Pátria em perigo e da República honesta e ordeira rematavam a comunicação, que urgia transmitir ao país. E como se impunha, também, solenizar com extremo respeito e profundo sentimento nacional tão dolorosa perda o Executivo aproveitou o mesmo ensejo e o mesmo número da folha oficial para fixar, através do decreto n. 5.057 de 15 de Dezembro, trinta dias de luto geral, sendo os primeiros quinze dias de luto pesado e os restantes de luto aliviado. ${ }^{(988)}$

No dia 16, segunda-feira, as duas Câmaras do Congresso reuniram-se separadamente pelas $14 \mathrm{~h}$.. Às $18 \mathrm{~h} 30 \mathrm{~m}$ responderam à chamada cento e trinta e quatro deputados e senadores reunidos, em sessão conjunta, para elegerem o novo Presidente da República, dentro das disposições fixadas pela Lei n. ${ }^{\circ} 833 .{ }^{(989)}$ Por maioria de dois terços foi escolhido o almirante Canto e Castro: num primeiro escrutínio entraram na urna 125 listas quando eram necessários I3I votantes para a eleição ser válida, pelo que se fez segundo escrutínio, em que o referido oficial da Armada obteve I 37 votos das I 38 listas entradas. Concluída a eleição S. Ex. ${ }^{a}$ dá entrada na sala, sendo recebido com grandes aclamações. Profere o compromisso marcado na Constituição e lê um agradecimento ao Congresso. Repetem-se as aclamações e S. Ex. ${ }^{\circ}$ sae da sala, encerrando o Sr. Presidente a sessão. ${ }^{(990)}$

Na sessão vespertina do Senado houve várias intervenções de pesar e de indignação pelo trágico evento.

O Presidente Zeferino Falcão abriu os trabalhos dizendo que a sessão era dedicada à memória do falecido Presidente da República como preito ao exemplo da vida do Sr. Dr. Sidónio Pais, que exercera uma benéfica influência nos destinos nacionais (Muitos apoia-

\footnotetext{
(987) Cf. Diário do Governo. I série (272) 15 de Dezembro de 1918, p. 2169.

(988) Ibidem, p. 2170.

(989) Ibidem (273) 16 de Dezembro de 1918.

(990) Cf. Diário do Congresso. Sessão n. 26 em 16 de Dezembro de 1918, p. I.
} 
dos) ${ }^{(991)}$ e propondo que os trabalhos fossem suspensos em sinal de sentimento depois dos oradores inscritos terem usado da palavra. E o primeiro a fazê-lo foi o líder da maioria Castro Lopes com uma alocução curta da qual extractamos esta ilustrativa passagem: $\mathrm{Sr}$. Presidente: desde as 23 horas e 55 minutos de sábado até agora temos passado as horas mais amargas de há uns bons tempos a esta parte, porque o Sr. Dr. Sidónio Pais era a figura mais grandiosa que a Pátria perdeu. E, Sr. Presidente, se alguém alguma vez foi injusto para com êle, terá hoje de reconhecer que essa enorme figura de português, que tanto mereceu da sua Pátria e tantas glórias Ihe deu, era um grande patriota e comovidamente ajoelhará sobre o seu túmulo(992). Seguiu-se-lhe o senador representante dos Serviços Públicos, Carneiro de Moura, que começou por lembrar o convite que os colegas funcionários públicos Ihe haviam feito, meses atrás, para cumprimentar o Presidente da República em Belém e agradecer-lhe o decreto promulgado sobre subvenções. Acedera ao convite, entre outras razões, por conhecer e ser amigo de Sidónio Pais desde os tempos de Coimbra. E embora, volvidos esses meses, o seu «estado de alma» fosse diferente - entenda-se: desiludido e desagradado com certos aspectos da política seguida — sentia-se no dever de lamentar, em nome dos Directores-Gerais e Chefes de Serviço, o trágico acontecimento e de alertar para a tremenda responsabilidade que sobre nós pesa, tópico recorrente no seu discurso simultaneamente elegíaco e crítico, assente num utopismo anti-individualista e num tradicionalismo progressista e anti-decadentista. ${ }^{(993)}$

Em nome da minoria monárquica Mário Monteiro associou-se às comovidas expressões até então proferidas, sublinhando que entre Sidónio Pais e os monárquicos havia um ponto de contacto em matéria fundamental de administração política: a convicção de que Portugal não poderia realizar as condições necessárias quer para o seu desenvolvimento, progresso e bem-estar, quer até para os níveis mínimos e indispensáveis à sua própria sobrevivência, sem a intemerata e intransigente defesa dos princípios políticos conservadores; separava-os, porém, o modo prático de realizar tão alto pensamento: eles entendiam que a restauração do regime monárquico constituía a condição sine qua non, ao passo que Sidónio Pais propôs-se demonstrar praticamente, que o podia ser com 0 regime republicano. ${ }^{(994)}$

Por seu turno, o senador católico Pinto Coelho começou por considerar o crime praticado como um dos maiores crimes que neste momento podiam ser cometidos contra a pátria portuguesa, porque ao contrário da revolução de 1910 , infelizmente estéril em homens de grande estatura política, a revolução de 1917 produzira Um homem com uma tal estatura para ser chefe, que todos nós, sem o mínimo esforço, antes com o mais espontâneo respeito, como chefe o acatávamos e venerávamos. ${ }^{(995)}$ E prosseguindo, reconheceu ter sido criminoso o acto que interrompeu a obra heróica iniciada por Sidónio Pais, mas em vez dos clamores de Vingança! Vingança! espalhados pela imprensa, ${ }^{\left({ }^{996}\right)}$ recomendava

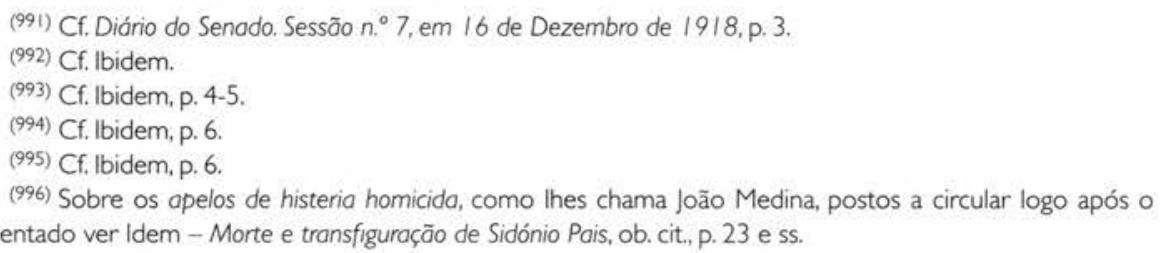


que se clamasse Justiça! Justiça! célere e dura, e se homenageasse a memória desse grande homem continuando e fecundando a sua gloriosa obra.

Mais oradores intervieram - Queiroz Veloso, Machado Santos, Oliveira Santos, Ribeiro do Amaral, Costa Couraça, Afonso de Melo,Arnaut Furtado, João José da Costa, Jorge Guimarães, Luis Firmino de Oliveira, Alfredo da Silva, Augusto Cerqueira e Novais da Cunha - exaltando todos as qualidades e as virtudes do ilustre morto, condenando todos com veemência o crime e homenageando em uníssono a sua memória. E um deles - Ribeiro do Amaral - em conformidade com a sua arreigada e natural crença católica rematou a alocução dizendo: Sr. Presidente: o Sr. Dr. Sidónio Pais não cumpriu a sua obra que devia ser grandiosa a avaliar pelo que ele já fizera em tam pouco tempo. Julgo, porém, que ela se consumará, porque todos nós, portugueses, devemos ter o desejo, o afan, de a concluir, para que esta Pátria tenha uma época de felicidade e de justiça. Ele, no seio de Deus onde se encontra, velará por todos nós, e o seu sangue derramado redimirá esta infeliz terra que, em verdade, quási o não merecia.(997)

$\mathrm{Na}$ Câmara dos Deputados não foi menor a comoção e a dramaticidade dos discursos proferidos perante todo o Governo aí presente.

De acordo com o ritual o Presidente da Mesa,António Lino Neto, comunicou a notícia do assassínio do Presidente da República, que elogiou, condenando com veemência o vil atentado. De seguida, vários oradores inscritos pediram para se associarem à evocação da figura e à reprovação do acto, tendo até intervido Martinho Nobre de Melo, deputado eleito pelo P.N.R., que nunca comparecera no hemiciclo por se considerar antiparlamentarista. Para além dele usaram da palavra o Presidente do Governo Provisório e o Secretário de Estado da Marinha e interino dos Negócios Estrangeiros, e os deputados Almeida Pires (líder da maioria), Aires de Ornelas pela minoria monárquica, Pinheiro Torres pelos católicos, o socialista João de Castro, Costa Lobo, Lobo de Ávila Lima, Joaquim Crisóstomo, Amâncio de Alpoim, António Cidrais, o machadista José Carlos da Maia, Feliciano da Costa, Botelho Moniz e Pedro Fazenda. Amigos, adeptos, adversários e ex-cúmplices políticos não destoaram quanto ao essencial, confirmando, aliás, a prática habitual de elogiar na morte os que eram duramente fustigados em vida...

A sessão foi interrompida por meia hora, em sinal de sentimento, e ao ser reaberta, - líder da maioria governamental mandou para a Mesa um projecto de lei, para o qual requerera a urgência e a dispensa do Regimento, suspendendo, até à revisão constitucional, alguns artigos do decreto n. ${ }^{\circ} 3.996$ de 30 de Março de 1918, e fixando doutrina sobre o exercício das funções do Chefe de Estado, a eleger, nos termos do $\S 2 .^{\circ}$ do artigo $38^{\circ}$ da Constituição de 1911 e sobre o exercício do Poder Executivo até à posse do novo Presidente da República - efectivada somente em 30 de Dezembro.(998) $\bigcirc$ projecto foi discutido, aprovado e a sessão encerrada sem mais assunto.

Em três dias, como se acaba de ver, o presidencialismo, que correspondera à Ideia Nova tão enfaticamente anunciada e repetida por Sidónio Pais no auge da sua campa-

(997) Cf. Diário do Senado. Sessão n. ${ }^{\circ}$ 7, em 16 de Dezembro de 1918, p. 9.

(998) Ver Congresso da República. Proclamação. Diário do Governo. I série (282) 30 de Dezembro de 1918. 
nha carismática por uma República honesta e ordeira, foi sacudido para o limbo numa manobra hábil, tendente a reconciliar a situação sidonista com certas franjas da oposição republicana.

A atitude posterior dos monárquicos e das próprias figuras centrais da rede sidonista deram o seu concurso para que, aos solavancos e ao ritmo das contorsões de um estado de guerra civil iminente, os democráticos tão detestados e temidos acabassem por impor a sua força e a sua organização partidária, regressando à esfera do Poder.

\section{Últimas homenagens e funeral nacional}

Esse regresso já não faz parte do âmbito da nossa narrativa.

Concentramo-nos, por isso, de novo em Sidónio e no seu cadáver, que do Hospital de S. José foi transportado para Belém, no dia 15, para ser embalsamado, operação executada no dia 16 e concluída pelas 18 h, após o que se encarregaram de vestir o defunto.

É muito significativo do ponto de vista mítico-simbólico que, para além da farda de Chefe das Forças de Terra e Mar, e das condecorações condizentes com a sua dignidade oficial, lhe tenham prendido na farda um pequeno crucifixo de madeira preta semelhante a pau santo, encastoado em metal branco parecendo prata e com a imagem de Jesus Cristo do mesmo metal; e ainda à volta do pescoço e directamente sobre a epiderme ha um cordão de oiro tendo suspensos dois crucifixos de madeira semelhando ebano, encastoados em metal branco parecendo prata, duas medalhas de metal analogo e uma medalha de esmalte com argola de metal amarello tendo o aspecto de oiro. Os crucifixos são um maior e outro mais pequeno e muito semelhantes. Em ambos existe sobre a cruz a imagem de Jesus Christo em metal da mesma natureza do que circumda os crucifixos. Uma das medaIhas tem n'uma das faces a imagem do Coração da Virgem Maria.A outra medalha mostra n'uma das faces egualmente a imagem do Coração de Jesus vendo-se em volta a seguinte inscripção: Aimé soit par tout le sacré coeur de Dieu. Na outra face vê-se uma imagem da Virgem Maria rodeada por uma inscripção pouco legivel, onde no emtanto se póde divisar: Sacré coeur priez pour nous. A medalha de esmalte apresenta n'uma das faces a imagem de Nossa Senhora da Conceição e na outra tem escripto o seguinte: Saint Maria Imaculada ore pro nobis. ${ }^{(999)}$

Não é de excluir, antes pelo contrário, que a fervorosa devoção da Condessa de Ficalho tenha tido algo a ver com a colocação de alguma(s) destas imagens santas, ${ }^{(1000)}$ tanto mais que ela acorreu logo para Belém e lá permaneceu, como se lê na imprensa: a Condessa de Ficalho não abandonou o quarto particular do finado. Depois de vestido, os familiares mais próximos - irmãos e filhos - despediram-se do saudoso morto, sendo então este colocado numa urna exposta no referido quarto particular, a fim de que pudesse receber o preito de homenagem de todos quantos desejassem fazê-lo.

(999) Cf. AGUIAR, Asdrubal António de - Exames periciais no cadaver do Presidente da República Dr. Sidonio Paes no vestuario e na arma aggressora, ob. cit. p. 34.

(1000) Ver SILVA, Armando Barreiros Malheiro da - Sidónio e sidonismo. História e mito, dissert. cit., vol. 2. p. 1030-1039. 
Dentro do programa estabelecido que culminava com um funeral religioso no dia 21 , sábado, o Grande Morto estaria exposto no Palácio de Belém até ao dia 18, sendo depois transferido para o salão nobre da Câmara Municipal e aí exposto até aos preparativos do cortejo fúnebre. Segundo a imprensa milhares de pessoas desfilaram perante o cadaver do sr. dr. Sidonio Paes. Enão se limitaram a desfilar. Muitas delas deixaram o nome escrito nas folhas de bordadura negra destinadas ao registo de um gesto consagrado pela liturgia finissecular da morte. Ao todo contamos, inscritas em 398 folhas pautadas, 5.514 homens e 2.922 mulheres, perfazendo um total de 8.436, a que podemos ainda somar 1.154 indivíduos de ambos os sexos - a cifra global é, portanto, de 9.590 - identificados mediante cartão de pêsames. ${ }^{(1001)}$

Entretanto em Coimbra, um dos principais espaços da bio-geografia de Sidónio Pais, a sua morte foi solenemente sentida pela Universidade, cujos órgãos e Faculdades se hão-de associar ao funeral, querendo mesmo perpetuar a memória de tão destacado membro.(1002)

Logo que soube do trágico evento, a Academia reuniu em Assembleia Geral na Sala dos Capelos e de pé, por aclamação, aprovou uma proposta para que fosse celebrada uma missa na Capela da Universidade, encerrada ao culto desde a implantação da República. A Academia decidiu ainda deslocar-se a Lisboa para participar no funeral e, apesar das dificuldades de transporte, algumas centenas de estudantes rumaram à capital, de capa e batina, para prestarem a derradeira homenagem àquele que fora, durante alguns meses, o ídolo de uma boa parte dos portugueses. ${ }^{(1003)} \mathrm{A}$ missa proposta realizou-se no dia 19, sendo celebrante o doutor António Garcia Ribeiro de Vasconcelos, tendo assistido o Bispo Conde, o Reitor da Universidade, muitos professores, as autoridades civis e militares e muitos estudantes. O Boletim da Diocese de Coimbra perpetuou, de forma lapidar, essa e outras homenagens de cariz religioso:

No dia 14 perto da meia noite o grande homem, o heroe, o Presidente da República Dr. Sidonio Paes cahiu varado pelas balas dos sicários.

Não quiz Deus fazer mais um milagre para salvar a vida a quem tam ousadamente a expunha. Já assim procedera para com os martyres, e este foi um martyr da Patria e quem sabe se tambem da Religião, pois que a Maçonaria o considerava como um renegado. Bendictos os designios da Divina Providencia que talvez quizesse evitar que este Grande Chefe de Estado morresse de desgostos e ingratidões.

(1001) [Folhas de pêsames, Dezembro de 19/8]. (Arquivo de Eurico Cameira). Os valores apresentados exigem o seguinte esclarecimento: várias das pessoas que assinaram fizeram-no em seu nome e no de familiares, amigos e instituiçōes às quais pertenciam; em caso de dúvida na leitura dos nomes optou-se por incluí-los no grupo dos homens, substancialmente mais elevado que o das mulheres; e a par das cerca de quatrocentas folhas assinadas foram entregues cartões cujos elementos de identificação constam de uma lista dactilografada em vinte e seis folhas em papel timbrado da Secretoria da Presidência da República.

(1002) Correspondência, Telegramas (Arquivo da Universidade de Coimbra). Correspondência (Arquivo de Sidónio Pais - Subsistema D. Maria dos Prazeres Bessa Pais e Filhos). A Universidade de Coimbra no século XX. Actas da Faculdade de Ciências vol, I (1911-1927), ob. cit., p. 132-133; e A Universidade de Coimbra no século XX.Actos da Foculdade de Letros, vol. I (1911-1925), ob. cit., p. 154-155..

(1003) Cf. GOMES, Joaquim Ferreira - A Universidade de Coimbra durante a primeira república (1910-1926), ob. cit, p. 316-317. 
No dia 16 o Exmo Sr. Bispo Conde celebrou Missa por elle na sua capella particular, apresentou pessoalmente os seus pezames á Auctoridade Militar e Civil de Coimbra e fez expedir ao Chefe do Governo o telegrama seguinte: «Apresento condolencias infame assassinato Presidente da Republica martyr do dever patriotico - Bispo Conde.

No dia 19 tambem S. Ex. ${ }^{\circ}$ Rev.ma assistiu na Capella da Universidade a uma Missa celebrada por alma do Presidente da Republica por iniciativa e a pedido da briosa Academia. Foi celebrante o Ex.mo Sr. Bispo Conde, assim como os outros Ex.mos Prelados, esperavam o imponentissimo e sentidissimo cortejo.

Foi um funeral digno d'este grande homem e digno duma Nação que quer ser grande. $^{(1004)}$

Pedaço de prosa do jornalismo católico institucional que exprime bem a aproximação equívoca da Igreja à figura de Sidónio e à sua política, a ponto de o celebrar como Mártir e Santo, embora se soubesse que ele era um incrédulo e vivesse em pecado nas palavras eloquentes de Mons. Masela.

Uma semana mediou a grande cerimónia de homenagem e de despedida. Semana de consternação, de dor e de grande tensão política que reflectiu, com grande nitidez, a clivagem funda e bipolarizadora que agitava, então, a sociedade portuguesa e o paroxismo mítico-simbólico do imaginário nacional. Assim se entende que as romagens de saudade e de comoção impressionassem, que o cortejo fúnebre — relatado de um modo intenso e impressivo no jornal A Situação do dia 24 e em cuja capa se lê a evocação Ao Herói que morreu Mártir - constituísse uma extraordinária manifestação de sentimento para citarmos as palavras do Diário de Noticias de 22 de Dezembro e que durante o préstito, todo ele feito a pé, sob chuva e por um trajecto algo sinuoso — rua do Arsenal,Terreiro do Paço (onde o cortejo foi organizado), rua Augusta, Rossio com passagem junto ao Teatro Nacional (em cujo terraço assistiu à passagem do cortejo um numeroso grupo de crianças), Chiado, rua do Alecrim, rua 24 de Julho, Santos, Janelas Verdes e Belém - tivesse havido o disparo de tiros, situações de pânico, feridos e mortos... (1005)

Durante e após o préstito circularam de mão em mão as catorze folhinhas (cuja autoria é atribuível a Alfredo de Magalhães) contendo um perfil hagiográfico, mais que biográfico, do Grande Morto, ${ }^{(1006)}$ muitas pagelas e santinhos em memória da alma do Presidente Sidonio Paes, vários tipos de postais de eterna saudade e um caudal imenso de sonetos, quadras, poesias de variável extensão e de recorte literário muito desigual inundou as páginas dos jornais e nutriu o pranto colectivo, carpido semanas a fio.(1007) Durante e após o funeral foi lembrada pelo jornal A Situação a construção de Um Monumento ao Grande Português Sidónio Pais através da subscrição aberta Aos que muito o amaram $^{(1008)}$ — ideia interrompida com o regresso dos democráticos à governança do

(1004) Cf. |4-21 de Dezembro. Boletim da Diocese de Coimbra. Coimbra (19) Janeiro de 1919, p. 296-297.

(1005) SILVA, Armando Barreiros Malheiro da - Sidónio e sidonismo. História e mito, dissert. cit, vol. 2, p. 1013 $-1029$.

(1006) Ver lbidem, p. 1062-1070.

(1007) Ver Ibidem, p. 1040-1061.

(1008) Ver sobre o assunto MEDINA, João - Morte e transfiguração de Sidónio Pais, ob. cit., p. 42-43. 
país e retomada, sem concretização, pela Ditadura Nacional e pelo Estado Novo(1009) - e bem mais lírico e sentimental foi o alvitre lançado, no Diário Nacional de Aires de Ornelas, ${ }^{(1010)}$ por D. Maria Madalena Trigueiros de Martel Patrício da oferta à filha do Grande Morto, D. Maria Sidónia, de um colar de pérolas, denominado colar de lágrimas, oferta sentida como prenda de noivado à gentil filha do glorioso Presidente da República, sr. dr. Sidónio Pais, que vai casar brevemente, para que ela assim pudesse levar no dote as nossas lágrimas, as lágrimas que todas choramos pela morte de seu Pai!.(1011) Esse colar existe e é uma pérola da sensibilidade feminina...

Enfim, durante e após essas grandiosas manifestações de pesar, Sidónio Pais não se transfigurou em Mito entendido como lenda, ${ }^{(10 / 2)}$ porque o que essas manifestações deixam perscrutar é, já em plena dimensão mítico-simbólica, a transfiguração do Herói prometeico e milenarista em Mártir e Santo da liturgia cristã-católica messiânica.

(1009) Sobre as vicissitudes da memória de Sidónio Pais até à actualidade ver SILVA, Armando B. Malheiro da e TRIGUEIROS, António Júlio Limpo - Sidónio Pais. De Caminha ao Panteão Nacional, ob. cit. , p. 5 I-68.

(1010) Cf. Diário Nacional, 28 de Dezembro de 1918, p. I.

(1011) Cit. por MEDINA, João - Morte e transfiguração de Sidónio Pais, ob. cit., p. 44-45. O autor refere aí que a ideia de converter as lágrimas em pérolas para a casadoira Maria Sidónia parece porém não ter chegado a concretizar-se (p. 45), mas, ao contrário do que sucedeu com o monumento à memória do "Grande Morto», o colar foi feito e oferecido.

(1012) Nesta acepção parece situar-se GARRIDO, Álvaro - Sidónio Pais: a edificação do mito. História. Lisboa. Nova Série, 16:2 (Nov., 1994); e, também, MEDINA, João - Varões republicanos. Quatro retratos de vultos políticos da I República: Machado Santos, Afonso Costa, João Chagas e Sidónio Pais. Clio. Revisto do Centro de História da Universidade de Lisboa. Lisboa, nova série, 2, 1997, p. 174. 


\section{Fontes e Bibliografia}

\section{I - Arquivos ou Sistemas de Informação}

\section{[Institucionais]}

Administração do Concelho de Barcelos [Livro de Testamentos Cerrados, n. 55 (I878-1879)]. in Arquivo Municipal de Barcelos.

Administração do Concelho de Caminha [Testamentos cerrados, I83I], in Arquivo Municipal de Caminha.

Archives du Ministère des Affaires Etrangères. [Légation de la République Française en Portugal, Z- Europe/Portugal, 1917-1918, vols. I a I5].

Archivio Segreto Vaticano. [Nunziatura Apostolica di Lisbona, 1912-1922, vários dossiers e correspondência diplomática].

Arquivo da Biblioteca do Seminário Maior Episcopal de Coimbra, [Livro do movimento literário, nos 1,5 e 6$]$.

Arquivo da C.P.. [Edifício das Relações Públicas e Secretaria Geral e Estação de St. ${ }^{a}$ Apolónia]. [Acta da reunião de 24 de Fevereiro de 191 I da Comissão especial para o estudo das reclamações do pessoal sobre a Caixa de Reformas e Pensões e livro das actas do Conselho de Administração da Companhia Real dos Caminhos de Ferro Portugueses, 1910-1911].

Arquivo da Escola Secundária Avelar Brotero, Coimbra. [Livro das actas do Conselho Escolar da Escola Industrial Brotero, 1889-1916, Livro de termos de posse, 1899-1925, Copiadores, 1904-1906 e 1906-1907].

Arquivo da Escola Secundária de Monserrate, Viana do Castelo [Livro dos termos de exames de passagem de disciplinas ou partes de disciplinas, feitas por alumnos estranhos no Lyceu Nacional de Vianna do Castello, 1886].

Arquivo da Polícia de Segurança do Estado. [Propaganda apreendida, 1919-1926], in Instituto dos Arquivos Nacionais/Torre do Tombo.

Arquivo da Polícia de Vigilância e Defesa do Estado. [Processo de Alberto da Silva Pais, Vila Real, coronel comandante do regimento de Infantaria, cad. 7713 , ref. ${ }^{2} \mathrm{P} 30 / \mathrm{Porto} / 45 \mathrm{I}$ ], in Instituto dos Arquivos Nacionais/Torre do Tombo.

Arquivo da Universidade de Coimbra. [Processos dos professores, Correspondência da Reitoria, livro da Congregação da Faculdade de Matemática de Coimbra, $1899-1910$, livro da matrícula das Faculdades Académicas da Universidade, anno lectivo de 1887 a 1888, livro dos Bedéis ou Serviço dos Lentes de Matemática, 1906-1909 e 1909-1911, e Polícia Académica, 1906-1907 .

Arquivo do Governo Civil de Lisboa. [Livros de correspondência expedida, 1909-1920 e 1911-1933], in Instituto dos Arquivos Nacionais/Torre do Tombo.

Arquivo do Tribunal da Boa Hora, Lisboa. [Autos civeis de acção com processo ordinário (investigação de paternidade ilegítima), em que são Autores D. Ema Manso Preto, viúva, na qualidade 
de representante legal de sua filha menor, Maria Olga. Réus D. Maria dos Prazeres Martins Bessa Paes viúva, por si e como representante de seus filhos menores puberes, D. Maria Bessa Paes, Afonso Bessa Paes e Pedro Bessa Paes, Sidónio Bessa Paes e António Bessa Paes, 4 de Julho de 1919].

Arquivo Histórico do Ministério dos Negócios Estrangeiros. [Legação de Portugal em Berlim, 1912-1916; Processos individuais e vários Processos temáticos catalogados].

Arquivo Histórico Militar. [Processos individuais e I. a Divisão, Secção 35. ${ }^{\mathrm{a}}$, 1914 -1919 - C.E.P.; e $\left.36^{\mathrm{a}}, 1914-1925\right]$.

Arquivo Histórico Municipal de Coimbra. [A Proclamação da República em Coimbra. Exposição.Arquivo Histórico Municipal (Torre de Almedina) 5 a 18 de Outubro de 1991. Coimbra: Câmara Municipal de Coimbra, 1991, Auto da proclamação da República nos Paços do Concelho de Coimbra, livro de actas da Câmara Municipal de Coimbra, 1910-1911, copiador de correspondência recebida, 1910-1911 e copiador de correspondência expedida, 1910-1913]

Arquivo Histórico Parlamentar da Assembleia da República. [Eleições 1911-círculo de Aveiro, eleições 1918 (todos os círculos), processos de Deputados e Senadores, pareceres, projectos, etc. da Assembleia Constituinte 1911 e das legislaturas de $1911-1912$ e 1918 e actas da Comissão de Finanças de 1911-1912].

Biblioteca e Arquivo da Academia Militar, [Livro das habilitações académicas, 1890-92].

Conservatória do Registo Civil de Amarante, [Livro de Casamentos, 1895, assento n. ${ }^{\circ} 2$ ].

Ministério do Interior, [Livros de registo de correspondência e correspondência recebida (maços

78 a 82 e 470 a 472) e expedida, 1917-1918], in Arquivos Nacionais/Torre do Tombo.

National Archives, Washington], [State Department Papers, 1910-1919, microfilm, rol I a 10].

Politisches Archiv des Auswärtigen Amts [Bonn], [Legação de Portugal em Berlim, Acten, 1908$-1917]$.

Public Record Office. [FO 371/2759 a 371/3370 e FO 395/196].

Registo Notarial de Barcelos, [Notas do Tabelião Manuel Cardoso e Silva, Livro 73], in Arquivo Distrital de Braga.

\section{[Pessoais/Familiares]}

Alberto de Serpa, Colecção [Carta de Francisco Homem Christo de 17 de Setembro de 1893 para o Redactor do Primeiro de Janeiro (519), carta de José d'Alpuim de 31 de Outubro de 1914, carta de Alves da Veiga, Ministro em Bruxelas, de 10 de Fevereiro de 1913 para Machado Santos e textos manuscritos de Brito Camacho s.d. (162-1 a 3): As Leis, Reflexões e Trabalhos parlamentares], in Biblioteca Pública Municipal do Porto.

Antero de Figueiredo, Fundo de Manuscritos [Correspondência: cartas de Alfredo de Magalhães para Antero de Figueredo, Conde Azevedo e Carlos de Passos, 1918-1936], in Biblioteca Pública Municipal do Porto.

Arquivo da Familia Coelho da Rocha [Documentos avulsos e fotos], in Cláudio Coelho da Rocha (Porto) e in D. Maria Augusta e D. Claudina Helena Coelho da Rocha (Caminha, Coimbra e Lisboa).

Arquivo de Alberto Cardoso Martins de Menezes Macedo (Margaride). [Recortes de imprensa e opúsculos publicados], in D. Adelaide Menezes de Morais (Guimarães).

Arquivo de António Maria de Azevedo Machado Santos. [Correspondência avulsa, pastas/dossiers com publicações periódicas, cartas, relatórios, apontamentos, etc.], in D. Maria Júlia Machado Santos Mimoso e Dr. Rui Brás Mimoso (Lisboa).

Arquivo de Augusto de Vasconcelos. [Documentação distribuída pela Secção Médico, Político e Diplomata e por várias Subsecções, além dos Subsistemas: Legação de Portugal em Madrid 
(1911-1917), Legação de Portugal em Londres (1918-1919) e Delegação Portuguesa na Sociedade das Nações (1924-1936)], in D. Isabel Vasconcelos Gaivão (Lisboa).

Arquivo de Bernardino Machado. [Recortes de imprensa], in Arquivo Municipal de Vila Nova de Famalicão.

Arquivo de Brito Camacho. [Correspondência], in Sr.joão Canijo (Porto) e [Documentação diversa: textos manuscritos, recortes de jornal, números avulsos de periódicos, panfletos, etc.], in D. Otilia de Brito Camacho Brando (Lisboa e Aljustrel).

Arquivo de Egas Moniz. [Correspondência avulsa, 1918], in Casa-Museu Egas Moniz (Avanca).

Arquivo de Eurico Cameira. [Correspondência avulsa, apontamentos e lista de cartões de pêsames e de nomes registados diante da urna do Presidente da República Sidónio Pais], in Dr. Desembargador Nuno Cameira (Valadares) e Sr. Eurico Cameira (Porto).

Arquivo de Joaquim Filipe Rosado Fernandes [integra Subsistema António Miguel Sousa Fernandes, A.M.S.F.]. [dois Albuns: «Ao Sabor da Maré...» com recortes, cartas, telegramas, relatórios, fotos etc.; «A Obra dos Bandidos», com recortes e páginas de jornal; e uma carta avulsa, mais Aditamento ao testamento de 15 de Agosto de 1914 e annotações de 31 de Março de 1916 e 8 de Dezembro do mesmo anno], in Prof. Doutor Rui Miguel Rosado Fernandes (Lisboa).

Arquivo de João Tamagnini Barbosa. [Correspondência pessoal e política, apontamentos diversos e autógrafos (completos e truncados), documentação do Centro Republicano Dr. Sidónio Pais e do Partido Nacional Republicano Presidencialista, folhetos, brochuras impressas e fotografias]. in Sr. João Tamagnini Mendes de Carvalho (Lisboa).

Arquivo de Sidónio Pais. [Documentação relativa a Sidónio Pais e distribuída pela Secção Militar, Lente e Político (1887-1918) e doze Subsecções orgânicas, além de oito Subsistemas: Escola Industrial Brotero, Ministério do Fomento, Ministério das Finanças, Legação de Portugal em Berlim, Presidência da República, Viúva D. Maria dos Prazeres Bessa Paes e Filhos (António Bessa Paes e Pedro Bessa Paes), Capitão Sidónio Bessa Paes e Dr.Afonso Bessa Paes], in Eng. ${ }^{\circ}$ Sidónio Freitas Branco Paes (Lisboa), Dr. António Paes Cardoso (Porto) e Dra Maria Sidónio Paes Cardoso Padez (Lisboa).

Arquivo de Teófilo Duarte. [Álbum de recortes e correspondência sobre Sidonio Paes e o seu Consulado e sobre outros temas, e documentos avulsos], in Dr.Teófilo Castro Duarte (Fronteira).

Arquivo Relvas, [em organização: Correspondência Geral para José Mascarenhas Relvas, pasta relativa ao Ministério Relvas 1919, dossiers do Subsistema Ministério das Finanças do Governo Provisório da República e pastas do Subsistema Legação de Portugal em Madrid], in CasaMuseu José Relvas (Alpiarça).

Arquivo Oliveira Salazar. IInformação sobre os acontecimentos políticos ocorridos entre 1917 e 1920 sendo Presidente da República, sucessivamente, Dr. Sidónio Bernardino Cardoso da Silva Paes, o Almirante joão do Canto e Castro da Silva Antunes e o Dr. António José de Almeida (AOS/CO/ PR-6) e Realização na Igreja dos Jerónimos, em Lisboa, das exéquias por alma do Dr. Sidónio Pais e trasladação do corpo para o túmulo definitivo, 1953 (AOS/CO/PC-76B)], in Instituto dos Arquivos Nacionais/Torre do Tombo.

Biblioteca e Arquivo de José Mendes Ribeiro Norton de Matos. [Livraria em fase de catalogação e numerosos dossiers, correspondência, diários, etc. em fase de estudo e inventariação], in Sr. Jorge Calheiros Esculcas e Filhos, D. Maria Emilia Norton de Matos d'Albuquerque Calheiros de Vasconcelos Porto e Dr. José Maria Norton de Matos d'Albuquerque Calheiros (Ponte de Lima).

Espólio Augusto Casimiro, D.5, [sobretudo caixas 2, 3, 4, 11, 18, 22 e 26], in Biblioteca Nacional, Secção de Reservados e Espólios.

Espólio Aires d'Omelas, E.35, [caixas I a 5], in Biblioteca Nacional, Secção de Reservados e Espólios.

Espólio Bourbon e Meneses, E.13, [sobretudo caixas 4 e 5], in Biblioteca Nacional, Secção de Reservados e Espólios. 
Espólio Fernando Pessoa, E. 3, [em microfilme, projectos e fragmentos: 477, 2514, 31 13, 3130 , $3214,3934,3935,3936,4376,4377,4391,4400,6406,6433,7474,7477,7562,8127,8147 \mathrm{e}$ 8408], in Biblioteca Nacional, Secção de Reservados e Espólios.

[Espólio] - Colecção Gomes da Costa, E. 4, [caixas I a 5], in Biblioteca Nacional, Secção de Reservados e Espólios.

Espólio Jaime Batalha Reis, E. 4, [caixas I a 40 e em especial caixas 10 a 24], in Biblioteca Nacional, Secção de Reservados e Espólios.

Espólio Lopes de Oliveira, E. 27, [caixas I a I I], in Biblioteca Nacional, Secção de Reservados e Espólios.

Espólio Paiva Couceiro, E. 34, [caixas I a 4], in Biblioteca Nacional, Secção de Reservados e Espólios.

Espólio Ricardo Jorge, E. 18, [caixas 1, 2 e 31 com correspondência e documentos vários], in Biblioteca Nacional, Secção de Reservados e Espólios.

\section{2 - Periódicos}

$A B C$ : revista portuguesa. Lisboa (1920-1930).

Academia de Coimbra. Coimbra (1886).

Acção : quinzenário do Núcleo da Acção Nacional. Lisboa (1919).

OAçoreano Ocidental : semanário independente. Santa Cruz (1917-1919).

OAlgarve. Faro (1918).

Alma Académica : orgão da Associação Académica do Liceu Camões. Lisboa (1917-1918).

Alma Nacional. Lisboa (1910).

A Alma Nova : jornal académico, Lisboa (1918-1919).

Alma Portuguesa.: semanario porta-voz dos Nucleos do Partido Republicano Presidencialista. Lisboa (1923-1924).

Almanaque de A Luta. Lisboa (1911).

Almanaque do Exercito ou lista geral de antiguidades dos officiaes combatentes e não combatentes do Exercito e empregados civis publicado por ordem do Ministério da Guerra em conformidade do disposto no artigo $75 .^{\circ}$ do decreto com força de lei de 7 de setembro de 1899 referido a 30 de Junho de 1908. Lisboa (1908).

Almanaque do "Nornal de Notícias». Porto (1914-1918).

Anuário da Universidade de Coimbra. Coimbra (1886-1918).

Arquivo Democratico. Lisboa (Ago. 1907-Mar.-Out. 1909).

Arquivo Nacional : revista. Lisboa (1932-1942).

Arquivo Republicano. Lisboa (Jan. 1910-Fev. 1912).

Aurora do Lima.Viana do Castelo (1918-1919).

OAveirense. Aveiro (1911-1912).

370 A Beira : semanário republicano. Santa Comba Dão (1919-1921).

A Beira-Mar: semanario republicano dos interesses do concelho de Espinho e das classes trabalhadoras. Espinho (1918).

O Bejense. Beja (1918).

O Binoculo. Albergaria-a-Velha (1917-1919).

Boletim da Associação Central da Agricultura Portuguesa. Lisboa (1914-1920).

Boletim Republicano do Distrito de Bragança. Bragança. I (1919).

A Briosa. Coimbra (1912-1917).

O Caixeiro Português. Lisboa (1917-1918).

O Caminhense. Caminha (1912).

O Caminhense. Caminha (1972-1994). 
O Campanario.Valença (1918).

O Campeão das Províncias. Aveiro (1911-1912).

A Capital. Lisboa (1911-1918).

Cinco de Outubro. Guarda (1918-1919).

Cinco de Outubro. Régua (1918).

Cinco de Dezembro : quinzenário defensor da causa sidonista. Guimarães (1918-1919).

O 5 de Dezembro : revista comemorativa. Lourenço Marques (5 Dez. 1918).

Clarim das Ruas. Coimbra (1897).

Combate : orgão do Partido Nacionalista do Distrito. Braga (|9|0-|9||).

O Combate : semanário : orgão central do Partido Socialista Português. Lisboa (1914-1919).

Coimbra-Club : revista quinzenal illustrada. Coimbra (1907-1908).

O Comercio de Coimbra. Coimbra (1898-1910).

O Comercio do Porto. Porto (1911-1918).

O Comercio de Viseu. : órgão da Junta Distrital da causa monárquica.Viseu (191-1919).

O Conimbricense. Coimbra (1885-1910).

Conta da Gerência da Direcção-Geral da Contabilidade Pública. Lisboa (1917-1918).

O Correio de Caminha. Caminha (1918-1919).

0 Correiro de Cantanhede : semanário : órgão da Liga Regionalista. Cantanhede (1918-1919).

Correio Elvense. Elvas (1917-1918).

Correio da Manhã. Lisboa (1921).

O De Aveiro. Aveiro (1916-1919).

O Democrata : semanário : órgão do Partido Republicano Português. Angra do Heroísmo (19|8).

O Democrata. Aveiro (1911-1912).

O Desagravo : defensor dos interesses de Mangualde e Nelas. Mangualde (1918).

O Dezembrista : semanário : órgão dos Núcleos Republicanos Sidonistas. Lisboa (1920-1921).

O Dia. Lisboa (1917-1920).

Diário dos Açores. Ponta Delgada (1917-1918).

Diário do Governo. 1. ${ }^{\circ}$ série. Lisboa (1911-1912, 1917-1918).

Diário de Lisboa. Lisboa (1924-1940).

Diário da Manhã. Lisboa (1931).

Diário Nacional. Lisboa (1917-1919).

Diário de Notícias. Lisboa (1911-1935).

Diário das Sessões da Assembleia Nacional. Lisboa. 48 (I5 Dez. 1966) 873-874.

Diário das Sessões da Camara dos Deputados. Lisboa (1911-1919).

Diário das Sessões do Congresso. Lisboa (1918).

Diário das Sessões do Senado. Lisboa (19|1-19|9).

A Ditadura : periódico do Fascismo Português. Lisboa (1926).

Doze de Outubro de 1918. Coimbra. N. ${ }^{\circ}$ Único (1919).

O Eco Taurino Literario e llustrado. Lisboa (1918).

O Eco Teatral e Cinematográfico. Lisboa (1918).

O Economista Português : revista financeira, económica, social e colonial. Lisboa (1918).

Ecos do Lena. Batalha (1918).

Ecos da Matriz. Caminha (1959-Fev. 1975).

Ecos do Minho. Braga (1917-1919).

Ecos da Mocidade. Coimbra (1906).

Ecos da Mourisca. Mourisca (1918-1919).

Ecos de Sintra. Sintra (13 Dez. 1944) I.

A Época. Lisboa (1919-1922).

O Espectro. Esposende (1918-1919).

O Esposendense. Esposende (1918). 
A Estrela de Caminha. Caminha (1882-1886).

Fantoches : bastidores da política e dos negócios. Lisboa (1923-1924)

Flôr do Tamega. Amarante (1895-1903).

Fraternidade Militar. Coimbra (1887).

A Gazeta das Aldeias. Lisboa (19|4-1918).

A Gazeta dos Caminhos de Ferro. Lisboa (1911-1918).

Gazeta da Figueira. Figueira da Foz (1918-1919).

Gil Vicente. Guimarães (1918-1919).

Ideia Nacional : revista semanal política. Lisboa (1915-1916).

Ilustração Católica. Braga (1914-1918).

Ilustração Portuguesa. Lisboa. $2^{\text {a }}$ série. (1906-1919).

O Imparcial : jornal republicano presidencialista. Lisboa (1923).

0 Intransigente. Lisboa (1911-1914).

O Jornal : diário : órgão do Partido Republicano Conservador. Lisboa (1919).

O jornal : semanário republicano independente. Portalegre (1918).

Jornal Caminhense. Caminha (1902-1912).

Jornal de Estudantes. Coimbra (1896).

Jornal de Notícias. Porto (1911-1920).

Jornal da Tarde. Lisboa (1918-1919).

Justiça : semanário unionista. Braga (19|8).

O Liberal. Lisboa (1918).

A Liberdade. Aveiro (1911).

Liberdade. Porto (1914-1919).

A Liberdade : jornal independente do povo e para o povo. Lisboa (1917-1918).

A Lucta . Lisboa (1906-1918).

A Manhã. Lisboa (1917-1918).

O Marchante : jornal independente. Coimbra (1904-1906).

O Marinhense: semanário republicano democrático : defensor dos interesses da Marinha Grande.

Marinha Grande (1917-1918).

O Minho : semanário do Partido Republicano Evolucionista.Viana do Castelo (1918).

A Monarquia. Lisboa (1917-1918).

A Montanha. Lisboa (1918).

O Movimento Operário : boletim da União Operária Nacional. Lisboa (1917-1918).

O Mundo. Lisboa (1910-1919).

O Nacional : folha conservadora. Funchal (1918-1919).

A Noite. Lisboa (1920).

O Norte. Porto (1917-1918).

Notícias de Caminha. Caminha (1908-1918).

Notícios de Coimbra. Coimbra (1907-1910).

372 Notícias de Évora. Évora (1918).

Notícias de Viana.Viana do Castelo (1929).

A Opinião. Lisboa (1917-1918).

Orçamento da despesa para o ano de ... Lisboa (1917-1918, 1918-1919).(1)

A Ordem. Lisboa (1917-1918).

O Paiz. Lisboa (1915).

Pátria : jornal diário monárquico. Porto (1917-1919).

A Pátria Nova. Lisboa (1919).

(1) Cada Ministério publicou separadamente o seu Orçamento e Respectivo Desenvolvimento de Despesa. 
Pátria Nova. Coimbra (1910).

Pavões. Coimbra (1904-1905).

Pela Grei : revista para o ressurgimento nacional, pela formação e intervenção de uma opinião pública consciente (1918-1919).

Portugal. Lisboa (1919-1920).

Portugal : órgão de estudantes republicanos. Coimbra (1896).

Portugal Maior : grande revista mensal. Lisboa (1937).

O Primeiro de Janeiro. Porto (1900-1918).

O Primeiro de Maio. Coimbra (1890-1891).

A Propaganda : defensor dos interesses da região do Douro. Vila Real (1915-1918).

Proposta orçamental da receita e despesa para o ano de... Lisboa (1917-1918, 1918-1919).(II)

O Progresso do Alentejo. Évora (1918).

República. Lisboa (1911-1918).

República Nova. Lisboa. I/2 (1919).

Resistência. Coimbra (1908-1911).

O Ressurgir : órgão dos caixeiros. Viseu (1918-1919).

Revista Militar. Lisboa (1890-1918).

Revolta. Coimbra (1909-1910).

A Revolta : semanário de propaganda libertária. Lisboa (1918).

Revolução. Lisboa (1932-33).

Revolução : diário nacional-sindicalista da tarde Lisboa (1932).

Revolução de Dezembro. Lisboa (1922).

Revolução Nacional. Lisboa (1934).

O Século. Lisboa (1910-1936).

O Seringa. Funchal (1918).

O Serralheiro : órgão mensário. Lisboa (1918).

Sidonista. Lisboa (1922).

A Situação. Lisboa (1918-1922).

A Situação : edição nocturna de «A Situação». Lisboa (1918).

A Suspensão : diário republicano da manhã. Lisboa. I (I8 Dez. 1919).

Tempo. Lisboa (1918-1922).

A Terra. Margão (Índia). ( J Jan. 1919).

OTrabalho : órgão das classes trabalhadoras. Angra do Heroísmo (1917-1918).

Tribuno Popular. Coimbra (1905-1907).

A União.Viana do Castelo (1919).

União Nacional. Leiria (6 Dez. 1931) I-2.

A Vanguarda : diário da manhã. Lisboa (1917-1920).

Victoria. Lisboa (1919).

Vida Política. Lisboa (1911-1913).

O Vigilante : semanário republicano e anti-clerical. Funchal (1918-1919).

A Victoria da Republica : almanach para 1892. Lisboa (1891).

A Voz da Mocidade : semanário republicano conservador. Lamego (1918-1919).

Voz do Povo. Águeda (1918).

Voz Pública. Lisboa (1918).

A Voz do Trabalho : publicação quinzenal independente - Associação de Classe dos Empregados das Indústrias Têxteis no Norte de Portugal e Órgão de Classe. Porto (1917-1918).

(II) Cada Ministério publicou separadamente a sua Proposta Orçamental. 


\section{3 - Testemunhos, ensaios e estudos}

AGOSTINHO, José - Cartas patrioticas : Dr. Sidonio Paes, illustre Presidente da Republica Portugueza. Porto : Livraria Editora A. J. d'Almeida, [1919].

AGOSTINHO, José - Cartas patrioticas. 1 - O Grande libertodor. Porto : Livraria Editora A.J. d'Almeida, [1919].

AGOSTINHO, José - Cartas patrioticas. N. ${ }^{\circ} 4$ - O Illustre vice-almirante, snr. João do Canto e Castro Silva Antunes, actual presidente da republica. Lisboa : Livraria Editora A. J. d'Almeida, 1919.

AGUIAR,Asdrubal António de - Exames periciaes no cadaver do presidente da república dr. Sidonio Paes, no vestuario e na arma aggressora. Lisboa : Instituto de Medicina Legal de Lisboa, 1921.

AGUILAR, Manuel Busquets de - Páginas de memórias : Sidónio Pais. Roteiro de Viana. Viana do Castelo. 13 (Ago. 1971).

ALBIEZ, Carlota Amélia Garcia Moreira da Silva de - [Quem dá aos pobres empresta a Deus.] : Homenagem a sua excelencia o senhor dr. Sidonio Paes presidente da republica portugueza : em beneficio da Assistencia 5 de Dezembro. [S. I. : s. n., 19--]. - Assinado: Ondina.

ALBUQUERQUE, António de - Sidónio na lenda : estudo crítico. Lisboa : Lumen Empresa Internacional Editora, 1922.

ALLEGRO, José Luciano Sollari — Para a história da monarquia do norte. [S. I.] : J. L. S. A., 1988.

ALMEIDA, João de - Carta aberta ao sr.Tamagnini Barbosa. A Guarda. (1 I Jan. 1919) 2.

Um Ano de política. Revista de Portugal. Lisboa. I:2 (24 Ago. 1919) 75-76. - Assinado: S. C.

BARRETO, Garcia - A Cidade dos Lacraus : romance. Lisboa : Editorial Escritor, 1994.

BELL, Aubrey F. E. - The Third portuguese revolution. The Contemporary review. London 626 (Feb. 1918) 200-206.

O Bem-Amado : recolha de Alfredo Ferreira. Lisboa: Papelaria Camões, 1919.

BENOIT, Pierre — Le Prêtre Jean. Paris : Albin Michel, 1952.

BOTTO, António - À Memoria de Sidonio Pais : nos Jeronymos : soneto. Revista de Portugal. Lisboa. I:2 (24 Ago. 1919) 67.

BRAGANÇA, Afonso de - Abaixo! : panfleto politico semanal : numero primeiro dedicado á memoria do grande portuguez que foi Sidonio Paes. In Amostras sem valor: ecos e «sueltos» políticos. Figueira da Foz: A. de B., 1921.

BRAGANÇA, Afonso de - Sidonio Pais, na intimidade. Revista de Portugal. Lisboa. 1:2 (24 Ago. 1919) 68-75.

BURNAY, Eduardo - Sete anos depois... a Republica nova : carta ao sr. Sidonio Paes, inclito e invicto restaurador da ordem. Lisboa : Lamas Mota e C. ${ }^{\text {, }}$ [19--]. (III)

BURNAY, Eduardo — Um ano depois... a Morte! : carto ao Diário de Notícias. Lisboa :Tipografia Universal, 1918.

CAMACHO, Brito - À Margem. A Lucta. Lisboa. (18 Set. 1919) I.

CAMACHO, Brito - Matéria vaga. Lisboa : Guimarães \& C. a , 1934. p. 31-38.

CAMPOS, Eurico de - Quem são os assassinos do Dr. Sidónio Pais? : estudo de investigação criminal. Coimbra : Livraria Editora F. França Amado, 1919.

Uma Carta : Sidónio Pais, filho, defende a memoria de seu pae. A Época. Lisboa. (20 Out. 1923) 1.

Carta aberta : José Julio da Costa, assassino do Dr. Sidonio Paes : o Governo fez Justiça, prova-o no gesto da prisão do assassino do malogrado Presidente Doutor Sidónio Pais que não oculta nem abriga assassinos : que saiba levar ao fim tão simpático gesto e o seu acto ficará imorredoiro na memória de todos os portugueses. Lisboa : Imprensa Artística, [1928]. I f. - Assinado: Um grupo de portugueses.

(iii) Exemplar consultado no A.S.P., com dedicatória do Autor. 
CARVALHO, Domitila de - Lição às alunas do Liceu de Garrett, no $30{ }^{\circ}$ dia do falecimento do sr. dr. Sidónio Paes. Lisboa : Oficinas Graficas Editoras, [1919].

CASA LIQUIDADORA. Lisboa - Catálogo do $21 .^{\circ}$ leilão, antiguidades : objectos de arte, objectos raros, quadros, livros, jóias, gravuras, desenhos, moveis de vários estilos, porcelanas, faianças, bronzes, esculturas, cristaes, pratas, miniaturas, colchas bordadas e de damasco, aguarelas, etc., etc. : tendo pertencido alguns dos objectos descritos a s. ex. ${ }^{\circ}$ o Presidente da República Dr. Sidonio Paes : os leilões realizam-se sob a direç̧ão de: Maria Guilhermina de Jesus. Nos dias 22 de Maio de 1923 e seguintes ás 8 horas da noite. Lisboa: [C. L.], 1923.

CASIMIRO,Augusto - Sidónio Pais : algumas notas sobre a intervenção de Portugal na grande guerra. Porto : Livraria Chardron, 1919.

CASTRO, Augusto de - Uma noite com Sidónio. In Homens e sombras. Retratos e ilustrações por Eduardo Malta. Lisboa : Empresa Nacional de Publicidade, [1958]. p. 121-126.

Catorze folhas avulsas e numeradas. [S. I. : s. n., 19--].

Uma Cerimónia impressionante : a urna do presidente Sidónio Pais foi hoje transladada para a sala do Capítulo dos Jerónimos na presença dos srs. presidente da República e do Conselho, membros do Governo e outras altas individualidades. Diário Popular. Lisboa. (14 Dez. 1953) I.

53 anos depois a memória de um passado recente : Martinho Nobre de Melo recorda para - Expresso os tempos de ministro da Justiça de Sidónio Paes e de ministro dos Negócios Estrangeiros de Gomes da Costa. Expresso Revista . Lisboa. (26 Maio 1979) 9-R.

Como o grande escritor e académico francês Pierre Benoit reconstituiu a morte de Sidónio no seu romance «Le Prêtre Jean». Diário da Manhã. Lisboa. (I 4 Dez. 1953) I-2.

O Corpo do presidente Sidónio Pais, numa grave cerimónia, ficou, ontem, na Sala do Capítulo do Mosteiro dos Jerónimos, até onde o acompanharam os chefes do Estado e do Governo, ministros e outras individualidades. Século. Lisboa. (I5 Dez. 1953) I.

COSTA, Cunha e - Ao Correr da penna. A Época. Lisboa. (1 Ago. 1919) I.

COSTA, Cunha e - A lgreja católica e Sidónio Paes. Coimbra : Coimbra Editora, 1921.

COSTA, Cunha e - A Nossa intervenção na guerra : a proposito de um artigo de «A Lucta». A Época. Lisboa. (2 Ago. 1919) I.

COSTA, Cunha e - Resposta à letra. A Época. Lisboa. (29 Jul. 1919) I.

COSTA, Cunha e - Sidonio Paes. A Época. Lisboa. (27 Jul. 1919) I.

COSTA, Cunha e - Sidonio Paes e a nossa intervenção na guerra. A Época. Lisboa. (28 Jul. 1919) I.

COSTA, Cunha e - Sidonio Paes e o «Sidonismo». A Epoca. Lisboa. (15 Dez. 1919) I.

COSTA, Feliciano - Dr. Egas Moniz : um ano de política : para a história da fase política que vai de dezembro de 1917 até dezembro de 1918: o que se lê do sr. dr. Sidónio Pais. A Situação. Lisboa. (I Set. 1919) I-2.

COSTA, Feliciano da - Sidonio Paes : carta aberta ao sr. Sidonio de Bessa Paes. O Imparcial :jornal republicano presidencialista. Lisboa. (13 Nov. 1923) I.

COSTA, Feliciano — Sidonio Paes e o sr.dr.Azevedo Neves : a propósito dum artigo recentemente publicado. A Tarde. Lisboa. (13 Out. 1923) 2.

COSTA, Luís da Silva — Aos Portuguêses!... Coimbra :Tip. de O Despertar, 1918.

COSTA, Maria Velho da - Missa in albis. Lisboa : Círculo de Leitores, 1989.

COSTA, Rita de Jesus Dias da - Luto nacional. A Guarda. (I Jan. 1919) 2.

CRISTO FILHO, Homem — Les Porte flambeaux. Paris : Éditions Fast, [1919].

CRISTO FILHO, Homem — Le Portugal contre l'Allemagne. Paris : Éditions Fast, 1918.

CUNHA, Francisco Xavier da - Elogio funebre do Dr. Sidonio Paes, presidente da republica portugueza: discurso pronunciado na matriz da Candelaria, por monsenhor ..., nas solemnes exequias mandadas celebrar pela Grande Commissão Portugueza Pró-Patria, no dia 23 de Janeiro de 1919. Rio de Janeiro : Pap.Vallelle, 1919.

Da elegia que Fernando Pessoa em 1920 publicou «À Memória do Presidente-Rei Sidónio Pais». Diário da Manhã. Lisboa. (14 Dez. 1953) I e 4. 
Dezembro de 1917 : um golpe de Estado : a revolução de 8 de Dezembro. Lisboa : João Romano Torres \& C. ${ }^{\text {a }}$. [post 1917].

O Dr. Alfredo de Magalhães fala ao «Notícias de Viana». Notícias de Viana. Número especial ( 8 Ago. 1929) $2 p$.

DUARTE, Teófilo — Sidónio Pais e o seu consulado. Lisboa : Portugália, [194I]. p. 15-16.

...E esta, hein? Forum estudante. Lisboa .5 (Mar. 1992) 54-56. Assinado: J. P. S.

...E eu vi um homem furar por entre dois polícias e visar com uma arma a figura varonil que avançava... Diário da Manhã. Lisboa. (14 Dez. 1953) I-2.

As Eleições presidenciais desde 24 de Agosto de 1911 a 15 de Março de 1928. Arquivo Nacional. Lisboa. 162 (13 Fev. 1935) 104-107.

O Espólio de um Presidente : o leilão dos quadros e objectos de arte de Sidónio Paes por vontade da familia. Diário de Lisboa. Lisboa. (23 Maio 1923) 5.

FAZENDA, Pedro - A Crise politica : em Portugal. Lisboa : Lumen Empresa Internacional Editora, 1921.

FEIO, Maria - Patria e coração : a festa das crianças em Sintra promovida pelo chefe do Estado. Lisboa : Gremio Técnico Português, 1918.

$\mathrm{FEIO}$, Maria - Sidonio Paes atravez do coração. Lisboa : Lumen Empresa Internacional Editora, 1921.

FERREIRA,António Aurélio da Costa - O Dr. Sidonio Pais : ensaio de ethologia. Revista de Historia. Lisboa. 9:33/36 (1920) 69-70.

FERREIRA, José Gomes - Revolução necessária: Lisboa : Diabril, 1975.

FERRO, António - Salazor, le Portugal et son Chef. Paris : Grasset, 1934.

FERRO, António - Sinfonia heroica. O Jornal : órgão do Partido Republicano Conservador. Lisboa. (5 Dez. 1919) I.

FICALHO, Condessa de - A Transladação : simples impressões sinceras. Lisboa : Livraria Aillaud, 1919.

FIGUEIREDO, Fidelino de - Como dirigi a Bibliotheca Nacional : Fevereiro de 1918 a Fevereiro de 1919. Lisboa : Livraria Clássica Editora A. M. Teixeira, 1919.

A Figura de Sidonio Pais : a homenagem prestada pelo sr. ministro da Instrução à memoria do grande Presidente, outras se devem seguir : Sidonio deve ter, em Lisboa, uma rua com o seu nome. Diário da Manhã. Lisboa. (I I Mar. 1932) I-2.

FONTES, Vital — Servidor de reis e de presidentes. Compilação de Rogerio Perez. Lisboa : Editora Marítimio-Colonial, 1945.

GARCIA, Chianca de - Os Verdes anos da república. Diário de Lisboa. Lisboa. (30 Nov. 1979) 3; (29 Dez. 1979) 3. In História de Portugal dos tempos pré-históricos aos nossos dias. X-A República 1 - Sonhos e malogros. Dir. João Medina. Amadora : Ediclube, 1993. p. 272-278.

GARCIA, Fernando - Sidonio Paes : um ensaio de psychologia politica. Setubal : Associação Setubalense de Caridade, 1921.

GOMES, Manuel Teixeira - Londres maravilhosa e outras páginas dispersas. Colectânea, notas e prefácio de Castelo Branco Chaves. Lisboa : Portugália Editora, [19--]. p. |32-141.

GOUVEIA, Sérgio — O Dr. Sidonio Paes e a republica nova : 1910-1918. Lisboa : M. Pinto, 1918.

GUERRA, Álvaro - Café República : folhetim do mundo vivido em Vila Velha (1914-1945). Lisboa: O Jornal, 1982.

Há 13 anos... Como foi festejada em Lisboa a notícia da assinatura do armistício. Diário da Manhã. Lisboa. (II Nov. 1931).

Homenagem nacional a Sidónio Pais com a maior solenidade e na presença do Chefe do Estado, do Senhor Presidente do Conselho, do Senhor Cardeal Patriarca de Lisboa, do Governo e do Corpo Diplomático foram transladados os restos mortais de Sidónio. Diário da Manhã. Lisboa. (15 Dez. 1953) I.

O Leilão do espólio de Sidonio Paes. ABC. Lisboa 126 (14 Dez. 1922). 
LEITÃO,Artur - Situação política : cartas a um conselheiro da república e resposta de sua excelência. Coimbra :Tipografia França Amado, 1918.

LIMA, Campos - O Reino da Traulitánia : 25 dias de reacção monárquica no Porto. Porto : Renascença Portuguesa, 1919.

Uma Linda ideia de mulher.Appelo ás mulheres portuguezas! Vae casar a filha de Sidonio Paes. $O$ «Collar de Lágrimas». Presente de noivado das portuguezas á filha do «libertadon». Tributo de gratidão e de saudade. Diário Nacional. Lisboa. (23 Dez. 1918) I; (25 Dez. 1918) I; (29 Dez. 1918) I; ( J Jan. 1919) I; (18 Jan. 1919) I.

LORAINE, A. G. - Portugal and the allies : a message to Great Britain. With a foreword by E.M. Tenison and a note on the treaties between England and Portugal. London : Hazell, Watson \&Viney, 1918.

MACHADO, Alfredo - Presidencialismo, parlamentarismo : reflexões sobre um projecto de revisão constitucional. [Lisboa] : Imprensa Henriquina, 1918.

MACHADO, António Pinto - Justiça política : descrição de factos passados nas campanhas ao Sul d'Angola em 1914-1915, assim como dos acontecimentos políticos de 1918-1919: transcrição textual dum desenvolvido relatório do Ex.mo Snr. major de cavalaria Alberto Cardoso Martins de Menezes Macêdo (Margaride) no qual se leem importantes documentos. Guimarães : A.P.M., 1932.

MACHADO, Bernardino - A Monsieur Lloyd George Premier Ministre d'Angleterre : 2 Juin 1918. [S. I.: s. n.], 1918.

MACHADO, Bernardino — Ao País! O Perigo alemão em Portugal. Paris : Imprimerie Artistique «LuX», 1918.

MACHADO, Bernardino - No Exilio. Famalicão :Tipografia Minerva, 1922.

MACHADO, Bernardino — La Vérité sur le Portugal. Paris : Ligue pour la Défense de la République Portugaise à l'Étranger, 1919.

MACHADO, Bernardino [et al.] — La Situation au Portugal. Paris : Imprimerie Artistique «Lux»,, 1918.

MAIA, Abilio - Na morte de Sidonio Paes : com uma nota referente ao actual momento politico de Portugal.Tuy :Tipografia Regional, 1919.

MARGARIDE, Alberto - [Os Cargos civis e militares que...]. Guimarães : A. M., [1928].

MARGARIDE, Alberto - A Hora da justiça : Maio de 1934. Vila Nova de Famalicão :A.M., 1934

MARINHO, José - Oração funebre proferida nas exequias solemnes que, por alma do snr. Presidente da Republica, dr. Sidonio Paes, de saúdosa memoria foram mandadas celebrar na Catedral de Coritiba, pelo Consul de Portugal, Dr.Aristides de Sousa Mendes, no dia 21 de Dezembro de 1918, e em que oficiou de pontifical o exmo. e rvmo. snr. D. Alberto Jose Gonsalves, Bispo de Ribeirão Preto. Coritiba: [s. n.], 1918.

MARTINS, Marlia Carneiro - Dr. Sidonio Paes, o martir da demagogia : de 5 de Dezembro de 1917 a 14 de Dezembro de 1918: cobarde assassinio : poesias inéditas, apreciações, artigos, homenagens de diversos estadistas, poetas, escritores e jornalistas nacionais e estrangeiros, com as fotogravuras do inolvidavel Chefe de Estado, Tamagnini Barbosa,Teofilo Duarte, Feliciano da Costa, Eurico Cameira, Jorge Botelho Moniz, José A. da Silva Basto, etc. Lisboa : Augusto Martins, [19--]. fasc. 2.

MARTINS, Rocha - Memorias sobre Sidonio Paes. Lisboa : Sociedade Editorial ABC, 1921.

MARTINS, Rocha - A Monarquia do Norte. Lisboa : Editorial ABC, 1922.

MARTINS, Rocha — Vultos e sombras : Sidonio e o II de Novembro. Diário de Notícias. Lisboa. (12 Dez. 1933) I.

MELO, Martinho Nobre de - Sidonio, o grande iniciador da era nova. A Situação : diario republicano da tarde. Lisboa. (16 Dez. 1930) I e 7.

MELO, Ribeiro de - A Justificação de um protesto : conferencia realisada no Grémio Luiz de Camões, em Coritiba, no dia 7 de Setembro de 1918 perante a Colonia Portugueza do Paraná, da Republica dos Estados Unidos do Brazil, onde o autor exerceu o logar de Consul de 2. classe, cujas funções 
cessaram por força do mais ilegal atentado aos seus direitos de funcionario de carreira. Coritiba: Livraria Mundial, 1918.

MENDES, Aristides - Para a historia... : a minha defeza no processo disciplinar que me foi instaurado por desafecto às instituições republicanas. Coimbra : Coimbra Editora, 1921.

MONIZ, Egas — Um ano de politica. Lisboa : Portugal-Brasil, 1919.

MONIZ, Jorge Botelho - Memórias de um ajudante de campo de Sidónio Pais. A Situação. Lisboa. (21 Mar. 1927) 8; (22 Mar. 1927) I; (24 Mar. 1927) I e 8; (14 Dez. 1929) I; (16 Dez. 1930) । e 3.

MONIZ, Jorge Botelho - Portugal na grande guerra : Sidonio Pais não desmoronou o C.E.P... Diário de Lisboa.. Lisboa. (28 Nov. 1924) 5.

MONTALVÃO, Bruno de - Perfil de Sidonio Pais : apreciações pessoais e políticas. Lisboa : Edições Expansão, 1942.

MONTEIRO, Campos - A Eterna Miseria : Maio, 1918:Teatro Sá da Bandeira : Concerto em honra de s. ex. ${ }^{a}$ o sr. Presidente da Republica. Dr. Sidonio Paes e a favor das victimas do tifo: Porto, 19 Maio 1918. Porto:Tip. Agência de Publicidade, 1918.

MOTA, Gomes - [Ao Grande môrto, ao grande presidente] :no l. ${ }^{\circ}$ aniversario da morte do Dr. Sidonio Paes, Presidente da Republica em Portugal, benemerito da patria chamado á divina presença em 14 de Dezembro de 1918: homenagem do auctor. [S.I. : s. n., 19--].

NETO, Roma - A Morte do Dr. Sidonio Pais e a actual situação política, 1917-1919: resumo dos acontecimentos da República Nova. Lisboa : Henrique Torres, [1919].

NEVES,Azevedo - Momentos politicos : trez ditadores: Sidonio Pais, Mussolini e Primo de Rivera. Diário de Lisboa. Lisboa. (9 Out. 1923) 2.

NEVES, Azevedo - [Réplica : do ilustre professor e director do Instituto de Medicina Legal, ..., recebemos a seguinte carta]. Diário de Lisboa. Lisboa. (20 Out. 1923) 5.

No Mosteiro dos Jerónimos : a transladação da urna do presidente Sidónio Pais para a sala do Capítulo teve grande solenidade. Diário de Notícias. Lisboa. (15 Dez. 1953) I.

NUNES, Leopoldo; LEITÃO,António - Os Grandes obreiros da revolução nacional. Lisboa : Editorial Obreiros, 1950. Fasc. I (incompleto): Sidónio Pais. p. 15-32. 8 de Dezembro. Tempo. Lisboa. (24 Nov. 1918) I.Assinado: A. P.

PACHECO, Fernando Assis - Trabalhos e paixões de Benito Prada, galego da Província de Ourense, que veio a Portugal ganhar a vida. Porto : Edições Asa, 1993.

PACHECO, Óscar - A Jazida de Sidónio. Acção : semanário portugues para portugueses. Lisboa. (12 Dez. 1936) 6.

[PAIVA, Raul] - A Memoria do Dr. Sidonio Paes : o seu funeral Lisboa : Livraria Barateira, [19--].

PAIVA, Raul - À Memoria do Dr. Sidonio Paes : lindas cantigas ao fado. Lisboa : Livraria Romero, [19--].

PAIVA, Raul - À Morte do chefe do estado Dr. Sidonio Paes. Lisboa : Editor Livraria Barateira, [19--].

PESSOA, Fernando - À Memória do Presidente-Rei Sidónio Pais. Acção : orgão do Núcleo de Acção Nacional. Lisboa. 4 (27 Fev. 1920).

PESSOA, Fernando [et al.] - À Memória do Presidente-Rei Sidónio Paes. Porto : Petrus, 1951. (Colecção Quinhentista). Co-aut.: Petrus e Fernando Garcia.

PIMENTA, A. - Salvem a Patria! :Valsa triste para piano : à memoria do grande portuguez Dr. Sidonio Paes. Porto : Livraria A. J. d'Almeida, [19--].

PIMENTA, Alfredo - A Situação política : conferencia realisada no Salão Nobre da Liga Naval Portuguesa na noite de 26 Fevereiro de 1918. Lisboa : Livraria Ferreira, 1918.

PORTELA, Artur - Memorias de outros tempos : o Palacio encantado da condessa de Ficalho, as obras de caridade de Sidonio Pais, Bernardino Machado e Mayer Garção, a história de um ramo de cravos côr de rosa, uma festa em Sintra e um Natal feliz para os pobres. Diário de Lisboa. Lisboa. (15 Dez. 1921) 3. 
PORTO DA CRUZ,Visconde do - Naquela noite de tragédia... Notícias : diário da manhã fundado em 1926. Lourenço Marques. (14 Dez. 1959) I e I5.

PORTO DA CRUZ, Visconde do - Paixão e morte de Sidonio... e o mais que se seguiu.... : memorias e apontamentos para a historia. Funchal :Tipografia Esperança, 1928.

PORTO DA CRUZ, Visconde do — Sidónio. Diário da Madeira. Funchal. (14 Dez. 1939) I e 4.

Um Português maior que jámais será esquecido. Portugal Maior : grande revista mensal. Lisboa. I (Mar. 1937).

Os Precursores. Diário da Manhã. Lisboa. (23 Ago. 1933) I. - Assinado: P. R.

Os Precursores do Estado Novo : o Exercito concentrando-se em volta da prestigiosa figura do presidente Sidonio Paes estabelece a segunda ditadura militar, novo anceio de libertação nacional contra a política facciosa dos partidos. O Século. Número especial (28 Maio 1936) 5.

QUARTIM, António Tomás — Sidónio Pais : Homenagem . Viana : [s. n.]. 1919.

Quem era o Dr. Sidonio Paes : suas qualidades e biografia. Lisboa : Livraria Barateira, [19--].

REDONDO, Belo - A Morte do Rei. In Grandes repórteres portugueses da I República : os Casos vibrantes, anedóticos, dramáticos, confidenciais descritos pelos próprios jornalistas que os viveram: selecta jornalística Lisboa : Foto-Jornal Edições e Artes Gráficas, 1986. p. 51-55.

REGO, José Lins do - O Moleque Ricardo. Lisboa : Livros do Brasil, [post 1935]. I. ${ }^{\text {a ed.: }} 1935$.

Rememorando Dr. Sidonio Paes. Voz de Belém. Lisboa. (25 Dez. 1934) 3-4.

Os Restos mortais de Sidónio Pais foram hoje transladados para a sala do Capítulo dos Jerónimos numa imponente cerimónia a que presidiu o Chefe do Estado. Diário de Lisboa. Lisboa. (14 Dez.1953) I e 8.

RODRIGUES, Bettencourt — Sidonio Paes e as nossas relações com o Brasil. A Situação. Lisboa. (14 Dez. 1920) 1-2.

SARDINHA, António - E agora? In Na feira dos mitos : idéas \& factos. Lisboa : Livraria Universal de Armando J. Tavares, 1926. p. 277-278.

Sidonio Paes. llustração Portuguesa.. Lisboa. (24 Mar. 1919) 221-224.

Sidónio Pais contra Pimenta de Castro : evocação histórica no aniversário da carta escrita pelo presidente Arriaga ao chamado ditador Pimenta de Castro. Arquivo Nacional. Lisboa. 315 (19 Jan. 1938) 40-41.

Sidonio Paes e o messianismo ditatorial, In PAIS, Sidónio - Um ano de ditadura : discursos e alocuções ... Coligidos e ordenados por Feliciano de Carvalho com um estudo político de João de Castro. Lisboa : [s. n.], 1924. p. 9-34.

Sidonio Paes na memoria de Portugal : [no funeral de Sidonio Paes martir da Patria, assassinado em Lisboa, aos quatorze de Dezembro de mil novecentos e desoito, pelos maos portugueses aos quaes a sua grandeza fazia sombra, e levado para os Jeronymos em cortejo de verdadeira apotheose nacional, a vinte e um do mesmo mez e anno]. Com prefácio de Henrique Fonseca Chaves. Lisboa : Empreza do Diario de Noticias, 1920.

Sidónio Pais nos Jerónimos. Século llustrado. Lisboa. (19 Dez. 1953) I.

Sidónio Pais o pacificador. Diário da Manhã. Lisboa. (14 Dez. 1953) I e 6.

SILVA, Duarte - O Salvador da pátria portuguesa : Bicas, 20 de Agosto de 1918. [S. I. : s. n.], 1918. If.

SOUSA, Eduardo de - O Dezembrismo e a sua política na guerra.: para a historia do Dezembrismo: depoimento duma testemunha. Porto: Companhia Portuguesa Editora, 1919.

SOUSA, Fernando de - Sidonio Paes e alma da Egreja. A Epoca. Lisboa. (14 Dez. 1920) I.

A Trouxe-Mouxe : os amigos de Sidonio Paes, seriam seus inimigos? A Guarda. (11 Jan. 1919) 2.

VASCONCELOS, Alexandre Botelho de - A Revolução de Sidónio Pais : relatório do coronel de cavalaria... Arquivo Nocional. Lisboa. 4 (Set./I8 Dez. 1935).

Verdades, João v. Martins, José Augusto Tito Gonçalves

VILARES, Artur - A Leva da Morte. Lisboa : Livros Horizonte, 1988. 


\section{I. Sidónio Pais: bibliografia activa}

Ephemerides astronomicas para o anno de 1904, calculadas para o merediano do Real Observatorio Astronomico da Universidade de Coimbra. Coimbra : Imprensa da Universidade, 1903.

PAIS, Sidónio - As Forças e os movimentos : definições e postulados da Mecanica. Coimbra : Imprensa da Universidade, 1902. [Dissertação para o concurso a um logar de professor do 3. grupo das Escolas industriaes].

PAIS, Sidónio - Introdução à teoria dos erros das observações : dissertação inaugural para o acto de conclusões magnas na Faculdade de Mathematica. Coimbra : Imprensa da Universidade, I 898.

PAIS, Sidónio - Oração de «sapientia» recitada na sala grande dos actos da Universidade de Coimbra no dia 16 de Outubro de 1908. Coimbra : Imprensa da Universidade, 1909.

PAIS, Sidónio - Oração de «sapientia» recitada na sala grande dos actos da Universidade de Coimbra no dia 16 de Outubro de 1908, pelo .... Lente cathedratico da Faculdade de Mathematica. In FACULDADE DE CIÊNCIAS DA UNIVERSIDADE DE COIMBRA - Orações de sapiência: século XX. Coimbra: Faculdade de Ciências e Tecnologia da Universidade de Coimbra, 1997, p. 37-50.

PAIS, Sidónio - Series de numeros. Coimbra : Imprensa da Universidade, 1898. [Dissertação para concurso a um logar de lente substituto da Faculdade de Mathematica da Universidade de Coimbra.]

PAIS, Sidónio - Theses de mathematicas puras e applicadas que sob a presidencia do illustrissimo e excellentissimo senhor doutor Luiz da Costa e Almeida, do Conselho de Sua Magestade, lente de prima, decano e director da Faculdade de Mathematica, director do Observatorio Astronomico da Universidade de Coimbra, commendador da Ordem Militar de Nosso Senhor Jesus Christo, etc., etc., Se propõe defender na Universidade de Coimbra, nos dias ... e de ... de 1898, para obter o grau de Doutor... Coimbra : Imprensa da Universidade, 1898.

PAIS, Sidónio - Um ano de ditadura : discursos e alocuções. Coligidos e ordenados por Feliciano de Carvalho com um estudo político de João de Castro. Lisboa : [s. n.], 1924.

\section{2 - Sidónio e Sidonismo: verbetes em enciclopédias e dicionários}

BIVAR, Artur - Sidonismo. In Dicionário Geral e Analógico da Língua Portuguesa. Porto : Edições «Ouro», 1948.Vol. I, p. $1065-1066$.

COSTA, J.Almeida; MELO, A. Sampaio e - Sidonismo. In Dicionário da Língua Portuguesa. 5. ${ }^{\text {e ed. }}$ Porto: Porto Editora, [19-]. p. 1311.

FERREIRA, David - Pais, Sidónio Bernardino Cardoso da Silva. In Dicionário de História de Portugal. Dir. Joel Serrão. Porto : Iniciativas Editoriais, 1965-1971, vol. 3, p. 281-288.

MACHADO, José Pedro — Sidonismo. In Grande Dicionário da Língua Portuguesa. Lisboa : Amigos do Livro, 1981, vol. 11 , p. 159.

MORAIS,António - Sidonismo. In Novo dicionário compacto da Língua Portuguesa. Lisboa : Editorial Confluência, 1960, vol. 2, p. 2196.

MOREIRA, António - Pais, Sidónio (Coimbra, 1/5//872-Lisboa, 14/12/19/8). In Dicionário Enciclopédico da História de Portugal. Lisboa : Publicações Alfa, 1991, vol. 2, p. 73.

Pais, Sidónio. In Grande enciclopédia portuguesa e brasileira. Lisboa; Rio de Janeiro : Editorial Enciclopédia, [post 1935], vol. 19, p. 992.

Pais, Sidónio Bernardino Cardoso da Silva. In 0 Grande livro dos portugueses : 4000 personalidades em texto e imagem : nomes, datas, factos com 980 ilustrações. Lisboa : Círculo de Leitores, 1990, p. 392.

Pais, Sidónio Bernardino Cardoso da Silva. In Lello Universal : dicionário enciclopédico luso-brasileiro em 2 volumes. Porto : Lello \& Irmão, 1981, vol. 2, p. 434. 
Pais, Sidónio Bernardino da Silva. In Grande enciclopédia Delta Larousse. Rio de Janeiro : Editora Delta, 1972, vol. 11. p. 5034.

SERPA, Eduardo - Pais, Sidónio Bernardino Cardoso da Silva. in Enciclopédia Luso-Brasileira de Cultura, vol. 14. Lisboa: Editorial Verbo, 1969, cols. 1671-1672.

\section{3 - Estudos monográficos}

\subsection{I - Conjuntura 1890-1926}

ALEXANDRE,Valentim - Ideologia, economia e política : a questão colonial na implantação do Estado Novo. Análise Social. Lisboa. 28:123/124 (1993) 11117-1136.

ALMEIDA, José [et al.] - Materiais para a história do advento do fascismo em Portugal. Análise Social. Lisboa. I 5:58 (1979) 393-450.

Co-aut:: José Machado Pais, Manuel Vilaverde Cabral.

ALMEIDA, Ramos de - 5 Outubro 1910 : proclamação da República : comemoração do $45^{\circ}$ aniversário 1955. [Porto : Comissão das Comemorações composta por Dr. Armando Castro, Arq. Artur Andrade, Dr. Guedes Pinheiro, Dr. Júlio Semêdo, Dr. Mário Cal Brandão, Silva Petiz e Oliveira Valença], 1955.

ALVES, Rui Manuel - A Aviação portuguesa na guerra 14-18: vítima da «República Nova» e do esquecimento. História. 88 (Fev. 1986) 46-67.

AMARO, António Rafael - A Seara Nova nos anos vinte e trinto (1921-1939) : memória, cultura e poder. Viseu : Universidade Católica Portuguesa, 1995.

AMARAL,Augusto Ferreira do - A Aclamação e Dom Manuel II : estudo histórico-político do primeiro ministério de D. Manuel II, baseado em numerosos documentos inéditos, incluindo cartas do Rei. Lisboa : Empresa Nacional de Publicidade, 1966.

ANTUNES, José Freire — O Império com pés de barro : colonização e descolonização: as ideologias em Portugal. Lisboa : Publicações Dom Quixote, 1980.

AZEVEDO, Manuel Roque - Inquérito sobre o partido republicano evolucionista (1912-1919). Nova História. 1. ${ }^{\circ}$ República Portuguesa. Lisboa. 2 (Dez. 1984) 74-1 22.

$\mathrm{BABO}$, Jorge - A Tragédia portuguesa: dos mitos às realidades, 1820-1975. Lisboa: Ulisseia, I991.

BAENA, Miguel Sanches de — Diário de D. Manuel e estudo sobre o regicídio. Lisboa : Publicações Alfa, 1990.

BAENA, Miguel Sanches de - Mouzinho de Albuquerque : a última batalha. Lisboa : Publicações Alfa, 1990.

BAPTISTA, Jacinto - O Cinco de Outubro. 2. ed. corrigida e aumentada. Lisboa : Editora Arcádia, 1965.

BAPTISTA, Jacinto - Um Jornal na revolução : «O Mundo» de 5 de Outubro de 1910. Lisboa : Seara Nova, 1966.

BAPTISTA, Jacinto - Surgindo vem ao longe a nova aurora... : para a história do diário sindicalista A Batalha, 1919-1927. Lisboa : Livraria Bertrand, 1977.

BARREIRA, Cecilia - Nacionalismo e modernismo : de Homem Cristo Filho a Almado Negreiros. Lisboa : Assírio e Alvim, 1981.

BARREIRA, Cecilia - Sondagens em torno da cultura e das ideologias em Portugal (sécs. $X \mid X-X X$ ). Lisboa : Editorial Polemos, 1983.

BARROSO, João - Os Liceus : organização pedagógica e administrativa (I836-1960). Lisboa : Fundação Calouste Gulbenkian : Junta Nacional de Investigação Científica e Tecnológica, 1995, 2 vol.

BENDER, Gerald J. - Angola sob o domínio português : mito e realidade. Lisboa : Livraria Sá da Costa, 1980. 
BIZARRO,A. H. — El-rei D. Manuel II na Grande Guerra : factos e testemunhos. [S. I.] : Fundação da Casa de Bragança, 1952.

BOLÉO, Luísa Paiva - Oito presidentes para a história (conclusão) : até ao fim da república. Magazine Público. Lisboa. (14 Jan. 1996) 30-35.

BOLÉO, Luísa Paiva - Oito presidentes para a história (1910-1926) : República primeiro acto. Magazine Público. Lisboa. (7 Jan. 1996) 36.

BRANCO, João de Freitas - Viana da Mota : uma contribuição para o estudo da sua personalidade e da sua obra. 2. ${ }^{\text {e }}$ ed. Lisboa : Fundação Calouste Gulbenkian, 1987.

BRANDÃO, José - A Noite sangrenta. Lisboa : Publicações Alfa, 1991.

BRÉCHON, Robert - Estranho estrangeiro : uma biografia de Fernando Pessoa. Lisboa : Círculo de Leitores, 1997.

CABRAL, ManuelVilaverde - O Desenvolvimento do capitalismo em Portugal no século XIX. Lisboa: A Regra do Jogo, 1976.

CABRAL, Manuel Vilaverde - O Operariado nas vésperas da república (1909-1910): seguido de extractos da «Inquirição pelas associações de classe sobre a situação do operariado" (1909-1910). Lisboa : Editorial Presença; Gabinete de Investigações Sociais, 1977.

CABRAL, Manuel Vilaverde - Portugal na alvorada do século XX : forças sociais, poder político e crescimento económico de 1890 a 1914. Lisboa : A Regra do Jogo, 1979.

CABRAL, Manuel Vilaverde - Sobre o fascismo e o seu advento em Portugal : ensaio de interpretação a pretexto de alguns livros recentes. Análise Social. Lisboa. $12: 48$ (1976) 873-915.

CARRILHO, Maria — Forças armadas e mudança política em Portugal no séc. XX:para uma explicação sociológica do papel dos militares. Lisboa : Imprensa Nacional-Casa da Moeda, 1985.

CARVALHO, David de -Os Sindicatos operários e a república burguesa (1910-1926). Lisboa : [s.n.], 1977.

CARVALHO, Serra de - O IV Presidente da República Portuguesa nasceu em Caminha. Ecos da Matriz. Caminha. 14:157 (Maio 1972) 3.

CASTRO, Armando de - A Economia portuguesa do século XX (1900-1925). Lisboa : Edições 70, 1973.

CASTRO, Armando de - Ensaios sobre cultura e história. Porto : Editorial Inova, 1969.

CASTRO, Armando de - Lições História de Portugal. Lisboa : Editorial Caminho, 1982-1983. 2 vol.

CASTRO, Armando de - A Revolução industrial em Portugal no século XIX. Porto : Limiar, 1976. I. ${ }^{a}$ ed. : Introdução ao estudo da economia portuguesa : fim do século XVIII a princípios do século XIX. Lisboa : Edições Cosmos, 1947.

CASTRO, Armando de - O Sistema colonial português em África (meados do século $X X$ ). 2. ${ }^{\text {a }}$ ed. Lisboa : Editorial Caminho, 1980.

CATROGA, Fernando - O Céu da memória: cemitério romântico e culto cívico dos mortos : 1756 -1911. Coimbra: Livraria Minerva Editora, 1999.

CATROGA, Fernando - Os Inícios do positivismo em Portugal : o seu significado político-social. Revista da História das Ideias. Coimbra. I (1977) 287-394.

CATROGA, Fernando - José Falcão, um lente republicano. Biblos. Coimbra. 52 (1976) 275$-303$.

CATROGA, Fernando - A Militância laica e a descristianização da morte em Portugal, 1865 - 1911. Coimbra : Faculdade de Letras da Universidade de Coimbra, 1988. 2 vol.

CATROGA, Fernando - O Republicanismo em Portugal : da formação ao 5 de Outubro de 1910. Coimbra : Faculdade de Letras, 1991. 2 vol.

O 5 de Outubro visto por um participante : ao redor da revolução. Inédito apresentado por Fernando de Matos Rodrigues. História. Lisboa. 48 (Out. 1982) 25-36.

CLARENCE-SMITH, Gervase - O Terceiro império português (1825-1975). Lisboa: Editorial Teorema, 1985. 
COELHO, Maria Teresa Pinto - Apocalipse e regeneração : o Ultimatum e a mitologia da Pátria na literatura finissecular. Lisboa : Edições Cosmos, 1996.

COLÓQUIO «O FACISMO EM PORTUGAL», Lisboa, 1980 - Actas. Lisboa : A Regra do Jogo, 1982.

CONGRESSO «HISTÓRIA DA UNIVERSIDADE», Coimbra, 1990 - Universidade(s), História, Memória, Perspectivas : actas... Coimbra : Comissão Organizadora do Congresso, 1991. 5 vol.

O Congresso sindicalista de 1911. Prefácio, notas e selecção de textos de César de Oliveira. Porto: Afrontamento, 1971.

CONGRESSO «A VIDA DA REPÚBLICA PORTUGUESA, 1890-1990», Lisboa, 1990 - [Actas]. Lisboa: Cooperativa de Estudos e Documentação; Universitária Editora, 1991-1995. 2 vol.

CORREIA, Natália - A Questão académica de 1907. Prefácio de Mário Braga. Lisboa : Editorial Minotauro; Seara Nova, [19--].

COSTA, José Joaquim Ribeiro da - Óscar Carmona (1869-1951) : Elementos para o estudo biográfico do Primeiro Presidente da República do Estado Novo : dissertação de mestrado na Faculdade de Ciências Sociais e Humanas da Universidade Nova. Lisboa : Universidade Nova 1993.

COSTA, Ramiro da - O Desenvolvimento do capitalismo em Portugal. 2, ed. Lisboa : Assírio \& Alvim, 1976.

COSTA, Ramiro da - Elementos para a história do movimento operário em Portugal. Lisboa : Assírio e Alvim, 1979. 2 vol. - Vol. I: 1820-1929; vol. 2: 1930-1975.

CRUZ, Manuel Braga da - As Origens da democracia cristã e o salazarismo. Lisboa : Editorial Presença; Gabinete de Investigações Sociais, 1980.

CRUZEIRO, Maria Eduarda - Costumes estudantis de Coimbra no século XIX : tradição e conservação institucional. Análise Social. Lisboa. I5:60 (1979) 795-838.

CRUZEIRO, Maria Eduarda - Capital simbólico e memória institucional : a propósito da Universidade no século XIX. Análise Social. Lisboa. 24:101-102 (1988) 593-607.

CUNHA, Norberto Amadeu Ferreira Gonçalves da — Génese e evolução do ideário de Abel Salazar. Braga : Universidade do Minho, 1989. 2 vol.

Dissertação de doutoramento em História da Filosofia e Cultura Portuguesa apresentada à Universidade do Minho.

DEROU, Jean — Les Relations franco-portugaises a l'époque de la première république parlementaire libérale (5 Octobre 1910 - 28 Mai 1926). Paris : Sorbonne, 1986.

DIAS, Augusto da Costa - A Crise da consciência pequeno-burguesa. I - O nacionalismo literário da geração de 90. Lisboa : Portugália Editora, 1964.

DÓRIA, A. Álvaro — Gabinete de Leitura : um livro, uma época. Bracara Augusta. Braga. 33:75-76 (Jan.-Dez. 1979) 41 I-482; 34:78 (Jul.-Dez. 1980) 731-935.

EKSTEINS, Modris - Le Sacre du printemps : la Grande Guerre et la naissance de la modernité. Paris : Plon, 1991.

Emilio Costa e o sindicalismo : da fromação libertária à Casa Sindical. Selecção, introd. e notas António Ventura e Alberto Pedroso. Lisboa : Seara Nova, 1977.

ENCONTRO SOBRE A ALTA DE COIMBRA, I, Coimbra, 1987 - Alta de Coimbra : História, arte, tradição: actas. Coimbra : Grupo de Arqueologia e Arte do Centro, 1988.

O Estado Novo: das Origens ao fim da autarcia 1926-1959. Lisboa : Editorial Fragmentos, 1987. 2 vol.

ESTEVES, Maria da Encarnação Vieira — Apóstolo de Fátima : Cón. Manuel Nunes Formigão: Braga: Secretariado Nacional do Apostolado da Oração, 1993.

Estudos de história contemporânea portuguesa : homenagem ao professor Victor de Sá. Org. do Centro de História da Universidade do Porto. Lisboa : Livros Horizonte, 1991.

Estudos e ensaios em homenagem a Vitorino Magalhães Godinho. Lisboa : Livraria Sá da Costa Editora, 1988. 
FERNANDES, Rogério - Uma Experiência de formação de adultos na 1. ${ }^{\circ}$ República : a Universidade Livre para Educação Popular, 1911-1917. Lisboa : Câmara Municipal, 1993.

Fernando Pessoa no seu tempo. Lisboa : Biblioteca Nacional, 1988.

FERRÃO, Carlos - Desfazendo mentiras e calúnias. Lisboa : Editorial «O Século», 1967.

FERRÃO, Carlos - Em defesa da república. Lisboa : Edições Inquérito, 1963.

FERRÃO, Carlos - Em defesa da verdade. Lisboa : Editorial «O Século», 1962.

FERRÃO, Carlos - O Integralismo e a república : autópsia de um mito. Lisboa : Editorial Inquérito; Editorial «O Século», $1964-1965.3$ vol.

FERRÃO, Carlos - A Obra da república. Lisboa : Editorial «O Século», 1966.

FERREIRA, António Matos - A Igreja e a república. In MEDINA, João - História de Portugal. Vol. X-A República : sonhos e malogros. Amadora : Ediclube, 1993. p. 339-361.

FERREIRA, José Medeiros - O Comportamento político dos miltares : forças armadas e regimes políticos em Portugal no séc. XX. Lisboa : Editorial Estampa, 1992.

FERREIRA, José Medeiros - As Intervenções militares na sociedade portuguesa. Lisboa : Instituto de Estudos para o Desenvolvimento, 1983.

FERREIRA, José Medeiros - Mudanças de regime político e forças armadas em Portugal : o trânsito da monarquia para a república. Nova História. Lisboa. 2 (Dez. 1984) 3-13.

FERREIRA, José Medeiros - Portugal na Conferência de Paz, Paris, 1919. Lisboa : Quetzal Editores, 1992.

FERREIRA, José Medeiros - Revisão histórica da participação de Portugal na primeira guerra mundial: a dimensão ibérico-insular. Boletim do Instituto Histórico da llha Terceira. Angra do Heroísmo. 43:2 (1985) 635-647.

A Formação de Portugal contemporâneo, 1900-1980. Análise Social . Lisboa. 18:72/74 (1982) 649-1500; 19:77/79 (1983) 421-1260.

FORTUNA, Carlos - O Fio da meada : o algodão de Moçambique, Portugal e a economia-mundo (1860-1960). Porto : Centro de Estudos Sociais; Edições Afrontamento, 1993.

Fotobiografia de Fernando Pessoa. Organização, introdução e notas de João Rui de Sousa; prefácio de Eduardo Lourenço. Lisboa : Imprensa Nacional-Casa da Moeda; Biblioteca Nacional, 1988.

FRAGA, Luís Manuel Alves de - O Fim da ambiguidade: a estratégia nacional portuguesa de 19/41916. Lisboa: Universitária Editora, 2001.

FRANÇA, José Augusto - Os Anos vinte em Portugal : estudo de factos sócio-culturais. Lisboa : Editorial Presença, 1992.

FRANCO, Graça - A Censura à imprensa (1 820-1974). Lisboa :Tecnicelpa; Universidade Católica Portuguesa; Imprensa Nacional-Casa da Moeda, 1993.

FREIRE, João - Anarquistas e operários : ideologia, ofício e práticas sociais: o anarquismo e o operariado em Portugal, 1900-1940. Porto : Edições Afrontamento, 1992.

GALLAGHER, Tom - Conservatism, dictatorship and fascism in Portugal, 1914-45. In Fascists and conservatives : the radical right and the establishment in twentiteh-century Europe. Ed. Martin Blinkhorn. London: Unwin Hyman, 1990. p. 157-175.

GALLAGHER, Tom - Portugal : a twentieth-century interpretation. Manchester : Manchester University Press, 1983.

GAMA, António - O Espaço na revolução republicana de 1910. Revista de História das Ideias. Coimbra. 7 (1985) 335-346.

GODINHO, Vitorino Magalhães - A Estrutura da antiga sociedade portuguesa. Lisboa : Arcádia, 1971.

GODINHO, Vitorino Magalhães — Introdução à história económica. Lisboa : Livros Horizonte, [19--].

GOMES, Joaquim Ferreira - Estudos para a história da Universidade de Coimbra. Coimbra : J. F. G., 1991. 
GOMES, Joaquim Ferreira - A Universidade de Coimbra durante a primeira República (1910-1926). Lisboa : Instituto de Inovação Educacional, 1990.

GUISADO, Alfredo Pedro - Tempo de Orfeu (1915-1918) : com um estudo de Urbano Tavares Rodrigues. Lisboa : Portugália Editora, 1969.

História de Portugal dos tempos pré-históricos aos nossos dias. Dir. João Medina. Amadora : Ediclube, 1993.

Vol. 10: A República : sonhos e malogros; vol. II: A República : o nó górdio e as espadas.

HOMEM, Amadeu Carvalho - Conciliação e confronto no discurso republicano (1870-1890). Revista de História das Ideias. Coimbra. 7 (1985) 281-312.

HOMEM,Amadeu Carvalho - Do «lluminismo» ao positivismo : Joaquim António da Silva Cordeiro e a sua obra. Revista de História das Ideias. Coimbra. 3 (1981) 29-76.

HOMEM, Amadeu Carvalho - A Ideia republicana em Portugal : o contributo de Teófilo Braga. Coimbra : Livraria Minerva, 1989.

HOMEM,Amadeu Carvalho - Identidade nacional e contemporaneidade. Revista de História das Ideias. Coimbra. 17 (1995) 595.

HOMEM, Amadeu Carvalho - A Propaganda republicana (1870-1910). Coimbra : A. C. H., 1990.

HONRADO, Fernando - Os Fuzilados de Outubro : Lisboa - 1921. Colaboração de Maria Manuela de Moura. Lisboa : Acontecimento, Estudos e Edições, 1995.

Jaime Cortesão e a Maçonaria. Apresentação de José Esteves Pereira. Prelo. Lisboa. N. especial (Dez. 1984) 43-53.

JUSTINO, David - A Formação do espaço económico nacional. Portugal 1810-1913,2 vols. Lisboa: Vega, 1988-1989.

KAGAN, Donald - A Primeira guerra mundial (1914-1918). In Sobre as origens da guerra e a preservação da paz. Lisboa : Edições Temas da Actualidade, 1995. vol. I, p. 89-263.

KEEGAN, John - O Rosto da batalha. Lisboa : Editorial Fragmentos, 1987.

LAINS, Pedro - A Economia portuguesa no século XIX: crescimento económico e comércio externo, 1851-1913. Lisboa : Imprensa Nacional Casa da Moeda, 1995.

LAMY, Alberto Sousa - A Academia de Coimbra, 1537-1990: história, praxe, boémia e estudo : partidas e piadas : organismos académicos. Lisboa : Rei dos Livros, 1990.

LEAL, Ernesto Castro - António Ferro : espaço político e imaginário social (19/8-32). Lisboa : Ediçōes Cosmos, 1994.

LEAL, Ernesto Castro - Nação e nacionalismo: a Cruzada Nacional D. Nuno Álvares Pereira e as origens do estado Novo (1918-1938). Lisboa: Edições Cosmos, 1999.

LEAL, Ernesto Castro - Partidos e grupos políticos na I República. In MEDINA, João - História de Portugal. Vol. X-A República : sonhos e malogros. Amadora : Ediclube, 1993. p. 287-318.

LEAL, Ernesto Castro - Projecção pública do símbolo Nun'Álvares (1918-1931). Revista da Faculdade de Letras. Lisboa. 5. ${ }^{a}$ série. 15 (1993) 67-80.

LEAL, Ernesto Castro - Quirino Avelino de Jesus, um católico «pragmático» : notas para o estudo crítico da relação existente entre publicismo e política (1894-1926). Lusitania Sacra. Lisboa. 2. ${ }^{a}$ série. 6 (1994) 355-389.

LEITE, Joana Pereira - Colonialismo e industrialização de Moçambique : pacto colonial, dinamização das exportações e «import-substitution», 1930-74. Ler História. Lisboa. 24 (1993) 53-74.

LEMOS, Mário Matos e - O Duelo em Portugal depois da implantação da República. Revista de História das Ideias. Coimbra. 15 (1993) 561-597.

LENCASTRE, Maria José de — Fernando Pessoa : uma fotobiografia. 3. ${ }^{a}$ ed. Lisboa : Imprensa Nacional-Casa da Moeda; Porto : Centro de Estudos Pessoanos, 1984.

LÉONARD, Yves - Salazarismo e fascismo. Lisboa : Editorial Inquérito, 1998.

LOPES, Fernando Farelo - A I. ${ }^{a}$ República: da «ditadura» democrática à violação das regras do jogo. Risco. Lisboa. I (Primavera 1985) 121-128 
LOPES, Fernando Farelo - A Revista «Pela Grei» : doutrina e prática políticas. Análise Social. Lisboa. 18:72/74 (1982) 759-772.

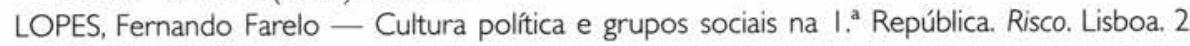
(Verão 1985) 51-61.

LOPES, Fernando Farelo - Poder político e caciquismo na 1. ${ }^{a}$ república portuguesa. Lisboa : Editorial Estampa, 1994.

LOUREIRO, José Pinto — OTeatro em Coimbra : elementos para a sua história, 1526-1910. Coimbra: Câmara Municipal, 1959.

LOURINHO, Manuel Hermenegildo - Prisioneiros portugueses na Alemanha. Porto : M. H. L. [1980].

MACEDO, Jorge Borges de - O Bloqueio continental : economia e guerra peninsular. Lisboa : Delfos, 1962.

MACEDO, Jorge Borges de — Problemas da história da indústria portuguesa no século XVIII. Lisboa: Associação Industrial Portuguesa, 1963.

MAGALHÃES, José Calvet de - História das relações diplomáticas entre Portugal e os Estados Unidos da América (1776-1911). Mem Martins : Publicações Europa-América, 1991.

MARQUES, A. H. de Oliveira - Afonso Costa. Lisboa : Editora Arcádia, 1972.

MARQUES, A. H. de Oliveira - Ensaios de história da I república portuguesa. Lisboa : Livros Horizonte, 1988.

MARQUES, A. H. de Oliveira - Estudos sobre Portugal no século $X X$. I - Aspectos do poder executivo, 1900-1932. O Tempo e O Modo. Lisboa $47 / 48$ (1967) 270-295; $54 / 55$ (1967) 774$788 ; 62 / 63$ (1968) 709-715; 67 (1969) 87-96; 71/72 (1969) 473-486.

MARQUES, A. H. de Oliveira - História da Maçonaria portuguesa.. Lisboa: Editorial Presença, 1990-1997. 3 vol. [Vol. I: Das origens ao triunfo; vol. 2: Política e Maçonaria, 1820-1869 (1. parte); vol. 3: Política e Maçonaria |820-/869].

MARQUES, A. H. de Oliveira - A Maçonaria portuguesa e o Estado Novo. 2. ${ }^{\text {a }}$ ed. rev. e aumentada. Lisboa : Publicações Dom Quixote, 1983.

MARQUES, A. H. de Oliveira; COSTA, Fernando Marques da - Bernardino Machado. Lisboa : Montanha, 1978.

MARQUES, Fernando Pereira - Do exército providencial ao exército salazarista, In COLÓQUIO «O FASCISMO EM PORTUGAL», Lisboa, 1980 - Actas. Lisboa :A Regra do Jogo, 1982. p. 195 205.

MARQUES, Fernando Pereira - Exército e sociedade em Portugal : no declínio do Antigo Regime e advento do liberalismo. Lisboa : A Regra do Jogo, 1981.

MARQUES, Fernando Pereira - Um Golpe de estado : contributo para o estudo da questão militar no Portugal de oitocentos. Lisboa : Editorial Fragmentos, 1989.

MARQUES, Fernando Pereira - Os Militares, a crise do Antigo Regime e o advento do liberalismo. In O Liberalismo na Península Ibérica na primeira metade do século XIX. Lisboa : Livraria Sá da Costa, 1982. vol. I, p. $143-153$.

MARTINHO, António Manuel Pelicano Matoso - A Escola Avelar Brotero, 1884 -1 974 : contributo para a história do ensino técnico-profissional.. Guarda : [Instituto Politécnico], 1993. [Dissertação de Doutoramento em Ciências da Educação (na área de especialização da História da Educação) apresentada à Faculdade de Psicologia e de Ciências da Educação, da Universidade de Coimbra].

MARTINS, António Viana — Da I República ao Estado Novo. Lisboa : Iniciativas Editoriais, 1976.

MARTINS, Ferreira - Figuras e factos da colonização portuguesa. Com prefácio do almirante João de Azevedo Coutinho. Lisboa : [s. n.], 1944.

MARTINS, Ferreira - Portugal na Grande Guerra. Lisboa : Editorial Ática, 1934-1935. 2 vols.

Materiais para a história da questão ográria em Portugal, sécs. XIX e XX. Selecção, prefácio e notas de Manuel Vilaverde Cabral. Porto : Inova, 1974. 
MATOS, Luís Salgado de - Comentário ao artigo de Kathleen Schwartzmann. Análise Social. Lisboa. 17:65 (1981) 163-166.

MEDEIROS, Fernando - Capitalismo e pré-capitalismo nos campos em Portugal no período entre as duas Guerras. Análise Social. Lisboa. 12:46 (1976) 288-314.

MEDEIROS, Fernando - A Sociedade e a economia portuguesa nas origens do salazarismo. Lisboa: A Regra do Jogo, 1978.

MEDINA, João - O Caso Dreyfus em Portugal. Revista da Faculdade de Letras. Lisboa. 5. a série. 16/17 (1994) 117-231.

MEDINA, João - As Conferências do Casino e o socialismo em Portugal. Lisboa : Publicações Dom Quixote, 1984.

MEDINA, João - A Imagem da república : ensaio de iconologia histórica sobre a origem e metamorfose da imagem feminina republicana. Revista da Faculdade de Letras. Lisboa. 5. ${ }^{\text {a }}$ série. 15 (1993) 8I-90.

MEDINA, João — "Oh a República!...» : estudos sobre o republicanismo e a primeira república portuguesa. Lisboa : Instituto Nacional de Investigação Científica, 1990.

MEDINA, João - Salazar e os foscistas : salazarismo e nacional-sindicalismo, a história dum conflito, 1932/1935. Amadora : Livraria Bertrand, 1978.

MENDES, José Amado - A Área económica de Coimbra : estrutura e desenvolvimento industrial, 1867-1927. Coimbrae : Comissão de Coordenação da Região Centro, 1984.

MENSURADO, Maria Paula — Os Presidentes da República em Portugal. História. Lisboa. 90/91 (Abr.-Maio 1986) 4-4I.

MESQUITA, José Carlos Vilhena — Teixeira Gomes o escritor burguês.Histório. Lisboa. (1988) 20-33.

MIRANDA, Sacuntala de - Portugal : o círculo vicioso da dependência (I890-1939). Lisboa :Teorema, 1991.

MÓNICA, Maria Filomena - Uma Aristocracia operária : os chapeleiros (1870-1914). Análise Social. Lisboa. 60 (1979) 859-945.

MÓNICA, Maria Filomena - A Formação da classe operária portuguesa : antologia da imprensa operário (1850-1934). Lisboa : Fundação Calouste Gulbenkian, 1982.

MONTEIRO, Henrique Pires - Os Portugueses na Guerra. Porto : Lello \& Irmão, [1935] (Enciclopédia pela Imagem).

Mostra Nacional Bernardino Machado, 25 Abril a 14 Maio 1995 : catálogo.Vila Nova de Famalicão: Câmara Municipal, 1995.

MOTA, Francisco Teixeira da - Alves dos Reis : uma história portuguesa. Lisboa : Público; Contexto Editora, 1997, 4 vol

Acto I: A Paixão por Angola; acto II: $E$ as notas fizeram-se dinheiro; acto III: O Sonho desfeito ; acto IV: O Julgamento final..

MOURA, Francisco Pereira - Por onde vai a economia portuguesa? Lisboa : Dom Quixote, 1969.

MOURA, Francisco Pereira [et al.] — Estudo sobre a indústria portuguesa. Lisboa : Associação Industrial Portuguesa, 1957.

MOURA, Francisco Pereira; PINTO, Luís M.Teixeira — Problemas do crescimento português. Lisboa: Associação Industrial Portuguesa, 1958.

MOURA, José Barata — Miguel Bombarda e o materialismo. In Pensar a cultura portuguesa : homenagem ao Prof. Doutor Francisco José da Gama Caeiro. Lisboa : Edições Colibri; Departamento de Filosofia da Faculdade de Letras da Universidade de Lisboa, 1993. p. 167-206.

O Movimento Operário em Portugal. Coord. Maria Filoménia Mónica, Maria de Fátima Patriarca. Análise Social. Lisboa. N. ${ }^{\circ}$ especial. $67 / 69$ (1981).

NASCIMENTO,Adriano do - Homens ilustres: Bernardino Machado : breves apontamentos, cartas inéditas. Coimbra : [s. n.], 1957. 
NEPOMUCENO, Rui - As Crises de subsistência na história da Madeira : ensaio histórico. Lisboa: Editorial Caminho, 1994.

NETO, Rui - O Regicídio de 1908. História. Lisboa. Nova série. 26 (Nov. 1996) 10-25.

NOGUEIRA, César - Notas para a história do socialismo em Portugal (1871-1910). Lisboa : Portugália Editora, 1964-1966. 2 vol.

NOGUEIRA, Franco - Salazar.Vol. I - A Mocidade e os princípios (1889-1928) : estudo biográfico. Coimbra : Atlântida, 1977.

OLIVEIRA, César de - O Operariado e a república democrática (1910-1914).2. ed. Lisboa :Seara Nova, 1974.

OLIVEIRA, Fernando Correia de - A Entrada de Portugal na I Guerra Mundial, segundo Nuno Severiano Teixeira, para a Flandres, legitimar o regime. Leituras \& Sons. Suplemento Público (8 Fev. 1997) I-3.

PAIS, José Machado — Sousa Martins e suas memórias sociais : sociologia de uma crença popular. Lisboa : Gradiva, 1994.

PAYNE, Stanley G.- Autoritarisme portugais et autoritarismes européens. Revista de História das Ideias. Coimbra. 16 (1994) 7-18.

PEREIRA, José Pacheco - Questões sobre o movimento operário português e a revolução russa de 1917. Porto: Afrontamento, 1971.

PEREIRA, Miriam Halpern — Dos revoluções liberais ao Estado Novo. Lisboa : Editorial Presença, 1994.

PEREIRA, Miriam Halpern — Livre-cámbio e desenvolvimento económico: Portugal na segunda metade

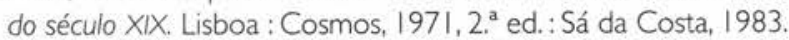

PERFECTO, Miguel Angel - Influências ideológicas no projecto de corporativismo político-social da ditadura de Primo de Rivera (1923-1930). Penélope. Lisboa. 5 (1991) 99-108.

PINTASSILGO, Joaquim - A Regeneração pela educação na escola primária da I. ${ }^{a}$ República. Cultura : revista de História e teoria das ideias. Lisboa. 2. série. 8 (1996) |I 5-133.

PINTO, António Costa - O Fascismo e a crise da primeira república : os nacionalistas lusitanos (1923-25). Penélope. Lisboa. 3 (Jun. 1989) 44-62.

PINTO, António Costa - A Ideologia do fascismo revisitada : Zeev Sternhall e os seus críticos. Ler História. Lisboa. 6 (1985) 109-120.

PINTO, António Costa - O Salazarismo e o fascismo europeu : problemas de interpretação nas ciêncios sociais. Lisboa : Editorial Estampa, 1992. p. 87-1 12.

PINTO,António Costa - O Salazarismo na recente investigação sobre o fascismo europeu : velhos problemas, velhas respostas? Análise Social. Lisboa. 25:108/109 (1990) 695-713.

PINTO, Jaime Nogueira — A Direita e as direitas. Lisboa : Difel, 1996.

PRATA, Manuel Alberto Carvalho - A Academia de Coimbra (1880-1926) : sociedade, cultura e política. Coimbra, 1994. 2 vol. [Dissertação de doutoramento em Ciências da Educação (na área de especialização da História da Educação) apresentada à Faculdade de Psicologia e Ciências da Educação da Universidade de Coimbra].

QUEIRÓS, António José - O Jornal portuense A Montanha e as relações luso-espanholas (19111926). Amarante : Edições do Tâmega, 1997.

RAMOS, Rui - A Ideia republicana e a história da República em Portugal : a propósito de alguns livros recentes. Análise Social.. Lisboa. 27:I I 5 (1992) 229-239.

RAVARA, António Pinto - Àcerca das eleições de 1911. Clio. Lisboa. 3 (1981) 127-151.

REIS, Jaime - O Atraso económico português em perspectiva histórica (1860-1913). Análise Social. Lisboa. 80 (1984) 7-28.

REIS, Carlos - As Conferências do Casino. Lisboa : Publicações Alfa, 1990.

REIS, Jaime - A Industrialização num país de desenvolvimento lento e tardio : Portugal (18701913). Análise Social. Lisboa. 96 (1987) 207-227.

REIS, Jaime - A 'Lei da fome' : as origens do proteccionismo cerealifero, 1889-19|4. In AAgricultura latifundiária na Península Ibérica. Oeiras : Fundação Calouste Gulbenkian, 1980. 
REIS, José Carlos - Sobre a identidade ideológica dos Annales: a polémica e uma hipótese. História. São Paulo. 15 (1996) 111-127.

ROCHA, Bento Coelho da - No Centenário do Prof. Doutor Luciano Pereira da Silva. Caminiana. Caminha. 2:3 (Dez. 1980) 83-91.

RODRIGUES, Alice Correia Godinho - Ideal republicano e reforma da Universidade de Coimbra. Revista de História das Ideias. Coimbra.7 (1985) 316-318.

RODRIGUES, Edgar - Breve história do pensamento e das lutas sociais em Portugal. Lisboa : Assírio \& Alvim, 1977.

RODRIGUES, Edgar - O Despertar operário em Portugal (|834-19|1). Lisboa : Sementeira, 1980.

RODRIGUES, Manuel Augusto - A Universidade de Coimbra e os seus reitores : para uma história da instituição. Coimbra : Arquivo da Universidade, 1990.

RODRIGUES, Vítor Luís Gaspar — Implantação da república em Portugal : serviço de campanha: relatório apresentado pelo Tenente Fernando Mauro d'Assumpção Carmo. Revista de História das Ideias. Coimbra. 7 tomo 2 (1985) 463-497.

ROSA, Elzira Machado - Bernardino Machado, protagonista de mudança.Vila Nova de Famalicão: Câmara Municipal, 1991.

ROSA, João Mendes - Pad'Zé: o cavaleiro da utopia. Aldeia de Joanes: Junta de Freguesia, 2000.

ROSAS, Fernando - Cinco pontos em torno do estudo comparado do fascismo. Vértice. Coimbra. 13 (Abr. 1989) 21-37.

ROSMANINHO, Nuno - O Princípio de uma urevolução urbanística» no Estado Novo : os primeiros programas da cidade universitária de Coimbra (1934-1940). Coordenação e apresentação de Luís Reis Torgal. Coimbra : Minerva Editora, 1996.

SÁ, Vítor de - Movimento operário e sindicalismo em Portugal. Porto : Federação dos Sindicatos dos Trabalhadores Têxteis, Lanifícios e Vestuário de Portugal, 1980. (Cadernos da Revista Técnica do Trabalho).

SAMUEL, Paulo - A Renascença portuguesa : um perfil documental. Porto : Fundação Engenheiro António de Almeida, 1990.

SANTOS, Alfredo Ribeiro dos - A Renascença Portuguesa : um movimento cultural portuense. Pref. José Augusto Seabra. Porto : Fundação Eng. António de Almeida, 1990.

SANTOS, Eduardo dos - O Incidente de Naulila na história e no direito internacional. Studia. Lisboa. 40 (1978) 107-249.

SANTOS, Fernando Piteira - Na transição do «constitucionalismo monárquico» para o «constitucionalismo republicano» : a crise do Partido Socialista e a crise do Partido Republicano. Análise Social. Lisboa. 18:72/74 (1982) 673-709.

SANTOS, Fernando Piteira - Portugal império : do mito ao conceito jurídico. Revista da Faculdade de Letras. Lisboa. 5. ${ }^{a}$ série. 2 (Dez. 1984) 43-53.

SANTOS, Fernando Piteira - Raul Proença e a «Alma Nacional» : da colaboração com António José de Almeida à ruptura. Mem Martins : Publicações Europa-América, [19--].

SARAIVA, António José - A Tertúlia ocidental : estudos sobre Antero de Quental, Oliveira Martins, Eça de Queiroz e outros. 2. ed. rev. incluindo um capítulo inédito. Lisboa : Gradiva ; Público, 1996.

SARAIVA, Jorge António Lima - Academismo, ideologia e história : o Instituto de Coimbra (19101945). Coimbra: Faculdade de Letras, 1993.

Dissertação de Mestrado apresentada à Faculdade de Letras da Universidade de Coimbra.

SARAIVA, José António; SILVA,Vicente Jorge - 025 de Abril visto da história : do 25 de Abril às presidenciais falando do século XIX, da república, de Salazar. Amadora : Livraria Bertrand, 1976.

SARAIVA, José Hermano - Evocação de António Cândido. Memórias da Academia das Ciências de Lisboa. Classe Letras. Lisboa. 27 (1988) 113-128.

SARAIVA, Mário - O Caso clínico de Fernando Pessoa. Post-Fácio do Prof. Doutor Luís Duarte Santos. Lisboa : Edições Referendo, 1990. 
SARDICA, José Miguel — A Dupla face do franquismo na crise da monarquia portuguesa. Lisboa : Edições Cosmos, 1994.

SCHWARTZMANN, Kathleen C. - Instabilidade democrática nos países semiperiféricos : a Primeira República portuguesa. In O Estado Novo : das origens ao fim da autarcia, 1926-1959. Lisboa : Editorial Fragmentos, 1987. vol. I, p. 145-163.

SCHWARTZMANN, Kathleen C.-Contributo para a sistematização dum aparente caos político: o caso da Primeira República Portuguesa. Análise Social. Lisboa. 17:65 (1981) I6I.

SCHWARTZMANN, Kathleen C. - Resposta a Luís Salgado de Matos. Análise Social. Lisboa. $17: 65$ (1981) 167-168.

SEABRA, Jorge [et al.] — O C.A. D. C. de Coimbra, a democracia cristã e os inícios do Estado Novo (1905-1934): uma abordagem a partir dos Estudos Sociais (1905-1911), Imparcial (1912-1919) e Estudos (1922-1934). Prefácio de Manuel Augusto Rodrigues. Coimbra: Faculdade de Letras, 1993. Co-aut::António Rafael Amaro, João Paulo Avelãs Nunes.

Seara Nova : antologia. Organização, prefácio e notas de Sotomayor Cardia. Lisboa : Publicações Alfa, 1990.

SERRA, João Bonifácio - Do 5 de Outubro ao 28 de Maio : a instabilidade permanente. In Portugal contemporâneo. Dir.António Reis. Lisboa : Publicações Alfa, 1990. vol. 3, p. I3-84.

SERRÃO, Joel — Da «Regeneração» à República. Lisboa : Livros Horizonte, 1990.

SERRÃO, Joel —Do sebastianismo ao socialismo em Portugal. Lisboa : Livros Horizonte, 1969.

SERRÃO, Joel - Du Socialisme libertaire a l'anarchisme. Arquivos do Centro Cultural Português. Paris. II (1982) 331-368.

SERRÃO, Joel - Liberalismo, socialismo, republicanismo : antologia de pensamento político português. 2. ${ }^{\text {a }}$ ed. Lisboa : Livros Horizonte, 1979.

SERRÃO, Joel - República se chamava. In SANTOS, Machado - A Revolução portuguesa 1907 -1910. Lisboa : Assírio e Alvim, 1982, p.VII-L.

SERRÃO, Joel — Sampaio Bruno : o homem e o pensamento. Lisboa : Inquérito, 1958.

SERRÃO, Joel - Temas oitocentistas : para a história de Portugal no século passado. Lisboa : Ática: Portugália, 1959-1962.2 vol.

SILBERT, Albert — Do Portugal de Antigo Regime ao Portugal oitocentista. Lisboa : Livros Horizonte, 1972.

SILBERT, Albert - Le Portugal méditerranéen à la fin de l'Ancien Régime XVIII'me siècle - début du XIXème siècle : contribution à l'histoire agraire comparée. Paris : SEVPEN, 1966.2 vol.

SILBERT, Albert — Le Problème agraire portugais au temps des premières cortès libérales (I8221823). Paris: PUF, 1968.

SILVA, Amaro Carvalho da - O Partido nacionalista no contexto do nacionalismo católico (19011910) : subsídios para a História Contemporânea Portuguesa. Lisboa : Edições Colibri, 1996.

SILVA, Armando B. Malheiro da - Aus einem diplomatischen wanderleben de Friedrich Rosen. Relações luso-alemãs e impressões de um diplomata alemão em Portugal, 1912-1916. In Portugal, Indien und Deutschland: Portugal, Índia e Alemanha: akten derV Deutsch Portugiesischen Arbeitsgesprachelactos do V Encontro Luso-Alemão (Kohn/Colónia-1998). Koln/Lisboa:Zentrum Portugiesischesprachige Welt-Universitat zur Koln/Centro de Estudos Históricos-Universidade Nova de Lisboa, 2000, p. 447-483 (em colaboração com Mário Matos).

SILVA, Armando B. Malheiro da - Os Conspiradores no sul da Galiza: as incursões monárquicas (1912) na literatura portuguesa. Bracara Augusta, Braga, 48 (1998-99) 44I-478.

SILVA, Armando B. Malheiro da - Egas Moniz e a política: notas avulsas para uma biografia indiscreta. In Egas Moniz em livre exame. Coimbra: Minerva. Coimbra, 2000, 237-31 I. Org. Ana Leonor Pereira e joão Rui Pita.

SILVA, Armando B. Malheiro da - A Escrita (vária) da história da I República portuguesa. Ler História, Lisboa, 38 (2000) 197-254. 
SILVA, Armando B. Malheiro da - Leonardo Coimbra e o Integralismo Lusitano. Bracara Augusta. Braga. 36:81/82 (Jan.-Dez. 1982) 433-489.

SILVA, Armando B. Malheiro da; GARCIA, José Luís Lima - Norton de Matos e a oposição à política colonial de Salazar. Revista de História das Ideias. Coimbra. 17 (1995) 349-404.

SILVA, Joaquim Palminha da - De «caso» de cariz político e mentalidade inovadora (1907) a caso bem confuso (1988)? : Armazéns Grandella : como nasceram e o que foram. História. Lisboa. 112 (Set. 1988) 4-27.

SILVA, Joaquim Palminha da - Entre o mapa cor-de-rosa e o 5 de Outubro: 1 de Fevereiro de 1908: o regicídio. História. Lisboa. 137 (Fev. 1990) 5-44.

SILVA, Joaquim Palminha da - Jaime Batalha Reis na Rússia dos Sovietes ou dez dias que abalaram um diplomata português. Lisboa : Edições Afrontamento, 1984.

SILVA, Joaquim Palminha da - Na Lisboa de 1900: a «Belle Époque» existiu? História. Lisboa. 136 (Jan. 1991) 5-48.

SILVA, Joaquim Palminha da - Portugal : religiosidade cívica e fanatismo messiânico. História. Lisboa. 14:163 (Abr. 1993) 67-73.

SILVA, Joaquim Palminha da - O Portugal suicidário de Camilo a Sá-Carneiro. História. Lisboa. 14:147 (Dez. 1991) 4-33 - 14:149 (Fev. 1992) 68-81. I - A Ideia de fim-de-pátria. História. Lisboa. 14:147 (Dez. 1991) 4-33;2 - A «Doença de pátria». História. Lisboa. 14:148 (Jan. 1992) 4-27; 3 - O Funeral da pátria. Histório. Lisboa. 14:149 (Fev. 1992) 68-81.

SILVA, Orlando - Manuel Laranjeira, 1877-1912 : vivências e imagens de uma época. [S.l.: s.n.]. 1992.

SMITH,Vincent - As Relações políticas luso-britânicas, 1910-1916. Lisboa : [s.n.], 1975.

SOARES, António José - Saudades de Coimbra. Coimbra : Livraria Almedina, 1985. Vol. I: 1901-1916. vol. 2: 1917-1933.

SOUSA, Jorge Pais - Bissaya Barreto: ordem e progresso. Coimbra: Livraria Minerva, 1999.

TEIXEIRA, Nuno Severiano - A Fome e a saudade : os prisioneiros portugueses na Grande Guerra. Penélope. Lisboa. 8 (1992) 91-114.

TEIXEIRA, Nuno Severiano - A Independência conservadora. Diário de Notícias. Lisboa. (29 Dez. 1984) 3.

TEIXEIRA, Nuno Severiano - O Poder e a guerra, 1914-1918: objectivos nacionais e estratégias políticas na entrada de Portugal na Grande Guerra. Lisboa : Editorial Estampa, 1996.

TEIXEIRA, Nuno Severiano - Portugal de 1914 a 1918. In História do Século XX. Vol. 2 - 1914 -1918 :I Guerra Mundial. Lisboa : Publicações Alfa, 1995.

TEIXEIRA, Nuno Severiano - O Ultimatum inglês : politica externa e politica interna no Portugal de 1890. Lisboa : Publicações Alfa, 1990.

TELO, António José - Os Açores e o controlo do Atlântico (1 898-1948). Porto : Edições Asa, 1993.

TELO, António José - A Busca frustrada do desenvolvimento. In Portugal contemporâneo. Dir. António Reis. Lisboa : Publicações Alfa, 1990, vol. 3, p. 123-170.

TELO, António José - Decadência e queda da I república portuguesa. Lisboa : A Regra do Jogo, 1980-1984. 2 vol.

TELO, António José - Economia e império no Portugal contemporâneo. Lisboa : Edições Cosmos, 1994.

TORGAL, Luís Reis - Quid Petis? : os «doutoramentos» na Universidade de Coimbra. Revista de História das Ideias. Coimbra. 15 (1993) 177-316.

TORRE GÓMEZ, Hipólito de la - Antagonismo y fractura peninsular: España-Portugal 1910-1919. Madrid : Espasa-Calpe, 1983.

TORRE GÓMEZ, Hipólito de la - Conspiração contra Portugal (1910-1912) : as relações políticas entre Portugal e Espanha. Lisboa : Livros Horizonte, 1978.

TORRE GÓMEZ, Hipólito de la - Do «perigo espanhol» à amizade peninsular : Portugal-Espanha, 1919-1930. Lisboa : Editorial Estampa, 1985. 
TORRE GÓMEZ, Hipólito de la - Na encruzilhada da Grande Guerra : Portugal-Espanha 1913-1919. Lisboa : Editorial Estampa, 1980.

TORRES, Adelino - O Império português entre o real e o imaginário. Lisboa : Escher, 1991.

TORRES, Flausino — Leituras históricas : as origens da república. Lisboa : Prelo Editora, 1965.

VALENTE, Vasco Pulido - Crentes e conversos : a República na província (Outubro de 1910 - Maio de 191 I). Análise Social. Lisboa. I1:41 (1975) p. 17-30.

VALENTE,Vasco Pulido - As Duas tácticas da monarquia perante a revolução. Lisboa : Publicações Dom Quixote, 1974.

VALENTE,Vasco Pulido - Moderados e radicais na I República : da conciliação ao terror (Outubro de 1910 - Agosto de 1911). Análise Social. Lisboa. II:42/43 (1975) 232-265.

VALENTE, Vasco Pulido - O Poder e o povo : a revolução de 1910. Lisboa : Publicações Dom Quixote, 1976.

VALENTE, Vasco Pulido - Portugal e a guerra de 14-18. OTempo e o Modo. Lisboa. 33 (1965) 1202-1215.

VALENTE, Vasco Pulido - A Revolta do grelo. Lisboa : Assírio e Alvim, 1974.

VALENTE, Vasco Pulido - Revoluções : a «república velha» : ensaio de interpretação política. Análise Social. Lisboa. 27:I I5 (1992) 7-63.

VASCONCELOS, Maria José Teixeira de - Na Sombra de Pascoaes : fotobiografia. Lisboa :Vega, 1993.

VENTURA, António - Entre a república e a acracia : o pensamento e a aç̧ão de Emilio Costa (1897-19/4). Lisboa : Edições Colibri, 1994.

VENTURA, António - O Imaginário seareiro : ilustradores e ilustrações da Revista Seara Nova (1921-1927). Lisboa : Instituto Nacional de Investigação Científica, 1989.

VENTURA, António - A Maçonaria e a república. In História de Portugal dos tempos pré-históricos aos nossos dias. Vol. X-A República : sonhos e malogros. Dir. João Medina. Amadora : Ediclube, 1993, p. 319-338.

VIDIGAL, Luís - Cidadania, caciquismo e poder : Portugal, 1890-1916 : estudos. Lisboa : Livros Horizonte, 1988.

VIDIGAL, Luís - O Estabelecimento da república em Portugal : problemas e hipóteses. História. Lisboa. 85 (Nov. 1985) 64-87.

VILAS BOAS, Manuel [et al.] — Fátima : os lugares da profecia. Lisboa : Círculo de Leitores, 1993. Co-aut: Francisco de Oliveira, Vitor Frazão, Jorge Barros.

VILELA, Mário - Alma nacional : revista republicana (1910): linguagem e ideologia. Porto : Livraria Civilização, 1977.

XAVIER, Alberto - História da greve académica de 1907. Coimbra : Coimbra Editora, 1962.

WHEELER, Douglas L. - História política de Portugal, 1910-1926. Mem Martins : Publicações Europa-América, [19--].

WHEELER, Douglas L. - A Primeira república e a história. Análise Social. Lisboa. 15:56 (1978) 865-872.

\subsubsection{Período sidonista (1917-1918)}

ANTUNES, José Freire — A Cadeira de Sidónio ou a memória do presidencialismo. Mem Martins : Publicações Europa-América, [19--].

ANTUNES, José Freire - «Os Cadetes de Sidónio». Diário de Notícias. Lisboa. (Fev. 1982) 8.

ANTUNES, José Freire - Sidónio revisitado por um jornalista. Diário de Lisboa. Lisboa. (1 I Fev. 1982) 2.

AZEVEDO, Ana Paula — As Más horas da Boa-Hora. Expresso Revista. Lisboa. (19 Jun. 1993)

BARROSO, Alfredo - Sidónio Pais, o artilheiro de Deus. In - Janela indiscreta : diários, crónicas e retratos. Lisboa : Quetzal, 1994. p. 201-207. 
BERNARDINO,Teresa - Sidónio o presidencialista.Diário de Notícias. Lisboa. (1 I Maio 1982) 7. BRANDÃO, José - Sidónio : contribuição para a história do presidencialismo. Lisboa : Perspectiva \& Realidades, 1983. [Reed.: Lisboa : Publicações Alfa, 1990].

CABRAL, Manuel Vilaverde - A Grande Guerra e o sidonismo : esboço interpretativo. Análise Social. Lisboa. I5:58 (1979) 373-392.

CARVALHO, Serra de - O IV Presidente da república portuguesa nasceu em Caminha. Ecos da Matriz. Caminha. (Maio 1972) 3-4.

DACOSTA, Fernando - As Seduções de Sidónio. Visão. Lisboa. 247 (1 I/17 Dez. 1997) 56-63.

«O Drama de Sidónio e a crise de constitucionalidade em | 918 : : [«Encontro de Gerações». Ciclo de coloquios 1967/68, no Centro de Cultura Popular. Debate orientado por Dr. Henrique Barrillaro Ruas e participado por Dr. Bento Coelho da Rocha e Dr. José Vaz Serra de Moura, estudante de Direito]. Diário de Notícias. Lisboa. (5 Dez. 1967).

ELOY, António - Sidónio : contribuição para a história do presidencialismo. Revista Expresso. Lisboa. (24 Set. 1983).

FARIA, Manuel Lopes - Ainda a segunda morte de Sidónio Pais : resposta a um autodidacta. Diário de Lisboa. Lisboa. (15 Fev. 1982) 2.

FARIA, Manuel Lopes - A Segunda morte de Sidónio Pais ou os malefícios do amadorismo. Diário de Lisboa. Lisboa. (9 Fev. 1982) 2.

FARINHA, Luís — Sidónio Pais em Berlim. História. Lisboa. Nova série. $16: 2$ (Nov. 1994) 28-37.

FIGUEIREDO, Nelson de - Pontos altos da nossa trajectória dentro desta casa : o enterro de Sidónio Pais. Revista da Associação dos Antigos Alunos do Colégio Militar. Lisboa. 12:49 (Out.Dez. 1977) 16-17.

GARRIDO, Álvaro - Sidónio Pais : a edificação do mito. História. Lisboa. Nova série. $16: 2$ (Nov. 1994) 38-67.

GOMES, Fátima Freitas; VERÍSSIMO, Nelson — A Madeira e o sidonismo. Funchal : Direcção Regional dos Assuntos Culturais, Governo Regional da Madeira, 1983.

GONÇALVES, José António Sequeira - Sidónio Pais e a participação portuguesa na guerra de 1914-1918. Lisboa, 1989. 2 vol.

Dissertação de Mestrado orientada pelo Professor Doutor João Medina e apresentada à Faculdade de Letras da Universidade de Lisboa. Texto fotocopiado.

ISIDRO, João - A Propósito do livro de José Brandão : a cada época seu sidonismo. Tempo Magazine : suplemento Tempo. (14 Jul. 1983) 8.

LEAL, Ernesto Castro - Sidonismo e juventude : o Centro Federal Mocidade Republicana (1918). Diário de Notícias. Lisboa. (II Jan. 1987).

LEITE, Manuel da Costa — Os Erros do Sidónio. Público. Lisboa. (26 Jul. 1990).

MATA, Aida Maria Reis da; OLIVEIRA, José Fernando Vieira Lizardo Gomes Coelho de — Intranquilidade e repressão no consulado sidonista. Lisboa, 1981. [Texto fotocopiado].

MEDINA, João - Da «República Nova» ao «Estado Novo» : sidonismo e salazarismo. História. Lisboa. 3 (Jan. 1979) 2-13.

MEDINA, João - Um Documento inédito : o ingresso de Sidónio Pais na Maçonaria. Diário de Lisboa. Lisboa. (26 Jan. 1981) 3-4.

MEDINA, João — Fernando Pessoa e o messias : sobre a visão messiânica de Pessoa e o seu ideário político. In ENCONTRO INTERNACIONAL DE FERNANDO PESSOA : Um Século de Pessoa, Lisboa, 1988 - Actas do colóquio. Lisboa : Secretaria de Estado da Cultura, 1990. p. $229-239$.

MEDINA, João - João Chagas entre dois ditadores. Diário de Lisboa. Lisboa. (10 Mar. 1981).

MEDINA, João - A Liga de Acção Nacional e o sidonismo. Diário Popular. Lisboa. (21 Dez. 1978).

MEDINA, João - Manuel Teixeira Gomes e Sidónio Pais. Clio. Lisboa. 2 (1980) 117 - 129.

MEDINA, João - Morte e transfiguração de Sidónio Pais. Lisboa : Edição Cosmos, 1994. 
MEDINA, João - A Resistência dos democráticos durante o sidonismo. Diário de Notícias. Lisboa. (31 Ago. 1982).

MEDINA, João - Sérgio e Sidónio : estudo do ideário sergiano na revista 'Pela Grei' (1918-1919). In Estudos sobre António Sérgio. Lisboa : Centro de História da Universidade de Lisboa, Instituto Nacional de Investigação Científica, 1988. p. 7-30.

MEDINA, João - Sérgio sidonista. Diário Popular. Lisboa. (4 Dez. 1978).

MEDINA, João - Sidónio Pais, chefe carismático. Revista da Faculdade de Letras. Lisboa. 5. ${ }^{3}$ série. 2 (Dez. 1984) 79-89.

MEDINA, João - Varões republicanos : quatro retratos de vultos políticos da I república : Machado Santos, Afonso Costa, João Chagas e Sidónio Pais. Clio. Lisboa. Nova série. 2 (1997) 153-174.

MENDANHA, Vítor - Presidente da república assassinado em Lisboa : a política de Sidónio. Correio da Manhã. Lisboa. (4 Mar. 1984) 28-29.

MENESES, Filipe Ribeiro de - União Sagrada e sidonismo: Portugal em guerra (19/6-18). Lisboa: Edições Cosmos, 2000.

PAIXÃO, Vítor Braga - A Constituinte de 1911 : Teófilo, Afonso, Sidónio... Anais da Academia Portuguesa da História. Lisboa. 2. ${ }^{a}$ série. 23:2 (1976) 36-41.

PEREIRA, José Pacheco - As Lutas operárias contra a carestia de vida em Portugal : a greve geral de Novembro de 1918. Porto: Portucalense Editora, 1971.

PEREIRA, José Pacheco - O Sidonismo e o movimento operário. Diário de Notícias. $2 .^{\circ}$ Caderno Cultura. Lisboa. (23 Nov. 1978) 19.

Um Perfil e uma obra : Sidónio Pais. Vida Mundial. Lisboa. 1487 (8 Dez. 1967) 25-28.

PINTO,António Costa - O Fim da «República Nova» : com a morte de Sidónio Pais ruía também a experiência de congregação das forças conservadoras : o partido único só com o projecto político de Salazar encontraria terreno fértil. Diário de Notícias. Lisboa. (6 Jan. 1981).

PINTO, Jorge - I - As Origens do fascismo em Portugal : a ditadura de Sidónio Pais. Voz Popular. Lisboa. (5 Set. 1978) 23.

O Presidencialismo português. Selecção e notas de José Pedro Gonçalves. Lisboa : Iniciativas Editoriais, 1971.

PROENÇA, Maria Cândida — A Experiência sidonista. História. Lisboa. 63 (Jan. 1984) 48-75.

RAMALHO, Miguel Nunes - Sidónio Pais diplomata e conspirador: 1912-1917. Lisboa: Edições Cosmos, 1998. [Texto fotocopiado].

RAPOSO,A. Cunha - O Mistério do crime de 14 de Dezembro. In Os Grandes enigmas de entre duas guerras. Lisboa: Amigos do Livro, [19--]. Tomo I, p. 213-254.

REGO, Raul — Os Cadetes de Sidónio. Diário de Notícios. Lisboa. (23 Jan. 1982) 8.

ROCHA, Francisco Canais; LABAREDAS, Maria Rosalina - Os Trabalhadores rurais do Alentejo e o sidonismo. Lisboa : Edições I de Outubro, 1982.

ROCHA JÚNIOR - Frases da hora final : o «Diário de Notícias» também teve a sua. Diário de Notícias. Lisboa. 101 (29 Dez. 1964).

394 ROSAS, Fernando - A Crise do liberalismo e as origens do «autoritarismo moderno» e do estado novo em Portugal. Penélope. Lisboa. 2 (Fev. 1989) 98-114.

SÁ, Vítor de - Reflexão (cronológica) sobre o sidonismo. Revista da Faculdade de Letras. Série História. Porto. 2. ${ }^{\mathrm{a}}$ série. 6 (1989) 355-361.

SAMARA, Maria Alice - Sidónio Pais. In VIEIRA, Joaquim (dir) — Fotobiografias século XX. Lisboa: Círculo de Leitores, 2002.

SERRÃO, Joel - Pessoa entre Sidónio e D. Sebastião. Diário de Notícias. 2. ${ }^{\circ}$ Caderno História. Lisboa. (4 Mar. 1980) I3.

Sidónio nasceu há 100 anos : Caminha responde. Observador. Lisboa. 62 (28 Abr. 1972) 58-59.

SILVA, Armando B. Malheiro da - A Alemanha no princípio do século XX à luz da correspondência consular portuguesa. In Portugal und Deutschland auf dem Weg nach Europa = Portugal 
e a Alemanha a caminho da Europa. Org. Marlia dos Santos Lopes, Ulrich Knefelkamp, Peter Hanenberg. Pfaffenweiler: Centaurus, 1995. p. 47-67.

SILVA,Armando B. Malheiro da - Os Católicos e a «República Nova» (1917-1918) : da «questão religiosa» à mitologia nacional. Lusitonia Sacra. Lisboa. 2. ${ }^{a}$ série. 8/9 (1996/1997) 385-499.

SILVA, Armando B. Malheiro da - Sidónio e sidonismo entre a história e a literatura. Revista de História das Ideias, Coimbra, 21 (2000) 307-388.

SILVA, Armando B. Malheiro da — Sidónio e sidonismo: história e mito: dissertação de doutoramento em História Contemporânea de Portugal. Braga: Universidade do Minho, 1997.2 vol.

SILVA, Armando B. Malheiro da - Síntese do projecto Sidónio e sidonismo. História e mito. Itinerarium, Braga, 44 (1999) 501-524.

SILVA,Armando B. Malheiro da ; DAMÁSIO, Luís Pimenta de Castro - António Cândido, Sidónio Pais e a elite política amarantina, 1850-1922. Elementos para o estudo das raízes familiares de Amadeo de Souza Cardoso. Amarante: Câmara Municipal, 2000. [Prefácio de Augustina Bessa-Luís].

SILVA, Armando B. Malheiro da;TRIGUEIROS, António Júlio Limpo — Sidónio Pais: de Caminha ao Panteão Nacional : retalhos ideológico-políticos, histórico-biográficos e genealógicos da memória. Viana do Castelo: Centro de Estudos Regionais, 1999.

SILVA,Armando B. Malheiro da - A República e o reformismo democrático - autoritário (1890-1926): uma proposta interpretativa. In Portugal-Brasil, uma visão interdisciplinar do século XX. Coimbra : Quarteto Editora, 2003, p. 46-62.

SILVA, Joaquim Palminha - Jaime Batalha Reis na Rússia dos sovietes ou dez dias que abalaram um diplomata português. Porto : Edições Afrontamento, 1984.

SUBTIL, José - Sidónio Pais : a ideia e a palavra. Diário de Notícias. Suplemento «História». Lisboa. (1I Ago. 1983) 7.

TELO, António José - Oitenta anos depois: compreender Sidónio. História, Lisboa, 20, nova série, 9 (Dezembro 1998) II-25.

TELO, António José - Prefácio: Sidónio Pais na história. In RAMALHO, Miguel Nunes — Sidónio Pais diplomata e conspirador: 1912-1917. Lisboa: Edições Cosmos, 1998.

TELO, António José - O Sidonismo e o movimento operário português : luta de classes em Portugal, 1917-1919. Lisboa: Ulmeiro, 1977.

TRIGUEIROS, António Júlio Limpo; SILVA,Armando B. Malheiro da — Os Paes de Barcelos : subsídios genealógicos para a biografia do presidente da república Sidónio Paes. Barcelos-Revista. Barcelos. 2. ${ }^{\text {a }}$ série. 5 (1994) 107-182.

VALENTE, Vasco Pulido - Estudos sobre Sidónio Pais. In Estudos sobre a crise nacional. Lisboa : Imprensa Nacional-Casa da Moeda, 1980. p. 243-318.

VARGAS, José Manuel de Jesus - Sidónio Pais, deputado e ministro (1911-1912) : trabalho para 0 Seminário 'O Sidonismo' dirigido pelo Prof. Dr. João Medina, 1980/1981. Lisboa, 1981.

Texto fotocopiado. 

ANEXOS 



\section{I - Sidónio Pais, cronologia breve}

1872 - nasceu em Caminha, no dia I de Maio.

1888 - alistou-se voluntariamente no Regimento de Infantaria n. 23 , a 12 de Dezembro.

1888-90 ...- frequentou os preparatórios na Universidade de Coimbra para ingresso na Escola do Exército.

1892 - concluiu o curso da Escola do Exército como sargento graduado cadete do Regimento de Artilharia n. ${ }^{\circ}$ I, promovido a $2{ }^{\circ}$ Tenente para a arma de Artilharia, em Dezembro.

1898 - completou o curso na Faculdade de Matemática da Universidade de Coimbra cujo curso completou em 1898 , sendo premiado no $5 .^{\circ}$ ano;

defendeu e publicou para conclusão do curso e obtenção do grau de doutor três trabalhos: Theses de Matemáticas Puras e Aplicadas; Introdução à Teoria dos Erros e das Observações e Série dos Números.

1899 - foi nomeado lente substituto da Faculdade de Matemática da Universidade de Coimbra, a 12 de Janeiro.

1902 - concorreu ao ensino comercial e industrial com o opúsculo As Forças e os Movimentos, Definições e Postulados da Mecânica, tendo ingressado como professor da Escola Industrial Brotero de Coimbra.

1905 - foi nomeado Director da Escola Industrial Brotero, cargo em que se manteve até 1911.

1906 - foi promovido a Capitão, em 29 de Dezembro.

1908 - proferiu a Oração de Sapiência de abertura do ano lectivo 1908-09 da Universidade de Coimbra como lente da Faculdade de Matemática.

1910-11 - foi empossado Presidente da Comissão Administrativa Municipal de Coimbra; Vice-Reitor da Universidade de Coimbra;

Administrador da Companhia dos Caminhos-de-Ferro Portugueses.

1911 - foi iniciado na Loja Estrela de Alva de Coimbra:

Deputado às Constituintes pelo Distrito de Aveiro, passando directo à nova legislatu$\mathrm{ra}$;

nomeado Ministro do Fomento, em 3 de Setembro de 1911 e deixou o cargo a 2 de Novembro;

nomeado Ministro das Finanças, funções de que foi exonerado a seu pedido a 12 de Junho de 1912.

1912 - foi nomeado Ministro Plenipotenciário em Berlim, a 17 de Agosto. 
1916 - manteve-se em funções diplomáticas na Alemanha até 9 de Março de 1916, data de declaração de guerra a Portugal;

foi promovido a Major Graduado, em 18 de Março.

colocado por portaria de 18 de Março no Ministério dos Negócios Estrangeiros, onde «ficou demorado em serviço».

1917 - liderou o golpe militar iniciado a 5 e concluído vitorioso a 8 de Dezembro, tendo sido constituída uma Junta Revolucionária que assumiu o Governo da Nação, dissolveu o Congresso da República e destituiu o Presidente da República com data de II do mesmo mês;

assumiu funções de Chefe do Estado por decreto de 27 de Dezembro, e por deliberação do Conselho de Ministros.

1918 - revolta falhada de marinheiros democráticos a 8 de Janeiro; eleições por sufrágio universal masculino para o Congresso (Câmara dos Deputados e Senado, lugares reservados à representação partidária) e Presidência da República; restabelecimento das relações do Estado com a lgreja, pelo decreto .... assumiu as funções de Presidente da República, a 9 de Maio, em virtude da proclamação da Comissão Central de Apuramento Eleitoral; revolta democrática falhada a 12 de Outubro; assinatura das condições do Armistício e fim da Grande Guerra, a II de Novembro; greve geral da U.O.N. realizada a 18 de Novembro;

faleceu no dia 14 de Dezembro, assassinado na Estação do Rossio, quando iniciava a sua viagem ao Porto. 


\section{2 - Constituição Política da República Portuguesa Projecto [Dezembro de 1918$]^{(1013)}$}

\section{TÍTULO I \\ Da forma do Governo e do território da Nação Portuguesa}

Artigo 1. - A Nação Portuguesa, organizada em Estado Unitário, adopta como forma de govêrno a República, nos termos desta Constituição.

Art. $2^{\circ}$ - O território da Nação Portuguesa é o existente à data da proclamação da República.

§único. A Nação não renuncia aos direitos que tenha ou possa vir a ter sôbre qualquer outro território.

\section{TÍTULO ॥}

\section{Dos direitos e garantias individuais}

Art. $3 .^{\circ}-$ A Constituição garante a portugueses e estrangeiros, residentes no país, a inviolabilidade dos direitos concernentes à liberdade, à segurança individual e à propriedade, nos termos seguintes:

$1 .^{\circ}-$ Ninguém pode ser obrigado a fazer ou deixar de fazer alguma cousa senão em virtude da lei;

$2^{\circ}$ - A lei é igual para todos, e só obriga aquela que fôr promulgada nos termos desta Constituição;

3. - A República Portuguesa não admite privilégio de nascimento nem foros de nobreza e extingue os títulos nobiliárquicos e de conselho;

Os feitos cívicos e os actos militares podem ser galardoados com ordens honoríficas, condecorações ou diplomas especiais;

(1013) Câmara dos Deputados, 1918 - Projectos [SecçãoVIII, c× 98]. (Arquivo Histórico-Parlamentar); Dossier Projecto de Constituição, contendo dois jogos de provas tipográficas de versões diferentes, ambas corrigidas por Sidónio Pais e original dactiloscrito de uma dessas versões (a anterior à que se encontra aqui transcrita entregue pela Comissão Redactora na Presidência da República para ser lido e corrigido pelo Chefe do Estado. Uma cópia deste original existe no Arquivo Pessoal de Eurico Cameira. (Arquivo de Sidónio Pais - Subsistema Presidência da República); acervo documental na posse de Desembargador Dr. Nuno Cameira. (Arquivo de Eurico Cameira). O documento existente no Arquivo Histórico-Parlamentar, aqui transcrito, inclui já as últimas e ligeiras correç̧ões feitas por Sidónio Pais. 
Se as condecorações forem estrangeiras, a sua aceitação depende do consentimento do Govêrno Português;

$4^{\circ}$ - A liberdade de consciência e de crença é inviolável;

$5 .^{\circ}$ - O Estado reconhece a igualdade política e civil de todos os cultos e garante o seu exercício nos limites compatíveis com a ordem pública, as leis e os bons costumes, desde que não ofendam os princípios do direito público português;

6. ${ }^{\circ}$ Ninguém pode ser perseguido por motivo de religião, nem perguntado por autoridade alguma acerca da que professa;

7. Ninguém pode, por motivo de opinião religiosa, ser privado de um direito ou isentar-se do cumprimento de qualquer dever cívico;

$8 .^{\circ}$ É livre o culto público de qualquer religião nas casas para isso escolhidas ou destinadas pelos respectivos crentes, e que poderão sempre tomar forma exterior de templo; mas, no interesse da ordem pública e da liberdade individual e segurança dos cidadãos, uma lei especial fixará as condições do seu exercício;

9. ${ }^{\circ}$ Os cemitérios públicos terão carácter secular, ficando livre a todos os cultos religiosos a prática dos respectivos ritos, desde que não ofendam a moral pública, os princípios do direito público português e a lei;

$10 .^{\circ} \mathrm{O}$ ensino ministrado nos estabelecimentos de instrução do Estado será neutro em matéria religiosa;

11. 0 ensino primário elementar será obrigatório e gratuito;

12. A expressão do pensamento, seja qual fôr a sua forma, é completamente livre, sem dependência de caução, censura ou autorização prévia, mas o abuso dêste direito é punivel nos casos e pela forma que a lei determinar:

13..$^{\circ}$ O direito de reúnião e associação é livre. Leis especiais determinarão a forma e condições do seu exercício;

14. ${ }^{\circ}$ É garantida a inviolabilidade do domicilio. De noite, e sem consentimento do cidadão, só se poderá entrar na casa dêste a reclamação feita de dentro ou para acudir a vítimas de crimes ou desastres; de dia, só nos casos e pela forma que a lei determinar.

15. Ninguém poderá ser preso sem culpa formada a não ser nos casos de flagrante delito e nos seguintes: alta traição, falsificação de moeda, de notas de bancos nacionais e títulos de dívida pública portuguesa, homicídio voluntário, furto doméstico, roubo, falência fraudulenta e fogo pôsto;

16. Ninguém poderá ser conduzido à prisão ou nela conservado, estando já preso, se se oferecer a prestar caução idónea ou termo de residência, no caso em que a lei os admitir;

17. À excepção do flagrante delito, a prisão não poderá executar-se senão por ordem escrita da autoridade competente e em conformidade com a expressa disposição da lei;

$18^{\circ}$ Não haverá prisão por falta de pagamento de custas ou selos:

19. A instrução dos feitos crimes será contraditória, assegurando aos arguidos, antes e depois da formação da culpa, todas as garantias de defesa;

$20{ }^{\circ}$ Ninguém será sentenciado senão pela autoridade competente, por virtude de lei anterior e na forma por ela prescrita;

21. Não poderá ser estabelecida a pena de morte nem as penas corporais perpétuas ou de duração ilimitada. Exceptua-se, quanto à pena de morte, sómente o caso de guerra com país estrangeiro, em tanto quanto a aplicação dessa pena seja indispensável, e apenas no teatro de guerra.

$22 .^{\circ}$ Nenhuma pena passará da pessoa do delinquente. Portanto, não haverá em caso algum confiscação de bens, nem a infâmia do réu se transmitirá aos parentes, em qualquer grau;

$23 .^{\circ}$ É assegurado, exclusivamente em benefício do condenado, o direito de revisão de todas as sentenças condenatórias.

Leis especiais determinarão os casos e a forma da revisão. 
24. É garantido o direito de propriedade, salvo as limitações estabelecidas na lei;

25. É garantido o exercício de todo o género de trabalho, indústria e comércio, salvas as restrições da lei por utilidade pública;

Só o Poder Legislativo e os corpos administrativos poderão conceder o exclusivo de qualquer exploração comercial ou industrial; mas é privativo do Poder Legislativo apreciar essa utilidade.

26. Ninguém é obrigado a pagar contribuições que não tenham sido votadas pelo Poder Legislativo ou pelos corpos administrativos, legalmente autorizados a lançá-las, e cuja cobrança se não faça pela forma prescrita na lei;

$27 .^{\circ}$ O sigilo da correspondência é inviolável, salvo as disposições indispensáveis em tempo de guerra;

28. É reconhecido o direito à assistência pública;

29. ${ }^{\circ}$ Todo o cidadão poderá apresentar aos poderes do Estado reclamações, queixas e petições, e poderá expor, nos termos legais, ao tribunal competente qualquer infraç̧ão da Constituição e reclamar a efectiva responsabilidade dos infractores;

$300^{\circ}$ Dar-se há o habeas corpus sempre que o indivíduo sofrer ou se encontrar em iminente perigo de sofrer violência ou coacção, por ilegalidade ou abuso do poder.

A garantia do habeas corpus só se suspenderá nos casos de estado de sítio por sedição, conspiração, rebelião ou invasão estrangeira.

Uma lei especial regulará a extensão desta garantia e o seu processo.

31. A qualquer empregado do Estado, de corpos administrativos ou de companhias que tenham contratos com o Estado, é garantido o seu emprêgo, com os direitos a êle inerentes, durante o serviço militar a que fôr obrigado.

$32 .^{\circ} \mathrm{O}$ estado civil e os respectivos registos são da exclusiva competência da autoridade civil;

$33 .^{\circ}$ Se alguma sentença criminal fôr executada e vier a provar-se depois, pelos meios legais competentes, que foi injusta a condenação, terá o condenado ou os seus herdeiros, o direito de haver reparação de perdas e danos, que será feita pela Fazenda Nacional, precedendo sentença nos termos da lei;

34. Fora dos casos expressos na lei, ninguém, ainda que em estado anormal das suas faculdades mentais, pode ser privado da sua liberdade pessoal, sem que preceda autorização judicial, salvo caso de urgência devidamente comprovado e requerendo-se imediatamente a necessária confirmação judicial.

$35 .^{\circ}$ Toda a pessoa internada ou detida num estabelecimento de alienados ou em cárcere privado, assim como o seu representante legal e qualquer parente ou amigo, pode, a todo o tempo, requerer ao juiz respectivo que, procedendo às investigações necessárias, o ponha imediatamente em liberdade, se fôr caso disso.

36. É lícito a todos os cidadãos resistir a qualquer ordem que infrinja as garantias individuais, se não estiverem legalmente suspensas.

\section{TÍTULO III \\ Da soberania e dos poderes do Estado}

Art. $5^{\circ}$ A soberania reside essencialmente em a Nação.

Art. 6. São órgãos da soberania nacional o Poder Legislativo, o Poder Executivo e o Poder Judicial, independentes e harmónicos entre si.

Art. 7. Nenhum dos poderes do Estado pode, separada ou conjuntamente, suspender a Constituição ou restringir os direitos nela consignados, salvos os casos na mesma taxativamente expressos. 


\section{SECÇÃO I \\ Do Poder Legislativo}

Art. 7..$^{\circ}$ O Poder Legislativo é exercido pelo Congresso da República, formado por duas câmaras, que se denominam Câmara dos Deputados e Senado.

$\S 1 .^{\circ}$ Os membros do Congresso são representantes da Nação e não dos colégios que os elegem.

$\S 2{ }^{\circ}$ Ninguém pode ser Senador com menos de trinta e cinco anos de idade e Deputado com menos de vinte e cinco.

Pode todavia ser deputado quem tendo menos de vinte e cinco anos, houver já exercido funções legislativas.

Art. $8 .^{\circ} \mathrm{A}$ Câmara dos Deputados compõe-se de cento e vinte membros que são eleitos por sufrágio directo dos cidadãos eleitores.

§ único.A organização dos colégios eleitorais, a forma e o processo de eleição serão regulados por lei especial.

Art. 9. O Senado será composto de sessenta membros, sendo uma parte representativa de circunscrições administrativas e outra parte representativa de categorias profissionais.

$\S$ único. A representação das circunscrições administrativas e das categorias profissionais, a forma e o processo da eleição serão regulados por lei especial.

Art. 10. Para a eleição da Câmara dos Deputados e do Senado em Congresso não constituinte, os colégios eleitorais reunir-se-hão por direito próprio, se não forem convocados pelo Poder Executivo, antes de findar a legislatura.

A reunião efectuar-se-ha no primeiro domingo depois dos sessenta dias seguintes ao termo da legislatura; exceptuam-se os casos de estarem suspensas as garantias nos precisos termos desta Constituição, ou de existir calamidade pública ou grave perturbação da ordem. Só nestes casos o Poder Executivo designará o dia da reunião, fora das condições citadas, dando contas, logo que se constitua o Congresso, do uso que tiver feito desta autorização, se não a houver prestado à Câmara dos Deputados legalmente constituída e reunida nos termos da Constituição.

Art. 11. Os Deputados são eleitos por três anos e os Senadores são eleitos por seis anos.

Os Deputados e Senadores que forem eleitos para preencher as vagas ocorridas por morte ou outra causa, só exercerão o mandato pelo tempo que restava ao substituído.

Art. 12. ${ }^{\circ}$ Todas as vezes que houver de se proceder a eleições de Deputados, o Senado será renovado em metade dos seus membros.

$\S$ único. Para a primeira renovação do Senado, constituído nos termos do artigo 9. desta Constituição, a sorte decidirá sôbre as circunscrições administrativas e categorias profissionais cujos representantes devem sair.

Nas subsequentes renovações, a antiguidade da eleição decidirá quais os Senadores que devem sair.

Art. 13. ${ }^{\circ}$ O Congresso da República reúne, por direito próprio, na capital da Nação, no dia I de Dezembro de cada ano. A sessão legislativa durará quatro meses, podendo ser prorrogada ou adiada somente por deliberação própria tomada em sessão conjunta das duas Câmaras.

Cada legislatura durará três anos.

Art. 14. ${ }^{\circ} \mathrm{O}$ Congresso poderá ser convocado extraordinariamente pela têrça parte dos seus membros ou pelo Poder Executivo.

Art. 15. ${ }^{\circ}$ O Congresso abrirá em sessão conjunta das duas Câmaras para tomar conhecimento da mensagem do Presidente da República. As duas Câmaras funcionarão separadamente em sessões públicas; funcionarão em sessão secreta quando houver deliberação especial, funcionarão em sessão conjunta nos casos previstos nesta Constituição; e encerrar-se-hão no mesmo dia. 
As deliberações de cada uma das Câmaras serão tomadas por maioria de votos, achandose presente a maioria absoluta dos seus membros, que não estiverem ausentes com licença da respectiva Câmara.

$\S$ único. A cada uma das Câmaras compete verificar e reconhecer os poderes dos seus membros, eleger a sua Mesa, organizar o seu Regimento interno e regular a sua polícia interior.

Art. 16. As sessões conjuntas das duas Câmaras serão presididas pelo mais velho dos seus presidentes em exercicio.

Art. 17. ${ }^{\circ}$ Os Deputados e Senadores são invioláveis pelas opiniões e votos que emitirem no exercício do seu mandato. $O$ seu voto é livre e independente de quaisquer insinuações ou instruções.

Art. 1 8. Durante o exercicio das funções legislativas, nenhum membro do Congresso poderá ser jurado, perito ou testemunha sem autorização da respectiva Câmara.

Art. 19. Nenhum Deputado ou Senador poderá ser ou estar preso durante o período das sessões sem prévia licença da sua Câmara, excepto em flagrante delito a que seja aplicável pena maior ou equivalente na escala penal.

Art. $20^{\circ}$ Se algum Deputado ou Senador fôr processado criminalmente, levado o processo até a pronúncia, o juiz comunicá-lo há à respectiva Câmara, a qual decidirá se o Deputado ou Senador deve ser suspenso e se o processo deve seguir no intervalo das sessões ou depois de findas as funções do arguido.

Art. 21. A suspensão das garantias constitucionais, por iniciativa do Poder Executivo, não impede o funcionamento do Congresso; mas êste não pode discutir essa suspensão emquanto ela vigorar, podendo apenas fixar o prazo da sua duração.

Art. $22{ }^{\circ}$ Os membros do Congresso terão, durante as sessões, um subsídio que será fixado pelo Congresso Constituinte para os Congressos ordinários que se lhe seguirem.

Art. 23. ${ }^{\circ}$ Nenhum membro do Congresso, depois de eleito, poderá celebrar contratos com - Poder Executivo nem aceitar dêste ou de qualquer Govêrno estrangeiro emprêgo retribuido ou comissão subsidiada.

$\S 10^{\circ}$ Exceptuam-se desta última proibição:

1. As missões diplomáticas e os comissariados da República de duração não superior a seis meses;

$2^{\circ}$ As comissões ou comandos militares;

3. ${ }^{\circ}$ Os cargos de acesso e as promoções legais;

4..$^{\circ}$ As nomeações que por lei são feitas pelo Govêrno, precedendo concurso.

$\S 2 .^{\circ}$ Nenhum Deputado ou Senador poderá servir lugares nos conselhos administrativos, gerentes ou fiscais de emprêsas ou sociedades constituídas por contrato ou concessão especial do Estado ou que dêste hajam privilégio não conferido por lei genérica, subsídio ou garantia de rendimento (salvo o que, por delegação do Govêrno, representar nela os interêsses do Estado) e outrossim não poderá ser concessionário, contratador ou sócio de firmas contratadoras de concessões, arrematações ou empreitadas de obras públicas e operações financeiras com o Estado.

§ único. A inobservância dos preceitos contidos neste artigo ou no antecedente importa, de pleno direito, perda do mandato e anulação dos actos e contratos neles referidos.

Art. $25^{\circ}$ Os membros do Congresso que renunciarem o mandato ou o perderem por faltas, não poderão ser nomeados pelo Poder Executivo até ao fim da legislatura a que pertencerem, para quaisquer funções públicas, salvo quando por lei as nomeações sejam precedidas de concurso.

Art. 26. Perdem o mandato os membros do Congresso que faltarem a mais de dez sessões seguidas sem justificarem as suas faltas.

Perde o mandato legislativo o Deputado ou Senador que aceitar o cargo de Ministro e Secretário de Estado. 


\section{Da Câmara do Deputados}

Art. 27. É privativa da Câmara dos Deputados a iniciativa:

a) Sôbre impostos;

b) Sôbre a organização das fôrças de terra e mar;

c) Sôbre a discussão de medidas propostas pelo Poder Executivo;

d) Sôbre a revisão constitucional;

e) Sôbre a prorrogação e o adiamento da sessão legislativa.

\section{Do Senado}

Art. 28. Ao Senado compete privativamente aprovar ou rejeitar, por votação secreta, as propostas de nomeação dos chefes de missões diplomáticas e dos governadores para as províncias do ultramar e dos comissariados da República.

§único. Estando encerrado o Congresso, o Poder Executivo só poderá fazer, a título provisório, as nomeações de que trata êste artigo.

\section{Das atribuições do Congresso da República}

Art. 29. Compete privativamente ao Congresso da República:

1. Fazer leis, suspendê-las e revogá-las;

$2^{\circ}$ Velar pela observância da Constituição e das leis e promover o bem geral da Nação;

3. Orçar a receita e fixar a despesa da República, anualmente, tomar as contas da receita e despesa de cada exercício financeiro e votar anualmente os impostos;

$\S 1 .^{\circ}$ Nenhum aumento de despesa ou diminuição de receita, autorizados por lei promulgada depois da apresentação do Orçamento Geral do Estado à Câmara dos Deputados, poderão ser incluídos nesse orçamento.

$\S 2 .^{\circ}$ Quando o projecto de lei do Orçamento Geral do Estado não estiver votado até o dia 15 de Junho, continua vigorando no próximo ano económico o Orçamento do ano anterior.

4. Autorizar o Poder Executivo a realizar empréstimos e outras operações de crédito, que não sejam de dívida flutuante, estabelecendo ou aprovando préviamente as condições gerais em que devem ser feitos;

5. Regular o pagamento da dívida interna e externa;

6. ${ }^{\circ}$ Resolver sôbre a organização da defesa nacional;

$7 .^{\circ}$ Criar e suprimir empregos públicos, fixar as atribuições dos respectivos empregados e estipular-Ihes os vencimentos;

$8 .^{\circ}$ Criar e suprimir alfândegas;

9. Determinar o pêso, o valor, a inscrição, o tipo e a denominação das moedas;

$10 .^{\circ}$ Fixar o padrão dos pesos e medidas;

$11 .^{\circ}$ Criar bancos de emissão, regular a emissão bancária e tributá-la;

12. Resolver sôbre os limites dos territórios da Nação;

13. ${ }^{\circ}$ Fixar, nos termos das leis especiais, os limites das divisões administrativas do país e resolver sôbre a sua organização geral;

14. Autorizar o Poder Executivo a fazer a guerra, se não couber o recurso à arbitragem ou esta se malograr, salvo caso de agressão iminente ou efectiva por fôrças estrangeiras, e a fazer a paz;

15. Resolver definitivamente sôbre tratados e convenções; 
16. Declarar em estado de sítio, com suspensão total ou parcial das garantias constitucionais, um ou mais pontos do território nacional, no caso de agressão iminente ou effectiva por fôrças estrangeiras ou no de perturbação interna.

§ 1. Não estando reunido o Congresso, exercerá esta atribuição o Poder Executivo.

$\S 2 .^{\circ}$ O Poder Executivo, durante o estado de sítio, restringir-se-há, sempre que seja possível, nas medidas de repressão contra as pessoas, a impor a detenção; mas usará de meios enérgicos e eficazes para restabelecer a ordem pública, sempre que as circunstâncias os imponham.

$\S 3 .^{\circ}$ Reunido o Congresso, no prazo de trinta dias, o que poderá ter lugar por direito próprio, o Poder Executivo Ihe relatará, motivando-as, as medidas de excepção que houverem sido tomadas e por cujo abuso são responsáveis as autoridades respectivas.

17. Organizar o Poder Judicial nos termos da presente Constituição;

18..$^{\circ}$ Conceder amnistia;

19. Apreciar a oportunidade do julgamento do Presidente da República, nos termos do artigo $69^{\circ}$ desta Constituição;

20. Deliberar sôbre a revisão da Constituição, nos termos do artigo 87.';

$21 .^{\circ}$ Determinar a aplicação e autorizar a alienação dos bens nacionais;

$22{ }^{\circ}$ Votar os regulamentos elaborados para a execução das leis, os quais serão considerados provisórios emquanto não tiverem a aprovação do Congresso;

$23 .^{\circ}$ Continuar no exercício das suas funções legislativas, depois de terminada a respectiva legislatura, se por algum motivo as eleições não tiverem sido feitas nos prazos constitucionais.

$\S$ único. Esta ampliação de funções prolongar-se-há até a realização das eleições que devem mandar ao Congresso os seus novos membros.

Art. $30^{\circ}$ As autorizações concedidas pelo Poder Legislativo ao Poder Executivo não poderão ser aproveitadas mais de uma vez, no intervalo das sessões legislativas, e caducarão logo que estas recomecem.

\section{Da iniciativa, formação e promulgação das leis e resoluções}

Art. $31 .^{\circ}$ Salvo o disposto no artigo $27 .^{\circ}$, a iniciativa de todos os projectos de lei compete indistintamente a qualquer dos membros do Congresso.

Art. $32 .^{\circ} \mathrm{O}$ projecto de lei adoptado numa das Câmaras será submetido à outra; e, se esta o aprovar, enviá-lo-há ao Presidente da República.

Art. $33 .^{\circ} \mathrm{O}$ projecto de uma Câmara, emendado na outra, voltará à primeira, que se aceitar as emendas, o enviará assim modificado, ao Presidente da República. Se a Câmara iniciadora não aprovar as emendas propostas ao projecto pela outra Câmara, serão estas com êle submetidas à votação das duas Câmaras, reunidas em sessão conjunta. $O$ texto do projecto de lei aprovado será enviado ao Presidente da República.

Art. $34 .^{\circ}$ O projecto de lei aprovado pelo Congresso, e enviado ao Presidente da República será por êste assinado e promulgado dentro de quinze dias da apresentação.

Não o promulgando, deve o Presidente da República remetê-lo ao Presidente do Congresso, acompanhado das considerações que justificam o seu veto. $O$ presidente do Congresso, submetêlo-há, dentro de dez dias da sua recepção, à votação nominal e sem discussão dos membros do Congresso, reunido em sessão conjunta.

O projecto de lei, será convertido em lei, se obtiver a aprovação de, pelo menos, dois terços do número de membros do Congresso que não estiverem ausentes, com licença da respectiva Câmara. Será enviado ao Presidente da República para ser assinado e promulgado dentro de dez dias da apresentação.

Art. $35 .^{\circ}$ A fórmula da promulgação pelo Presidente da República, é a seguinte: «Em nome da Nação, o Congresso da República decreta, e eu promulgo a lei (ou resolução) seguinte». 
Art. 36. ${ }^{\circ}$ No caso de o Presidente da República não promulgar qualquer projecto de lei, ou resolução, até o último dia dos prazos designados no artigo $344^{\circ}$ desta Constituição, o presidente do Congresso assinará o projecto, fazendo-o promulgar no Diário do Govêrno para valer como lei.

A fórmula da promulgação é a seguinte:

«Em nome da Nação, e nos termos do artigo 36. da Constituição, o Congresso da República decreta e promulga a lei (ou resolução) seguinte».

Art. 37. ${ }^{\circ}$ O projecto de lei aprovado numa das Câmaras, será enviado à outra, que sôbre êle deverá pronunciar-se o mais tardar na sessão legislativa seguinte àquela em que tenha sido aprovado. No caso de não ser o projecto votado pela segunda Câmara, será considerado como rejeitado, devendo voltar a ser apreciado pela Câmara iniciadora.

Sendo aprovado por esta, voltará à outra Câmara; e não sendo por esta votado dentro da sessão legislativa, será submetido à votação do Congresso, reunido em sessão conjunta.

Art. 38. ${ }^{\circ}$ No caso de rejeição pura e simples, por uma das Câmaras, do projecto já aprovado na outra, proceder-se-há como se o projecto tivesse sofrido emendas em vez de rejeição.

Art. $39^{\circ}$ Os projectos definitivamente rejeitados não poderão ser renovados na mesma sessão legislativa.

\section{SECÇÃO ॥ \\ Do Poder Executivo}

Art. $400^{\circ}$ O Poder Executivo é exercido pelo Presidente da República.

$\S$ único. O Presidente da República exerce o Poder Executivo por intermédio de Ministros e Secretários de Estado.

Art. $41 .^{\circ}$ O Presidente da República representa a Nação nas relações gerais do Estado, tanto internas como externas.

Art. $42 .^{\circ}$ O Presidente da República é o chefe das fôrças de terra e mar e exerce o seu comando por intermédio dos organismos próprios.

Art. $43 .^{\circ}$ O Presidente da República só pode ser discutido publicamente pelos seus actos políticos e sempre com o respeito devido à alta dignidade do seu cargo.

Art. $44 .^{\circ}$ Compete ao Presidente da República:

1. Expor pessoalmente, nas sessões de abertura do Congresso e em mensagens à Câmara dos Deputados, as necessidades sôbre que deve recair a atenção dos seus membros e solicitar-Ihes as respectivas providências legislativas.

§ único.As declarações e mensagens do Presidente da República nunca poderão ser discutidas na sua presença.

$2^{\circ}$ Enviar directamente à Câmara dos Deputados, nos primeiros quinze dias de Janeiro de cada ano, o Orçamento Geral do Estado do ano económico seguinte.

$3 .^{\circ}$ Nomear e demitir livremente os Ministros e Secretários de Estado, que devem ser cidadãos com capacidade eleitoral.

4. ${ }^{\circ}$ Convocar extraordináriamente a reunião do Congresso.

$5^{\circ}$ Promulgar e fazer publicar e correr as leis e as resoluções do Congresso, expedindo os decretos, instruções e regulamentos adequados à boa execução das mesmas.

6. Prover todos os cargos civis e militares e exonerar, suspender e demitir os respectivos funcionários na conformidade das leis, ficando sempre a estes ressalvado o recurso aos tribunais competentes.

7. Representar a Nação perante o estrangeiro e dirigir a política externa da República, sem prejuizo das atribuições do Congresso. 
8. Declarar, por período não excedente a trinta dias, o estado de sítio, com suspensão total ou parcial das garantias constitucionais, em qualquer ponto ou em toda a extensão do território nacional nos casos de agressão estrangeira ou grave perturbação interna, nos termos do $\S 1 .^{\circ}$ do n. ${ }^{\circ} 16^{\circ}$ do artigo $29 .^{\circ}$ desta Constituição.

9. Negociar tratados de aliança, de comércio, de paz e de arbitragem e ajustar outras convenções internacionais. Estes tratados e convenções serão submetidos à ratificação do Congresso.

$10^{\circ}$ Indultar e comutar penas.

$11 .^{\circ}$ Prover a tudo quanto fôr relativo à segurança interna e externa do Estado, na forma da Constituição.

12. Abrir os créditos indispensáveis para prover às despesas causadas por calamidade pública, grave perturbação interna ou operações de guerra nas colónias, devendo explicar à Câmara dos Deputados o uso que fizer desta atribuição.

Art. 45. ${ }^{\circ}$ O Presidente da República tem o direito de veto, nos termos desta Constituição, sôbre os projectos de lei aprovados pelo Congresso.

Art. $46^{\circ}{ }^{\circ}$ Todos os diplomas assinados pelo Presidente da República serão referendados pelo Ministro ou Ministros respectivos.

$\S$ único. A referenda importa as responsabilidades política, civil e criminal dos Ministros: a responsabilidade política perante o Presidente da República e as responsabilidades civil e criminal, perante os tribunais competentes, na qualidade de simples funcionário do Estado.

Art. $47 .^{\circ}$ Os Ministros não podem acumular o exercício de outro emprêgo ou função pública, aplicando-se-lhes as proibições e mais disposições enumeradas no artigo $24 .^{\circ}$ e seu parágrafo.

Art. $48 .^{\circ}$ Os Ministros não podem tomar parte nas sessões do Congresso; mas podem comparecer perante as suas comissões, a convite das mesmas; se não comparecerem, devem fornecer informações escritas sôbre os pontos de consulta.

\section{Dos crimes de responsabilidade}

Art. 49. ${ }^{\circ}$ São crimes de responsabilidade os actos do Presidente da República e seus agentes que atentarem:

1. ${ }^{\circ}$ Contra a existência política da Nação:

$2^{\circ}$ Contra a Constituição e contra o regime republicano;

3. ${ }^{\circ}$ Contra o livre exercício dos poderes do Estado.

$4 .^{\circ}$ Contra a segurança interna do país.

\section{Da eleição do Presidente da República}

Art. $500^{\circ}$ A eleição do Presidente da República realizar-se-há por sufrágio directo dos cidadãos portugueses, nos termos da lei eleitoral que regular a eleição dos membros do Congresso.

Art. 51 . $^{\circ}$ Só pode ser eleito Presidente da República o cidadão português filho de pais portugueses, nascido em território português, maior de 35 anos, e no pleno gôzo dos seus direitos civis e políticos.

Art. 52. ${ }^{\circ}$ São inelegíveis para o cargo de Presidente da República:

a) As pessoas das familias que reinaram em Portugal;

b) Os parentes consanguineos ou afins em $1 .^{\circ}$ ou $2 .^{\circ}$ grau, por direito civil, do Presidente que sai do cargo, mas só quanto à primeira eleição posterior à sua saída;

c) Os estrangeiros, embora naturalizados. 
Art. 53. ${ }^{\circ}$ O Presidente é eleito por um período normal de quatro anos. Pode ser reeleito para o período seguinte. Não pode voltar a ser reeleito sem terem decorrido pelo menos quatro anos sôbre o termo do seu mandato, nunca podendo servir por mais de dois períodos presidenciais seguidos.

$\S$ único. O Presidente deixa normalmente o exercício das suas funções no dia 5 de Outubro em que completar o quadriénio do exercício presidencial.

$\S$ único. Se ocorrer a morte do cidadão eleito para suceder ao Presidente em exercício, repetir-se-há a eleição em um dos domingos compreendidos entre trinta e sessenta dias a contar da data do falecimento.

Art. 55. ${ }^{\circ}$ Ao tomar posse do cargo, o Presidente pronunciará, em sessão conjunta das Câmaras do Congresso, sob a presidência do mais velho dos presidentes, esta declaração de compromisso.

«Afirmo solenemente, pela minha honra, manter e cumprir, com lealdade e fidelidade, a Constituição da República, observar as leis, promover o bem geral da Nação, sustentar e defender a integridade e a independência da Pátria».

Art. 56. ${ }^{\circ}$ No caso de vacatura da Presidência da República, por morte, renúncia ou qualquer outra causa, assumirá imediatamente o cargo de Presidente o cidadão eleito nos termos do artigo 54. ${ }^{\circ}$ desta Constituição, começando a contar-se o período presidencial na data da posse.

Se não houver cidadão eleito, o Poder Executivo será desde logo exercido por uma Junta Nacional, composta pelo presidente do Supremo Tribunal de Justiça e pelos presidentes eleitos pelas duas Câmaras de Congresso, os quais não perdem o seu mandato legislativo.

Os membros da Junta Nacional farão imediata declaração de compromisso, nos termos do artigo $55^{\circ}$ desta Constituição, o qual deve ser publicado no Diário do Govêrno.

A Junta Nacional convocará os colégios eleitorais no dia imediato àquele em que a vacatura ocorrer; a eleição do Presidente da República será efectuada em um dos domingos que se seguirem entre trinta e sessenta dias posteriores à data da convocação.

$\S$ único. Os diplomas promulgados pela Junta Nacional devem ser assinados pelo menos por dois dos seus membros, os quais devem permanecer na capital da Nação.A fórmula da promulgação das leis (ou resolução) é a seguinte: «Em nome da Nação, o Congresso da República decreta e a Junta Nacional promulga a lei (ou resolução) seguinte:

Art. 57..$^{\circ}$ O Presidente não pode ausentar-se do território nacional sem permissão do Congresso, sob pena de perder o cargo.

Art. 58. No caso de saída do Presidente da República para fora do continente da República, - Poder Executivo será exercido, durante a sua ausência, pela Junta Nacional.

O mesmo sucederá se o presidente eleito nos termos do artigo $54 .^{\circ}$ desta Constituição se encontrar ausente no estrangeiro no dia em que tiver de tomar posse do cargo.

Art. $59^{\circ}$ O Presidente perceberá um subsídio que será fixado antes da sua eleição e não poderá ser alterado durante o período do seu mandato.

$\S$ único. Para a instalação da secretaria da Presidência e para a residência e cómodo pessoal do Presidente da República e sua familia, o Congresso designará a propriedade ou propriedades nacionais.

Art. $600^{\circ}$ Os membros da Junta Nacional não podem ausentar-se da capital da Nação sem licença das duas Câmaras do Congresso, sob pena de perderem durante três anos os cargos que exercerem, bem como os seus direitos civis e políticos.

No caso de ser aplicável esta sanção, fará parte temporáriamente da Junta Nacional o legítimo substituto da pessoa que nela incorrer, a qual por sua vez fica sujeita a idêntica caução.

Ainda no mesmo caso, reunir-se há por direito próprio aquela das Câmaras cuja presidência tiver vagado e procederá à eleição do novo presidente, que deve fazer parte desde logo da Junta Nacional.

$\S$ único. Os membros da Junta Nacional, quando exercerem o Poder Executivo, perceberão um subsídio que será fixado pelo Congresso. 


\section{SECÇÃO III \\ Do Poder Judicial}

Art. 61. ${ }^{\circ}$ O Poder Judicial da República terá por órgãos um Supremo Tribunal de Justiça e tribunais de primeira e segunda instância.

$\S$ único. O Supremo Tribunal de Justiça terá a sua sede na capital da Nação. Os tribunais de primeira e segunda instância serão distribuídos pelo país, conforme as necessidades da administração da justiça o exigirem.

Art. $62{ }^{\circ}$ Os juízes do quadro da magistratura judicial são vitalícios e inamovíveis e as suas nomeações, demissões, suspensões, promoções, transferência e colocações fora do quadro serão feitas nos termos da lei orgânica do Poder Judicial.

Art. $63 .^{\circ}$ É mantida a instituição do júri.

Art. $644^{\circ}$ Os juízes serão irresponsáveis nos seus julgamentos, salvo as excepções consignadas na lei.

Art. $65 .^{\circ}$ Nenhum juiz poderá aceitar do Govêrno funções remuneradas. Quando convier ao serviço público, o Govêrno poderá requisitar os juízes que entender necessários para quaisquer comissões permanentes ou temporárias, sendo as nomeações feitas nos termos que a respectiva lei orgânica determinar.

Art. $66^{\circ}$ As sentenças e ordens do Poder Judicial serão executadas por oficiais judiciários privativos, aos quais as autoridades competentes serão obrigadas a prestar auxilio quando invocado por êles.

Art. $67 .^{\circ}$ O Poder Judicial, desde que, nos feitos submetidos a julgamento, qualquer das partes impugnar a validade dos diplomas emanados das corporações com autoridade pública ou dos actos dos agentes do Poder Executivo, que tiverem sido invocados, apreciará a sua legitimidade.

Art. $688^{\circ}$ Só o Supremo Tribunal de Justiça é competente para conhecer da inconstitucionalidade das leis e dos delitos, tanto políticos como comuns, praticados pelo Presidente da República.

Art. 69..$^{\circ}$ Quando uma lei fôr julgada inconstitucional pelo Supremo Tribunal de Justiça, será publicada no Diário do Govêrno a respectiva sentença, sendo essa lei declarada nula e de nenhum efeito, ninguém lhe devendo obediência.

Art. $700^{\circ}$ Se o Presidente da República fôr processado por delito comum, será imediatamente julgado pelo Supremo Tribunal de Justiça; se fôr processado por algum dos crimes de responsabilidades designados nos do artigo $499^{\circ}$ desta Constituição, o processo será levado até a pronúncia e oTribunal comunicá-la-há ao Congresso que, em sessão conjunta e secreta das duas câmaras, decidirá se o Presidente da República deve ser imediatamente julgado ou se o seu julgamento deve realizar-se depois de terminadas as suas funções.

\section{TITULO IV \\ Das instituições locais administrativas}

Art. $71 .^{\circ}$ A organização e atribuições dos corpos administrativos serão reguladas pelos princípios seguintes:

a) Código administrativo contendo disposições gerais:

b) Concessão de autonomia administrativa aos municípios, por meio de cartas orgânicas, aprovadas pelos mesmos, quando não contrariem as disposições da lei geral;

c) Federação dos municípios contíguos, quando se tratar da administração e exploração de ramos de serviço em proveito comum;

d) Exercício do referendum, nos termos determinados por lei;

e) Representação de minorias; 
f) Autonomia financeira dos corpos administrativos na forma que a lei determinar;

g) O poder executivo dos corpos administrativos é exercido pelo seu presidente, que, juntamente com os restantes membros, constitui o poder deliberativo.

$\S$ único. As deliberações dos corpos administrativos poderão ser modificadas ou anuladas pelos tribunais do contencioso, quando forem ofensivas das leis e regulamentos de ordem geral.

\section{TİTULO V \\ Da Administração das províncias ultramarinas}

Art. $72 .^{\circ}$ As colónias portuguesas constituem organismos administrativos e financeiros autónomos, sob a superintendência e fiscalização da metrópole.

Art. 73..$^{\circ}$ No diploma orgânico de cada colónia serão estabelecidos os preceitos e normas fundamentais do seu govêrno e administração em harmonia com o seu grau de desenvolvimento e condições especiais.

Art. 74. ${ }^{\circ}$ Quando estiver encerrado o Congresso poderá o Presidente da República tomar as medidas que julgar necessárias e urgentes para as províncias ultramarinas.

$\S$ único. Aberto o Congresso o Presidente da República fundamentará em mensagem as medidas tomadas.

\section{TÍTULO VI \\ Disposições gerais}

Art. $75 .^{\circ}$ Todos os portugueses, cada qual segundo as suas aptidões, são obrigados ao serviço militar para sustentar a independência e a integridade da Patria e da Constituição.

Art. $76^{\circ}$ A fôrça pública é essencialmente obediente e não pode formular petições ou representações colectivas nem reunir senão por autorização ou ordem da autoridade competente. Os corpos armados não podem deliberar.

Art. $77^{\circ}$ Leis especiais providenciarão acêrca da organização e administração das fôrças militares de terra e mar em todo o território da República.

Art. 78..$^{\circ}$ Para os condenados por crime e delitos eleitorais não há indulto. Pode todavia a Câmara, a propósito de cuja eleição foram cometidos aqueles crimes ou delitos, tomar a iniciativa da concessão da amnistia, quando a votem dois têrços dos seus membros e só depois de os condenados haverem cumprido metade da pena, quando esta seja de prisão.A amnistia não pode abranger as custas e selos do processo, as multas e as despesas de procuradoria.

412

Art. 79. A República Portuguesa, sem prejuízo do pactuado nos seus tratados de aliança, preconiza o princípio da arbitragem como o melhor meio de dirimir as questões internacionais.

Art. $800^{\circ}$ São cidadãos portugueses, para o efeito de exercício dos direitos políticos, todos aqueles que a lei considere como tais.

$\S$ único. A lei civil regula os termos em que o cidadão português perde ou readquire esta qualidade.

Art. $811^{\circ}$ Uma lei especial fixará os casos e as condições em que o Estado concederá pensões à familias dos militares mortos no serviço da República, ou aos militares inutilizados em razão do mesmo serviço. 
Art. $82{ }^{\circ}$ Continuam em vigor, emquanto não forem revogados ou revistos pelo Poder Legislativo, as leis e decretos com fôrça de lei até hoje existentes, e que como lei ficam valendo, no que explícita ou implicitamente não fôr contrário ao sistema de Govêrno adoptado pela Constituição e aos princípios nela consagrados.

Art. $83 .^{\circ}$ É mantida a legislação em vigor que extinguiu e dissolveu em Portugal a Companhia de Jesus, as sociedades nela filiadas, qualquer que seja a sua denominação, e todas as congregações religiosas e ordens monásticas, que jámais serão admitidas em território português.

Art. $84^{\circ}$ Serão mantidos os direitos da Nação sôbre o padroado português no Oriente.

Art. $85^{\circ}$ Subsiste o colégio de preparação das missões ultramarinas, regulando-se a organização e 0 aproveitamento das mesmas em lei especial.

Art. $86 . .^{\circ} \mathrm{O}$ mandato do Presidente da República que tomar posse em data diferente de 5 de Outubro termina em 5 de Outubro do ano em que se completar o quadriénio presidencial.

Art. $87 .^{\circ} \mathrm{O}$ regulamento da polícia do Congresso e a nomeação dos seus empregados é da competência da comissão administrativa, que será constituida pelos presidentes e primeiros secretários das Mesas das duas Câmaras, por um Senador e dois Deputados eleitos pelas respectivas Câmaras.

O presidente desta comissão será o mais velho dos Presidentes das Câmaras; o secretário será o primeiro Secretário da Câmara dos Deputados; o tesoureiro será escolhido de entre os três vogais eleitos.

\section{TÍTULO VII \\ Da revisão constitucional e disposições transitórias}

Art. 88. A Constituição da República Portuguesa será revista de dez em dez anos, a contar da promulgação desta, e, para êsse efeito, terá poderes constituintes o Congresso, cujo mandato abranger a época da revisão.

§1. Se fôr aprovada por dois terços dos membros do Congresso, em sessão conjunta das duas Câmaras, a revisão poderá ser efectuada depois de findo o ano de 1923.

$\S 2 .^{\circ}$ A revisão a que se refere o parágrafo anterior só poderá ser iniciada depois de decorrido, pelo menos, um ano sôbre a deliberação tomada pela Câmara dos Deputados.

$\S 3 .^{\circ} \mathrm{Em}$ nenhum caso, quer a revisão se faça ao fim do período, como indica o $\S 1 .^{\circ}$, o Congresso não poderá ocupar-se da revisão constitucional sem que sejam designadas precisamente as alterações projectadas ao mesmo tempo que fôr designada a época da revisão.

$\S 4 .^{\circ}$ Nenhuma alteração constitucional pode ser admitida à discussão quando o seu intuito seja abolir a forma republicana do Govêrno.

Art. $89 .^{\circ} \mathrm{O}$ actual Presidente da República terminará o seu mandato em 5 de Outubro de 1923, podendo ser reeleito nos termos desta Constituição.

Art. $90^{\circ}$ Aprovada esta Constituição, será logo decretada e promulgada pela Mesa do Congresso Constituinte e assinada pelos membros desta.

Manuel Bravo Junior

Seraphim Joaquim de Morais Junior

José Luís dos Santos Costa

António Lino Netto (a)

José d'Almeida Correia (a)

Francisco Xavier Esteves, relator

(a) Com declarações 



\title{
3 - Carta de H. Martinet, Arquitecto Paisagista, para o Sr. Martet, Chefe do Secretariado do Presidente do Conselho francês ${ }^{(1014)}$
}

\author{
Paris, le II Décembre 1918
}

\section{Monsieur}

En ma simple qualité de citoyen républicain français, qui ne demande, personnellement, aucune faveur, j'ai eu l'honneur d'adresser, à Mr. Godin, d'abord, à vous ensuite, une demande d'audience de quelques minutes auprès de Monsieur le Président du Conseil des Ministres, pour Mr.Affonso Costa, ancien président du Conseil des Ministres du Portugal.

Si je suis ainsi intervenu, c'est non-seulement comme secrétaire du Comité France-Portugal, mais aussi parce que Mr Bernardino Machado, toujours président constitutionnel de la République du Portugal, et Mr. Affonso Costa, veulent bien m'honorer de leur amitié et que, par suite de l'expérience que j'ai acquise au cours de mes longs séjours au Portugal, je me rends compte que ce pays est aujourd'hui soumis à un régime qui peut être comparé à celui de la Grèce, sous le règne de Constantin et à celui de la Roumanie, sous la présidence de Marghiloman.

Je sais, de la meilleure source, que la situation, dans ce pays, est sur le point de changer et qu'il y aurait un grand intérêt à ne pas laisser compromettre par les éléments germanophiles, une situation qui pourrait être excellente pour la France.

Vous avez bien voulu me faire téléphoner, il y a quelques jours, que Monsieur le Président du Conseil, en raison de son départ imminent pour l'Alsace, ne pouvait pas reçevoir Mr. Affonso Costa et qu'il l'engageait à se mettre en rapport avec le Ministère des Affaires Etrangères.

Or, en raison de l'importance des communications à faire, et de la personnalité de Mr. Affonso Costa, une entrevue avec Mr. Clémenceau, si courte qu'elle puisse être, semble devoir être très utile.

Je me permets donc, tout en me rendant parfaitement compte, veuillez le croire, de la nécessité de ménager le temps si précieux de Mr le Président du Conseil, de vous prier d'intervenir à nouveau, pour que l'entrevue sollicitée ait lieu. Si cette dernière demande, que je crois, par acquit de conscience, devoir vous adresser, ne devait pas avoir de résultat, j'aurais le très vif regret de renoncer, en ce qui me concerne, à intervenir, si modeste que puisse être mon concours, dans une question, qui, j'en ai le très vif sentiment, présente un sérieux intérêt pour mon pays.

Dans l'espoir qu'une solution favorable pourra intervenir, un jour prochain, je vous prie de vouloir bien agréer, Monsieur, l'expression de mes sentiments très distingués.

Martinet

P.S. - Partant demain matin en voyage, pour quelques jours, je me permets de vous rappeler que Mr. Affonso Costa qui, le II novembre, jour de l'armistice, a adressé à Monsieur le Président du Conseil, des télégrammes de félicitations restés, jusqu'ici sans réponse, habite toujours au MacMahon Palace Hôtel, Avenue Mac-Mahon.

(1014) Z. Europe 1840 Portugal, Ambassadeur Français à Lisbonne, 1918, livre p. 115 e 115 bis. (Archives du Ministère des Affaires Etrangères). 



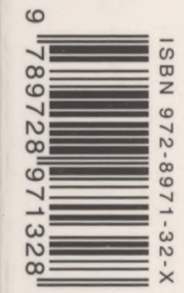

$\bullet$

$$
\text { Série }
$$

Investigaçäo

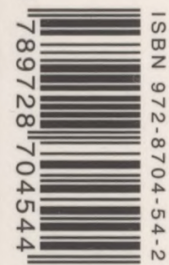

\section{Imprensa da Universidade de Coimbra}

Coimbra University Press

2006 